Non

$=-2.15$

Biomass Energy Data Book

1. (1)

(1)

(2)

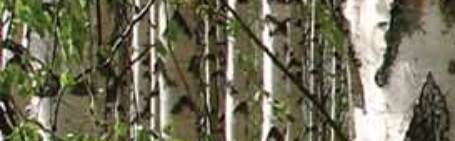

1.

1.

.

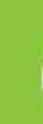

(10) U.S. Department of Energy

Energy Efficiency and Renewable Energy

Bringing you a prosperous future where energy is clean, abundant, reliable, and affordable

16

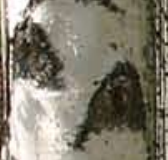

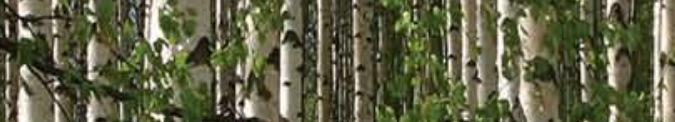

Hixt
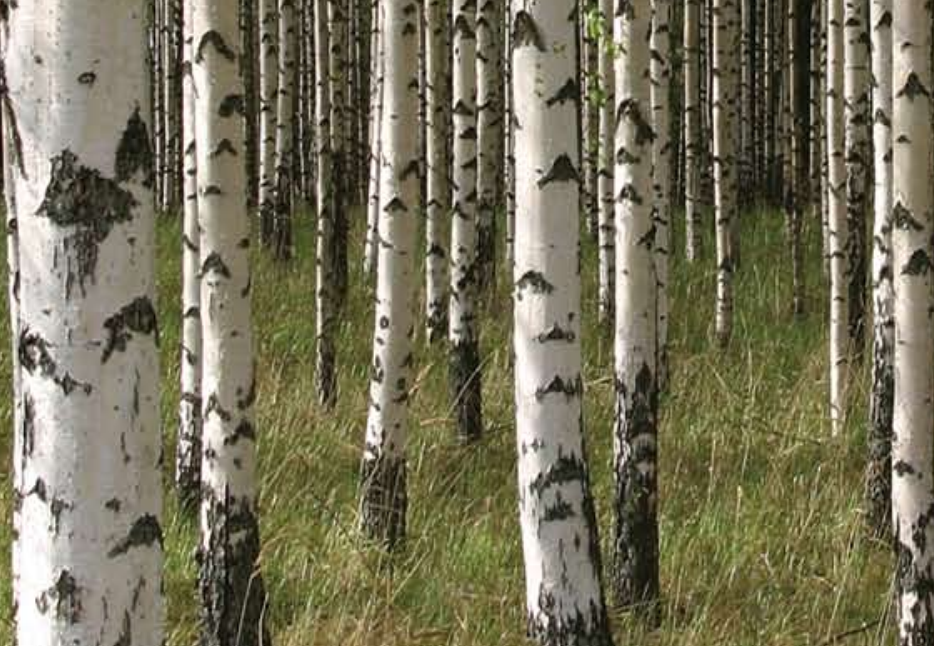

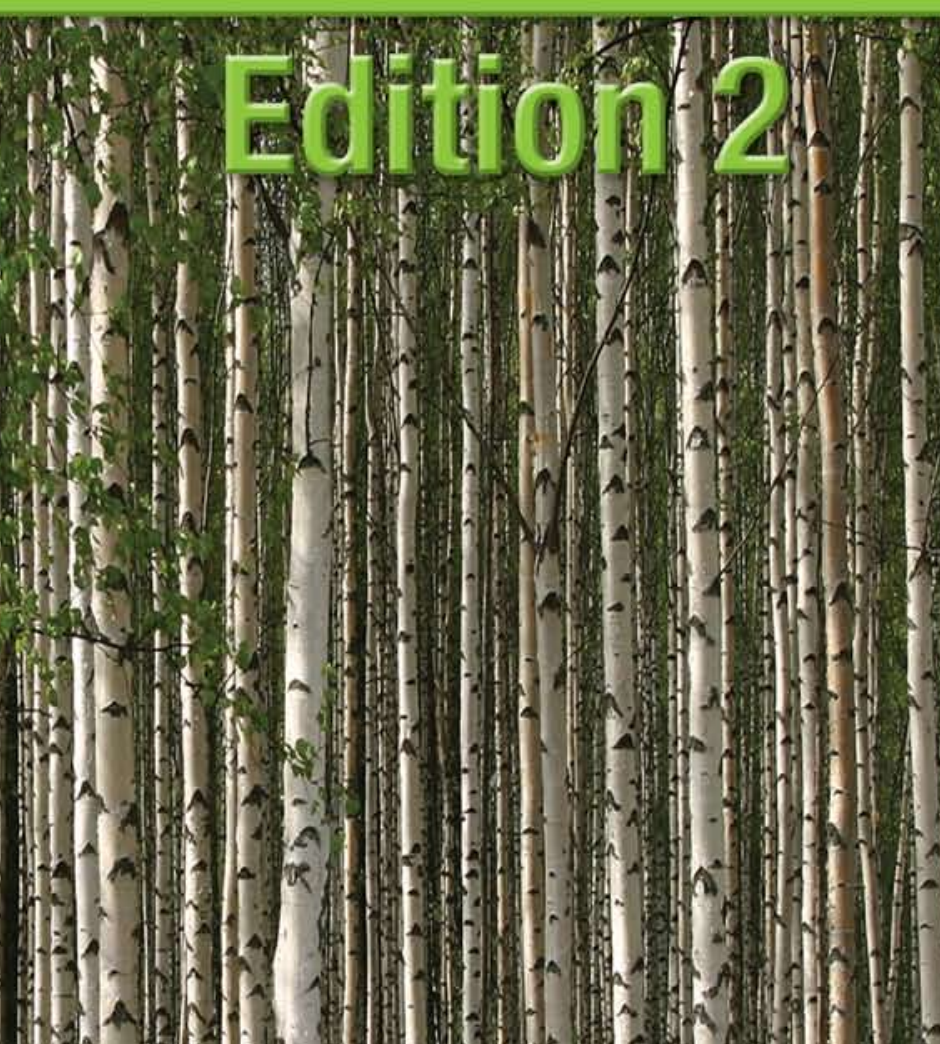

(5)

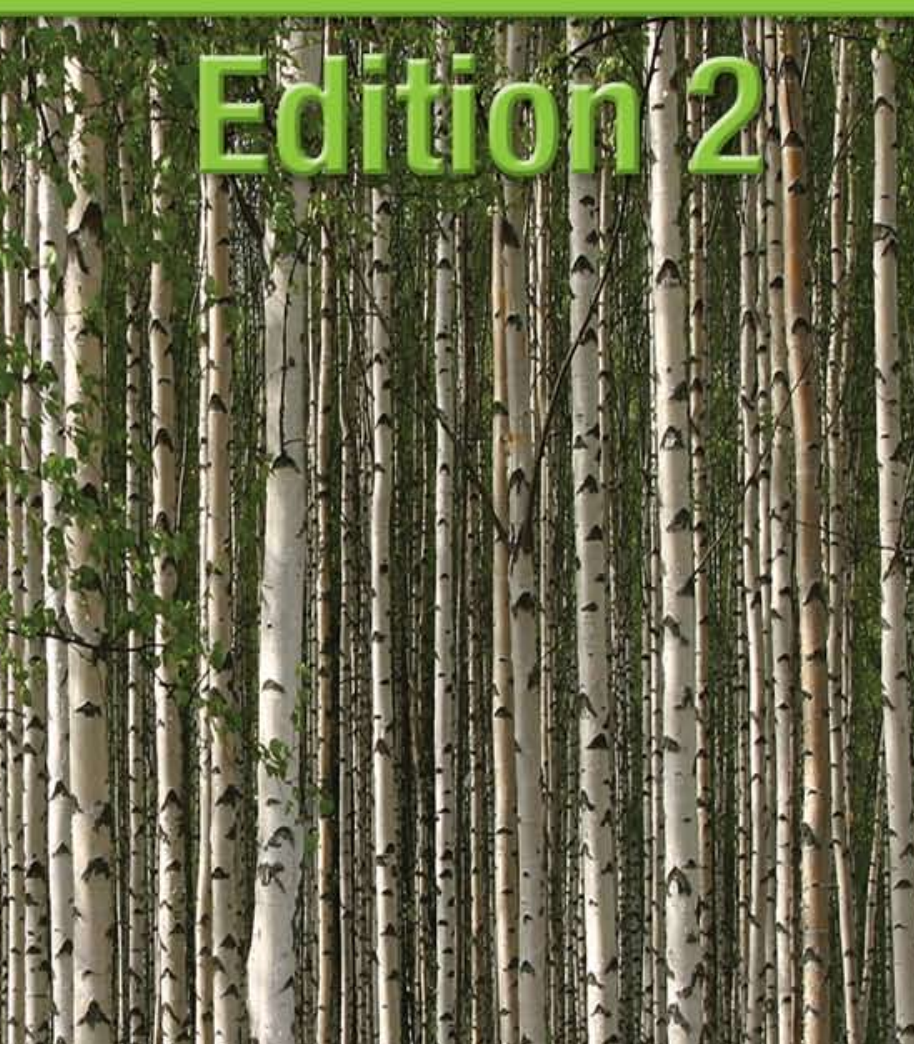

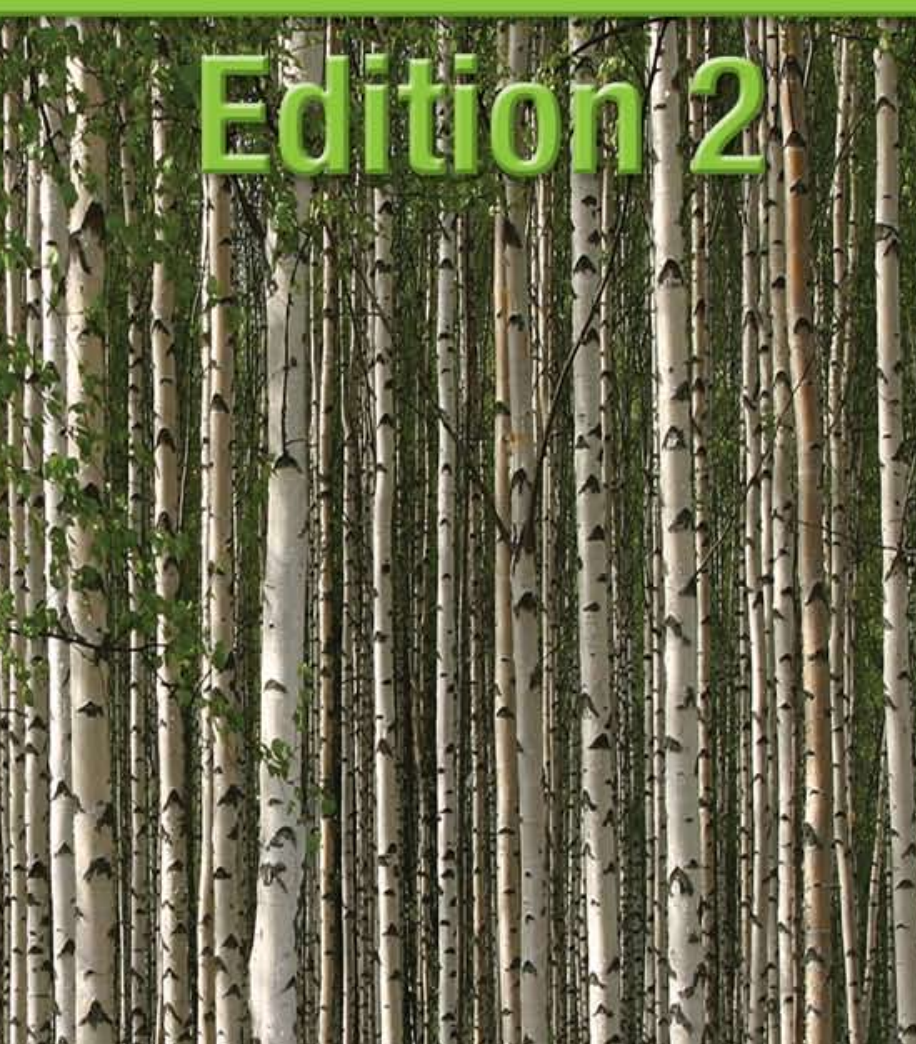

1. 1 . 19 4 인

Het

10

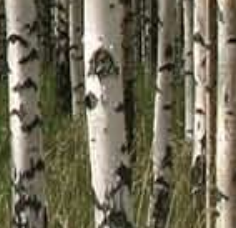

I.

if. i.

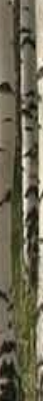




\section{GOVERNMENT LINKS}

\author{
U.S. DEPARTMENT OF AGRICULTURE \\ Agricultural Research Service \\ Forest Service \\ National Agricultural Library \\ National Agricultural Statistics Service \\ U.S. DEPARTMENT OF ENERGY \\ Energy Efficiency and Renewable Energy \\ Biomass Program \\ Alternative Fuels Data Center \\ Clean Cities \\ Fuel Economy \\ Biomass Energy Data Book \\ Buildings Energy Data Book \\ Power Technologies Data Book \\ Transportation Energy Data Book \\ Energy Information Administration \\ OAK RIDGE NATIONAL LABORATORY \\ Center for Transportation Analysis \\ USA.GOV \\ FEDERAL GOVERNMENT - FEDSTATS \\ U.S. BUREAU OF LABOR STATISTICS \\ U.S. CENSUS BUREAU \\ U.S. DEPARTMENT OF COMMERCE \\ Bureau of Economic Analysis \\ U.S. ENVIRONMENTAL PROTECTION AGENCY
}

\author{
www.usda.gov \\ www.ars.usda.gov \\ www.fs.fed.us \\ www.nal.usda.gov \\ www.nass.usda.gov \\ www.energy.gov \\ www.eere.energy.gov \\ www.eere.energy.gov/biomass \\ www.eere.energy.gov/afdc \\ www.eere.energy.gov/cleancities \\ www.fueleconomy.gov \\ cta.ornl.gov/bedb \\ www.btscoredatabook.net \\ www.nrel.gov/analysis/power_databook \\ cta.ornl.gov/data \\ www.eia.doe.gov \\ www.ornl.gov \\ cta.ornl.gov \\ www.usa.gov \\ www.fedstats.gov \\ www.bls.gov \\ www.census.gov \\ www.commerce.gov \\ www.bea.gov \\ www.epa.gov
}

\section{NON GOVERNMENT LINKS}

American Corn Growers Association

American Soybean Association

National Biodiesel Board

National Oilseed Processors Association

National Ethanol Vehicle Coalition

Pellet Fuels Institute

Renewable Fuels Association

www.acga.org

www.soygrowers.com

www.biodiesel.org

www.nopa.org

www.e85fuel.com

pelletheat.org

www.ethanolrfa.org 


\title{
BIOMASS ENERGY DATA BOOK: EDITION 2
}

\author{
Lynn Wright \\ Consultant \\ Oak Ridge, Tennessee \\ Bob Boundy \\ Roltek \\ Clinton, Tennessee \\ Philip C. Badger \\ General Bioenergy, Inc. \\ Florence, Alabama \\ Bob Perlack \\ Stacy Davis \\ Oak Ridge National Laboratory \\ Oak Ridge, Tennessee \\ Draft - January 2009 \\ Prepared for the \\ Office of the Biomass Program \\ Energy Efficiency and Renewable Energy \\ U.S. Department of Energy \\ Prepared by the \\ Oak Ridge National Laboratory \\ Oak Ridge, Tennessee 37831-6073 \\ managed by \\ UT-BATTELLE, LLC \\ for the \\ U.S. DEPARTMENT OF ENERGY \\ under Contract No. DE-AC05-00OR22725
}




\section{DOCUMENT AVAILABILITY}

Reports produced after January 1, 1996, are generally available free via the U.S. Department of Energy (DOE) Information Bridge:

Web site: http://www.osti.gov/bridge

Reports produced before January 1, 1996, may be purchased by members of the public from the following source:

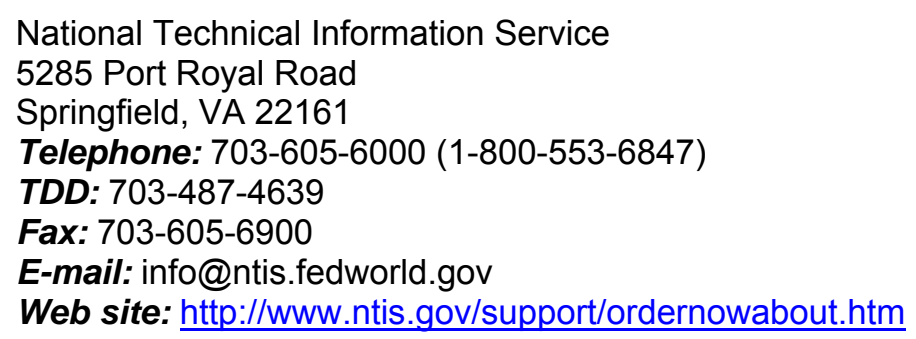

Reports are available to DOE employees, DOE contractors, Energy Technology Data Exchange (ETDE) representatives, and International Nuclear Information System (INIS) representatives from the following source:

Office of Scientific and Technical Information

P.O. Box 62

Oak Ridge, TN 37831

Telephone: 865-576-8401

Fax: 865-576-5728

E-mail: reports@adonis.osti.gov

Web site: http://www.osti.gov/contact.html

This report was prepared as an account of work sponsored by an agency of the United States Government. Neither the United States government nor any agency thereof, nor any of their employees, makes any warranty, express or implied, or assumes any legal liability or responsibility for the accuracy, completeness, or usefulness of any information, apparatus, product, or process disclosed, or represents that its use would not infringe privately owned rights. Reference herein to any specific commercial product, process, or service by trade name, trademark, manufacturer, or otherwise, does not necessarily constitute or imply its endorsement, recommendation, or favoring by the United States Government or any agency thereof. The views and opinions of authors expressed herein do not necessarily state or reflect those of the United States Government or any agency thereof. 
Users of the Biomass Energy Data Book are encouraged to comment on errors, omissions, emphases, and organization of this report to one of the persons listed below. Information on an existing table should be referred to Ms. Stacy Davis, Oak Ridge National Laboratory.

\section{Stacy C. Davis}

Oak Ridge National Laboratory

National Transportation Research Center

2360 Cherahala Boulevard

Knoxville, Tennessee 37932

Telephone: (865) 946-1256

FAX: (865) 946-1314

E-mail: DAVISSC@ornl.gov

Web Site Location: cta.ornl.gov

\section{Zia Haq}

Office of the Biomass Program

Department of Energy, EE-2E

Forrestal Building

1000 Independence Avenue, S.W.

Washington, DC 20585

Telephone: (202) 586-2869

FAX: (202) 586-1640

E-mail: Zia.Haq@ee.doe.gov

Web Site Location:

http://www.eere.energy.gov/

The Biomass Energy Data Book

can be found on the Web at: cta.ornl.gov/bedb 



\section{TABLE OF CONTENTS}

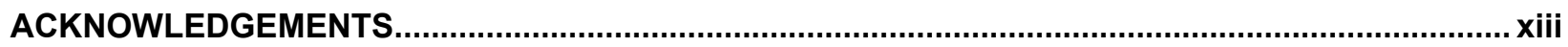

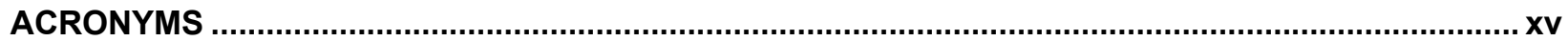

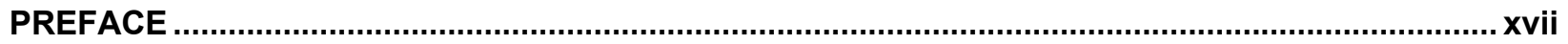

ABSTRACT

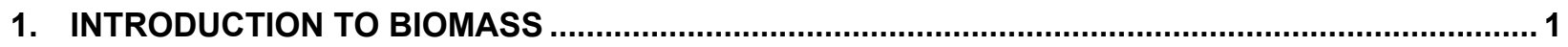

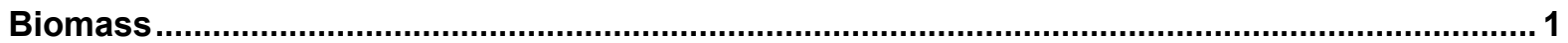

Table 1.1 Energy Production by Source, 1973-2007 ........................................................ 2

Table 1.2 Energy Consumption by Source, 1973-2007 ...................................................... 3

Table 1.3 Renewable Energy Consumption by Source, 1973-2007 …....................................... 4

Table 1.4 Renewable Energy Consumption for Industrial and Transportation Sectors,

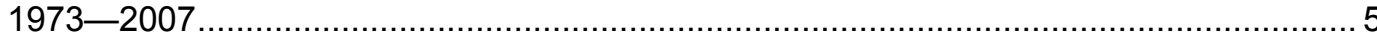

Table 1.5 Renewable Energy Consumption for Residential and Commercial Sectors,

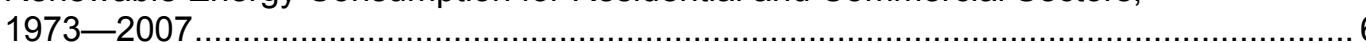

Table 1.6 Industrial Biomass Energy Consumption and Electricity Net Generation by Industry

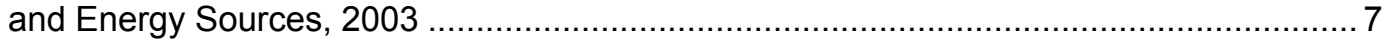

Figure 1.1 Summary of Biomass Energy Consumption, 2007 ................................................ 8

Table 1.7 Scenario Estimate of Collectable Biomass from Agricultural Activity ............................ 9

Table 1.8 Scenario Estimate of Collectable Biomass Assuming Yield Changes........................... 11

Table 1.9 Scenario Estimate of Collectable Biomass Assuming Moderate Yield and Land Use Changes

Table 1.10 Scenario Estimate of Collectable Biomass Assuming High Yields and Major Land Use Changes

Figure 1.2 Major Uses of Land in the United States, 2002 ............................................... 17

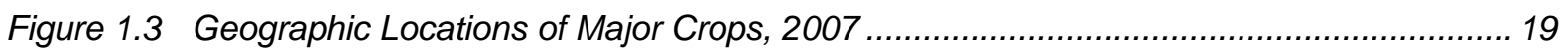

Figure 1.4 Summary of Potentially Available Forest Resources............................................ 21

Future Energy Crop Supply Potential—Cellulosic Biomass .................................................... 22

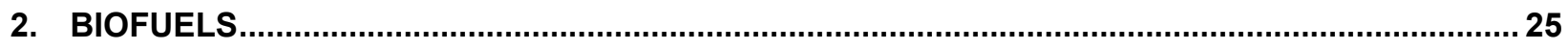

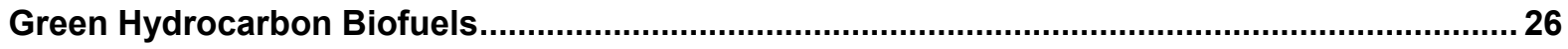

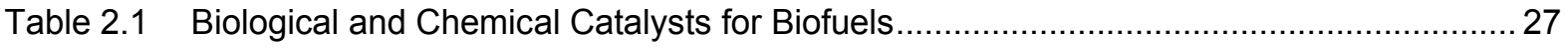




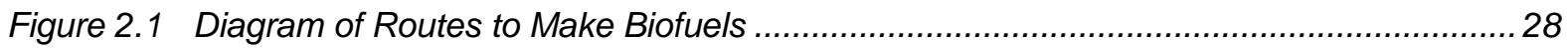

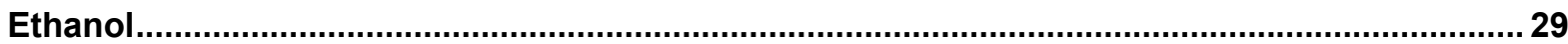

Table 2.2 Specifications Contained in ASTM D 4806 Standard Specification for Denatured Fuel Ethanol for Blending with Gasoline ........................................................................ 30

Table 2.3 Fuel Property Comparison for Ethanol, Gasoline and No. 2 Diesel ............................... 31

\section{Ethanol Production}

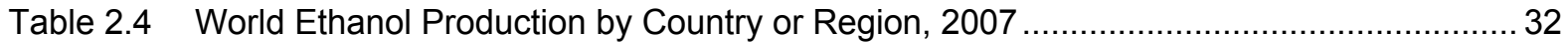

Table 2.5 U.S. Fuel Ethanol Imports by Country, 2002-2007 ….................................................. 33

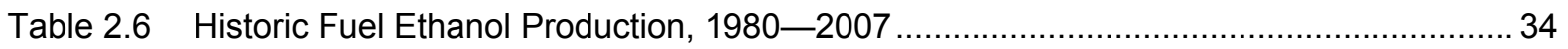

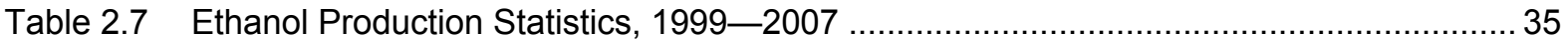

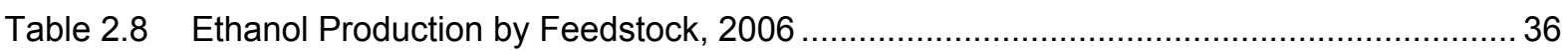

Table 2.9 Ethanol Production by Plant Energy Source, 2006 .................................................... 37

Figure 2.2 Ethanol Production Facilities Current and Under Construction, January 24, 2008 .......... 38

Figure 2.3 The Ethanol Production Process - Wet Milling ...................................................... 39

Figure 2.4 The Ethanol Production Process - Dry Milling ................................................ 40

Figure 2.5 The Production of Ethanol from Cellulosic Biomass .................................................. 41

\section{Ethanol Consumption}

Table 2.10 Ethanol Consumption in E85 and Gasohol, 1995-2006

\section{Economics}

Table 2.11 Gasoline and Ethanol: Comparison of Current and Potential Production Costs in North America

Table 2.12 Undenatured Ethanol Cash Operating Expenses and Net Feedstock Costs for Dry-milling Process by Plant Size, 2002.

Table 2.13 Economic Contribution of the Ethanol Industry, 2006............................................. 46

Figure 2.6 Ethanol Net Energy Balances and Greenhouse Gas Emissions............................... 47

Figure 2.7 Comparisons of Energy Inputs and GHG Emissions for Three Ethanol Scenarios and Gasoline

Figure 2.8 Comparative Results between Ethanol and Gasoline Based on an Evaluation by the GREET Model.

Table 2.14 Comparison of Ethanol Energy Balance With and Without Inclusion of Coproduct Energy Credits 
Biodiesel.

\section{Biodiesel Production}

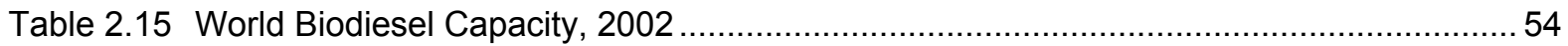

Figure 2.9 Active Commercial Biodiesel Production Facilities, January 25, 2008........................ 55

Figure 2.10 Commercial Biodiesel Production Facilities Under Construction or Expansion,

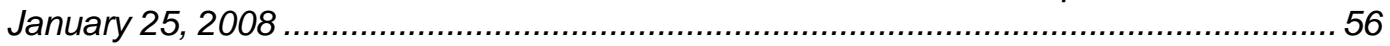

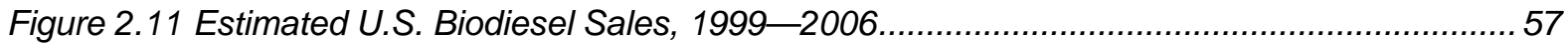

Table 2.16 Composition of Various Oils and Fats Used for Biodiesel ............................................. 58

Figure 2.12 Typical Proportions of Chemicals Used to Make Biodiesel .......................................... 59

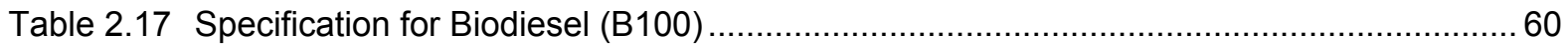

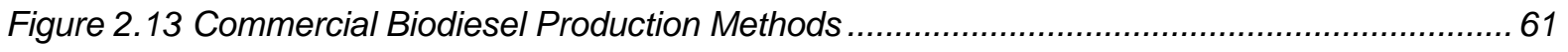

\section{Biodiesel Consumption}

Table 2.18 Average Biodiesel (B100 and B20) Emissions Compared to Conventional Diesel...... 62

\section{Economics}

Table 2.19 Estimated Impacts from Increased Use of Biodiesel ......

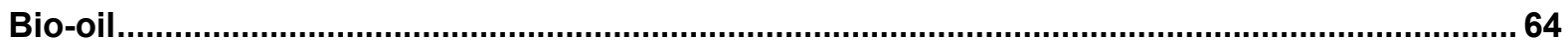

Table 2.20 Output Products by Method of Pyrolysis ............................................................. 64

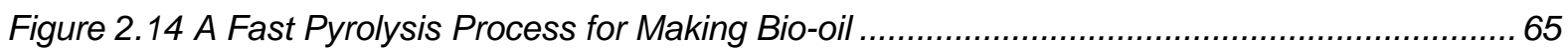

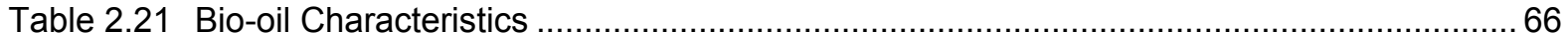

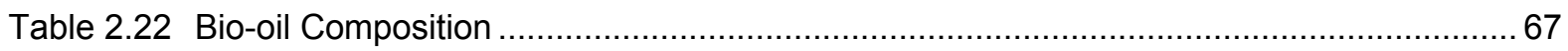

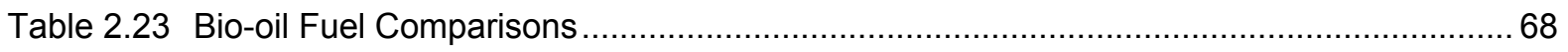

\section{Taxes and Incentives}

Table 2.24 Annotated Summary of Biofuel and Biomass Electric Incentives as of September 2008: Online Information Resources

Table 2.25 Federal and State Alternative Fuel Incentives, 2007 …............................................ 70

3. BIOPOWER

Table 3.1 Biomass Power Technology in Commercial/Demonstration Phase

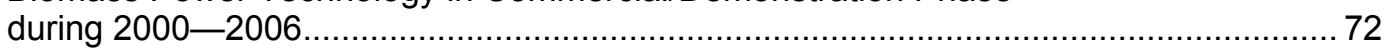

Table 3.2 Alkali Content and Slagging Potential of Various Biofuels........................................... 73 


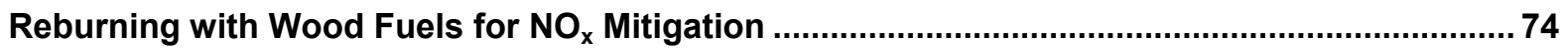

Table 3.3 Typical Uncontrolled Emission Factors or Steam Generator Fuels................................ 75

Table 3.4 Range in Elemental Composition of Industrial Wood Ash Samples and

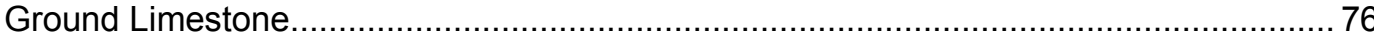

Table 3.5 Biomass Power Technology Fuel Specifications and Capacity Range ..........................77

Table 3.6 New Renewable Capacity Supplying Green Power Markets, 2004 ….......................... 78

Table 3.7 New Renewable Capacity Supported through Utility Green Pricing Programs, 2004 ...... 79

Table 3.8 Utility Green Pricing Programs Using Biomass and Biomass Based Resources............. 80

Table 3.9 Competitive Electricity Markets Retail Green Power Product Offerings,

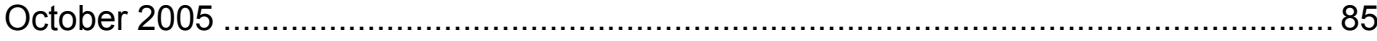

Table 3.10 Renewable Energy Certificate Product Offerings, October 2005 ................................ 87

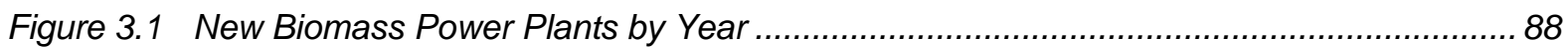

Figure 3.2 Biomass Power Plant Capacity by Year ............................................................. 88

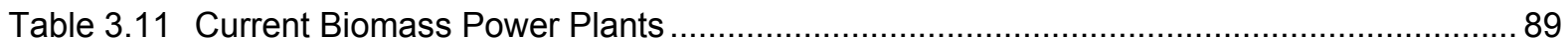

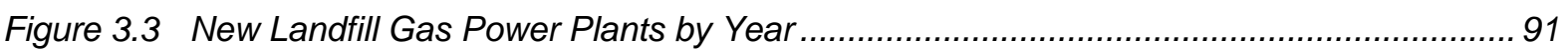

Figure 3.4 Landfill Gas Power Plant Capacity by Year .......................................................... 91

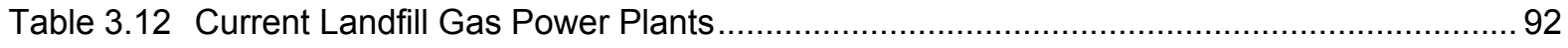

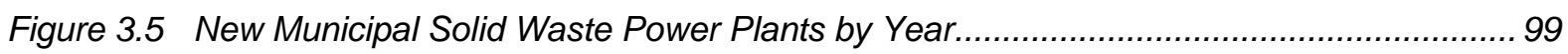

Figure 3.6 Municipal Solid Waste Power Plant Capacity by Year............................................... 99

Table 3.13 Current Municipal Solid Waste Power Plants ......................................................... 100

Table 3.14 Total Net Generation of Electricity by State from Wood and Wood Waste, 2005 ......... 102

Table 3.15 Net Generation and Fuel Consumption at Power Plants Consuming Coal and Biomass by State and Plant Name, 2003

\section{Fossil Fuel Displacement by Biopower}

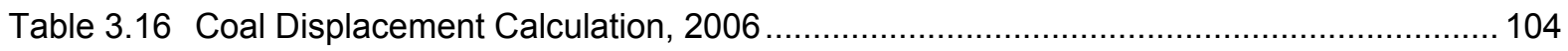

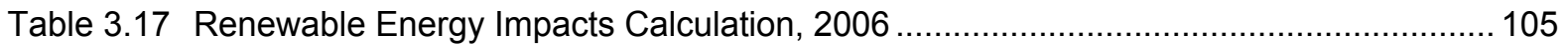

Table 3.18 Number of Home Electricity Needs Met Calculation, 2006 ....................................... 106

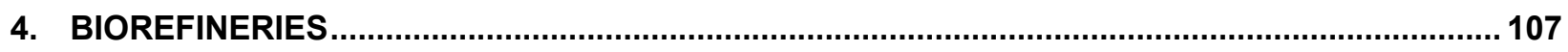

Table 4.1 Lignocellulosic Biorefineries by Scale and State of Development.............................. 108

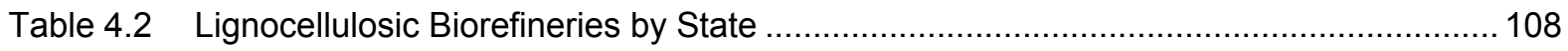


Figure 4.1 Major DOE Biorefinery Project Locations ........................................................... 109

Table 4.3 Fuels, Technologies and Feedstocks in Planned Biorefineries as of 2008 .................. 110

Table 4.4 Federal and State Investments in Lignocellulosic Biorefineries as of 2008................. 111

Table 4.5 State and Private Investment in Biorefineries for Biofuels and Bioproducts ................. 112

Table 4.6 Recently Completed U.S. Department of Energy Biorefinery Projects.......................... 113

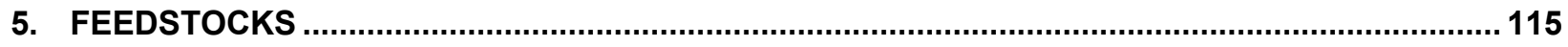

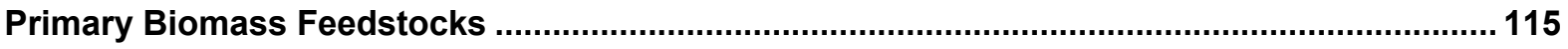

Grains

Table 5.1 Barley: Area, Yield, Production, and Value, 1996-2007 …..................................... 116

Table 5.2 Barley: Area, Yield, and Production, by State, 2005-2007 …................................... 117

Table 5.3 Barley Production Costs and Returns per Planted Acre by Region, Excluding Government Payments, 2006-2007 ........................................................................ 118

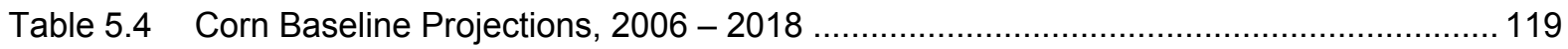

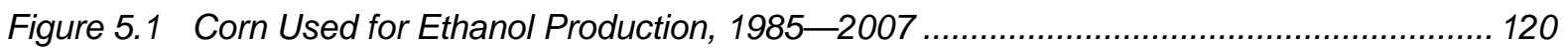

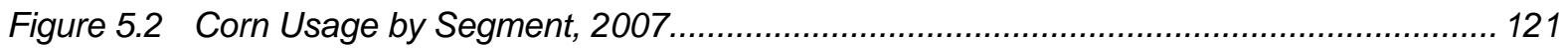

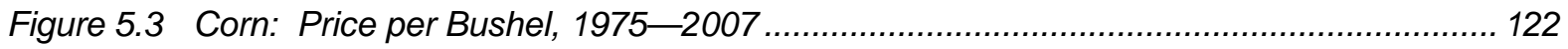

Table 5.5 Corn: Area, Yield, Production, and Value, 1996-2007 ......................................... 123

Table 5.6 Corn: Area, Yield, and Production, by State, 2005-2007 ….................................... 124

Figure 5.4 Corn for Grain, Harvested Acres, 2002.......................................................... 125

Figure 5.5 Corn Acres, Planted and Harvested, 1975-2007............................................ 126

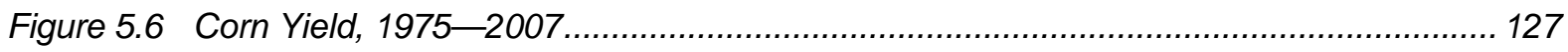

Table 5.7 Corn: Supply and Disappearance, 1996-2007 .................................................. 129

Table 5.8 Corn for Grain: Marketing Year Average Price and Value, by State, Crop of 2005, 2006, and 2007

Table 5.9 Corn Production Costs and Returns per Planted Acre by Region, Excluding Government Payments, 2006-2007.

Table 5.10 Oats: Area, Yield, Production, and Value, 1996-2007 ........................................... 132

Table 5.11 Oats: Area, Yield, and Production, by State, 2005-2007 .......................................... 133

Table 5.12 Oats Production Costs and Returns per Planted Acre by Region, Excluding Government Payments, 2006-2007 
Table 5.13 Rice: Area, Yield, Production and Value, 1996-2007 ............................................ 135

Table 5.14 Rice: Area, Yield, and Production by State, 2005-2007 ........................................ 136

Table 5.15 Rice Production Costs and Returns per Planted Acre by Region, Excluding Government Payments, 2006-2007

Figure 5.7 Sorghum for Grain, Harvested Acres, 2002 ......................................................... 138

Figure 5.8 Sorghum: Price per Bushel, 1975-2007 ....................................................... 139

Table 5.16 Sorghum: Area, Yield, Production, and Value, 1996-2007 .................................... 140

Table 5.17 Sorghum: Area, Yield, and Production, by State, 2005-2007 …............................ 141

Table 5.18 Sorghum Production Costs and Returns per Planted Acre by Region, Excluding Government Payments, 2006-2007....................................................................... 142

Table 5.19 Wheat Baseline Projections, 2006-2018 ............................................................... 143

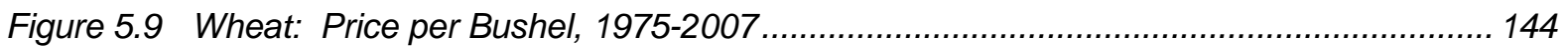

Table 5.20 Wheat: Area, Yield, Production, and Value, 1996-2007 …..................................... 145

Table 5.21 Wheat: Area, Yield, and Production, by State, 2005-2007 …................................ 146

Table 5.22 Wheat: Supply and Disappearance, 1996-2007 ............................................... 147

Table 5.23 Wheat: Marketing Year Average Price and Value, by State, Crop of 2005, 2006, and 2007

Table 5.24 Wheat Production Costs and Returns per Planted Acre by Region, Excluding Government Payments, 2006-2007.

\section{Oilseeds}

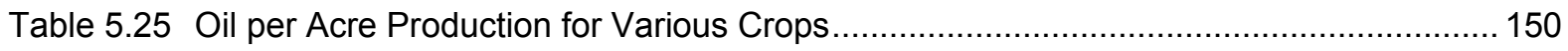

Table 5.26 Cotton: Area, Yield, Production, and Value, 1996-2007 ......................................... 151

Table 5.27 Cotton: Area, Yield, and Production by State, 2005-2007 ...................................... 152

Table 5.28 Cotton Production Costs and Returns per Planted Acre by Region, Excluding Government Payments, 2006-2007

Table 5.29 Soybeans and Products Baseline Projections, 2006--2018 …................................. 154

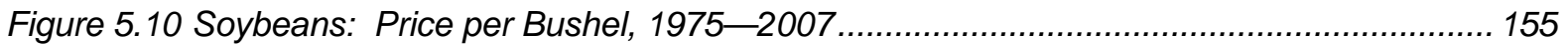

Table 5.30 Soybeans: Area, Yield, Production, and Value, 1996-2007 ................................... 156

Table 5.31 Soybeans: Area, Yield, and Production, by State, 2005-2007 ................................ 157

Table 5.32 Soybeans: Supply and Disappearance, 1995-2006 ........................................... 158 
Table 5.33 Soybeans for Beans: Marketing Year Average Price and Value, by State, Crop of 2006, 2006, and 2007

Figure 5.11 Soybeans for Beans, Harvested Acres in the United States, 2002 160

Table 5.34 Soybean Production Costs and Returns per Planted Acre by Region, Excluding Government Payments, 2006-2007

\section{Perennial Energy Crops}

Figure 5.12 Projected Total Switchgrass, 2017 162

Figure 5.13 Location of Areas Where Switchgrass is Likely to be Grown on Cropland...... 163

Figure 5.14 Location of Areas Where Woody Crops are Likely to be Grown on Cropland 164

\section{Primary Forest Resources}

Figure 5.15 Total Availability of Logging Residue from Timberlands, 2007. 165

Figure 5.16 Total Availability of Fuel Treatment Thinnings from Timberlands, 2007. 166

Figure 5.17 Total Availability of Other Removal Residue from Timberlands, 2007. 167

Table 5.35 Estimated Availability of Primary Forest Residues, 2007 168

\section{Agricultural Residues}

Figure 5.18 Total Availability of Corn Stover Residue, 2007 169

Figure 5.19 Total Availability of Wheat Straw Residue, 2007. 170

Table 5.36 Estimated Availability of Corn Stover, Wheat Straw, and other Crop Residues 171

Secondary Biomass Feedstocks 172

Table 5.37 U.S. Forest Service - Woody Biomass Utilization Grantees 2007 \& 2008. 173

\section{Manure}

Figure 5.20 Feedlot Capacity and Distribution, 2004

\section{Mill Wastes}

Table 5.38 Primary Mill Residue Production and Use by State, 2007

Figure 5.21 Unused Mill Residues in the U.S. by County

\section{Pellet Fuels}

Table 5.39 Pellet Fuel Shipments from Pellet Fuel Manufacturers........................................... 178

Table 5.40 Pellet and Cordwood Appliance Shipments from Manufacturers, 1998-2007 ............ 179

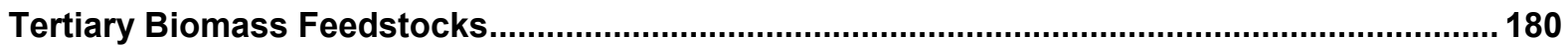




\section{Urban Residues}

Figure 5.22 Total Construction and Demolition Debris Wood Residues, 2007............................... 181

Table 5.41 Construction and Demolition Wood Debris by State, 2007....................................... 182

Figure 5.23 Total Municipal Solid Waste Wood Residues, 2007............................................. 183

Table 5.42 Municipal Solid Waste Landfill Wood Residue by State, 2007 ..................................... 184

Landfill Gas

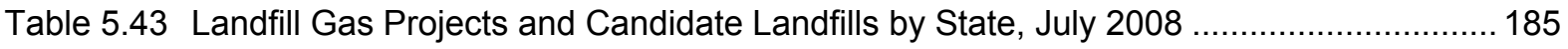

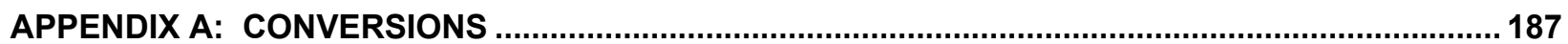

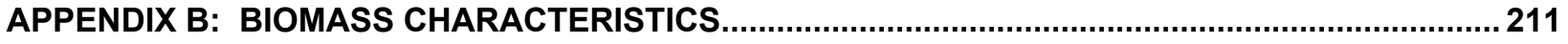

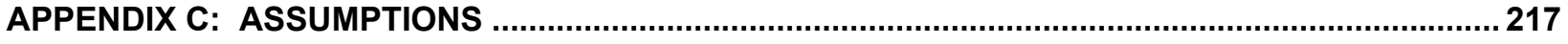

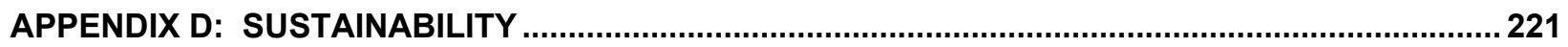

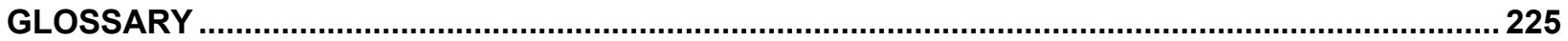




\section{ACKNOWLEDGEMENTS}

The authors would like to express their gratitude to the many individuals who assisted in the preparation of this document. First, we would like to thank the U.S. Department of Energy's Energy Efficiency and Renewable Energy (EERE) staff in the Office of the Biomass Program for their support of this second edition of the Biomass Energy Data Book. Our team of thorough reviewers include:

We would also like to thank Jamie Payne of Oak Ridge National Laboratory (ORNL), who designed the cover. Finally, this book would not have been possible without the dedication of Debbie Bain (ORNL), who masterfully prepared the manuscript. 


\section{ACRONYMS}

$\begin{array}{ll}\text { AEO } & \text { Annual Energy Outlook } \\ \text { ARS } & \text { Agricultural Research Service, USDA } \\ \text { ASABE } & \text { American Society of Agricultural and Biological Engineers } \\ \text { ASTM } & \text { American Society for Testing and Materials } \\ \text { Btu } & \text { British thermal units } \\ \text { CES } & \text { Cooperative Extension Service } \\ \text { CO2 } & \text { Carbon dioxide } \\ \text { CRP } & \text { Conservation Reserve Program } \\ \text { d.b.h. } & \text { Diameter at breast height } \\ \text { DOE } & \text { Department of Energy } \\ \text { EERE } & \text { Office of Energy Efficiency and Renewable Energy } \\ \text { EIA } & \text { Energy Information Administration } \\ \text { EPA } & \text { Environmental Protection Agency } \\ \text { EPAct } & \text { Energy Policy Act } \\ \text { ERS } & \text { Economic Research Service } \\ \text { Etoh } & \text { Ethanol } \\ \text { FTE } & \text { Fuel Treatment Evaluator } \\ \text { FY } & \text { Fiscal Year } \\ \text { GAO } & \text { United States Government Accountability Office } \\ \text { GHG } & \text { Greenhouse Gas } \\ \text { GPRA } & \text { Government Performance Results Act } \\ \text { GW } & \text { Gigawatt } \\ \text { IEA } & \text { International Energy Agency } \\ \text { LFG } & \text { Landfill Gas } \\ \text { MJ } & \text { Megajoule } \\ \text { MMBtu } & \text { Million British thermal units } \\ \text { MW } & \text { Megawatt } \\ \text { MSW } & \text { Municipal Solid Waste } \\ \text { NASS } & \text { National Agricultural Statistics Service } \\ \text { NEMS } & \text { National Energy Modeling System } \\ \text { NOAA } & \text { National Oceanic \& Atmospheric Administration } \\ \text { NREL } & \text { National Renewable Energy Laboratory } \\ \text { NRCS } & \text { National Resources Conservation Service } \\ \text { ORNL } & \text { Oak Ridge National Laboratory } \\ \text { PNNL } & \text { Pacific Northwest National Laboratory } \\ \text { PPA } & \text { Power Purchase Agreement } \\ \text { RPS } & \text { Renewable Portfolio Standard } \\ \text { SEO } & \text { State Energy Office } \\ \text { SRIC } & \text { Short Rotation Intensive Culture } \\ \text { SSEB } & \text { Southern States Energy Board } \\ \text { TBD } & \text { To Be Determined } \\ \text { TVA } & \text { Tennessee Valley Authority } \\ \text { USDA } & \text { United States Department of Agriculture } \\ \text { USFS } & \text { United States Forest Service } \\ & \end{array}$




\section{PREFACE}

The Department of Energy, through the Biomass Program in the Office of Energy Efficiency and Renewable Energy, has contracted with Oak Ridge National Laboratory to prepare this Biomass Energy Data Book. The purpose of this data book is to draw together, under one cover, biomass data from diverse sources to produce a comprehensive document that supports anyone with an interest or stake in the biomass industry. Given the increasing demand for energy, policymakers and analysts need to be well-informed about current biomass energy production activity and the potential contribution biomass resources and technologies can make toward meeting the nation's energy demands. This is the second edition of the Biomass Energy Data Book and it is only available online in electronic format. Because there are many diverse online sources of biomass information, the Data Book provides links to many of those valuable information sources. Biomass energy technologies used in the United States include an extremely diverse array of technologies - from wood or pellet stoves used in homes to large, sophisticated biorefineries producing multiple products. For some types of biomass energy production, there are no annual inventories or surveys on which to base statistical data. For some technology areas there are industry advocacy groups that track and publish annual statistics on energy production capacity, though not necessarily actual production or utilization. The Department of Energy's Energy Information Administration (EIA) produces annual estimates of biomass energy utilization and those estimates are included in this data book. Information from industry groups are also provided to give additional detail. An effort has been made to identify the best sources of information on capacity, production and utilization of most of the types of biomass energy currently being produced in this country. It is certain, however, that not all biomass energy contributions have been identified. With the rapid expansion in biomass technologies that is occurring, bioenergy production information may not yet be available, or may be proprietary.

It is even more difficult to track the diverse array of biomass resources being used as feedstocks for biomass energy production. Since most of the biomass resources currently being used for energy or bioproducts are residuals from industrial, agricultural or forestry activities, there is no way to systematically inventory biomass feedstock collection and use and report it in standard units. All biomass resource availability and utilization information available in the literature are estimates, not inventories of actual collection and utilization. Biomass utilization information is derived from biomass energy production data, but relies on assumptions about energy content and conversion efficiencies for each biomass type and conversion technology. Biomass availability data relies on understanding how much of a given biomass type (e.g., corn grain) is produced, alternate demands for that biomass type, economic profitability associated with each of those alternate demands, environmental impacts of collection of the biomass, and other factors such as incentives. This book presents some of the information needed for deriving those estimates, as well as providing biomass resource estimates that have been estimated by either ORNL staff or other scientists. For estimates derived from ORNL analysis, the methodology has been documented in Appendix $\mathrm{C}$ and additional references have been provided. In all cases it should be recognized that estimates are not precise and different assumptions will change the results. 


\begin{abstract}
The Biomass Energy Data Book is a statistical compendium prepared and published by Oak Ridge National Laboratory (ORNL) under contract with the Office of the Biomass Program in the Energy Efficiency and Renewable Energy (EERE) program of the Department of Energy (DOE). Designed for use as a convenient reference, the book represents an assembly and display of statistics and information that characterize the biomass industry, from the production of biomass feedstocks to their end use, including discussions on sustainability.

This is the second edition of the Biomass Energy Data Book which is only available online in electronic format. There are five main sections to this book. The first section is an introduction which provides an overview of biomass resources and consumption. Following the introduction to biomass is a section on biofuels which covers ethanol, biodiesel and Bio-oil. The biopower section focuses on the use of biomass for electrical power generation and heating. The fourth section is on the developing area of biorefineries, and the fifth section covers feedstocks that are produced and used in the biomass industry. The sources used represent the latest available data. There are also four appendices which include frequently needed conversion factors, a table of selected biomass feedstock characteristics, assumptions for selected tables and figures, and discussions on sustainability. A glossary of terms and a list of acronyms are also included for the reader's convenience.
\end{abstract}




\section{INTRODUCTION TO BIOMASS}

\section{BIOMASS OVERVIEW}

Biomass is defined as any organic matter that is available on a renewable or recurring basis. It includes all plants and plant derived materials, including agricultural crops and trees, wood and wood residues, grasses, aquatic plants, animal manure, municipal residues, and other residue materials. Plants (on land or in water) use the light energy from the sun to convert water and carbon dioxide to carbohydrates, fats, and proteins along with small amounts minerals. The carbohydrate component includes cellulose and hemi-cellulose fibers which gives strength to plant structures and lignin which binds the fibers together. Some plants store starches and fats (oils) in seeds or roots and simple sugars can be found in plant tissues.

In 2007, biomass production contributed 3.6 quadrillion Btu of energy to the 71.7 quadrillion Btu of energy produced in the United States or about $5 \%$ of total energy production. Since a substantial portion of U.S. energy is imported, the more commonly quoted figure is that biomass consumption amounted to 3.6 quadrillion Btu of energy of the 101.6 quadrillion Btu of energy consumed in the United States in 2007 or about $3.5 \%$. At present, wood resources contribute most to the biomass resources consumed in the United States and most of that is used in the generation of electricity and industrial process heat and steam. However, the contribution of biofuels has doubled since 2005 and now amounts to close to one third of all biomass consumed. While most biofuels feedstocks are currently starches, oils and fats derived from the agricultural sector, whole plants and plant residues will soon be an important feedstock for cellulosic biofuels. Algae are being developed as a source of both oil and cellulosic feedstocks. The industrial sector (primarily the wood products industry) used about 1.4 quadrillion Btu in 2007. The residential and commercial sectors consume 0.06 quadrillion Btu of biomass; however, this figure may understate consumption in these sectors due to unreported consumption, such as home heating by wood collected on private property. The use of biomass fuels such as ethanol and biodiesel by the transportation sector is now at about 0.6 quadrillion Btu. This is less than the total number of biofuels produced because some liquid biofuels are used by other sources.

The Renewable Fuels Association characterized 2007 as a year that ushered in a new energy era for America. The enactment of the Energy Independence and Security Act of 2007 (H.R. 6) coupled increased vehicle efficiency with greater renewable fuel use. The law increased the Renewable Fuel Standard (RFS) to 36 billion gallons of annual renewable fuel use by 2022 and required that 60 percent of the new RFS be met by advanced biofuels, including cellulosic ethanol.

To stimulate progress in this direction, the Department of Energy's (DOE) Biomass Program awarded cost-sharing contracts in 2007 to six companies to develop commercial scale integrated biorefineries using cellulosic biomass. One of the commercial scale projects, Range Fuels, broke ground for construction of the first cellulosic ethanol biorefinery near Soperton, Georgia during 2007. An existing corn to ethanol company, Poet, LLC began construction of a cellulosic to ethanol unit at an existing facility in Scotland, S.D. during 2007. To facilitate innovation in cellulosic biomass conversion technologies, DOE awarded 9 cost-sharing contracts for the development of small-scale cellulosic biorefineries. Recipients ranged from existing pulp and paper companies and existing ethanol companies to new companies working in collaboration with universities and private sector supporters. Many new types of technologies are being developed by the small-scale biorefinery efforts (see Biorefinery Section).

With the passage of the 2008 Farm Bill in May of 2008, USDA extended or instituted several programs that provide incentives for the development of advanced biofuels using cellulosic biomass. 
In 2007 biomass accounted for just over half of the renewable energy production in the United States.

Table 1.1

Energy Production by Source, 1973-2007

(Quadrillion Btu)

\begin{tabular}{|c|c|c|c|c|c|c|c|c|c|c|c|c|c|}
\hline \multirow[b]{2}{*}{ Year } & \multicolumn{5}{|c|}{ Fossil Fuels } & \multirow[b]{2}{*}{$\begin{array}{c}\text { Nuclear } \\
\text { Electric } \\
\text { Power }\end{array}$} & \multicolumn{6}{|c|}{ Renewable Energy $^{a}$} & \multirow[b]{2}{*}{ Total } \\
\hline & Coal & $\begin{array}{c}\text { Natural } \\
\text { Gas (Dry) }\end{array}$ & $\begin{array}{c}\text { Crude } \\
\mathrm{Oil}^{\mathrm{b}}\end{array}$ & $\begin{array}{c}\text { Natural } \\
\text { Gas } \\
\text { Plant } \\
\text { Liquids }\end{array}$ & Total & & $\begin{array}{l}\text { Hydro- } \\
\text { electric } \\
\text { Power }\end{array}$ & Biomass $^{d}$ & $\begin{array}{c}\text { Geo- } \\
\text { thermal }\end{array}$ & Solar & Wind & Total & \\
\hline 1973 & 13.99 & 22.19 & 19.49 & 2.57 & 58.24 & 0.91 & 2.86 & 1.53 & 0.04 & NA & NA & 4.43 & 63.58 \\
\hline 1974 & 14.07 & 21.21 & 18.57 & 2.47 & 56.33 & 1.27 & 3.18 & 1.54 & 0.05 & NA & NA & 4.77 & 62.37 \\
\hline 1975 & 14.99 & 19.64 & 17.73 & 2.37 & 54.73 & 1.90 & 3.15 & 1.50 & 0.07 & NA & NA & 4.72 & 61.36 \\
\hline 1976 & 15.65 & 19.48 & 17.26 & 2.33 & 54.72 & 2.11 & 2.98 & 1.71 & 0.08 & NA & NA & 4.77 & 61.60 \\
\hline 1977 & 15.75 & 19.57 & 17.45 & 2.33 & 55.10 & 2.70 & 2.33 & 1.84 & 0.08 & NA & NA & 4.25 & 62.05 \\
\hline 1978 & 14.91 & 19.49 & 18.43 & 2.25 & 55.07 & 3.02 & 2.94 & 2.04 & 0.06 & NA & NA & 5.04 & 63.14 \\
\hline 1979 & 17.54 & 20.08 & 18.10 & 2.29 & 58.01 & 2.78 & 2.93 & 2.15 & 0.08 & NA & NA & 5.17 & 65.95 \\
\hline 1980 & 18.60 & 19.91 & 18.25 & 2.25 & 59.01 & 2.74 & 2.90 & 2.48 & 0.11 & NA & NA & 5.49 & 67.23 \\
\hline 1981 & 18.38 & 19.70 & 18.15 & 2.31 & 58.53 & 3.01 & 2.76 & 2.60 & 0.12 & NA & NA & 5.48 & 67.01 \\
\hline 1982 & 18.64 & 18.32 & 18.31 & 2.19 & 57.46 & 3.13 & 3.27 & 2.66 & 0.10 & NA & NA & 6.03 & 66.62 \\
\hline 1983 & 17.25 & 16.59 & 18.39 & 2.18 & 54.42 & 3.20 & 3.53 & 2.90 & 0.13 & NA & 0.00 & 6.56 & 64.18 \\
\hline 1984 & 19.72 & 18.01 & 18.85 & 2.27 & 58.85 & 3.55 & 3.39 & 2.97 & 0.16 & 0.00 & 0.00 & 6.52 & 68.92 \\
\hline 1985 & 19.33 & 16.98 & 18.99 & 2.24 & 57.54 & 4.08 & 2.97 & 3.02 & 0.20 & 0.00 & 0.00 & 6.18 & 67.80 \\
\hline 1986 & 19.51 & 16.54 & 18.38 & 2.15 & 56.58 & 4.38 & 3.07 & 2.93 & 0.22 & 0.00 & 0.00 & 6.22 & 67.18 \\
\hline 1987 & 20.14 & 17.14 & 17.67 & 2.22 & 57.17 & 4.75 & 2.63 & 2.87 & 0.23 & 0.00 & 0.00 & 5.74 & 67.66 \\
\hline 1988 & 20.74 & 17.60 & 17.28 & 2.26 & 57.87 & 5.59 & 2.33 & 3.02 & 0.22 & 0.00 & 0.00 & 5.57 & 69.03 \\
\hline 1989 & 21.36 & 17.85 & 16.12 & 2.16 & 57.48 & 5.60 & 2.84 & 3.16 & 0.32 & 0.06 & 0.02 & 6.39 & 69.48 \\
\hline 1990 & 22.49 & 18.33 & 15.57 & 2.17 & 58.56 & 6.10 & 3.05 & 2.74 & 0.34 & 0.06 & 0.03 & 6.21 & 70.87 \\
\hline 1991 & 21.64 & 18.23 & 15.70 & 2.31 & 57.87 & 6.42 & 3.02 & 2.78 & 0.35 & 0.06 & 0.03 & 6.24 & 70.53 \\
\hline 1992 & 21.69 & 18.38 & 15.22 & 2.36 & 57.66 & 6.48 & 2.62 & 2.93 & 0.35 & 0.06 & 0.03 & 5.99 & 70.13 \\
\hline 1993 & 20.34 & 18.58 & 14.49 & 2.41 & 55.82 & 6.41 & 2.89 & 2.91 & 0.36 & 0.07 & 0.03 & 6.26 & 68.50 \\
\hline 1994 & 22.20 & 19.35 & 14.10 & 2.39 & 58.04 & 6.69 & 2.68 & 3.03 & 0.34 & 0.07 & 0.04 & 6.16 & 70.89 \\
\hline 1995 & 22.13 & 19.08 & 13.89 & 2.44 & 57.54 & 7.08 & 3.21 & 3.10 & 0.29 & 0.07 & 0.03 & 6.70 & 71.32 \\
\hline 1996 & 22.79 & 19.34 & 13.72 & 2.53 & 58.39 & 7.09 & 3.59 & 3.16 & 0.32 & 0.07 & 0.03 & 7.17 & 72.64 \\
\hline 1997 & 23.31 & 19.39 & 13.66 & 2.50 & 58.86 & 6.60 & 3.64 & 3.11 & 0.32 & 0.07 & 0.03 & 7.18 & 72.63 \\
\hline 1998 & 24.05 & 19.61 & 13.24 & 2.42 & 59.31 & 7.07 & 3.30 & 2.93 & 0.33 & 0.07 & 0.03 & 6.66 & 73.04 \\
\hline 1999 & 23.30 & 19.34 & 12.45 & 2.53 & 57.61 & 7.61 & 3.27 & 2.97 & 0.33 & 0.07 & 0.05 & 6.68 & 71.91 \\
\hline 2000 & 22.74 & 19.66 & 12.36 & 2.61 & 57.37 & 7.86 & 2.81 & 3.01 & 0.32 & 0.07 & 0.06 & 6.26 & 71.49 \\
\hline 2001 & 23.55 & 20.17 & 12.28 & 2.55 & 58.54 & 8.03 & 2.24 & 2.63 & 0.31 & 0.07 & 0.07 & 5.32 & 71.89 \\
\hline 2002 & 22.73 & 19.44 & 12.16 & 2.56 & 56.89 & 8.14 & 2.69 & 2.71 & 0.33 & 0.06 & 0.11 & 5.90 & 70.94 \\
\hline 2003 & 22.09 & 19.69 & 12.03 & 2.35 & 56.16 & 7.96 & 2.82 & 2.82 & 0.33 & 0.06 & 0.11 & 6.15 & 70.26 \\
\hline 2004 & 22.85 & 19.09 & 11.50 & 2.47 & 55.91 & 8.22 & 2.69 & 3.01 & 0.34 & 0.06 & 0.14 & 6.25 & 70.38 \\
\hline 2005 & 23.19 & 18.57 & 10.96 & 2.33 & 55.06 & 8.16 & 2.70 & 3.14 & 0.34 & 0.07 & 0.18 & 6.43 & 69.65 \\
\hline 2006 & 23.79 & 18.99 & 10.80 & 2.36 & 55.94 & 8.21 & 2.87 & 3.32 & 0.34 & 0.07 & 0.26 & 6.87 & 71.02 \\
\hline 2007 & 23.50 & 19.82 & 10.80 & 2.40 & 56.52 & 8.41 & 2.46 & 3.58 & 0.35 & 0.08 & 0.32 & 6.80 & 71.73 \\
\hline
\end{tabular}

Source:

Energy Information Administration, Monthly Energy Review, July 2008. Table 1.2, www.eia.doe.gov/emeu/mer/overview.html

Note: NA $=$ Not available.

${ }^{a}$ End-use consumption and electricity net generation.

${ }^{\mathrm{b}}$ Includes lease condensate.

${ }^{c}$ Conventional hydroelectric power.

d Wood, waste, and alcohol fuels (ethanol blended into motor gasoline). 
Table 1.2

Energy Consumption by Source, 1973-2007 (Quadrillion Btu)

\begin{tabular}{|c|c|c|c|c|c|c|c|c|c|c|c|c|}
\hline \multirow[b]{2}{*}{ Year } & \multicolumn{4}{|c|}{ Fossil Fuels } & \multirow[b]{2}{*}{$\begin{array}{c}\text { Nuclear } \\
\text { Electric } \\
\text { Power }\end{array}$} & \multicolumn{6}{|c|}{ Renewable Energy ${ }^{a}$} & \multirow[b]{2}{*}{ Total $^{\mathrm{d}, \mathrm{h}}$} \\
\hline & Coal & $\begin{array}{c}\text { Natural } \\
\text { Gas }^{\text {b }}\end{array}$ & $\begin{array}{l}\text { Petro- } \\
\text { leum }^{\mathrm{c}, \mathrm{d}}\end{array}$ & Total $^{\mathrm{e}}$ & & $\begin{array}{l}\text { Hydro- } \\
\text { electric } \\
\text { Power }^{f}\end{array}$ & Biomass $^{\mathrm{d}, \mathrm{g}}$ & $\begin{array}{c}\text { Geo- } \\
\text { thermal }\end{array}$ & Solar & Wind & Total & \\
\hline 1973 & 12.97 & 22.51 & 34.84 & 70.32 & 0.91 & 2.86 & 1.53 & 0.04 & NA & $\mathrm{NA}$ & 4.43 & 75.71 \\
\hline 1974 & 12.66 & 21.73 & 33.45 & 67.91 & 1.27 & 3.18 & 1.54 & 0.05 & NA & NA & 4.77 & 73.99 \\
\hline 1975 & 12.66 & 19.95 & 32.73 & 65.35 & 1.90 & 3.15 & 1.50 & 0.07 & NA & NA & 4.72 & 72.00 \\
\hline 1976 & 13.58 & 20.35 & 35.17 & 69.10 & 2.11 & 2.98 & 1.71 & 0.08 & NA & NA & 4.77 & 76.01 \\
\hline 1977 & 13.92 & 19.93 & 37.12 & 70.99 & 2.70 & 2.33 & 1.84 & 0.08 & NA & NA & 4.25 & 78.00 \\
\hline 1978 & 13.77 & 20.00 & 37.97 & 71.86 & 3.02 & 2.94 & 2.04 & 0.06 & NA & NA & 5.04 & 79.99 \\
\hline 1979 & 15.04 & 20.67 & 37.12 & 72.89 & 2.78 & 2.93 & 2.15 & 0.08 & NA & NA & 5.17 & 80.90 \\
\hline 1980 & 15.42 & 20.24 & 34.20 & 69.83 & 2.74 & 2.90 & 2.48 & 0.11 & NA & NA & 5.49 & 78.12 \\
\hline 1981 & 15.91 & 19.75 & 31.93 & 67.57 & 3.01 & 2.76 & 2.60 & 0.12 & NA & NA & 5.48 & 76.17 \\
\hline 1982 & 15.32 & 18.36 & 30.23 & 63.89 & 3.13 & 3.27 & 2.66 & 0.10 & NA & NA & 6.03 & 73.15 \\
\hline 1983 & 15.89 & 17.22 & 30.05 & 63.15 & 3.20 & 3.53 & 2.90 & 0.13 & NA & 0.00 & 6.56 & 73.04 \\
\hline 1984 & 17.07 & 18.39 & 31.05 & 66.50 & 3.55 & 3.39 & 2.97 & 0.16 & 0.00 & 0.00 & 6.52 & 76.71 \\
\hline 1985 & 17.48 & 17.70 & 30.92 & 66.09 & 4.08 & 2.97 & 3.02 & 0.20 & 0.00 & 0.00 & 6.18 & 76.49 \\
\hline 1986 & 17.26 & 16.59 & 32.20 & 66.03 & 4.38 & 3.07 & 2.93 & 0.22 & 0.00 & 0.00 & 6.22 & 76.76 \\
\hline 1987 & 18.01 & 17.64 & 32.87 & 68.52 & 4.75 & 2.63 & 2.87 & 0.23 & 0.00 & 0.00 & 5.74 & 79.17 \\
\hline 1988 & 18.85 & 18.45 & 34.22 & 71.56 & 5.59 & 2.33 & 3.02 & 0.22 & 0.00 & 0.00 & 5.57 & 82.82 \\
\hline 1989 & 19.07 & 19.60 & 34.21 & 72.91 & 5.60 & 2.84 & 3.16 & 0.32 & 0.06 & 0.02 & 6.39 & 84.94 \\
\hline 1990 & 19.17 & 19.60 & 33.55 & 72.33 & 6.10 & 3.05 & 2.74 & 0.34 & 0.06 & 0.03 & 6.21 & 84.65 \\
\hline 1991 & 18.99 & 20.03 & 32.85 & 71.88 & 6.42 & 3.02 & 2.78 & 0.35 & 0.06 & 0.03 & 6.24 & 84.61 \\
\hline 1992 & 19.12 & 20.71 & 33.53 & 73.40 & 6.48 & 2.62 & 2.93 & 0.35 & 0.06 & 0.03 & 5.99 & 85.96 \\
\hline 1993 & 19.84 & 21.23 & 33.74 & 74.84 & 6.41 & 2.89 & 2.91 & 0.36 & 0.07 & 0.03 & 6.26 & 87.60 \\
\hline 1994 & 19.91 & 21.73 & 34.56 & 76.26 & 6.69 & 2.68 & 3.03 & 0.34 & 0.07 & 0.04 & 6.16 & 89.26 \\
\hline 1995 & 20.09 & 22.67 & 34.44 & 77.26 & 7.08 & 3.21 & 3.10 & 0.29 & 0.07 & 0.03 & 6.71 & 91.17 \\
\hline 1996 & 21.00 & 23.09 & 35.67 & 79.78 & 7.09 & 3.59 & 3.16 & 0.32 & 0.07 & 0.03 & 7.17 & 94.18 \\
\hline 1997 & 21.45 & 23.22 & 36.16 & 80.87 & 6.60 & 3.64 & 3.11 & 0.32 & 0.07 & 0.03 & 7.18 & 94.77 \\
\hline 1998 & 21.66 & 22.83 & 36.82 & 81.37 & 7.07 & 3.30 & 2.93 & 0.33 & 0.07 & 0.03 & 6.66 & 95.18 \\
\hline 1999 & 21.62 & 22.91 & 37.84 & 82.43 & 7.61 & 3.27 & 2.97 & 0.33 & 0.07 & 0.05 & 6.68 & 96.82 \\
\hline 2000 & 22.58 & 23.82 & 38.26 & 84.73 & 7.86 & 2.81 & 3.01 & 0.32 & 0.07 & 0.06 & 6.26 & 98.98 \\
\hline 2001 & 21.91 & 22.77 & 38.19 & 82.90 & 8.03 & 2.24 & 2.63 & 0.31 & 0.07 & 0.07 & 5.32 & 96.33 \\
\hline 2002 & 21.90 & 23.56 & 38.23 & 83.75 & 8.14 & 2.69 & 2.71 & 0.33 & 0.06 & 0.11 & 5.89 & 97.86 \\
\hline 2003 & 22.32 & 22.90 & 38.81 & 84.08 & 7.96 & 2.82 & 2.82 & 0.33 & 0.06 & 0.11 & 6.15 & 98.21 \\
\hline 2004 & 22.47 & 22.93 & 40.29 & 85.83 & 8.22 & 2.69 & 3.02 & 0.34 & 0.06 & 0.14 & 6.26 & 100.35 \\
\hline 2005 & 22.80 & 22.58 & 40.39 & 85.82 & 8.16 & 2.70 & 3.15 & 0.34 & 0.07 & 0.18 & 6.44 & 100.51 \\
\hline 2006 & 22.45 & 22.19 & 39.96 & 84.66 & 8.21 & 2.87 & 3.37 & 0.34 & 0.07 & 0.26 & 6.92 & 99.86 \\
\hline 2007 & 22.77 & 23.64 & 39.82 & 86.25 & 8.41 & 2.46 & 3.61 & 0.35 & 0.08 & 0.32 & 6.83 & 101.60 \\
\hline
\end{tabular}

Source:

Energy Information Administration, Monthly Energy Review, July 2008. Table 1.3, www.eia.doe.gov/emeu/mer/overview.html

Note: $N A=$ Not available.

${ }^{a}$ End-use consumption and electricity net generation.

${ }^{\mathrm{b}}$ Natural gas, plus a small amount of supplemental gaseous fuels that cannot be identified separately.

${ }^{c}$ Petroleum products supplied, including natural gas plant liquids and crude oil burned as fuel. Beginning in 1993, also includes ethanol blended into other gasoline.

d Beginning in 1993, ethanol blended into motor gasoline is included in both "Petroleum and "biomass," but is counted only once in total consumption.

e Includes coal coke net imports.

${ }^{f}$ Conventional hydroelectric power.

${ }^{g}$ Wood, waste, and alcohol fuels (ethanol blended into motor gasoline).

${ }^{\mathrm{h}}$ Includes coal coke net imports and electricity net imports, which are not separately displayed. 
Except for corn and soybeans, all biomass resources being used in 2007 for energy are some type of residue or waste. Corn grain is used for ethanol and soybeans are used for biodiesel fuel.

Table 1.3

Renewable Energy Consumption by Source, 1973-2007 (Trillion Btu)

\begin{tabular}{|c|c|c|c|c|c|c|c|c|c|}
\hline \multirow[b]{2}{*}{ Year } & \multirow{2}{*}{$\begin{array}{c}\text { Hydro-electric } \\
\text { Power }^{\mathrm{a}}\end{array}$} & \multicolumn{4}{|c|}{ Biomass } & \multirow{2}{*}{$\begin{array}{c}\text { Geo- } \\
\text { thermal }^{\mathrm{e}}\end{array}$} & \multirow[b]{2}{*}{ Solar ${ }^{f}$} & \multirow[b]{2}{*}{ Wind $^{g}$} & \multirow[b]{2}{*}{ Total } \\
\hline & & Wood $^{\mathrm{b}}$ & Waste $^{c}$ & Biofuels $^{d}$ & Total & & & & \\
\hline 1973 & $2,861.45$ & $1,527.01$ & 2.06 & NA & $1,529.07$ & 42.61 & $\overline{N A}$ & NA & $4,433.12$ \\
\hline 1974 & $3,176.58$ & $1,537.76$ & 1.90 & NA & $1,539.66$ & 53.16 & NA & NA & $4,769.40$ \\
\hline 1975 & $3,154.61$ & $1,496.93$ & 1.81 & NA & $1,498.73$ & 70.15 & NA & NA & $4,723.49$ \\
\hline 1976 & $2,976.27$ & $1,711.48$ & 1.89 & NA & $1,713.37$ & 78.15 & NA & NA & $4,767.79$ \\
\hline 1977 & $2,333.25$ & $1,836.52$ & 1.81 & NA & $1,838.33$ & 77.42 & NA & NA & $4,249.00$ \\
\hline 1978 & $2,936.98$ & $2,036.15$ & 1.46 & NA & $2,037.61$ & 64.35 & NA & NA & $5,038.94$ \\
\hline 1979 & $2,930.69$ & $2,149.85$ & 2.05 & NA & $2,151.91$ & 83.79 & NA & NA & $5,166.38$ \\
\hline 1980 & $2,900.14$ & $2,473.86$ & 1.64 & NA & $2,475.50$ & 109.78 & NA & NA & $5,485.42$ \\
\hline 1981 & $2,757.97$ & $2,495.56$ & 88.00 & 12.83 & $2,596.39$ & 123.04 & NA & NA & $5,477.40$ \\
\hline 1982 & $3,265.56$ & $2,510.05$ & 119.00 & 34.51 & $2,663.56$ & 104.75 & NA & NA & $6,033.86$ \\
\hline 1983 & $3,527.26$ & $2,684.27$ & 157.00 & 63.18 & $2,904.45$ & 129.34 & NA & 0.03 & $6,561.07$ \\
\hline 1984 & $3,385.81$ & $2,685.82$ & 208.00 & 77.23 & $2,971.05$ & 164.90 & 0.06 & 0.07 & $6,521.87$ \\
\hline 1985 & $2,970.19$ & $2,686.77$ & 236.32 & 93.02 & $3,016.11$ & 198.28 & 0.11 & 0.06 & $6,184.75$ \\
\hline 1986 & $3,071.18$ & $2,562.13$ & 262.86 & 106.98 & $2,931.98$ & 219.18 & 0.15 & 0.04 & $6,222.52$ \\
\hline 1987 & $2,634.51$ & $2,463.16$ & 289.00 & 122.66 & $2,874.82$ & 229.12 & 0.11 & 0.04 & $5,738.59$ \\
\hline 1988 & $2,334.27$ & $2,576.66$ & 315.33 & 124.12 & $3,016.11$ & 217.29 & 0.09 & 0.01 & $5,567.77$ \\
\hline 1989 & $2,837.26$ & $2,679.62$ & 354.36 & 125.59 & $3,159.57$ & 317.16 & 55.29 & 22.03 & $6,391.32$ \\
\hline 1990 & $3,046.39$ & $2,216.17$ & 408.08 & 111.21 & $2,735.45$ & 335.80 & 59.72 & 29.01 & $6,206.37$ \\
\hline 1991 & $3,015.94$ & $2,214.08$ & 439.72 & 128.61 & $2,782.41$ & 346.25 & 62.69 & 30.80 & $6,238.08$ \\
\hline 1992 & $2,617.44$ & $2,313.47$ & 473.20 & 145.97 & $2,932.64$ & 349.31 & 63.89 & 29.86 & $5,993.14$ \\
\hline 1993 & $2,891.61$ & $2,259.77$ & 479.34 & 170.51 & $2,909.62$ & 363.72 & 66.46 & 30.99 & $6,262.39$ \\
\hline 1994 & $2,683.46$ & $2,323.82$ & 515.32 & 190.40 & $3,029.54$ & 338.11 & 68.55 & 35.56 & $6,155.21$ \\
\hline 1995 & $3,205.31$ & $2,369.87$ & 531.48 & 202.39 & $3,103.73$ & 293.89 & 69.86 & 32.63 & $6,705.42$ \\
\hline 1996 & $3,589.66$ & $2,437.03$ & 576.99 & 144.94 & $3,158.96$ & 315.53 & 70.83 & 33.44 & $7,168.42$ \\
\hline 1997 & $3,640.46$ & $2,370.99$ & 550.60 & 186.82 & $3,108.42$ & 324.96 & 70.24 & 33.58 & $7,177.65$ \\
\hline 1998 & $3,297.05$ & $2,184.16$ & 542.30 & 205.00 & $2,931.46$ & 328.30 & 69.79 & 30.85 & $6,657.46$ \\
\hline 1999 & $3,267.58$ & $2,214.17$ & 540.16 & 213.16 & $2,967.48$ & 330.92 & 68.79 & 45.89 & $6,680.67$ \\
\hline 2000 & $2,811.12$ & $2,261.72$ & 510.80 & 240.52 & $3,013.04$ & 316.80 & 66.39 & 57.06 & $6,264.40$ \\
\hline 2001 & $2,241.86$ & $2,005.83$ & 363.88 & 257.60 & $2,627.31$ & 311.26 & 65.45 & 69.62 & $5,315.51$ \\
\hline 2002 & $2,689.02$ & $1,995.28$ & 402.01 & 308.88 & $2,706.17$ & 328.31 & 64.39 & 105.33 & $5,893.22$ \\
\hline 2003 & $2,824.53$ & $2,002.04$ & 401.34 & 413.70 & $2,817.09$ & 330.55 & 63.62 & 114.57 & $6,150.36$ \\
\hline 2004 & $2,690.08$ & $2,121.25$ & 388.72 & 513.36 & $3,023.33$ & 341.08 & 64.50 & 141.75 & $6,260.74$ \\
\hline 2005 & $2,702.94$ & $2,156.35$ & 403.22 & 594.59 & $3,154.16$ & 342.58 & 66.13 & 178.09 & $6,443.90$ \\
\hline 2006 & $2,869.04$ & $2,171.73$ & 407.23 & 794.99 & $3,373.95$ & 342.88 & 72.22 & 263.74 & $6,921.82$ \\
\hline 2007 & $2,463.01$ & $2,165.11$ & 431.36 & $1,018.39$ & $3,614.85$ & 352.96 & 80.41 & 318.83 & $6,830.07$ \\
\hline
\end{tabular}

Source:

Energy Information Administration, Monthly Energy Review, July 2008, Table 10.1., www.eia.doe.gov/emeu/mer/renew.html

Note: NA $=$ Not available.

${ }^{a}$ Conventional hydroelectric power.

${ }^{\mathrm{b}}$ Wood, black liquor, and other wood waste.

${ }^{c}$ Municipal solid waste, landfill gas, sludge waste, tires, agricultural byproducts, and other biomass.

${ }^{d}$ Ethanol blended into motor gasoline.

e Geothermal electricity net generation, heat pump, and direct use energy.

${ }^{f}$ Solar thermal and photovoltaic electricity net generation, and solar thermal direct use energy.

${ }^{\mathrm{g}}$ Wind electricity net generation. 
Ethanol provided $90 \%$ of the renewable transportation fuels consumed in the United States in 2007 while biodiesel accounted for about 10\%. In the industrial sector, biomass accounted for nearly all of the renewable energy consumed.

Table 1.4

Renewable Energy Consumption for Industrial and Transportation Sectors, 1973-2007 (Trillion Btu)

\begin{tabular}{|c|c|c|c|c|c|c|c|c|c|c|c|}
\hline \multirow[b]{3}{*}{ Year } & \multicolumn{8}{|c|}{ Industrial Sector ${ }^{\mathrm{a}}$} & \multirow{2}{*}{\multicolumn{3}{|c|}{$\begin{array}{c}\text { Transportation Sector } \\
\text { Biomass }\end{array}$}} \\
\hline & \multirow[b]{2}{*}{$\begin{array}{l}\text { Hydro- } \\
\text { electric } \\
\text { Power }^{b}\end{array}$} & \multicolumn{5}{|c|}{ Biomass } & \multirow[b]{2}{*}{$\begin{array}{c}\text { Geo- } \\
\text { thermal }^{\mathrm{e}}\end{array}$} & \multirow[b]{2}{*}{ Total } & & & \\
\hline & & Wood $^{c}$ & Waste $^{d}$ & $\begin{array}{c}\text { Fuel } \\
\text { Ethanol }^{\mathrm{f}}\end{array}$ & $\begin{array}{c}\text { Losses } \\
\text { and Co- } \\
\text { products }^{\mathrm{g}}\end{array}$ & Total & & & $\begin{array}{c}\text { Fuel } \\
\text { Ethanol }^{\text {h }}\end{array}$ & Biodiesel $^{g}$ & Total \\
\hline 1973 & 34.77 & $1,164.85$ & NA & $\mathrm{NA}$ & $\mathrm{NA}$ & $1,164.85$ & NA & $1,199.63$ & $\mathrm{NA}$ & $\mathrm{NA}$ & $\overline{\mathrm{NA}}$ \\
\hline 1974 & 33.20 & $1,159.07$ & NA & NA & NA & $1,159.07$ & NA & $1,192.28$ & NA & NA & NA \\
\hline 1975 & 32.32 & $1,063.27$ & NA & NA & NA & $1,063.27$ & NA & $1,095.59$ & NA & NA & NA \\
\hline 1976 & 33.37 & $1,219.88$ & NA & NA & NA & $1,219.88$ & NA & $1,253.25$ & NA & NA & NA \\
\hline 1977 & 32.60 & $1,281.25$ & NA & NA & NA & $1,281.25$ & NA & $1,313.85$ & NA & NA & NA \\
\hline 1978 & 31.56 & $1,400.42$ & NA & NA & NA & $1,400.42$ & NA & $1,431.99$ & NA & NA & NA \\
\hline 1979 & 34.09 & $1,404.86$ & NA & NA & NA & $1,404.86$ & NA & $1,438.96$ & NA & NA & NA \\
\hline 1980 & 32.84 & $1,600.00$ & NA & NA & NA & $1,600.00$ & NA & $1,632.84$ & NA & NA & NA \\
\hline 1981 & 33.04 & $1,602.00$ & 86.72 & 0.09 & 5.83 & $1,694.64$ & NA & $1,727.68$ & 6.86 & NA & 6.86 \\
\hline 1982 & 33.05 & $1,516.00$ & 117.69 & 0.21 & 15.51 & $1,649.41$ & NA & $1,682.46$ & 18.66 & NA & 18.66 \\
\hline 1983 & 33.26 & $1,690.00$ & 155.29 & 0.31 & 28.18 & $1,873.77$ & NA & $1,907.03$ & 34.41 & NA & 34.41 \\
\hline 1984 & 33.00 & $1,679.00$ & 203.57 & 0.53 & 34.23 & $1,917.33$ & NA & $1,950.33$ & 42.11 & NA & 42.11 \\
\hline 1985 & 33.02 & $1,645.00$ & 229.64 & 0.87 & 41.02 & $1,916.52$ & NA & $1,949.55$ & 50.75 & NA & 50.75 \\
\hline 1986 & 33.02 & $1,610.00$ & 255.70 & 0.92 & 46.98 & $1,913.60$ & NA & $1,946.62$ & 58.61 & NA & 58.61 \\
\hline 1987 & 32.94 & $1,576.00$ & 281.77 & 1.03 & 53.66 & $1,912.45$ & NA & $1,945.39$ & 67.42 & NA & 67.42 \\
\hline 1988 & 32.64 & $1,625.00$ & 307.71 & 0.96 & 54.12 & $1,987.78$ & NA & $2,020.42$ & 68.50 & NA & 68.50 \\
\hline 1989 & 28.40 & $1,583.56$ & 200.41 & 1.00 & 54.59 & $1,839.56$ & 1.80 & $1,869.76$ & 69.48 & NA & 69.48 \\
\hline 1990 & 30.95 & $1,441.91$ & 192.32 & 0.84 & 48.21 & $1,683.28$ & 1.90 & $1,716.13$ & 61.65 & NA & 61.65 \\
\hline 1991 & 29.68 & $1,409.85$ & 184.67 & 1.02 & 55.61 & $1,651.16$ & 2.10 & $1,682.93$ & 71.53 & NA & 71.53 \\
\hline 1992 & 30.51 & $1,461.22$ & 178.51 & 1.15 & 62.97 & $1,703.86$ & 2.20 & $1,736.57$ & 81.37 & NA & 81.37 \\
\hline 1993 & 29.59 & $1,484.35$ & 181.16 & 1.21 & 73.52 & $1,740.24$ & 2.40 & $1,772.23$ & 95.57 & NA & 95.57 \\
\hline 1994 & 62.19 & $1,579.77$ & 199.25 & 1.44 & 81.79 & $1,862.25$ & 2.80 & $1,927.23$ & 106.98 & NA & 106.98 \\
\hline 1995 & 54.70 & $1,652.08$ & 195.03 & 1.57 & 85.89 & $1,934.56$ & 3.00 & $1,992.26$ & 114.79 & NA & 114.79 \\
\hline 1996 & 60.77 & $1,683.50$ & 223.55 & 1.11 & 61.38 & $1,969.53$ & 2.90 & $2,033.21$ & 82.31 & NA & 82.31 \\
\hline 1997 & 58.06 & $1,730.61$ & 184.02 & 1.47 & 81.01 & $1,997.11$ & 3.10 & $2,058.27$ & 104.05 & NA & 104.05 \\
\hline 1998 & 54.54 & $1,603.44$ & 180.35 & 1.49 & 88.08 & $1,873.35$ & 3.00 & $1,930.89$ & 115.15 & NA & 115.15 \\
\hline 1999 & 48.66 & $1,619.52$ & 171.04 & 1.15 & 91.60 & $1,883.31$ & 4.10 & $1,936.07$ & 120.20 & NA & 120.20 \\
\hline 2000 & 42.18 & $1,635.93$ & 145.11 & 1.30 & 101.20 & $1,883.53$ & 4.40 & $1,930.12$ & 137.64 & NA & 137.64 \\
\hline 2001 & 32.50 & $1,442.64$ & 128.60 & 2.64 & 109.83 & $1,683.72$ & 4.76 & $1,720.98$ & 143.70 & 1.09 & 144.79 \\
\hline 2002 & 38.91 & $1,396.44$ & 146.35 & 3.21 & 132.86 & $1,678.85$ & 4.79 & $1,722.55$ & 171.01 & 1.34 & 172.35 \\
\hline 2003 & 43.24 & $1,363.32$ & 142.44 & 4.54 & 173.77 & $1,684.06$ & 3.40 & $1,730.70$ & 232.74 & 1.81 & 234.55 \\
\hline 2004 & 32.56 & $1,475.73$ & 131.63 & 6.41 & 210.48 & $1,824.25$ & 3.80 & $1,860.61$ & 292.07 & 3.57 & 295.64 \\
\hline 2005 & 31.95 & $1,451.73$ & 148.25 & 6.98 & 241.02 & $1,847.98$ & 4.30 & $1,884.23$ & 334.11 & 11.58 & 345.69 \\
\hline $\begin{array}{l}2006 \\
2007\end{array}$ & $\begin{array}{l}28.76 \\
22.50\end{array}$ & $\begin{array}{l}1,515.19 \\
1,456.63\end{array}$ & $\begin{array}{l}140.25 \\
151.00\end{array}$ & $\begin{array}{r}9.43 \\
11.78\end{array}$ & $\begin{array}{l}301.18 \\
378.88\end{array}$ & $\begin{array}{l}1,966.04 \\
1,998.29\end{array}$ & $\begin{array}{l}4.40 \\
4.70\end{array}$ & $\begin{array}{l}1,999.20 \\
2,025.49\end{array}$ & $\begin{array}{l}451.22 \\
563.57\end{array}$ & $\begin{array}{l}31.96 \\
62.65\end{array}$ & $\begin{array}{l}483.17 \\
626.22\end{array}$ \\
\hline
\end{tabular}

Source:

Energy Information Administration, Monthly Energy Review, July 2008, Table 10.2b, www.eia.doe.gov/emeu/mer/renew.html

Note: $N A=$ Not available.

a Industrial sector fuel use, including that at industrial combined-heat-and-power (CHP) and industrial electricity plants.

${ }^{\mathrm{b}}$ Conventional hydroelectric power.

${ }^{\mathrm{c}}$ Wood, black liquor, and other wood waste.

${ }^{\mathrm{d}}$ Municipal solid waste, landfill gas, sludge waste, tires, agricultural byproducts, and other biomass.

e Geothermal heat pump and direct use energy.

${ }^{f}$ Ethanol blended into motor gasoline.

${ }^{g}$ Losses and co-products from the production of fuel ethanol and biodiesel. Does not include natural gas, electricity, and other non-biomass energy used in the production of fuel ethanol and biodiesel-these are included in the industrial sector consumption statistics for the appropriate energy source.

${ }^{h}$ The ethanol portion of motor fuels (such as E10 and E85) consumed by the transportation sector. 
In 2007, biomass accounted for about $83 \%$ of the renewable energy used in the residential sector and about $87 \%$ of the renewable energy used in the commercial sector.

Table 1.5

Renewable Energy Consumption for Residential and Commercial Sectors, 1973-2007 (Trillion Btu)

\begin{tabular}{|c|c|c|c|c|c|c|c|c|c|c|c|}
\hline \multirow[b]{3}{*}{ Year } & \multicolumn{4}{|c|}{ Residential Sector } & \multicolumn{7}{|c|}{ Commercial Sector $^{\mathrm{a}}$} \\
\hline & \multirow{2}{*}{$\begin{array}{l}\text { Biomass } \\
\text { Wood }^{b}\end{array}$} & \multirow[b]{2}{*}{$\begin{array}{c}\text { Geo- } \\
\text { thermal }^{\mathrm{c}}\end{array}$} & \multirow[b]{2}{*}{ Solar ${ }^{d}$} & \multirow[b]{2}{*}{ Total } & \multirow[b]{2}{*}{$\begin{array}{l}\text { Hydro- } \\
\text { electric }\end{array}$} & \multicolumn{4}{|c|}{ Biomass } & \multirow[b]{2}{*}{$\begin{array}{c}\text { Geo- } \\
\text { thermal }^{\mathrm{c}}\end{array}$} & \multirow[b]{2}{*}{ Total } \\
\hline & & & & & & Wood $^{b}$ & Waste & $\begin{array}{c}\text { Fuel } \\
\text { Ethanol }\end{array}$ & Total & & \\
\hline 1973 & 354.10 & NA & $\mathrm{NA}$ & 354.10 & NA & 6.71 & $\mathrm{NA}$ & NA & 6.71 & $\mathrm{NA}$ & 6.71 \\
\hline 1974 & 370.95 & NA & NA & 370.95 & NA & 7.02 & NA & NA & 7.02 & NA & 7.02 \\
\hline 1975 & 425.41 & NA & NA & 425.41 & NA & 8.07 & NA & NA & 8.07 & NA & 8.07 \\
\hline 1976 & 481.63 & NA & NA & 481.63 & NA & 9.10 & NA & NA & 9.10 & NA & 9.10 \\
\hline 1977 & 541.78 & NA & NA & 541.78 & NA & 10.29 & NA & NA & 10.29 & NA & 10.29 \\
\hline 1978 & 621.85 & NA & NA & 621.85 & NA & 11.83 & NA & NA & 11.83 & NA & 11.83 \\
\hline 1979 & 728.08 & NA & NA & 728.08 & NA & 13.81 & NA & NA & 13.81 & NA & 13.81 \\
\hline 1980 & 850.00 & NA & NA & 850.00 & NA & 21.00 & NA & NA & 21.00 & NA & 21.00 \\
\hline 1981 & 870.00 & NA & NA & 870.00 & NA & 21.00 & NA & 0.05 & 21.05 & NA & 21.05 \\
\hline 1982 & 970.00 & NA & NA & 970.00 & NA & 22.00 & NA & 0.13 & 22.13 & NA & 22.13 \\
\hline 1983 & 970.00 & NA & NA & 970.00 & NA & 22.00 & NA & 0.28 & 22.28 & NA & 22.28 \\
\hline 1984 & 980.00 & NA & NA & 980.00 & NA & 22.00 & NA & 0.36 & 22.36 & NA & 22.36 \\
\hline 1985 & 1010.00 & NA & NA & 1010.00 & NA & 24.00 & NA & 0.38 & 24.38 & NA & 24.38 \\
\hline 1986 & 920.00 & NA & NA & 920.00 & NA & 27.00 & NA & 0.47 & 27.47 & NA & 27.47 \\
\hline 1987 & 850.00 & NA & NA & 850.00 & NA & 29.00 & NA & 0.55 & 29.55 & NA & 29.55 \\
\hline 1988 & 910.00 & NA & NA & 910.00 & NA & 32.00 & NA & 0.55 & 32.55 & NA & 32.55 \\
\hline 1989 & 920.00 & 5.00 & 52.68 & 977.68 & 0.69 & 76.48 & 22.00 & 0.52 & 98.99 & 2.50 & 102.18 \\
\hline 1990 & 580.00 & 5.50 & 55.90 & 641.40 & 1.43 & 65.74 & 27.77 & 0.51 & 94.01 & 2.80 & 98.24 \\
\hline 1991 & 610.00 & 5.90 & 57.77 & 673.67 & 1.37 & 68.44 & 26.49 & 0.45 & 95.38 & 3.00 & 99.75 \\
\hline 1992 & 640.00 & 6.40 & 59.75 & 706.15 & 1.27 & 72.03 & 32.45 & 0.47 & 104.95 & 3.20 & 109.42 \\
\hline 1993 & 550.00 & 6.80 & 61.69 & 618.49 & 1.03 & 75.60 & 33.39 & 0.20 & 109.19 & 3.40 & 113.62 \\
\hline 1994 & 520.00 & 6.20 & 63.53 & 589.73 & 0.96 & 71.72 & 34.52 & 0.19 & 106.43 & 4.20 & 111.58 \\
\hline 1995 & 520.00 & 6.60 & 64.73 & 591.33 & 1.22 & 72.38 & 40.20 & 0.14 & 112.72 & 4.50 & 118.44 \\
\hline 1996 & 540.00 & 7.00 & 65.44 & 612.44 & 1.30 & 75.67 & 53.03 & 0.15 & 128.84 & 5.30 & 135.44 \\
\hline 1997 & 430.00 & 7.50 & 65.02 & 502.52 & 1.23 & 73.39 & 57.61 & 0.30 & 131.29 & 5.70 & 138.22 \\
\hline 1998 & 380.00 & 7.70 & 64.66 & 452.36 & 1.23 & 64.01 & 54.16 & 0.29 & 118.47 & 7.10 & 126.80 \\
\hline 1999 & 390.00 & 8.50 & 63.73 & 462.23 & 1.17 & 66.62 & 53.92 & 0.22 & 120.75 & 6.70 & 128.63 \\
\hline 2000 & 420.00 & 8.60 & 61.36 & 489.96 & 1.02 & 71.47 & 47.26 & 0.38 & 119.11 & 7.60 & 127.73 \\
\hline 2001 & 370.00 & 9.45 & 59.85 & 439.30 & 0.69 & 66.79 & 24.54 & 0.34 & 91.67 & 8.27 & 100.63 \\
\hline 2002 & 380.00 & 10.20 & 58.75 & 448.95 & 0.13 & 68.66 & 25.88 & 0.47 & 95.00 & 8.75 & 103.89 \\
\hline 2003 & 400.00 & 13.00 & 58.15 & 471.15 & 0.74 & 71.44 & 29.03 & 0.84 & 101.30 & 11.00 & 113.04 \\
\hline 2004 & 410.00 & 14.00 & 58.74 & 482.74 & 1.05 & 70.32 & 34.24 & 0.84 & 105.40 & 12.00 & 118.45 \\
\hline 2005 & 450.00 & 15.90 & 60.63 & 526.53 & 0.86 & 69.65 & 34.25 & 0.90 & 104.80 & 13.60 & 119.26 \\
\hline 2006 & 410.00 & 18.30 & 67.19 & 495.49 & 0.93 & 64.73 & 36.31 & 1.21 & 102.25 & 14.00 & 117.18 \\
\hline 2007 & 460.00 & 22.00 & 74.40 & 556.40 & 0.70 & 64.74 & 37.42 & 1.51 & 103.67 & 14.40 & 118.77 \\
\hline
\end{tabular}

Source:

Energy Information Administration, Monthly Energy Review, July 2008, Table 10.2a, www.eia.doe.gov/emeu/mer/renew.html

Note: $N A=$ Not available

${ }^{a}$ Commercial sector fuel use, including that at commercial combined-heat-and-power (CHP) and commercial electricity-only plants.

${ }^{\mathrm{b}}$ Wood, black liquor, and other wood waste.

${ }^{c}$ Geothermal heat pump and direct use energy.

d Solar thermal direct use energy and photovoltaic electricity generation. Small amounts of commercial sector are included in the residential sector. 
Total industrial biomass energy consumption was approximately 1,533 trillion Btu in 2003. The bulk of industrial biomass energy consumption is derived from forestlands. More than one-half of this total is black liquor - a pulping mill by-product containing unutilized wood fiber and chemicals. Black liquor is combusted in recovery boilers to recover valuable chemicals and to produce heat and power. Wood and wood wastes generated in primary wood processing mills account for another third of total industrial biomass energy consumption. The data contained in this table are from a survey of manufacturers that is conducted every four years by the EIA.

Table 1.6

Industrial Biomass Energy Consumption and Electricity Net Generation by Industry and Energy Sources, 2003

\begin{tabular}{|c|c|c|c|c|c|}
\hline \multirow[b]{2}{*}{ Industry } & \multirow[b]{2}{*}{ Energy Source } & \multicolumn{4}{|c|}{ Biomass Energy Consumption (Trillon Btus) } \\
\hline & & Total & For Electricity & $\begin{array}{c}\text { For Useful } \\
\text { Thermal } \\
\text { Output }\end{array}$ & $\begin{array}{c}\text { Net } \\
\text { Generation } \\
\text { (Million }\end{array}$ \\
\hline Total & Total & $1,532.947$ & 378.706 & $1,154.242$ & 29,001 \\
\hline \multirow[t]{2}{*}{ Agriculture, Forestry, and Mining } & Total & 9.010 & 2.720 & 6.290 & 167 \\
\hline & Agricultural Byproducts/Crops & 9.010 & 2.720 & 6.290 & 167 \\
\hline Manufacturing & Total & $1,444.208$ & 375.986 & $1,068.222$ & 28,834 \\
\hline \multirow[t]{6}{*}{ Food and Kindred Industry Products } & Total & 41.318 & 5.176 & 36.142 & 104 \\
\hline & Agricultural Byproducts/Crops & 37.153 & 4.073 & 33.079 & 28 \\
\hline & Other Biomass Gases & 0.278 & 0.217 & 0.062 & 8 \\
\hline & Other Biomass Liquids & 0.067 & 0.067 & - & 5 \\
\hline & Tires & 0.379 & 0.179 & 0.201 & 14 \\
\hline & Wood/Wood Waste Solids & 3.441 & 0.641 & 2.801 & 49 \\
\hline \multirow[t]{4}{*}{ Lumber } & Total & 216.442 & 16.364 & 200.078 & 1,499 \\
\hline & Sludge Waste & 0.058 & 0.019 & 0.039 & 3 \\
\hline & Wood/Wood Waste Liquids & 0.248 & 0.080 & 0.168 & 12 \\
\hline & Wood/Wood Waste Solids & 216.137 & 16.265 & 199.872 & 1,483 \\
\hline \multirow[t]{11}{*}{ Paper and Allied Products } & Total & $1,150.781$ & 352.138 & 798.643 & 27,039 \\
\hline & Agricultural Byproducts/Crops & 1.131 & 0.092 & 1.040 & 7 \\
\hline & Black Liquor & 814.120 & 239.340 & 574.780 & 18,311 \\
\hline & Landfill Gas & 0.310 & 0.063 & 0.247 & 7 \\
\hline & Municipal Solid Waste & 2.274 & 0.427 & 1.848 & 53 \\
\hline & Other Biomass Liquids & 0.071 & 0.034 & 0.037 & 2 \\
\hline & Other Biomass Solids & 0.741 & 0.586 & 0.155 & 59 \\
\hline & Sludge Waste & 10.136 & 3.536 & 6.600 & 251 \\
\hline & Tires & 7.540 & 2.627 & 4.913 & 253 \\
\hline & Wood/Wood Waste Liquids & 21.019 & 4.697 & 16.322 & 416 \\
\hline & Wood/Wood Waste Solids & 293.439 & 100.738 & 192.701 & 7,679 \\
\hline \multirow[t]{7}{*}{ Chemicals and Allied Products } & Total & 3.870 & 0.745 & 3.125 & 43 \\
\hline & Landfill Gas & 0.214 & 0.041 & 0.173 & 4 \\
\hline & Municipal Solid Waste & 1.398 & 0.122 & 1.276 & 12 \\
\hline & Other Biomass Liquids & 0.073 & 0.014 & 0.059 & 0 \\
\hline & Other Biomass Solids & 0.004 & 0.001 & 0.003 & 0 \\
\hline & Sludge Waste & 0.300 & 0.072 & 0.228 & 9 \\
\hline & Wood/Wood Waste Solids & 1.881 & 0.496 & 1.385 & 18 \\
\hline Other $^{a}$ & Total & 31.797 & 1.564 & 30.233 & 149 \\
\hline \multirow[t]{3}{*}{ Nonspecified $^{b}$} & Total & 79.730 & - & 79.730 & - \\
\hline & Landfill Gas & 74.730 & - & 74.730 & - \\
\hline & Municipal Solid Waste & 5.000 & - & 5.000 & - \\
\hline
\end{tabular}

\section{Sources:}

Energy Information Administration, Form EIA-906, "Power Plant Report," Government Advisory Associates, Resource Recovery Yearbook and Methane Recovery Yearbook; and analysis conducted by the Energy Information Administration, Office of Coal, Nuclear, Electric and Alternate Fuels.

Notes: Totals may not equal sum of components due to independent rounding.

- = Not Applicable.

a Other includes Apparel; Petroleum Refining; Rubber and Misc. Plastic Products; Transportation Equipment; Stone, Clay, Glass, and Concrete Products; Furniture and Fixtures; and related industries.

${ }^{\mathrm{b}}$ Primary purpose of business is not specified. 
Biomass is the single largest source of renewable energy in the United States. Biomass, which includes biofuels, waste and woody materials, surpassed hydroelectric power in 2005 and by 2007 accounted for $53 \%$ of all renewable energy consumption. In 2007, biomass contributed about $3.7 \%$ of the total U.S. energy consumption of 101 quadrillion Btu. Wood, wood waste, and black liquor from pulp mills is the single largest source accounting for more than two-thirds of total biomass energy consumption. Wastes (which include municipal solid waste, landfill gas, sludge waste, tires, agricultural by-products, and other secondary and tertiary sources of biomass) accounts for about $20 \%$ of total biomass consumption. The remaining share is alcohol fuel derived principally from corn grain.

Figure 1.1

Summary of Biomass Energy Consumption, 2007

\section{Total $=101.47$ Quadrillion Btu $\quad$ Total $=6.83$ Quadrillion Btu}

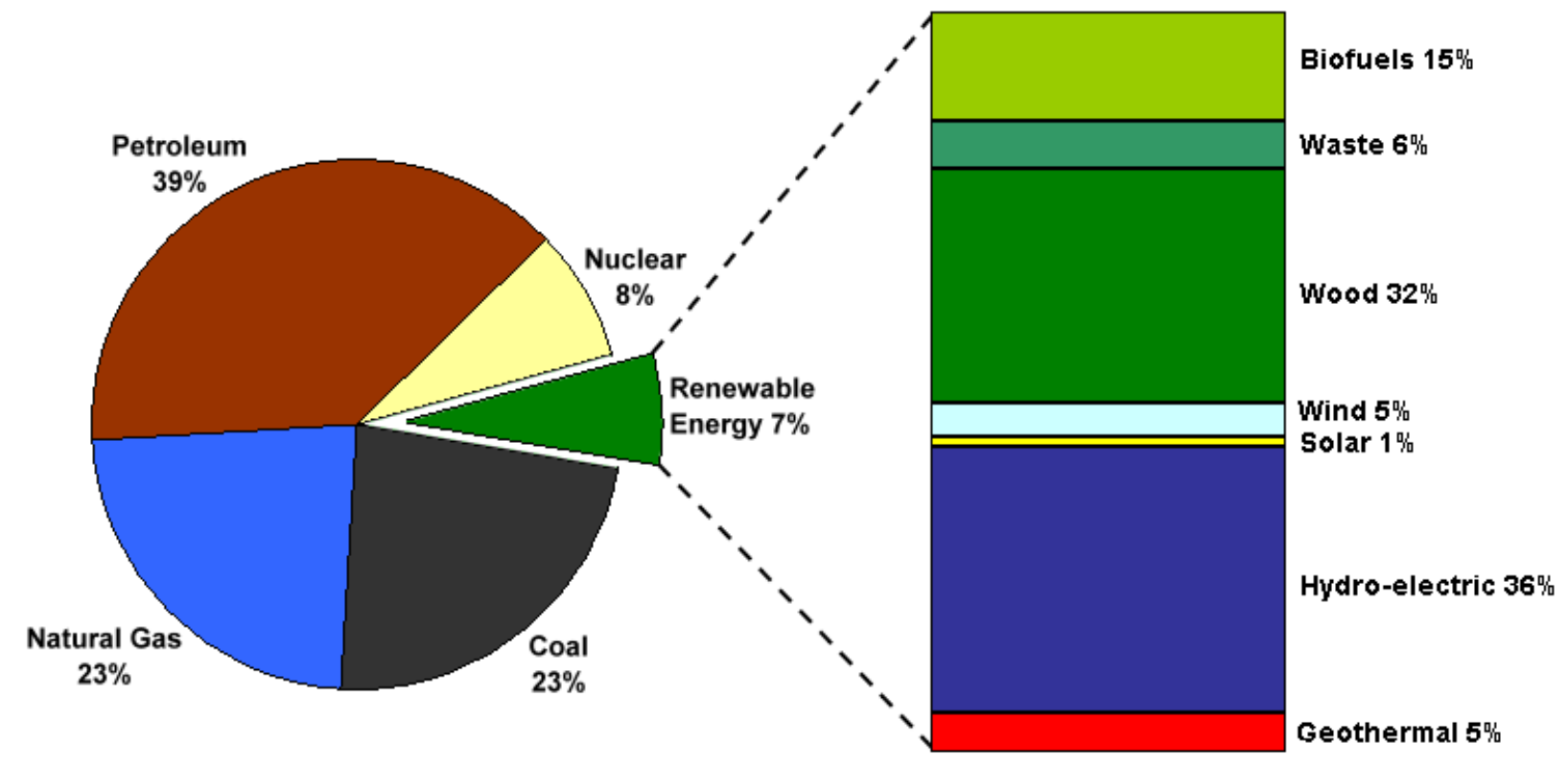

\section{Source:}

Energy Information Administration, Monthly Energy Review, July 2008.

http://www.eia.doe.gov/emeu/mer/contents.html 
Approximately 492 million dry tons of biomass residues were produced from agricultural lands in the United States in 2001 with less than 200 million dry tons of biomass deemed sustainably collectable. The baseline scenario calculations of potentially sustainably collectable biomass shown below, considered numerous factors affecting soil sustainability, such as water and wind erosion, crop management, and as the efficiency of the existing residue collection equipment.

Table 1.7

Scenario Estimate of Collectable Biomass from Agricultural Activity 2001 Baseline Scenario

\begin{tabular}{|c|c|c|c|c|c|c|c|}
\hline Crop & $\begin{array}{c}\text { Acres } \\
\text { harvested or } \\
\text { reserved }\end{array}$ & $\begin{array}{c}\text { Crop } \\
\text { Product } \\
\text { Yield }\end{array}$ & Fiber Yield & $\begin{array}{l}\text { Residue } \\
\text { Yield }\end{array}$ & $\begin{array}{c}\text { Total } \\
\text { cropland } \\
\text { plant mass }\end{array}$ & $\begin{array}{c}\text { Total residue } \\
\text { produced }\end{array}$ & $\begin{array}{l}\text { Estimate of } \\
\text { Collectable } \\
\text { Biomass }\end{array}$ \\
\hline & million acres & \multicolumn{3}{|c|}{ dry tons/acre/year } & \multicolumn{3}{|c|}{ million dry tons/year } \\
\hline Corn & 68.8 & 3.3 & NA & 3.3 & 450.0 & 225.0 & 94.6 \\
\hline Sorghum & 8.6 & 1.4 & NA & 1.4 & 24.8 & 12.4 & 0.5 \\
\hline Barley & 4.3 & 1.2 & NA & 1.8 & 12.8 & 7.7 & 0.8 \\
\hline Oats & 1.9 & 0.8 & NA & 1.7 & 4.8 & 3.2 & 0.1 \\
\hline Wheat-winter & 31.3 & 1.1 & NA & 1.9 & 95.4 & 60.1 & 8.9 \\
\hline Wheat-spring & 17.5 & 0.9 & NA & 1.2 & 35.5 & 20.1 & 2.2 \\
\hline Soybeans & 73.0 & 1.1 & NA & 1.6 & 193.0 & 115.8 & 0.2 \\
\hline Rice & 3.3 & 2.9 & NA & 4.3 & 23.7 & 14.2 & 5.7 \\
\hline Cotton lint & 13.8 & 0.3 & NA & 1.0 & 17.7 & 13.3 & 2.7 \\
\hline Alfalfa & 23.8 & 3.0 & NA & 0.0 & 70.6 & 0.0 & 0.0 \\
\hline Other hay & 39.7 & 1.7 & NA & 0.0 & 67.4 & 0.0 & 0.0 \\
\hline Silage corn & 6.1 & 6.6 & NA & 0.0 & 40.8 & 0.0 & 0.0 \\
\hline Silage sorghum & 0.3 & 4.4 & NA & 0.0 & 1.5 & 0.0 & 0.0 \\
\hline Other Crops & 20.1 & 1.0 & NA & 1.0 & 20.1 & 20.1 & 18.1 \\
\hline Double Crops & & & & & & & 0.0 \\
\hline Crop failure & 10.0 & 0.5 & NA & 0.0 & 5.0 & 0.0 & 0.0 \\
\hline Summer fallow & 21.0 & 0.0 & NA & 0.0 & 0.0 & 0.0 & 0.0 \\
\hline Grasses (CRP) & 25.4 & 2.0 & NA & 0.0 & 50.8 & 0.0 & 0.0 \\
\hline Trees (CRP) & 2.2 & 2.0 & NA & 0.0 & 4.4 & 0.0 & 0.0 \\
\hline Environment (CRP) & 6.4 & 2.0 & NA & 0.0 & 12.7 & 0.0 & 0.0 \\
\hline Unaccounted & 3.0 & 0.0 & NA & 0.0 & 0.0 & 0.0 & 0.0 \\
\hline Pasture & 67.5 & 1.5 & NA & 0.0 & 101.3 & 0.0 & 0.0 \\
\hline Wood fiber & 0.1 & 0.0 & 6.0 & 2.0 & 0.8 & 0.2 & 0.2 \\
\hline Perennials & 0.0 & 0.0 & 0.0 & 0.0 & 0.0 & 0.0 & 0.0 \\
\hline Manure & NA & NA & NA & NA & NA & 54.9 & 35.1 \\
\hline Fats \& greases & NA & NA & NA & NA & NA & 3.5 & 0.9 \\
\hline MSW & NA & NA & NA & $\mathrm{NA}$ & NA & & 23.7 \\
\hline Totals & 448.1 & & & & 1233.1 & 550.5 & 193.7 \\
\hline
\end{tabular}

Source:

Selected Columns from Table B.2 (page 56) of Perlack, R.D., Wright L.L., Turhollow, A.F., Graham, R.L., Stokes, B.H., and Erbach, DC 2005, Biomass as Feedstock For a Bioenergy and Bioproducts Industry: The Technical Feasibility of a Billion-Ton Annual Supply. DOE/GO-102005-2135 also ORNL/TM-2005/66. A joint U.S. Department of Energy and U.S. Department of Agriculture report available online at: http://www.eere.energy.gov/biomass/publications.html

Notes: Some totals may differ slightly from the original source due to rounding differences.

MSW=Municipal Solid Waste.

The scenario is not a modeled prediction - it shows a possible outcome with reasonable assumptions.

Collectable biomass includes starches and oils as well as lignocellulosic materials. NA $=$ Not Available.

Crop acres harvested estimates reflect USDA numbers reported for 2001. 


\section{Table 1.7 (Continued)}

Scenario Estimate of Collectable Biomass from Agricultural Activity

2001 Baseline Scenario

Recent publications (e.g., Wilhelm et. al.) suggest soil carbon considerations may limit sustainably collectable agricultural residues below the numbers calculated.

Recommended Additional Reading:

(1) R.L. Graham, R. Nelson, J. Sheehan, R.D. Perlack and L.L. Wright. Current and Potential U.S. Corn Stover Supplies. Agron. J. 99:1-11 (2007)

(2) W.W. Wilhelm, J.M.F. Johnson, D.L. Karlen, and D.T. Lightle. Corn Stover to Sustain Soil Organic Carbon Further Constrains Biomass Supply. Agron. J. 99:1665-1667 (2007) 
Approximately 492 million dry tons of biomass residues were produced from agricultural lands in the United States in 2001 with less than 200 million dry tons of biomass deemed sustainably collectable. The scenario shown below suggests that more than 400 million dry tons could be sustainably collected with moderate changes in agricultural activity. Assumptions included crop yield increases of up to 25\%, moderate crop management changes on water and wind erosion (such as increase in no-till acres) moderate changes in residue to grain ratios, as well as moderate changes in the efficiency of residue collection equipment.

Table 1.8

Scenario Estimate of Collectable Biomass Assuming Yield Changes 25\% Crop Yield Increases - No Perennial Energy Crops

\begin{tabular}{|c|c|c|c|c|c|c|c|}
\hline Crop & $\begin{array}{c}\text { Acres } \\
\text { harvested or } \\
\text { reserved }\end{array}$ & $\begin{array}{l}\text { Crop } \\
\text { Product } \\
\text { Yield }\end{array}$ & Fiber Yield & $\begin{array}{l}\text { Residue } \\
\text { Yield }\end{array}$ & $\begin{array}{c}\text { Total } \\
\text { cropland } \\
\text { plant mass }\end{array}$ & $\begin{array}{l}\text { Total residue } \\
\text { produced }\end{array}$ & $\begin{array}{l}\text { Estimate of } \\
\text { Collectable } \\
\text { Biomass }\end{array}$ \\
\hline & million acres & \multicolumn{3}{|c|}{ dry tons/acre/year } & \multicolumn{3}{|c|}{ million dry tons/year } \\
\hline Corn & 76.6 & $\overline{4.1}$ & $\overline{\mathrm{NA}}$ & 4.1 & 626.2 & 313.1 & $\overline{225.2}$ \\
\hline Sorghum & 6.8 & 1.7 & NA & 1.7 & 22.8 & 11.4 & 3.1 \\
\hline Barley & 3.7 & 1.5 & NA & 2.2 & 13.8 & 8.3 & 3.4 \\
\hline Oats & 1.6 & 0.9 & NA & 1.9 & 4.5 & 3.0 & 0.7 \\
\hline Wheat-winter & 33.3 & 1.4 & NA & 2.3 & 121.8 & 76.7 & 27.4 \\
\hline Wheat-spring & 19.0 & 1.1 & NA & 1.4 & 46.3 & 26.2 & 7.4 \\
\hline Soybeans & 71.4 & 1.2 & NA & 1.8 & 213.3 & 128.0 & 2.6 \\
\hline Rice & 3.4 & 3.4 & NA & 5.1 & 28.5 & 17.1 & 10.3 \\
\hline Cotton lint & 12.3 & 0.4 & NA & 1.1 & 18.4 & 13.8 & 5.5 \\
\hline Alfalfa & 23.8 & 3.4 & NA & 0.0 & 81.2 & 0.0 & 0.0 \\
\hline Other hay & 34.2 & 2.0 & NA & 0.0 & 66.8 & 0.0 & 0.0 \\
\hline Silage corn & 6.1 & 7.6 & NA & 0.0 & 46.9 & 0.0 & 0.0 \\
\hline Silage sorghum & 0.3 & 5.1 & NA & 0.0 & 1.7 & 0.0 & 0.0 \\
\hline Other Crops & 20.1 & 1.2 & NA & 1.2 & 23.1 & 23.1 & 22.8 \\
\hline Double Crops & & & & & & & 12.0 \\
\hline Crop failure & 10.0 & 0.5 & NA & 0.0 & 5.0 & 0.0 & 0.0 \\
\hline Summer fallow & 21.0 & 0.0 & NA & 0.0 & 0.0 & 0.0 & 0.0 \\
\hline Grasses (CRP) & 25.4 & 2.0 & NA & 0.0 & 50.8 & 0.0 & 25.4 \\
\hline Trees (CRP) & 2.2 & 2.0 & NA & 0.0 & 4.4 & 0.0 & 2.2 \\
\hline Environment (CRP) & 6.4 & 2.0 & NA & 0.0 & 12.7 & 0.0 & 0.0 \\
\hline Unaccounted & 3.0 & 0.0 & NA & 0.0 & 0.0 & 0.0 & 0.0 \\
\hline Pasture & 67.5 & 1.5 & NA & 0.0 & 101.3 & 0.0 & 0.0 \\
\hline Wood fiber & 0.1 & 0.0 & 6.0 & 2.0 & 0.8 & 0.2 & 0.2 \\
\hline Perennials & 0.0 & 0.0 & 0.0 & 0.0 & 0.0 & 0.0 & 0.0 \\
\hline Manure & NA & NA & NA & NA & NA & 68.0 & 43.5 \\
\hline Fats \& greases & NA & NA & NA & NA & NA & 5.0 & 2.0 \\
\hline MSW & NA & NA & NA & NA & NA & NA & 29.4 \\
\hline Totals & 448.2 & & & & 1490.3 & 693.9 & 423.1 \\
\hline
\end{tabular}

Source:

Selected columns from Table B.3 (page 56) of Perlack, R.D., Wright L.L., Turhollow, A.F., Graham, R.L., Stokes, B.H., and Erbach, DC 2005. Biomass as Feedstock For a Bioenergy and Bioproducts Industry: The Technical Feasibility of a Billion-Ton Annual Supply. DOE/GO-102005-2135 also ORNL/TM-2005/66. A joint U.S. Department of Energy and U.S. Department of Agriculture report available online at: http://www.eere.energy.gov/biomass/publications.html. The Perlack et al. numbers were based on USDA's 2001 Agricultural Statistics.

Notes: Some totals may differ slightly from the original source due to rounding differences.

MSW=Municipal Solid Waste.

The scenario is not a modeled prediction - it shows a possible outcome with yield and acreage changes. 
Table 1.8 (Continued)

Scenario Estimate of Collectable Biomass Assuming Yield Changes

25\% Crop Yield Increases - No Perennial Energy Crops

Collectable biomass includes starches and oils as well as lignocellulosic materials. NA $=$ Not Available.

Crop acres harvested estimates reflect USDA numbers projected for 2014.

Recent publications (e.g., Wilhelm et. al.) suggest soil carbon considerations may limit sustainably collectable agricultural residues below the numbers calculated.

\section{Recommended Additional Reading:}

(1) R.L. Graham, R. Nelson, J. Sheehan, R.D. Perlack and L.L. Wright. Current and Potential U.S. Corn Stover Supplies. Agron. J. 99:1-11 (2007)

(2) W.W. Wilhelm, J.M.F. Johnson, D.L. Karlen, and D.T. Lightle. Corn Stover to Sustain Soil Organic Carbon Further Constrains Biomass Supply. Agron. J. 99:1665-1667 (2007) 
Approximately 492 million dry tons of biomass residues were produced from agricultural lands in the United States in 2001 with less than 200 million dry tons of biomass deemed sustainably collectable. The moderate yield and land use change future scenario shown below suggests that close to 600 million dry tons could be sustainably collected with moderate changes in agricultural activity and land-use changes. Assumptions included crop yield increases of up to 25\%, moderate crop management changes on water and wind erosion (such as increase in no-till acres), moderate changes in residue to grain ratios, moderate changes in the efficiency of residue collection equipment and addition of perennial energy crops to the agricultural landscape on Conservation Reserve Program (CRP) land and pasture land.

Table 1.9

Scenario Estimate of Collectable Biomass Assuming Moderate Yield and Land Use Changes 25\% Crop Yield Increases - Plus Perennial Energy Crops

\begin{tabular}{|c|c|c|c|c|c|c|c|}
\hline \multirow[t]{2}{*}{ Crop } & $\begin{array}{c}\text { Acres } \\
\text { harvested or } \\
\text { reserved }\end{array}$ & $\begin{array}{c}\text { Crop } \\
\text { Product } \\
\text { Yield }\end{array}$ & Fiber Yield & $\begin{array}{l}\text { Residue } \\
\text { Yield }\end{array}$ & $\begin{array}{c}\text { Total } \\
\text { cropland } \\
\text { plant mass }\end{array}$ & $\begin{array}{c}\text { Total residue } \\
\text { produced }\end{array}$ & $\begin{array}{l}\text { Estimate of } \\
\text { Collectable } \\
\text { Biomass* }\end{array}$ \\
\hline & million acres & \multicolumn{3}{|c|}{ dry tons/acre/year } & \multicolumn{3}{|c|}{ million dry tons/year } \\
\hline Corn & 76.6 & $\overline{4.1}$ & $\overline{\mathrm{NA}}$ & 4.1 & 626.2 & 313.1 & 225.2 \\
\hline Sorghum & 6.8 & 1.7 & NA & 1.7 & 22.8 & 11.4 & 3.1 \\
\hline Barley & 3.7 & 1.5 & NA & 2.2 & 13.8 & 8.3 & 3.4 \\
\hline Oats & 1.6 & 0.9 & NA & 1.9 & 4.5 & 3.0 & 0.7 \\
\hline Wheat-winter & 33.3 & 1.4 & NA & 2.3 & 121.8 & 76.7 & 27.4 \\
\hline Wheat-spring & 19.0 & 1.1 & NA & 1.4 & 46.3 & 26.2 & 4.5 \\
\hline Soybeans & 71.4 & 1.2 & NA & 1.8 & 255.9 & 170.6 & 15.3 \\
\hline Rice & 3.4 & 3.4 & NA & 5.1 & 28.5 & 17.1 & 10.3 \\
\hline Cotton lint & 12.3 & 0.4 & NA & 1.1 & 18.4 & 13.8 & 5.5 \\
\hline Alfalfa & 23.8 & 3.4 & NA & 0.0 & 81.2 & 0.0 & 0.0 \\
\hline Other hay & 34.2 & 2.0 & NA & 0.0 & 66.8 & 0.0 & 0.0 \\
\hline Silage corn & 6.1 & 7.6 & NA & 0.0 & 46.9 & 0.0 & 0.0 \\
\hline Silage sorghum & 0.3 & 5.1 & NA & 0.0 & 1.7 & 0.0 & 0.0 \\
\hline Other Crops & 20.1 & 1.2 & NA & 1.2 & 23.1 & 23.1 & 22.8 \\
\hline Double Crops & & & & & & & 12.0 \\
\hline Crop failure & 10.0 & 0.5 & NA & 0.0 & 5.0 & 0.0 & 12.0 \\
\hline Summer fallow & 16.0 & 0.0 & NA & 0.0 & 0.0 & 0.0 & 0.0 \\
\hline Grasses (CRP) & 15.4 & 2.0 & NA & 0.0 & 30.8 & 0.0 & 15.4 \\
\hline Trees (CRP) & 2.2 & 2.0 & NA & 0.0 & 4.4 & 0.0 & 2.2 \\
\hline Environment (CRP) & 6.4 & 2.0 & NA & 0.0 & 12.7 & 0.0 & 0.0 \\
\hline Unaccounted & 3.0 & 0.0 & NA & 0.0 & 0.0 & 0.0 & 0.0 \\
\hline Pasture & 42.5 & 1.5 & NA & 0.0 & 63.8 & 0.0 & 0.0 \\
\hline Wood fiber & 5.1 & 0.0 & 6.0 & 2.0 & 40.8 & 10.2 & 0.2 \\
\hline Perennials & 35.0 & 0.4 & 0.0 & 0.0 & 175.0 & 162.8 & 146.5 \\
\hline Manure & NA & NA & NA & NA & NA & 68.0 & 43.5 \\
\hline Fats \& greases & NA & NA & NA & NA & NA & 5.0 & 2.0 \\
\hline MSW & NA & NA & NA & NA & NA & NA & 29.4 \\
\hline Totals & 448.2 & & & & $1,690.4$ & 909.3 & 581.4 \\
\hline
\end{tabular}

Source:

Selected columns from Table B.5 (page 58) of Perlack, R.D., Wright L.L., Turhollow, A.F., Graham, R.L., Stokes, B.H., and Erbach, DC 2005. Biomass as Feedstock For a Bioenergy and Bioproducts Industry: The Technical Feasibility of a Billion-Ton Annual Supply. DOE/GO-102005-2135 also ORNL/TM-2005/66. A joint U.S. Department of Energy and U.S. Department of Agriculture report available online at: http://www.eere.energy.gov/biomass/publications.html. (scroll down to feedstocks)

Notes: Some totals may differ slightly from the original source due to rounding differences.

MSW=Municipal Solid Waste.

Biomass Energy Data Book: Edition 2 -- DRAFT 
Table 1.9 (Continued)

Scenario Estimate of Collectable Biomass Assuming Moderate Yield and Land Use Changes 25\% Crop Yield Increases - Plus Perennial Energy Crops

The scenario is not a modeled prediction - it shows a possible outcome with yield and land-use changes.

Collectable biomass includes starches and oils as well as lignocellulosic materials. NA $=$ not available

Crop acres harvested estimates reflect USDA predictions for 2014 modified by scenario assumptions of possible land-use change opportunities.

Recent publications (e.g., Wilhelm et. al.) suggest soil carbon considerations may limit sustainably collectable agricultural residues below the numbers calculated.

Recommended Additional Reading:

(1) R.L. Graham, R. Nelson, J. Sheehan, R.D. Perlack and L.L. Wright. Current and Potential U.S. Corn Stover Supplies. Agron. J. 99:1-11 (2007)

(2) W.W. Wilhelm, J.M.F. Johnson, D.L. Karlen, and D.T. Lightle. Corn Stover to Sustain Soil Organic Carbon Further Constrains Biomass Supply. Agron. J. 99:1665-1667 (2007) 
Approximately 492 million dry tons of biomass residues were produced from agricultural lands in the United States in 2001 with less than 200 million dry tons of biomass deemed sustainably collectable. The high yield, high change future scenario shown below suggests that close to 1 billion dry tons of biomass could be sustainably collected with major changes in crop genetic potential and land-use changes. Assumptions include crop yield increases of up to 50\%, major crop management changes on water and wind erosion resulting from all crop acres in no-till management, major changes in residue to grain ratios, major changes in the efficiency of residue collection equipment and addition of 55 million acres of highyield perennial energy crops to the agricultural landscape on Conservation Reserve Program (CRP) land, pasture land and marginal cropland.

Table 1.10

Scenario Estimate of Collectable Biomass Assuming High Yields and Major Land Use Changes $50 \%$ Crop Yield Increases, Soybean changes, Perennial Energy Crops on 55 Million Acres

\begin{tabular}{|c|c|c|c|c|c|c|c|}
\hline \multirow[t]{2}{*}{ Crop } & $\begin{array}{c}\text { Acres } \\
\text { harvested or } \\
\text { reserved }\end{array}$ & $\begin{array}{c}\text { Crop } \\
\text { Product } \\
\text { Yield }\end{array}$ & Fiber Yield & $\begin{array}{c}\text { Residue } \\
\text { Yield }\end{array}$ & $\begin{array}{c}\text { Total } \\
\text { cropland } \\
\text { plant mass }\end{array}$ & $\begin{array}{c}\text { Total } \\
\text { residue } \\
\text { produced }\end{array}$ & $\begin{array}{c}\text { Estimate of } \\
\text { Collectable } \\
\text { Biomass }\end{array}$ \\
\hline & million acres & \multicolumn{3}{|c|}{ dry tons/acre/year } & \multicolumn{3}{|c|}{ million dry tons/year } \\
\hline Corn & 76.6 & 4.9 & $\mathrm{NA}$ & 4.9 & 751.4 & 375.7 & 343.2 \\
\hline Sorghum & 6.8 & 1.9 & NA & 1.9 & 25.9 & 12.9 & 6.8 \\
\hline Barley & 3.7 & 1.7 & NA & 2.6 & 16.0 & 9.6 & 6.6 \\
\hline Oats & 1.6 & 1.0 & NA & 2.1 & 5.0 & 3.3 & 1.2 \\
\hline Wheat-winter & 30.3 & 1.6 & NA & 2.7 & 128.3 & 80.8 & 40.9 \\
\hline Wheat-spring & 17.0 & 1.2 & NA & 1.6 & 48.0 & 27.1 & 10.9 \\
\hline Soybeans & 63.4 & 1.3 & NA & 2.6 & 247.4 & 164.9 & 47.9 \\
\hline Rice & 3.4 & 3.9 & NA & 5.8 & 32.6 & 19.6 & 14.7 \\
\hline Cotton lint & 12.3 & 0.4 & NA & 1.2 & 19.9 & 14.9 & 8.9 \\
\hline Alfalfa & 23.8 & 3.9 & NA & 0.0 & 91.8 & 0.0 & 0.0 \\
\hline Other hay & 29.2 & 2.2 & NA & 0.0 & 64.5 & 0.0 & 0.0 \\
\hline Silage corn & 6.1 & 8.6 & NA & 0.0 & 53.1 & 0.0 & 0.0 \\
\hline Silage sorghum & 0.3 & 5.8 & NA & 0.0 & 1.9 & 0.0 & 0.0 \\
\hline Other Crops & 20.1 & 1.3 & NA & 1.3 & 26.1 & 26.1 & 27.5 \\
\hline Double Crops & & & & & & & 19.0 \\
\hline Crop failure & 8.0 & 0.5 & NA & 0.0 & 4.0 & 0.0 & 0.0 \\
\hline Summer fallow & 16.0 & 0.0 & NA & 0.0 & 0.0 & 0.0 & 0.0 \\
\hline Grasses (CRP) & 15.4 & 2.0 & NA & 0.0 & 30.8 & 0.0 & 15.4 \\
\hline Trees (CRP) & 2.2 & 2.0 & NA & 0.0 & 4.4 & 0.0 & 2.2 \\
\hline Environment (CRP) & 6.4 & 2.0 & NA & 0.0 & 12.7 & 0.0 & 0.0 \\
\hline Unaccounted & 3.0 & 0.0 & NA & 0.0 & 0.0 & 0.0 & 0.0 \\
\hline Pasture & 42.5 & 1.5 & NA & 0.0 & 63.8 & 0.0 & 0.0 \\
\hline Wood fiber & 5.1 & 0.0 & 6.0 & 2.0 & 40.8 & 10.2 & 9.2 \\
\hline Perennials & 55.0 & 0.6 & 0.0 & 7.4 & 440.0 & 409.2 & 368.3 \\
\hline Manure & NA & NA & NA & NA & NA & 68.0 & 43.5 \\
\hline Fats \& greases & NA & NA & NA & NA & NA & 5.0 & 2.0 \\
\hline MSW & $\mathrm{NA}$ & NA & NA & NA & NA & & 29.4 \\
\hline Totals & 448.2 & & & & 2108.4 & 1227.3 & 997.6 \\
\hline
\end{tabular}

Source:

Selected columns from Table B.5 (page 58) of Perlack, R.D., Wright L.L., Turhollow, A.F., Graham, R.L., Stokes, B.H., and Erbach, DC 2005. Biomass as Feedstock for a Bioenergy and Bioproducts Industry: The Technical Feasibility of a Billion-Ton Annual Supply. DOE/GO-102005-2135 also ORNL/TM-2005/66. A joint U.S. Department of Energy and U.S. Department of Agriculture report available online at: http://www1.eere.energy.gov/biomass/publications.html. The Perlack et al. numbers were based on USDA's 2001 Agricultural Statistics.

Notes: Some totals may differ slightly from the original source due to rounding differences. MSW=Municipal Solid Waste 
Table 1.10 (Continued)

Scenario Estimate of Collectable Biomass Assuming High Yields and Major Land Use Changes $50 \%$ Crop Yield Increases, Soybean changes, Perennial Energy Crops on 55 Million Acres

The scenario is not a modeled prediction - it shows a possible outcome with yield and land-use changes.

Collectable biomass includes starches and oils as well as lignocellulosic materials; NA $=$ Not Available

Crop acres harvested estimates reflect USDA predictions for 2014 modified by scenario assumptions of possible land-use change opportunities.

Recent publications (e.g., Wilhelm et. al.) suggest soil carbon considerations may limit sustainably collectable agricultural residues below the numbers calculated.

Recommended Additional Reading:

(1) R.L. Graham, R. Nelson, J. Sheehan, R.D. Perlack and L.L. Wright. Current and Potential U.S. Corn Stover Supplies. Agron. J. 99:1-11 (2007)

(2) W.W. Wilhelm, J.M.F. Johnson, D.L. Karlen, and D.T. Lightle. Corn Stover to Sustain Soil Organic Carbon Further Constrains Biomass Supply. Agron. J. 99:1665-1667 (2007) 
The United States has a total land area in all 50 states of 2.263 billion acres. Based on the 2002 land use inventory, $20 \%$ of that land was categorized as cropland and $29 \%$ as forest-use land, thus about $49 \%$ of U.S. land is a potential source of biomass residuals or biomass crops for bioenergy. Grassland pasture and range land is, for the most part, too dry to provide much biomass resources. Miscellaneous, special use land and urban land may be a source of post-consumer biomass residuals, but are not areas where biomass crops could be produced on a large scale.

Figure 1.2

Major Uses of Land in the United States, 2002

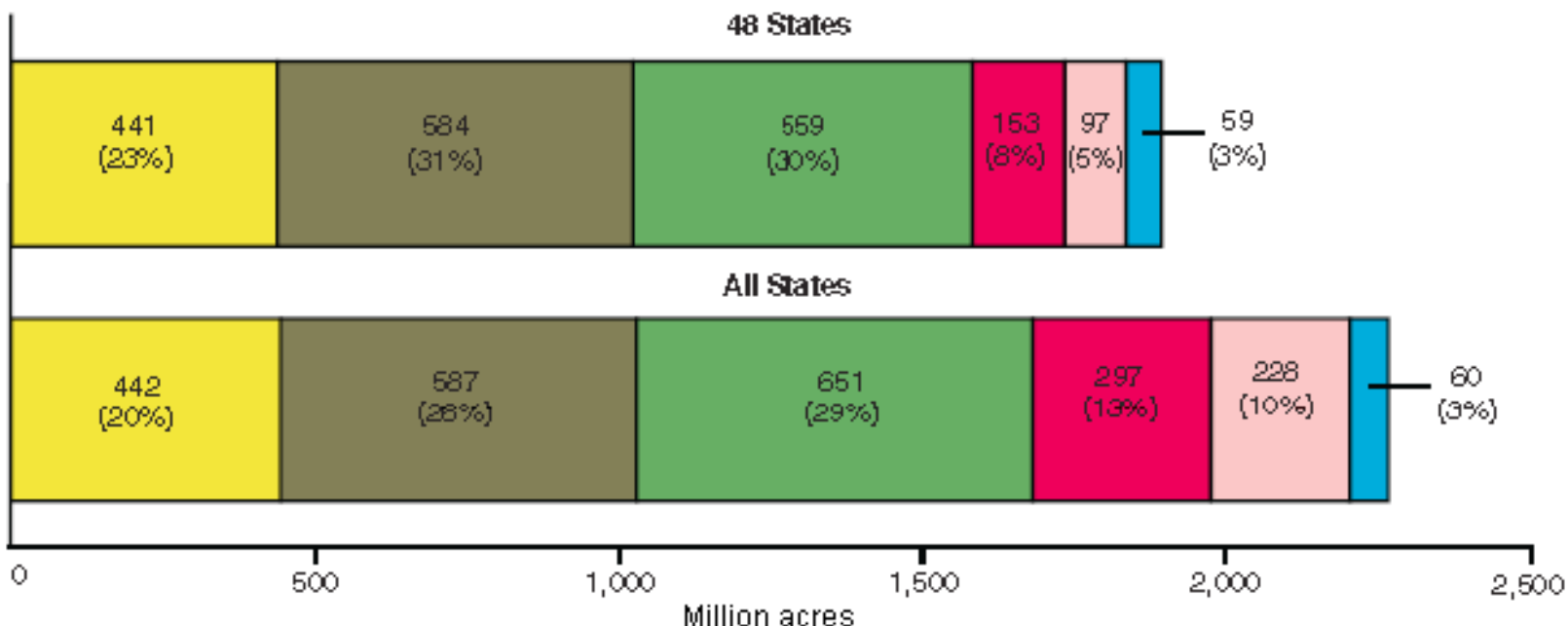

$\square$ Cropland

Grassland, pasture, and range
Forest-use land

Special uses
Miscellaneous land

Urban land

U.S. land use categories differ slightly depending on who is reporting the results. The numbers below published in 2006, but based on a 2002 land inventory, were generated by the Economic Research Service (ERS) of USDA. They have been producing similar estimates since 1945. Other USDA organizations, the Natural Resources Conservation Service (NRCS) and the Forest Service (FS) place land into somewhat different categories. URL's for NRCS and FS estimates are given below. The NRCS divides the land into additional sub-categories (such as a "Federal land" category), and only gives values for the lower 48 states. The Forest Service documents only deal with forest land, but include a larger area of the U.S. in that category (747 million acres based on 1997 inventory data). However, ERS in a 2002 publication on land use stated that 105 million acres in the special uses category overlaps with forestland. If that area is added to the ERS forestland category then it nearly matches the NRCS forest land use estimate. Definitions of the ERS land use categories follow. NRCS and FS land use references can be found at: www.nrcs.usda.gov/technical/nri02/landuse.pdf and by searching for publications by Alig at: www.treesearch.fs.fed.us/pubs.

\section{Source:}

Lubowski, R.N., Vesterby, M., Bucholtz, S., Baez, A., Roberts, M.J. 2006. "Major Uses of Land in the United States, 2002," USDA Economic Research Service, Economic Information Bulletin Number 14, May 2006. www.ers.usda.gov/publications/eib14. 
Figure 1.2 (Continued)

Major Uses of Land in the United States, 2002

Notes: Cropland: All land in the crop rotation, including cropland used for crops, land with crop failure, summer fallow, idle cropland (including Conservation Reserve Program land), and cropland used only for pasture. Cropland in Alaska and Hawaii total less than 0.4 million acres.

Grassland pasture and range: Permanent grassland and other nonforested pasture and range.

Forest-use land: Total forest land as classified by the U.S. Forest Service includes grazed forest land (134 million acres) as well as other forest land (517 million acres). It does not include land in the special uses category that is forested. This category includes a small amount of rural residential area within forested areas.

Special Uses: This land includes recreation and wildlife areas, national defense areas, and land used for rural highways, roads and railroad rights-of-way, and rural airports. It also includes 11 million acres for farmsteads and farm roads.

Miscellaneous land: This includes tundra, deserts, bare rock areas, snow and ice fields, swamps, marshes, and other unclassified areas generally of low agricultural value.

Urban land: Urban lands are newly separated from special use lands in the 2006 Major Land Uses report prepared by ERS. Urban areas are based on Census Bureau definitions which identify "urban clusters" based primarily on population density, not political boundaries. 
Current commodity crop locations are good indicators of where biomass resources can be cultivated.

Figure 1.3

Geographic Locations of Major Crops, 2007

(Yield per harvested acre by county)
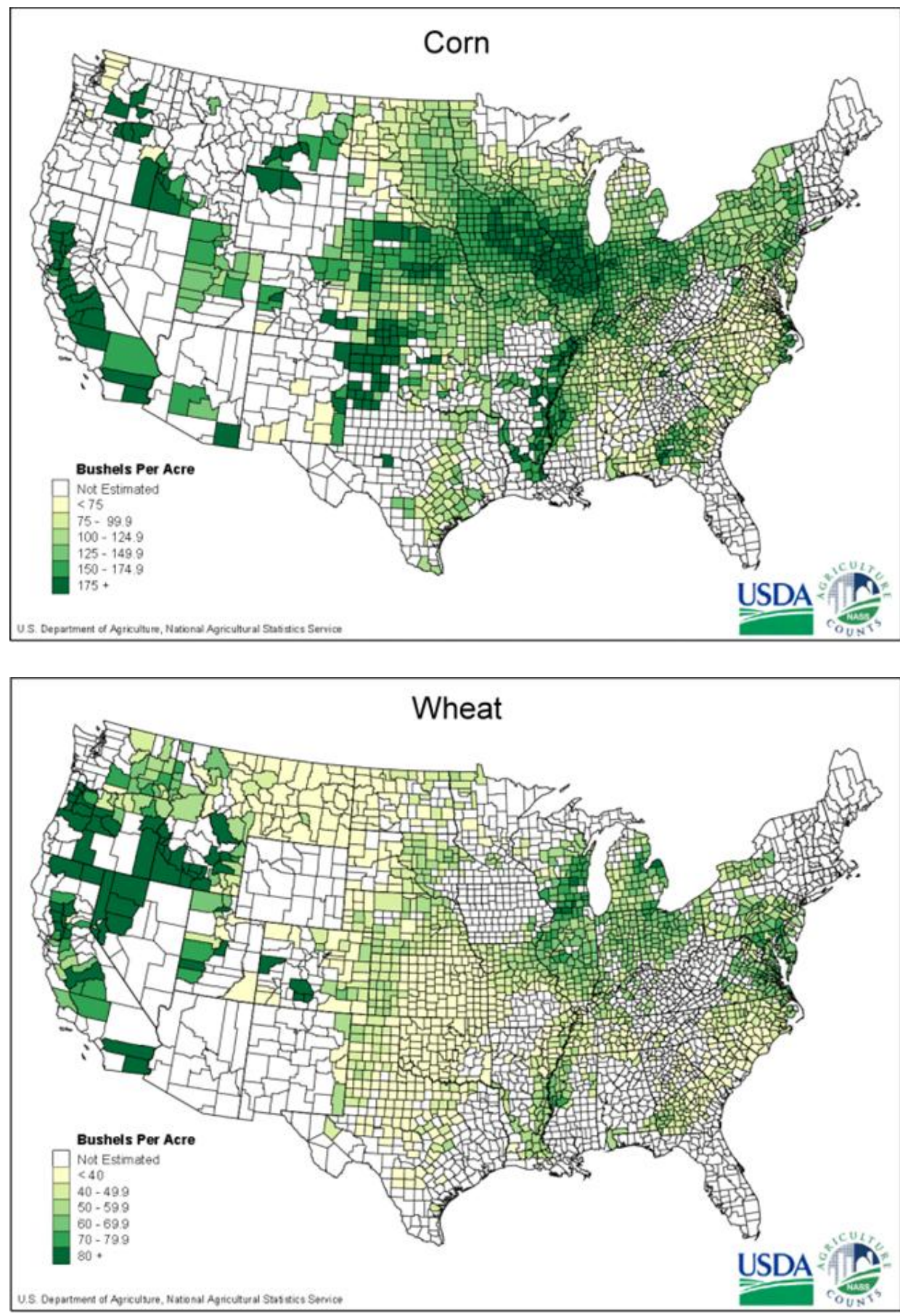
Figure 1.3 (Continued)

Geographic Locations of Major Crops, 2007

(Yield per harvested acre by county)
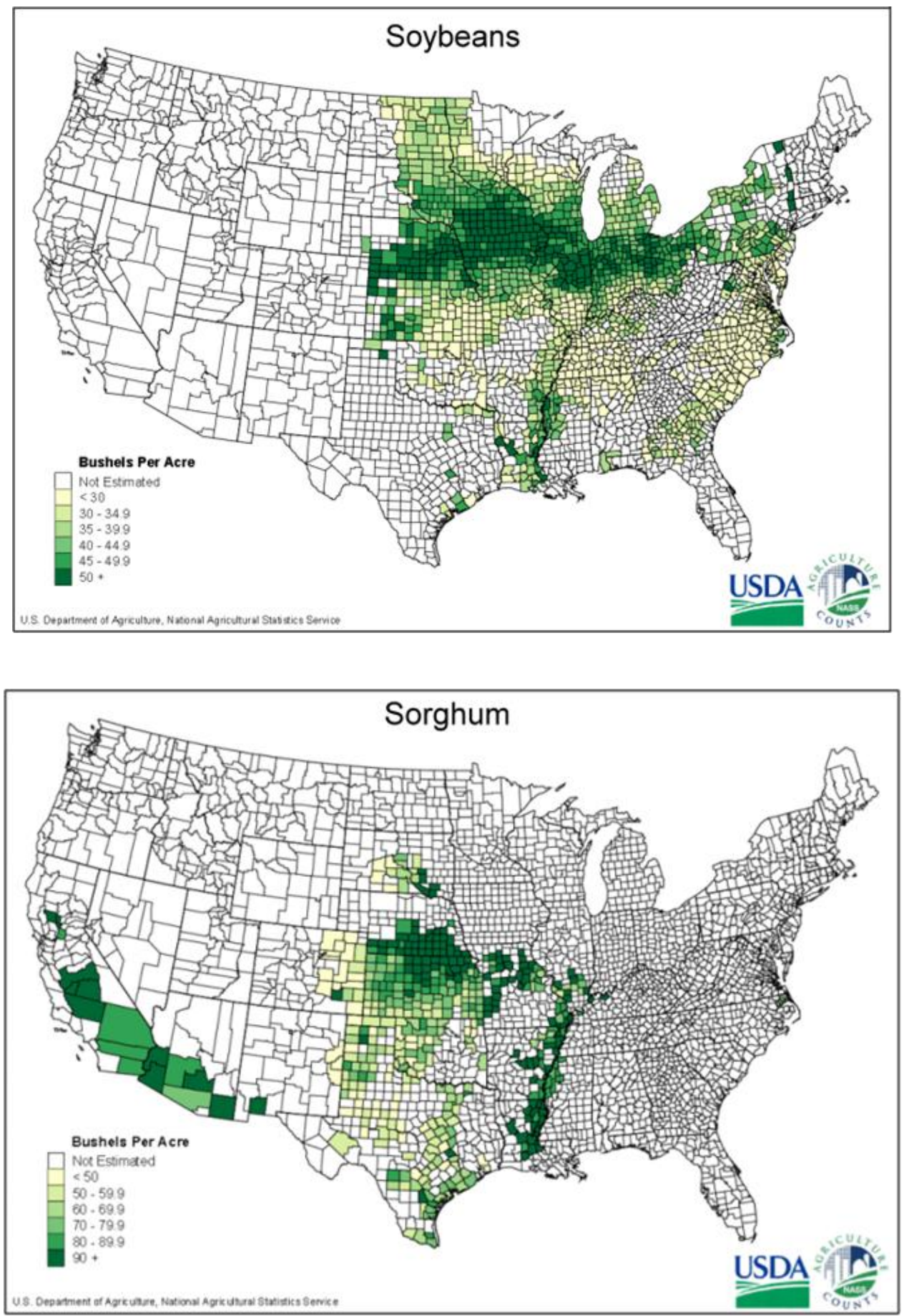

Source:

U.S. Department of Agriculture, National Agricultural Statistics Service. http://www.nass.usda.gov/Charts and Maps/A to Z/index.asp\#h . 
In 2004 biomass derived from forestlands contributed about 142 million dry tons to the total annual consumption of biomass (190 million dry tons). Based on assumptions outlined in a joint DOE and USDA analysis published in 2005 (Perlack et. al.), the amount of forestland-derived biomass that could be sustainably produced is approximately 368 million dry tons annually - more than 2.5 times the 2004 consumption level. The categories of the forest resource summarized below include wood that is already being used as well as available but unexploited resources, and new resources that could become available in the future due to additional acres of forestland, enhanced growth due to better management, or more efficient handling and utilization of existing resources.

Figure 1.4

Summary of Potentially Available Forest Resources

(FIGURE WILL BE UPDATED)

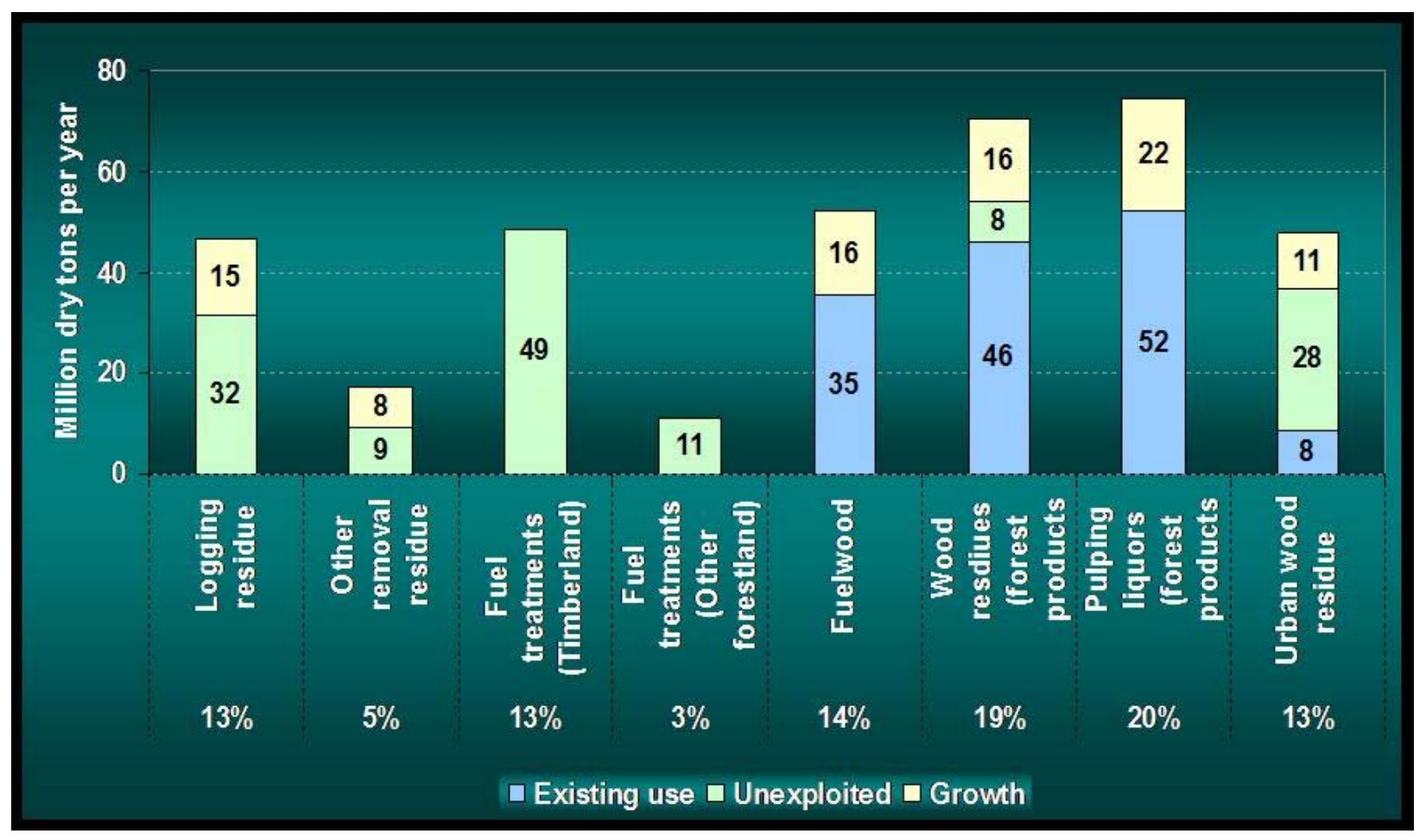

\section{Source:}

Perlack, R.D., Wright L.L., Turhollow, A.F., Graham, R.L., Stokes, B.H., and Erbach, DC 2005. Biomass as Feedstock for a Bioenergy and Bioproducts Industry: The Technical Feasibility of a Billion-Ton Annual Supply. DOE/GO-102005-2135 also ORNL/TM-2005/66. A joint U.S. Department of Energy and U.S. Department of Agriculture report available online at:

http:/www1.eere.energy.gov/biomass/publications.html 


\title{
FUTURE ENERGY CROP SUPPLY POTENTIAL-CELLULOSIC BIOMASS
}

\author{
"Woodchips, Stalks, and Switchgrass" - Cellulosic Biomass:
}

Cellulosic feedstocks such as switchgrass first came to the attention of many in America when President Bush spoke in his January 31, 2006, State of the Union address of producing biofuels by 2012 using "woodchips, stalks and switchgrass" as the source of cellulosic biomass for producing ethanol. The President also put forward the advanced energy initiative which supported a $22 \%$ increase in cleanenergy research and set a goal of replacing $75 \%$ of the oil imports from the Middle-east by 2025 . The 2007 State of the Union address re-enforced the concept of using cellulosic biomass for producing ethanol. The president ramped up the goals for alternative fuel use by proposing that the U.S. reduce gasoline consumption by $20 \%$ in ten years.

The legislation that was passed in 2007 to support the President's goals, the Energy Independence and Security Act (EISA) of 2007 (H.R. 6), established Renewable Fuel Standards that will require, by 2022, very large supplies of cellulosic biomass in addition to the grains and oils already being used. The potential exists in the U.S. for large supplies since cellulosic biomass can include everything from primary biomass sources of energy crops and forest thinnings or residuals harvested or collected directly from the land, to secondary biomass sources such as sawmill residuals, to tertiary biomass sources of postconsumer residuals that often end up in landfills. Biomass resources also include the gases that result from anaerobic digestion of animal manures or organic materials in landfills.

The estimated potential future availability of agricultural and forestry biomass in the U.S. was reported in 2005 in a joint DOE and USDA document entitled "Biomass as Feedstock For a Bioenergy and Bioproducts Industry: The Technical Feasibility of a Billion-Ton Annual Supply;" A summary table from that report indicates a technical availability of less than 200 million dry tons from the agriculture sector with yields, collection technology and crop management approaches in place in 2001. However scenarios of possible future changes in crop genetic potential, crop management and harvest technology, and in use of perennial energy crops (such as switchgrass) suggests that either about 400 million, 600 million or nearly 1 billion dry tons could be technically derived from the agricultural sector. Details on individual crops are provided in the Feedstocks Section of the Biomass Energy Data Book. The ultimate limit for the amount of biomass that can be sustainably produced on agricultural land in the United States depends on land availability. The areas of the country with adequate rainfall and soil quality for production and harvest of energy crops are roughly the same areas where major crops are currently produced in the United States. The major crops (especially corn) are the primary source of lignocellulosic biomass from the agricultural sector. Changes in the way that land is managed will be necessary for increasing biomass resource availability in the U.S. An update of the biomass supply assessment is currently underway including consideration of economic constraints. The current summary tables will be replaced with updated information when they become available.

One of the larger unexploited sources of cellulosic biomass is wood that needs to be removed from forests to reduce the risk of forest fires. Well over 8 billion dry tons of biomass has been identified by the U.S. Forest Service as needing fuel treatment removal (Perlack et. al., 2005). The amount of this biomass potentially available for bioenergy uses is estimated to be about 60 million dry tons annually. This estimate takes into consideration factors affecting forest access, residue recovery and the desirability of using some of the recoverable biomass for conventional wood products. The fraction that could be available annually for bioenergy and bioproducts is less than $1 \%$ of the total size of the fuel treatment biomass resource. The other large underutilized sources of woodchips are logging residues and urban wood residues. In the case of forest biomass, the relatively high costs of removal, handling, and transportation have not, in the past, compared favorably to their relatively low value as bioenergy resources. Factors affecting the rate at which this source of material will become available for bioenergy includes public opinion toward this type of removal, as well as delivered costs and the extent to which technology is developed for utilizing small diameter wood for products other than bioenergy. The compost market already competes for urban wood resources. 
A factor that could greatly affect the amount of wood used for bioenergy, especially of forest fuel treatment removals, is that the definition of "renewable biomass" in EISA 2007 does not include thinnings and residues from federal forests, and some woody feedstocks from private forests except where that biomass is "obtained from the immediate vicinity of buildings, and other areas regularly occupied by people, or of public infrastructure, at risk from wildfire." While the legislation does not prohibit the use of forest thinnings and fuel reduction treatments from federal forests for bioenergy or bioproducts, it does exclude them from qualifying as feedstocks suitable for meeting the Renewable Fuel Standard targets in EISA 2007. Bills were introduced in both the Senate (S. 2558) and House (H.R. 5236) in an attempt to revise the definitions to include sustainably collected fuel reduction treatments from federal forestlands. Those bills have been referred to committees.

The Biomass Research and Development Technical Advisory Committee has provided numerous recommendations to DOE, USDA and other Federal Agencies on the research and development needed to ensure that a broad portfolio of diverse domestic feedstocks is available for our nation's energy and chemical supplies. The Executive Summary of The Roadmap for Bioenergy and Biobased Products in the U.S. states that significant research breakthroughs are needed in a number of key area including advances in plant science to improve the cost effectiveness of converting biomass to fuel, power, and products. Additionally, it recommends that R\&D in geographical information systems will help the U.S. more accurately identify biomass availability. Finally, it recommends a focus on advancements in harvesting methods for both agricultural and forest resources. Additionally, the report Increasing Feedstock Production for Biofuels: Economic Drivers, Environmental Implications, and the Role of Research was released in 2008.

\section{Sources:}

The White House. 2007 and 2008 State of the Union addresses. http://www.whitehouse.gov/news

The Energy Independence and Security Act of 2007 (H.R.6); final version: http://thomas.loc.gov/cgibin/query/z?c110:H.R.6

Perlack, R.D., Wright L.L., Turhollow, A.F., Graham, R.L., Stokes, B.H., and Erbach, DC 2005. Biomass as Feedstock for a Bioenergy and Bioproducts Industry: The Technical Feasibility of a Billion-Ton Annual Supply. DOE/GO-102005-2135 also ORNL/TM-2005/66. A joint U.S. Department of Energy and U.S. Department of Agriculture report available online at: http://www1.eere.energy.gov/biomass/publications.html

Biomass Research and Development Technical Advisory Committee. The Roadmap for Bioenergy and Biobased Products in the Unites States, October 2007. At: http://www1.eere.energy.gov/biomass/pdfs/obp roadmapv2 web.pdf

Biomass Research and Development Technical Advisory Committee. Increasing Feedstock Production for Biofuels: Economic Drivers, Environmental Implications, and the Role of Research, 2008. Available at: $\underline{\text { http://www.brdisolutions.com }}$ 
Biomass Energy Data Book: Edition 2 -- DRAFT 


\section{BIOFUELS}

\section{BRIEF OVERVIEW}

A variety of fuels can be produced from biomass resources including liquid fuels, such as, ethanol, methanol, biodiesel, Fischer-Tropsch diesel and gasoline, and gaseous fuels, such as hydrogen and methane. Biofuels are primarily used to fuel vehicles, but can also fuel engines or fuel cells for electricity generation.

\section{FUELS}

\section{Ethanol}

Ethanol is most commonly made by converting the carbohydrate from biomass into sugar, which is then converted into ethanol in a fermentation process similar to brewing beer. Ethanol is the most widely used biofuel today with 2008 capacity expected to be 12 billion gallons per year based on starch crops, such as corn. Ethanol produced from cellulosic biomass is currently the subject of extensive research, development and demonstration efforts.

\section{Biodiesel}

Biodiesel is produced through a process in which organically derived oils are combined with alcohol (ethanol or methanol) in the presence of a catalyst to form ethyl or methyl ester. The biomass-derived ethyl or methyl esters can be blended with conventional diesel fuel or used as a neat fuel $(100 \%$ biodiesel). Biodiesel can be made from any vegetable oil, animal fats, waste vegetable oils, or microalgae oils. Soybeans and Canola (rapeseed) oils are the most common vegetable oils used today.

\section{Bio-oil}

A totally different process than that used for biodiesel production can be used to convert biomass into a type of fuel similar to diesel which is known as bio-oil. The process, called fast or flash pyrolysis, occurs when heating compact solid fuels at temperatures between 350 and 500 degrees Celsius for a very short period of time (less than 2 seconds). While there are several fast pyrolysis technologies under development, there are only two commercial fast pyrolysis technologies as of 2008. The bio-oils currently produced are suitable for use in boilers for electricity generation. There is currently ongoing research and development to produce bio-oil of sufficient quality for transportation applications.

\section{Other Hydrocarbon Biofuels}

Biomass can be gasified to produce a synthesis gas composed primarily of hydrogen and carbon monoxide, also called syngas or biosyngas. Syngas produced today is used directly to generate heat and power but several types of biofuels may be derived from syngas. Hydrogen can be recovered from this syngas, or it can be catalytically converted to methanol or ethanol. The gas can also be run through a biological reactor to produce ethanol or can also be converted using Fischer-Tropsch catalyst into a liquid stream with properties similar to diesel fuel, called Fischer-Tropsch diesel. However, all of these fuels can also be produced from natural gas using a similar process.

A wide range of single molecule biofuels or fuel additives can be made from lignocellulosic biomass. Such production has the advantage of being chemically essentially the same as petroleum-based fuels. Thus modifications to existing engines and fuel distribution infrastructure are not required. Additional information on green hydrocarbon fuels can be found on the Green Hydrocarbon Biofuels page.

\section{Source:}

U.S. Department of Energy, Energy Efficiency and Renewable Energy, http://www.eere.energy.gov/RE/bio fuels.html 


\section{GREEN HYDROCARBON BIOFUELS}

A biofuel is a liquid transportation fuel made from biomass. A wide range of single molecule biofuels or fuel additives can be made from lignocellulosic biomass including:

- Ethanol or ethyl alcohol

- Butanol or butyl alcohol

- Hydroxymethylfurfural (HMF) or furfural

- y-valerolactone (GVL)

- Ethyl levulinate (ELV)

The production of hydrocarbon biofuels from biomass has many advantages:

- "Green" hydrocarbon fuels are chemically essentially the same as petroleum-based fuels. Thus modifications to existing engines and fuel distribution infrastructure are not required.

- "Green" hydrocarbon fuels are energy equivalent to petroleum-based fuels, thus no mileage penalty is encountered from their use.

- "Green" hydrocarbon fuels are immiscible in water. This allows the biofuels to self-separate from water which eliminates the high cost associated with water separation by distillation.

- "Green" hydrocarbon fuels are produced at high temperatures, which translates into faster reactions and smaller reactors. This allows for the fabrication and use of portable processing units that allow the conversion of biomass closer to the biomass source.

- The amount of water required for processing "Green" hydrocarbon fuels from biomass, if any, is minimal.

- The heterogeneous catalysts used for the production of "Green" hydrocarbon biofuels are inherently recyclable, allowing them to be used for months or years.

Additionally, "Green" gasoline or diesel biofuels, which are a mixture of compounds, can be synthesized from lignocellulosic biomass by catalytic deoxygenation. Green diesel can also be made via the catalytic deoxygenation of fatty acids derived from virgin or waste vegetable oils or animal fats.

Biofuels can be produced using either biological (e.g., yeast) or chemical catalysts with each having advantages and disadvantages (see Table 2.1). Chemical catalysts range from solid heterogeneous catalysts to homogeneous acids. As shown in Figure 2.1, most biofuel production pathways use chemical catalysts.

\section{Source:}

NSF. 2008. Breaking the Chemical and Engineering Barriers to Lignocellulosic Biofuels: Next Generation Hydrocarbon Biorefineries, Ed. George Huber. University of Massachusetts Amherst, National Science Foundation, Bioengineering, Environmental, and Transport Systems Division, Washington DC 
Table 2.1

Biological and Chemical Catalysts for Biofuels

\begin{tabular}{lll}
\hline & \multicolumn{1}{c}{ Biological Catalysts } & \multicolumn{1}{c}{ Chemical Catalysts } \\
\hline Products & Alcohols & A Wide Range of Hydrocarbon Fuels \\
\hline Reaction Conditions & Less than $70^{\circ} \mathrm{C}, 1 \mathrm{~atm}$ & $10-1200^{\circ} \mathrm{C}, 1-250$ atm \\
\hline Residence Time & $2-5$ days & 0.01 second to 1 hour \\
\hline Selectivity & $\begin{array}{l}\text { Can be tuned to be very selective } \\
\text { (greater than 95\%) }\end{array}$ & $\begin{array}{l}\text { Depends on reaction. New catalysts } \\
\text { need to be developed that are greater } \\
\text { than 95\% selective. }\end{array}$ \\
Catalyst Cost & $\begin{array}{l}\text { \$0.50/gallon ethanol (cost for cellulase } \\
\text { enzymes, and they require sugars to } \\
\text { grow) } \$ 0.04 / \text { gallon of corn ethanol }\end{array}$ & $\begin{array}{l}\text { \$0.01/gallon gasoline (cost in mature } \\
\text { petroleum industry) }\end{array}$ \\
& $\begin{array}{l}\text { Sterilize all Feeds (enzymes are being } \\
\text { developed that do not require sterilization } \\
\text { of feed) }\end{array}$ & No sterilizaton needed \\
\hline Sterilization & Not possible & Yes with Solid Catalysts \\
\hline Recyclability & $2,000-5,000$ tons/day & $100-2,000$ tons/day \\
\hline Size of Cellulosic Plant & & \\
\hline
\end{tabular}

\section{Source:}

NSF. 2008. Breaking the Chemical and Engineering Barriers to Lignocellulosic Biofuels: Next Generation Hydrocarbon Biorefineries, Ed. George Huber, University of Massachusetts Amherst, National Science Foundation, Bioengineering, Environmental, and Transport Systems Division, Washington DC. 
Figure 2.1

Diagram of Routes to Make Biofuels

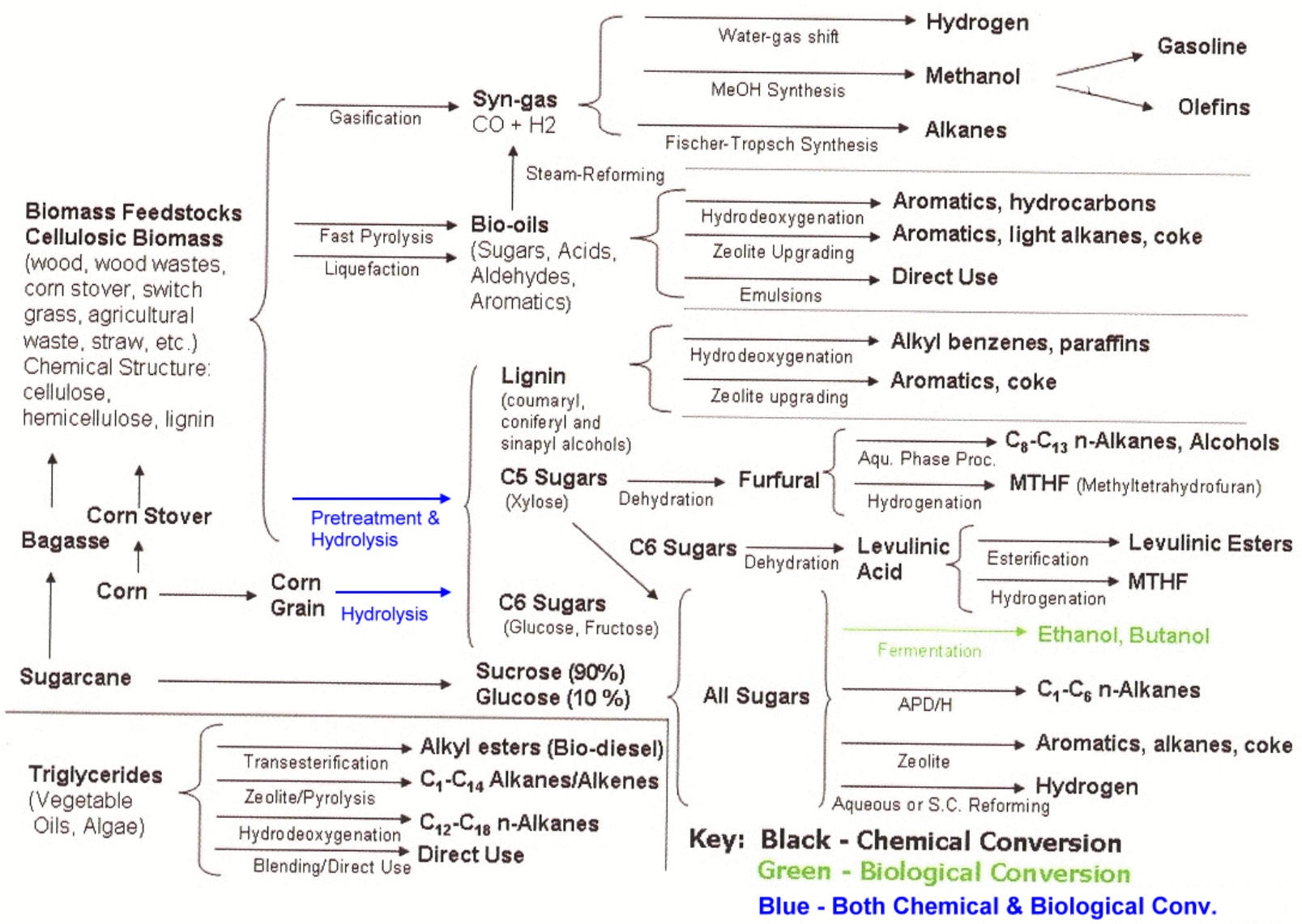

\section{Source:}

NSF. 2008. Breaking the Chemical and Engineering Barriers to Lignocellulosic Biofuels: Next Generation Hydrocarbon Biorefineries, Ed. George Huber, University of Massachusetts Amherst, National Science Foundation, Bioengineering, Environmental, and Transport Systems Division, Washington DC. 


\section{ETHANOL OVERVIEW}

There are two types of ethanol produced in the United States - fermentation ethanol and synthetic ethanol. Fermentation ethanol (or bioethanol) is produced from corn or other biomass feedstocks and is by far the most common type of ethanol produced, accounting for more than $90 \%$ of all ethanol production. Fermentation ethanol is mainly produced for fuel, though a small share is used by the beverage industry and the industrial industry. Synthetic ethanol is produced from ethylene, a petroleum by-product, and is used mainly in industrial applications. A small amount of synthetic ethanol is exported to other countries.

Ethanol is the most widely used biofuel today. In 2005, more than 3.6 billion gallons were added to gasoline in the United States to improve vehicle performance and reduce air pollution. Ethanol is currently produced using a process similar to brewing beer where starch crops are converted into sugars, the sugars are fermented into ethanol, and the ethanol is then distilled into its final form.

Ethanol is used to increase octane and improve the emissions quality of gasoline. In many areas of the United States today, ethanol is blended with gasoline to form an E10 blend (10\% ethanol and $90 \%$ gasoline), but it can be used in higher concentrations, such as E85, or in its pure form E100. All automobile manufacturers that do business in the United States approve the use of E10 in gasoline engines; however, only flex fuel vehicles (FFVs) are designed to use E85. Pure ethanol or E100 is used in Brazil but is not currently compatible with vehicles manufactured for the U.S. market. Manufacturer approval of ethanol blends is found in vehicle owners' manuals under references to refueling or gasoline.

Bioethanol from cellulosic biomass materials (such as agricultural residues, trees, and grasses) is made by first using pretreatment and hydrolysis processes to extract sugars, followed by fermentation of the sugars. Although producing bioethanol from cellulosic biomass is currently more costly than producing bioethanol from starch crops, the U.S. Government has launched a Biofuels Initiative with the objective of quickly reducing the cost of cellulosic bioethanol. Researchers are working to improve the efficiency and economics of the cellulosic bioethanol production process. When cellulosic bioethanol becomes commercially available, it will be used exactly as the bioethanol currently made from corn grain.

\section{Source:}

DOE Energy Efficiency and Renewable Energy, http://www1.eere.energy.gov/biomass/abcs biofuels.html and http://www1.eere.energy.gov/biomass/bioethanol 
Below are the primary quality specifications for denatured fuel ethanol for blending with gasoline meeting Federal requirements. The state of California has additional restrictions that apply in addition to the performance requirements in ASTM D 4806.

Table 2.2

Specifications Contained in ASTM D 4806 Standard Specification for Denatured Fuel Ethanol for Blending with Gasoline

\begin{tabular}{|c|c|c|}
\hline Property & Specification & ASTM Test Methoc \\
\hline Ethanol volume \%, min & 92.1 & D 5501 \\
\hline Methanol, volume \%. max & 0.5 & \\
\hline Solvent-washed gum, $\mathrm{mg} / 100 \mathrm{ml} \max$ & 5 & D 381 \\
\hline Water content, volume $\%$, max & 1 & E 203 \\
\hline Denaturant content, volume $\%$, min & 1.96 & \\
\hline volume $\%$, max & 4.76 & \\
\hline Inorganic Chloride content, mass ppm (mg/L) max & 40 & D 512 \\
\hline Copper content, mg/kg, max & 0.1 & D1688 \\
\hline $\begin{array}{l}\text { Acidity (as acetic acid } \mathrm{CH} 3 \mathrm{COOH}) \text {, mass percent } \\
(\mathrm{mg} / \mathrm{L}), \max \end{array}$ & 0.007 & D1613 \\
\hline $\mathrm{pHe}$ & $6.5-9.0$ & D 6423 \\
\hline Appearance & \multicolumn{2}{|c|}{$\begin{array}{l}\text { Visibly free of suspended or precipitated } \\
\text { contaminants (clear \& bright) }\end{array}$} \\
\hline
\end{tabular}

\section{Source:}

Renewable Fuels Association, Industry Guidelines, Specifications, and Procedures.

http://www.ethanolrfa.org/industry/resources/guidelines/

Note: $\mathrm{ASTM}=$ American Society for Testing and Materials 
Table 2.3

Fuel Property Comparison for Ethanol, Gasoline and No. 2 Diesel

\begin{tabular}{|c|c|c|c|}
\hline Property & Ethanol & Gasoline & No. 2 Diesel \\
\hline Chemical Formula & $\mathrm{C} 2 \mathrm{H} 5 \mathrm{OH}$ & $\mathrm{C} 4$ to $\mathrm{C} 12$ & $\mathrm{C} 3$ to $\mathrm{C} 25$ \\
\hline Molecular Weight & 46.07 & $100-105$ & $\approx 200$ \\
\hline Carbon & 52.2 & $85-88$ & $84-87$ \\
\hline Hydrogen & 13.1 & $12-15$ & $33-16$ \\
\hline Oxygen & 34.7 & 0 & 0 \\
\hline Specific gravity, $60^{\circ} \mathrm{F} / 60^{\circ} \mathrm{F}$ & 0.796 & $0.72-0.78$ & $0.81-0.89$ \\
\hline Density, lb/gal @ 60 F & 6.61 & $6.0-6.5$ & $6.7-7.4$ \\
\hline Boiling temperature, ${ }^{\circ} \mathrm{F}$ & 172 & $80-437$ & $370-650$ \\
\hline Reid vapor pressure, psi & 2.3 & $8-15$ & 0.2 \\
\hline Research octane no. & 108 & $90-100$ & -- \\
\hline Motor octane no. & 92 & $81-90$ & -- \\
\hline$(R+M) / 2$ & 100 & $86-94$ & N/A \\
\hline Cetane no.(1) & -- & $5-20$ & $40-55$ \\
\hline Fuel in water, volume $\%$ & 100 & Negligible & Negligible \\
\hline Water in fuel, volume $\%$ & 100 & Negligible & Negligible \\
\hline Freezing point, ${ }^{\circ} \mathrm{F}$ & -173.2 & -40 & $-40-30^{b}$ \\
\hline Centipoise @ 60 $\mathrm{F}$ & 1.19 & $0.37-0.44^{\mathrm{a}}$ & $2.6-4.1$ \\
\hline Flash point, closed cup, ${ }^{\circ} \mathrm{F}$ & 55 & -45 & 165 \\
\hline Autoignition temperature, ${ }^{\circ} \mathrm{F}$ & 793 & 495 & $\approx 600$ \\
\hline Lower & 4.3 & 1.4 & 1 \\
\hline Higher & 19 & 7.6 & 6 \\
\hline Btu/gal @ 60 F & 2,378 & $\approx 900$ & $\approx 700$ \\
\hline Btu/lb @ 60F & 396 & $\approx 150$ & $\approx 100$ \\
\hline Btu/lb air for stoichiometric mixture @ 60 F & 44 & $\approx 10$ & $\approx 8$ \\
\hline Higher (liquid fuel-liquid water) Btu/lb & 12,800 & $18,800-20,400$ & $19,200-20000$ \\
\hline Lower (liquid fuel-water vapor) Btu/lb & 11,500 & $18,000-19,000$ & $18,000-19,000$ \\
\hline Higher (liquid fuel-liquid water) Btu/gal & 84,100 & 124,800 & 138,700 \\
\hline Lower (liquid fuel-water vapor) Btu/gal @ 60 F & $76,000^{\mathrm{a}}$ & 115,000 & 128,400 \\
\hline Mixture in vapor state, Btu/cubic foot @ 68 F & 92.9 & 95.2 & $96.9^{c}$ \\
\hline Fuel in liquid state, Btu/lb or air & 1,280 & 1,290 & - \\
\hline Specific heat, Btu/lb ${ }^{\circ} \mathrm{F}$ & 0.57 & 0.48 & 0.43 \\
\hline Stoichiometric air/fuel, weight & 9 & $14.7^{\mathrm{a}}$ & 14.7 \\
\hline Volume \% fuel in vaporized stoichiometric mixture & 6.5 & 2 & - \\
\hline
\end{tabular}

\section{Source:}

U.S. Department of Energy, Office of Energy Efficiency and Renewable Energy, Alternative Fuels Data Center, http://www.eere.energy.gov/afdc/altfuel/fuel properties.html

\footnotetext{
${ }^{a}$ Calculated.

b Pour Point, ASTM D 97.

${ }^{c}$ Based on Cetane.
} 
The U.S. and Brazil produced about 88 percent of the world's fuel ethanol in 2007.

Table 2.4

World Fuel Ethanol Production by Country or Region, 2007

(Millions of gallons, all grades)

\begin{tabular}{lr}
\hline Country & $\mathbf{2 0 0 7}$ \\
\hline U.S. & $6,498.6$ \\
Brazil & $5,019.2$ \\
European Union & 570.3 \\
China & 486.0 \\
Canada & 211.3 \\
Thailand & 79.2 \\
Colombia & 74.9 \\
India & 52.8 \\
Central America & 39.6 \\
Australia & 26.4 \\
Turkey & 15.8 \\
Pakistan & 9.2 \\
Peru & 7.9 \\
Argentina & 5.2 \\
Paraguay & 4.7 \\
\hline Total & $\mathbf{1 3 , 1 0 1 . 1}$ \\
\hline
\end{tabular}

Source:

Renewable Fuels Association, Industry Statistics, http://www.ethanolrfa.org/industry/statistics/\#E

Note: Some countries listed in the table titled: "U.S. Fuel Ethanol Imports by Country" do not appear in this table because they process ethanol (dehydration) rather than produce it from feedstock. 
The United States imports a small percentage of ethanol from countries that are usually within relatively close geographic proximity.

Table 2.5

U.S. Fuel Ethanol Imports by Country, $2002-2007$ (Millions of gallons)

\begin{tabular}{lcccccc}
\hline Country & $\mathbf{2 0 0 2}$ & $\mathbf{2 0 0 3}$ & $\mathbf{2 0 0 4}$ & $\mathbf{2 0 0 5}$ & $\mathbf{2 0 0 6}$ & $\mathbf{2 0 0 7}$ \\
\hline Brazil & 0 & 0 & 90.3 & 31.2 & 433.7 & 188.8 \\
Costa Rica & 12 & 14.7 & 25.4 & 33.4 & 35.9 & 39.3 \\
El Salvadore & 4.5 & 6.9 & 5.7 & 23.7 & 38.5 & 73.3 \\
Jamaica & 29 & 39.3 & 36.6 & 36.3 & 66.8 & 75.2 \\
Trinadad \& Tobago & 0 & 0 & 0 & 10.0 & 24.3 & 42.7 \\
Canada & 0 & 0 & 0 & 0.0 & 0 & 5.4 \\
China & 0 & 0 & 0 & 0.0 & 0 & 4.5 \\
\hline Total & $\mathbf{4 5 . 5}$ & $\mathbf{6 0 . 9}$ & $\mathbf{1 5 8 . 0}$ & $\mathbf{1 3 4 . 6}$ & $\mathbf{5 9 9 . 2}$ & $\mathbf{4 2 9 . 2}$ \\
\hline
\end{tabular}

\section{Source:}

Renewable Fuels Association, http://www.ethanolrfa.org/industry/statistics/

Note: Some countries listed in this table do not appear in the table titled: "World Ethanol Production by Country" because they process ethanol (dehydration) rather than produce it from feedstock. 
Fuel ethanol production has been on the rise in the U.S. since 1980, though production has increased dramatically in recent years. Fuel ethanol production increased nearly 300\% between 2000 and 2007.

Table 2.6

Historic Fuel Ethanol Production, 1980-2007

\begin{tabular}{lc}
\hline Year & Millions of Gallons \\
\hline 1980 & 175 \\
1981 & 215 \\
1982 & 350 \\
1983 & 375 \\
1984 & 430 \\
1985 & 610 \\
1986 & 710 \\
1987 & 830 \\
1988 & 845 \\
1989 & 870 \\
1990 & 900 \\
1991 & 950 \\
1992 & 1,100 \\
1993 & 1,200 \\
1994 & 1,350 \\
1995 & 1,400 \\
1996 & 1,100 \\
1997 & 1,300 \\
1998 & 1,400 \\
1999 & 1,470 \\
2000 & 1,630 \\
2001 & 1,770 \\
2002 & 2,130 \\
2003 & 2,800 \\
2004 & 3,400 \\
2005 & 3,904 \\
2006 & 4,855 \\
2007 & 6,500 \\
\hline
\end{tabular}

\section{Source:}

Renewable Fuels Association, Industry Statistics, August 15, 2008, http://www.ethanolrfa.org/industry/statistics/\#E 
Between 1999 and 2007, the number of ethanol plants in the U.S. more than doubled, accompanied by a rapid rise in production capacity. Additional information on specific plant locations and up-to-date statistics can be obtained at the Renewable Fuels Association, www.ethanolrfa.org/industry/statistics/ .

Table 2.7

Ethanol Production Statistics, 1999-2007 (As of January of each year)

\begin{tabular}{|c|c|c|c|c|c|c|c|c|c|}
\hline Year & $\overline{1999}$ & 2000 & 2001 & 2002 & 2003 & 2004 & 2005 & 2006 & 2007 \\
\hline Total Ethanol Plants & 50 & 54 & 56 & 61 & 68 & 72 & 81 & 95 & 110 \\
\hline $\begin{array}{l}\text { Ethanol Production } \\
\text { Capacity (million } \\
\text { gallons per year) }\end{array}$ & $1,701.7$ & $1,748.7$ & $1,921.9$ & $2,347.3$ & $2,706.8$ & $3,100.8$ & $3,643.7$ & $4,336.4$ & $5,493.4$ \\
\hline $\begin{array}{l}\text { Plants Under } \\
\text { Construction }\end{array}$ & 5 & 6 & 6 & 13 & 11 & 15 & 16 & 31 & 76 \\
\hline $\begin{array}{l}\text { Capacity Under } \\
\text { Construction (million } \\
\text { gallons per year) }\end{array}$ & 77.0 & 91.5 & 64.7 & 390.7 & 483.0 & 598.0 & 754.0 & $1,778.0$ & $5,635.5$ \\
\hline $\begin{array}{l}\text { Farmer Owned Plants } \\
\text { Farmer Owned } \\
\text { Capacity (million } \\
\text { gallons per year) }\end{array}$ & 293.3 & 340.3 & 473.0 & 645.6 & 796.6 & $1,041.1$ & $1,388.6$ & $1,677.1$ & $1,677.1$ \\
\hline $\begin{array}{l}\text { Percent of Total } \\
\text { Capacity that is Farmer } \\
\text { Owned }\end{array}$ & $17 \%$ & $19 \%$ & $25 \%$ & $28 \%$ & $29 \%$ & $34 \%$ & $38 \%$ & $39 \%$ & $39 \%$ \\
\hline $\begin{array}{l}\text { Farmer Owned Plants } \\
\text { Under Construction }\end{array}$ & 5 & 3 & 3 & 10 & 8 & 12 & 10 & 4 & 4 \\
\hline $\begin{array}{l}\text { Farmer Owned } \\
\text { Capacity Under } \\
\text { Construction (million } \\
\text { gallons per year) }\end{array}$ & 77 & 60 & 60 & 335 & 318 & 447 & 450 & 187 & 187 \\
\hline $\begin{array}{l}\text { Percent of Total Under } \\
\text { Construction Capacity }\end{array}$ & $100 \%$ & $66 \%$ & $71 \%$ & $86 \%$ & $66 \%$ & $75 \%$ & $60 \%$ & $11 \%$ & $11 \%$ \\
\hline $\begin{array}{l}\text { States with Ethanol } \\
\text { Plants }\end{array}$ & 17 & 17 & 18 & 19 & 20 & 19 & 18 & 20 & 21 \\
\hline
\end{tabular}

\section{Source:}

Renewable Fuels Association, Table titled: "Ethanol Industry Overview," www.ethanolrfa.org/industry/statistics/ 
Although ethanol can be made from a wide variety of feedstocks, the vast majority of ethanol is made from corn. Future cellulosic production methods using grasses and woody plant material may eventually account for a sizeable share, but in the near term, corn remains the dominant feedstock.

Table 2.8

Ethanol Production by Feedstock, 2006

\begin{tabular}{lrrrr}
\hline Plant Feedstock & $\begin{array}{c}\text { Capacity (million } \\
\text { galllons/year) }\end{array}$ & $\begin{array}{l}\text { \% of Capacity } \\
\text { Corn }\end{array}$ & No. of Plants & \% of Plants \\
Corn/Milo & 4,516 & $92.7 \%$ & 85 & $83.3 \%$ \\
Corn/Wheat & 162 & $3.3 \%$ & 5 & $4.9 \%$ \\
Corn/Barley & 90 & $1.8 \%$ & 2 & $2.0 \%$ \\
Milo/Wheat & 40 & $0.8 \%$ & 1 & $1.0 \%$ \\
Waste Beverage & 40 & $0.8 \%$ & 1 & $1.0 \%$ \\
Cheese Whey $_{\text {Sugars \& Starches }}$ & 16 & $0.3 \%$ & 5 & $4.9 \%$ \\
Total & 8 & $0.2 \%$ & 2 & $2.0 \%$ \\
\hline
\end{tabular}

Source:

Environmental Protection Agency, Office of Transportation and Air Quality Renewable Fuel Standard Program - Draft Regulatory Impact Analysis, September 2006, EPA420-D-06-008.

${ }^{a}$ Includes seed corn.

${ }^{\mathrm{b}}$ Includes brewery waste. 
The great majority of ethanol production facilities operating in the United States use natural gas as their energy source.

Table 2.9

Ethanol Production by Plant Energy Source, 2006

\begin{tabular}{lrrrr}
\hline & \multicolumn{2}{c}{ Capacity } & & \\
Energy Source & MMGal/year & \% of Capacity & No. of Plants & \% of Plants \\
\hline Natural Gas ${ }^{\mathrm{a}}$ & 4,671 & $95.9 \%$ & 98 & $96.1 \%$ \\
Coal & 102 & $2.1 \%$ & 2 & $2.0 \%$ \\
Coal \& Biomass & 50 & $1.0 \%$ & 1 & $1.0 \%$ \\
Syrup & 49 & $1.0 \%$ & 1 & $1.0 \%$ \\
\hline Total & $\mathbf{4 , 8 7 2}$ & $\mathbf{1 0 0 . 0 \%}$ & $\mathbf{1 0 2}$ & $\mathbf{1 0 0 . 0 \%}$ \\
\hline
\end{tabular}

\section{Source:}

Environmental Protection Agency, Office of Transportation and Air Quality, Renewable Fuel Standard Program - Draft Regulatory Impact Analysis, September 2006, EPA420-D-06-008.

${ }^{a}$ Includes a natural gas facility which is considering transitioning to coal. 
The majority of ethanol production facilities are concentrated where corn is grown. However, the geographic distribution of biorefineries is beginning to spread as feedstocks other than corn are increasingly used. For an up-to-date listing of all production facilities, visit the Renewable Fuels Association at: http://www.ethanolrfa.org/

Figure 2.2

Ethanol Production Facilities Current and Under Construction, January 24, 2008

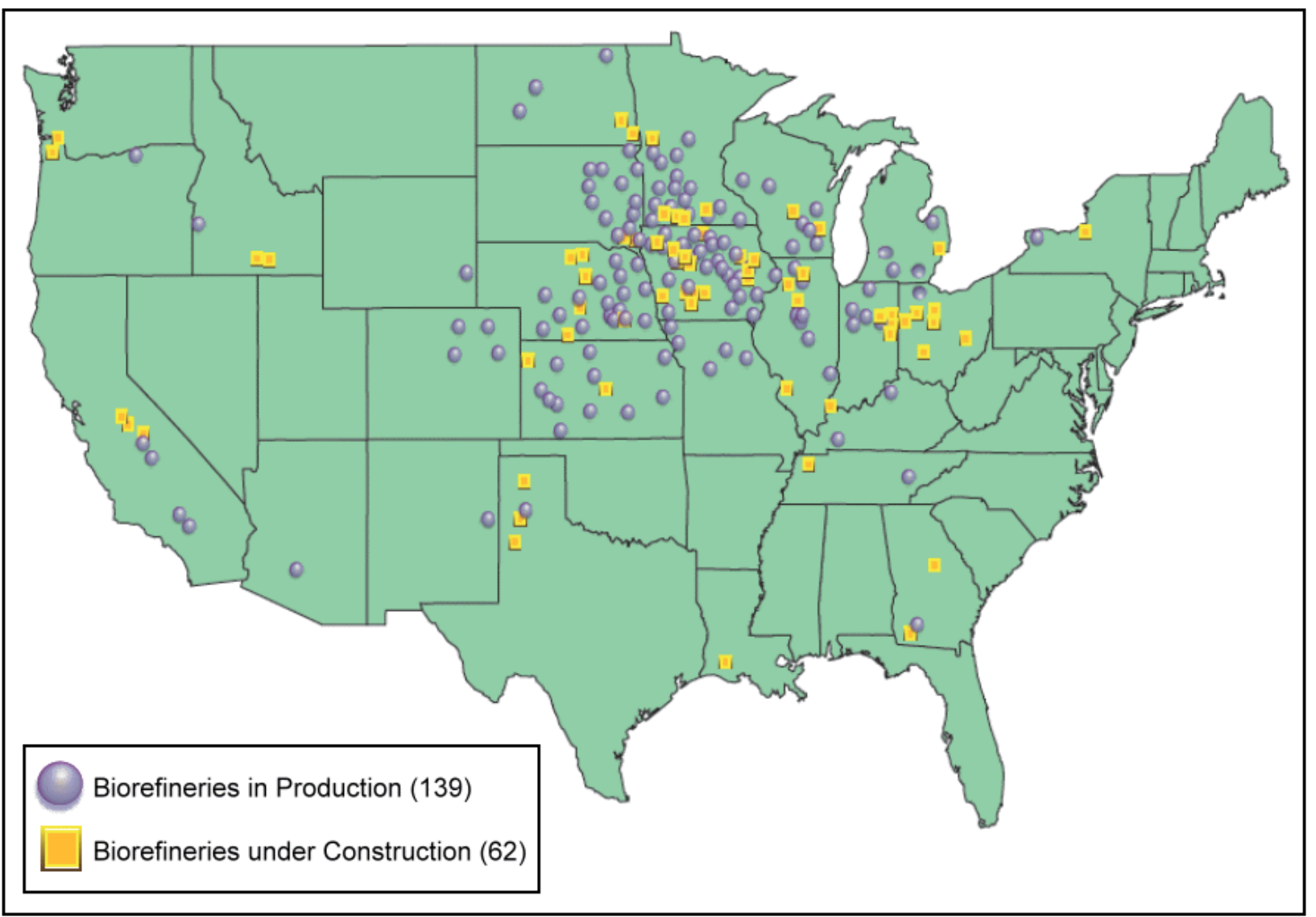

\section{Source:}

Renewable Fuels Association, http://www.ethanolrfa.org/ 
The production of ethanol or ethyl alcohol from starch or sugar-based feedstocks is among man's earliest ventures into value-added processing. While the basic steps remain the same, the process has been considerably refined in recent years, leading to a very efficient process. There are two production processes: wet milling and dry milling. The main difference between the two is in the initial treatment of the grain.

Figure 2.3

The Ethanol Production Process - Wet Milling

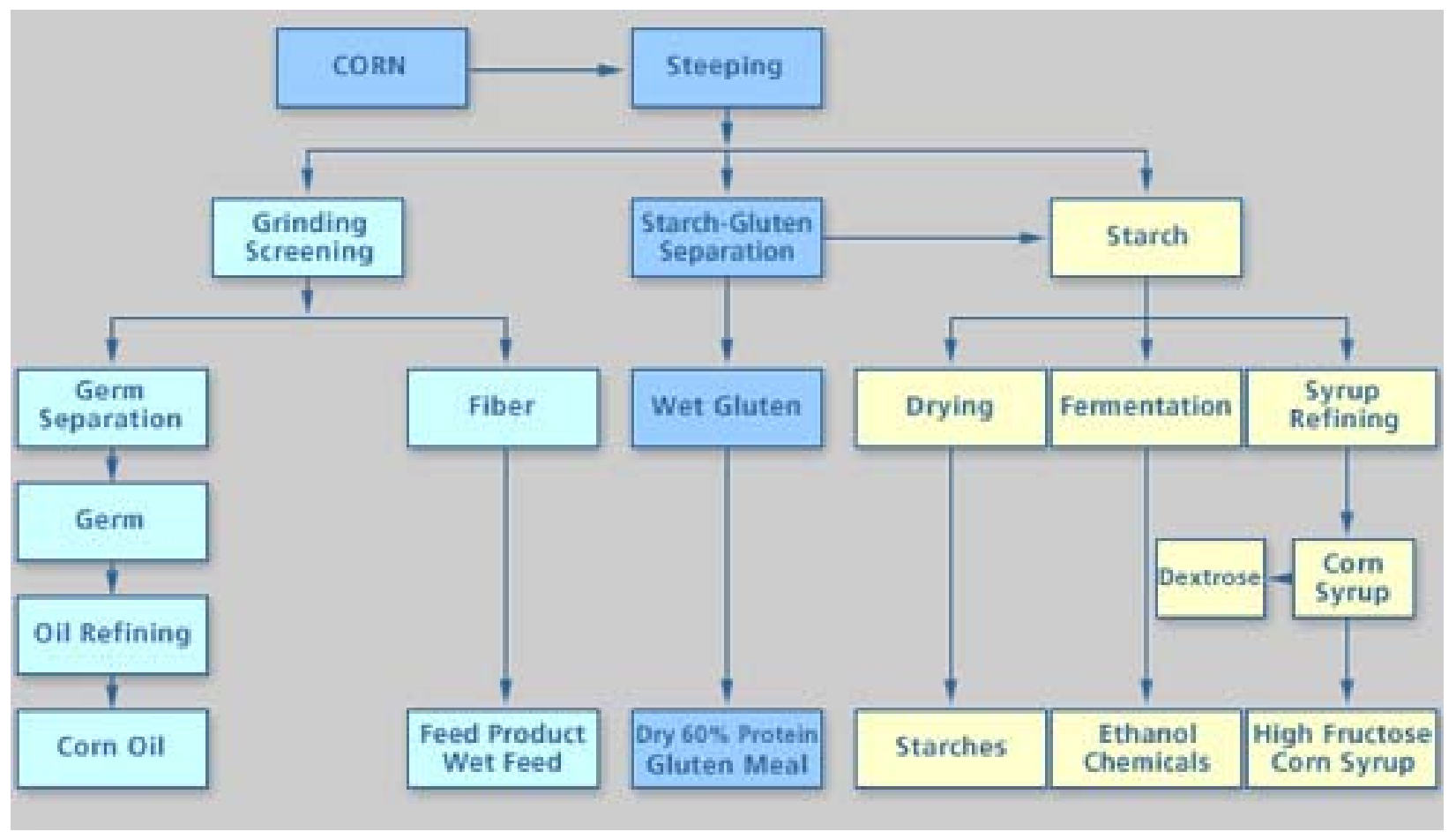

In wet milling, the grain is soaked or "steeped" in water and dilute sulfurous acid for 24 to 48 hours. This steeping facilitates the separation of the grain into its many component parts.

After steeping, the corn slurry is processed through a series of grinders to separate the corn germ. The corn oil from the germ is either extracted on-site or sold to crushers who extract the corn oil. The remaining fiber, gluten and starch components are further segregated using centrifugal, screen and hydroclonic separators.

The steeping liquor is concentrated in an evaporator. This concentrated product, heavy steep water, is co-dried with the fiber component and is then sold as corn gluten feed to the livestock industry. Heavy steep water is also sold by itself as a feed ingredient and is used as a component in Ice Ban, an environmentally friendly alternative to salt for removing ice from roads.

The gluten component (protein) is filtered and dried to produce the corn gluten meal co-product. This product is highly sought after as a feed ingredient in poultry broiler operations.

The starch and any remaining water from the mash can then be processed in one of three ways: fermented into ethanol, dried and sold as dried or modified corn starch, or processed into corn syrup. The fermentation process for ethanol is very similar to the dry mill process.

\section{Source:}

Renewable Fuels Association, http://www.ethanolrfa.org/resource/made/ 
Figure 2.4

The Ethanol Production Process - Dry Milling

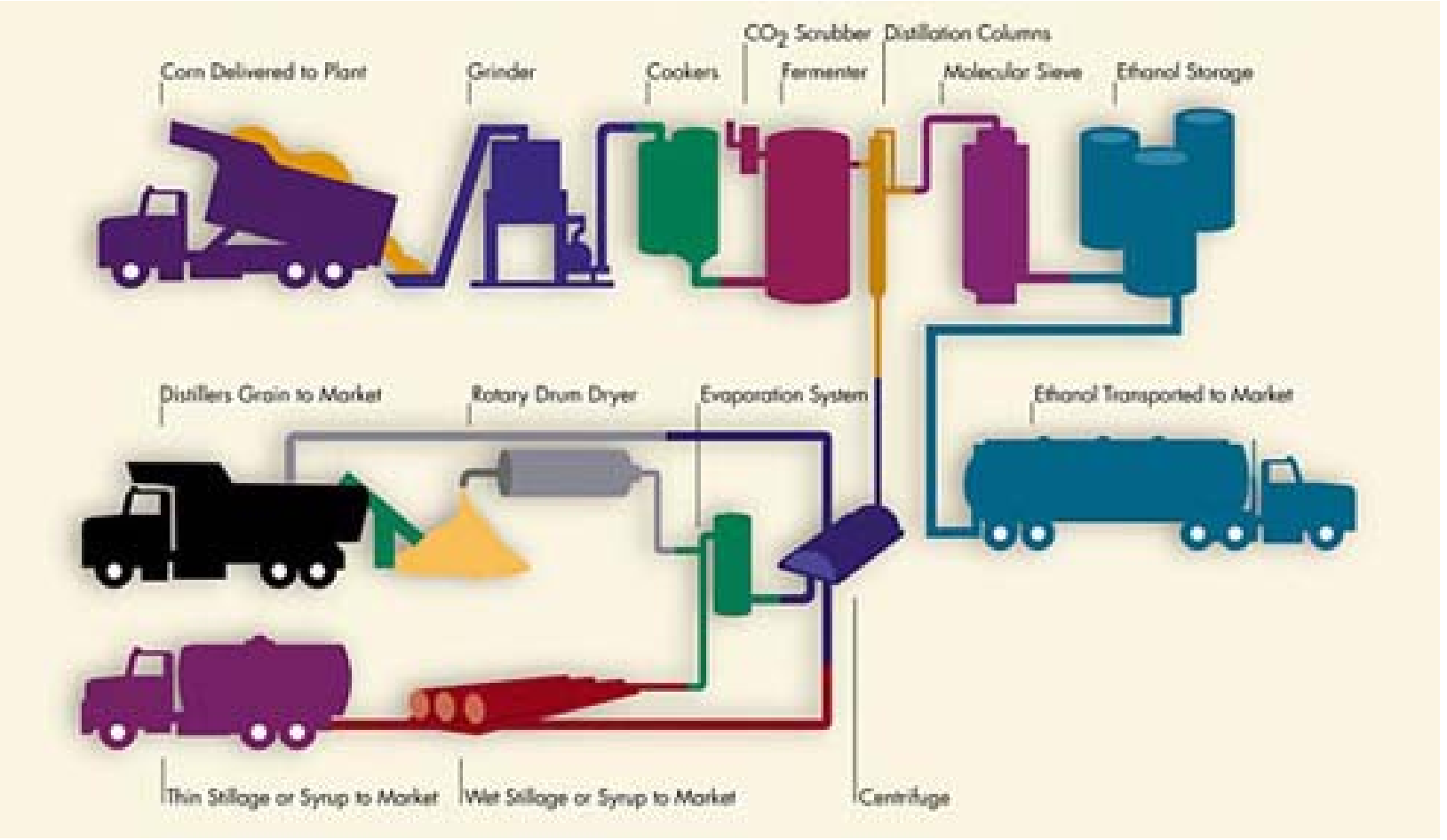

In dry milling, the entire corn kernel or other starchy grain is first ground into flour, which is referred to in the industry as "meal" and processed without separating out the various component parts of the grain. The meal is slurried with water to form a "mash." Enzymes are added to the mash to convert the starch to dextrose, a simple sugar. Ammonia is added for $\mathrm{pH}$ control and as a nutrient to the yeast.

The mash is processed in a high-temperature cooker to reduce bacteria levels ahead of fermentation. The mash is cooled and transferred to fermenters where yeast is added and the conversion of sugar to ethanol and carbon dioxide (CO2) begins.

The fermentation process generally takes about 40 to 50 hours. During this part of the process, the mash is agitated and kept cool to facilitate the activity of the yeast. After fermentation, the resulting "beer" is transferred to distillation columns where the ethanol is separated from the remaining "stillage." The ethanol is concentrated to 190 proof using conventional distillation and is then dehydrated to approximately 200 proof in a molecular sieve system.

The anhydrous ethanol is blended with about $5 \%$ denaturant (such as natural gasoline) to render it undrinkable and thus not subject to beverage alcohol tax. It is then ready for shipment to gasoline terminals or retailers.

The stillage is sent through a centrifuge that separates the coarse grain from the solubles. The solubles are then concentrated to about $30 \%$ solids by evaporation, resulting in Condensed Distillers Solubles (CDS) or "syrup." The coarse grain and the syrup are dried together to produce dried distillers grains with solubles (DDGS), a high quality, nutritious livestock feed. The CO2 released during fermentation is captured and sold for use in carbonating soft drinks and the manufacture of dry ice.

\section{Source:}

Renewable Fuels Association, http://www.ethanolrfa.org/resource/made/ 
This process flow diagram shows the basic steps in production of ethanol from cellulosic biomass. While cellulosic ethanol is not yet commercial in the U.S., it has been demonstrated by several groups, and commercial facilities are being planned in North America. Note that there are a variety of options for pretreatment and other steps in the process and that some specific technologies combine two or all three of the hydrolysis and fermentation steps within the shaded box. Chart courtesy of the National Renewable Energy Laboratory.

Figure 2.5

The Production of Ethanol from Cellulosic Biomass

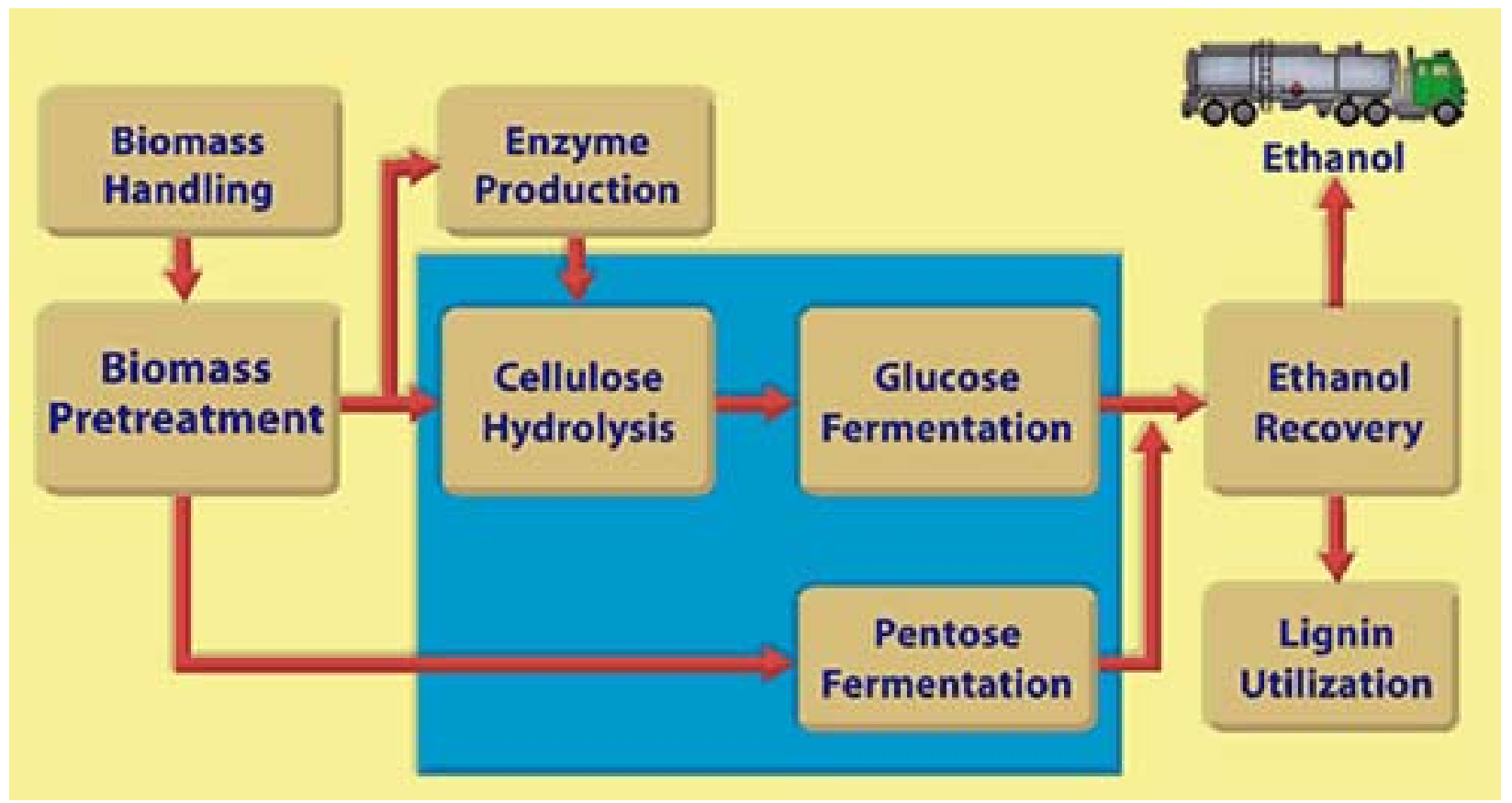

Hydrolysis is the chemical reaction that converts the complex polysaccharides in the raw feedstock to simple sugars. In the biomass-to-bioethanol process, acids and enzymes are used to catalyze this reaction.

Fermentation is a series of chemical reactions that convert sugars to ethanol. The fermentation reaction is caused by yeast or bacteria, which feed on the sugars. Ethanol and carbon dioxide are produced as the sugar is consumed.

Process Description. The basic processes for converting sugar and starch crops are well-known and used commercially today. While these types of plants generally have a greater value as food sources than as fuel sources there are some exceptions to this. For example, Brazil uses its huge crops of sugar cane to produce fuel for its transportation needs. The current U.S. fuel ethanol industry is based primarily on the starch in the kernels of feed corn, America's largest agricultural crop.

1. Biomass Handling. Biomass goes through a size-reduction step to make it easier to handle and to make the ethanol production process more efficient. For example, agricultural residues go through a grinding process and wood goes through a chipping process to achieve a uniform particle size.

2. Biomass Pretreatment. In this step, the hemicellulose fraction of the biomass is broken down into simple sugars. A chemical reaction called hydrolysis occurs when dilute sulfuric acid is mixed with the biomass feedstock. In this hydrolysis reaction, the complex chains of sugars that make up the hemicellulose are broken, releasing simple sugars. The complex 
Figure 2.5 (Continued)

The Production of Ethanol from Cellulosic Biomass

hemicellulose sugars are converted to a mix of soluble five-carbon sugars, xylose and arabinose, and soluble six-carbon sugars, mannose and galactose. A small portion of the cellulose is also converted to glucose in this step.

3. Enzyme Production. The cellulase enzymes that are used to hydrolyze the cellulose fraction of the biomass are grown in this step. Alternatively the enzymes might be purchased from commercial enzyme companies.

4. Cellulose Hydrolysis. In this step, the remaining cellulose is hydrolyzed to glucose. In this enzymatic hydrolysis reaction, cellulase enzymes are used to break the chains of sugars that make up the cellulose, releasing glucose. Cellulose hydrolysis is also called cellulose saccharification because it produces sugars.

5. Glucose Fermentation. The glucose is converted to ethanol, through a process called fermentation. Fermentation is a series of chemical reactions that convert sugars to ethanol. The fermentation reaction is caused by yeast or bacteria, which feed on the sugars. As the sugars are consumed, ethanol and carbon dioxide are produced.

6. Pentose Fermentation. The hemicellulose fraction of biomass is rich in five-carbon sugars, which are also called pentoses. Xylose is the most prevalent pentose released by the hemicellulose hydrolysis reaction. In this step, xylose is fermented using Zymomonas mobilis or other genetically engineered bacteria.

7. Ethanol Recovery. The fermentation product from the glucose and pentose fermentation is called ethanol broth. In this step the ethanol is separated from the other components in the broth. A final dehydration step removes any remaining water from the ethanol.

8. Lignin Utilization. Lignin and other byproducts of the biomass-to-ethanol process can be used to produce the electricity required for the ethanol production process. Burning lignin actually creates more energy than needed and selling electricity may help the process economics.

Converting cellulosic biomass to ethanol is currently too expensive to be used on a commercial scale. Researchers are working to improve the efficiency and economics of the ethanol production process by focusing their efforts on the two most challenging steps:

- Cellulose hydrolysis. The crystalline structure of cellulose makes it difficult to hydrolyze to simple sugars, ready for fermentation. Researchers are developing enzymes that work together to efficiently break down cellulose.

- Pentose fermentation. While there are a variety of yeast and bacteria that will ferment sixcarbon sugars, most cannot easily ferment five-carbon sugars, which limits ethanol production from cellulosic biomass. Researchers are using genetic engineering to design microorganisms that can efficiently ferment both five- and six-carbon sugars to ethanol at the same time.

\section{Source:}

Renewable Fuels Association, http://www.ethanolrfa.org/resource/made/, and the Department of Energy, Energy Efficiency and Renewable Energy, http://www1.eere.energy.gov/biomass/abcs biofuels.html

Note: See Appendix B, Table B1 "Characteristics of Selected Feedstocks and Fuels." 
Ethanol is used as an oxygenate, blended with gasoline to be used as gasohol in conventional vehicles.

The amount of ethanol used in gasohol dwarfs the amount used in E85.

Table 2.10

Ethanol Consumption in E85 and Gasohol, 1995-2006

(Thousands of gallons)

\begin{tabular}{rrrrrr}
\hline & \multicolumn{1}{c}{$\begin{array}{c}\text { Percent of } \\
\text { E85 }\end{array}$} & \multicolumn{1}{c}{ Total } & $\begin{array}{c}\text { Ethanol in } \\
\text { Gasohol }\end{array}$ & $\begin{array}{c}\text { Percent of } \\
\text { Total }\end{array}$ & \multicolumn{1}{c}{ Total } \\
\hline $\mathbf{1 9 9 5}$ & 166 & $0.02 \%$ & 934,615 & $99.98 \%$ & 934,781 \\
$\mathbf{2 0 0 0}$ & 10,530 & $0.94 \%$ & $1,114,313$ & $99.06 \%$ & $1,124,843$ \\
$\mathbf{2 0 0 1}$ & 12,756 & $1.08 \%$ & $1,173,323$ & $98.92 \%$ & $1,186,079$ \\
$\mathbf{2 0 0 2}$ & 15,513 & $1.06 \%$ & $1,450,721$ & $98.94 \%$ & $1,466,234$ \\
$\mathbf{2 0 0 3}$ & 22,420 & $1.15 \%$ & $1,919,572$ & $98.85 \%$ & $1,941,992$ \\
$\mathbf{2 0 0 4}$ & 26,844 & $1.10 \%$ & $2,414,167$ & $98.90 \%$ & $2,441,011$ \\
$\mathbf{2 0 0 5}$ & 32,363 & $1.16 \%$ & $2,756,663$ & $98.84 \%$ & $2,789,026$ \\
$\mathbf{2 0 0 6}$ & 37,435 & $0.99 \%$ & $3,729,168$ & $99.01 \%$ & $3,766,603$ \\
\hline
\end{tabular}

Source:

U.S. Department of Energy, Energy Information Administration, Alternatives to Traditional Transportation Fuels, 2006, Table C1. Washington DC, October 2008, Web site:

http://www.eia.doe.gov/cneaf/alternate/page/atftables/afvtransfuel II.html\#consumption

Note: Gallons of E85 and gasohol do not include the gasoline portion of the blended fuel. 
While the current production cost for gasoline is significantly less than for ethanol, gasoline production cost is projected to increase over time. Production cost for ethanol is projected to decrease over time.

Table 2.11

Gasoline and Ethanol: Comparison of Current and Potential Production Costs in North America (U.S. dollars per gasoline-equivalent liter)

\begin{tabular}{lccc}
\hline & $\mathbf{2 0 0 2}$ & $\mathbf{2 0 1 0}$ & Post-2010 \\
\hline Gasoline & $\$ 0.21$ & $\$ 0.23$ & $\$ 0.25$ \\
Ethanol from corn & $\$ 0.43$ & $\$ 0.40$ & $\$ 0.37$ \\
Ethanol from cellulose (poplar) & $\$ 0.53$ & $\$ 0.43$ & $\$ 0.27$ \\
\hline
\end{tabular}

\section{Source:}

International Energy Agency, Biofuels for Transport, Table 4.6.

Note: Gasoline gate cost based on $\$ 24 /$ barrel oil in 2002, $\$ 30 /$ barrel in 2020; corn ethanol from IEA, with about $1 \%$ per year cost reduction in future; cellulosic costs from IEA based on NREL estimates. 
Twenty-one ethanol dry mill processing plants contributed to the survey results reported here. The costs reported are 2002 dollars.

Table 2.12

Undenatured Ethanol Cash Operating Expenses and Net Feedstock Costs for Dry-milling Process by Plant Size, 2002

\begin{tabular}{llrrr}
\hline Feedstock & Unit & All Dry Mills & Small & Large \\
\hline Corn & $1,000 \mathrm{bu}$ & 193,185 & 103,213 & 89,972 \\
Sorghum & $1,000 \mathrm{bu}$ & 10,409 & $\mathrm{~N} / \mathrm{A}$ & 10,409 \\
Other & $1,000 \mathrm{ton}$ & 44.9 & $\mathrm{~N} / \mathrm{A}$ & 44.9 \\
Alcohol production: & & & & \\
Fuel & $1,000 \mathrm{gal}$ & 548,684 & 275,900 & 272,784 \\
Industrial & $1,000 \mathrm{gal}$ & 1,000 & 1,000 & \\
Total & $1,000 \mathrm{gal}$ & 549,684 & 276,900 & 272,784 \\
Ethanol yield & Gal//gu & 2.6623 & 2.6828 & 2.649 \\
Feedstock costs & Dol./gal & 0.8030 & 0.7965 & 0.8095 \\
Byproducts credits: & & & & \\
Distiller's dried grains & Dol./gal & 0.2520 & 0.2433 & 0.261 \\
Carbon dioxide & Dol./gal & 0.0060 & 0.0038 & 0.008 \\
Net feedstock costs & Dol./gal & 0.5450 & 0.5494 & 0.5405 \\
Cash operating expenses: & & & & \\
Electricity & Dol./gal & 0.0374 & 0.04 & 0.0349 \\
Fuels & Dol./gal & 0.1355 & 0.1607 & 0.1099 \\
Waste management & Dol./gal & 0.0059 & 0.0077 & 0.0041 \\
Water & Dol./gal & 0.0030 & 0.0044 & 0.0015 \\
Enzymes & Dol./gal & 0.0366 & 0.0377 & 0.0365 \\
Yeast & Dol./gal & 0.0043 & 0.0039 & 0.0046 \\
Chemicals & Dol./gal & 0.0229 & 0.0231 & 0.0228 \\
Denaturant & Dol./gal & 0.0348 & 0.0356 & 0.0339 \\
Maintenance & Dol./gal & 0.0396 & 0.0319 & 0.0474 \\
Labor & Dol./gal & 0.0544 & 0.0609 & 0.0478 \\
Administrative costs & Dol./gal & 0.0341 & 0.0357 & 0.0325 \\
Other & Dol./gal & 0.0039 & 0.0035 & 0.0043 \\
\hline Total & Dol./gal & $\mathbf{0 . 4 1 2 4}$ & $\mathbf{0 . 4 4 5 1}$ & $\mathbf{0 . 3 8 0 2}$ \\
\hline Total cash costs and net & & & & \\
feedstock costs & Dol./gal & $\mathbf{0 . 9 5 7 4}$ & $\mathbf{0 . 9 9 4 5}$ & $\mathbf{0 . 9 2 0 7}$ \\
\hline Source: & & & &
\end{tabular}

Source:

Shapouri, H. and Gallagher, P. 2005. USDA's Ethanol Cost of Production Survey, U.S. Department of Agriculture, Agricultural Economic Report Number 841. July 2005.

Note: Dol - dollars, bu - bushels, gal - gallons. 
The ethanol industry spent $\$ 6.7$ billion in 2006 to produce an estimated 4.9 billion gallons of ethanol. Most of this spending was for corn and other grains used as raw material to make ethanol though a significant amount was spent on new construction. All expenditures for operations, transportation and spending for new plants under construction added an estimated $\$ 41.9$ billion in additional gross output in the U.S. economy, increased household earnings by nearly $\$ 6.7$ billion, and created over 163,034 jobs.

Table 2.13

Economic Contribution of the Ethanol Industry, 2006

\begin{tabular}{|c|c|c|c|c|}
\hline \multirow[b]{2}{*}{ Industry } & \multirow[b]{2}{*}{$\begin{array}{c}\text { Spending } \\
\text { (Mil 2005\$) }\end{array}$} & \multicolumn{3}{|c|}{ Impact } \\
\hline & & $\begin{array}{c}\text { Output } \\
\text { (Mil 2005\$) }\end{array}$ & $\begin{array}{c}\text { Earnings } \\
\text { (Mil 2005\$) }\end{array}$ & $\begin{array}{c}\text { Employment } \\
\text { (Jobs) }\end{array}$ \\
\hline Construction & $2,100.0$ & $9,337.4$ & $2,223.3$ & 54,861 \\
\hline Plus initial changes & & $2,100.0$ & & \\
\hline Total & & 9337.4 & 2223.3 & 54861 \\
\hline \multicolumn{5}{|l|}{ Annual Operations } \\
\hline Farm Products/Agriculture & $4,062.5$ & $11,278.4$ & $2,157.2$ & 62,278 \\
\hline Industrial Chemicals & 299.8 & $1,009.6$ & 214.2 & 4,355 \\
\hline Petroleum Refineries & 181.3 & 497.8 & 98.2 & 1,839 \\
\hline Electricity, Natural Gas, Water & $1,570.4$ & $4,655.6$ & $1,016.5$ & 19,712 \\
\hline Maintenance and Repair & 127.4 & 340.3 & 120.8 & 3,318 \\
\hline Business Services & 294.0 & 840.3 & 222.1 & 5,075 \\
\hline Earnings paid to households & 156.8 & 371.4 & 103.7 & 2,805 \\
\hline Rail, truck, barge & 409.8 & $1,196.0$ & 328.1 & 7,100 \\
\hline Subtotal & $7,102.1$ & $20,189.5$ & $4,334.8$ & 108,173 \\
\hline \multicolumn{5}{|l|}{ Plus initial changes: } \\
\hline Value of ethanol production & & $10,795.0$ & 156.8 & \\
\hline Value of co-products & & $1,595.9$ & & \\
\hline Total Annual Operations & & $32,580.0$ & $4,491.6$ & 108,173 \\
\hline Total & & $41,917.9$ & $6,714.8$ & 163,034 \\
\hline
\end{tabular}

\section{Source:}

John M. Urbanchuk, Director, LECG, LLC, 1255 Drummers Lane, Suite 320, Wayne, PA 19087, www.lecg.com . 
Figure 2.6

Ethanol Net Energy Balances and Greenhouse Gas Emissions

The net energy balance and greenhouse gas emissions associated with ethanol production have been analyzed by multiple groups in the past 5 years. Some analysts have shown negative energy input to output balances while others have shown neutral to positive balances. Greenhouse gas emission estimates have also varied accordingly. Some differences can be explained by use of older versus new data, by inclusion or exclusion of co-products and by use of different system boundaries. Alexander Farrell and others in the Energy and Resources Group at the University of California, Berkeley, recently developed the Biofuel Analysis MetaModel (EBAMM) to investigate these issues. The group first replicated the results of six published studies with EBAMM then adjusted all six analyses to (a) add coproduct credit where needed, (b) apply a consistent system boundary, (c) account for different energy types, and (d) calculate policy relevant metrics.

The results shown below in figures $A$ \& $B$ show the original and adjusted values for the six studies, EBAMM generated values for 3 cases including $\mathrm{CO} 2$ intensive ethanol, ethanol today, and cellulosic ethanol, and a gasoline comparison. Equalizing system boundaries among studies reduces scatter in the results. All studies show that ethanol made from conventionally grown corn can have greenhouse gas emissions that are slightly more or less than gasoline per unit of energy but that conventional corn ethanol requires much less petroleum inputs. The model suggests that ethanol produced from cellulosic materials reduces both GHG's and petroleum inputs substantially.
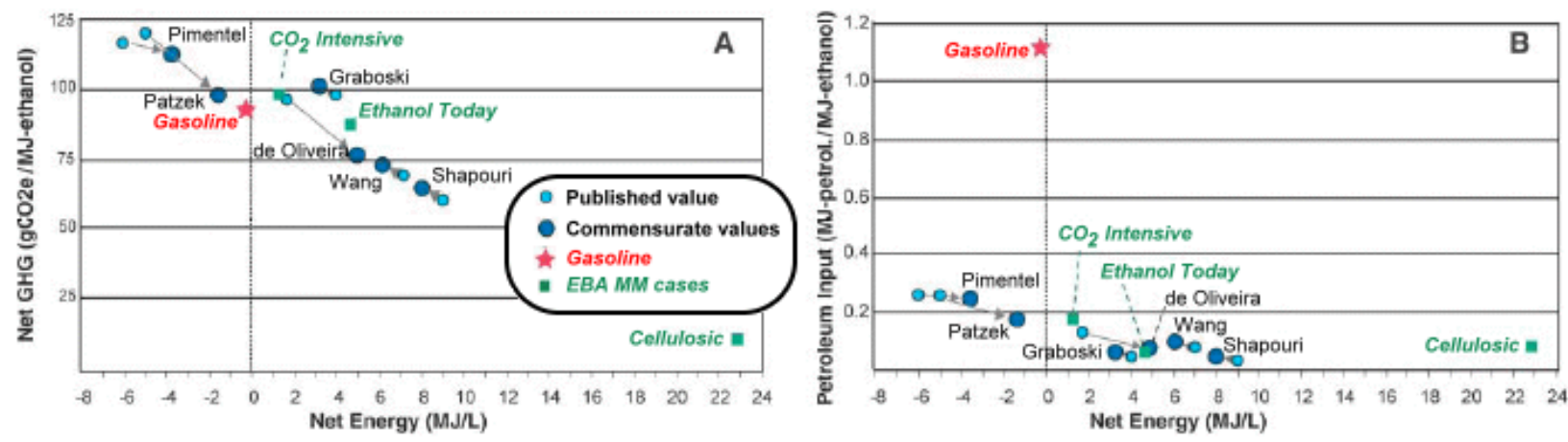

\section{Source:}

A.E. Farrell, R.J. Plevin, B.T. Turner, A.D. Jones, M. O'Hare, D.M. Kammen, 2006. Ethanol Can Contribute To Energy and Environmental Goals, Science, Vol 311, January 27.

Note: gCO2e (as shown in Figure A above) is grams of $\mathrm{CO} 2$ equivalent.

\section{Additional References:}

T. Patzek. Crit. Rev. Plant Sci. 23, 519 (2004).

D. Pimentel, T. Patzek, Nat. Resourc. Res. 14, 65(2005).

M.E.D. de Oliveira, B.E. Vaughn, E.J. Rykiel, Bioscience, 55, 593(2005).

H. Shapouri, A. McAloon, The 2001 Net Energy Balance of Corn Ethanol (U.S. Department of Agriculture, Washington, DC, 2004).

M. Graboski, Fossil Energy Use in the Manufacture of Corn Ethanol (National Corn Growers Association, Washington, DC, 2002), www.ncga.com/ethanol/main

M. Wang, Development and Use of GREET 1.6 Fuel-Cycle Model for Transportation Fuels and Vehicle Technologies (Tech. Rep. ANL/ESD/TM-163, Argonne National Laboratory, Argonne, IL, 2001), http://www.transportation.anl.gov/pdfs/TA/153.pdf 
Figure 2.7

Comparisons of Energy Inputs and GHG Emissions for Three Ethanol Scenarios and Gasoline

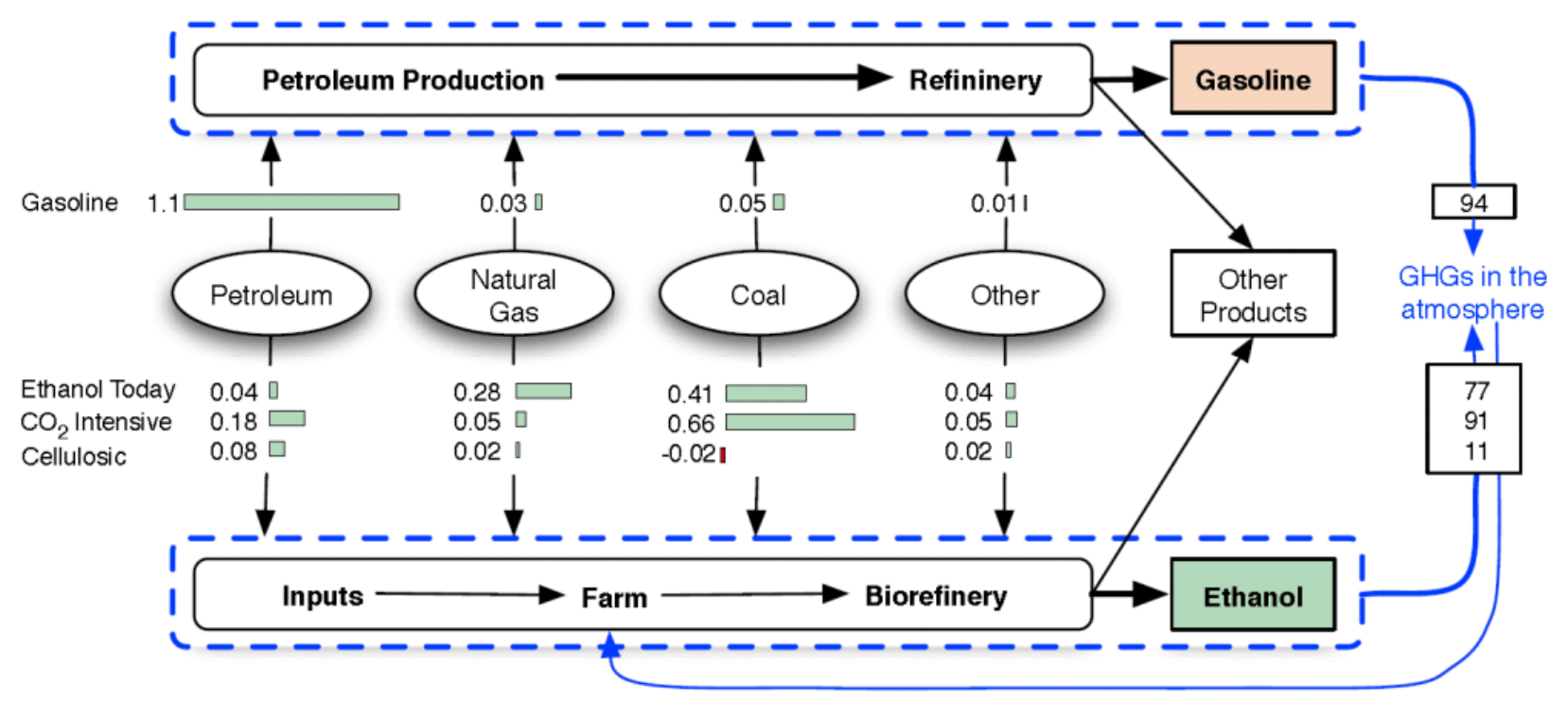

The graphic above was developed by the Energy and Resources group at the University of California, Berkeley using their Biofuel Analysis MetaModel. It is comparing the intensity of primary energy inputs (MJ) per MJ of fuel produced (ethanol or gasoline) and of net greenhouse gas emissions (kg CO2 equivalent) per MJ. For gasoline both petroleum feedstock and petroleum energy inputs are included. "Other" includes nuclear and hydroelectric generation. The Ethanol Today case includes typical values for the current U.S. corn ethanol industry. The $\mathrm{CO} 2$ intensive case assumes the ethanol is produced in a lignite-fired biorefinery located far from where the corn is grown. The Cellulosic case assumes ethanol is produced from switchgrass grown locally. Cellulosic ethanol is expected to have an extremely low intensity for all fossil fuels and a very slightly negative coal intensity due to electricity sales that would displace coal.

\section{Source:}

A.E. Farrell, R.J. Plevin, B.T. Turner, A.D. Jones, M. O'Hare, D.M. Kammen, 2006. "Ethanol Can Contribute To Energy and Environmental Goals," Science, Vol 311, January 27, 2006, www.science.org 
Figure 2.6 includes a data point from M. Wang based on use of the GREET (Greenhouse gases, Regulated Emissions, and Energy Use in Transportation) model. This page provides more information about this public domain model that is available at:

http://www.transportation.anl.gov/software/GREET/index.html

Figure 2.8

Comparative Results between Ethanol and Gasoline Based on an Evaluation by the GREET Model

Producing Ethanol

$(\mathrm{E}+\mathrm{OH})$ from Corn:

0.74 million Btu

Fossil Energy Input
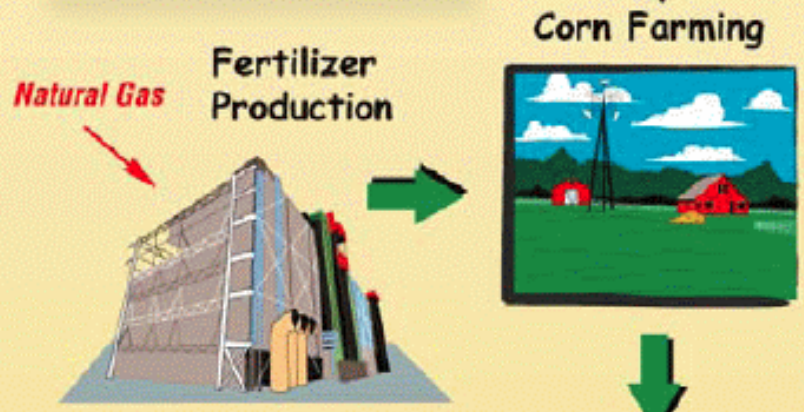

Fertilizers

Natural Gas

— Liquefied Petroleum Gas

Electricity

Diesel Fuel

\section{Transportation \\ Corn}

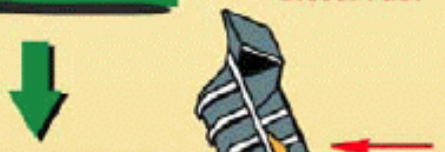

- Diesel

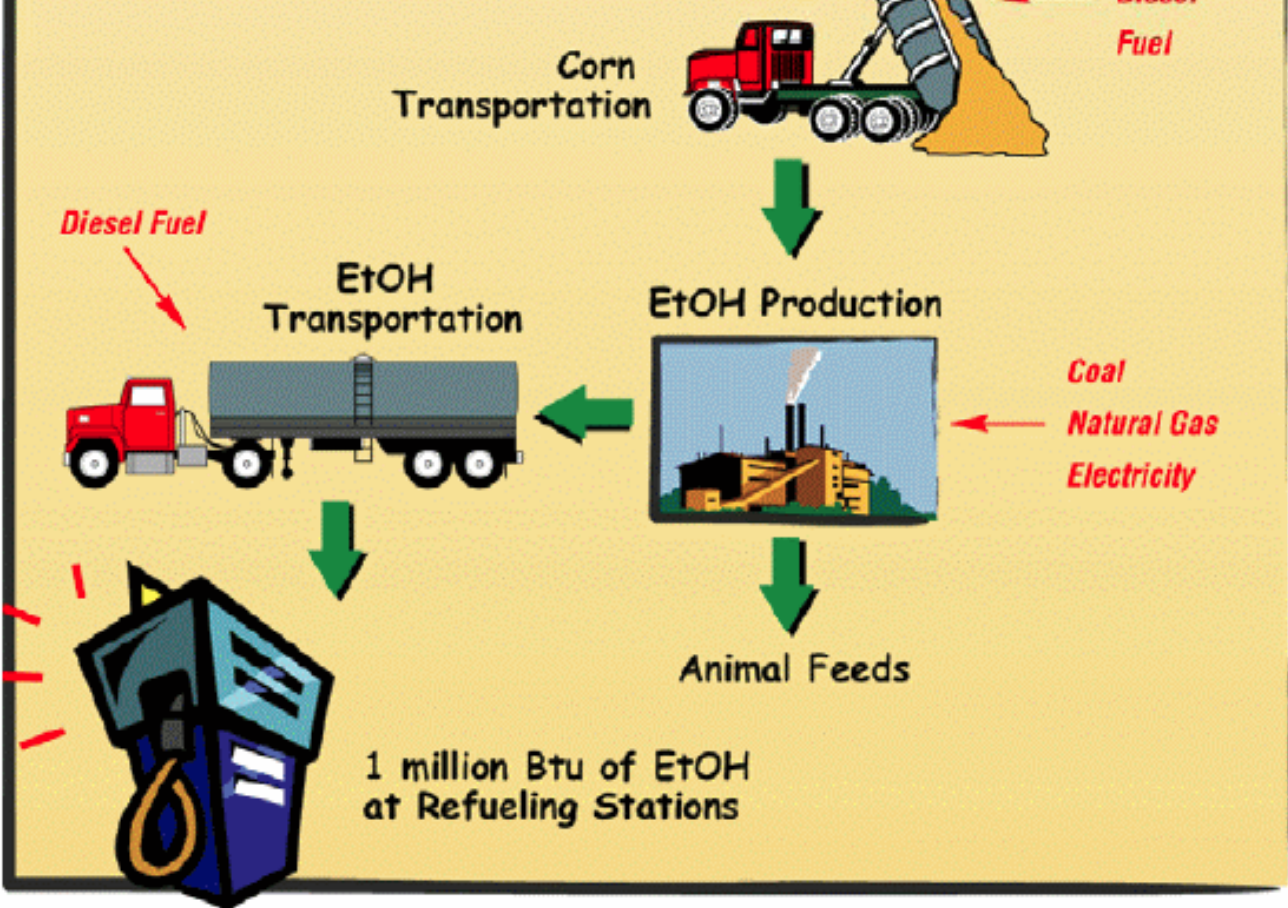


Figure 2.8 (Continued)

Comparative Results between Ethanol and Gasoline Based on an Evaluation by the GREET Model

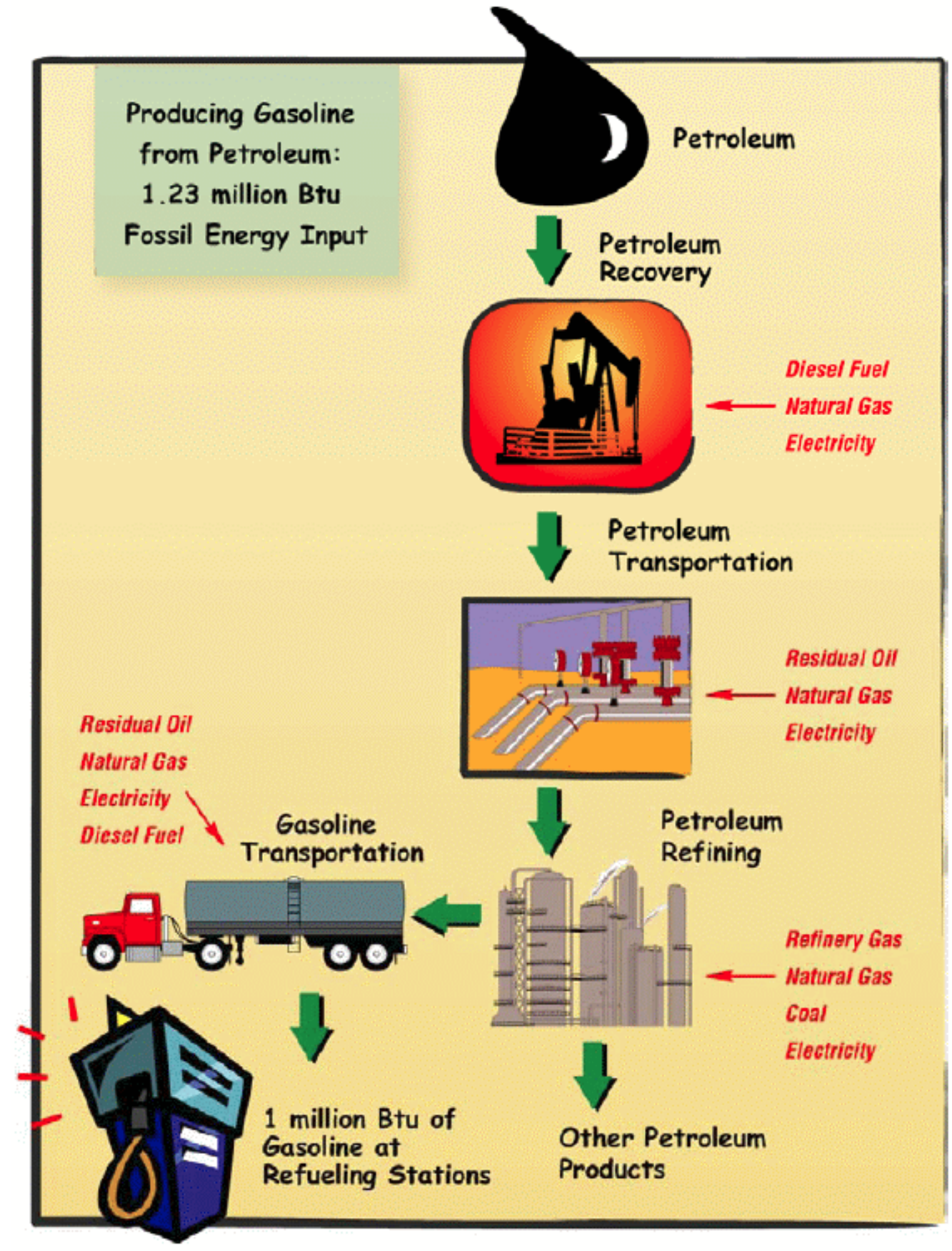

The GREET model was developed by Argonne National Laboratory under the sponsorship of the U.S. Department of Energy's Office of Energy Efficiency and Renewable Energy in order to fully evaluate energy and emission impacts of advanced vehicle technologies and new transportation fuels. The first version of this public domain model was released in 1996. Since then, Argonne has continued to update and expand the model with GREET 1.7 version now available. The model allows researchers and analysts to evaluate various vehicle and fuel combinations on a full fuel-cycle basis that includes wells to wheels and the vehicle cycle through material recovery and vehicle disposal.

For a given vehicle and fuel system, GREET separately calculates the following:

- Consumption of total energy (energy in non-renewable and renewable sources) and fossil fuels (petroleum, natural gas, and coal). 
Figure 2.8 (Continued)

Comparative Results between Ethanol and Gasoline Based on an Evaluation by the GREET Model

- Emissions of CO2-equivalent greenhouse gases - primarily carbon dioxide, methane, and nitrous oxide.

- Emissions of five criteria pollutants: volatile organic oxide, particulate matter with size smaller than 10 micron (PM10), and sulfur oxides.

GREET includes more than $\mathbf{3 0}$ fuel-cycle pathway groups and the following vehicle technologies:

- Conventional spark-ignition engines

- Direct injection, compression ignition engines

- Grid-connected hybrid electric vehicles

- Grid-independent hybrid electric vehicles

- Battery-powered electric vehicles

- Fuel-cell vehicles.

\section{Sources:}

Figures: Michael Wang, The Debate on Energy and Greenhouse Gas Emissions Impacts of Fuel Ethanol, Energy Systems Division Seminar Argonne National Laboratory August 3, 2005.

Text: Argonne National Laboratory, Transportation Technology R\&D Center, http://www.transportation.anl.gov/software/GREET/index.html 
Table 2.14

Comparison of Ethanol Energy Balance With and Without Inclusion of Coproduct Energy Credits

Tables A and B, from a paper by $\mathrm{H}$. Shapouri and A. McAloon, show the effects of partitioning the energy inputs to coproducts as well as to the ethanol produced at wet and dry mills.

Table A summarizes the input energy requirements, by phase of ethanol production on a Btu per gallon basis (LHV) for 2001, without byproduct credits. Energy estimates are provided for both dry- and wetmilling as well as an industry average. In each case, corn ethanol has a positive energy balance, even before subtracting the energy allocated to byproducts.

Table B presents the final net energy balance of corn ethanol adjusted for byproducts. The net energy balance estimate for corn ethanol produced from wet-milling is 27,729 Btu per gallon, the net energy balance estimate for dry-milling is 33,196 Btu per gallon, and the weighted average is 30,528 Btu per gallon. The energy ratio is 1.57 and 1.77 for wet- and dry-milling, respectively, and the weighted average energy ratio is 1.67 .

Table A

Energy Use and Net Energy Value Per Gallon Without Coproduct Energy Credits, 2001

\begin{tabular}{lrrr}
\hline \multirow{2}{*}{ Production Process } & \multicolumn{2}{c}{ Milling Process } & Weighted \\
\cline { 2 - 3 } average
\end{tabular}

Table B

Energy Use and Net Energy Value Per Gallon with Coproduct Energy Credits, 2001

\section{Source:}

H. Shappouri, A. McAloon, The 2001 Net Energy Balance of Corn Ethanol, U.S. Department of Agriculture, Washington, DC, 2004. 


\section{BIODIESEL OVERVIEW}

Biodiesel is a clean burning alternative fuel produced from domestic, renewable resources. The fuel is a mixture of fatty acid alkyl esters made from vegetable oils, animal fats or recycled greases. Where available, biodiesel can be used in compression-ignition (diesel) engines in its pure form with little or no modifications. Biodiesel is simple to use, biodegradable, nontoxic, and essentially free of sulfur and aromatics. It is usually used as a petroleum diesel additive to reduce levels of particulates, carbon monoxide, hydrocarbons and air toxics from diesel-powered vehicles. When used as an additive, the resulting diesel fuel may be called $\mathrm{B} 5, \mathrm{~B} 10$ or $\mathrm{B} 20$, representing the percentage of the biodiesel that is blended with petroleum diesel.

In the United States, most biodiesel is made from soybean oil or recycled cooking oils. Animal fats, other vegetable oils, and other recycled oils can also be used to produce biodiesel, depending on their costs and availability. In the future, blends of all kinds of fats and oils may be used to produce biodiesel. Biodiesel is made through a chemical process called transesterification whereby the glycerin is separated from the fat or vegetable oil. The process leaves behind two products -- methyl esters (the chemical name for biodiesel) and glycerin (a valuable byproduct usually sold to be used in soaps and other products).

Fuel-grade biodiesel must be produced to strict industry specifications (ASTM D6751) in order to insure proper performance. Biodiesel is the only alternative fuel to have fully completed the health effects testing requirements of the 1990 Clean Air Act Amendments. Biodiesel that meets ASTM D6751 and is legally registered with the Environmental Protection Agency is a legal motor fuel for sale and distribution. Raw vegetable oil cannot meet biodiesel fuel specifications; therefore, it is not registered with the EPA and it is not a legal motor fuel.

\section{Sources:}

U.S. Department of Energy, Energy Efficiency and Renewable Energy, www.eere.energy.gov/RE/bio fuels.html; National Biodiesel Board, www.biodiesel.org/resources/biodiesel basics/default.shtm 
During 2002, Europe, in general, and particularly the EU countries of Germany, France and Italy, were the dominant producers of biodiesel worldwide.

Table 2.15

World Biodiesel Capacity, 2002

(Million gallons)

\begin{tabular}{lrc}
\hline Country & Capacity $^{\mathrm{a}}$ & Typical use \\
\hline United States & 18.49 & blends $<25 \%$ \\
IEA North America & $\mathbf{1 8 . 4 9}$ & \\
\hline Austria & 8.45 & blends $<25 \%$ \\
Belgium & 9.51 & \\
Denmark & 0.79 & \\
France & 101.97 & mainly $5 \%$ \\
Germany & 165.11 & $100 \%$ biodiesel; some blends \\
Italy & 63.14 & blends $<25 \%$ \\
Spain & 2.38 & \\
Sweeden & 4.49 & blends $<25 \%$ \\
UK & 1.59 & \\
EU & 357.42 & \\
\hline Poland & 21.13 & \\
IEA Europe & $\mathbf{3 7 8 . 5 6}$ & \\
World & 397.05 & \\
\hline
\end{tabular}

Source:

International Energy Agency, Biofuels for Transport: An International Perspective, page 30, Table 1.1, May 2004.

Note: Production of biodiesel in 2003 is roughly $65 \%$ of capacity. Some minor production (e.g. India, Africa) not reported.

${ }^{a}$ Feedstock in the United States is soy; in Europe, rapeseed and sunflower. 
Figure 2.9

Active Commercial Biodiesel Production Facilities, January 25, 2008

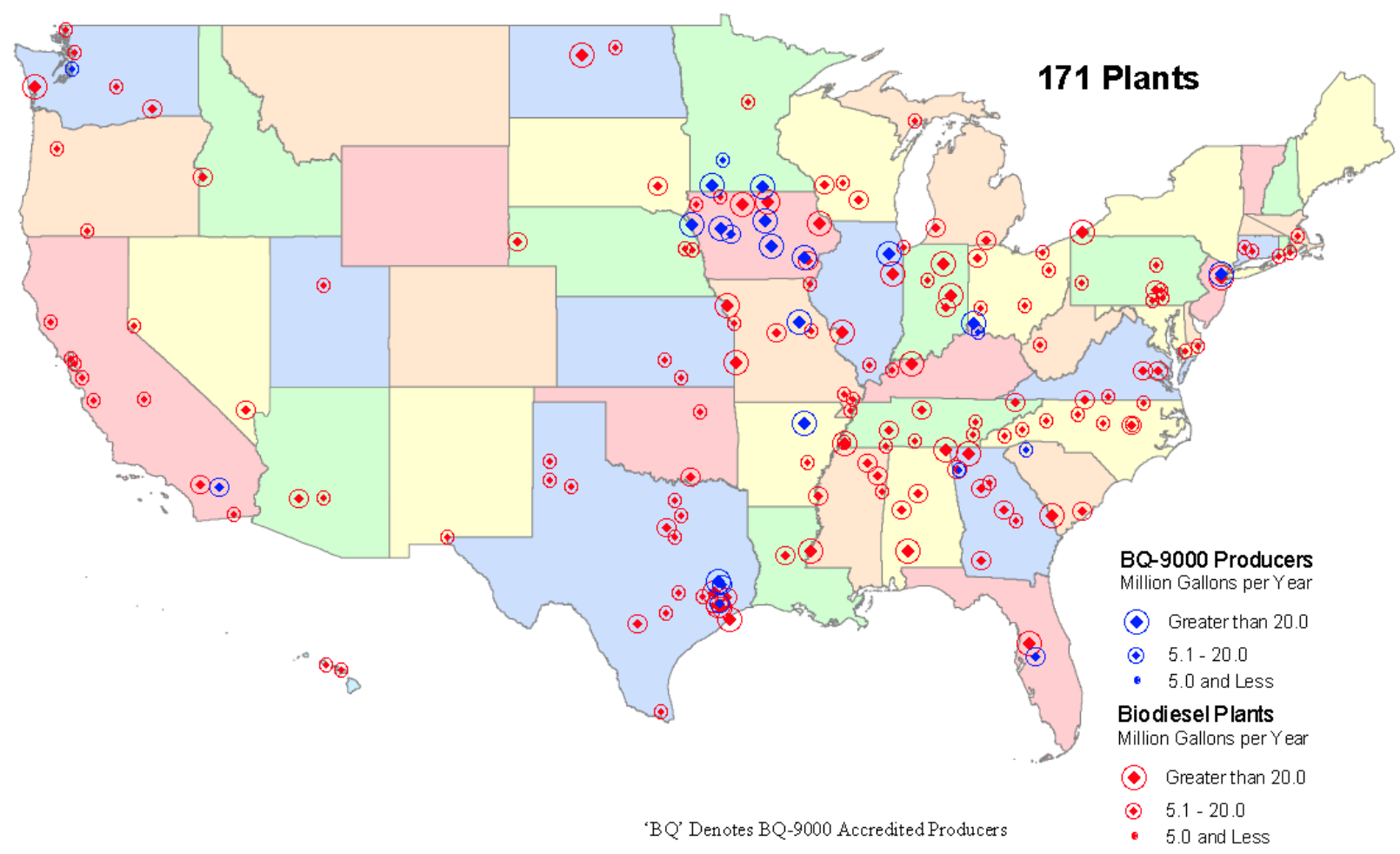

Source:

National Biodiesel Board, Existing Plants - Production Map \& Table,

http://www.nbb.org/resources/fuelfactsheets/default.shtm

\section{Notes:}

1. BQ-9000 is a cooperative and voluntary national program for the accreditation of producers of biodiesel fuel. To learn more about BQ-9000 Accreditation, visit: http://www.bq-9000.org/

2. For the most current listing of production facilities including company name, state, city, capacity, and primary feedstock used, follow the link listed under source following the map. 
Figure 2.10

Commercial Biodiesel Production Facilities Under Construction or Expansion, January 25, 2008

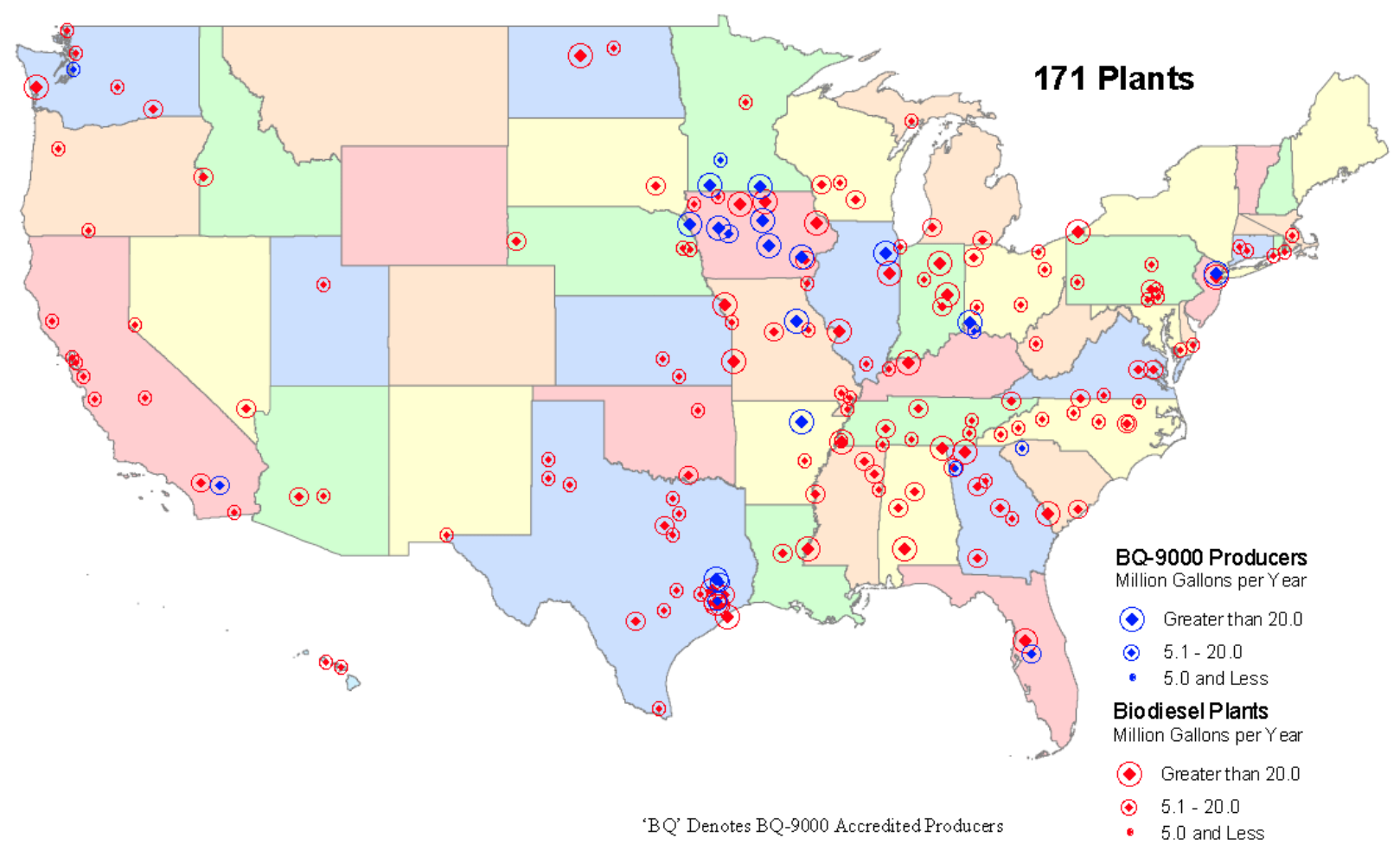

\section{Source:}

National Biodiesel Board, Biodiesel Plants under Construction, http://www.nbb.org/resources/fuelfactsheets/default.shtm

Note: For the most current listing of production facilities including company name, state, city, capacity, and primary feedstock used, follow the link listed under source. 
The sale of biodiesel has been on the rise since 1999, but the most notable growth was between 2004 and 2006 when sales increased ten-fold to 250 million gallons.

Figure 2.11

Estimated U.S. Biodiesel Sales, 1999-2006

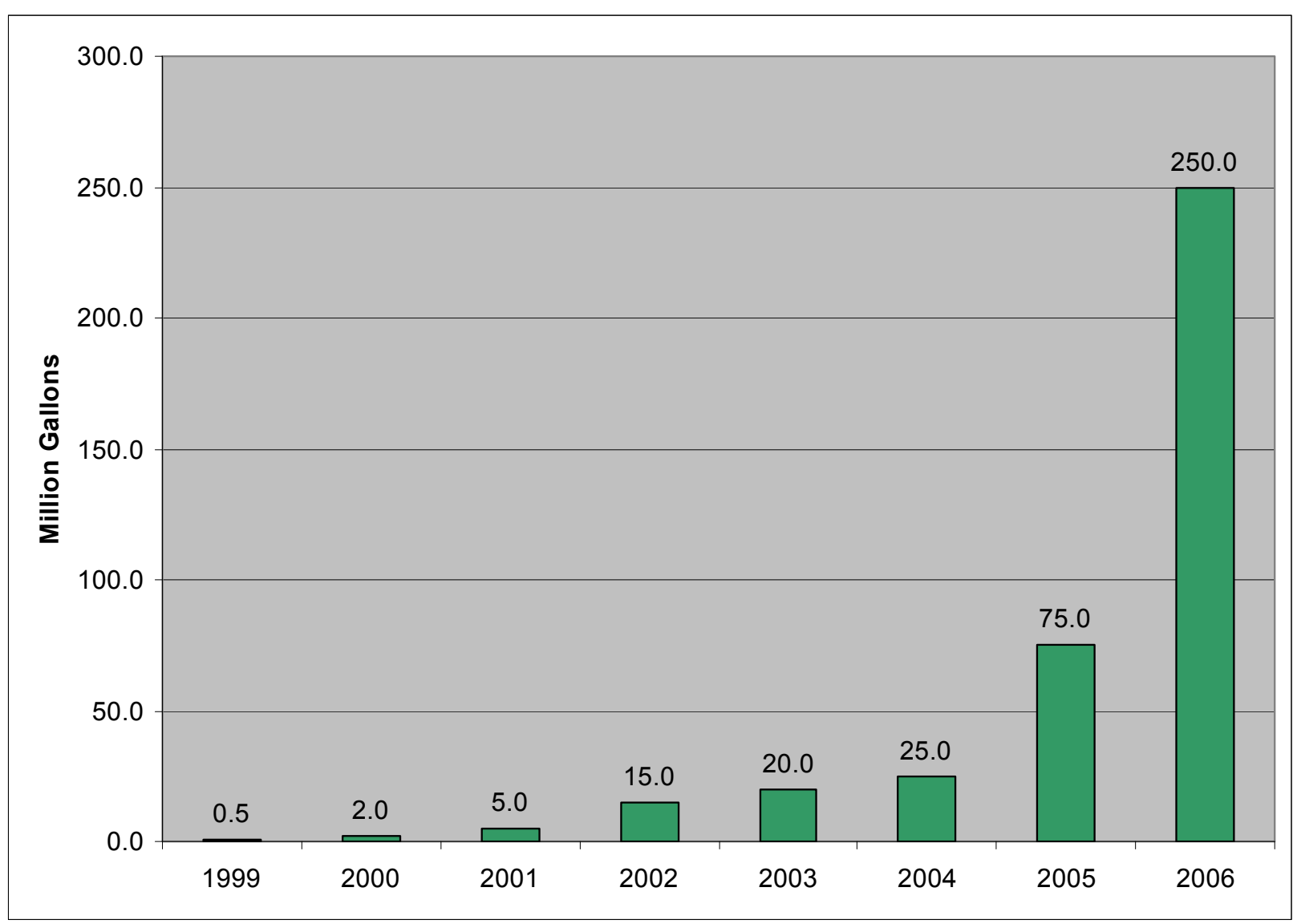

\section{Source:}

National Biodiesel Board, Biodiesel Fact Sheets, Biodiesel Sales Graph FY99-FY06, http://www.biodiesel.org/resources/fuelfactsheets/default.shtm

Note: Years refer to fiscal year October 1 through September 30. 
It is extremely important to realize that vegetable oils are mixtures of tryglycerides from various fatty acids. The composition of vegetable oils varies with the plant source. The table below indicates the percentages of each type of fatty acid that is in common vegetable oils or animal fats. The two numbers at the top of each column represents the number of carbon atoms and double bonds (e.g. 16:0 refers to the 16 carbon atoms and 0 double bonds found in the long chain of Palmitic acid). See text on Typical Proportions of Chemicals Used to Make Biodiesel (Figure 2.12) for a description of several types of tryglycerides that are found in vegetable oils.

Table 2.16

Composition of Various Oils and Fats Used for Biodiesel (Percentage of each type of fatty acid common to each type of feedstock)

\begin{tabular}{|l|l|l|l|l|l|l|l|l|}
\hline Oil or fat & $\mathbf{1 4 : 0 0}$ & $\mathbf{1 6 : 0 0}$ & $\mathbf{1 8 : 0 0}$ & $\mathbf{1 8 : 0 1}$ & $\mathbf{1 8 : 0 2}$ & $\mathbf{1 8 : 0 3}$ & $\mathbf{2 0 : 0 0}$ & $\mathbf{2 2 : 0 1}$ \\
\hline Soybean & & $6-10$ & $2-5$ & $20-30$ & $50-60$ & $5-11$ & & \\
\hline Corn & $1-2$ & $8-12$ & $2-5$ & $19-49$ & $34-52$ & trace & & \\
\hline Peanut & & $8-9$ & $2-3$ & $50-60$ & $20-30$ & & & \\
\hline Olive & & $9-10$ & $2-3$ & $73-84$ & $10-12$ & trace & & \\
\hline Cottonseed & $0-2$ & $20-25$ & $1-2$ & $23-35$ & $40-50$ & trace & & \\
\hline $\begin{array}{l}\text { Hi Linoleic } \\
\text { Safflower }\end{array}$ & & 5.9 & 1.5 & 8.8 & 83.8 & & & \\
\hline $\begin{array}{l}\text { Hi Oleic } \\
\text { Safflower }\end{array}$ & & 4.8 & 1.4 & 74.1 & 19.7 & & & \\
\hline $\begin{array}{l}\text { Hi Oleic } \\
\text { Rapeseed }\end{array}$ & & 4.3 & 1.3 & 59.9 & 21.1 & 13.2 & & \\
\hline $\begin{array}{l}\text { Hi Erucic } \\
\text { Rapeseed }\end{array}$ & & 3.0 & 0.8 & 13.1 & 14.1 & 9.7 & 7.4 & 50.7 \\
\hline Butter & $7-10$ & $24-26$ & $10-13$ & $28-31$ & $1-2.5$ & $.2-.5$ & & \\
\hline Lard & $1-2$ & $28-30$ & $12-18$ & $40-50$ & $7-13$ & $0-1$ & & \\
\hline Tallow & $3-6$ & $24-32$ & $20-25$ & $37-43$ & $2-3$ & & & \\
\hline Linseed Oil & & $4-7$ & $2-4$ & $25-40$ & $35-40$ & $25-60$ & & \\
\hline $\begin{array}{l}\text { Yellow } \\
\text { grease } \\
\text { (typical) }\end{array}$ & 2.43 & 23.24 & 12.96 & 44.32 & 6.97 & 0.67 & & \\
\cline { 2 - 9 } & & $16: 1=3$. & & & & & & \\
\hline
\end{tabular}

Source:

J. Van Gerpen, B. Shanks, and R. Pruszko, D. Clements, and G. Knothe, 2004, Biodiesel Production Technology, National Renewable Energy Laboratory subcontractor report NREL/SR-510-36244, chapter 1, page 1. Please see this document for a full discussion. Available on-line in DOE's biomass document database. Search by author or title. http://www1.eere.energy.gov/biomass/document database.html 
Figure 2.12

Typical Proportions of Chemicals Used to Make Biodiesel

The most cursory look at the literature relating to biodiesel reveals the following relationship for production of biodiesel from fats and oils:

$100 \mathrm{lbs}$ of oil $+10 \mathrm{lbs}$ of methanol $\rightarrow 100 \mathrm{lbs}$ of biodiesel $+10 \mathrm{lbs}$ of glycerol - This equation is a simplified form of the following transesterfication reaction:

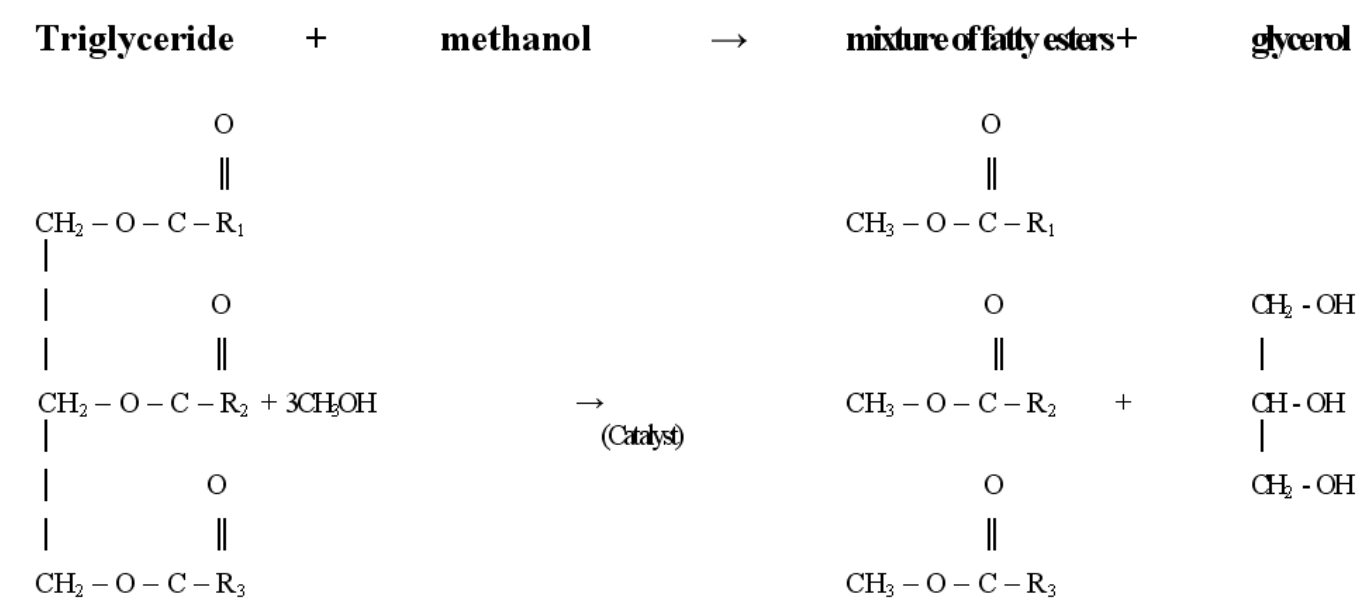

$R_{1}, R_{2}$, and $R_{3}$ in the above equation are long chains of carbons and hydrogen atoms, sometimes called fatty acid chains. There are five types of chains that are common in soybean oil and animal fats shown below (others are present in small amounts).

$\begin{array}{llr}\text { Palmitic: } & \mathrm{R}=-\left(\mathrm{CH}_{2}\right)_{14}-\mathrm{CH}_{3} & 16 \text { carbons, } 0 \text { double bonds }(16: 0) \\ \text { Stearic: } & \mathrm{R}=-\left(\mathrm{CH}_{2}\right)_{16}-\mathrm{CH}_{3} & 18 \text { carbons, } 0 \text { double bonds }(18: 0) \\ \text { Oleic: } & \mathrm{R}=-\left(\mathrm{CH}_{2}\right)_{7} \mathrm{CH}=\mathrm{CH}\left(\mathrm{CH}_{2}\right)_{7} \mathrm{CH}_{3} & 18 \text { carbons, } 1 \text { double bonds }(18: 1) \\ \text { Linoleic: } & \mathrm{R}=-\left(\mathrm{CH}_{2}\right)_{7} \mathrm{CH}=\mathrm{CH}-\mathrm{CH}_{2}-\mathrm{CH}=\mathrm{CH}\left(\mathrm{CH}_{2}\right)_{4} \mathrm{CH}_{3} \\ & & 18 \text { carbons, } 2 \text { double bonds (18:2) } \\ \text { Linolenic: } & \mathrm{R}=-\left(\mathrm{CH}_{2}\right)_{7} \mathrm{CH}=\mathrm{CH}-\mathrm{CH}_{2}-\mathrm{CH}=\mathrm{CH}-\mathrm{CH}_{2}-\mathrm{CH}=\mathrm{CH}-\mathrm{CH}_{2}-\mathrm{CH}_{3} \\ & & 18 \text { carbons, } 3 \text { double bonds (18:3) }\end{array}$

As indicated, a short-hand designation for these chains is two numbers separated by a colon. The first number designates the number of carbon atoms in the chain and the second number designates the number of double bonds. Note that the number of carbon atoms includes the carbon that is double bonded to the oxygen atom at one end of the fatty acid (called the carboxylic carbon). This is the end that the methanol attaches to when methyl ester is produced.

\section{Source:}

J. Van Gerpen, B. Shanks, and R. Pruszko, D. Clements, and G. Knothe, 2004, Biodiesel Production Technology" National Renewable Energy Laboratory subcontractor report NREL/SR-510-36244, chapter 1, page 1. Available on-line in DOE's biomass document database. Search by author or title. http://www1.eere.energy.gov/biomass/document database.html 
The parameters for B100 fuel are specified through the biodiesel standard, ASTM D 6751. This standard identifies the parameters that pure biodiesel (B100) must meet before being used as a pure fuel or being blended with petrodiesel. The National Biodiesel Board has adopted ASTM biodiesel specifications.

Table 2.17

Specification for Biodiesel (B100)

\begin{tabular}{|c|c|c|c|}
\hline Property & ASTM Method & Limits & Units \\
\hline Flash Point & D93 & $130 \mathrm{~min}$. & Degrees C \\
\hline Water \& Sediment & D2709 & 0.050 max. & $\%$ vol. \\
\hline Kinematic Viscosity, $40 \mathrm{C}$ & D445 & $1.9-6.0$ & $\mathrm{~mm} 2 / \mathrm{sec}$. \\
\hline Sulfated Ash & D874 & 0.020 max. & $\%$ mass \\
\hline Sulfur & D5453 & 0.05 max. & $\%$ mass \\
\hline Copper Strip Corrosion & D130 & No. 3 max. & \\
\hline Cetane & D613 & $47 \mathrm{~min}$. & \\
\hline Cloud Point & D2500 & Report & Degrees C \\
\hline Carbon Residue $100 \%$ sample & $\mathrm{D} 4530^{\mathrm{a}}$ & 0.050 max. & $\%$ mass \\
\hline Acid Number & D664 & 0.80 max. & $\mathrm{mg} \mathrm{KOH/gm}$ \\
\hline Free Glycerin & D6584 & 0.020 max. & $\%$ mass \\
\hline Total Glycerin & D6584 & 0.240 max. & $\%$ mass \\
\hline $\begin{array}{l}\text { Phosphorus Content } \\
\text { Distillation Temp, Atmospheric Equivalent }\end{array}$ & D 4951 & 0.001 max. & $\%$ mass \\
\hline Temperature, $90 \%$ Recovered & D 1160 & 360 max. & Degrees C \\
\hline
\end{tabular}

Source:

National Biodiesel Board, Biodiesel Fact Sheets, Biodiesel Production \& Quality Standards, http://www.biodiesel.org/resources/fuelfactsheets/

Alternate source providing explanations for the various specifications can be found at: J. Van Gerpen, B. Shanks, and R. Pruszko, D. Clements, and G. Knothe, 2004. Biodiesel Production Technology. National Renewable Energy Laboratory subcontractor report NREL/SR-510-36244; Chapter 1, page 23. Available on-line in DOE's biomass document database. Search by author or title, http://www1.eere.energy.gov/biomass/document database.html

Notes: To meet special operating conditions, modifications of individual limiting requirements may be agreed upon between purchaser, seller and manufacturer.

A considerable amount of experience exists in the United States with a $20 \%$ blend of biodiesel with $80 \%$ diesel fuel (B20). Although biodiesel (B100) can be used, blends of over $20 \%$ biodiesel with diesel fuel should be evaluated on a case-by-case basis until further experience is available.

${ }^{a}$ The carbon residue shall be run on the $100 \%$ sample. 


\section{Figure 2.13}

\section{Commercial Biodiesel Production Methods}

The production processes for biodiesel are well known. There are three basic routes to biodiesel production from oils and fats:

1. Base catalyzed transesterification of the oil.

2. Direct acid catalyzed transesterification of the oil.

3. Conversion of the oil to its fatty acids and then to biodiesel.

Most of the biodiesel produced today uses the base catalyzed reaction for several reasons:

- It is low temperature and pressure.

- It yields high conversion (98\%) with minimal side reactions and reaction time.

- It is a direct conversion to biodiesel with no intermediate compounds.

- No exotic materials of construction are needed.

The chemical reaction for base catalyzed biodiesel production is depicted below. One hundred pounds of fat or oil (such as soybean oil) are reacted with 10 pounds of a short chain alcohol in the presence of a catalyst to produce 10 pounds of glycerin and 100 pounds of biodiesel. The short chain alcohol, signified by $\mathrm{ROH}$ (usually methanol, but sometimes ethanol) is charged in excess to assist in quick conversion. The catalyst is usually sodium or potassium hydroxide that has already been mixed with the methanol. R', R", and R"' indicate the fatty acid chains associated with the oil or fat which are largely palmitic, stearic, oleic, and linoleic acids for naturally occurring oils and fats.

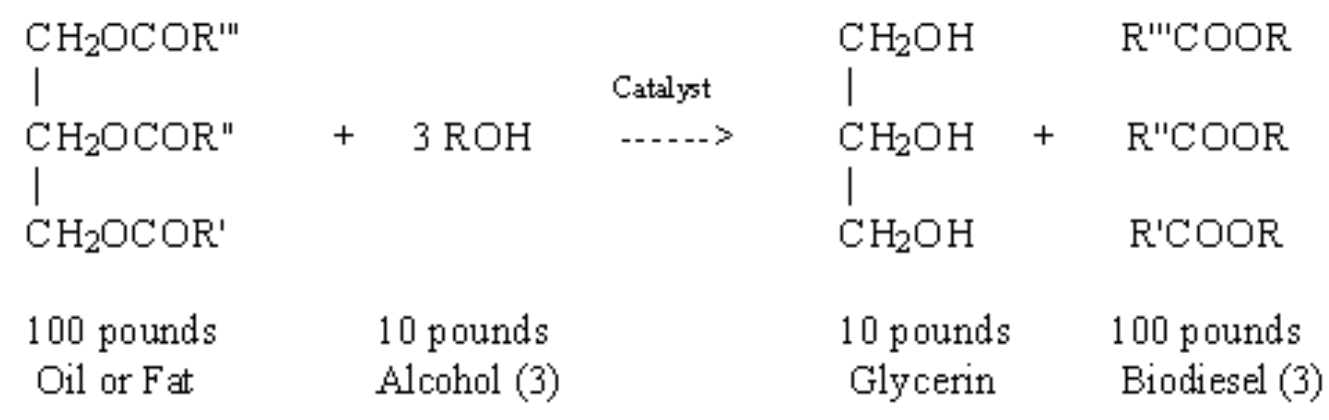

\section{Source:}

National Biodiesel Board, Fact Sheet "Biodiesel Production and Quality," http://www.biodiesel.org/resources/fuelfactsheets/default.shtm

Note: The term glycerin may include glycerol and related co-products of the glycerol production process. 
The results of a study conducted by the EPA on the emissions produced by biodiesel show that except for nitrogen oxides (NOx), regulated and non regulated emissions from both B100 (100\% biodiesel) and B20 (20\% biodiesel) are significantly lower than for conventional petroleum based diesel.

Table 2.18

Average Biodiesel (B100 and B20) Emissions Compared to Conventional Diesel

\begin{tabular}{lcc}
\hline Emission Type & B100 & B20 \\
\cline { 2 - 3 } & \multicolumn{2}{c}{ Emissions in relation to conventional diesel } \\
\hline Regulated & & $-20 \%$ \\
\hline Total Unburned Hydrocarbons & $-67 \%$ & $-12 \%$ \\
Carbon Monoxide & $-48 \%$ & $-12 \%$ \\
Particulate Matter & $-47 \%$ & $+2 \%$ \\
NOx & $+10 \%$ & $-20 \%^{a}$ \\
\hline Non-Regulated & & $-13 \%$ \\
\hline Sulfates & $-100 \%$ & $-50 \%{ }^{\mathrm{c}}$ \\
PAH (Polycyclic Aromatic Hydrocarbons) & $-80 \%$ & $-10 \%$ \\
nPAH (nitrated PAH's) & $-90 \%$ & \\
Ozone potential of speciated HC & $-50 \%$ & \\
\hline
\end{tabular}

Source:

National Biodiesel Board, Biodiesel Fact Sheets, Emissions, http://www.biodiesel.org/resources/fuelfactsheets/

Note: Testing was performed by the EPA. The full report titled A Comprehensive Analysis of Biodiesel Impacts on Exhaust Emissions can be found at: www.epa.gov/otaq/models/biodsl.htm

B100 is $100 \%$ Biodiesel while B20 is a blend of $20 \%$ Biodiesel and $80 \%$ conventional petroleum based diesel.

${ }^{a}$ Estimated from B100 result.

${ }^{\mathrm{b}}$ Average reduction across all compounds measured.

${ }^{\mathrm{c}}$ 2-nitroflourine results were within test method variability. 
The market effects of increased biodiesel production and use in the United States would likely drive up the price of soybean oil while driving down the price for soybean meal used in livestock feed. The overall net impact on farm incomes is estimated to be an increase of about $0.3 \%$.

Table 2.19

Estimated Impacts from Increased Use of Biodiesel

\begin{tabular}{lccc}
\hline & Market scenario (percentage change from baseline) & Medium & High \\
\hline Soybean oil production & 0.3 & 0.8 & 1.6 \\
Soybean oil price & 2.8 & 7.2 & 14.1 \\
Soybean meal price & -0.7 & -1.7 & -3.3 \\
Soybean price & 0.4 & 1 & 2 \\
Livestock price ("broilers”) & -0.3 & -0.7 & -1.4 \\
US net farm income & 0.1 & 0.2 & 0.3 \\
\hline
\end{tabular}

\section{Source:}

International Energy Agency, Biofuels for Transport: An International Perspective, May 2004. Page 96, Table 4.12. 


\section{BIO-OIL}

\section{BIO-OIL OVERVIEW}

A totally different process than that used to produce biodiesel can be used to convert biomass into a renewable diesel fuel known as bio-oil. The process, called fast or flash pyrolysis, occurs by heating compact solid fuels in the absence of air at temperatures between 400 and 500 degrees Celsius for a very short period of time (less than 2 seconds) and then condensing the resulting vapors within 2 seconds. While there are several fast pyrolysis technologies under development, there are only two commercial fast pyrolysis technologies as of 2008. The bio-oils currently produced are suitable for use in boilers or in turbines designed to burn heavy oils for electricity generation. There is currently ongoing research and development to upgrade bio-oil into transportation fuels.

DynaMotive Energy Systems is commercializing a proprietary fast pyrolysis process that converts forest and agricultural residue into liquid bio-oil and char. The company is in the process of launching the first bio-oil cogeneration facility in West Lorne, Ontario, in collaboration with Erie Flooring and Wood Products Company. The flooring company provides the wood residue and DynaMotive's 2.5-megawatt plant uses its fast pyrolysis technology and a gas turbine to supply power to the wood product company's mills and lumber kilns. DynaMotive is now in the process of building a second 200 ton-per-day plant in Guelph, Ontario.

Ensyn Group Inc. has commercialized a fast pyrolysis technology under the name of Rapid Thermal Processing RTP[tm]. This technology is based on the biomass refining concept, where value added chemicals are produced in addition to a consistent quality bio-oil. Ensyn has four RTP[tm] facilities in commercial operation; a new facility and a bio-oil refining plant are currently under construction. Three of the commercial facilities are in Wisconsin and one is near Ottawa, Canada. The largest of these facilities, built in 1996, processes about 75 green tons per day of mixed hardwood wastes. Ensyn currently produces about 30 chemical products from RTP[tm] bio-oil with lower value remnant bio-oil used for boiler fuel. Ensyn is just beginning to enter the energy market.

\section{Sources:}

DynaMotive Energy Systems Corporation, http://www.dynamotive.com/

Ensyn Group Inc., http://www.ensyn.com/

Table 2.20

Output Products by Method of Pyrolysis

\begin{tabular}{lccc}
\hline Process & Liquid & Char & Gas \\
\hline Fast Pyrolysis & $75 \%$ & $12 \%$ & $13 \%$ \\
Carbonization & $30 \%$ & $35 \%$ & $35 \%$ \\
Gasification & $5 \%$ & $10 \%$ & $85 \%$ \\
\hline
\end{tabular}

Source: Czernik, Stefan. Review of Fast Pyrolysis of Biomass. National Renewable Energy Laboratory, 2002. 
Bio-oil has many of the advantages of petroleum fuels since it can be stored, pumped and transported. It is currently being combusted directly in boilers, gas turbines, and slow and medium speed diesels for heat and power applications.

Figure 2.14

A Fast Pyrolysis Process for Making Bio-oil

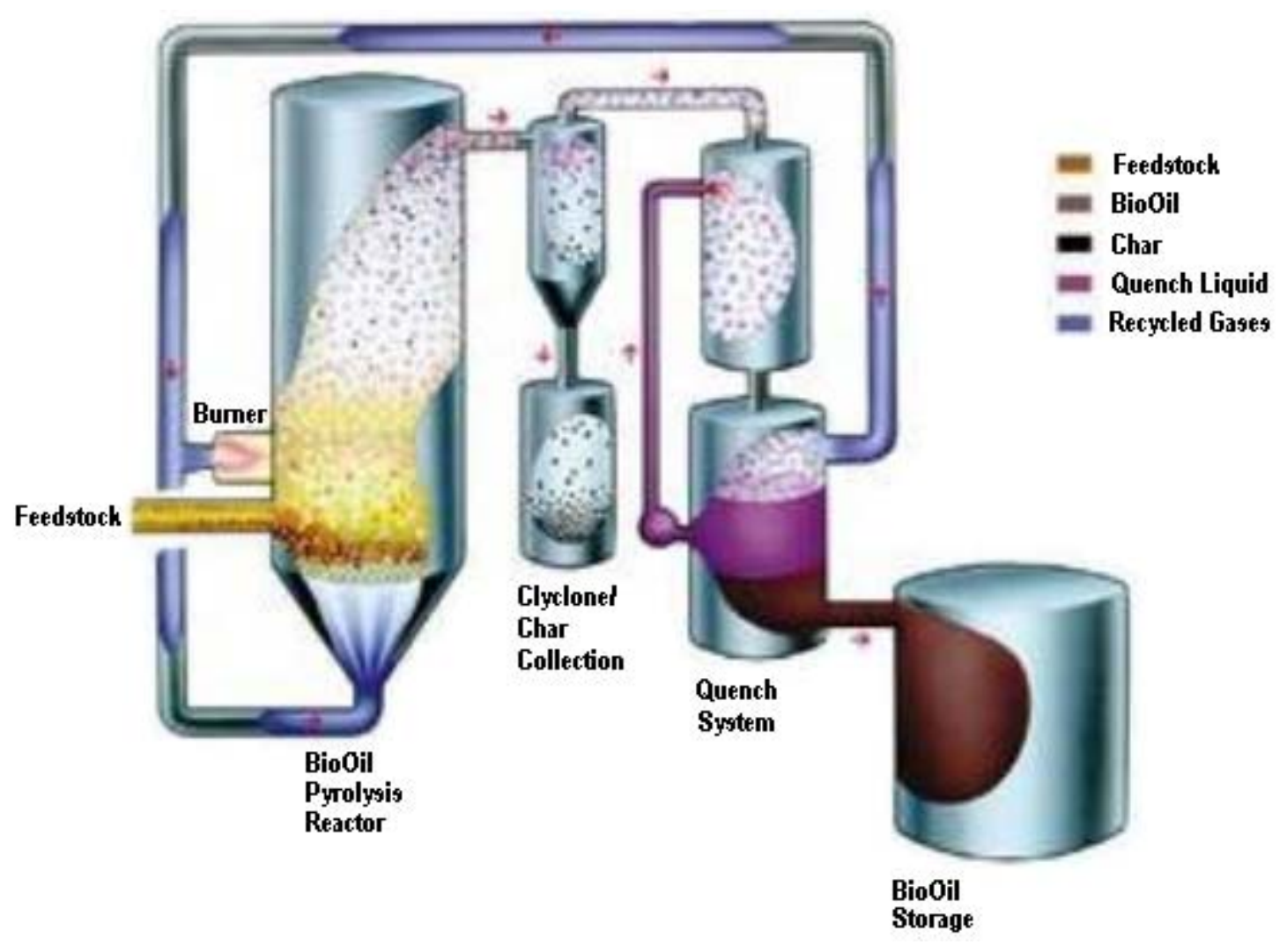

Source: http://www.dynamotive.com/biooil/technology.html 
"Bio-oil is a dark brown, free flowing liquid comprised of highly oxygenated compounds. As a fuel, bio-oil is considered to be $\mathrm{CO}_{2}$ neutral, and emits no $\mathrm{SO}_{x}$ and low NOx when combusted. Bio-oil density is high at $1.2 \mathrm{kgs} / \mathrm{litre}$. Heating value on a weight basis is approximately $40 \%$ to that of diesel. On a volume basis the heating value compared to diesel is approximately 55\%." -DynaMotive.

Table 2.21

Bio-oil Characteristics

\begin{tabular}{lcc}
\hline & \multicolumn{2}{c}{ Feedstock } \\
\cline { 2 - 3 } \multicolumn{1}{c}{ Bio-oil Characteristics } & $\begin{array}{c}\text { Pine 53\% Spruce 47\% } \\
\text { (including bark) }\end{array}$ & Bagasse \\
\hline $\mathrm{pH}$ & 2.4 & 2.6 \\
Water Content wt\% & 23.4 & 20.8 \\
Methanol Insoluable Solids (Lignin content wt\%) & 24.9 & 23.5 \\
Solids Content wt\% & $<0.10$ & $<0.10$ \\
Ash Content wt\% & $<0.02$ & $<0.02$ \\
Density kg/L & 1.19 & 1.2 \\
Low Heating Mj/kg & 16.4 & 15.4 \\
Kinematic Viscosity cSt @ $20^{\circ} \mathrm{C}$ & 40 & 50 \\
Kinematic Viscosity cSt @ $80^{\circ} \mathrm{C}$ & 6 & 7 \\
\hline
\end{tabular}

\section{Source:}

DynaMotive, http://www.dynamotive.com/biooil/whatisbiooil.html

Note: wt $\%$ =percent by weight. The exact composition of bio-oil may vary depending on feedstock and processing. The table above is based on the fast pyrolysis method using the specific feedstock listed in the table. Other companies also produce bio-oil using other conversion processes and feedstocks and the resulting bio-oil properties can vary widely.

$\mathrm{SO}_{\mathrm{x}}=$ Sulfur oxides.

$\mathrm{NO}_{\mathrm{x}}=$ Nitrogen oxides.

$\mathrm{CO}_{2}=$ Carbon dioxide . 
"Bio-oil is miscible with alcohols such as ethanol and methanol but is immiscible with hydrocarbons. The following table lists the chemical composition of major bio-oil constituents." -DynaMotive.

Table 2.22

Bio-oil Composition

\begin{tabular}{lcc}
\hline Concentrations wt\% & $\begin{array}{c}\text { Feedstock: Pine 53\% Spruce } \\
\text { 47\% (including bark) }\end{array}$ & Bagasse \\
\hline Water & 23.4 & 20.8 \\
Methanol Insoluable Solids \& Lignin & 24.9 & 23.5 \\
Cellubiosan & 1.9 & - \\
Glyoxal & 1.9 & 2.2 \\
Hydroxyacetaldehyde & 10.2 & 10.2 \\
Levoglucosan & 6.3 & 3.0 \\
Formaldehyde & 3.0 & 3.4 \\
Formic Acid & 3.7 & 5.7 \\
Acetic Acid & 4.2 & 6.6 \\
Acetol & 4.8 & 5.8 \\
\hline
\end{tabular}

Source:

DynaMotive, http://www.dynamotive.com/biooil/whatisbiooil.html

Note: $w t \%$ =percent by weight. The exact composition of bio-oil may vary depending on feedstock and processing. The table above is based on the fast pyrolysis method using the specific feedstock listed in the table. Other companies also produce bio-oil using other conversion processes and feedstocks and the resulting bio-oil properties can vary widely. 
"Bio-oil fuels have unique characteristics that distinguish them from petroleum-based (hydro-carbon) products. The table below illustrates the primary differences between bio-oil and other fuels including light and heavy fuel oil." -DynaMotive

Table 2.23

Bio-oil Fuel Comparisons

\begin{tabular}{lccc}
\hline & BioTherm $\AA$ Bio-oil & Light Fuel Oil & Heavy Fuel Oil \\
\hline Heat of combustion Btu/lb & 7,100 & 18,200 & 17,600 \\
Heat of combustion MJ/liter & 19.5 & 36.9 & 39.4 \\
Viscosity (centistokes) $50^{\circ} \mathrm{C}$ & 7 & 4 & 50 \\
Viscosity (centistokes) $80^{\circ} \mathrm{C}$ & 4 & 2 & 41 \\
Ash \% by weight & $<0.02$ & $<0.01$ & 0.03 \\
Sulphur \% by weight & Trace & 0.15 to 0.5 & 0.5 to 3 \\
Nitrogen \% by weight & Trace & 0 & 0.3 \\
Pour Point ${ }^{\circ} \mathrm{C}$ & -33 & -15 & -18 \\
Turbine NOx g/MJ & $<0.7$ & 1.4 & $\mathrm{~N} / \mathrm{A}$ \\
Turbine SOx g/MJ & 0 & 0.28 & $\mathrm{~N} / \mathrm{A}$ \\
\hline
\end{tabular}

\section{Source:}

DynaMotive, http://www.dynamotive.com/biooil/whatisbiooil.html

Notes: The exact characteristics of Bio-oil may vary depending on feedstock and processing. The table above is based on the fast pyrolysis method using feedstock composed of $53 \%$ pine and $47 \%$ spruce including bark. Other companies also produce bio-oil using other conversion processes and feedstocks and the resulting bio-oil properties can vary widely.

$\mathrm{N} / \mathrm{A}=$ Not Available 
Table 2.24

Annotated Summary of Biofuel and Biomass Electric Incentives as of September 2008: Online Information Resources

\author{
Yacobucci B D. Biofuels Incentives: A Summary of Federal Programs - Updated July 29, 2008 \\ http://assets.opencrs.com/rpts/RL33572 20080729.pdf
}

This 18 page document is easily readable and well-organized. It first describes Federal programs supporting research, development and deployment of biofuels and biomass electric, then has tables showing the legislative incentives that were updated by the Energy Independence and Security Act of 2007 (EISA 2007) and added by the 2008 Farm Bill - The Food, Conservation, and Energy Act of 2008.

U.S. Department of Agriculture. 2008 Farm Bill Side-By-Side. Title IX: Energy

http://www.ers.usda.gov/FarmBill/2008/Titles/TitlelXEnergy.htm

This is an extremely useful document providing brief descriptions of 2008 Farm Bill provisions and authorizations relevant to energy with comparisons to similar provisions in the previous farm bill where they existed. The document also links to energy provisions in other sections of the 2008 Farm Bill.

Energy Efficiency and Renewable Energy State Activities and Partnerships

http://apps1.eere.energy.gov/states/maps/renewable portfolio states.cfm

A Department of Energy site that contains a map linking to descriptions of state Renewable Portfolio Standards (RPS) as of June 2007 (created by DSIRE - Database of State Incentives for Renewables \& Efficiency). The site also contains a list summarizing state RPS levels with links to the administrative offices.

DSIRE - Database for State Incentives for Renewables \& Efficiency http://www.dsireusa.org/

The DSIRE website, which is kept up-to date claims to be a comprehensive source of information on state, local, utility, and federal incentives that promote renewable energy and energy efficiency. The site contains many summary maps and tables that can be downloaded as PowerPoint files.

American Wind Energy Association

http://www.awea.org/pubs/factsheets/State RPS Fact Sheet.pdf

This website contains a very nicely done 2-page fact sheet with one page containing a table that summarizes RPS requirements of 25 states and includes more detail than similar tables on other websites.

Renewable Fuels Association. Renewable Fuels Standard

http://www.ethanolrfa.org/resource/standard/

The Renewable Fuels Standard webpage on the Renewable Fuels Association site describes amendments to the 2005 Renewable Fuels Standard, and summarizes pertainent sections of EISA 2007.

Cantwell M. Comprehensive Guide to Federal Biofuel Incentives. 2006 http://cantwell.senate.gov/services/Biofuels/Comprehensive Guide to Federal\%20Biofuel In

This 25 page document is a very comprehensive and easily readable guide to federal legislation resulting from EPACT 2005 (of which several incentives are still in effect). It also contains information on Federal agency program authorizations for supporting the research, development and deployment of biofuels, and biomass electric technologies. It is valuable for comparison with them more recent EISA 2007 bill and the 2008 Farm Bill. 
These states have laws and incentives for alternative fuels production and/or use.

Table 2.25

Federal and State Alternative Fuel Incentives, 2007

\begin{tabular}{|c|c|c|c|c|c|c|c|c|}
\hline State & Biodiesel & Ethanol & $\begin{array}{l}\text { Natural } \\
\text { gas }\end{array}$ & $\begin{array}{l}\text { Liquefied } \\
\text { petroleum } \\
\text { gas (LPG) }\end{array}$ & $\begin{array}{c}\text { Electric } \\
\text { vehicles (EV and } \\
\text { NEV) }\end{array}$ & $\begin{array}{c}\text { Hydrogen fuel } \\
\text { cells }\end{array}$ & Blends & $\begin{array}{c}\text { Alternative } \\
\text { fuel-all }\end{array}$ \\
\hline Federal US & 22 & 20 & 17 & 17 & 0 & 21 & 2 & 17 \\
\hline Alabama & 0 & 0 & 2 & 1 & 0 & 0 & 0 & 0 \\
\hline Alaska & 1 & 1 & 1 & 1 & 2 & 1 & 0 & 1 \\
\hline Arizona & 4 & 3 & 9 & 10 & 9 & 7 & 0 & 5 \\
\hline Arkansas & 6 & 4 & 5 & 5 & 3 & 4 & 3 & 3 \\
\hline California & 18 & 17 & 25 & 19 & 28 & 20 & 1 & 16 \\
\hline Colorado & 6 & 6 & 9 & 7 & 5 & 5 & 1 & 5 \\
\hline Connecticut & 2 & 3 & 8 & 6 & 6 & 4 & 0 & 2 \\
\hline Delaware & 4 & 2 & 3 & 3 & 2 & 2 & 0 & 2 \\
\hline Dist. of Columbia & 3 & 3 & 4 & 3 & 3 & 3 & 0 & 3 \\
\hline Florida & 7 & 8 & 3 & 3 & 4 & 7 & 0 & 3 \\
\hline Georgia & 5 & 4 & 5 & 3 & 5 & 4 & 1 & 3 \\
\hline Hawaii & 5 & 7 & 4 & 5 & 4 & 5 & 2 & 4 \\
\hline Idaho & 4 & 4 & 2 & 2 & 1 & 1 & 4 & 0 \\
\hline Illinois & 9 & 12 & 5 & 4 & 5 & 3 & 2 & 2 \\
\hline Indiana & 9 & 9 & 4 & 2 & 3 & 2 & 13 & 2 \\
\hline lowa & 11 & 13 & 7 & 6 & 8 & 6 & 5 & 6 \\
\hline Kansas & 5 & 7 & 4 & 4 & 4 & 2 & 1 & 2 \\
\hline Kentucky & 4 & 3 & 4 & 2 & 1 & 1 & 2 & 1 \\
\hline Louisiana & 5 & 4 & 5 & 3 & 4 & 2 & 0 & 2 \\
\hline Maine & 7 & 8 & 6 & 6 & 6 & 5 & 1 & 5 \\
\hline Maryland & 4 & 3 & 1 & 1 & 2 & 1 & 0 & 1 \\
\hline Massachusetts & 1 & 1 & 3 & 1 & 1 & 1 & 0 & 1 \\
\hline Michigan & 8 & 6 & 4 & 4 & 4 & 5 & 4 & 4 \\
\hline Minnesota & 7 & 9 & 4 & 4 & 6 & 5 & 2 & 4 \\
\hline Mississippi & 3 & 2 & 5 & 3 & 1 & 1 & 0 & 1 \\
\hline Missouri & 7 & 6 & 5 & 4 & 5 & 4 & 4 & 3 \\
\hline Montana & 7 & 8 & 4 & 4 & 3 & 3 & 2 & 2 \\
\hline Nebraska & 4 & 4 & 4 & 4 & 2 & 2 & 1 & 2 \\
\hline Nevada & 3 & 3 & 4 & 4 & 3 & 3 & 0 & 3 \\
\hline New Hampshire & 3 & 1 & 1 & 1 & 2 & 1 & 0 & 1 \\
\hline New Jersey & 5 & 5 & 7 & 6 & 6 & 5 & 1 & 4 \\
\hline New Mexico & 11 & 8 & 8 & 6 & 7 & 8 & 2 & 6 \\
\hline New York & 11 & 12 & 16 & 10 & 12 & 12 & 1 & 9 \\
\hline North Carolina & 12 & 10 & 6 & 6 & 6 & 5 & 6 & 5 \\
\hline North Dakota & 6 & 3 & 0 & 0 & 0 & 1 & 5 & 0 \\
\hline Ohio & 2 & 2 & 1 & 1 & 1 & 2 & 0 & 3 \\
\hline Oklahoma & 6 & 7 & 7 & 7 & 7 & 4 & 0 & 4 \\
\hline Oregon & 8 & 8 & 6 & 5 & 8 & 5 & 3 & 5 \\
\hline Pennsylvania & 5 & 5 & 5 & 2 & 3 & 2 & 0 & 3 \\
\hline Puerto Rico & 0 & 0 & 0 & 0 & 0 & 0 & 0 & 0 \\
\hline Rhode Island & 5 & 4 & 4 & 4 & 6 & 4 & 0 & 4 \\
\hline South Carolina & 6 & 6 & 3 & 4 & 4 & 4 & 1 & 3 \\
\hline South Dakota & 6 & 7 & 1 & 2 & 0 & 0 & 8 & 0 \\
\hline Tennessee & 5 & 4 & 3 & 3 & 2 & 1 & 0 & 1 \\
\hline Texas & 8 & 8 & 11 & 11 & 8 & 8 & 1 & 7 \\
\hline Utah & 2 & 2 & 8 & 7 & 8 & 5 & 1 & 2 \\
\hline Vermont & 4 & 3 & 3 & 2 & 3 & 2 & 1 & 3 \\
\hline Virginia & 10 & 9 & 9 & 7 & 8 & 7 & 1 & 7 \\
\hline Washington & 16 & 14 & 10 & 9 & 12 & 7 & 7 & 6 \\
\hline West Virginia & 3 & 2 & 3 & 3 & 4 & 3 & 0 & 3 \\
\hline Wisconsin & 12 & 9 & 8 & 7 & 8 & 8 & 0 & 7 \\
\hline Wyoming & 0 & 2 & 1 & 0 & 0 & 0 & 1 & 0 \\
\hline Totals & 327 & 311 & 287 & 244 & 245 & 224 & 90 & 188 \\
\hline
\end{tabular}

\section{Source:}

U.S. Department of Energy, Energy Efficiency and Renewable Energy, Alternative Fuels Data Center. (Additional resources: www.eere.energy.gov/afdc/laws/incen laws.html)

Note: Because an incentive may apply to more than one alternative fuel, adding the totals for each row will result in counting one incentive multiple times. 


\section{BIOPOWER}

\section{BIOMASS POWER OVERVIEW}

Biomass power technologies convert renewable biomass fuels to heat and electricity using processes similar to that used with fossil fuels. Next to hydropower, more electricity is generated from biomass than any other renewable energy resource in the United States. A key attribute of biomass is its availability upon demand - the energy is stored within the biomass until it is needed. Other forms of renewable energy are dependent on variable environmental conditions such as wind speed or sunlight intensity.

Today in parts of the developing world, biomass is primarily used to provide heat for cooking and comfort. Technologies have now been developed which can generate electricity from the energy in biomass fuels. Biomass technologies are highly scalable - small enough to be used on a farm or in remote villages, or large enough to provide power for a small city.

There are four primary classes of biopower systems: direct-fired, co-fired, gasification, and modular systems. Most of today's biopower plants are direct-fired systems that are similar to most fossil-fuel fired power plants. The biomass fuel is burned in a boiler to produce high-pressure steam. This steam is introduced into a steam turbine, where it flows over a series of aerodynamic turbine blades, causing the turbine to rotate. The turbine is connected to an electric generator, so as the steam flow causes the turbine to rotate, the electric generator turns and electricity is produced. Biomass power boilers are typically in the 20-50 MW range, compared to coal-fired plants in the 100-1500 MW range. The small capacity plants tend to be lower in efficiency because of economic trade-offs; efficiency-enhancing equipment cannot pay for itself in small plants. Although techniques exist to push biomass steam generation efficiency over $40 \%$, actual plant efficiencies are often in the low $20 \%$ range.

Co-firing involves substituting biomass for a portion of coal in an existing power plant furnace. It is the most economic near-term option for introducing new biomass power generation. Because much of the existing power plant equipment can be used without major modifications, cofiring is far less expensive than building a new biopower plant. Compared to the coal it replaces, biomass reduces sulphur dioxide $\left(\mathrm{SO}_{2}\right)$, nitrogen oxides $\left(\mathrm{NO}_{\mathrm{x}}\right)$, and other air emissions. After "tuning" the boiler for peak performance, there is little or no loss in efficiency from adding biomass. This allows the energy in biomass to be converted to electricity with the high efficiency (in the $33-37 \%$ range) of a modern coal-fired power plant.

Biomass gasifiers operate by heating biomass in an oxygen-limited environment where the solid biomass breaks down to form a flammable gas. The producer gas can be cleaned and filtered to remove problem chemical compounds. The producer gas can be used in more efficient power generation systems called combined-cycles, which combine gas turbines and steam turbines to produce electricity. The efficiency of these systems can reach 40 to 50 percent. Additionally, gasifiers are sometimes located next to existing coal or natural gas boilers and used to fire or supplement the fuels to these boilers.

Modular systems employ some of the same technologies mentioned above, but on a smaller scale that is more applicable to villages, farms, and small industry. These systems are now under development and could be most useful in remote areas where biomass is abundant and electricity is scarce. There are many opportunities for these systems in developing countries.

\section{Source:}

U.S. Department of Energy, Energy Efficiency and Renewable Energy, http://www1.eere.energy.gov/biomass/abcs biopower.html 
Table 3.1

Biomass Power Technology in Commercial/Demonstration Phase during 2000-2006

\begin{tabular}{|c|c|c|c|c|}
\hline $\begin{array}{l}\text { Technology } \\
\text { Category }\end{array}$ & $\begin{array}{l}\text { Biomass Conversion } \\
\text { Technology }\end{array}$ & $\begin{array}{l}\text { Primary Energy Form } \\
\text { Produced }\end{array}$ & $\begin{array}{l}\text { Primary Energy } \\
\text { Conversion and } \\
\text { RecoveryTechnology }\end{array}$ & $\begin{array}{l}\text { Final Energy } \\
\text { Products }\end{array}$ \\
\hline Direct combustion & Stove/Furnace & Heat & Heat exchanger & Hot air, hot water \\
\hline Direct combustion & Pile burners & Heat, steam & Steam turbine & Electricity \\
\hline Direct combustion & Stoker grate boilers & Heat, steam & Steam turbine & Electricity \\
\hline Direct combustion & $\begin{array}{l}\text { Suspension boilers: Air } \\
\text { spreader stoker or cyclonic }\end{array}$ & Heat, steam & Steam turbine & Electricity \\
\hline Direct combustion & $\begin{array}{l}\text { Fluidized-bed combustor } \\
\text { FB - bubbling CFB- } \\
\text { circulating }\end{array}$ & Heat, steam & Steam turbine & Electricity \\
\hline Direct combustion & $\begin{array}{l}\text { Co-firing in coal-fired boilers } \\
\text { (several types) }\end{array}$ & Heat, steam & Steam turbine & Electricity \\
\hline $\begin{array}{l}\text { Gasification } \\
\text { (atmospheric) }\end{array}$ & $\begin{array}{l}\text { updraft, counter current } \\
\text { fixed bed }\end{array}$ & Low Btu producer gas & $\begin{array}{l}\text { Combustion boiler }+ \\
\text { steam generator and } \\
\text { turbine }\end{array}$ & $\begin{array}{l}\text { Process heat or } \\
\text { heat plus } \\
\text { electricity }\end{array}$ \\
\hline $\begin{array}{l}\text { Gasification } \\
\text { (atmospheric) }\end{array}$ & Downdraft, moving bed & Low Btu producer gas & $\begin{array}{l}\text { Spark engine (internal } \\
\text { combustion) }\end{array}$ & Power, electricity \\
\hline $\begin{array}{l}\text { Gasification } \\
\text { (atmospheric) }\end{array}$ & $\begin{array}{l}\text { Circulating Fluidized Bed } \\
\text { (CFB) dual vessel }\end{array}$ & $\begin{array}{l}\text { medium Btu producer } \\
\text { gas }\end{array}$ & $\begin{array}{l}\text { Burn gas in boiler w/ } \\
\text { Steam Turbine }\end{array}$ & Electricity \\
\hline $\begin{array}{l}\text { Gasification } \\
\text { (atmospheric) }\end{array}$ & Co-fueling in CFB gasifiers & $\begin{array}{l}\text { Low or medium Btu } \\
\text { producer gas }\end{array}$ & $\begin{array}{l}\text { Combustion turbine or } \\
\text { boiler and steam turbine }\end{array}$ & Electricity \\
\hline Slow pyrolysis & Kilns or retorts & Charcoal & Stoves and furnaces & Heat \\
\hline Fast (flash) pyrolysis & Reactors & $\begin{array}{l}\text { Pyrolysis oil (bio-oil), } \\
\text { charcoal }\end{array}$ & $\begin{array}{l}\text { Combustion turbines, } \\
\text { boilers, diesel engines, } \\
\text { furnaces, catalytic } \\
\text { reactors }\end{array}$ & $\begin{array}{l}\text { Heat, electricity, } \\
\text { synthetic liquid } \\
\text { fuels, (BTL) }\end{array}$ \\
\hline Anerobic digestion & Digesters, landfills & Biogas (medium Btu gas) & $\begin{array}{l}\text { Spark ignition engines, } \\
\text { combustion turbines, }\end{array}$ & Heat, electricity \\
\hline
\end{tabular}

\section{Source:}

Compiled by Lynn Wright, Oak Ridge, TN.

Note: See Glossary for definitions of terms found under the "Technology Category" column.

The following references are suggested for further reading:

Overend, Ralph. 2003. "Heat, Power and Combined Heat and Power," Chapter 3 in: Sims, R. Bioenergy Options for a Cleaner Environment: In Developed and Developing Countries, Elsiver, ISBN: 0-08044351-6, 193 pages.

Broek, R. van den, Faaij, A., and van Wijk, J. 1995, Biomass Combustion Power Generation Technologies, Study performed within the framework of the extended JOULE-IIA programme of CECDGXII, project "Energy from Biomass: An Assessment of Two Promising Systems for Energy Production," Department of Science, Technology and Society, Utrech University, Utrecht (Report no. 95029). Available at Web site: http://www.chem.uu.nl/nws/www/publica/95029.htm 
Many biomass fuels cause slagging and other forms of deposit formation during combustion. These deposits can reduce heat transfer, reduce combustion efficiency, and damage combustion chambers when large particles break off. Research has focused on two alkali metals, potassium and sodium, and silica, all elements commonly found in living plants. In general, it appears that faster growing plants (or faster growing plant components such as seeds) tend to have higher concentrations of alkali metal and silica. Thus materials such as straw, nut hulls, fruit pits, weeds, and grasses tend to create more problems when burned than wood from a slow growing tree.

Potassium and sodium metals, whether in the form of oxides, hydroxides, or metallo-organic compounds tend to lower the melting point of ash mixtures containing various other minerals such as silica (SiO2). The high alkali content (up to 35\%) in the ash from burning annual crop residues lowers the fusion or 'sticky temperature' of these ashes from 2200' $F$ for wood ash to as low as 1300' $F$. This results in serious slagging on the boiler grate or in the bed and fouling of convection heat transfer surfaces. Even small percentages (10\%) of some of these high alkali residues burned with wood in conventional boilers will cause serious slagging and fouling in a day or two, necessitating combustion system shutdown.

A method to predict slagging and fouling from combustion of biomass fuels has been adapted from the coal industry. The method involves calculating the weight in pounds of alkali (K2O + Na2O) per million Btu in the fuel as follows:

$$
\begin{aligned}
& 1 \times 106 \quad \text { Ib Alkali } \\
& \text {-------- } X \quad \% \text { Ash } X \% \text { Alkali of the Ash }= \\
& \text { Btu/lb MM Btu }
\end{aligned}
$$

This method combines all the pertinent data into one Index Number. A value below $0.4 \mathrm{Ib} / \mathrm{MM}$ Btu is considered a fairly low slagging risk. Values between 0.4 and $0.8 \mathrm{Ib} / \mathrm{MM}$ Btu will probably slag with increasing certainty of slagging as $0.8 \mathrm{lb} / \mathrm{MM}$ Btu is approached. Above $0.8 \mathrm{lb} / \mathrm{MM}$ Btu, the fuel is virtually certain to slag and foul.

\begin{tabular}{|c|c|c|c|c|c|c|}
\hline \multirow[b]{2}{*}{ Fuel } & \multirow[b]{2}{*}{ Btu/lb (dry) } & \multirow[b]{2}{*}{ Ash \% } & \multicolumn{3}{|c|}{ Total Alkali } & \multirow[b]{3}{*}{ Minimal Slagging } \\
\hline & & & $\%$ in Ash & Ib/ton & Ib/MMBtu & \\
\hline WOOD & & & & & & \\
\hline Pine Chips & 8,550 & $0.70 \%$ & $3.00 \%$ & 0.4 & 0.07 & $.4 \mathrm{lb} / \mathrm{MMBtu}$ \\
\hline White Oak & 8,165 & $0.40 \%$ & $31.80 \%$ & 2.3 & 0.14 & \\
\hline Hybrid Poplar & 8,178 & $1.90 \%$ & $19.80 \%$ & 7.5 & 0.46 & \\
\hline Urban Wood Waste & 8,174 & $6.00 \%$ & $6.20 \%$ & 7.4 & 0.46 & Probable Slagging \\
\hline \multicolumn{6}{|l|}{ "Clean" } & \\
\hline Tree Trimmings & 8,144 & $3.60 \%$ & $16.50 \%$ & 11.9 & 0.73 & \\
\hline \multicolumn{6}{|l|}{ PITS, NUTS, SHELLS } & \multirow{8}{*}{ Certain Slagging } \\
\hline Almond Shells & 7,580 & $3.50 \%$ & $21.10 \%$ & 14.8 & 0.97 & \\
\hline Refuse Derived Fuel & 5,473 & $9.50 \%$ & $9.20 \%$ & 17.5 & 1.60 & \\
\hline \multicolumn{6}{|l|}{ STRAWS } & \\
\hline Switch Grass & 7,741 & $10.10 \%$ & $15.10 \%$ & 30.5 & 1.97 & \\
\hline Wheat Straw-average & 7,978 & $5.10 \%$ & $31.50 \%$ & 32.1 & 2.00 & \\
\hline Wheat Straw-hi alkali & 7,167 & $11.00 \%$ & $36.40 \%$ & 80.0 & 5.59 & \\
\hline Rice Straw & 6,486 & $18.70 \%$ & $13.30 \%$ & 49.7 & 3.80 & \\
\hline Bagasse - washed & 8,229 & $1.70 \%$ & $12.30 \%$ & 4.2 & 0.25 & \\
\hline
\end{tabular}

Table 3.2

Alkali Content and Slagging Potential of Various Biofuels

Source:

Thomas R. Miles, Thomas R. Miles Jr., Larry L. Baxter, Bryan M. Jenkins, Laurance L. Oden, "Alkali Slagging Problems with Biomass Fuels," First Biomass Conference of the Americas: Energy, Environment, Agriculture, and Industry, Volume 1, 1993. 


\section{REBURNING WITH WOOD FUELS FOR NOx MITIGATION}

Reburning is a combustion modification technology based on the principle that hydrocarbon fragments $(\mathrm{CH})$ can react with Nitrogen Oxides $\left(\mathrm{NO}_{\mathrm{x}}\right)$. Reburning is accomplished by secondary fuel injection downstream of the fuel-lean primary combustion zone or a furnace. The second stage or reburning zone is usually operated at an overall fuel-rich condition, allowing a significant fraction of the primary $\mathrm{NO}_{\mathrm{x}}$ to be reduced to N2 and other nitrogenous species. In the third zone, additional air is introduced to establish overall fuel-lean conditions and allow for the burnout of remaining fuel fragments.

Reburning studies with coal and natural gas have shown $\mathrm{NO}_{x}$ emission reductions of $50-60 \%$ with about $15 \%$ of the heat input coming from the reburn fuel. In contrast, experimental results have shown $\mathrm{NO}_{\mathrm{x}}$ reductions as high as $70 \%$ using approximately $10-15 \%$ wood heat input.

The stoichiometric ratio in the reburn zone was the single most important variable affecting $\mathrm{NO}_{\mathrm{x}}$ reduction. The highest reductions were found at a reburn stoichiometric ratio of 0.85 .

One additional benefit of using wood instead of natural gas for reburning-it is difficult to mix natural gas into the products of the primary combustion zone since the gas must be injected from the wall, at relatively low flows. Wood particles, which must be transported to the furnace by a carrier medium (likely candidates are air or flue gas), would have a ballistic effect upon entering the furnace that would enhance cross-stream mixing compared to natural gas.

\section{Source:}

Brouwer, J., N.S. Harding, M.P. Heap, J.S. Lighty, and D.W. Pershing, 1997, An Evaluation of Wood Reburning for $\mathrm{NO}_{x}$ Reduction from Stationary Sources, final report to the DOE/TVA Southeastern Regional Biomass Energy Program, Muscle Shoals, AL, Contract No. TV-92271 (available at www.bioenergyupdate.com). 
The following table shows EPA data for uncontrolled emissions from the combustion of different fuels. Note that wood compares favorably with the other fuels except for particulate emissions (PM). However particulates are relatively easy to control and can be captured with cyclones and baghouses.

Table 3.3

Typical Uncontrolled Emission Factors for Steam Generator Fuels (Nanograms/Joule and Pounds/Million Btu) Heat Input

\begin{tabular}{|c|c|c|c|c|c|c|c|c|c|c|c|c|}
\hline \multirow[b]{2}{*}{ Fuel Type } & \multicolumn{2}{|c|}{ PM } & \multicolumn{2}{|c|}{$\mathrm{NO}_{2}$} & \multicolumn{2}{|r|}{$\mathrm{SO}_{2}$} & \multicolumn{2}{|r|}{$\mathrm{CO}$} & \multicolumn{2}{|r|}{$\mathrm{HC}$} & \multicolumn{2}{|c|}{ Trace Metals $^{e}$} \\
\hline & $\mathrm{NG/J}$ & LB/MMbtu & $\mathrm{NG/J}$ & LB/MMbtu & $\mathrm{NG/J}$ & LB/MMbtu & $\mathrm{NG} / \mathrm{J}$ & LB/MMbtu & $\mathrm{NG/J}$ & LB/MMbtu & $\mathrm{NG} / \mathrm{J}$ & LB/MMbtu \\
\hline $\mathrm{Coal}^{\mathrm{a}}$ & 1,093 & 2.540 & 387 & 0.90 & 2450 & 5.700 & $\overline{13}$ & 0.030 & 2 & 0.005 & 4 & 0.009 \\
\hline Oil (residual) ${ }^{b}$ & 96 & 0.230 & ${ }^{d} 170$ & ${ }^{\mathrm{d}} 0.39$ & 1,400 & 3.220 & 14 & 0.030 & 3 & 0.010 & 0.07 & 0.0002 \\
\hline Oil (distillate) ${ }^{c}$ & 6 & 0.010 & ${ }^{d} 100$ & ${ }^{\mathrm{d}} 0.23$ & 220 & 0.510 & 16 & 0.040 & 3 & 0.010 & - & - \\
\hline Natural Gas & 4 & 0.010 & ${ }^{d} 100$ & ${ }^{\mathrm{d}} 0.23$ & 0.3 & 0.001 & 7 & 0.020 & 1 & 0.003 & c & 0 \\
\hline Wood & 2,100 & 4.880 & 110 & 0.25 & 9 & 0.020 & - & - & - & - & - & - \\
\hline Solid Waste & 1,400 & 3.220 & 130 & 0.31 & 210 & 0.490 & - & - & - & - & - & - \\
\hline
\end{tabular}

Source:

Federal Register, Tuesday, June 19, 1984, p.25106, Vol. 49, No. 119.

${ }^{a}$ Based on high-sulfur (3.5 percent by weight), high-ash (10.6 percent by weight) coal burned in a spreader stoker coal-fired steam generating unit.

${ }^{\mathrm{b}}$ Based on high-sulfur oil (3.0 percent by weight).

${ }^{\mathrm{c}}$ Based on low-sulfur oil (0.5 percent by weight.

${ }^{\mathrm{d}}$ Assumes no combustion air preheat.

e Based on lead to illustrate general level of trace metal emissions. 
For the purpose of agricultural soil amendment, wood ash application is similar to lime application. Both materials can benefit crop productivity but wood ash has an added advantage of supplying additional nutrients. Both materials are also alkaline and could cause crop damage if over applied or misused.

Table 3.4

Range in Elemental Composition of Industrial Wood Ash Samples and Ground Limestone

\begin{tabular}{|c|c|c|}
\hline Element & Wood Ash $^{\mathrm{a}}$ & Limestone \\
\hline Macroelements & \multicolumn{2}{|c|}{ Concentration in \% } \\
\hline Calcium & $15(2.5-33)$ & 31 \\
\hline Potassium & $2.6(0.1-13)$ & 0.13 \\
\hline Aluminum & $1.6(0.5-3.2)$ & 0.25 \\
\hline Magnesium & $1.0(0.1-2.5)$ & 5.1 \\
\hline Iron & $0.84(0.2-2.1)$ & 0.29 \\
\hline Phosphorus & $0.53(0.1-1.4)$ & 0.06 \\
\hline Manganese & $0.41(0-1.3)$ & 0.05 \\
\hline Sodium & $0.19(0-0.54)$ & 0.07 \\
\hline Nitrogen & $0.15(0.02-0.77)$ & 0.01 \\
\hline Microelements & \multicolumn{2}{|c|}{ Concentration in $\mathrm{mg} / \mathrm{kg}$} \\
\hline Arsenic & $6(3-10)$ & . \\
\hline Boron & $123(14-290)$ & . \\
\hline Cadmium & $3(0.2-26)$ & 0.7 \\
\hline Chromium & $57(7-368)$ & 6 \\
\hline Copper & $70(37-207)$ & 10 \\
\hline Lead & $65(16-137)$ & 55 \\
\hline Mercury & $1.9(0-5)$ & . \\
\hline Molybdenum & $19(0-123)$ & . \\
\hline Nickel & $20(0-63)$ & 20 \\
\hline Selenium & $0.9(0-11)$ & . \\
\hline Zinc & $233(35-1250)$ & 113 \\
\hline \multicolumn{3}{|c|}{ Other Chemical Properties } \\
\hline $\mathrm{CaCO}_{3}$ Equivalent & $43 \%(22-92 \%)$ & $100 \%$ \\
\hline $\mathrm{pH}$ & $10.4(9-13.5)$ & 9.9 \\
\hline$\%$ Total solids & $75(31-100)$ & 100 \\
\hline
\end{tabular}

\section{Source:}

Mark Risse and Glen Harris. Soil Acidity and liming Internet Inservice Training, Best Management Practices for Wood Ash Used as an Agricultural Soil Amendment, http://hubcap.clemson.edu/ blpprt/bestwoodash.html

${ }^{\mathrm{a}}$ Mean and (Range) taken from analysis of 37 ash samples. 
Table 3.5

Biomass Power Technology Fuel Specifications and Capacity Range

\begin{tabular}{|c|c|c|c|c|}
\hline $\begin{array}{c}\text { Biomass Conversion } \\
\text { Technology }\end{array}$ & Commonly used fuel types $^{a}$ & $\begin{array}{l}\text { Particle Size } \\
\text { Requirements }\end{array}$ & $\begin{array}{c}\text { Moisture Content } \\
\text { Requirements (wet } \\
\text { basis) }^{\text {b }}\end{array}$ & $\begin{array}{c}\text { Average capacity range / link to } \\
\text { examples }\end{array}$ \\
\hline Stove/Furnace & $\begin{array}{l}\text { Solid wood, pressed logs, wood } \\
\text { chips and pellets }\end{array}$ & $\begin{array}{l}\text { Limited by stove size } \\
\text { and opening }\end{array}$ & $10-30 \%$ & $15 \mathrm{kWt}$ to ? \\
\hline Pile burners & $\begin{array}{l}\text { Virtually any kind of wood } \\
\text { residues }^{c} \text { or agricultural residues }{ }^{d} \\
\text { except wood flour }\end{array}$ & $\begin{array}{l}\text { Limited by grate size } \\
\text { and feed opening }\end{array}$ & $<65 \%$ & 4 to $110 \mathrm{MWe}$ \\
\hline $\begin{array}{l}\text { Pile burner fed with } \\
\text { underfire stoker (biomass } \\
\text { fed by auger below bed) }\end{array}$ & $\begin{array}{l}\text { Sawdust, non-stringy bark, } \\
\text { shavings, chips, hog fuel }\end{array}$ & $0.25-2$ in $(6-38 \mathrm{~mm})$ & $10-30 \%$ & 4 to $110 \mathrm{MWe}$ \\
\hline Stoker grate boilers & $\begin{array}{l}\text { Sawdust, non-stringy bark, } \\
\text { shavings, end cuts, chips, chip } \\
\text { rejects, hog fuel }\end{array}$ & $0.25-2$ in $(6-50 \mathrm{~mm})$ & $\begin{array}{l}10-50 \% \text { (keep } \\
\text { within } 10 \% \text { of design } \\
\text { rate) }\end{array}$ & $\begin{array}{l}20 \text { to } 300 \text { MWe many in } 20 \text { to } 50 \\
\text { MWe range }\end{array}$ \\
\hline Suspension boilers Cyclonic & $\begin{array}{l}\text { Sawdust. Non-stringy bark, } \\
\text { shavings, flour, sander dust }\end{array}$ & 0.25 in $(6 \mathrm{~mm}) \max$ & $<15 \%$ & many $<30 \mathrm{MWe}$ \\
\hline $\begin{array}{l}\text { Suspension boilers, Air } \\
\text { spreader-stoker }\end{array}$ & $\begin{array}{l}\text { Wood flour, sander dust, and } \\
\text { processed sawdust, shavings }\end{array}$ & $\begin{array}{l}0.04 \text { in }-0.06 \text { in }(1-1.6 \\
\mathrm{mm})\end{array}$ & $<20 \%$ & $1.5 \mathrm{MWe}$ to $30 \mathrm{MWe}$ \\
\hline $\begin{array}{l}\text { Fluidized-bed combustor } \\
\text { (FB- bubbling or CFB- } \\
\text { circulating) }\end{array}$ & $\begin{array}{l}\text { Low alkali content fuels, mostly } \\
\text { wood residues or peat no flour or } \\
\text { stringy materials }\end{array}$ & $<2$ in $(<50 \mathrm{~mm})$ & $<60 \%$ & $\begin{array}{l}\text { Many at } 20 \text { to } 25 \mathrm{MWe} \text {, up to } 300 \\
\text { Example } 1 \\
\text { Example } 2\end{array}$ \\
\hline $\begin{array}{l}\text { Co-firing: pulverized coal } \\
\text { boiler }\end{array}$ & $\begin{array}{l}\text { Sawdust, non-stringy bark, } \\
\text { shavings, flour, sander dust }\end{array}$ & $<0.25$ in $(<6 \mathrm{~mm})$ & $<25 \%$ & Up to $1500 \mathrm{MWe}^{\mathrm{e}}$ Example \\
\hline Co-firing: cyclones & $\begin{array}{l}\text { Sawdust, non-stringy bark, } \\
\text { shavings, flour, sander dust }\end{array}$ & $<0.5$ in $(<12 \mathrm{~mm})$ & $10-50 \%$ & 40 to $1150 \mathrm{MWe}^{\mathrm{e}}$ Example \\
\hline $\begin{array}{l}\text { Co-firing: stokers, fluidized } \\
\text { bed }\end{array}$ & $\begin{array}{l}\text { Sawdust, non-stringy bark, } \\
\text { shavings, flour, hog fuel }\end{array}$ & $<3$ in $(<72 \mathrm{~mm})$ & $10-50 \%$ & $\mathrm{MWe}^{\mathrm{e}}$ Example \\
\hline $\begin{array}{l}\text { Counter current, fixed bed } \\
\text { (updraft) atmospheric }\end{array}$ & $\begin{array}{l}\text { Chipped wood or hog fuel, rice } \\
\text { hulls, dried sewage sludge }\end{array}$ & $\begin{array}{l}0.25-4 \text { in }(6-100 \\
\mathrm{mm})\end{array}$ & $<20 \%$ & $\begin{array}{l}5 \text { to } 90 \mathrm{MWt},+ \text { up to } 12 \mathrm{MWe} \\
\text { Example }\end{array}$ \\
\hline $\begin{array}{l}\text { Downdraft, moving bed } \\
\text { atmospheric gasifier }\end{array}$ & $\begin{array}{l}\text { Wood chips, pellets, wood scrapes, } \\
\text { nut shells }\end{array}$ & $<2$ in $(<50 \mathrm{~mm})$ & $<15 \%$ & 25-100 kWe Example \\
\hline $\begin{array}{l}\text { Circulating fluidized bed } \\
\text { (CFB), dual vessel, gasifier }\end{array}$ & $\begin{array}{l}\text { Most wood and chipped agricultural } \\
\text { residues but no flour or stringy } \\
\text { materials }\end{array}$ & $0.25-2$ in $(6-50 \mathrm{~mm})$ & $15-50 \%$ & $\sim 5$ to $10 \mathrm{MWe}$ Example \\
\hline Fast pyrolysis & $\begin{array}{l}\text { Variety of wood and agricultural } \\
\text { resources }\end{array}$ & $0.04-0.25$ in (1-6 mm ) & $<10 \%$ & $\begin{array}{l}\sim 2.5 \mathrm{MWe} \text { Example } 1 \\
\text { Example 2 }\end{array}$ \\
\hline Anerobic digesters & $\begin{array}{l}\text { Animal manures \& bedding, food } \\
\text { processing residues, brewery by- } \\
\text { products, other industry organic } \\
\text { residues }\end{array}$ & NA & $\begin{array}{l}65 \text { to } 99.9 \% \text { liquid } \\
\text { depending on type, } \\
\text { i.e., } 0.1 \text { to } 35 \% \\
\text { solids }\end{array}$ & $\begin{array}{l}145 \text { to } 1700 \times 103 \mathrm{kWhr} / \mathrm{yr} \\
\text { Example } 1 \\
\text { Example } 2\end{array}$ \\
\hline
\end{tabular}

Source:

Compiled by Lynn Wright, Oak Ridge, TN.

a Primary source for fuel types is: Badger, Phillip C. 2002, Processing Cost Analysis for Biomass Feedstocks, ORNL/TM-2002/199. Available at http://bioenergy.ornl.gov/main.aspx (search by title or author)

${ }^{b}$ Most primary biomass, as harvested, has a moisture content (MC) of 50 to $60 \%$ (by wet weight) while secondary or tertiary sources of biomass may be delivered at between 10 and $30 \%$. A lower MC always improves efficiency and some technologies require low MC biomass to operate properly while others can handle a range of MC.

${ }^{c}$ Wood residues may include forest logging residues and storm damaged trees (hog fuel), primary mill residues (e.g., chipped bark and chip rejects), secondary mill residues (e.g., dry sawdust), urban wood residues such as construction and demolition debris, pallets and packaging materials, tree trimmings, urban land clearing debris, and other wood residue components of municipal solid waste (as wood chips).

${ }^{d}$ Agricultural residues may include straws and dried grasses, nut hulls, orchard trimmings, fruit pits, etc. Slagging may be more of a problem in some types of combustion units with high alkali straws and grasses, unless the boilers have been specially designed to handle these type fuels.

${ }^{\mathrm{e}}$ The biomass component of a co-firing facility will usually be less than the equivalent of $50 \mathrm{MWe}$. 
There are three distinct markets for green power in the United States. In regulated markets, a single utility may provide a green power option to its customers through "green pricing," which is an optional service or tariff offered to customers. These utilities include investor-owned utilities, rural electric cooperatives, and other publicly-owned utilities. More than 500 utilities in 34 states offer green pricing or are in the process of preparing programs.

In restructured (or competitive) electricity markets, retail electricity customers can choose from among multiple electricity suppliers, some of which may offer green power. Electricity markets are now open to full competition in a number of states, while others are phasing in competition.

Finally, consumers can purchase green power through "renewable energy certificates." These certificates represent the environmental attributes of renewable energy generation and can be sold to customers in either type of market, whether or not they already have access to a green power product from their existing retail power provider.

Utility market research shows that a majority of customer respondents is likely to state that they would pay at least \$5 more per month for renewable energy. And business and other nonresidential customers, including colleges and universities, and government entities, are increasingly interested in green power.

Table 3.6

New Renewable Capacity Supplying Green Power Markets, 2004

\begin{tabular}{lrrrc}
\hline \multicolumn{1}{c}{ Source } & MW in Place & Percent & MW Planned & Percent \\
\hline Wind & $2,045.6$ & 91.6 & 364.5 & 80.1 \\
Biomass & $\mathbf{1 3 5 . 6}$ & $\mathbf{6 . 1}$ & $\mathbf{5 8 . 8}$ & $\mathbf{1 2 . 9}$ \\
Solar & 8.1 & 0.4 & 0.4 & 0.1 \\
Geothermal & 35.5 & 1.6 & 0.0 & 0.0 \\
Small Hydro & 8.5 & 0.4 & 31.3 & 6.9 \\
\hline Total & $\mathbf{2 , 2 3 3 . 3}$ & $\mathbf{1 0 0 . 0}$ & $\mathbf{4 5 5 . 0}$ & $\mathbf{1 0 0 . 0}$ \\
\hline
\end{tabular}

\section{Source:}

National Renewable Energy Laboratory, Power Technologies Energy Data Book, Chapter 3, Table 3.6.5, http://www.nrel.gov/analysis/power databook/chapter3.html

Note: $M W=$ megawatt. 
Green pricing is an optional utility service that allows customers an opportunity to support a greater level of utility company investment in renewable energy technologies. Participating customers pay a premium on their electric bill to cover the extra cost of the renewable energy. Many utilities are offering green pricing to build customer loyalty and expand business lines and expertise prior to electric market competition. As of 2003, 36 utilities in 19 states had implemented green pricing options that used or included biomass feedstocks.

Table 3.7

New Renewable Capacity Supported through Utility Green Pricing Programs, 2004

\begin{tabular}{lcccc}
\hline \multicolumn{1}{c}{ Source } & MW in Place & Percent & MW Planned & Percent \\
\hline Wind & 584.0 & 82.8 & 139.7 & 61.1 \\
Biomass & 76.3 & 10.8 & 57.5 & 25.1 \\
Solar & 6.1 & 0.9 & 0.2 & 0.1 \\
Geothermal & 30.5 & 4.3 & 0.0 & 0.0 \\
Small Hydro & 8.5 & 1.2 & 31.3 & 13.7 \\
\hline Total & $\mathbf{7 0 5 . 5}$ & $\mathbf{1 0 0 . 0}$ & $\mathbf{2 2 8 . 7}$ & $\mathbf{1 0 0 . 0}$ \\
\hline
\end{tabular}

Source:

National Renewable Energy Laboratory, Power Technology Energy Data Book, Table 3.7.1, http://www.nrel.gov/analysis/power databook/chapter3.html

Note: $M W=$ megawatt. 
There are a growing number of utilities offering green pricing programs that utilize biomass resources.

Table 3.8

Utility Green Pricing Programs Using Biomass and Biomass Based Resources (Updated September 2007)

\begin{tabular}{|c|c|c|c|c|c|}
\hline $\begin{array}{l}\text { State } \\
A L\end{array}$ & $\begin{array}{l}\text { Utility Name } \\
\text { Alabama Electric Cooperative: City of Andalusia, Baldwin } \\
\text { Electric Membership Cooperative, City of Brundidge, } \\
\text { Central Alabama Electric Cooperative, Clarke- } \\
\text { Washington Electric Membership Cooperative, Coosa } \\
\text { Valley Electric Cooperative, Covington Electric } \\
\text { Cooperative, Dixie Electric Cooperative, City of Elba, } \\
\text { City of Opp, Pea River Electric Cooperative, Pioneer } \\
\text { Electric Cooperative, South Alabama Electric } \\
\text { Cooperative, Southern Pine Electric Cooperative, } \\
\text { Tallapoosa River Electric Cooperative, Wiregrass }\end{array}$ & $\begin{array}{c}\text { Program Name } \\
\text { Green Power Choice }\end{array}$ & $\begin{array}{r}\text { Type } \\
\text { landfill gas }\end{array}$ & $\begin{array}{c}\text { Start Date } \\
2006\end{array}$ & $\begin{array}{l}\text { Premium } \\
2.0 \phi / \mathrm{kWh}\end{array}$ \\
\hline$\overline{\mathrm{AL}}$ & Alabama Power Company & $\begin{array}{l}\text { Renewable Energy } \\
\text { Rate }\end{array}$ & $\begin{array}{l}\text { biomass co-firing } \\
\text { (wood) }\end{array}$ & $2003 / 2000$ & $4.5 \phi / \mathrm{kWh}$ \\
\hline$\overline{A L}$ & $\begin{array}{l}\text { TVA: Cherokee Electric Coop, City of Athens Electric } \\
\text { Department, Cullman Electric Coop, Cullman Power } \\
\text { Board, Decatur Utilities, Florence Utilities, Guntersville } \\
\text { Electric Board, Hartselle Utilities, Huntsville Utilities, Joe } \\
\text { Wheeler EMC, Marshall-DeKalb Electric Coop, Muscle } \\
\text { Shoals Electric Board, North Alabama Electric Coop, } \\
\text { Sand Mountain Electric Coop, Scottsboro Electric Power } \\
\text { Board, Sheffield Utilities, Tuscumbia Electric Department }\end{array}$ & Green Power Switch & landfill gas, PV, wind & 2000 & $2.67 \phi / \mathrm{kWh}$ \\
\hline$\overline{A Z}$ & Salt River Project & EarthWise Energy & $\begin{array}{l}\text { central PV, wind, } \\
\text { landfill gas, small } \\
\text { hydro, geothermal }\end{array}$ & $1998 / 2001$ & $3.0 \phi / \mathrm{kWh}$ \\
\hline $\mathrm{AZ}$ & Tucson Electric & GreenWatts & landfill gas, PV & 2000 & $10 \phi / \mathrm{kWh}$ \\
\hline$\overline{\mathrm{CA}}$ & Anaheim Public Utilities & $\begin{array}{l}\text { Green Power for the } \\
\text { Grid }\end{array}$ & wind, landfill gas & 2002 & $1.5 \phi / \mathrm{kWh}$ \\
\hline $\mathrm{CA}$ & Los Angeles Department of Water and Power & $\begin{array}{l}\text { Green Power for a } \\
\text { Green LA }\end{array}$ & wind, landfill gas & 1999 & $3.0 \phi / \mathrm{kWh}$ \\
\hline$\overline{\mathrm{CA}}$ & Sacramento Municipal Utility District & Greenergy & $\begin{array}{l}\text { wind, landfill gas, } \\
\text { hydro, PV }\end{array}$ & 1997 & $\begin{array}{l}1.0 \phi / \mathrm{kWh} \text { or } \\
\$ 6 / \text { month }\end{array}$ \\
\hline $\mathrm{DE}$ & Delaware Electric Cooperative & $\begin{array}{l}\text { Renewable Energy } \\
\text { Rider }\end{array}$ & landfill gas & 2006 & $0.2 \phi / \mathrm{kWh}$ \\
\hline FL & $\begin{array}{l}\text { Alabama Electric Cooperative: CHELCO, Escambia } \\
\text { River Electric Cooperative, Gulf Coast Electric } \\
\text { Cooperative, West Florida Electric Cooperative }\end{array}$ & Green Power Choice & landfill gas & 2006 & $2.0 \phi / \mathrm{kWh}$ \\
\hline $\mathrm{FL}$ & City of Tallahassee/Sterling Planet & Green for You & biomass, $\mathrm{PV}$ & 2002 & $1.6 \phi / \mathrm{kWh}$ \\
\hline $\mathrm{FL}$ & Florida Power \& Light / Green Mountain Energy & Sunshine Energy & biomass, wind, $\mathrm{PV}$ & 2004 & $0.975 \phi / \mathrm{kWh}$ \\
\hline$\overline{F L}$ & Gainesville Regional Utilities & GRUgreen Energy & landfill gas, wind, $\mathrm{PV}$ & 2003 & $2.0 \phi / \mathrm{kWh}$ \\
\hline FL & Keys Energy Services / Sterling Planet & $\begin{array}{l}\text { GO GREEN: USA } \\
\text { Green }\end{array}$ & wind, biomass, $\mathrm{PV}$ & 2004 & $1.60 \phi / \mathrm{kWh}$ \\
\hline $\mathrm{FL}$ & Keys Energy Services / Sterling Planet & $\begin{array}{l}\text { GO GREEN: Florida } \\
\text { Ever Green }\end{array}$ & $\begin{array}{l}\text { solar hot water, PV, } \\
\text { biomass }\end{array}$ & 2004 & $2.75 \phi / \mathrm{kWh}$ \\
\hline $\mathrm{FL}$ & Tampa Electric Company (TECO) & $\begin{array}{l}\text { Renewable Energy } \\
\text { Program }\end{array}$ & $\begin{array}{l}\text { PV, landfill, biomass } \\
\text { co-firing (wood) }\end{array}$ & 2000 & $2.5 \phi / \mathrm{kWh}$ \\
\hline
\end{tabular}

Continued on next page 
Table 3.8 (Continued)

Utility Green Pricing Programs Using Biomass and Biomass Based Resources (Updated September 2007)

\begin{tabular}{|c|c|c|c|c|c|}
\hline State & Utility Name & Program Name & Type & Start Date & Premium \\
\hline GA & $\begin{array}{l}\text { Georgia Electric Membership Corporation (35 of } 42 \\
\text { coops offer program): Altamaha EMC, Amicalola EMC, } \\
\text { Canoochee EMC, Carroll EMC, Central Georgia EMC, } \\
\text { Cobb EMC, Coastal Electric, Colquitt EMC, Coweta- } \\
\text { Fayette EMC, Diverse Power, Flint Energies, Grady } \\
\text { EMC, GreyStone Power, Habersham EMC, Hart EMC, } \\
\text { Irwin EMC, Jackson EMC, Jefferson Energy, Little } \\
\text { Ocmulgee EMC, Middle Georgia EMC, Mitchell EMC, } \\
\text { Ocmulgee EMC, Oconee EMC, Planters EMC, Rayle } \\
\text { EMC, Sawnee EMC, Slash Pine EMC, Snapping Shoals } \\
\text { EMC, Southern Rivers Energy, Sumter EMC, Three } \\
\text { Notch EMC, Tri-County EMC, Upson EMC, Walton } \\
\text { EMC, Washington EMC }\end{array}$ & Green Power EMC & $\begin{array}{l}\text { landfill gas, PV in } \\
\text { schools }\end{array}$ & 2001 & $\begin{array}{l}2.0 \phi / \mathrm{kWh}- \\
3.3 \phi / \mathrm{kWh}\end{array}$ \\
\hline$\overline{G A}$ & Georgia Power & Green Energy & landfill gas, solar & 2006 & $4.5 \phi / \mathrm{kWh}$ \\
\hline$\overline{\mathrm{GA}}$ & $\begin{array}{l}\text { TVA: Blue Ridge Mountain EMC, North Georgia EMC, } \\
\text { Tri-State EMC }\end{array}$ & Green Power Switch & landfill gas, $\mathrm{PV}$, wind & 2000 & $2.67 \phi / \mathrm{kWh}$ \\
\hline IL & City of St. Charles/ComEd and Community Energy, Inc. & TBD & wind, landfill gas & 2003 & Contribution \\
\hline IL & $\begin{array}{l}\text { Dairyland Power Cooperative: Jo-Carroll } \\
\text { Energy/Elizabeth }\end{array}$ & \begin{tabular}{|l|} 
Evergreen \\
Renewable Energy \\
Program
\end{tabular} & $\begin{array}{l}\text { landfill gas, biogas, } \\
\text { hydro, wind }\end{array}$ & 1997 & $1.5 \phi / \mathrm{kWh}$ \\
\hline IN & Duke Energy & GoGreen Power & $\begin{array}{l}\text { wind, PV, landfill gas, } \\
\text { digester gas }\end{array}$ & 2001 & $2.5 \phi / \mathrm{kWh}$ \\
\hline IN & $\begin{array}{l}\text { Hoosier Energy (5 of } 17 \text { coops offer program): } \\
\text { Southeastern Indiana REMC, South Central Indiana } \\
\text { REMC, Utilities District of Western Indiana REMC, } \\
\text { Decatur County REMC, Daviess-Martin County REMC }\end{array}$ & EnviroWatts & landfill gas & 2001 & $\begin{array}{l}2.0 \phi / \mathrm{kWh}- \\
4.0 \phi / \mathrm{kWh}\end{array}$ \\
\hline IN & $\begin{array}{l}\text { Wabash Valley Power Association (7 of } 27 \text { coops offer } \\
\text { program): Boone REMC, Hendricks Power Cooperative, } \\
\text { Kankakee Valley REMC, Miami-Cass REMC, Tipmont }\end{array}$ & EnviroWatts & landfill gas & 2000 & $\begin{array}{l}0.9 \phi / \mathrm{kWh}- \\
1.0 \phi / \mathrm{kWh}\end{array}$ \\
\hline IA & Alliant Energy & Second Nature & landfill gas, wind & 2001 & $2.0 \phi / \mathrm{kWh}$ \\
\hline $\mathrm{IA}$ & $\begin{array}{l}\text { Associated Electric Cooperative, Inc.: Access Energy } \\
\text { Cooperative, Chariton Valley Electric Cooperative, } \\
\text { Southern lowa Electric Cooperative }\end{array}$ & varies by utility & biomass, wind & 2003 & $\begin{array}{l}2.0 \phi / \mathrm{kWh}- \\
3.5 \phi / \mathrm{kWh}\end{array}$ \\
\hline IA & $\begin{array}{l}\text { Dairyland Power Cooperative: Allamakee- } \\
\text { Clayton/Postville, Hawkeye Tri-County/Cresco, } \\
\text { Heartland Power/Thompson \& St. Ansgar }\end{array}$ & \begin{tabular}{|l|} 
Evergreen \\
Renewable Energy \\
Program
\end{tabular} & $\begin{array}{l}\text { hydro, wind, landfill } \\
\text { gas, biogas }\end{array}$ & 1998 & $3.0 \phi / \mathrm{kWh}$ \\
\hline IA & Farmers Electric Cooperative & Green Power Project & biodiesel, wind & 2004 & Contribution \\
\hline IA & $\begin{array}{l}\text { lowa Association of Municipal Utilities (84 of } 137 \text { munis } \\
\text { offer program) Afton, Algona, Alta Vista, Aplington, } \\
\text { Auburn, Bancroft, Bellevue, Bloomfield, Breda, Brooklyn, } \\
\text { Buffalo, Burt, Callender, Carlisle, Cascade, Coggon, } \\
\text { Coon Rapids, Corning, Corwith, Danville, Dayton, } \\
\text { Durant, Dysart, Earlville, Eldridge, Ellsworth, Estherville, } \\
\text { Fairbank, Farnhamville, Fontanelle, Forest City, Gowrie, } \\
\text { Grafton, Grand Junction, Greenfield, Grundy Center, } \\
\text { Guttenberg, Hopkinton, Hudson, Independence, } \\
\text { Keosauqua, La Porte City, Lake Mills, Lake View, } \\
\text { Laurens, Lenox, Livermore, Maquoketa, Marathon, } \\
\text { McGregor, Milford, Montezuma, Mount Pleasant, Neola, } \\
\text { New Hampton, Ogden, Orient, Osage, Panora, Pella, } \\
\text { Pocahontas, Preston, Readlyn, Rockford, Sabula, } \\
\text { Sergeant Bluff, Sibley, Spencer, Stanhope, State Center, } \\
\text { Stratford, Strawberry Point, Stuart, Tipton, Villisca, } \\
\text { Vinton, Webster City, West Bend, West Liberty, West } \\
\text { Point, Westfield, Whittemore, Wilton, Winterset }\end{array}$ & Green City Energy & wind, biomass, PV & 2003 & \begin{tabular}{|l|} 
Varies by uti \\
lity
\end{tabular} \\
\hline
\end{tabular}

Continued on next page 
Table 3.8 (Continued)

Utility Green Pricing Programs Using Biomass and Biomass Based Resources (Updated September 2007)

\begin{tabular}{|c|c|c|c|c|c|}
\hline State & Utility Name & Program Name & Type & Start Date & Premium \\
\hline KY & $\begin{array}{l}\text { East Kentucky Power Cooperative: Blue Grass Energy, } \\
\text { Clark, Cumberland, Fleming-Mason, Grayson, Inter- } \\
\text { County Energy, Jackson, Licking Valley, Nolin, Owen } \\
\text { Electric, Salt River, Shelby, South Kentucky }\end{array}$ & EnviroWatts & landfill gas & 2002 & $2.75 \phi / \mathrm{kWh}$ \\
\hline $\mathrm{KY}$ & $\begin{array}{l}\text { TVA: Bowling Green Municipal Utilities, Franklin Electric } \\
\text { Plant Board, Hopkinsville Electric System, Murray } \\
\text { Electric System, Pennyrile Rural Electric Coop, Tri- } \\
\text { County Electric, Warren Rural Electric Coop }\end{array}$ & Green Power Switch & landfill gas, PV, wind & 2000 & $2.67 \phi / \mathrm{kWh}$ \\
\hline LA & Entergy Gulf States & Green Pricing & biomass & 2007 & $2.5 \phi / \mathrm{kWh}$ \\
\hline $\mathrm{MI}$ & Consumers Energy & Green Generation & $\begin{array}{l}68 \% \text { wind, } 32 \% \\
\text { landfill gas }\end{array}$ & 2005 & $1.67 \phi / \mathrm{kWh}$ \\
\hline $\mathrm{MI}$ & DTE Energy & GreenCurrents & wind, biomass & 2007 & $\begin{array}{l}2.0 \phi / \mathrm{kWh}- \\
2.5 \phi / \mathrm{kWh}\end{array}$ \\
\hline $\mathrm{Ml}$ & Lansing Board of Water and Light & $\begin{array}{l}\text { GreenWise Electric } \\
\text { Power }\end{array}$ & $\begin{array}{l}\text { landfill gas, small } \\
\text { hydro }\end{array}$ & 2001 & $3.0 \phi / \mathrm{kWh}$ \\
\hline $\mathrm{Ml}$ & Upper Peninsula Power Company & NatureWise & $\begin{array}{l}\text { wind, landfill gas and } \\
\text { animal waste } \\
\text { methane }\end{array}$ & 2004 & $4.0 \phi / \mathrm{kWh}$ \\
\hline $\mathrm{Ml}$ & We Energies & Energy for Tomorrow & $\begin{array}{l}\text { wind, landfill gas, } \\
\text { hydro }\end{array}$ & 2000 & $2.04 \phi / \mathrm{kWh}$ \\
\hline$\overline{M N}$ & Alliant Energy & Second Nature & landfill gas, wind & 2002 & $2.0 \phi / \mathrm{kWh}$ \\
\hline MN & $\begin{array}{l}\text { Central Minnesota Municipal Power Agency: Blue Earth, } \\
\text { Delano, Glencoe, Granite Falls, Janesville, Kenyon, }\end{array}$ & $\begin{array}{l}\text { Green Energy } \\
\text { Program }\end{array}$ & wind, landfill gas & 2000 & $\begin{array}{l}1.5 \phi / \mathrm{kWh}- \\
2.5 \phi / \mathrm{kWh}\end{array}$ \\
\hline MN & $\begin{array}{l}\text { Dairyland Power Cooperative: Freeborn-Mower } \\
\text { Cooperative / Albert Lea, People's / Rochester, Tri- }\end{array}$ & \begin{tabular}{|l} 
Evergreen \\
Renewable Energy
\end{tabular} & $\begin{array}{l}\text { hydro, wind, landfill } \\
\text { gas, biogas }\end{array}$ & 1998 & $1.5 \phi / \mathrm{kWh}$ \\
\hline MS & $\begin{array}{l}\text { TVA: 4-County Electric Power Association, Alcorn } \\
\text { Electric Power Association, Central Electric Power }\end{array}$ & Green Power Switch & landfill gas, $P V$, wind & 2000 & $2.67 \phi / \mathrm{kWh}$ \\
\hline MO & $\begin{array}{l}\text { Associated Electric Cooperative, Inc.: Black River } \\
\text { Electric Cooperative, Boone Electric Cooperative, }\end{array}$ & varies by utility & biomass, wind & 2003 & $\begin{array}{l}2.0 \phi / \mathrm{kWh}- \\
3.5 \phi / \mathrm{kWh}\end{array}$ \\
\hline $\mathrm{NE}$ & Omaha Public Power District & $\begin{array}{l}\text { Green Power } \\
\text { Program }\end{array}$ & landfill gas, wind & 2002 & $3.0 \phi / \mathrm{kWh}$ \\
\hline NC & Dominion North Carolina Power & NC GreenPower & $\begin{array}{l}\text { biomass, hydro, } \\
\text { landfill gas, PV, wind }\end{array}$ & 2003 & $\begin{array}{l}2.5 \phi / \mathrm{kWh}- \\
4.0 \phi / \mathrm{kWh}\end{array}$ \\
\hline $\mathrm{NC}$ & Duke Energy & NC GreenPower & $\begin{array}{l}\text { biomass, hydro, } \\
\text { landfill gas, PV, wind }\end{array}$ & 2003 & $\begin{array}{l}2.5 \phi / \mathrm{kWh}- \\
4.0 \phi / \mathrm{kWh}\end{array}$ \\
\hline $\mathrm{NC}$ & $\begin{array}{l}\text { ElectriCities: Town of Apex, Town of Cornelius, } \\
\text { Fayetteville PWC, Town of Granite Falls, Greenville } \\
\text { Utilities, City of High Point, City of Kinston, City of } \\
\text { Laurinburg, City of Lexington, City of Monroe, City of } \\
\text { New Bern, City of Newton, City of Shelby, City of }\end{array}$ & NC GreenPower & $\begin{array}{l}\text { biomass, hydro, } \\
\text { landfill gas, PV, wind }\end{array}$ & 2003 & $\begin{array}{l}2.5 \phi / \mathrm{kWh}- \\
4.0 \phi / \mathrm{kWh}\end{array}$ \\
\hline $\mathrm{NC}$ & $\begin{array}{l}\text { NC Electric Cooperatives (21 of } 27 \text { coops offer } \\
\text { program): Albemarle Electric Membership Corp., Blue } \\
\text { Ridge Electric Membership Corp., Brunswick Electric } \\
\text { Membership Corp., Carteret Craven Electric Coop., } \\
\text { Central Electric Membership Corp., Edgecombe-Martin } \\
\text { County Electric Membership Corp., EnergyUnited, Four } \\
\text { County Electric Membership Corp., French Broad } \\
\text { Electric Membership Corp., Haywood Electric } \\
\text { Membership Corp., Jones-Onslow Electric Membership } \\
\text { Corp., Lumbee River Electric Membership Corp., Pee } \\
\text { Dee Electric Membership Corp., Piedmont Electric } \\
\text { Membership Corp., Randolph Electric Membership } \\
\text { Corp., Roanoke Electric Membership Corp., Rutherford }\end{array}$ & NC GreenPower & $\begin{array}{l}\text { biomass, hydro, } \\
\text { landfill gas, PV, wind }\end{array}$ & 2003 & $\begin{array}{l}2.5 \phi / \mathrm{kWh}- \\
4.0 \phi / \mathrm{kWh}\end{array}$ \\
\hline NC & Progress Energy / CP\&L & NC GreenPower & \begin{tabular}{|l} 
biomass, hydro, \\
landfill gas, PV, wind
\end{tabular} & 2003 & $\begin{array}{l}2.5 \phi / \mathrm{kWh}- \\
4.0 \phi / \mathrm{kWh}\end{array}$ \\
\hline $\mathrm{NC}$ & TVA: Mountain Electric Cooperative & Green Power Switch & landfill gas, $P V$, wind & 2000 & $2.67 \phi / \mathrm{kWh}$ \\
\hline
\end{tabular}

Continued on next page 
Table 3.8 (Continued)

Utility Green Pricing Programs Using Biomass and Biomass Based Resources (Updated September 2007)

\begin{tabular}{|c|c|c|c|c|c|}
\hline State & Utility Name & Program Name & Type & Start Date & Premium \\
\hline $\mathrm{OH}$ & AEP Ohio & Green Pricing Option & landfill gas & 2007 & $0.7 \phi / \mathrm{kWh}$ \\
\hline $\mathrm{OH}$ & $\begin{array}{l}\text { American Municipal Power-Ohio / Green Mountain } \\
\text { Energy: City of Bowling Green, Cuyahoga Falls, } \\
\text { Westerville, Wyandotte, Yellow Springs }\end{array}$ & Nature's Energy & $\begin{array}{l}\text { small hydro, landfill } \\
\text { gas, wind }\end{array}$ & 2003 & $\begin{array}{l}1.3 \phi / \mathrm{kWh}- \\
1.5 \phi / \mathrm{kWh}\end{array}$ \\
\hline $\mathrm{OH}$ & Buckeye Power & EnviroWatts & landfill gas & 2006 & $2.0 \phi / \mathrm{kWh}$ \\
\hline $\mathrm{OH}$ & Duke Energy & GoGreen Power & $\begin{array}{l}\text { wind, PV, landfill gas, } \\
\text { digester gas }\end{array}$ & 2001 & $2.5 \phi / \mathrm{kWh}$ \\
\hline $\mathrm{OK}$ & $\begin{array}{l}\text { Associated Electric Cooperative, Inc.: Central Rural } \\
\text { Electric Cooperative }\end{array}$ & varies by utility & biomass, wind & 2003 & $\begin{array}{l}2.0 \phi / \mathrm{kWh}- \\
3.5 \phi / \mathrm{kWh}\end{array}$ \\
\hline OR & \begin{tabular}{|l|} 
Pacific Northwest Generating Cooperative: Blachly-Lane \\
Electric Cooperative, Central Electric Cooperative, \\
Clearwater Power, Consumers Power, Coos-Curry \\
Electric Cooperative, Douglas Electric Cooperative, Fall \\
River Rural Electric Cooperative, Lost River Electric \\
Cooperative, Raft River Rural Electric Cooperative, \\
Umatilla Electric Cooperative, West Oregon Electric \\
Cooperative, (11 of 15 coops offer program)
\end{tabular} & Green Power & landfill gas & 1998 & $\begin{array}{l}1.8 \phi / \mathrm{kWh}- \\
2.0 \phi / \mathrm{kWh}\end{array}$ \\
\hline OR & PacifiCorp: Pacific Power / 3Degrees & Blue Sky Habitat & wind, biomass, PV & 2002 & $\begin{array}{l}0.78 \phi / \mathrm{kWh} \\
+\$ 2.50 / \mathrm{mo}\end{array}$ \\
\hline OR & PacifiCorp: Pacific Power / 3Degrees & Blue Sky Usage & wind, biomass, PV & 2002 & $0.78 \phi / \mathrm{kWh}$ \\
\hline SC & Duke Energy Carolinas & $\begin{array}{l}\text { Palmetto Clean } \\
\text { Energy (PaCE) }\end{array}$ & $\begin{array}{l}\text { wind, solar, landfill } \\
\text { gas }\end{array}$ & 2008 & $4.0 \phi \mathrm{s} ; / \mathrm{kWh}$ \\
\hline SC & Progress Energy Carolinas & \begin{tabular}{|l|} 
Palmetto Clean \\
Energy (PaCE)
\end{tabular} & $\begin{array}{l}\text { wind, solar, landfill } \\
\text { gas }\end{array}$ & 2008 & $4.0 \phi / \mathrm{kWh}$ \\
\hline SC & $\begin{array}{l}\text { Santee Cooper: Aiken Electric Cooperative, Berkeley } \\
\text { Electric Cooperative, Blue Ridge Electric, Coastal } \\
\text { Electric Cooperative, Edisto Electric Cooperative, } \\
\text { Fairfield Electric Cooperative, Horry Electric } \\
\text { Cooperative, Laurens Electric Cooperative, Lynches } \\
\text { River Electric Cooperative, Marlboro Electric } \\
\text { Cooperative, Mid-Carolina Electric Cooperative, } \\
\text { Palmetto Electric Cooperative, Pee Dee Electric } \\
\text { Cooperative, Santee Electric Cooperative, Tri-County } \\
\text { Electric Cooperative, York Electric Cooperative }\end{array}$ & $\begin{array}{l}\text { Green Power } \\
\text { Program }\end{array}$ & landfill gas & 2001 & $3.0 \phi / \mathrm{kWh}$ \\
\hline SC & SCE\&G & $\begin{array}{l}\text { Palmetto Clean Ener } \\
\text { gy (PaCE) }\end{array}$ & $\begin{array}{l}\text { wind, solar, landfill } \\
\text { gas }\end{array}$ & 2008 & $4.0 \phi / \mathrm{kWh}$ \\
\hline TN & \begin{tabular}{|l|l} 
TVA: Alcoa Electric Department, Appalachian Electric \\
Cooperative, Athens Utility Board, Bristol Tennessee \\
Electric System, Brownsville Utility Department, Caney \\
Fork Electric Cooperative, Chickasaw Electric \\
Cooperative, Clarksville Department of Electricity, \\
Cleveland Utilities, Clinton Utilities Board, Cookeville \\
Electric Department, Covington Electric System, \\
Cumberland Electric Membership Corporation, Dickson \\
Electric Department, Duck River Electric Membership \\
Corporation, Dyersberg Electric System, City of \\
Elizabethton Electric System, EPB (Chattanooga), Erwin \\
Utilities, Etowah Utilities, Fayetteville Public Utilities, Fort \\
Loudon Electric Cooperative, Gallatin Department of \\
Electricity, Gibson Electric Membership Corporation, \\
Greeneville Light and Power System, Harriman Utility \\
Board, Holston Electric Cooperative, Johnson City \\
Power Board, Jackson Energy Authority, Knoxville \\
Utilities Board, Lafollette Utilities Board, Lawrenceburg \\
Power System, Lenoir City Utilities Board, Lexington \\
Electric System, Loudon Utilities, City of Maryville \\
Electric Department, McMinnville Electric System, Memph
\end{tabular} & Green Power Switch & landfill gas, $P V$, wind & 2000 & $2.67 \phi / \mathrm{kWh}$ \\
\hline
\end{tabular}

Continued on next page 
Table 3.8 (Continued)

Utility Green Pricing Programs Using Biomass and Biomass Based Resources (Updated September 2007)

\begin{tabular}{|c|c|c|c|c|c|}
\hline \begin{tabular}{|l} 
State \\
\end{tabular} & Utility Name & Program Name & Type & Start Date & \begin{tabular}{|r|} 
Premium \\
185
\end{tabular} \\
\hline$T X$ & Austin Energy (City of Austin) & GreenChoice & wind, landfill gas & $2000 / 1997$ & $1.85 \phi / \mathrm{kWh}$ \\
\hline VT & Central Vermont Public Service & CVPS Cow Power & biogas & 2004 & $4.0 \phi / \mathrm{kWh}$ \\
\hline VT & Green Mountain Power & \begin{tabular}{|l|} 
CoolHome / \\
CoolBusiness
\end{tabular} & wind, biomass & 2002 & Contribution \\
\hline WA & Benton County Public Utility District & $\begin{array}{l}\text { Green Power } \\
\text { Program }\end{array}$ & $\begin{array}{l}\text { landfill gas, wind, } \\
\text { hydro }\end{array}$ & 1999 & Contribution \\
\hline WA & Clallam County PUD & $\begin{array}{l}\text { Clallam County PUD } \\
\text { Green Power } \\
\text { Program }\end{array}$ & landfill gas & 2001 & $0.69 \phi / \mathrm{kWh}$ \\
\hline WA & Pacific County PUD & Green Power & landfill gas & 2002 & $1.05 \phi / \mathrm{kWh}$ \\
\hline WA & Peninsula Light & Green by Choice & wind, hydro, biogas & 2002 & $2.0 \phi / \mathrm{kWh}$ \\
\hline WA & Puget Sound Energy & $\begin{array}{l}\text { Green Power } \\
\text { Program }\end{array}$ & wind, $\mathrm{PV}$, biogas & 2002 & $1.25 \phi / \mathrm{kWh}$ \\
\hline WA & Seattle City Light & Seattle Green Power & PV, biogas & 2002 & Contribution \\
\hline WV & AEP Ohio & Green Pricing Option & landfill gas & 2007 & $0.7 \phi / \mathrm{kWh}$ \\
\hline WI & Alliant Energy & Second Nature & wind, landfill gas & 2000 & $2.0 \phi / \mathrm{kWh}$ \\
\hline WI & $\begin{array}{l}\text { Dairyland Power Cooperative: Barron Electric, Bayfield/ } \\
\text { Iron River, Chippewa / Cornell Valley, Clark / } \\
\text { Greenwood, Dunn / Menomonie, Eau Claire / Fall Creek, } \\
\text { Jackson / Black River Falls, Jump River / Ladysmith, } \\
\text { Oakdale, Pierce-Pepin / Ellsworth, Polk-Burnett / } \\
\text { Centuria, Price / Phillips, Richland, Riverland / Arcadia, } \\
\text { St. Croix / Baldwin, Scenic Rivers / Lancaster, Taylor / } \\
\text { Medford, Vernon / Westby }\end{array}$ & \begin{tabular}{|l|} 
Evergreen \\
Renewable Energy \\
Program
\end{tabular} & $\begin{array}{l}\text { hydro, wind, landfill } \\
\text { gas, biogas }\end{array}$ & 1998 & $1.5 \phi / \mathrm{kWh}$ \\
\hline WI & We Energies & Energy for Tomorrow & $\begin{array}{l}\text { landfill gas, PV, } \\
\text { hydro, wind }\end{array}$ & 1996 & $1.37 \phi / \mathrm{kWh}$ \\
\hline WI & $\begin{array}{l}\text { Wisconsin Public Power Inc. (34 of } 37 \text { munis offer } \\
\text { program): Algoma, Cedarburg, Florence, Kaukauna, } \\
\text { Muscoda, Stoughton, Reedsburg, Oconomowoc, } \\
\text { Waterloo, Whitehall, Columbus, Hartford, Lake Mills, } \\
\text { New Holstein, Richland Center, Boscobel, Cuba City, } \\
\text { Hustisford, Sturgeon Bay, Waunakee, Lodi, New } \\
\text { London, Plymouth, River Falls, Sun Prairie, Waupun, } \\
\text { Eagle River, Jefferson, Menasha, New Richmond, } \\
\text { Prairie du Sac, Slinger, Two Rivers, Westby }\end{array}$ & $\begin{array}{l}\text { Renewable Energy } \\
\text { Program }\end{array}$ & $\begin{array}{l}\text { small hydro, wind, } \\
\text { biogas }\end{array}$ & 2001 & $1.0 \phi / \mathrm{kWh}$ \\
\hline WI & Wisconsin Public Service & NatureWise & $\begin{array}{l}\text { wind, landfill gas, } \\
\text { biogas }\end{array}$ & 2002 & $1.86 \phi / \mathrm{kWh}$ \\
\hline
\end{tabular}

\section{Source:}

National Renewable Energy Laboratory, Golden, Colorado, http://apps3.eere.energy.gov/greenpower/markets/pricing.shtml?page=1

Notes: Utility green pricing programs may only be available to customers located in the utility's service territory. 
A growing number of states have companies that offer a range of green power products that allow consumers to purchase electricity generated in part or entirely from biomass resources.

Table 3.9

Competitive Electricity Markets Retail Green Power Product Offerings, October 2005

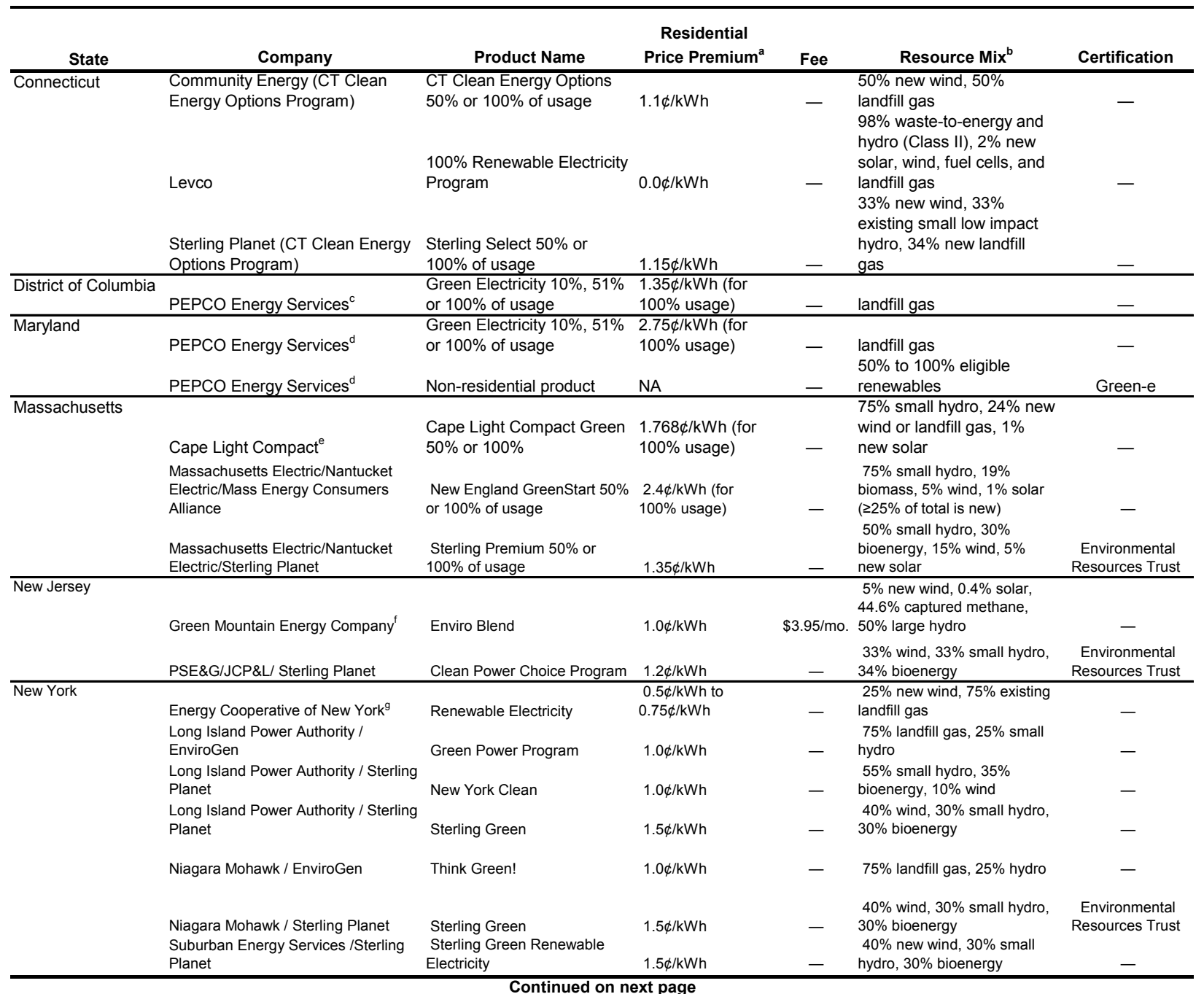


Table 3.9 (Continued)

Competitive Electricity Markets Retail Green Power Product Offerings, October 2005

\begin{tabular}{|c|c|c|c|c|c|c|}
\hline \multirow[t]{2}{*}{ Pennsylvania } & $\begin{array}{l}\text { Energy Cooperative of } \\
\text { Pennsylvania }^{\text {h }}\end{array}$ & EcoChoice 100 & $2.78 \phi / \mathrm{kWh}$ & - & $\begin{array}{l}89 \% \text { landfill gas, } \\
10 \% \text { wind, } 1 \% \\
\text { solar }\end{array}$ & Green-e \\
\hline & PEPCO Energy Services ${ }^{h}$ & $\begin{array}{l}\text { Green Electricity } \\
10 \%, 51 \% \text { or } 100 \% \\
\text { of usage }\end{array}$ & $\begin{array}{l}3.7 \phi / \mathrm{kWh} \text { (for } 100 \% \\
\text { usage) }\end{array}$ & - & $100 \%$ renewable & - \\
\hline \multicolumn{7}{|l|}{ Rhode Island } \\
\hline & $\begin{array}{l}\text { Narragansett Electric / } \\
\text { Sterling Planet }\end{array}$ & $\begin{array}{l}\text { Sterling Supreme } \\
100 \%\end{array}$ & $1.98 \phi / \mathrm{kWh}$ & - & $\begin{array}{l}40 \% \text { small hydro, } \\
25 \% \text { biomass, } \\
25 \% \text { new solar, } \\
10 \% \text { wind }\end{array}$ & $\begin{array}{r}\text { Environmental } \\
\text { Resources Trust }\end{array}$ \\
\hline \multicolumn{7}{|l|}{$\overline{T X}$} \\
\hline & Gexa Energy ${ }^{i}$ & Gexa Green & $-1.1 \phi / \mathrm{kWh}$ & - & $100 \%$ renewable & - \\
\hline$\overline{V A}$ & PEPCO Energy Services ${ }^{j}$ & $\begin{array}{l}\text { Green Electricity } \\
10 \%, 51 \% \text { or } 100 \% \\
\text { of usage }\end{array}$ & $\begin{array}{l}4.53 \phi / \mathrm{kWh} \text { (for } 100 \% \\
\text { usage) }\end{array}$ & - & landfill gas & - \\
\hline
\end{tabular}

Source:

National Renewable Energy Laboratory, Power Technologies Energy Data Book, Table 3.8.8, http://www.nrel.gov/analysis/power databook/chapter3.html

a Prices updated as of July 2005 and may also apply to small commercial customers. Prices may differ for large commercial/industrial customers and may vary by service territory.

${ }^{b}$ New is defined as operating or repowered after January 1, 1999 based on the Green-e TRC certification standards.

${ }^{c}$ Offered in PEPCO service territory. Product prices are for renewal customers based on annual average costs for customers in PEPCO's service territory $(6.8 \phi / \mathrm{kWh})$.

${ }^{d}$ Product offered in Baltimore Gas and Electric and PEPCO service territories. Price is for PEPCO service territory based on price to compare of $6.55 \phi / \mathrm{kWh}$. product.

Price premium is based on a comparison to the Cape Light Compact's standard electricity

${ }^{f}$ Green Mountain Energy offers products in Conectiv, JCPL, and PSE\&G service territories. Product prices are for PSE\&G (price to compare of $6.503 \phi / \mathrm{kWh}$ ).

${ }^{g}$ Price premium is for Niagara Mohawk service territory. Program only available in Niagara Mohawk service territory. Premium varies depending on energy taxes and usage.

${ }^{\mathrm{h}}$ Product prices are for PECO service territory (price to compare of $6.21 \mathrm{\phi} / \mathrm{kWh}$ ).

i Product prices are based on price to beat of $12.1 \phi / \mathrm{kWh}$ for TXU service territory (specifically Dallas, Texas) (Except where noted). Except for Gexa Green, which is listed in price per kWh, prices based on 1000 kwh of usage monthly, and include monthly fees.

${ }^{\mathrm{j}}$ Products are available in Dominion Virginia Power service territory. 
Renewable energy certificates (RECS)—also known as green tags, renewable energy credits, or tradable renewable certificates-represent the environmental attributes of power generated from renewable electric plants. A number of organizations offer green energy certificates separate from electricity service (i.e., customers do not need to switch from their current electricity supplier to purchase these certificates). Organizations that offer green certificate products using biomass resources are listed below.

Table 3.10

Renewable Energy Certificate Product Offerings, October 2005

\begin{tabular}{|c|c|c|c|c|c|}
\hline Certificate Marketer & Product Name & $\begin{array}{l}\text { Renewable } \\
\text { Resources }\end{array}$ & $\begin{array}{l}\text { Location of } \\
\text { Renewable } \\
\text { Resources }\end{array}$ & $\begin{array}{l}\text { Residential Price } \\
\text { Premium }\end{array}$ & Certification \\
\hline Blue Sky Energy Corp & $\begin{array}{l}\text { Greener Choice }{ }^{\mathrm{TM}} \text { Green } \\
\text { Tags }\end{array}$ & Landfill Gas & Utah & $1.95 \phi / \mathrm{kWh}$ & $\overline{-}$ \\
\hline $\begin{array}{l}\text { Bonneville Environmental } \\
\text { Foundation }\end{array}$ & Green Tags & $\begin{array}{l}\geq 98 \% \text { new wind, } \leq \\
1 \% \text { new solar, } \leq 1 \% \\
\text { new biomass }\end{array}$ & $\begin{array}{l}\text { Washington, } \\
\text { Oregon, Wyoming, } \\
\text { Montana, Alberta }\end{array}$ & $2.0 \phi / \mathrm{kWh}$ & Green-e \\
\hline $\begin{array}{l}\text { Clean Energy } \\
\text { Partnership/Sterling Planet }\end{array}$ & $\begin{array}{l}\text { National New Clean } \\
\text { Energy Mlx }\end{array}$ & $\begin{array}{l}24 \% \text { wind, } 25 \% \\
\text { biomass, } 50 \% \text { landfill } \\
\text { gas, } 1 \% \text { solar }\end{array}$ & National & $0.6 \phi / \mathrm{kWh}$ & $\begin{array}{l}\text { Environmental } \\
\text { Resources Trust }\end{array}$ \\
\hline $\begin{array}{l}\text { Maine Interfaith Power \& } \\
\text { Light/BEF }\end{array}$ & $\begin{array}{l}\text { Green Tags (supplied } \\
\text { by BEF) }\end{array}$ & $\begin{array}{l}\geq 98 \% \text { new } \text { wind, } \leq \\
1 \% \text { new solar, } \leq 1 \% \\
\text { new biomass }\end{array}$ & $\begin{array}{l}\text { Washington, } \\
\text { Oregon, Wyoming, } \\
\text { Montana, Alberta }\end{array}$ & $2.0 \phi / \mathrm{kWh}$ & - \\
\hline NativeEnergy & CoolHome & $\begin{array}{l}\text { New biogas and new } \\
\text { wind }\end{array}$ & $\begin{array}{l}\text { Vermont and } \\
\text { Pennsylvania } \\
\text { (biomass), South } \\
\text { Dakota (wind) }\end{array}$ & $\begin{array}{l}0.8 \phi / \mathrm{kWh}- \\
1.0 \phi / \mathrm{kWh}\end{array}$ & $a$ \\
\hline Sterling Planet & Green America & $\begin{array}{l}45 \% \text { new wind } 50 \% \\
\text { new biomass } 5 \% \text { new } \\
\text { solar }\end{array}$ & Nationwide & $1.6 \phi / \mathrm{kWh}$ & Green-e \\
\hline TerraPass Inc. & TerraPass & $\begin{array}{l}\text { Various (including } \\
\text { efficiency and CO2 } \\
\text { offsets) }\end{array}$ & Nationwide & $\sim \$ 11 /$ ton CO2 & $\overline{-}$ \\
\hline
\end{tabular}

Source:

National Renewable Energy Laboratory, Power Technologies Energy Data Book, Table 3.8.9, http://www.nrel.gov/analysis/power databook/chapter3.html

Note: - Information not available.

New is defined as operating or repowered after January 1, 1999 based on the Green-e TRC certification standards.

Most product prices are as of July 2005.

a The Climate Neutral Network certifies the methodology used to calculate the $\mathrm{CO} 2$ emissions offset. 
Figure 3.1

New Biomass Power Plants by Year

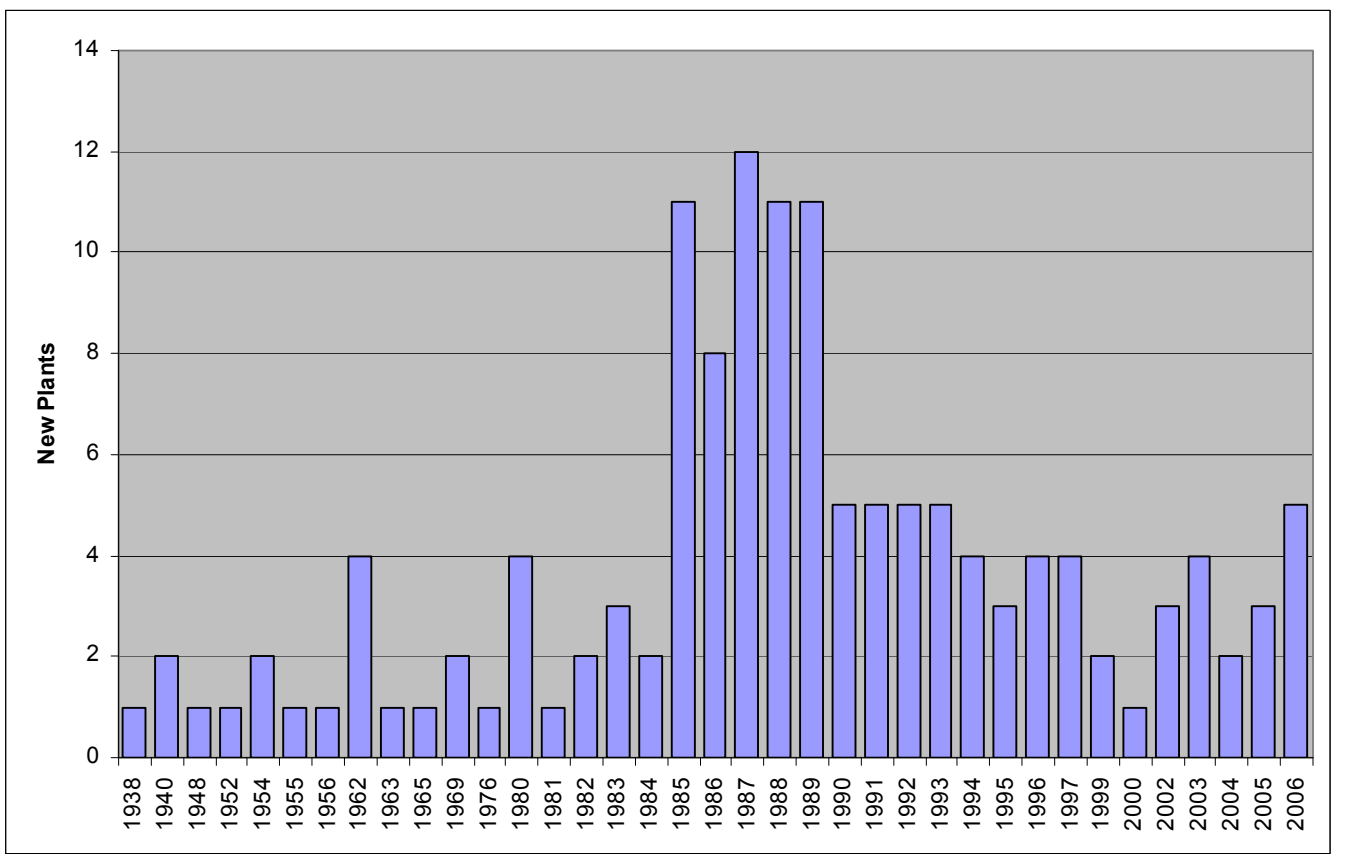

Figure 3.2

Biomass Power Plant Capacity by Year

(Megawatt hours)

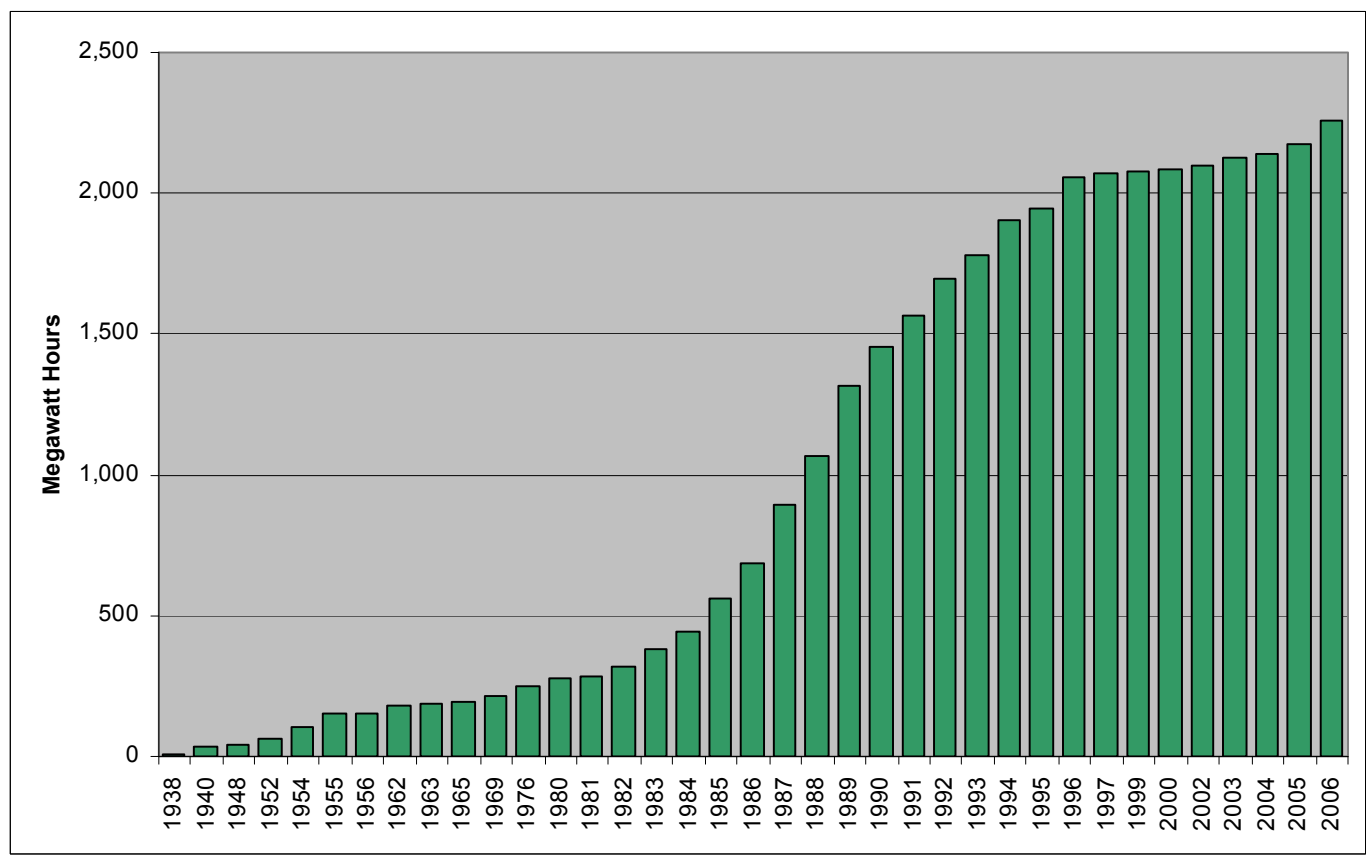

Source:

(National Electric Energy System (NEEDS) Database for IPM 2006, http://epa.gov/airmarkets/progsregs/epa-ipm/index.html

Notes:

1. Only years in which new plants were brought online are shown.

2. Power plant capacity based on NEEDS 2006 Data. 
Table 3.11

\section{Current Biomass Power Plants}

\begin{tabular}{|c|c|c|c|c|c|c|c|}
\hline Plant Name & $\begin{array}{l}\text { Boiler/Generator/C } \\
\text { ommitted Unit }\end{array}$ & State Name & County & Capacity MW & Heat Rate & Cogeneration & On-line Year \\
\hline Pacific Lumber & $G$ & California & Humboldt & 7.50 & 15826 & Yes & 1938 \\
\hline French Island & B & Wisconsin & La Crosse & 14.00 & 10400 & No & 1940 \\
\hline French Island & B & Wisconsin & La Crosse & 14.00 & 10400 & No & 1940 \\
\hline Berlin Gorham & B & New Hampshire & Coos & 5.00 & 15826 & No & 1948 \\
\hline Bay Front & B & Wisconsin & Ashland & 22.00 & 16190 & No & 1952 \\
\hline East Millinocket Mill & B & Maine & Penobscot & 19.04 & 15826 & Yes & 1954 \\
\hline Bay Front & B & Wisconsin & Ashland & 22.00 & 18720 & No & 1954 \\
\hline Schiller & B & New Hampshire & Rockingham & 47.20 & 12788 & No & 1955 \\
\hline Medford Operation & G & Oregon & Jackson & 3.10 & 15826 & Yes & 1956 \\
\hline Bryant Sugar House & B & Florida & Palm Beach & 6.63 & 15826 & Yes & 1962 \\
\hline Bryant Sugar House & $\mathrm{B}$ & Florida & Palm Beach & 6.63 & 15826 & Yes & 1962 \\
\hline Bryant Sugar House & B & Florida & Palm Beach & 6.63 & 15826 & Yes & 1962 \\
\hline Bryant Sugar House & $\mathrm{B}$ & Florida & Palm Beach & 6.63 & 15826 & Yes & 1962 \\
\hline Stone Container Florence Mill & B & South Carolina & Florence & 7.63 & 15826 & Yes & 1963 \\
\hline Medford Operation & G & Oregon & Jackson & 4.40 & 15826 & Yes & 1965 \\
\hline Rapids Energy Center & B & Minnesota & Itasca & 11.02 & 10079 & Yes & 1969 \\
\hline Rapids Energy Center & B & Minnesota & Itasca & 11.02 & 10079 & Yes & 1969 \\
\hline Somerset Plant & B & Maine & Somerset & 34.23 & 15826 & Yes & 1976 \\
\hline Century Flooring Co & G & Arkansas & Izard & 1.70 & 15826 & Yes & 1980 \\
\hline Forster Strong Mill & G & Maine & Franklin & 0.35 & 15826 & Yes & 1980 \\
\hline American Ref-Fuel of Niagara & B & New York & Niagara & 9.00 & 15826 & Yes & 1980 \\
\hline Stone Container Hopewell Mill & B & Virginia & Hopewell & 20.35 & 15826 & Yes & 1980 \\
\hline Diamond Walnut & G & California & San Joaquin & 4.20 & 15826 & Yes & 1981 \\
\hline Plummer Forest Products & G & Idaho & Benewah & 5.77 & 15000 & Yes & 1982 \\
\hline S D Warren Somerset & B & Maine & Cumberland & 26.88 & 15826 & No & 1982 \\
\hline Tamarack Energy Partnership & G & Idaho & Adams & 5.80 & 9650 & Yes & 1983 \\
\hline Snider Industries & G & Texas & Harrison & 5.00 & 15826 & Yes & 1983 \\
\hline Kettle Falls Generating Station & G & Washington & Stevens & 50.00 & 11860 & No & 1983 \\
\hline Agrilectric Power Partners Ltd & $\mathrm{B}$ & Louisiana & Calcasieu & 10.90 & 17327 & No & 1984 \\
\hline J C McNeil & $B$ & Vermont & Chittenden & 52.00 & 21020 & No & 1984 \\
\hline Wheelabrator Martell & G & California & Amador & 15.00 & 15826 & Yes & 1985 \\
\hline Pacific Oroville Power & B & California & Butte & 8.25 & 20081 & No & 1985 \\
\hline Pacific Oroville Power & B & California & Butte & 8.25 & 20081 & No & 1985 \\
\hline Mt Lassen Power & B & California & Lassen & 10.50 & 19607 & No & 1985 \\
\hline Sierra Pacific Susanville & B & California & Lassen & 12.60 & 15826 & Yes & 1985 \\
\hline Collins Pine Project & $\mathrm{B}$ & California & Plumas & 9.80 & 15826 & Yes & 1985 \\
\hline Burney Mountain Power & $B$ & California & Shasta & 9.75 & 18938 & No & 1985 \\
\hline Sierra Power & G & California & Tulare & 7.00 & 15826 & Yes & 1985 \\
\hline Ultrapower Chinese Station & $\mathrm{B}$ & California & Tuolumne & 19.80 & 20111 & No & 1985 \\
\hline Biomass One LP & $\mathrm{B}$ & Oregon & Jackson & 8.50 & 19236 & Yes & 1985 \\
\hline Biomass One LP & $\mathrm{B}$ & Oregon & Jackson & 14.00 & 14427 & Yes & 1985 \\
\hline Fairhaven Power & B & California & Humboldt & 17.30 & 21020 & No & 1986 \\
\hline Sierra Pacific Quincy Facility & $B$ & California & Plumas & 14.50 & 15826 & Yes & 1986 \\
\hline Sierra Pacific Quincy Facility & B & California & Plumas & 14.50 & 15826 & Yes & 1986 \\
\hline Sierra Pacific Burney Facility & B & California & Shasta & 18.00 & 15826 & Yes & 1986 \\
\hline DG Telogia Power & $\mathrm{B}$ & Florida & Liberty & 12.50 & 21020 & No & 1986 \\
\hline Wheelabrator Sherman Energy Facility & $\mathrm{B}$ & Maine & Penobscot & 21.00 & 11987 & Yes & 1986 \\
\hline Pinetree Power & $\mathrm{B}$ & New Hampshire & Grafton & 15.00 & 15033 & No & 1986 \\
\hline Co-Gen LLC & G & Oregon & Grant & 6.98 & 11987 & Yes & 1986 \\
\hline Wheelabrator Shasta & B & California & Shasta & 17.30 & 19254 & No & 1987 \\
\hline Wheelabrator Shasta & B & California & Shasta & 17.30 & 19254 & No & 1987 \\
\hline Wheelabrator Shasta & $\mathrm{B}$ & California & Shasta & 17.30 & 19254 & No & 1987 \\
\hline Boralex Fort Fairfield & B & Maine & Aroostook & 31.00 & 21020 & No & 1987 \\
\hline Indeck West Enfield Energy Center & B & Maine & Penobscot & 25.60 & 21020 & No & 1987 \\
\hline Indeck Jonesboro Energy Center & G & Maine & Washington & 26.80 & 9650 & No & 1987 \\
\hline Central Michigan University & G & Michigan & Isabella & 0.95 & 15826 & Yes & 1987 \\
\hline Hillman Power LLC & B & Michigan & Montmorency & 17.80 & 15655 & No & 1987 \\
\hline Pinetree Power Tamworth & $\mathrm{B}$ & New Hampshire & Carroll & 20.00 & 14972 & No & 1987 \\
\hline Bridgewater Power LP & $\mathrm{B}$ & New Hampshire & Grafton & 16.00 & 14232 & No & 1987 \\
\hline Hemphill Power \& Light & $\mathrm{B}$ & New Hampshire & Sullivan & 14.13 & 14605 & No & 1987 \\
\hline Co-Gen II LLC & G & Oregon & Douglas & 6.98 & 11987 & Yes & 1987 \\
\hline Rio Bravo Fresno & $B$ & California & Fresno & 24.30 & 18456 & No & 1988 \\
\hline Pacific Lumber & $\mathrm{B}$ & California & Humboldt & 8.67 & 15826 & Yes & 1988 \\
\hline Pacific Lumber & B & California & Humboldt & 8.67 & 15826 & Yes & 1988 \\
\hline Pacific Lumber & $\mathrm{B}$ & California & Humboldt & 8.67 & 15826 & Yes & 1988 \\
\hline Greenville Steam & $\mathrm{B}$ & Maine & Piscataquis & 16.10 & 13337 & No & 1988 \\
\hline Viking Energy of McBain & $\mathrm{B}$ & Michigan & Missaukee & 16.00 & 15982 & No & 1988 \\
\hline M L Hibbard & B & Minnesota & St. Louis & 15.30 & 14500 & Yes & 1988 \\
\hline ML Hibbard & $B$ & Minnesota & St. Louis & 33.30 & 14500 & Yes & 1988 \\
\hline
\end{tabular}

Continued on next page 
Table 3.11 (Continued) Current Biomass Power Plants

\begin{tabular}{|c|c|c|c|c|c|c|c|}
\hline Plant Name & $\begin{array}{l}\text { Boiler/Generator/C } \\
\text { ommitted Unit }\end{array}$ & State Name & County & Capacity MW & Heat Rate & Cogeneration & On-line Year \\
\hline Whitefield Power \& Light & $\mathrm{B}$ & New Hampshire & Coos & 14.50 & 13025 & No & 1988 \\
\hline Koopers Susquehanna Plant & B & Pennsylvania & Lycoming & 11.50 & 9650 & Yes & 1988 \\
\hline Viking Energy of Northumberland & B & Pennsylvania & Northumberland & 16.00 & 13500 & Yes & 1988 \\
\hline Wadham Energy LP & B & California & Colusa & 25.50 & 12637 & No & 1989 \\
\hline AES Mendota & B & California & Fresno & 25.00 & 17874 & No & 1989 \\
\hline HL Power & B & California & Lassen & 30.00 & 14944 & No & 1989 \\
\hline Rio Bravo Rocklin & B & California & Placer & 24.40 & 16645 & No & 1989 \\
\hline Burney Forest Products & B & California & Shasta & 15.50 & 16350 & Yes & 1989 \\
\hline Burney Forest Products & B & California & Shasta & 15.50 & 16350 & Yes & 1989 \\
\hline Sierra Pacific Loyalton Facility & B & California & Sierra & 14.00 & 15826 & Yes & 1989 \\
\hline Woodland Biomass Power Ltd & B & California & Yolo & 25.00 & 15302 & No & 1989 \\
\hline Boralex Stratton Energy & B & Maine & Franklin & 45.70 & 19601 & No & 1989 \\
\hline Worcester Energy & G & Maine & Washington & 13.00 & 14500 & No & 1989 \\
\hline Viking Energy of Lincoln & B & Michigan & Alcona & 16.00 & 13646 & No & 1989 \\
\hline Delano Energy & B & California & Kern & 27.00 & 17237 & No & 1990 \\
\hline Tracy Biomass & B & California & San Joaquin & 16.46 & 17342 & No & 1990 \\
\hline Jefferson Power LLC & G & Florida & Jefferson & 7.50 & 16258 & No & 1990 \\
\hline Somerset Plant & B & Maine & Somerset & 42.63 & 15826 & Yes & 1990 \\
\hline Craven County Wood Energy LP & B & North Carolina & Craven & 45.00 & 12622 & No & 1990 \\
\hline Alabama Pine Pulp & B & Alabama & Monroe & 32.09 & 15826 & Yes & 1991 \\
\hline Potlatch Southern Wood Products & B & Arkansas & Bradley & 10.00 & 15826 & Yes & 1991 \\
\hline Mecca Plant & $\mathrm{B}$ & California & Riverside & 23.50 & 14158 & No & 1991 \\
\hline Mecca Plant & B & California & Riverside & 23.50 & 14158 & No & 1991 \\
\hline Port Wentworth & B & Georgia & Chatham & 21.60 & 15826 & Yes & 1991 \\
\hline Boralex Beaver Livermore Falls & B & Maine & Androscoggin & 34.70 & 14309 & No & 1992 \\
\hline Pinetree Power Fitchburg & B & Massachusetts & Worcester & 17.00 & 15673 & No & 1992 \\
\hline Grayling Generating Station & B & Michigan & Crawford & 36.20 & 14597 & No & 1992 \\
\hline Lyonsdale Biomass LLC & B & New York & Lewis & 19.00 & 13230 & Yes & 1992 \\
\hline Ryegate Power Station & B & Vermont & Caledonia & 20.00 & 21020 & No & 1992 \\
\hline Delano Energy & B & California & Kern & 22.00 & 17237 & No & 1993 \\
\hline Cadillac Renewable Energy & B & Michigan & Wexford & 36.80 & 15470 & No & 1993 \\
\hline Boralex Chateaugay Power Station & B & New York & Franklin & 18.00 & 15094 & No & 1993 \\
\hline Sauder Power Plant & G & Ohio & Fulton & 3.60 & 14900 & Yes & 1993 \\
\hline Sauder Power Plant & G & Ohio & Fulton & 3.60 & 14900 & Yes & 1993 \\
\hline Ridge Generating Station & B & Florida & Polk & 47.10 & 21020 & No & 1994 \\
\hline Multitrade of Pittsylvania LP & B & Virginia & Pittsylvania & 26.55 & 13541 & No & 1994 \\
\hline Multitrade of Pittsylvania LP & B & Virginia & Pittsylvania & 26.55 & 13541 & No & 1994 \\
\hline Multitrade of Pittsylvania LP & B & Virginia & Pittsylvania & 26.55 & 13541 & No & 1994 \\
\hline Cox Waste to Energy & G & Kentucky & Taylor & 3.00 & 15826 & Yes & 1995 \\
\hline Agrilectric Power Partners Ltd & B & Louisiana & Calcasieu & 1.30 & 17327 & No & 1995 \\
\hline Genesee Power Station LP & B & Michigan & Genesee & 35.00 & 21020 & No & 1995 \\
\hline Okeelanta Cogeneration & B & Florida & Palm Beach & 24.97 & 13600 & Yes & 1996 \\
\hline Okeelanta Cogeneration & B & Florida & Palm Beach & 24.97 & 13600 & Yes & 1996 \\
\hline Okeelanta Cogeneration & B & Florida & Palm Beach & 24.97 & 13600 & Yes & 1996 \\
\hline Everett Cogen & B & Washington & Snohomish & 36.00 & 19000 & Yes & 1996 \\
\hline STEC-S LLC & B & Arkansas & Arkansas & 2.00 & 10265 & Yes & 1997 \\
\hline STEC-S LLC & $\mathrm{B}$ & Arkansas & Arkansas & 2.00 & 10265 & Yes & 1997 \\
\hline Sierra Pacific Lincoln Facility & $\mathrm{B}$ & California & Placer & 5.60 & 15826 & Yes & 1997 \\
\hline Sierra Pacific Lincoln Facility & B & California & Placer & 5.60 & 15826 & Yes & 1997 \\
\hline Sierra Pacific Anderson Facility & G & California & Shasta & 4.00 & 15826 & Yes & 1999 \\
\hline Minergy Neenah & G & Wisconsin & Winnebago & 6.50 & 15826 & Yes & 1999 \\
\hline Wheelabrator Shasta & G & California & Shasta & 3.50 & 19254 & No & 2000 \\
\hline Cox Waste to Energy & G & Kentucky & Taylor & 0.30 & 15826 & Yes & 2002 \\
\hline Colville Indian Power \& Veneer & G & Washington & Okanogan & 5.00 & 15826 & No & 2002 \\
\hline Colville Indian Power \& Veneer & G & Washington & Okanogan & 7.50 & 15826 & No & 2002 \\
\hline Ware Biomass Cogen & $\mathrm{C}$ & Massachusetts & a & 7.79 & 15826 & Yes & 2003 \\
\hline Scott Wood & C & Virginia & Amelia & 0.80 & 15826 & No & 2003 \\
\hline Scott Wood & C & Virginia & Amelia & 2.60 & 15826 & No & 2003 \\
\hline Sierra Pacific Aberdeen & $\mathrm{B}$ & Washington & Grays Harbor & 16.00 & 15826 & Yes & 2003 \\
\hline Sierra Pacific Lincoln Facility & G & California & Placer & 18.00 & 15826 & Yes & 2004 \\
\hline Forster Strong Mill & G & Maine & Franklin & 0.50 & 15826 & Yes & 2004 \\
\hline Puente Hills Energy Recovery & C & California & Los Angeles & 8.00 & 8911 & No & 2005 \\
\hline Worcester Energy & C & Maine & a & 24.56 & 8911 & No & 2005 \\
\hline Blue Spruce Farm Ana & C & Vermont & a & 0.26 & 8911 & No & 2005 \\
\hline APS Biomass I & C & Arizona & $a$ & 2.85 & 8911 & No & 2006 \\
\hline Buckeye Florida & C & Florida & Taylor & 25.00 & 8911 & No & 2006 \\
\hline Ware Cogeneration & C & Massachusetts & $a$ & 4.09 & 8911 & Yes & 2006 \\
\hline Central Minn. Ethano & $\mathrm{C}$ & Minnesota & $a$ & 0.95 & 8911 & No & 2006 \\
\hline Schiller Biomass Con & C & New Hampshire & a & 47.50 & 8911 & No & 2006 \\
\hline Fibrominn Biomass Power Plant & $\mathrm{c}$ & Minnesota & Switt & 55.00 & 8911 & No & 2007 \\
\hline
\end{tabular}

Source:

(National Electric Energy System (NEEDS) Database for IPM 2006, http://epa.gov/airmarkets/progsregs/epa-ipm/index.html 
Figure 3.3

New Landfill Gas Power Plants by Year

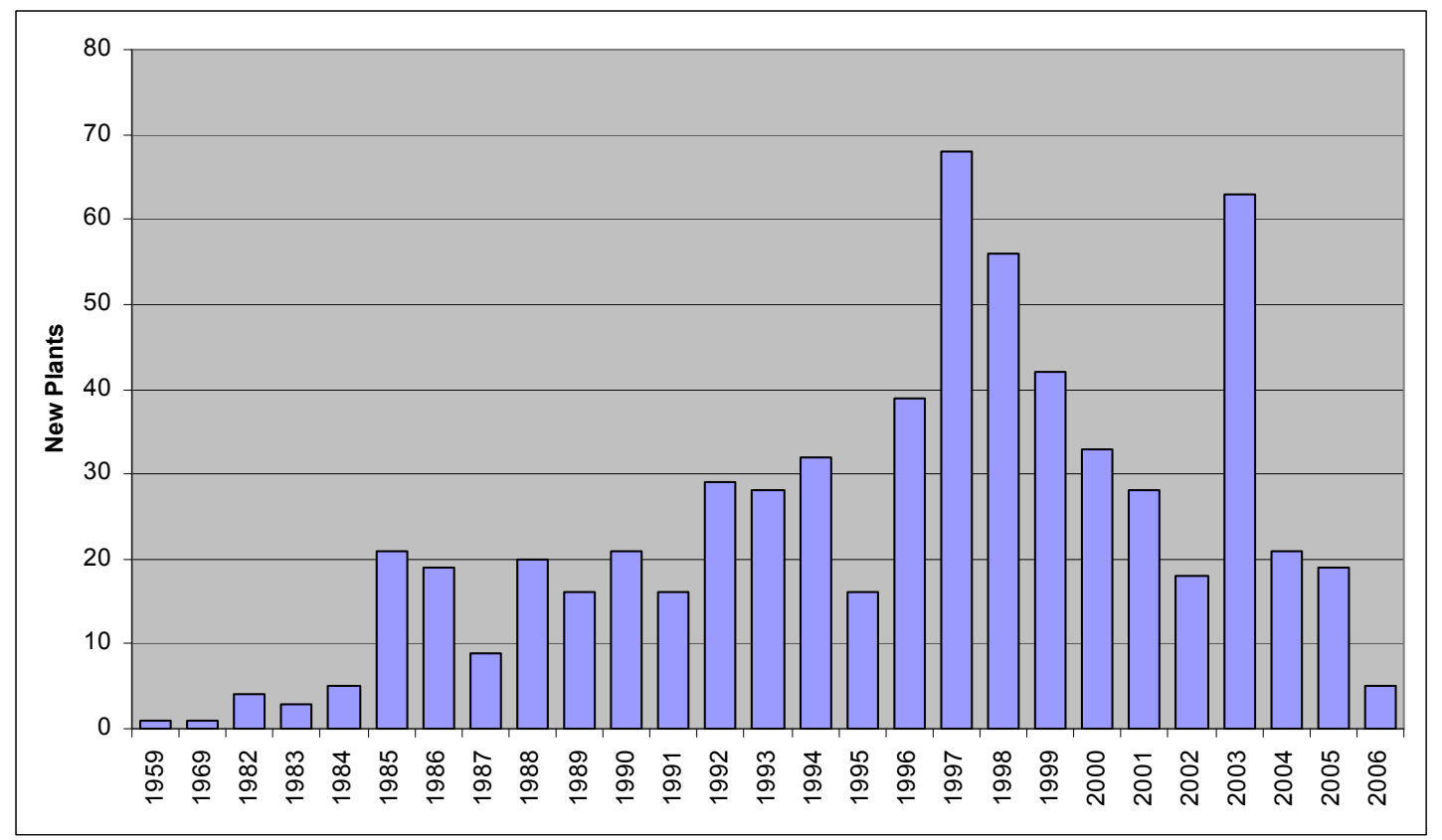

Figure 3.4

Landfill Gas Power Plant Capacity by Year (Megawatt hours)

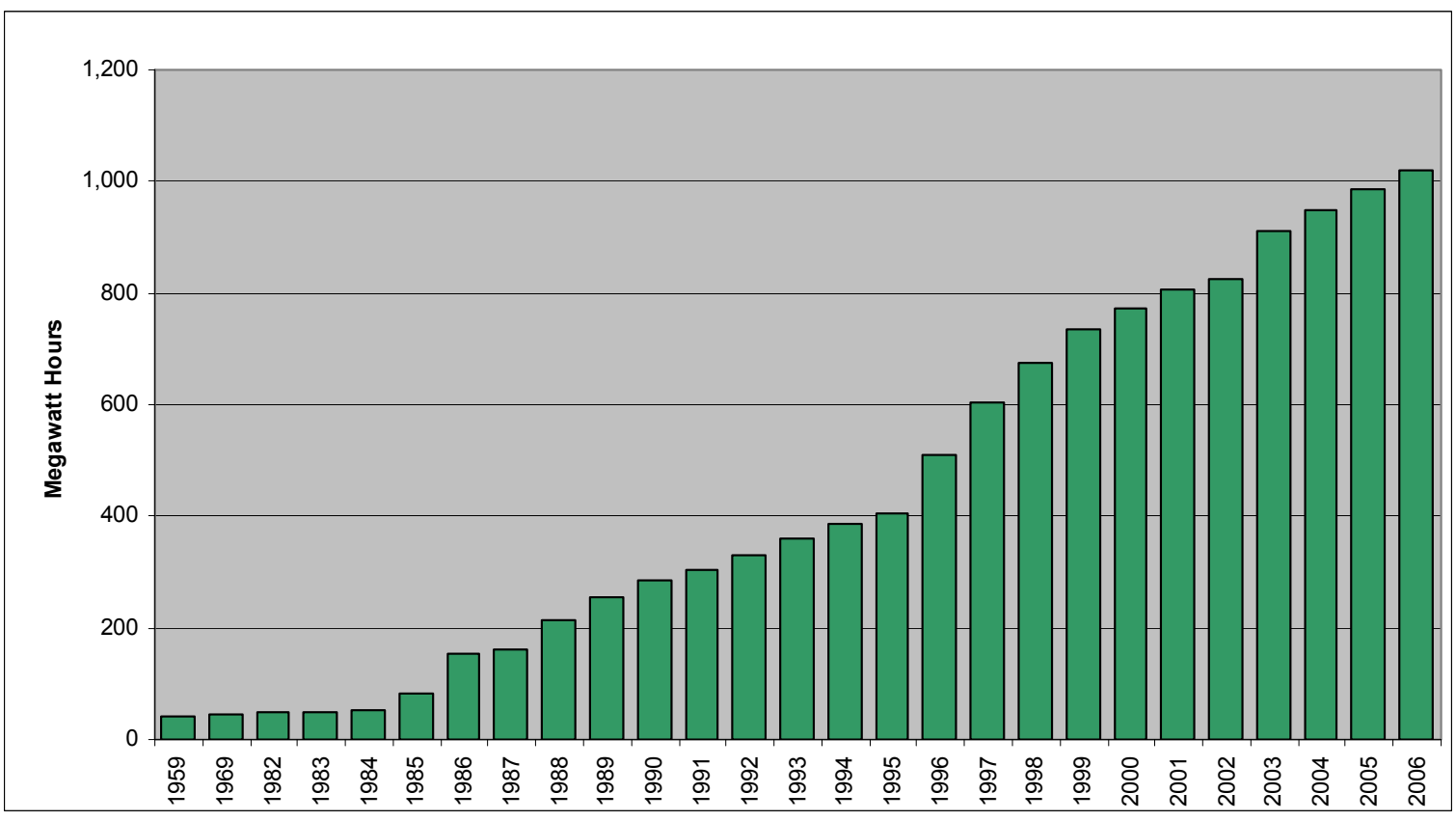

\section{Source:}

(National Electric Energy System (NEEDS) Database for IPM 2006,

http://epa.gov/airmarkets/progsregs/epa-ipm/index.html

\section{Notes:}

1. Only years in which new plants were brought online are shown.

2. Power plant capacity based on NEEDS 2006 Data. 
Table 3.12

Current Landfill Gas Power Plants

\begin{tabular}{|c|c|c|c|c|c|c|c|}
\hline Plant Name & $\begin{array}{l}\text { Boiler/Generator/Co } \\
\text { mmitted Unit }\end{array}$ & State Name & County & Capacity MW & Heat Rate & Cogeneration & On-line Year \\
\hline Grayson & $\bar{B}$ & California & Los Angeles & 42.00 & 14348 & No & 1959 \\
\hline Altamont Gas Recovery & G & California & Alameda & 2.90 & 18748 & No & 1969 \\
\hline Marsh Road Power Plant & G & California & San Mateo & 0.50 & 18412 & No & 1982 \\
\hline Marsh Road Power Plant & G & California & San Mateo & 0.50 & 18412 & No & 1982 \\
\hline Marsh Road Power Plant & G & California & San Mateo & 0.50 & 18412 & No & 1982 \\
\hline Marsh Road Power Plant & G & California & San Mateo & 0.50 & 18412 & No & 1982 \\
\hline Guadalupe Power Plant & G & California & Santa Clara & 0.50 & 13763 & No & 1983 \\
\hline Guadalupe Power Plant & G & California & Santa Clara & 0.50 & 13763 & No & 1983 \\
\hline Guadalupe Power Plant & G & California & Santa Clara & 0.50 & 13763 & No & 1983 \\
\hline Newby Island I & G & California & Santa Clara & 0.50 & 12991 & No & 1984 \\
\hline Newby Island I & G & California & Santa Clara & 0.50 & 12991 & No & 1984 \\
\hline Newby Island I & G & California & Santa Clara & 0.50 & 12991 & No & 1984 \\
\hline Newby Island I & G & California & Santa Clara & 0.50 & 12991 & No & 1984 \\
\hline Puente Hills Energy Recovery & G & California & Los Angeles & 1.10 & 36790 & No & 1984 \\
\hline American Canyon Power Plant & G & California & Napa & 0.70 & 10887 & No & 1985 \\
\hline American Canyon Power Plant & G & California & Napa & 0.70 & 10887 & No & 1985 \\
\hline Olinda Landfill Gas Recovery Plant & G & California & Orange & 1.70 & 12348 & No & 1985 \\
\hline Olinda Landfill Gas Recovery Plant & G & California & Orange & 1.70 & 12348 & No & 1985 \\
\hline Olinda Landfill Gas Recovery Plant & G & California & Orange & 1.70 & 12348 & No & 1985 \\
\hline Nove Power Plant & G & California & Contra Costa & 2.50 & 10205 & No & 1985 \\
\hline Nove Power Plant & G & California & Contra Costa & 2.50 & 10205 & No & 1985 \\
\hline Oxnard & G & California & Ventura & 1.70 & 13533 & No & 1985 \\
\hline Oxnard & G & California & Ventura & 1.70 & 13533 & No & 1985 \\
\hline Gude & G & Maryland & Montgomery & 1.30 & 14768 & No & 1985 \\
\hline Gude & G & Maryland & Montgomery & 1.30 & 14768 & No & 1985 \\
\hline Kinsleys Landfill & G & New Jersey & Gloucester & 0.50 & 10400 & No & 1985 \\
\hline Kinsleys Landfill & G & New Jersey & Gloucester & 0.50 & 10400 & No & 1985 \\
\hline Kinsleys Landfill & G & New Jersey & Gloucester & 0.50 & 10400 & No & 1985 \\
\hline Kinsleys Landfill & G & New Jersey & Gloucester & 0.50 & 10400 & No & 1985 \\
\hline Lebanon Methane Recovery & G & Pennsylvania & Lebanon & 0.60 & 14707 & No & 1985 \\
\hline Lebanon Methane Recovery & G & Pennsylvania & Lebanon & 0.60 & 14707 & No & 1985 \\
\hline Metro Gas Recovery & G & Wisconsin & Milwaukee & 2.90 & 17718 & No & 1985 \\
\hline Metro Gas Recovery & G & Wisconsin & Milwaukee & 2.90 & 17718 & No & 1985 \\
\hline Omega Hills Gas Recovery & G & Wisconsin & Washington & 2.90 & 18070 & No & 1985 \\
\hline Omega Hills Gas Recovery & G & Wisconsin & Washington & 2.90 & 18070 & No & 1985 \\
\hline Total Energy Facilities & G & California & Los Angeles & 4.73 & 12917 & Yes & 1986 \\
\hline Puente Hills Energy Recovery & $\mathrm{B}$ & California & Los Angeles & 22.50 & 11487 & No & 1986 \\
\hline Puente Hills Energy Recovery & B & California & Los Angeles & 22.50 & 11487 & No & 1986 \\
\hline Otay & G & California & San Diego & 1.70 & 12265 & No & 1986 \\
\hline Salinas & G & California & Monterey & 1.30 & 18136 & No & 1986 \\
\hline Santa Clara & G & California & Santa Clara & 1.30 & 11259 & No & 1986 \\
\hline Penrose Power Station & G & California & Los Angeles & 1.70 & 13169 & No & 1986 \\
\hline Penrose Power Station & G & California & Los Angeles & 1.70 & 13169 & No & 1986 \\
\hline Penrose Power Station & G & California & Los Angeles & 1.70 & 13169 & No & 1986 \\
\hline Penrose Power Station & G & California & Los Angeles & 1.70 & 13169 & No & 1986 \\
\hline Penrose Power Station & G & California & Los Angeles & 1.70 & 13169 & No & 1986 \\
\hline Toyon Power Station & G & California & Los Angeles & 1.70 & 13200 & No & 1986 \\
\hline Toyon Power Station & G & California & Los Angeles & 1.70 & 13200 & No & 1986 \\
\hline Toyon Power Station & G & California & Los Angeles & 1.70 & 13200 & No & 1986 \\
\hline Toyon Power Station & G & California & Los Angeles & 1.70 & 13200 & No & 1986 \\
\hline EQ Waste Energy Services & G & Michigan & Wayne & 0.50 & 11123 & Yes & 1986 \\
\hline EQ Waste Energy Services & G & Michigan & Wayne & 0.30 & 11123 & Yes & 1986 \\
\hline EQ Waste Energy Services & G & Michigan & Wayne & 0.30 & 11123 & Yes & 1986 \\
\hline EQ Waste Energy Services & G & Michigan & Wayne & 0.30 & 11123 & Yes & 1986 \\
\hline Guadalupe Power Plant & G & California & Santa Clara & 1.00 & 13763 & No & 1987 \\
\hline Nove Power Plant & G & California & Contra Costa & 2.50 & 10205 & No & 1987 \\
\hline Prince Georges County Brown Station Road & G & Maryland & Prince Georges & 0.74 & 12917 & Yes & 1987 \\
\hline Prince Georges County Brown Station Road & G & Maryland & Prince Georges & 0.74 & 12917 & Yes & 1987 \\
\hline Prince Georges County Brown Station Road & G & Maryland & Prince Georges & 0.74 & 12917 & Yes & 1987 \\
\hline Taylor Energy Partners LP & G & Pennsylvania & Lackawanna & 0.50 & 14512 & No & 1987 \\
\hline Taylor Energy Partners LP & G & Pennsylvania & Lackawanna & 0.40 & 14512 & No & 1987 \\
\hline Taylor Energy Partners LP & G & Pennsylvania & Lackawanna & 0.40 & 14512 & No & 1987 \\
\hline Taylor Energy Partners LP & G & Pennsylvania & Lackawanna & 0.40 & 14512 & No & 1987 \\
\hline Palos Verdes Gas to Energy & B & California & Los Angeles & 3.00 & 21020 & No & 1988 \\
\hline Palos Verdes Gas to Energy & B & California & Los Angeles & 3.00 & 21020 & No & 1988 \\
\hline Settlers Hill Gas Recovery & G & Illinois & Kane & 2.90 & 18340 & No & 1988 \\
\hline Lake Gas Recovery & G & Illinois & Cook & 2.90 & 17932 & No & 1988 \\
\hline Riverview Energy Systems & G & Michigan & Wayne & 2.81 & 17800 & No & 1988 \\
\hline Riverview Energy Systems & G & Michigan & Wayne & 2.81 & 17800 & No & 1988 \\
\hline Dunbarton Energy Partners LP & G & New Hampshire & Hillsborough & 0.59 & 10640 & No & 1988 \\
\hline Dunbarton Energy Partners LP & G & New Hampshire & Hillsborough & 0.59 & 10640 & No & 1988 \\
\hline Al Turi & G & New York & Orange & 0.70 & 15600 & No & 1988 \\
\hline Al Turi & G & New York & Orange & 0.70 & 15600 & No & 1988 \\
\hline Smithtown Energy Partners LP & G & New York & Suffolk & 0.60 & 21971 & No & 1988 \\
\hline Smithtown Energy Partners LP & G & New York & Suffolk & 0.60 & 21971 & No & 1988 \\
\hline Onondaga Energy Partners LP & G & New York & Onondaga & 0.60 & 12543 & No & 1988 \\
\hline Onondaga Energy Partners LP & G & New York & Onondaga & 0.60 & 12543 & No & 1988 \\
\hline Monroe Livingston Gas Recovery & G & New York & Monroe & 0.80 & 13146 & No & 1988 \\
\hline Monroe Livingston Gas Recovery & G & New York & Monroe & 0.80 & 13146 & No & 1988 \\
\hline Monroe Livingston Gas Recovery & G & New York & Monroe & 0.80 & 13146 & No & 1988 \\
\hline Archbald Power Station & B & Pennsylvania & Lackawanna & 20.00 & 21020 & Yes & 1988 \\
\hline DFW Gas Recovery & G & Texas & Denton & 2.90 & 18736 & No & 1988 \\
\hline DFW Gas Recovery & G & Texas & Denton & 2.90 & 18736 & No & 1988 \\
\hline Sycamore San Diego & G & California & San Diego & 0.70 & 10000 & No & 1989 \\
\hline Sycamore San Diego & G & California & San Diego & 0.70 & 10000 & No & 1989 \\
\hline Newby Island II & G & California & Santa Clara & 1.00 & 10998 & No & 1989 \\
\hline Newby Island II & G & California & Santa Clara & 1.00 & 10998 & No & 1989 \\
\hline Newby Island II & G & California & Santa Clara & 1.00 & 10998 & No & 1989 \\
\hline Coyote Canyon Steam Plant & B & California & Orange & 17.00 & 16797 & No & 1989 \\
\hline Altamont Gas Recovery & G & California & Alameda & 2.90 & 18748 & No & 1989 \\
\hline
\end{tabular}


Table 3.12 (Continued)

Current Landfill Gas Power Plants

\begin{tabular}{|c|c|c|c|c|c|c|}
\hline Plant Name & \begin{tabular}{|l|} 
Boiler/Generator/Co \\
mmitted Unit
\end{tabular} & State Name & County & Capacity MW & Heat Rate & Cogeneration \\
\hline CSL Gas Recovery & $\bar{G}$ & Florida & Broward & 2.90 & 11860 & No \\
\hline CSL Gas Recovery & G & Florida & Broward & 2.90 & 11860 & No \\
\hline CSL Gas Recovery & G & Florida & Broward & 2.90 & 11860 & No \\
\hline CID Gas Recovery & G & Illinois & Cook & 2.90 & 19051 & No \\
\hline CID Gas Recovery & G & Illinois & Cook & 2.90 & 19051 & No \\
\hline Tazewell Gas Recovery & G & Illinois & Tazewell & 0.80 & 11786 & No \\
\hline Tazewell Gas Recovery & G & Illinois & Tazewell & 0.80 & 11786 & No \\
\hline Al Turi & G & New York & Orange & 0.70 & 15600 & No \\
\hline Stowe Power Production Plant & G & Pennsylvania & Montgomery & 2.90 & 19515 & No \\
\hline San Marcos & G & California & San Diego & 0.70 & 17340 & No \\
\hline San Marcos & G & California & San Diego & 0.70 & 17340 & No \\
\hline Spadra Landfill Gas to Energy & B & California & Los Angeles & 8.50 & 14888 & No \\
\hline Byxbee Park Sanitary Landfill & G & California & Santa Clara & 1.00 & 10339 & No \\
\hline Byxbee Park Sanitary Landfill & G & California & Santa Clara & 1.00 & 10339 & No \\
\hline MM Yolo Power LLC Facility & G & California & Yolo & 0.45 & 23737 & No \\
\hline MM Yolo Power LLC Facility & G & California & Yolo & 0.45 & 23737 & No \\
\hline MM Yolo Power LLC Facility & G & California & Yolo & 0.45 & 23737 & No \\
\hline Lafayette Energy Partners LP & G & New Jersey & Sussex & 0.50 & 17767 & No \\
\hline Lafayette Energy Partners LP & G & New Jersey & Sussex & 0.50 & 17767 & No \\
\hline Oceanside Energy & G & New York & Nassau & 0.60 & 12392 & No \\
\hline Oceanside Energy & G & New York & Nassau & 0.60 & 12392 & No \\
\hline Oceanside Energy & G & New York & Nassau & 0.60 & 12392 & No \\
\hline Ridgewood Providence Power & G & Rhode Island & Providence & 1.70 & 11832 & No \\
\hline Ridgewood Providence Power & G & Rhode Island & Providence & 1.70 & 11832 & No \\
\hline Ridgewood Providence Power & G & Rhode Island & Providence & 1.70 & 11832 & No \\
\hline Ridgewood Providence Power & G & Rhode Island & Providence & 1.70 & 11832 & No \\
\hline Ridgewood Providence Power & G & Rhode Island & Providence & 1.70 & 11832 & No \\
\hline Ridgewood Providence Power & G & Rhode Island & Providence & 1.70 & 11832 & No \\
\hline Ridgewood Providence Power & G & Rhode Island & Providence & 1.70 & 11832 & No \\
\hline Ridgewood Providence Power & G & Rhode Island & Providence & 1.70 & 11832 & No \\
\hline Otay & G & California & San Diego & 1.70 & 12245 & No \\
\hline Oxnard & G & California & Ventura & 1.70 & 13533 & No \\
\hline New Milford Gas Recovery & G & Connecticut & Litchfield & 3.00 & 17053 & No \\
\hline Milam Gas Recovery & G & Illinois & St. Clair & 0.80 & 12888 & No \\
\hline Milam Gas Recovery & G & Illinois & St. Clair & 0.80 & 12888 & No \\
\hline Granger Electric Generating Station \#2 & G & Michigan & Clinton & 0.80 & 12740 & No \\
\hline Granger Electric Generating Station \#2 & G & Michigan & Clinton & 0.80 & 12740 & No \\
\hline Granger Electric Generating Station \#2 & G & Michigan & Clinton & 0.80 & 12740 & No \\
\hline High Acres Gas Recovery & G & New York & Monroe & 0.80 & 11852 & No \\
\hline High Acres Gas Recovery & G & New York & Monroe & 0.80 & 11852 & No \\
\hline High Acres Gas Recovery & G & New York & Monroe & 0.80 & 11852 & No \\
\hline High Acres Gas Recovery & G & New York & Monroe & 0.80 & 11852 & No \\
\hline Stowe Power Production Plant & G & Pennsylvania & Montgomery & 2.90 & 19515 & No \\
\hline Outagamie County Co-Generation Facility & G & Wisconsin & Outagamie & 0.80 & 12917 & Yes \\
\hline Outagamie County Co-Generation Facility & G & Wisconsin & Outagamie & 0.80 & 12917 & No \\
\hline Outagamie County Co-Generation Facility & G & Wisconsin & Outagamie & 0.80 & 12917 & No \\
\hline Kankakee Gas Recovery & G & Illinois & Kankakee & 0.80 & 11892 & No \\
\hline Kankakee Gas Recovery & G & Illinois & Kankakee & 0.80 & 11892 & No \\
\hline Woodland Landfill Gas Recovery & G & Illinois & Kane & 0.80 & 13196 & No \\
\hline Woodland Landfill Gas Recovery & G & Illinois & Kane & 0.80 & 13196 & No \\
\hline Sumpter Energy Associates & G & Michigan & Wayne & 0.80 & 13388 & No \\
\hline Sumpter Energy Associates & G & Michigan & Wayne & 0.80 & 13388 & No \\
\hline Sumpter Energy Associates & G & Michigan & Wayne & 0.80 & 13388 & No \\
\hline Sumpter Energy Associates & G & Michigan & Wayne & 0.80 & 13388 & No \\
\hline Sumpter Energy Associates & G & Michigan & Wayne & 0.80 & 13388 & No \\
\hline Sumpter Energy Associates & G & Michigan & Wayne & 0.80 & 13388 & No \\
\hline Sumpter Energy Associates & G & Michigan & Wayne & 0.80 & 13388 & No \\
\hline Sumpter Energy Associates & G & Michigan & Wayne & 0.80 & 13388 & No \\
\hline Sumpter Energy Associates & G & Michigan & Wayne & 0.80 & 13388 & No \\
\hline Sumpter Energy Associates & G & Michigan & Wayne & 0.80 & 13388 & No \\
\hline Venice Resources Gas Recovery & G & Michigan & Shiawassee & 0.80 & 16218 & No \\
\hline Venice Resources Gas Recovery & G & Michigan & Shiawassee & 0.80 & 16218 & No \\
\hline Turnkey Landfill Gas Recovery & G & New Hampshire & Strafford & 0.80 & 12840 & No \\
\hline Turnkey Landfill Gas Recovery & G & New Hampshire & Strafford & 0.80 & 12840 & No \\
\hline Turnkey Landfill Gas Recovery & G & New Hampshire & Strafford & 0.80 & 12840 & No \\
\hline Chestnut Ridge Gas Recovery & G & Tennessee & Anderson & 0.80 & 14268 & No \\
\hline Chestnut Ridge Gas Recovery & G & Tennessee & Anderson & 0.80 & 14268 & No \\
\hline Chestnut Ridge Gas Recovery & G & Tennessee & Anderson & 0.80 & 14268 & No \\
\hline Chestnut Ridge Gas Recovery & G & Tennessee & Anderson & 0.80 & 14268 & No \\
\hline I 95 Municipal Landfill Phase I & G & Virginia & Fairfax & 0.80 & 11031 & No \\
\hline I 95 Municipal Landfill Phase I & G & Virginia & Fairfax & 0.80 & 11031 & No \\
\hline | 95 Municipal Landfill Phase | & G & Virginia & Fairfax & 0.80 & 11031 & No \\
\hline I 95 Municipal Landfill Phase I & G & Virginia & Fairfax & 0.80 & 11031 & No \\
\hline Pheasant Run Landfill Gas Recovery & G & Wisconsin & Kenosha & 0.80 & 12475 & No \\
\hline Pheasant Run Landfill Gas Recovery & G & Wisconsin & Kenosha & 0.80 & 12475 & No \\
\hline BKK Landfill & G & California & Los Angeles & 4.40 & 21020 & No \\
\hline MM Yolo Power LLC Facility & G & California & Yolo & 0.60 & 23737 & No \\
\hline Sonoma Central Landfill Phase I & G & California & Sonoma & 0.70 & 13634 & No \\
\hline Sonoma Central Landfill Phase I & G & California & Sonoma & 0.70 & 13634 & No \\
\hline Sonoma Central Landfill Phase I & G & California & Sonoma & 0.70 & 13634 & No \\
\hline Sonoma Central Landfill Phase I & G & California & Sonoma & 0.70 & 13634 & No \\
\hline BJ Gas Recovery & G & Georgia & Gwinnett & 0.80 & 12460 & No \\
\hline BJ Gas Recovery & G & Georgia & Gwinnett & 0.80 & 12460 & No \\
\hline BJ Gas Recovery & G & Georgia & Gwinnett & 0.80 & 12460 & No \\
\hline Milam Gas Recovery & G & Illinois & St. Clair & 0.80 & 12888 & No \\
\hline Lake Gas Recovery & G & Illinois & Cook & 2.90 & 17932 & No \\
\hline Lake Gas Recovery & G & Illinois & Cook & 2.90 & 17932 & No \\
\hline Chicopee Electric & G & Massachusetts & Hampden & 0.90 & 14170 & No \\
\hline Chicopee Electric & G & Massachusetts & Hampden & 0.90 & 14170 & No \\
\hline Granger Electric Generating Station \#1 & G & Michigan & Clinton & 0.80 & 14015 & No \\
\hline Granger Electric Generating Station \#1 & $\mathrm{G}$ & Michigan & Clinton & 0.80 & 14015 & No \\
\hline
\end{tabular}


Table 3.12 (Continued)

Current Landfill Gas Power Plants

\begin{tabular}{|c|c|c|c|c|c|c|}
\hline Plant Name & \begin{tabular}{|l|} 
Boiler/Generator/Co \\
mmitted Unit
\end{tabular} & State Name & County & Capacity MW & Heat Rate & Cogeneration \\
\hline Lyon Development & $\bar{G}$ & Michigan & Oakland & 0.90 & 17641 & No \\
\hline Lyon Development & G & Michigan & Oakland & 0.90 & 17641 & No \\
\hline Lyon Development & G & Michigan & Oakland & 0.90 & 17641 & No \\
\hline Lyon Development & G & Michigan & Oakland & 0.90 & 17641 & No \\
\hline Lyon Development & G & Michigan & Oakland & 0.90 & 17641 & No \\
\hline Turnkey Landfill Gas Recovery & G & New Hampshire & Strafford & 0.80 & 12840 & No \\
\hline | 95 Landfill Phase II & G & Virginia & Fairfax & 0.80 & 10773 & No \\
\hline | 95 Landfill Phase II & G & Virginia & Fairfax & 0.80 & 10773 & No \\
\hline I 95 Landfill Phase II & G & Virginia & Fairfax & 0.80 & 10773 & No \\
\hline | 95 Landfill Phase II & G & Virginia & Fairfax & 0.80 & 10773 & No \\
\hline Richmond Electric & G & Virginia & Henrico & 0.90 & 14012 & No \\
\hline Richmond Electric & G & Virginia & Henrico & 0.90 & 14012 & No \\
\hline Marina Landfill Gas & G & California & Monterey & 0.70 & 12917 & No \\
\hline Twin Bridges Gas Recovery & G & Indiana & Hendricks & 0.80 & 11895 & No \\
\hline Twin Bridges Gas Recovery & G & Indiana & Hendricks & 0.80 & 11895 & No \\
\hline Twin Bridges Gas Recovery & G & Indiana & Hendricks & 0.80 & 11895 & No \\
\hline Twin Bridges Gas Recovery & G & Indiana & Hendricks & 0.80 & 11895 & No \\
\hline Prairie View Gas Recovery & G & Indiana & St. Joseph & 0.80 & 10991 & No \\
\hline Prairie View Gas Recovery & G & Indiana & St. Joseph & 0.80 & 10991 & No \\
\hline Prairie View Gas Recovery & G & Indiana & St. Joseph & 0.80 & 10991 & No \\
\hline Prairie View Gas Recovery & G & Indiana & St. Joseph & 0.80 & 10991 & No \\
\hline Granger Electric Generating Station \#1 & G & Michigan & Clinton & 0.80 & 14015 & No \\
\hline Ottawa Generating Station & G & Michigan & Ottawa & 0.80 & 11797 & No \\
\hline Ottawa Generating Station & G & Michigan & Ottawa & 0.80 & 11797 & No \\
\hline Ottawa Generating Station & G & Michigan & Ottawa & 0.80 & 11797 & No \\
\hline Ottawa Generating Station & G & Michigan & Ottawa & 0.80 & 11797 & No \\
\hline Ottawa Generating Station & G & Michigan & Ottawa & 0.80 & 11797 & No \\
\hline Ottawa Generating Station & G & Michigan & Ottawa & 0.80 & 11797 & No \\
\hline Grand Blanc Generating Station & G & Michigan & Genesee & 0.80 & 11080 & No \\
\hline Grand Blanc Generating Station & G & Michigan & Genesee & 0.80 & 11080 & No \\
\hline Grand Blanc Generating Station & G & Michigan & Genesee & 0.80 & 11080 & No \\
\hline Adrian Energy Associates LLC & G & Michigan & Lenawee & 0.80 & 13171 & No \\
\hline Adrian Energy Associates LLC & G & Michigan & Lenawee & 0.80 & 13171 & No \\
\hline Adrian Energy Associates LLC & G & Michigan & Lenawee & 0.80 & 13171 & No \\
\hline Woodlake Sanitary Services & G & Minnesota & Hennepin & 1.50 & 11749 & No \\
\hline Woodlake Sanitary Services & G & Minnesota & Hennepin & 1.50 & 11749 & No \\
\hline Woodlake Sanitary Services & G & Minnesota & Hennepin & 1.50 & 11749 & No \\
\hline EKS Landfill & G & Minnesota & Dakota & 1.50 & 12381 & No \\
\hline EKS Landfill & G & Minnesota & Dakota & 1.50 & 12381 & No \\
\hline EKS Landfill & G & Minnesota & Dakota & 0.80 & 12381 & No \\
\hline Suffolk Energy Partners LP & G & Virginia & Fairfax & 0.70 & 12500 & No \\
\hline Suffolk Energy Partners LP & G & Virginia & Fairfax & 0.70 & 12500 & No \\
\hline Suffolk Energy Partners LP & G & Virginia & Fairfax & 0.70 & 12500 & No \\
\hline Suffolk Energy Partners LP & G & Virginia & Fairfax & 0.70 & 12500 & No \\
\hline Peoples Generating Station & G & Michigan & Genesee & 2.20 & 9350 & No \\
\hline C \& C Electric & G & Michigan & Calhoun & 0.90 & 13697 & No \\
\hline C \& C Electric & G & Michigan & Calhoun & 0.90 & 13697 & No \\
\hline C \& C Electric & G & Michigan & Calhoun & 0.90 & 13697 & No \\
\hline Al Turi & G & New York & Orange & 0.70 & 15600 & No \\
\hline Brookhaven Facility & G & New York & Suffolk & 1.20 & 13158 & No \\
\hline Brookhaven Facility & G & New York & Suffolk & 1.20 & 13158 & No \\
\hline Brookhaven Facility & G & New York & Suffolk & 1.20 & 13158 & No \\
\hline Brookhaven Facility & G & New York & Suffolk & 1.20 & 13158 & No \\
\hline Coffin Butte & G & Oregon & Benton & 2.30 & 13151 & No \\
\hline Coffin Butte & G & Oregon & Benton & 0.74 & 13151 & No \\
\hline Coffin Butte & G & Oregon & Benton & 0.74 & 13151 & No \\
\hline Keystone Landfill & G & Pennsylvania & Lackawanna & 0.70 & 12125 & No \\
\hline Keystone Landfill & G & Pennsylvania & Lackawanna & 0.70 & 12125 & No \\
\hline Keystone Landfill & G & Pennsylvania & Lackawanna & 0.70 & 12125 & No \\
\hline Keystone Landfill & G & Pennsylvania & Lackawanna & 0.70 & 12125 & No \\
\hline Sonoma Central Landfill Phase II & G & California & Sonoma & 0.70 & 13643 & No \\
\hline Sonoma Central Landfill Phase II & G & California & Sonoma & 0.70 & 13643 & No \\
\hline Sonoma Central Landfill Phase II & G & California & Sonoma & 0.70 & 13643 & No \\
\hline Sonoma Central Landfill Phase II & G & California & Sonoma & 0.70 & 13643 & No \\
\hline Greene Valley Gas Recovery & G & Illinois & Du Page & 2.90 & 17551 & No \\
\hline Greene Valley Gas Recovery & G & Illinois & Du Page & 2.90 & 17551 & No \\
\hline Rockford Electric & G & Illinois & Ogle & 0.90 & 12317 & No \\
\hline Rockford Electric & G & Illinois & Ogle & 0.90 & 12317 & No \\
\hline Barre & G & Massachusetts & Worcester & 0.40 & 11941 & No \\
\hline Barre & G & Massachusetts & Worcester & 0.40 & 11941 & No \\
\hline Granger Electric Generating Station \#2 & G & Michigan & Clinton & 0.80 & 12740 & No \\
\hline Arbor Hills & G & Michigan & Washtenaw & 3.80 & 11860 & No \\
\hline Arbor Hills & G & Michigan & Washtenaw & 3.80 & 11860 & No \\
\hline Arbor Hills & G & Michigan & Washtenaw & 3.80 & 11860 & No \\
\hline Arbor Hills & G & Michigan & Washtenaw & 7.60 & 11860 & No \\
\hline Pine Bend & G & Minnesota & Dakota & 3.80 & 11860 & No \\
\hline Pine Bend & G & Minnesota & Dakota & 3.80 & 11860 & No \\
\hline Pine Bend & G & Minnesota & Dakota & 6.00 & 11860 & No \\
\hline Four Hills Nashua Landfill & G & New Hampshire & Hillsborough & 0.46 & 13152 & No \\
\hline Four Hills Nashua Landfill & G & New Hampshire & Hillsborough & 0.46 & 13152 & No \\
\hline Seneca Energy & G & New York & Seneca & 0.77 & 11012 & No \\
\hline Seneca Energy & G & New York & Seneca & 0.77 & 11012 & No \\
\hline Seneca Energy & G & New York & Seneca & 0.77 & 11012 & No \\
\hline Seneca Energy & G & New York & Seneca & 0.77 & 11012 & No \\
\hline Seneca Energy & G & New York & Seneca & 0.77 & 11012 & No \\
\hline Salem Energy Systems LLC & G & North Carolina & Forsyth & 3.30 & 16895 & No \\
\hline Keystone Landfill & G & Pennsylvania & Lackawanna & 0.70 & 12125 & No \\
\hline Keystone Landfill & G & Pennsylvania & Lackawanna & 0.70 & 12125 & No \\
\hline Keystone Landfill & G & Pennsylvania & Lackawanna & 0.70 & 12125 & No \\
\hline Pennsbury & G & Pennsylvania & Bucks & 2.67 & 9960 & No \\
\hline Pennsbury & G & Pennsylvania & Bucks & 2.67 & 9960 & No \\
\hline
\end{tabular}


Table 3.12 (Continued)

Current Landfill Gas Power Plants

\begin{tabular}{|c|c|c|c|c|c|c|c|}
\hline Plant Name & $\begin{array}{l}\text { Boiler/Generator/Co } \\
\text { mmitted Unit }\end{array}$ & State Name & County & Capacity MW & Heat Rate & Cogeneration & On-line Year \\
\hline Fairless Hills & $\bar{B}$ & Pennsylvania & Bucks & 20.00 & 10265 & Yes & 1996 \\
\hline Fairless Hills & $\mathrm{B}$ & Pennsylvania & Bucks & 20.00 & 10265 & Yes & 1996 \\
\hline Sunset Farms & G & Texas & Travis & 0.90 & 12845 & No & 1996 \\
\hline Sunset Farms & G & Texas & Travis & 0.90 & 12845 & No & 1996 \\
\hline Sunset Farms & G & Texas & Travis & 0.90 & 12845 & No & 1996 \\
\hline Pheasant Run Landfill Gas Recovery & G & Wisconsin & Kenosha & 0.80 & 12475 & No & 1996 \\
\hline Mallard Ridge Gas Recovery & G & Wisconsin & Walworth & 0.80 & 11500 & No & 1996 \\
\hline Mallard Ridge Gas Recovery & G & Wisconsin & Walworth & 0.80 & 11500 & No & 1996 \\
\hline Marina Landfill Gas & G & California & Monterey & 0.90 & 12917 & No & 1997 \\
\hline Miramar Landfill Metro Biosolids Center & G & California & San Diego & 1.56 & 10123 & Yes & 1997 \\
\hline Miramar Landfill Metro Biosolids Center & G & California & San Diego & 1.56 & 10123 & Yes & 1997 \\
\hline Miramar Landfill Metro Biosolids Center & G & California & San Diego & 1.56 & 10123 & Yes & 1997 \\
\hline Miramar Landfill Metro Biosolids Center & G & California & San Diego & 1.56 & 10123 & Yes & 1997 \\
\hline Girvin Landfill & G & Florida & Duval & 3.00 & 13806 & No & 1997 \\
\hline Biodyne Peoria & G & Illinois & Peoria & 0.80 & 15860 & No & 1997 \\
\hline Biodyne Peoria & G & Illinois & Peoria & 0.80 & 15860 & No & 1997 \\
\hline Biodyne Peoria & G & Illinois & Peoria & 0.80 & 15860 & No & 1997 \\
\hline Biodyne Peoria & G & Illinois & Peoria & 0.80 & 15860 & No & 1997 \\
\hline Biodyne Peoria & G & Illinois & Peoria & 0.80 & 15860 & No & 1997 \\
\hline Biodyne Springfield & G & Illinois & Sangamon & 0.60 & 23000 & No & 1997 \\
\hline Biodyne Springfield & G & Illinois & Sangamon & 0.60 & 23000 & No & 1997 \\
\hline Biodyne Springfield & G & Illinois & Sangamon & 0.60 & 23000 & No & 1997 \\
\hline Biodyne Springfield & G & Illinois & Sangamon & 0.60 & 23000 & No & 1997 \\
\hline Biodyne Lyons & G & Illinois & Cook & 0.90 & 15000 & No & 1997 \\
\hline Biodyne Lyons & G & Illinois & Cook & 0.90 & 15000 & No & 1997 \\
\hline Biodyne Lyons & G & Illinois & Cook & 0.90 & 15000 & No & 1997 \\
\hline Mallard Lake Electric & G & Illinois & Du Page & 3.80 & 9800 & No & 1997 \\
\hline Mallard Lake Electric & G & Illinois & Du Page & 3.80 & 9800 & No & 1997 \\
\hline Mallard Lake Electric & G & Illinois & Du Page & 3.80 & 9800 & No & 1997 \\
\hline Mallard Lake Electric & G & Illinois & Du Page & 7.60 & 9800 & No & 1997 \\
\hline South Barrington Electric & G & Illinois & Du Page & 0.80 & 12744 & No & 1997 \\
\hline South Barrington Electric & G & Illinois & Du Page & 0.80 & 12744 & No & 1997 \\
\hline Devonshire Power Partners LLC & G & Illinois & Cook & 1.00 & 11883 & No & 1997 \\
\hline Devonshire Power Partners LLC & G & Illinois & Cook & 1.00 & 11883 & No & 1997 \\
\hline Devonshire Power Partners LLC & G & Illinois & Cook & 1.00 & 11883 & No & 1997 \\
\hline Devonshire Power Partners LLC & G & Illinois & Cook & 1.00 & 11883 & No & 1997 \\
\hline Devonshire Power Partners LLC & G & Illinois & Cook & 1.00 & 11883 & No & 1997 \\
\hline Riveside Resource Recovery LLC & G & Illinois & Will & 0.90 & 12739 & No & 1997 \\
\hline Avon Energy Partners LLC & G & Illinois & Cook & 0.90 & 10367 & No & 1997 \\
\hline Avon Energy Partners LLC & G & Illinois & Cook & 0.90 & 10367 & No & 1997 \\
\hline Avon Energy Partners LLC & G & Illinois & Cook & 0.90 & 10367 & No & 1997 \\
\hline KMS Joliet Power Partners LP & G & Illinois & Will & 0.43 & 10000 & No & 1997 \\
\hline KMS Joliet Power Partners LP & G & Illinois & Will & 0.43 & 10000 & No & 1997 \\
\hline Wheeler Landfill Gas Recovery & G & Indiana & La Porte & 0.80 & 12270 & No & 1997 \\
\hline Taunton Landfill & G & Massachusetts & Bristol & 0.88 & 11754 & No & 1997 \\
\hline Taunton Landfill & G & Massachusetts & Bristol & 0.88 & 11754 & No & 1997 \\
\hline Lowell Landfill & G & Massachusetts & Middlesex & 0.78 & 9350 & No & 1997 \\
\hline Lowell Landfill & G & Massachusetts & Middlesex & 0.78 & 9350 & No & 1997 \\
\hline East Bridgewater & G & Massachusetts & Plymouth & 0.90 & 13410 & No & 1997 \\
\hline East Bridgewater & G & Massachusetts & Plymouth & 0.90 & 13410 & No & 1997 \\
\hline East Bridgewater & G & Massachusetts & Plymouth & 0.90 & 13410 & No & 1997 \\
\hline East Bridgewater & G & Massachusetts & Plymouth & 0.90 & 13410 & No & 1997 \\
\hline East Bridgewater & G & Massachusetts & Plymouth & 0.90 & 13410 & No & 1997 \\
\hline East Bridgewater & G & Massachusetts & Plymouth & 0.90 & 13410 & No & 1997 \\
\hline Halifax Electric & G & Massachusetts & Plymouth & 0.90 & 13629 & No & 1997 \\
\hline Halifax Electric & G & Massachusetts & Plymouth & 0.90 & 13629 & No & 1997 \\
\hline Halifax Electric & G & Massachusetts & Plymouth & 0.90 & 13629 & No & 1997 \\
\hline Granger Electric Generating Station \#2 & G & Michigan & Clinton & 0.80 & 12740 & No & 1997 \\
\hline Granger Electric Generating Station \#1 & G & Michigan & Clinton & 0.80 & 14015 & No & 1997 \\
\hline Turnkey Landfill Gas Recovery & G & New Hampshire & Strafford & 2.90 & 17620 & No & 1997 \\
\hline Turnkey Landfill Gas Recovery & G & New Hampshire & Strafford & 2.90 & 17620 & No & 1997 \\
\hline Ocean County Landfill & G & New Jersey & Ocean & 0.80 & 9350 & No & 1997 \\
\hline Ocean County Landfill & G & New Jersey & Ocean & 0.80 & 9350 & No & 1997 \\
\hline Ocean County Landfill & G & New Jersey & Ocean & 0.80 & 9350 & No & 1997 \\
\hline Ocean County Landfill & G & New Jersey & Ocean & 0.80 & 9350 & No & 1997 \\
\hline Ocean County Landfill & G & New Jersey & Ocean & 0.80 & 9350 & No & 1997 \\
\hline Ocean County Landfill & G & New Jersey & Ocean & 0.80 & 9350 & No & 1997 \\
\hline O'Brien Biogas IV LLC & G & New Jersey & Middlesex & 9.50 & 19943 & No & 1997 \\
\hline Seneca Energy & G & New York & Seneca & 0.77 & 11012 & No & 1997 \\
\hline Seneca Energy & G & New York & Seneca & 0.77 & 11012 & No & 1997 \\
\hline Lakeview Gas Recovery & G & Pennsylvania & Erie & 3.00 & 12517 & No & 1997 \\
\hline Lakeview Gas Recovery & G & Pennsylvania & Erie & 3.00 & 12517 & No & 1997 \\
\hline Ridgewood Providence Power & G & Rhode Island & Providence & 1.70 & 11832 & No & 1997 \\
\hline Mallard Ridge Gas Recovery & G & Wisconsin & Walworth & 0.80 & 11500 & No & 1997 \\
\hline Dane County Landfill \#2 Rodefeld & G & Wisconsin & Dane & 0.70 & 12596 & No & 1997 \\
\hline Dane County Landfill \#2 Rodefeld & G & Wisconsin & Dane & 0.70 & 12596 & No & 1997 \\
\hline Marina Landfill Gas & G & California & Monterey & 0.90 & 12917 & No & 1998 \\
\hline Visalia Landfill Gas Utilization Project & G & California & Tulare & 0.78 & 15410 & No & 1998 \\
\hline Visalia Landfill Gas Utilization Project & G & California & Tulare & 0.78 & 15410 & No & 1998 \\
\hline Lopez Landfill Gas Utilization Project & G & California & Los Angeles & 2.73 & 12698 & No & 1998 \\
\hline Lopez Landfill Gas Utilization Project & G & California & Los Angeles & 2.73 & 12698 & No & 1998 \\
\hline Hartford Landfill Gas Utilization Project & G & Connecticut & Hartford & 0.83 & 12503 & No & 1998 \\
\hline Hartford Landfill Gas Utilization Project & G & Connecticut & Hartford & 0.83 & 12503 & No & 1998 \\
\hline Hartford Landfill Gas Utilization Project & G & Connecticut & Hartford & 0.83 & 12503 & No & 1998 \\
\hline Volusia Landfill Gas Utilization Project & G & Florida & Volusia & 1.85 & 10333 & No & 1998 \\
\hline Volusia Landfill Gas Utilization Project & G & Florida & Volusia & 1.85 & 10333 & No & 1998 \\
\hline Settlers Hill Gas Recovery & G & Illinois & Kane & 2.90 & 18340 & No & 1998 \\
\hline Greene Valley Gas Recovery & G & Illinois & & 2.90 & 17551 & No & 1998 \\
\hline Quad Cities & $\mathrm{G}$ & Illinois & Rock Island & 0.90 & 16840 & No & 1998 \\
\hline
\end{tabular}


Table 3.12 (Continued)

Current Landfill Gas Power Plants

\begin{tabular}{|c|c|c|c|c|c|c|c|}
\hline Plant Name & $\begin{array}{l}\text { Boiler/Generator/Co } \\
\text { mmitted Unit }\end{array}$ & State Name & County & Capacity MW & Heat Rate & Cogeneration & On-line Year \\
\hline KMS Macon Power & $\bar{G}$ & Illinois & Macon & 0.80 & 12917 & No & 1998 \\
\hline KMS Macon Power & G & Illinois & Macon & 0.80 & 12917 & No & 1998 \\
\hline Metro Methane Recovery Facility & G & lowa & Polk & 0.80 & 12265 & No & 1998 \\
\hline Metro Methane Recovery Facility & G & lowa & Polk & 0.80 & 12265 & No & 1998 \\
\hline Metro Methane Recovery Facility & G & lowa & Polk & 0.80 & 12265 & No & 1998 \\
\hline Metro Methane Recovery Facility & G & lowa & Polk & 0.80 & 12265 & No & 1998 \\
\hline Metro Methane Recovery Facility & G & lowa & Polk & 0.80 & 12265 & No & 1998 \\
\hline Metro Methane Recovery Facility & G & lowa & Polk & 0.80 & 12265 & No & 1998 \\
\hline Metro Methane Recovery Facility & G & lowa & Polk & 0.80 & 12265 & No & 1998 \\
\hline Metro Methane Recovery Facility & G & lowa & Polk & 0.80 & 12265 & No & 1998 \\
\hline Sumpter Energy Associates & G & Michigan & Wayne & 0.80 & 13388 & No & 1998 \\
\hline Sumpter Energy Associates & G & Michigan & Wayne & 0.80 & 13388 & No & 1998 \\
\hline Sumpter Energy Associates & G & Michigan & Wayne & 0.80 & 13388 & No & 1998 \\
\hline Sumpter Energy Associates & G & Michigan & Wayne & 0.80 & 13388 & No & 1998 \\
\hline Sumpter Energy Associates & G & Michigan & Wayne & 0.80 & 13388 & No & 1998 \\
\hline Brent Run Generating Station & G & Michigan & Genesee & 0.80 & 11472 & No & 1998 \\
\hline Brent Run Generating Station & G & Michigan & Genesee & 0.80 & 11472 & No & 1998 \\
\hline Pine Tree Acres & G & Michigan & Macomb & 0.80 & 10976 & No & 1998 \\
\hline Pine Tree Acres & G & Michigan & Macomb & 0.80 & 10976 & No & 1998 \\
\hline Pine Tree Acres & G & Michigan & Macomb & 0.80 & 10976 & No & 1998 \\
\hline Pine Tree Acres & G & Michigan & Macomb & 0.80 & 10976 & No & 1998 \\
\hline Pine Tree Acres & G & Michigan & Macomb & 0.80 & 10976 & No & 1998 \\
\hline Balefill Landfill Gas Utilization Project & G & New Jersey & Bergen & 1.80 & 12611 & No & 1998 \\
\hline Balefill Landfill Gas Utilization Project & G & New Jersey & Bergen & 1.80 & 12611 & No & 1998 \\
\hline Monmouth Landfill Gas to Energy & G & New Jersey & Monmouth & 7.37 & 9960 & No & 1998 \\
\hline Al Turi & G & New York & Orange & 0.80 & 15600 & No & 1998 \\
\hline Al Turi & G & New York & Orange & 0.80 & 15600 & No & 1998 \\
\hline Seneca Energy & G & New York & Seneca & 0.77 & 11012 & No & 1998 \\
\hline Seneca Energy & G & New York & Seneca & 0.77 & 11012 & No & 1998 \\
\hline Seneca Energy & G & New York & Seneca & 0.77 & 11012 & No & 1998 \\
\hline Seneca Energy & G & New York & Seneca & 0.77 & 11012 & No & 1998 \\
\hline Seneca Energy & G & New York & Seneca & 0.77 & 11012 & No & 1998 \\
\hline Seneca Energy & G & New York & Seneca & 0.77 & 11012 & No & 1998 \\
\hline Seneca Energy & G & New York & Seneca & 0.77 & 11012 & No & 1998 \\
\hline Albany Landfill Gas Utilization Project & G & New York & Albany & 0.90 & 11914 & No & 1998 \\
\hline Albany Landfill Gas Utilization Project & G & New York & Albany & 0.90 & 11914 & No & 1998 \\
\hline Modern Landfill Production Plant & G & Pennsylvania & York & 3.00 & 10820 & No & 1998 \\
\hline Modern Landfill Production Plant & G & Pennsylvania & York & 3.00 & 10820 & No & 1998 \\
\hline Modern Landfill Production Plant & G & Pennsylvania & York & 3.00 & 10820 & No & 1998 \\
\hline Prince William County Landfill & G & Virginia & Prince William & 0.89 & 10206 & No & 1998 \\
\hline Prince William County Landfill & G & Virginia & Prince William & 0.89 & 10206 & No & 1998 \\
\hline Tacoma Landfill Gas Utilization Project & G & Washington & Pierce & 0.75 & 12917 & No & 1998 \\
\hline Tacoma Landfill Gas Utilization Project & G & Washington & Pierce & 0.75 & 12917 & No & 1998 \\
\hline BKK Landfill & G & California & Los Angeles & 4.40 & 12597 & No & 1999 \\
\hline Prima Desheha Landfill & G & California & Orange & 2.70 & 13752 & No & 1999 \\
\hline Prima Desheha Landfill & G & California & Orange & 2.70 & 13752 & No & 1999 \\
\hline North City Cogen Facility & G & California & San Diego & 0.88 & 12325 & No & 1999 \\
\hline North City Cogen Facility & G & California & San Diego & 0.88 & 12325 & No & 1999 \\
\hline North City Cogen Facility & G & California & San Diego & 0.88 & 12325 & No & 1999 \\
\hline North City Cogen Facility & G & California & San Diego & 0.88 & 12325 & No & 1999 \\
\hline Kiefer Landfill & G & California & Sacramento & 2.80 & 12917 & No & 1999 \\
\hline Kiefer Landfill & G & California & Sacramento & 2.80 & 12917 & No & 1999 \\
\hline Kiefer Landfill & G & California & Sacramento & 2.80 & 12917 & No & 1999 \\
\hline Tazewell Gas Recovery & G & Illinois & Tazewell & 0.80 & 11786 & No & 1999 \\
\hline Roxana Resource Recovery & G & Illinois & Madison & 0.90 & 10600 & No & 1999 \\
\hline Roxana Resource Recovery & G & Illinois & Madison & 0.90 & 10600 & No & 1999 \\
\hline Roxana Resource Recovery & G & Illinois & Madison & 0.90 & 10600 & No & 1999 \\
\hline Roxana Resource Recovery & G & Illinois & Madison & 0.90 & 10600 & No & 1999 \\
\hline Streator Energy Partners LLC & G & Illinois & La Salle & 0.90 & 10919 & No & 1999 \\
\hline Brickyard Energy Partners LLC & G & Illinois & Vermilion & 0.90 & 10793 & No & 1999 \\
\hline Brickyard Energy Partners LLC & G & Illinois & Vermilion & 0.90 & 10793 & No & 1999 \\
\hline Brickyard Energy Partners LLC & G & Illinois & Vermilion & 0.90 & 10793 & No & 1999 \\
\hline Dixon/Lee Energy Partners LLC & G & Illinois & Lee & 0.90 & 12101 & No & 1999 \\
\hline Dixon/Lee Energy Partners LLC & G & Illinois & Lee & 0.90 & 12101 & No & 1999 \\
\hline Dixon/Lee Energy Partners LLC & G & Illinois & Lee & 0.90 & 12101 & No & 1999 \\
\hline Dixon/Lee Energy Partners LLC & G & Illinois & Lee & 0.90 & 12101 & No & 1999 \\
\hline KMS Joliet Power Partners LP & G & Illinois & Will & 0.43 & 10000 & No & 1999 \\
\hline Deercroft Gas Recovery & G & Indiana & La Porte & 0.80 & 12030 & No & 1999 \\
\hline Deercroft Gas Recovery & G & Indiana & La Porte & 0.80 & 12030 & No & 1999 \\
\hline Deercroft Gas Recovery & G & Indiana & La Porte & 0.80 & 12030 & No & 1999 \\
\hline Deercroft Gas Recovery & G & Indiana & La Porte & 0.80 & 12030 & No & 1999 \\
\hline HMDC Kingsland Landfill & G & New Jersey & Bergen & 0.90 & 13406 & No & 1999 \\
\hline HMDC Kingsland Landfill & G & New Jersey & Bergen & 0.90 & 13406 & No & 1999 \\
\hline Blackburn Landfill Co-Generation & G & North Carolina & Catawba & 1.00 & 10433 & Yes & 1999 \\
\hline Blackburn Landfill Co-Generation & G & North Carolina & Catawba & 1.00 & 10433 & Yes & 1999 \\
\hline Charlotte Motor Speedway & G & North Carolina & Cabarrus & 4.30 & 14303 & No & 1999 \\
\hline Cuyahoga Regional Landfill & G & Ohio & Cuyahoga & 1.80 & 10374 & No & 1999 \\
\hline Cuyahoga Regional Landfill & G & Ohio & Cuyahoga & 1.80 & 10374 & No & 1999 \\
\hline P.E.R.C. & G & Washington & Pierce & 0.75 & 17782 & No & 1999 \\
\hline P.E.R.C. & G & Washington & Pierce & 0.75 & 17782 & No & 1999 \\
\hline P.E.R.C. & G & Washington & Pierce & 0.75 & 17782 & No & 1999 \\
\hline Roosevelt Biogas 1 & G & Washington & Klickitat & 2.10 & 10000 & No & 1999 \\
\hline Roosevelt Biogas 1 & G & Washington & Klickitat & 2.10 & 10000 & No & 1999 \\
\hline Roosevelt Biogas 1 & G & Washington & Klickitat & 2.10 & 10000 & No & 1999 \\
\hline Roosevelt Biogas 1 & G & Washington & Klickitat & 2.10 & 10000 & No & 1999 \\
\hline Tajiguas Landfill & G & California & Santa Barbara & 2.70 & 11332 & No & 2000 \\
\hline CSL Gas Recovery & G & Florida & Broward & 2.20 & 11860 & No & 2000 \\
\hline Upper Rock Energy Partners LLC & G & Illinois & Rock Island & 0.90 & 10828 & No & 2000 \\
\hline Upper Rock Energy Partners LLC & G & Illinois & Rock Island & 0.90 & 10828 & No & 2000 \\
\hline Upper Rock Energy Partners LLC & $\mathrm{G}$ & Illinois & Rock Island & 0.90 & 10828 & No & 2000 \\
\hline
\end{tabular}


Table 3.12 (Continued) Current Landfill Gas Power Plants

\begin{tabular}{|c|}
\hline Plant Name \\
\hline Countyside Genco LLC \\
\hline Countyside Genco LLC \\
\hline Countyside Genco LLC \\
\hline Countyside Genco LLC \\
\hline Countyside Genco LLC \\
\hline Countyside Genco LLC \\
\hline KMS Joliet Power Partners LP \\
\hline Randolph Electric \\
\hline Randolph Electric \\
\hline Randolph Electric \\
\hline Fall River Electric \\
\hline Fall River Electric \\
\hline Fall River Electric \\
\hline Grand Blanc Generating Station \\
\hline MM Nashville \\
\hline MM Nashville \\
\hline Roosevelt Biogas 1 \\
\hline Metro Gas Recovery \\
\hline Metro Gas Recovery \\
\hline Metro Gas Recovery \\
\hline Metro Gas Recovery \\
\hline Winnebago County Landfill Gas \\
\hline Winnebago County Landfill Gas \\
\hline Winnebago County Landfill Gas \\
\hline Pheasant Run Landfill Gas Recovery \\
\hline Pheasant Run Landfill Gas Recovery \\
\hline Pheasant Run Landfill Gas Recovery \\
\hline Pheasant Run Landfill Gas Recovery \\
\hline Tri Cities \\
\hline Tri Cities \\
\hline Tri Cities \\
\hline Tri Cities \\
\hline Tri Cities \\
\hline RCWMD Badlands Landfill Gas Project \\
\hline Biodyne Beecher \\
\hline Morris Genco LLC \\
\hline Morris Genco LLC \\
\hline Morris Genco LLC \\
\hline Model City Energy Facility \\
\hline Model City Energy Facility \\
\hline Model City Energy Facility \\
\hline Model City Energy Facility \\
\hline Model City Energy Facility \\
\hline Model City Energy Facility \\
\hline Model City Energy Facility \\
\hline Green Knight Energy Center \\
\hline Green Knight Energy Center \\
\hline Green Knight Energy Center \\
\hline Horry Land Fill Gas Site \\
\hline Horry Land Fill Gas Site \\
\hline Omega Hills Gas Recovery \\
\hline Superior Glacier Ridge Landfill \\
\hline Superior Glacier Ridge Landfill \\
\hline Berlin \\
\hline Berlin \\
\hline Berlin \\
\hline Marina Landfill Gas \\
\hline Altamont Gas Recovery \\
\hline Altamont Gas Recovery \\
\hline Quad Cities \\
\hline Brent Run Generating Station \\
\hline Elk City Station \\
\hline Elk City Station \\
\hline Elk City Station \\
\hline Elk City Station \\
\hline HMDC Kingsland Landfill \\
\hline Blackburn Landfill Co-Generation \\
\hline Pheasant Run Landfill Gas Recovery \\
\hline Pheasant Run Landfill Gas Recovery \\
\hline Pheasant Run Landfill Gas Recovery \\
\hline Pheasant Run Landfill Gas Recovery \\
\hline Ridgeview \\
\hline Ridgeview \\
\hline Ridgeview \\
\hline Colton Landfill \\
\hline Mid Valley Landfill \\
\hline Mid Valley Landfill \\
\hline Milliken Landfill \\
\hline Milliken Landfill \\
\hline Bradley \\
\hline Acme Landfill \\
\hline California Street \\
\hline South West Landfill \\
\hline South West Landfill \\
\hline South West Landfill \\
\hline Taylor County Landfill \\
\hline Bavarian LFGTE \\
\hline Bavarian LFGTE \\
\hline Bavarian LFGTE \\
\hline Bavarian LFGTE \\
\hline Green Valley LFGTE \\
\hline Green Valley LFGTE \\
\hline Green Valley LFGTE \\
\hline Laurel Ridge LFGTE \\
\hline Laurel Ridge LFGTE \\
\hline Laurel Ridge LFGTE \\
\hline Laurel Ridge LFGIE \\
\hline
\end{tabular}


Table 3.12 (Continued)

Current Landfill Gas Power Plants

\begin{tabular}{|c|c|c|c|c|c|c|c|}
\hline Plant Name & $\begin{array}{l}\text { Boiler/Generator/Co } \\
\text { mmitted Unit }\end{array}$ & State Name & County & Capacity MW & Heat Rate & Cogeneration & On-line Year \\
\hline PG Cnty Brown Station Road II & $\bar{G}$ & Maryland & Prince Georges & 0.98 & 12917 & No & 2003 \\
\hline PG Cnty Brown Station Road II & G & Maryland & Prince Georges & 0.98 & 12917 & No & 2003 \\
\hline PG Cnty Brown Station Road II & G & Maryland & Prince Georges & 0.98 & 12917 & No & 2003 \\
\hline PG Cnty Brown Station Road II & G & Maryland & Prince Georges & 0.98 & 12917 & No & 2003 \\
\hline Chicopee II LFG & $\mathrm{C}$ & Massachusetts & $\mathrm{a}$ & 5.42 & 12917 & No & 2003 \\
\hline Plainville LFG & $\mathrm{C}$ & Massachusetts & a & 5.32 & 12917 & No & 2003 \\
\hline Grand Blanc Generating Station & G & Michigan & Genesee & 0.80 & 11080 & No & 2003 \\
\hline Pine Tree Acres & G & Michigan & Macomb & 0.80 & 10976 & No & 2003 \\
\hline Pine Tree Acres & G & Michigan & Macomb & 0.80 & 10976 & No & 2003 \\
\hline Ontario LFGTE & G & New York & Ontario & 0.80 & 10500 & No & 2003 \\
\hline Ontario LFGTE & G & New York & Ontario & 0.80 & 10500 & No & 2003 \\
\hline Ontario LFGTE & G & New York & Ontario & 0.80 & 10500 & No & 2003 \\
\hline Ontario LFGTE & G & New York & Ontario & 0.80 & 10500 & No & 2003 \\
\hline Horry Land Fill Gas Site & G & South Carolina & Horry & 1.10 & 10523 & No & 2003 \\
\hline Reliant Energy Renewables Atascosita & G & Texas & Harris & 1.70 & 10518 & No & 2003 \\
\hline Reliant Energy Renewables Atascosita & G & Texas & Harris & 1.70 & 10518 & No & 2003 \\
\hline Reliant Energy Renewables Atascosita & G & Texas & Harris & 1.70 & 10518 & No & 2003 \\
\hline Reliant Energy Renewables Atascosita & G & Texas & Harris & 1.70 & 10518 & No & 2003 \\
\hline Reliant Energy Renewables Atascosita & G & Texas & Harris & 1.70 & 10518 & No & 2003 \\
\hline Reliant Baytown & G & Texas & Chambers & 1.00 & 10535 & No & 2003 \\
\hline Reliant Baytown & G & Texas & Chambers & 1.00 & 10535 & No & 2003 \\
\hline Reliant Baytown & G & Texas & Chambers & 1.00 & 10535 & No & 2003 \\
\hline Reliant Baytown & G & Texas & Chambers & 1.00 & 10535 & No & 2003 \\
\hline Reliant Bluebonnet & G & Texas & Harris & 1.00 & 11043 & No & 2003 \\
\hline Reliant Bluebonnet & G & Texas & Harris & 1.00 & 11043 & No & 2003 \\
\hline Reliant Bluebonnet & G & Texas & Harris & 1.00 & 11043 & No & 2003 \\
\hline Reliant Bluebonnet & G & Texas & Harris & 1.00 & 11043 & No & 2003 \\
\hline Reliant Coastal Plains & G & Texas & Galveston & 1.70 & 10353 & No & 2003 \\
\hline Reliant Coastal Plains & G & Texas & Galveston & 1.70 & 10353 & No & 2003 \\
\hline Reliant Coastal Plains & G & Texas & Galveston & 1.70 & 10353 & No & 2003 \\
\hline Reliant Coastal Plains & G & Texas & Galveston & 1.70 & 10353 & No & 2003 \\
\hline Reliant Conroe & G & Texas & Montgomery & 1.00 & 11168 & No & 2003 \\
\hline Reliant Conroe & G & Texas & Montgomery & 1.00 & 11168 & No & 2003 \\
\hline Reliant Conroe & G & Texas & Montgomery & 1.00 & 11168 & No & 2003 \\
\hline Reliant Security & G & Texas & Liberty & 1.70 & 9910 & No & 2003 \\
\hline Reliant Security & G & Texas & Liberty & 1.70 & 9910 & No & 2003 \\
\hline Reliant Security & G & Texas & Liberty & 1.70 & 9910 & No & 2003 \\
\hline Tessman Road LFG - A & $\mathrm{c}$ & Texas & Bexar & 2.47 & 12917 & No & 2003 \\
\hline Hutchins LFG & C & Texas & Dallas & 2.47 & 12917 & No & 2003 \\
\hline Ridgeview & G & Wisconsin & Manitowoc & 0.80 & 11054 & No & 2003 \\
\hline Sonoma Central Landfill Phase III & G & California & Sonoma & 0.70 & 12917 & No & 2004 \\
\hline Sonoma Central Landfill Phase III & G & California & Sonoma & 0.70 & 12917 & No & 2004 \\
\hline Simi Valley & $\mathrm{c}$ & California & Ventura & 2.57 & 12917 & No & 2004 \\
\hline Brickyard Recycling & $\mathrm{c}$ & Illinois & Vermilion & 0.19 & 12917 & No & 2004 \\
\hline Des Plaines Landfill & $\mathrm{c}$ & Illinois & Cook & 3.80 & 12917 & No & 2004 \\
\hline Westchester Landfill & $\mathrm{c}$ & Illinois & Cook & 3.33 & 12917 & No & 2004 \\
\hline Twiss Street (Westfi & $\mathrm{c}$ & Massachusetts & a & 0.46 & 12917 & No & 2004 \\
\hline Dairyland PPA Landfi & $\mathrm{c}$ & Minnesota & a & 2.85 & 12917 & No & 2004 \\
\hline Atlantic City Landfi & $\mathrm{C}$ & New Jersey & a & 1.44 & 12917 & No & 2004 \\
\hline Troy & $\mathrm{C}$ & New York & Rensselaer & 0.76 & 12917 & No & 2004 \\
\hline Broome County & $\mathrm{C}$ & New York & Broome & 0.67 & 12917 & No & 2004 \\
\hline Ontario County SLF & $\mathrm{c}$ & New York & Ontario & 3.04 & 12917 & No & 2004 \\
\hline Johnston LFG (MA RPS & $\mathrm{C}$ & Rhode Island & a & 2.50 & 12917 & No & 2004 \\
\hline Central LF & $\mathrm{c}$ & Rhode Island & a & 2.38 & 12917 & No & 2004 \\
\hline Charles County Landf & $\mathrm{c}$ & Virginia & Charles City & 4.56 & 12917 & No & 2004 \\
\hline Fauquier County Land & $\mathrm{c}$ & Virginia & Fauquier & 1.80 & 12917 & No & 2004 \\
\hline Shoosmith Landfill & c & Virginia & Chesterfield & 4.56 & 12917 & No & 2004 \\
\hline Dane County Landfill \#2 Rodefeld & G & Wisconsin & Dane & 0.80 & 11000 & No & 2004 \\
\hline Seven Mile Creek LFG & G & Wisconsin & Eau Claire & 0.98 & 10123 & No & 2004 \\
\hline Seven Mile Creek LFG & G & Wisconsin & Eau Claire & 0.98 & 10123 & No & 2004 \\
\hline Seven Mile Creek LFG & G & Wisconsin & Eau Claire & 0.98 & 10123 & No & 2004 \\
\hline Owl Creek-Richmond C & c & Georgia & Richmond & 3.80 & 13648 & No & 2005 \\
\hline New Paris Pike LF & c & Indiana & Pike & 1.52 & 13648 & No & 2005 \\
\hline Pearl Hollow Landfil & c & Kentucky & Hardin & 2.28 & 13648 & No & 2005 \\
\hline Crapo Hill Landfill & c & Massachusetts & a & 3.04 & 13648 & No & 2005 \\
\hline Glendale & $\mathrm{c}$ & Massachusetts & a & 1.14 & 13648 & No & 2005 \\
\hline Atlantic County Util & C & New Jersey & Atlantic & 1.52 & 13648 & No & 2005 \\
\hline IGENCO (Upton) & $\mathrm{C}$ & Pennsylvania & Franklin & 5.80 & 13648 & No & 2005 \\
\hline Lanchester & $\mathrm{C}$ & Pennsylvania & Lancaster & 0.88 & 13648 & No & 2005 \\
\hline Pine Hurst Acres & $\mathrm{C}$ & Pennsylvania & Northumberland & 0.05 & 13648 & No & 2005 \\
\hline Brookside Dairy & $\mathrm{C}$ & Pennsylvania & Indiana & 0.13 & 13648 & No & 2005 \\
\hline Wanner's Pride & c & Pennsylvania & Lancaster & 0.15 & 13648 & No & 2005 \\
\hline Rolling Hills & C & Pennsylvania & Berks & 2.00 & 13648 & No & 2005 \\
\hline Lee County Landfill & C & South Carolina & Lee & 1.90 & 13648 & No & 2005 \\
\hline Lee County Landfill & $\mathrm{c}$ & South Carolina & Lee & 1.90 & 13648 & No & 2005 \\
\hline Lee County Landfill & $\mathrm{C}$ & South Carolina & Lee & 1.90 & 13648 & No & 2005 \\
\hline Davis County & c & Utah & Davis & 0.95 & 13648 & No & 2005 \\
\hline Coventry LFG & c & Vermont & a & 4.56 & 13648 & No & 2005 \\
\hline Rodefeld Landfill Ga & $\mathrm{C}$ & Wisconsin & Dane & 3.80 & 13648 & No & 2005 \\
\hline Double S Dairy Diges & $\mathrm{C}$ & Wisconsin & Green Lake & 0.38 & 13648 & No & 2005 \\
\hline Los Reales LFG Expan & $\mathrm{c}$ & Arizona & $a$ & 1.90 & 13648 & No & 2006 \\
\hline Dekalb County Landfi & $\mathrm{C}$ & Georgia & De Kalb & 3.04 & 13648 & No & 2006 \\
\hline Harrisburg Facility & C & Pennsylvania & Dauphin & 20.82 & 13648 & No & 2006 \\
\hline Lee County Landfill & C & South Carolina & Lee & 1.90 & 13648 & No & 2006 \\
\hline Texas Mandate Landfill Gas & $\mathrm{c}$ & Texas & a & 5.00 & 13648 & No & 2006 \\
\hline Lee County Solid Waste Energy & $\mathrm{c}$ & Florida & Lee & 18.60 & 13648 & No & 2007 \\
\hline
\end{tabular}

Source:

(National Electric Energy System (NEEDS) Database for IPM 2006, http://epa.gov/airmarkets/progsregs/epa-ipm/index.html

\section{${ }^{a}$ Data are not available}


Figure 3.5

New Municipal Solid Waste Power Plants by Year

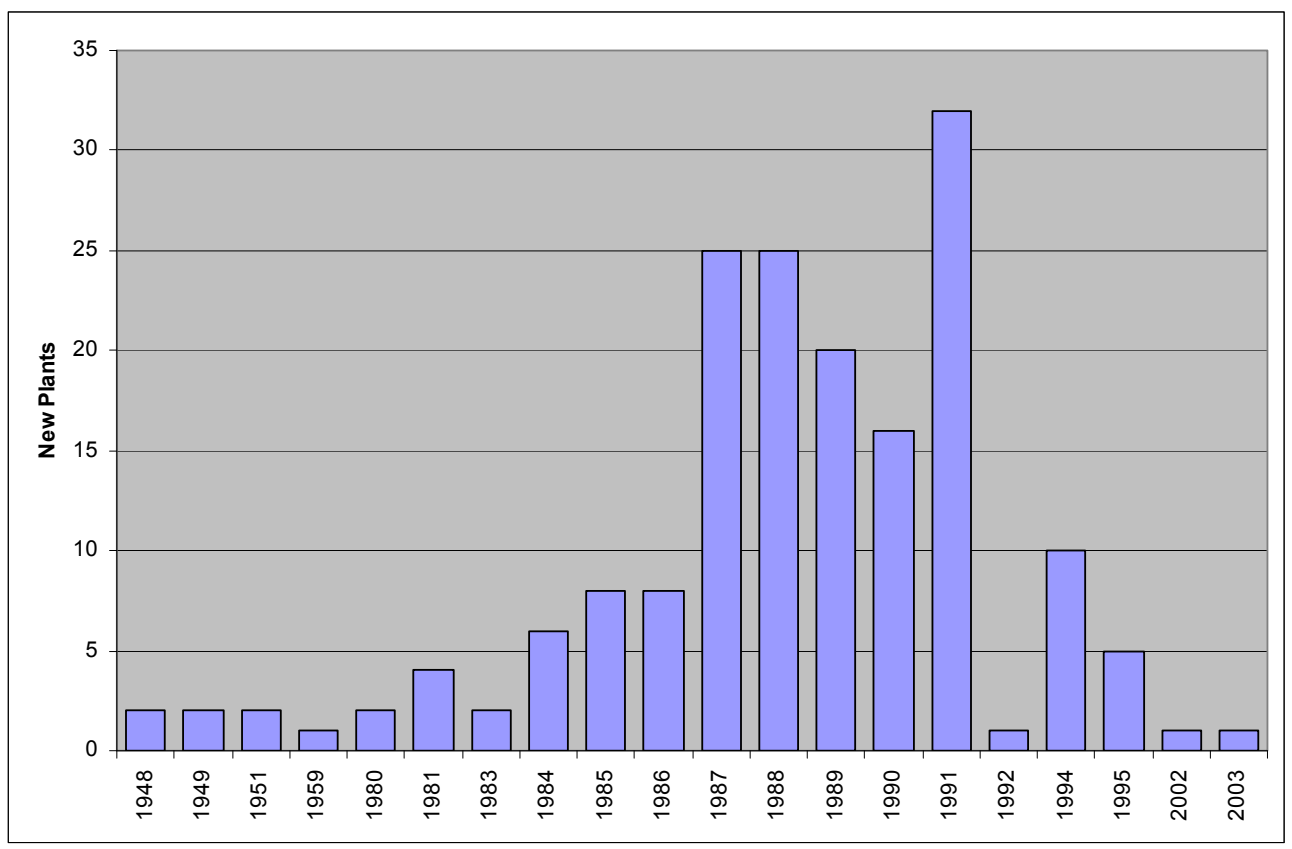

Figure 3.6

Municipal Solid Waste Power Plant Capacity by Year (Megawatt Hours)

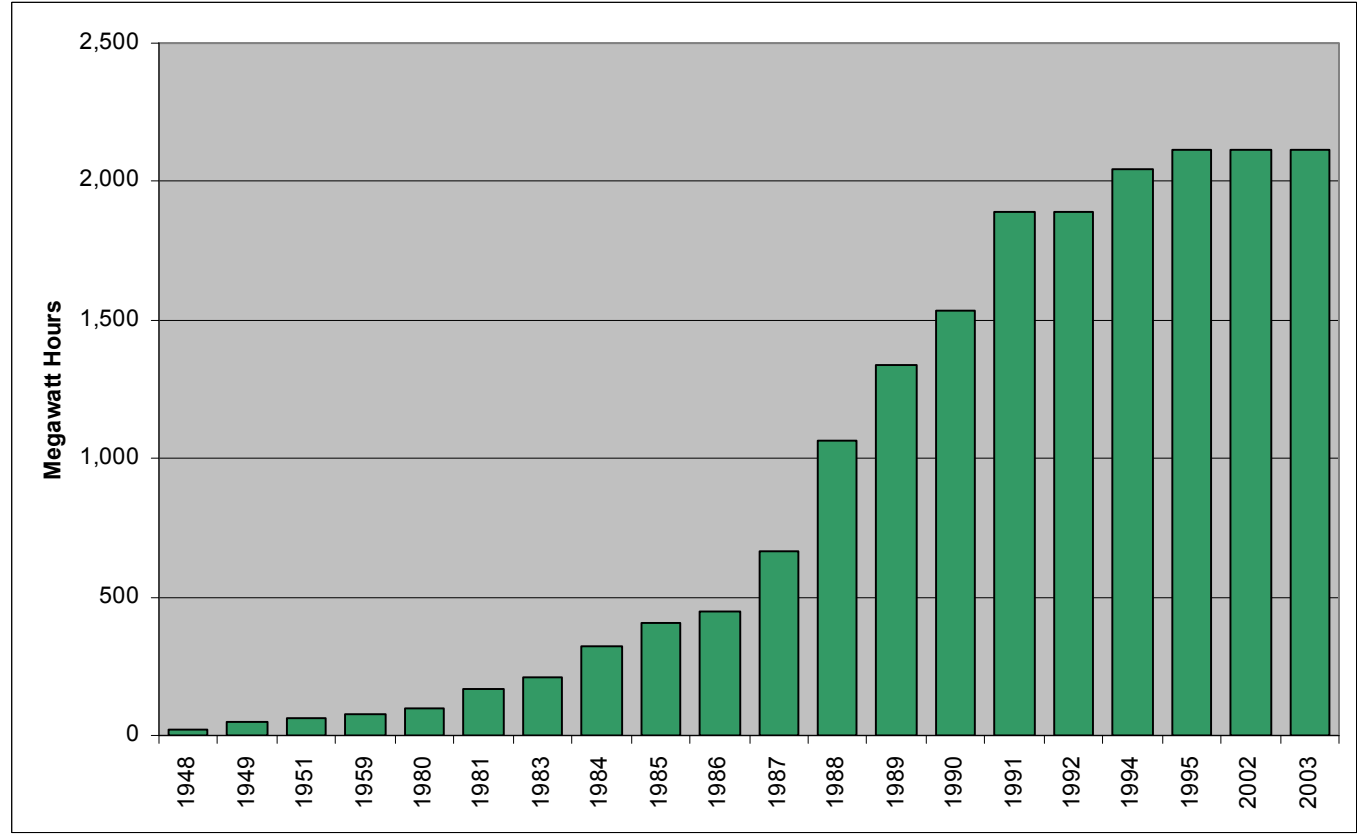

\section{Source:}

(National Electric Energy System (NEEDS) Database for IPM 2006, http://epa.gov/airmarkets/progsregs/epa-ipm/index.html

\section{Notes:}

1. Only years in which new plants were brought online are shown.

2. Power plant capacity based on NEEDS 2006 Data. 
Table 3.13

\section{Current Municipal Solid Waste Power Plants}

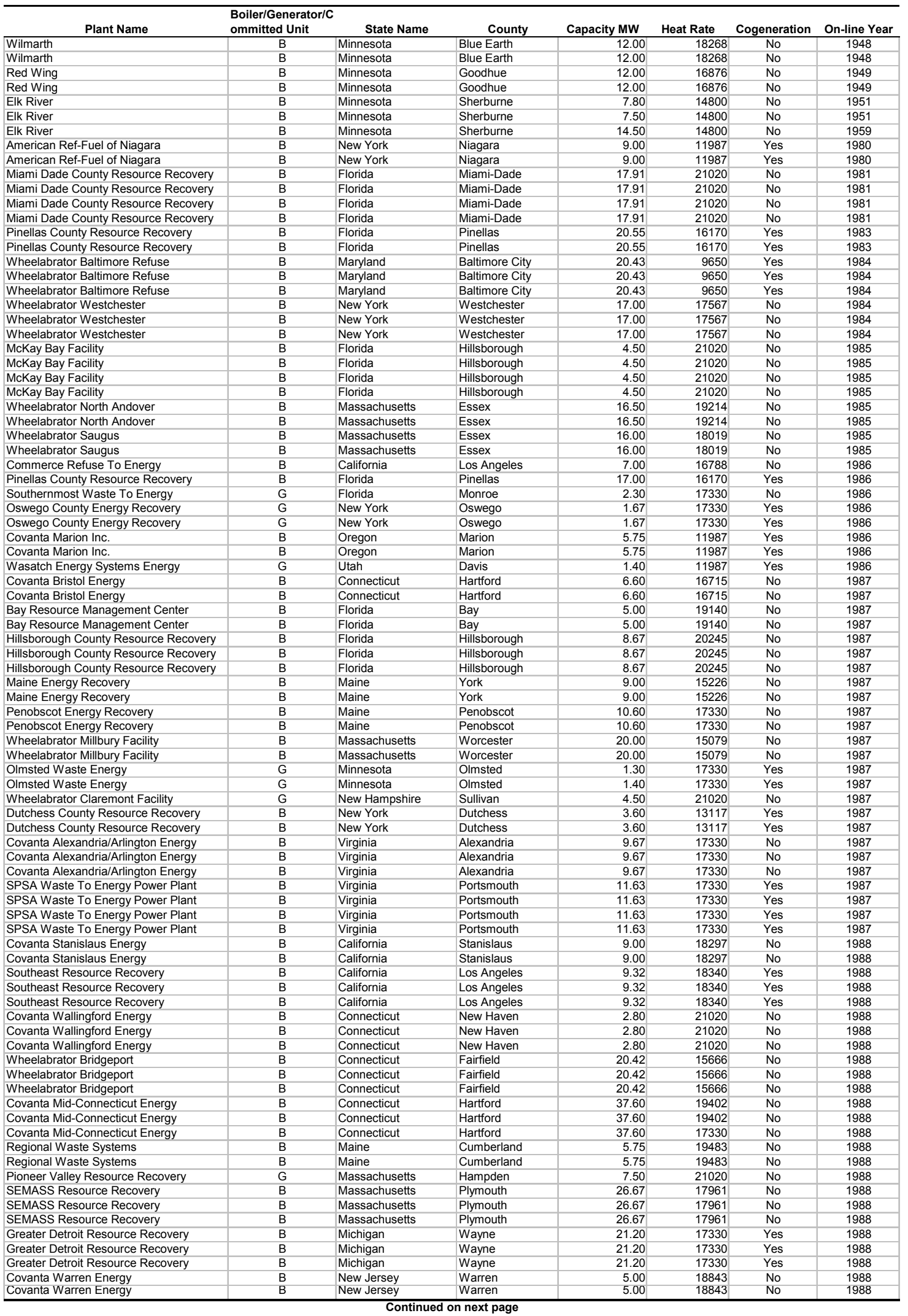


Table 3.13 (Continued)

\section{Current Municipal Solid Waste Power Plants}

\begin{tabular}{|c|c|c|c|c|c|c|c|}
\hline Plant Name & $\begin{array}{l}\text { Boiler/Generator/C } \\
\text { ommitted Unit }\end{array}$ & State Name & County & Capacity MW & Heat Rate & Cogeneration & On-line Year \\
\hline North County Regional Resource & B & Florida & Palm Beach & 21.75 & 17862 & No & 1989 \\
\hline North County Regional Resource & B & Florida & Palm Beach & 21.75 & 17862 & No & 1989 \\
\hline Covanta Haverhill & B & Massachusetts & Essex & 21.39 & 15734 & No & 1989 \\
\hline Covanta Haverhill & B & Massachusetts & Essex & 21.39 & 15734 & No & 1989 \\
\hline Kent County Waste to Energy Facility & B & Michigan & Kent & 7.85 & 9650 & Yes & 1989 \\
\hline Kent County Waste to Energy Facility & B & Michigan & Kent & 7.85 & 9650 & Yes & 1989 \\
\hline Covanta Hennepin Energy & B & Minnesota & Hennepin & 16.85 & 15894 & No & 1989 \\
\hline Covanta Hennepin Energy & B & Minnesota & Hennepin & 16.85 & 15894 & No & 1989 \\
\hline Wheelabrator Concord Facility & B & New Hampshire & Merrimack & 7.00 & 18592 & No & 1989 \\
\hline Wheelabrator Concord Facility & B & New Hampshire & Merrimack & 7.00 & 18592 & No & 1989 \\
\hline American Ref-Fuel of Hempstead & B & New York & Nassau & 22.57 & 16566 & No & 1989 \\
\hline American Ref-Fuel of Hempstead & B & New York & Nassau & 22.57 & 17330 & No & 1989 \\
\hline American Ref-Fuel of Hempstead & B & New York & Nassau & 22.57 & 17330 & No & 1989 \\
\hline Covanta Babylon Energy & B & New York & Suffolk & 7.18 & 21020 & No & 1989 \\
\hline Covanta Babylon Energy & B & New York & Suffolk & 7.18 & 21020 & No & 1989 \\
\hline York County Resource Recovery & B & Pennsylvania & York & 9.33 & 20113 & No & 1989 \\
\hline York County Resource Recovery & B & Pennsylvania & York & 9.33 & 20113 & No & 1989 \\
\hline York County Resource Recovery & B & Pennsylvania & York & 9.33 & 20113 & No & 1989 \\
\hline Charleston Resource Recovery Facility & B & South Carolina & Charleston & 4.75 & 17330 & Yes & 1989 \\
\hline Charleston Resource Recovery Facility & B & South Carolina & Charleston & 4.75 & 17330 & Yes & 1989 \\
\hline Covanta Lake County Energy & B & Florida & Lake & 6.25 & 20026 & No & 1990 \\
\hline Covanta Lake County Energy & B & Florida & Lake & 6.25 & 20026 & No & 1990 \\
\hline American Ref-Fuel of Essex & B & New Jersey & Essex & 10.00 & 11500 & No & 1990 \\
\hline American Ref-Fuel of Essex & B & New Jersey & Essex & 10.00 & 11500 & No & 1990 \\
\hline American Ref-Fuel of Essex & B & New Jersey & Essex & 40.00 & 11500 & No & 1990 \\
\hline Wheelabrator Gloucester LP & B & New Jersey & Gloucester & 6.00 & 19829 & No & 1990 \\
\hline Wheelabrator Gloucester LP & B & New Jersey & Gloucester & 6.00 & 19829 & No & 1990 \\
\hline MacArthur Waste to Energy Facility & B & New York & Suffolk & 2.30 & 21020 & No & 1990 \\
\hline MacArthur Waste to Energy Facility & B & New York & Suffolk & 2.30 & 17330 & No & 1990 \\
\hline Lancaster County Resource Recovery & B & Pennsylvania & Lancaster & 10.80 & 17820 & No & 1990 \\
\hline Lancaster County Resource Recovery & B & Pennsylvania & Lancaster & 10.80 & 17820 & No & 1990 \\
\hline Lancaster County Resource Recovery & B & Pennsylvania & Lancaster & 10.80 & 17820 & No & 1990 \\
\hline Covanta Fairfax Energy & B & Virginia & Fairfax & 19.75 & 17055 & No & 1990 \\
\hline Covanta Fairfax Energy & B & Virginia & Fairfax & 19.75 & 17055 & No & 1990 \\
\hline Covanta Fairfax Energy & B & Virginia & Fairfax & 19.75 & 17055 & No & 1990 \\
\hline Covanta Fairfax Energy & B & Virginia & Fairfax & 19.75 & 17055 & No & 1990 \\
\hline American Ref-Fuel of SE CT & B & Connecticut & New London & 6.00 & 18528 & No & 1991 \\
\hline American Ref-Fuel of SE CT & B & Connecticut & New London & 6.00 & 18528 & No & 1991 \\
\hline Pasco Cnty Solid Waste Resource & B & Florida & Pasco & 8.67 & 21020 & No & 1991 \\
\hline Pasco Cnty Solid Waste Resource & B & Florida & Pasco & 8.67 & 21020 & No & 1991 \\
\hline Pasco Cnty Solid Waste Resource & B & Florida & Pasco & 8.67 & 21020 & No & 1991 \\
\hline Wheelabrator South Broward & B & Florida & Broward & 19.30 & 17997 & No & 1991 \\
\hline Wheelabrator South Broward & B & Florida & Broward & 19.30 & 17997 & No & 1991 \\
\hline Wheelabrator South Broward & B & Florida & Broward & 19.30 & 17997 & No & 1991 \\
\hline Wheelabrator North Broward & B & Florida & Broward & 18.67 & 18534 & No & 1991 \\
\hline Wheelabrator North Broward & B & Florida & Broward & 18.67 & 18534 & No & 1991 \\
\hline Wheelabrator North Broward & B & Florida & Broward & 18.67 & 18534 & No & 1991 \\
\hline Camden Resource Recovery Facility & B & New Jersey & Camden & 10.00 & 20835 & No & 1991 \\
\hline Camden Resource Recovery Facility & B & New Jersey & Camden & 10.00 & 20835 & No & 1991 \\
\hline Camden Resource Recovery Facility & B & New Jersey & Camden & 10.00 & 20835 & No & 1991 \\
\hline Wheelabrator Hudson Falls, LLC & B & New York & Washington & 5.75 & 9650 & No & 1991 \\
\hline Wheelabrator Hudson Falls, LLC & B & New York & Washington & 5.75 & 9650 & No & 1991 \\
\hline Huntington Resource Recovery Facility & B & New York & Suffolk & 8.33 & 18674 & No & 1991 \\
\hline Huntington Resource Recovery Facility & B & New York & Suffolk & 8.33 & 18674 & No & 1991 \\
\hline Huntington Resource Recovery Facility & B & New York & Suffolk & 8.33 & 18674 & No & 1991 \\
\hline New Hanover County WASTEC & B & North Carolina & New Hanover & 0.57 & 9650 & Yes & 1991 \\
\hline New Hanover County WASTEC & B & North Carolina & New Hanover & 0.57 & 9650 & Yes & 1991 \\
\hline New Hanover County WASTEC & B & North Carolina & New Hanover & 0.57 & 9650 & Yes & 1991 \\
\hline American Ref-Fuel of Delaware Valley & B & Pennsylvania & Delaware & 13.33 & 18675 & No & 1991 \\
\hline American Ref-Fuel of Delaware Valley & B & Pennsylvania & Delaware & 13.33 & 18675 & No & 1991 \\
\hline American Ref-Fuel of Delaware Valley & B & Pennsylvania & Delaware & 13.33 & 18675 & No & 1991 \\
\hline American Ref-Fuel of Delaware Valley & B & Pennsylvania & Delaware & 13.33 & 18675 & No & 1991 \\
\hline American Ref-Fuel of Delaware Valley & B & Pennsylvania & Delaware & 13.33 & 18675 & No & 1991 \\
\hline American Ref-Fuel of Delaware Valley & B & Pennsylvania & Delaware & 13.33 & 18675 & No & 1991 \\
\hline Montenay Montgomery LP & B & Pennsylvania & Montgomery & 14.00 & 17330 & No & 1991 \\
\hline Montenay Montgomery LP & B & Pennsylvania & Montgomery & 14.00 & 17330 & No & 1991 \\
\hline Wheelabrator Spokane & B & Washington & Spokane & 13.00 & 18657 & No & 1991 \\
\hline Wheelabrator Spokane & B & Washington & Spokane & 13.00 & 18657 & No & 1991 \\
\hline MMWAC Resource Recovery Facility & G & Maine & Androscoggin & 2.10 & 17330 & No & 1992 \\
\hline Lee County Solid Waste Energy & B & Florida & Lee & 19.50 & 15175 & No & 1994 \\
\hline Lee County Solid Waste Energy & B & Florida & Lee & 19.50 & 15175 & No & 1994 \\
\hline Union County Resource Recovery & B & New Jersey & Union & 12.50 & 17339 & No & 1994 \\
\hline Union County Resource Recovery & B & New Jersey & Union & 12.50 & 17339 & No & 1994 \\
\hline Union County Resource Recovery & B & New Jersey & Union & 12.50 & 17339 & No & 1994 \\
\hline Onondaga County Resource Recovery & B & New York & Onondaga & 10.00 & 17330 & No & 1994 \\
\hline Onondaga County Resource Recovery & B & New York & Onondaga & 10.00 & 17330 & No & 1994 \\
\hline Onondaga County Resource Recovery & B & New York & Onondaga & 10.00 & 17330 & No & 1994 \\
\hline Wheelabrator Falls & B & Pennsylvania & Bucks & 24.05 & 15195 & No & 1994 \\
\hline Wheelabrator Falls & B & Pennsylvania & Bucks & 24.05 & 15195 & No & 1994 \\
\hline Wheelabrator Lisbon & B & Connecticut & New London & 6.50 & 16839 & No & 1995 \\
\hline Wheelabrator Lisbon & B & Connecticut & New London & 6.50 & 16839 & No & 1995 \\
\hline Montgomery County Resource Recovery & B & Maryland & Montgomery & 18.00 & 17172 & No & 1995 \\
\hline Montgomery County Resource Recovery & B & Maryland & Montgomery & 18.00 & 17172 & No & 1995 \\
\hline Montgomery County Resource Recovery & B & Maryland & Montgomery & 18.00 & 17172 & No & 1995 \\
\hline New Hanover County WASTEC & G & North Carolina & New Hanover & 1.90 & 9650 & Yes & 2002 \\
\hline Perham Incinerator & G & Minnesota & Otter Tail & 1.20 & 17330 & No & 2003 \\
\hline
\end{tabular}

\section{Source:}

(National Electric Energy System (NEEDS) Database for IPM 2006, http://epa.gov/airmarkets/progsregs/epa-ipm/index.html 
Table 3.14

Total Net Generation of Electricity by State from Wood and Wood Waste, 2005 (Thousand Kilowatt hours)

\begin{tabular}{|c|c|c|c|}
\hline State & $\begin{array}{c}\text { Wood/Wood } \\
\text { Waste }^{\text {a }}\end{array}$ & $\begin{array}{l}\text { Percent of all } \\
\text { Renewables }\end{array}$ & $\begin{array}{l}\text { Total from all } \\
\text { Renewables }\end{array}$ \\
\hline Alabama & $3,738,421$ & $26.89 \%$ & $13,903,838$ \\
\hline Arizona & 12058 & $0.19 \%$ & $6,484,059$ \\
\hline Arkansas & $1,706,996$ & $35.44 \%$ & $4,817,205$ \\
\hline California & $3,610,097$ & $5.70 \%$ & $63,280,278$ \\
\hline Connecticut & 7314 & $0.59 \%$ & $1,231,534$ \\
\hline Florida & $2,005,937$ & $43.32 \%$ & $4,630,013$ \\
\hline Georgia & $3,148,749$ & $43.38 \%$ & $7,258,184$ \\
\hline Idaho & 577,040 & $6.33 \%$ & $9,119,161$ \\
\hline Kentucky & 359,065 & $10.61 \%$ & $3,383,578$ \\
\hline Louisiana & $2,643,987$ & $74.79 \%$ & $3,535,442$ \\
\hline Maine & $3,786,633$ & $46.37 \%$ & $8,165,916$ \\
\hline Maryland & 195,466 & $8.44 \%$ & $2,316,510$ \\
\hline Massachusetts & 120,027 & $5.22 \%$ & $2,300,240$ \\
\hline Michigan & $1,801,330$ & $45.24 \%$ & $3,981,975$ \\
\hline Minnesota & 649,415 & $18.98 \%$ & $3,422,350$ \\
\hline Mississippi & $1,519,941$ & $99.65 \%$ & $1,525,285$ \\
\hline Montana & 65,245 & $0.68 \%$ & $9,652,594$ \\
\hline New Hampshire & 785733 & $28.67 \%$ & $2,740,802$ \\
\hline New York & 537,510 & $1.93 \%$ & $27,780,976$ \\
\hline North Carolina & $1,739,583$ & $24.04 \%$ & $7,234,871$ \\
\hline Ohio & 359,014 & $39.24 \%$ & 914,831 \\
\hline Oklahoma & 289,217 & $7.68 \%$ & $3,767,351$ \\
\hline Oregon & 809,306 & $2.48 \%$ & $32,589,968$ \\
\hline Pennsylvania & 687,496 & $15.07 \%$ & $4,561,646$ \\
\hline South Carolina & $1,697,465$ & $35.94 \%$ & $4,723,363$ \\
\hline Tennessee & 528,281 & $5.35 \%$ & $9,868,426$ \\
\hline Texas & 843,789 & $12.66 \%$ & $6,666,969$ \\
\hline Vermont & 410,491 & $25.14 \%$ & $1,632,789$ \\
\hline Virginia & $1,799,862$ & $45.20 \%$ & $3,981,778$ \\
\hline Washington & $1,419,394$ & $1.91 \%$ & $74,190,549$ \\
\hline Wisconsin & 824,996 & $27.18 \%$ & $3,034,797$ \\
\hline Total & $38,679,858$ & $11.63 \%$ & $332,697,278$ \\
\hline
\end{tabular}

Source:

Energy Information Administration, Renewable Energy Annual 2006, Table 1.17, http://www.eia.doe.gov/cneaf/solar.renewables/page/rea data/rea sum.html

Note: States not listed contained no data for wood/wood waste.

a Black liquor, and wood/woodwaste solids and liquids. 
Table 3.15 Net Generation and Fuel Consumption at Power Plants Consuming Coal and Biomass
by State and Plant Name, 2003

\begin{tabular}{|c|c|c|c|c|c|c|c|c|}
\hline \multirow[b]{2}{*}{ State } & \multirow[b]{2}{*}{ County } & \multirow[b]{2}{*}{ Plant Name } & \multirow{2}{*}{$\begin{array}{l}\text { Net Electricity } \\
\text { Generation } \\
\text { (Thousand } \\
\text { Kilowatthours) }\end{array}$} & \multirow{2}{*}{$\begin{array}{c}\text { Total Energy } \\
\text { Consumed } \\
\text { (MMBtu) }\end{array}$} & \multirow{2}{*}{$\begin{array}{c}\text { Energy } \\
\text { Consumed } \\
\text { from } \\
\text { Biomass } \\
\text { (MMBtu) }\end{array}$} & \multicolumn{3}{|c|}{$\begin{array}{c}\text { Percent of Energy Consumed } \\
\text { from }\end{array}$} \\
\hline & & & & & & Biomass & Coal & Other \\
\hline \multirow[t]{3}{*}{ New York } & Yates & AES Greenidge LLC & $1,040,354$ & $11,705,155$ & 99,328 & 0.85 & 98.90 & 0.25 \\
\hline & Jefferson & Black River Power LLC & 355,861 & $4,539,007$ & 9,635 & 0.21 & 74.06 & 25.73 \\
\hline & Niagara & WPS Power Niagara & 251,890 & $3,353,781$ & 28,760 & 0.86 & 98.21 & 0.94 \\
\hline \multirow[t]{8}{*}{ North Carolina } & Haywood & Canton North Carolina & 344,245 & $20,265,972$ & $9,641,230$ & 47.57 & 52.12 & 0.30 \\
\hline & Forsyth & Corn Products Winston Salem & 56,591 & $3,948,209$ & $3,441,379$ & 87.16 & 11.73 & 1.11 \\
\hline & Halifax & International Paper Roanoke Ra & 174,563 & $12,732,892$ & $8,624,055$ & 67.73 & 23.23 & 9.04 \\
\hline & Columbus & International Paper Riegelwood & 503,301 & $25,783,234$ & $18,114,256$ & 70.26 & 5.22 & 24.52 \\
\hline & Bladen & Elizabethtown Power LLC & 117,590 & $1,659,872$ & 383,987 & 23.13 & 76.87 & \\
\hline & Robeson & Lumberton & 83,280 & $1,075,248$ & 201,011 & 18.69 & 81.31 & \\
\hline & Martin & Weyerhaeuser Plymouth NC & 806,280 & $39,957,341$ & $32,330,211$ & 80.91 & 17.27 & 1.81 \\
\hline & Pickaway & Picway & 402,519 & $4,674,846$ & 29,550 & 0.63 & 98.86 & 0.51 \\
\hline Ohio & Ross & Mead Custom Paper & 532,453 & $15,151,763$ & $8,077,827$ & 53.31 & 45.29 & 1.40 \\
\hline \multirow[t]{5}{*}{ Pennsylvania } & Delaware & Chester Operations & 389,779 & $6,591,803$ & 23,657 & 0.36 & 54.54 & 45.10 \\
\hline & Northampton & Northhampton Generating LP & 820,274 & $8,762,273$ & 205,553 & 2.35 & 56.42 & 41.24 \\
\hline & Schuylkill & Kline Township Cogen Facility & 393,564 & $5,978,255$ & 423,384 & 7.08 & 92.01 & 0.91 \\
\hline & York & P H Glatfelter & 680,328 & $17,422,344$ & $8,766,181$ & 50.32 & 48.75 & 0.94 \\
\hline & Elk & Johnsonburg Mill & 279,550 & $8,572,138$ & $4,801,100$ & 56.01 & 38.92 & 5.07 \\
\hline \multirow[t]{3}{*}{ South Carolina } & Richland & International Paper Eastover F & 529,454 & $21,208,564$ & $16,189,319$ & 76.33 & 16.94 & 6.72 \\
\hline & Georgetown & International Paper Georgetown & 527,894 & $21,735,489$ & $17,702,311$ & 81.44 & 10.33 & 8.23 \\
\hline & Florence & Stone Container Florence Mill & 710,340 & $20,402,914$ & $12,541,662$ & 61.47 & 27.28 & 11.25 \\
\hline \multirow[t]{4}{*}{ Tennessee } & McMinn & Bowater Newsprint Calhoun Oper & 525,280 & $21,325,300$ & $15,574,553$ & 73.03 & 25.16 & 1.81 \\
\hline & Sullivan & Tennessee Eastman Operations & $1,239,569$ & $40,812,321$ & 300,054 & 0.74 & 98.39 & 0.88 \\
\hline & Hardin & Packaging Corp of America & 373,340 & $22,112,700$ & $18,034,060$ & 81.56 & 9.63 & 8.82 \\
\hline & Sullivan & Weyerhaeuser Kingsport Mill & 101,154 & $6,722,666$ & $5,825,213$ & 86.65 & 13.35 & \\
\hline \multirow[t]{6}{*}{ Virginia } & Bedford & Georgia Pacific Big Island & 52,032 & $3,357,369$ & $1,720,872$ & 51.26 & 46.83 & 1.91 \\
\hline & Isle of Wight & International Paper Franklin M & 776,727 & $25,587,752$ & $14,481,554$ & 56.60 & 22.09 & 21.32 \\
\hline & King William & St Laurent Paper West Point & 525,859 & $17,126,189$ & $12,851,000$ & 75.04 & 17.05 & 7.92 \\
\hline & Portsmouth City & SPSA Waste To Energy Power Pla & 173,116 & $5,415,699$ & $5,388,534$ & 99.50 & 0.00 & 0.50 \\
\hline & Hopewell City & Stone Container Hopewell Mill & 319,104 & $8,636,244$ & $6,255,293$ & 72.43 & 25.30 & 2.27 \\
\hline & Covington & Covington Facility & 671,771 & $29,004,636$ & $13,064,973$ & 45.04 & 42.23 & 12.72 \\
\hline Washington & Cowlitz & Weyerhaeuser Longview WA & 327,661 & $18,235,976$ & $14,422,210$ & 79.09 & 7.72 & 13.19 \\
\hline \multirow[t]{3}{*}{ West Virginia } & Preston & Albright & $1,669,380$ & $18,709,260$ & 1,806 & 0.01 & 99.79 & 0.20 \\
\hline & Pleasants & Willow Island & $1,095,678$ & $12,279,409$ & 196,900 & 1.60 & 98.02 & 0.37 \\
\hline & Kanawha & Union Carbide South Charleston & 21,488 & $3,309,914$ & 73,163 & 2.21 & 64.49 & 33.30 \\
\hline \multirow[t]{15}{*}{ Wisconsin } & Wood & Georgia Pacific Nekoosa Mill & 203,635 & $5,584,402$ & $3,224,101$ & 57.73 & 36.09 & 6.17 \\
\hline & Price & Fraser Paper & 36,422 & 334,360 & 113,361 & 33.90 & 66.10 & \\
\hline & Outagamie & International Paper Kaukauna M & 211,943 & $7,634,467$ & $3,344,608$ & 43.81 & 39.06 & 17.13 \\
\hline & Dane & Blount Street & 451,308 & $6,299,195$ & 180,864 & 2.87 & 80.63 & 16.50 \\
\hline & Manitowoc & Manitowoc & 315,087 & $4,761,246$ & 23,264 & 0.49 & 66.17 & 33.34 \\
\hline & Ashland & Bay Front & 296,711 & $4,529,448$ & $1,795,854$ & 39.65 & 58.60 & 1.75 \\
\hline & Lincoln & Packaging of America Tomahawk & 133,041 & $10,575,641$ & $7,959,582$ & 75.26 & 23.01 & 1.72 \\
\hline & Dane & Univ of Wisc Madison Charter S & 42,282 & $3,947,769$ & 323,026 & 8.18 & 82.18 & 9.64 \\
\hline & Dodge & Waupun Correctional Central He & 4,130 & 288,951 & 20,665 & 7.15 & 88.90 & 3.95 \\
\hline & Wood & Biron Mill & 246,244 & $4,614,572$ & 326,216 & 7.07 & 91.64 & 1.29 \\
\hline & Marinette & Niagara Mill & 114,749 & $3,000,275$ & 196,181 & 6.54 & 71.80 & 21.66 \\
\hline & Portage & Whiting Mill & 25,362 & $1,572,137$ & 208,755 & 13.28 & 78.43 & 8.29 \\
\hline & Wood & Wisconsin Rapids Pulp Mill & 374,930 & $12,125,962$ & $8,338,658$ & 68.77 & 26.14 & 5.10 \\
\hline & Marathon & Wausau Mosinee Paper Pulp & 122,059 & $12,335,121$ & $10,406,885$ & 84.37 & 13.37 & 2.26 \\
\hline & Sheboygan & Edgewater & $4,893,820$ & $47,746,013$ & 665,280 & 1.39 & 98.48 & 0.12 \\
\hline Total & & & $95,304,634$ & $1,709,675,399$ & $630,926,946$ & 36.90 & 53.78 & 9.32 \\
\hline
\end{tabular}

Source:

Energy Information Administration. Derived from Table 9: Net Generation and Fuel Consumption at Power Plants Consuming Coal and Biomass by State and Plant Name, 2003, http://www.eia.doe.gov/cneaf/solar.renewables/page/trends/table1.html

Notes: Blank cell indicates the plant had no consumption or other energy to report.

MMBtu = One million British thermal units. 
Table 3.16

Coal Displacement Calculation, 2006

\begin{tabular}{|c|c|c|c|c|c|c|}
\hline \multirow[t]{2}{*}{ Conversion Formu } & $\begin{array}{l}\text { Step } 1 \\
\text { Step } 2\end{array}$ & \multicolumn{5}{|c|}{$\begin{array}{l}\text { Capacity }(A) \times \text { Capacity Factor }(B) \times \text { Annual Hours }(C)=\text { Annual Electricity Generation }(D) \\
\text { Annual Electricity Generation }(D) \times \text { Conversion Efficiency }(E)=\text { Total Output }(F)\end{array}$} \\
\hline & Step 3 & \multicolumn{5}{|c|}{ Total Output (F) / Fuel Heat Rate $(G)=$ Quantity Fuel $(H)$} \\
\hline Technology & Wind & Geothermal & Biomass & Hydropower & PV & Solar Thermal \\
\hline (A) Capacity (kW) & $11,558,205$ & $2,232,495$ & $6,594,096$ & $78,312,583$ & 280,355 & 388,893 \\
\hline (B) Capacity Factor (\%) & $36.0 \%$ & $90.0 \%$ & $80.0 \%$ & $44.2 \%$ & $22.5 \%$ & $24.4 \%$ \\
\hline (C) Annual Hours & 8,760 & 8,760 & 8,760 & 8,760 & 8,760 & 8,760 \\
\hline (D) Annual Electricity Generation (kWh) & $36,449,954,187$ & $17,600,991,128$ & $46,211,427,727$ & $303,176,455,525$ & $552,579,314$ & $831,235,472$ \\
\hline (E) Conversion Efficiency (Btu/kWh) & 10,107 & 10,107 & 10,107 & 10,107 & 10,107 & 10,107 \\
\hline (F) Total Output (Million Btu) & $368,399,686$ & $177,893,217$ & $467,058,900$ & $3,064,204,435$ & $5,584,919$ & $8,401,296$ \\
\hline (G) Coal Heat Rate (Btu per short ton) & $20,411,000$ & $20,411,000$ & $20,411,000$ & $20,411,000$ & $20,411,000$ & $20,411,000$ \\
\hline (H) Coal (short tons) & $18,049,076$ & $8,715,556$ & $22,882,705$ & $150,125,150$ & 273,623 & 411,606 \\
\hline
\end{tabular}

\section{Source:}

National Renewable Energy Laboratory, Power Technologies Energy Data Book, Table 12.3, http://www.nrel.gov/analysis/power databook/chapter12.html

Original Sources: Capacity: EIA, Annual Energy Outlook 2006, DOE/EIA-0383 (2006) (Washington, DC, February 2006), Table A16.

Capacity Factors: Hydropower calculated from EIA, Annual Energy Outlook 2006, DOE/EIA-0383 (2006) (Washington, DC, February 2006), Table A16. All others based on DOE, Renewable Energy Technology Characterizations, EPRI TR-109496, 1997 and Program data.

Conversion Efficiency: EIA, Annual Energy Review 2004, DOE/EIA-0384(2004) (Washington, DC, August 2005), Table A6.

Heat Rate: Annual Energy Outlook 2006, DOE/EIA-0383 (2006) (Washington, DC, February 2006), Table F1.

Note: Capacity values exclude combined-heat-and-power (CHP) data but include end-use sector (industrial and commercial) non-CHP data. 
Table 3.17

Renewable Energy Impacts Calculation, 2006

\begin{tabular}{|c|c|c|c|c|c|c|}
\hline \multirow[t]{2}{*}{ Conversion Formula: } & $\begin{array}{l}\text { Step } 1 \\
\text { Step } 2 \\
\text { Step } 3\end{array}$ & \multicolumn{5}{|c|}{$\begin{array}{l}\text { Capacity }(A) \times \text { Capacity Factor }(B) \times \text { Annual Hours }(C)=\text { Annual Electricity Generation }(D) \\
\text { Annual Electricity Generation }(D) \times \text { Competing Heat Rate }(E)=\text { Annual Output }(F) \\
\text { Annual Output }(F) \times \text { Emissions Coefficient }(G)=\text { Annual Emissions Displaced }(H)\end{array}$} \\
\hline & Wind & Geothermal & Biomass & Hydropower & PV & Solar Thermal \\
\hline (A) Capacity (kW) & $11,558,205$ & $2,232,495$ & $6,594,096$ & $78,312,583$ & 280,355 & 388,893 \\
\hline (B) Capacity Factor (\%) & $36.0 \%$ & $90.0 \%$ & $80.0 \%$ & $44.2 \%$ & $22.5 \%$ & $24.4 \%$ \\
\hline (C) Annual Hours & 8,760 & 8,760 & 8,760 & 8,760 & 8,760 & 8,760 \\
\hline (D) Annual Electricity Generation (kWh) & $36,449,954,187$ & $17,600,991,128$ & $46,211,427,727$ & $303,176,455,525$ & $552,579,314$ & $831,235,472$ \\
\hline (E) Competing Heat Rate (Btu/kWh) & 10,107 & 10,107 & 10,107 & 10,107 & 10,107 & 10,107 \\
\hline (F) Annual Output (Trillion Btu) & 368.4 & 177.9 & 467.1 & $3,064.2$ & 5.6 & 8.4 \\
\hline (G) Carbon Coefficient (MMTCB/Trillion Btu) & 0.01783 & 0.01783 & 0.01783 & 0.01783 & 0.01783 & 0.01783 \\
\hline (H) Annual Carbon Displaced (MMTC) & 6.569 & 3.172 & 8.328 & 54.635 & 0.100 & 0.128 \\
\hline
\end{tabular}

\section{Source:}

National Renewable Energy Laboratory. Power Technologies Energy Data Book, Table 12.1, http://www.nrel.gov/analysis/power databook/chapter12.html

Original sources: Capacity: Projected values for the year 2006 from EIA, Annual Energy Outlook 2006, DOE/EIA-0383 (2006) (Washington, DC, February 2006), Table A16, 2006.

Capacity Factors: Hydropower calculated from EIA, Annual Energy Outlook 2005, DOE/EIA-0383 (2005) (Washington, DC, February 2005), Table A16. All others based on DOE, Renewable Energy Technology Characterizations, EPRI TR-109496, 1997 and Program data.

Heat Rate: EIA, Annual Energy Review 2004, DOE/EIA-0384(2004) (Washington, DC, August 2005), Table A6.

Carbon Coefficient: DOE, GPRA2003 Data Call, Appendix B, page B-16, 2003.

Notes: Capacity values exclude combined-heat-and-power (CHP) data but include end-use sector (industrial and commercial) non-CHP data. Competing heat rate from Fossil-Fueled Steam-Electric Plants heat rate. 
Table 3.18

Number of Home Electricity Needs Met Calculation, 2006

Conversion Formula: $\quad$ Step $1 \quad$ Capacity $(A) \times$ Capacity Factor $(B) \times$ Annual Hours $(C)=$ Annual Electricity Generation $(D)$

Step $2 \quad$ Annual Electricity Generation $(D) /$ Average Consumption $(E)=$ Number of Households $(F)$

\begin{tabular}{|c|c|c|c|c|c|c|}
\hline Technology & Wind & Geothermal & Biomass & Hydropower & PV & $\begin{array}{l}\text { Solar } \\
\text { Thermal }\end{array}$ \\
\hline (A) Capacity (kW) & $11,558,205$ & $2,232,495$ & $6,594,096$ & $78,312,583$ & 280,355 & 388,893 \\
\hline (B) Capacity Factor (\%) & $36.0 \%$ & $90.0 \%$ & $80.0 \%$ & $44.2 \%$ & $22.5 \%$ & $24.4 \%$ \\
\hline (C) Annual Hours & 8,760 & 8,760 & 8,760 & 8,760 & 8,760 & 8,760 \\
\hline $\begin{array}{l}\text { (D) Annual Electricity Generation } \\
\text { (kWh) } \\
\text { (E) Average Annual Household }\end{array}$ & $36,449,954,187$ & $17,600,991,128$ & $46,211,427,727$ & $303,176,455,525$ & $552,579,314$ & $831,235,472$ \\
\hline Electricity Consumption (kWh) & 11,576 & 11,576 & 11,576 & 11,576 & 11,576 & 11,576 \\
\hline (F) Number of Households & $3,148,804$ & $1,520,497$ & $3,992,068$ & $26,190,515$ & 47,736 & 71,808 \\
\hline
\end{tabular}

Source:

National Renewable Energy Laboratory, Power Technologies Data Book, Table 12.2, http://www.nrel.gov/analysis/power databook/chapter12.html

Original sources: Capacity: EIA, Annual Energy Outlook 2006, DOE/EIA-0383 (2006) (Washington, DC, February 2006), Table A16, 2006.

Capacity Factors: Hydropower calculated from EIA, Annual Energy Outlook 2005, DOE/EIA-0383 (2005) (Washington, DC, February 2005), Table A16. All others based on DOE, Renewable Energy Technology Characterizations, EPRI TR-109496, 1997 and Program data.

Household electricity Consumption: Calculated from EIA, Annual Energy Outlook 2006, DOE/EIA-0383 (2006) (Washington, DC, February), Tables A4 and A8, 2006.

Note: Capacity values exclude combined-heat-and-power (CHP) data but include end-use sector (industrial and commercial) non-CHP data. 


\section{BIOREFINERIES}

\section{BIOREFINERIES OVERVIEW}

As a petroleum refinery uses petroleum as the major input and processes it into many different products, a biorefinery uses biomass as the major input and processes it into many different products. Wet-mill and dry-mill corn processing plants and pulp and paper mills can be categorized as biorefineries since they produce multiple products from biomass. Ethanol production facilities produce ethanol and other products from the sugar and starch components of biomass. As of September 2008, the Renewable Fuels Association listed 168 operating ethanol biorefineries with a total production capacity of 9,961 million gallon per year (MGY). New construction and expansion would add another 3,790 MGY. Distillers grains, a high-value, protein rich product being used for livestock feed is the major co-product of the existing drymill ethanol biorefineries. Wet-mill ethanol biorefineries have the capacity to produce high fructose corn syrup, and a wide variety of chemical feedstocks such as citric acid, lactic acid, lysine and other products as well as ethanol. Research over the past several years has developed several technologies that have the capability of converting many types of lignocellulosic biomass resources into a wide range of products. The goal is for biorefineries to produce both high-volume liquid fuels and high-value chemicals or products in order to address national energy needs while enhancing operation economics. History was made in 2007 with the ground breaking for construction of the first commercial- scale lignocellulosic ethanol biorefinery in the U.S. The Range Fuels facility near Soperton, Georgia will use initially use wood residues from timber harvesting to produce ethanol and other products. Pulp and Papers mills are existing biorefineries that produce heat, and electricity as well as pulp or paper and some chemicals, but they also have the potential of producing very large amounts of biofuels and biomass power from processing residuals such as bark and black liquor. Three pulp production facilities were included among the 9 awarded funding in 2008 for building small-scale prototype biorefineries to test new ideas.

Two of the emerging biorefinery platforms are the sugar platform and the thermochemical platform (also known as the syngas platform) illustrated below. Sugar platform biorefineries would break biomass down into different types of component sugars for fermentation or other biological processing into various fuels and chemicals.

Thermochemical biorefineries would convert biomass to synthesis gas (hydrogen and carbon

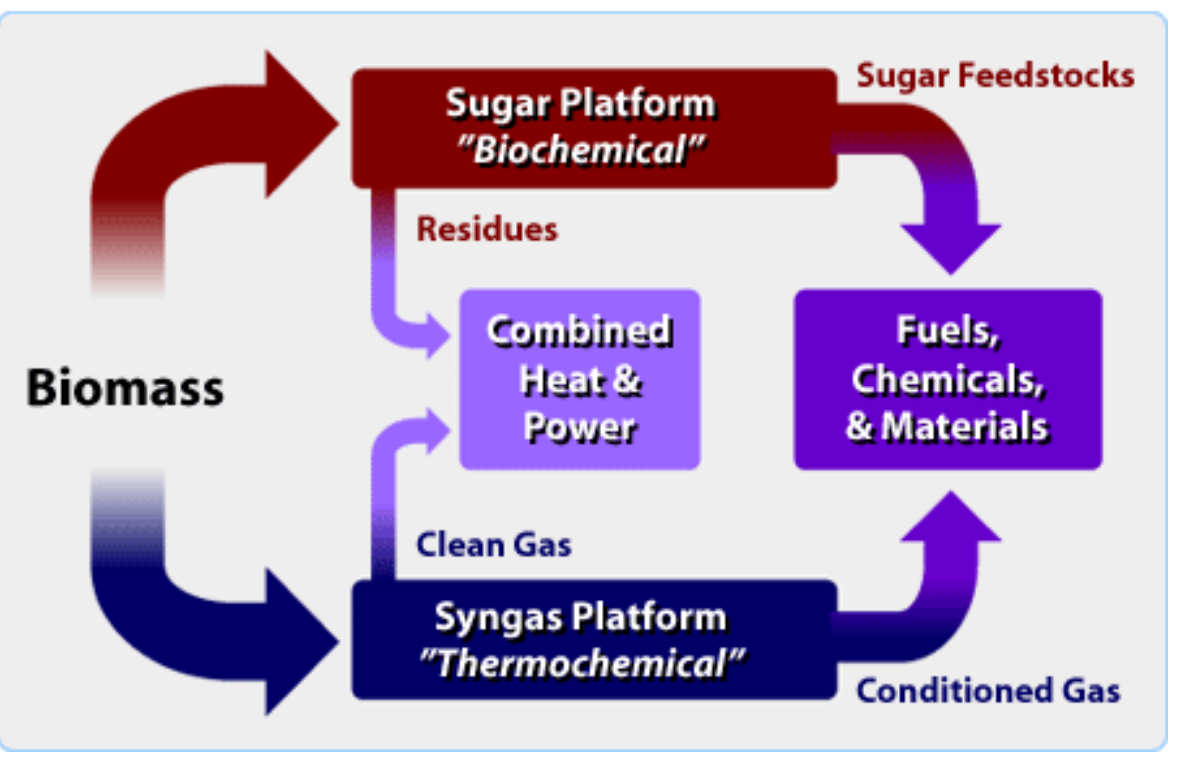
monoxide) or pyrolysis oil, the various components of which could be directly used as fuel. Several other biorefinery platforms are included among the medium and small-scale projects being cost-shared by the U.S. Department of Energy, state funding, and private investment.

\section{Source:}

National Renewable Energy Laboratory, Biomass Program, July 2008, http://www.nrel.gov/biomass/biorefinery.html 
As of July 2008, there were 55 cellulosic biorefineries either completed, under construction or in the planning stage in a total of 31 states across the country. Altogether they create an expected capacity of 629 million gallons per year (MGY) and a potential expansion to 995 MGY. Most of the demonstration and commercial scale facilities are scheduled to start operation on 2009 or 2010.

Table 4.1

Lignocellulosic Biorefineries by Scale and Stage of Development

\begin{tabular}{lccc}
\hline & Commercial Scale $^{\mathbf{a}}$ & Demonstration Scale $^{\mathbf{b}}$ & Pilot Scale $^{\mathbf{c}}$ \\
\hline Completed & - & 2 & 3 \\
Under Construction & 1 & 3 & 5 \\
Planning Status & 21 & 14 & 6 \\
\hline Total & 22 & 19 & 14 \\
\hline
\end{tabular}

Table 4.2

Lignocellulosic Biorefineries by State

\begin{tabular}{cccc}
\hline Alabama (2) & Indiana (2) & Minnesota (1) & Pennsylvania (3) \\
Arkansas (1) & lowa (1) & Missouri (1) & South Carolina (1) \\
California (2) & Kansas (1) & Montana (1) & South Dakota (1) \\
Colorado (3) & Kentucky (1) & Nebraska (1) & Tennessee (2) \\
Connecticut (1) & Louisiana (2) & Nevada (1) & Washington (1) \\
Florida (6) & Maine (1) & New York (3) & Wisconsin (3) \\
Georgia (1) & Maryland (1) & North Carolina (2) & Wyoming (1) \\
Hawaii (1) & Michigan (1) & Oregon (2) & \\
\hline
\end{tabular}

\section{Source:}

The information for these two tables is wholly derived from the fact sheet on cellulosic biofuels developed in July 2008 by Justin Mattingly, Fahran Robb, and Jetta Wong of the Environmental and Energy Study Institute (www.eesi.org). The EESI Fact Sheet provides many references for information summarized above.

Note: Four facilities have not disclosed their location.

${ }^{a}$ Commercial scale: uses at least 700 tons of feedstock per day to produce 10-20 MGY of biofuel.

${ }^{\mathrm{b}}$ Demonstration scale: uses approximately 70 tons of feedstock per day, yielding at least $1 \mathrm{MGY}$.

${ }^{\mathrm{c}}$ Pilot scale facilities are generally smaller and are used to develop new methods and technologies. 
Figure 4.1

Major DOE Biorefinery Project Locations

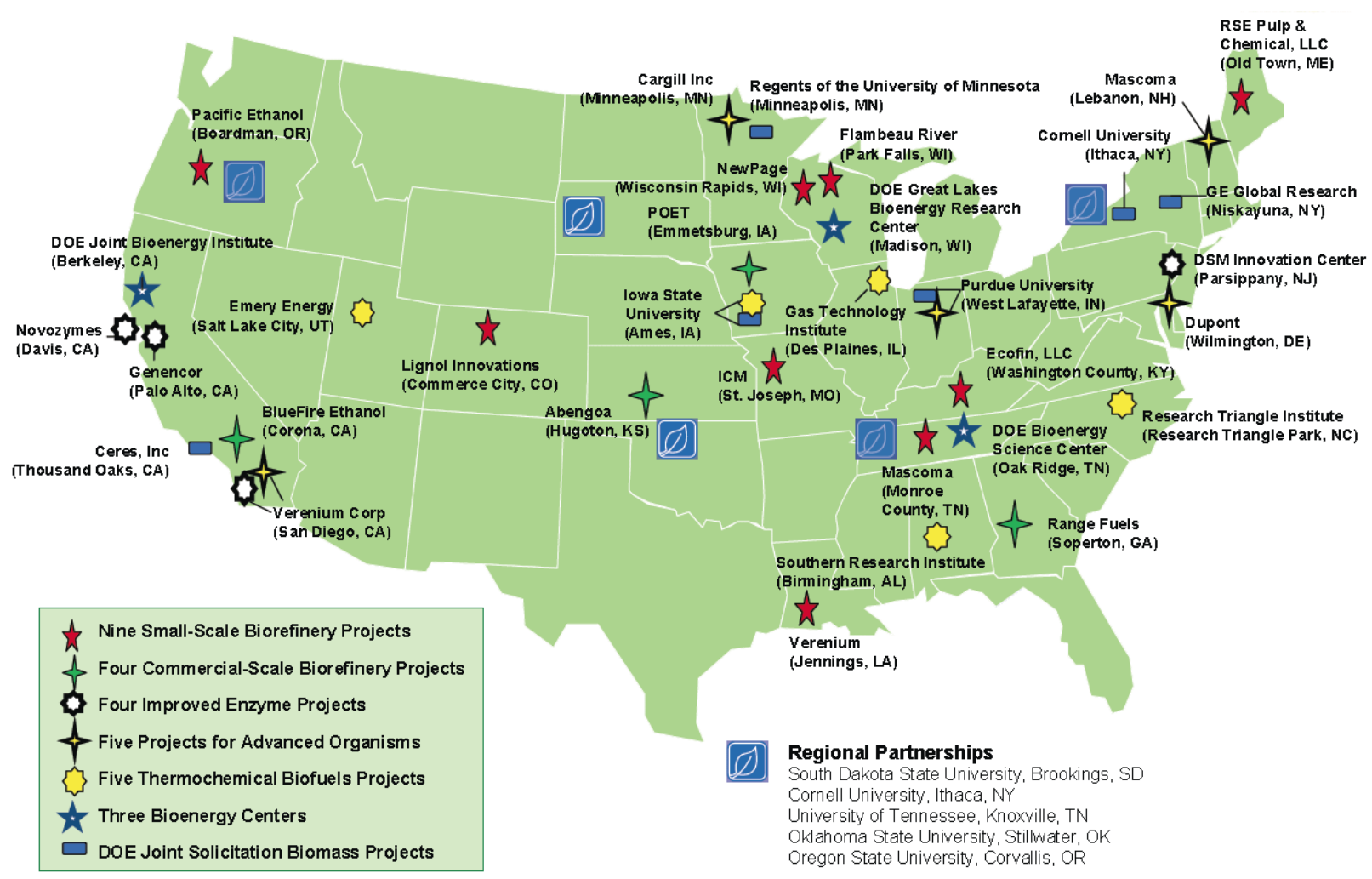

\section{Source:}

U.S. Department of Energy, Energy Efficiency and Renewable Energy, Biomass Program, http://www1.eere.energy.gov/biomass/pdfs/biofuels project locations.pdf 
Table 4.3

Fuels, Technologies and Feedstocks in Planned Biorefineries as of 2008

\begin{tabular}{|c|c|}
\hline \multicolumn{2}{|r|}{ Liquid Fuel Types Planned } \\
\hline Ethanol & Biogasoline \\
\hline Methanol & Fischer-Tropsch diesel fuel \\
\hline Bio-butanol & Renewable Crude Oil \\
\hline \multicolumn{2}{|c|}{ Technologies Involved in Producton of Biofuels and Bioproducts } \\
\hline Weak Acid Hydrolysis & Component of ethanol production, see databook fig. 2.4 \\
\hline Enzymatic hydrolysis & Component of ethanol production, see databook fig. 2.4 \\
\hline Engineered microbes & Component of ethanol production, see databook fig. 2.4 \\
\hline Specialty enzymes & Component of ethanol production, see databook fig. 2.4 \\
\hline Steam explosion hydrolysis & Alternative to weak acid hydrolysis for feedstock pretreatment \\
\hline Strong acid hydrolysis & Alternative to weak acid hydrolysis for feedstock pretreatment \\
\hline Hydrogenolysis process & $\begin{array}{l}\text { One of several patent descriptions found at } \\
\text { http://www.patentstorm.us/patents/4661643 }\end{array}$ \\
\hline Organosolv process & $\begin{array}{l}\text { One of several patent descriptions found at } \\
\underline{\text { http://www.patentgenius.com/patent/4470851 }}\end{array}$ \\
\hline Fischer-Tropsch process & See http://wikipedia.org/wiki/Fischer-Tropsch for explanation \\
\hline Gasification* & $\begin{array}{l}\text { A thermochemical process creating a synthesis gas that can be } \\
\text { transformed by catalysts or microbes to biofuels/bioproducts }\end{array}$ \\
\hline Biomass Fractionation* & $\begin{array}{l}\text { Separation of biomass components prior to pretreatment for a wide } \\
\text { variety of possible end-products }\end{array}$ \\
\hline Proprietary technologies* & Several proprietary technologies have been proposed \\
\hline \multicolumn{2}{|c|}{ Feedstocks Planned for Production of New Biofuels and Bioproducts } \\
\hline Agricultural Residues & Industry and Municipal Residuals \\
\hline Citrus Waste & Municipal solid waste \\
\hline Corn cobs, fiber and stover & Yellow/trap grease \\
\hline Grain, rice and wheat straw & Construction waste \\
\hline $\begin{array}{l}\text { Leafy material } \\
\text { Energy Crops } \\
\text { Miscanthus }\end{array}$ & $\begin{array}{l}\text { Urban wood waste } \\
\quad \text { Other Woody Biomass } \\
\text { Hazardous forest fuels (thinning \& slash) }\end{array}$ \\
\hline Specially bred energy cane & Material from habitat restoration \\
\hline $\begin{array}{l}\text { Switchgrass } \\
\text { Poplar, willow, and pine trees }\end{array}$ & Logging and mill residues \\
\hline
\end{tabular}

\section{Source:}

The information presented above is largely derived from the fact sheet on cellulosic biofuels developed in July 2008 by Justin Mattingly, Fahran Robb, and Jetta Wong of the Environmental and Energy Study Institute (www.eesi.org). Oak Ridge National Laboratory staff added links for additional information.

Note: More information can be found at: http://www1.eere.energy.gov/biomass/project factsheets.html 
Table 4.4

Federal and State Investments in Lignocellulosic Biorefineries as of 2008

The following companies were awarded DOE contracts in February 2007 totaling $\$ 385$ million in federal investment over four years. All projects are cost-shared by the private industry partner and other investors and some projects also receive state support.

\begin{tabular}{|c|c|c|c|c|}
\hline Company Name & Location & Size MGY* & Products & Feedstocks \\
\hline Range Fuels $^{a}$ & Soperton, GA & 40.0 & Ethanol, methanol & Wood residues and crops \\
\hline BLueFire Ethanol, Inc & Corona, CA & 19.0 & Ethanol & $\begin{array}{l}\text { green \& wood wastes } \\
\text { diverted from landfills }\end{array}$ \\
\hline Abengoa Bioenergy & Hugoton, KS & 11.4 & Ethanol \& power & Ag residues $\&$ switchgrass \\
\hline Poet, LLC ${ }^{a}$ & Emmitsburg, IA & 125.0 & Ethanol; $25 \%$ cellulosic & Corn fiber, cobs, stalks \\
\hline ALICO, Inc & LaBelle, FL & 13.9 & $\begin{array}{l}\text { Ethanol \& power (project } \\
\text { abandoned) }\end{array}$ & Urban residues \& energycane \\
\hline $\begin{array}{l}\text { Ingen Biorefinery } \\
\text { Partners, LLC }\end{array}$ & Shelly, ID & 18.0 & $\begin{array}{l}\text { Ethanol (project } \\
\text { abandoned) }\end{array}$ & $\begin{array}{l}\text { Straws from wheat, barley, } \\
\text { rice, corn and switchgrass }\end{array}$ \\
\hline
\end{tabular}

The following companies were awarded DOE contracts in January, April, and July 2008 for small scale biorefinery projects totaling $\$ 240$ in Federal investment over four years.

\begin{tabular}{|c|c|c|c|c|}
\hline Company Name & Location & Size MGY* & Products & Feedstocks \\
\hline ICM Incorporated & St. Joseph, MO & 1.5 & Ethanol \& other & $\begin{array}{l}\text { Corn fiber \& stover } \\
\text { switchgrass, sorghum }\end{array}$ \\
\hline Ecofin, LLC & Nicholasville, KY & 1.0 & Ethanol \& other & Corn cobs \\
\hline Mascoma Corp. ${ }^{c}$ & Vonore, TN & 2.0 & Ethanol \& other & Corn cobs \& switchgrass \\
\hline Pacific Ethanol & Boardman, OR & 2.7 & Ethanol \& other & Wood \& crop residues \\
\hline Verenium Corp ${ }^{b}$ & Jennings, LA & 1.5 & Ethanol \& other & $\begin{array}{l}\text { Ag \& wood residues \& energy } \\
\text { crops }\end{array}$ \\
\hline Lignol Innovations, Inc & Commerce City, CO & 2.0 & Ethanol, lignin, furfural & Wood residues \\
\hline $\begin{array}{l}\text { New Page (formerly } \\
\text { Stora Enso, N America) }\end{array}$ & Wisconsin Rapids, WI & 5.5 & Fischer-Tropsch liquids & Mill and forest residues \\
\hline RSE Pulp \& Chemical, LLC & Old Town, ME & 2.2 & Ethanol \& other & $\begin{array}{l}\text { Hemicelluloses extract from } \\
\text { wood }\end{array}$ \\
\hline $\begin{array}{l}\text { Flambeau River Biofuels, } \\
\text { LLC }\end{array}$ & Park Falls, WI & 6.0 & $\begin{array}{l}\text { Fischer-Tropsch liquids, } \\
\text { heat }\end{array}$ & Mill and forest residues \\
\hline
\end{tabular}

\section{Source:}

The information presented above is largely derived from the fact sheet on cellulosic biofuels developed in July 2008 by Justin Mattingly, Fahran Robb, and Jetta Wong of the Environmental and Energy Study Institute (www.eesi.org). Oak Ridge National Laboratory staff added more detail from the DOE Biomass Program Web site.

Notes: $M G Y=$ Million gallons per year.

\footnotetext{
${ }^{a}$ Listed on www.ethanolrfa.org Web site as under construction.

${ }^{\mathrm{b}}$ Listed on www.ethanolrfa.org Web site as operational.

${ }^{c}$ Dupont Danisco Cellulosic Ethanol, LLC has replaced Mascoma Corporation as the technology partner on the Vonore, TN project.
} 
Table 4.5

State and Private Investment in Biorefineries for Biofuels and Bioproducts

The following companies are currently planning demonstration or commercial facilities and have received significant state grants or other substantial private financial investments.

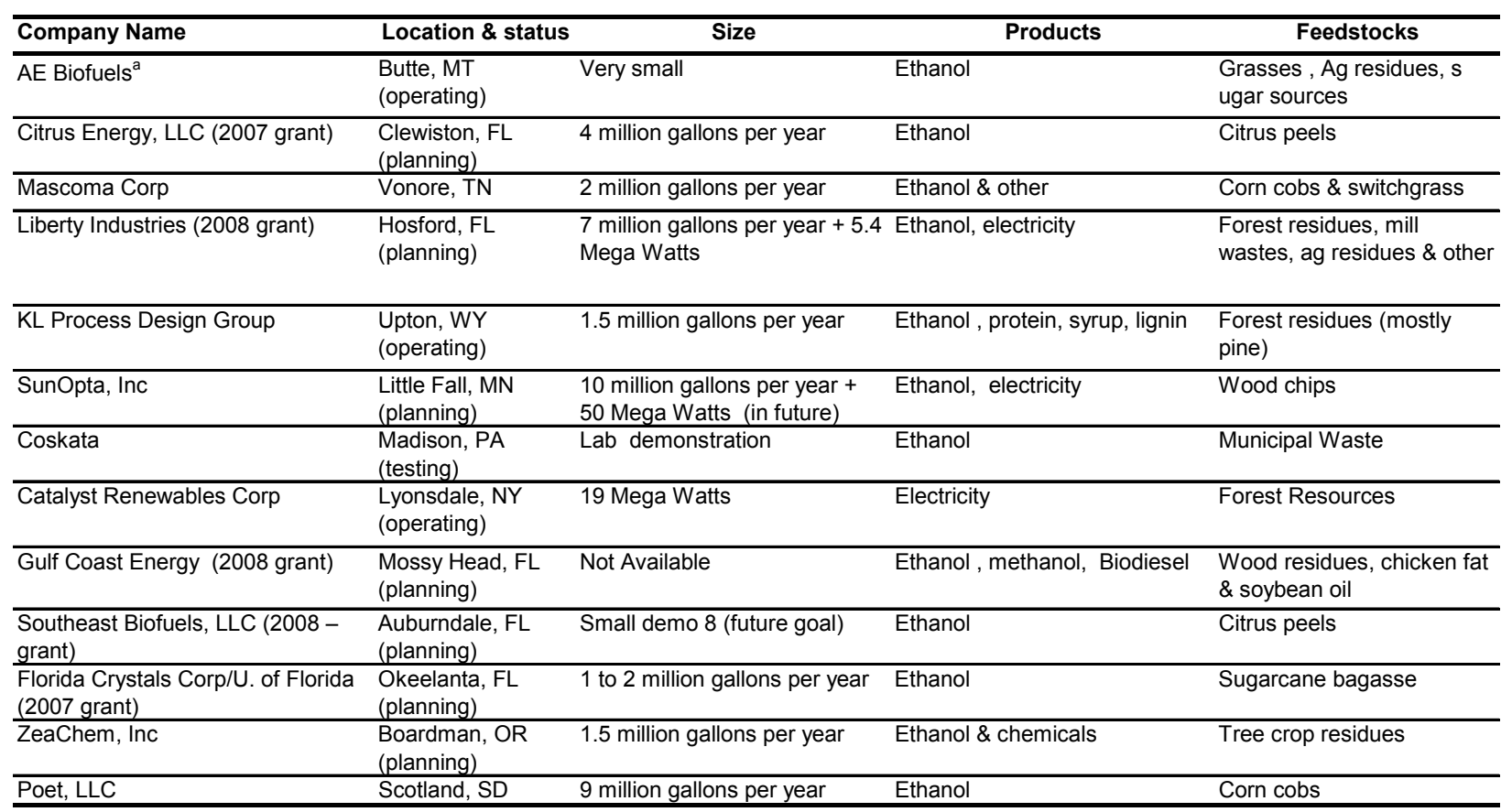

Source:

The list of state and private supported biorefinery projects was largely derived from the fact sheet on cellulosic biofuels developed in July 2008 by Justin Mattingly, Fahran Robb, and Jetta Wong of the Environmental and Energy Study Institute (www.eesi.org). Oak Ridge National Laboratory staff added more detail derived from examining state and company Web sites.

${ }^{a}$ AE Biofuels demonstration facility opened Aug 11, 2008.

${ }^{b}$ Dupont Danisco Cellulosic Ethanol, LLC has replaced Mascoma Corporation as the technology partner on the Vonore, TN project. This project received both substantial and state and Federal support.

${ }^{c}$ The KL Process Design Group began operaton using wood waste in January 2008. 
Below are seven projects relevant to the development of biorefinery technologies that were initiated during the 2000 to 2003 time frame by the U.S. Department of Energy. All projects have ended, some of the project partners are now involved in new biorefinery projects, while others have abandoned their efforts in this area.

Table 4.6

\section{Recently Completed U.S. Department of Energy Biorefinery Projects}

\begin{tabular}{|c|c|c|c|}
\hline Project name & $\begin{array}{l}\text { LeadPartner/ } \\
\text { Project Period }\end{array}$ & Project cost & Project Description and Status \\
\hline $\begin{array}{l}\text { Advanced Biorefining of } \\
\text { Distillers' Grain and Corn } \\
\text { Stover Blends: Pre- } \\
\text { Commercialization of a } \\
\text { Biomass-Derived Process } \\
\text { Technology }\end{array}$ & \begin{tabular}{ll|} 
Abengoa Bioenergy \\
Corporation \\
$2003-2007$
\end{tabular} & $\$ 17.7$ million & $\begin{array}{l}\text { Develop a process for pretreating a blend of distillers' grain (animal feed co-product } \\
\text { from corn ethanol production) and stover to allow ethanol production from both, while } \\
\text { leaving a high-protein animal feed. A large-scale pilot facility will be built for integration } \\
\text { with High Plains' ethanol plant in York, Nebraska. }\end{array}$ \\
\hline $\begin{array}{l}\text { Big Island Demonstration } \\
\text { project - Black Liquor }\end{array}$ & $\begin{array}{ll}\text { Georgia Pacific } & F Y \\
2000-2007 & \end{array}$ & NA & $\begin{array}{l}\text { The project involved the design and operation of a black liquor gasifier that was to be } \\
\text { integrated into Georgia-Pacific's Big Island facility in Virginia. This project anticipated } \\
\text { helping pulp and paper mills with the replacement of recovery boilers that are reaching } \\
\text { retirement. Current Status: The gasifier was built but the design did not function as } \\
\text { anticipated and no current information can be located regarding any further work on the } \\
\text { gasifier. }\end{array}$ \\
\hline $\begin{array}{l}\text { Making Industrial Biorefining } \\
\text { Happen }\end{array}$ & $\begin{array}{l}\text { Cargill-Dow LLC } \\
\text { FY 2003-2007 }\end{array}$ & $\$ 26$ million & $\begin{array}{l}\text { Develop and build a pilot-scale biorefinery that produces sugars and chemicals such as } \\
\text { lactic acid and ethanol from grain. Current Status: Cargill Dow LLC is now known as } \\
\text { NatureWorks LLC following Cargill's acquisition of The Dow Chemical Companies } \\
\text { interest in the venture. The NatureWorks LLC website suggests that all products are } \\
\text { currently made from corn starch. }\end{array}$ \\
\hline $\begin{array}{l}\text { Collection, Commercial } \\
\text { Processing, and Utilization } \\
\text { of Corn Stover/Making } \\
\text { Industrial Biorefining } \\
\end{array}$ & $\begin{array}{l}\text { Cargill-Dow LLC } \\
\text { FY 2003-2007 }\end{array}$ & NA & $\begin{array}{l}\text { Develop new technologies that assist in the harvesting, transport, storage, and } \\
\text { separation of corn residues. Engineer a fermentation system that will meet the } \\
\text { performance targets for the commercial manufacture of lactic acid and ethanol from } \\
\text { corn stover. Current Status: See description above. }\end{array}$ \\
\hline $\begin{array}{l}\text { Enhancement of Co- } \\
\text { Products from } \\
\text { Bioconversion of Muncipal } \\
\text { Solid Waste }\end{array}$ & $\begin{array}{l}\text { Masada OxyNol, } \\
\text { LLC } \\
\text { FY } 2001-2004\end{array}$ & NA & $\begin{array}{l}\text { The unit operations of the Masada OxyNol }{ }^{\mathrm{TM}} \text { process were to be examined and } \\
\text { research focused on improving conversion efficiencies, mitigating scale-up risks, and } \\
\text { improving the co-product quality and marketability. Current Status: The company now } \\
\text { called Pencor-Masada Oxynol signed an agreement in } 2004 \text { with the city of Middletown, } \\
\text { New York to build a waste-to-ethanol plant with a projected completion date in } 2008 \text {. } \\
\text { As of December } 2007 \text { the company was still trying to attract investors. The companies } \\
\text { website still indicates that the project is proceeding, though the city has taken the } \\
\text { company to court for failing to meet deadlines. }\end{array}$ \\
\hline $\begin{array}{l}\text { A New Biorefinery Platform } \\
\text { Intermediate }\end{array}$ & $\begin{array}{l}\text { Cargill, Inc. } \\
\text { FY } 2003-2007\end{array}$ & $\$ 6$ million & $\begin{array}{l}\text { Develop fermentative organisms and processes to ferment carbohydrates to 3- } \\
\text { hydroxypropionic acid (3-HP) and then make a slate of products from the 3-HP. } \\
\text { Current Status: Cargill does make ethanol from corn starch at multiple locations. Their } \\
\text { website suggests that the only current involvement in cellulosic ethanol is the funding } \\
\text { provided to lowa State University that includes money for an economic analysis of corn } \\
\text { stover production, harvest, handling and storage. }\end{array}$ \\
\hline $\begin{array}{l}\text { A Second Generation Dry } \\
\text { Mill Biorefinery }\end{array}$ & \begin{tabular}{|l|} 
Broin and \\
Associates FY 2003 \\
-2007
\end{tabular} & $\$ 5.4$ million & $\begin{array}{l}\text { Separate bran, germ, and endosperm from corn kernels prior to making ethanol from } \\
\text { the remaining starch. Investigate making high-value products, as well as ethanol and } \\
\text { animal feed from the separated fractions. Current Status: Broin and Associates, now } \\
\text { called POET, is pursuing "Project Liberty", a project that is constructing a cellulosic } \\
\text { ethanol production stream at their Scotland N.D. corn to ethanol facility. This project } \\
\text { was awarded DOE funding in February } 2007 \text { and corn cobs were harvested in } 2007 \text { as } \\
\text { feedstock for the facility. }\end{array}$ \\
\hline $\begin{array}{l}\text { Separation of Corn Fiber } \\
\text { and Conversion to Fuels } \\
\text { and Chemicals Phase II: } \\
\text { Pilot-Scale Operation }\end{array}$ & \begin{tabular}{l|} 
National Corn \\
Growers Association \\
FY 2003 - 2007
\end{tabular} & $\$ 2.4$ million & $\begin{array}{l}\text { Under a previous DOE-funded project, a process was developed for separation of } \\
\text { hemicellulose, protein, and oil from corn fiber. This project will pilot-scale test and } \\
\text { validate this process for commercial use. Current Status: ADM a partner in the NCGA } \\
\text { project announced in August } 2008 \text { that it was partnering with John Deere to harvest, }\end{array}$ \\
\hline $\begin{array}{l}\text { Integrated Corn-Based } \\
\text { Biorefinery }\end{array}$ & \begin{tabular}{|l|} 
E.I. du Pont de \\
Nemours \& Co., Inc. \\
FY 2003-2007
\end{tabular} & $\$ 18.2$ million & $\begin{array}{l}\text { Development of a biorefinery concept that converts both starch (such as corn) and } \\
\text { lignocellulose (such as corn stover) to fermentable sugars for production of value } \\
\text { added chemicals (like 1,3 propanediol) and fuel ethanol. Current status. Du Pont is } \\
\text { making major investments in bioenergy technologies. The chemical 1,3 propanediol is } \\
\text { now being commercial produced at DuPont Tate \& Lyle Bio Products, LLC. in Loudon, } \\
\text { Tennessee. DuPont and Genencor formed a joint venture company, DuPont Danisco } \\
\text { Cellulosic Ethanol LLC, in May } 2008 \text { and this company is now the lead partner on the } \\
\text { biorefinery project in Vonore, TN. }\end{array}$ \\
\hline
\end{tabular}

\section{Source:}

U. S. Department of Energy, Energy Efficiency and Renewable Energy, Biomass Program, September 2008, http://www1.eere.energy.gov/biomass/project factsheets.html. Web sites of all companies serving as project leaders or key partners on the DOE funded projects. 
Biomass Energy Data Book: Edition 2 -- DRAFT 


\section{FEEDSTOCKS}

\section{PRIMARY BIOMASS FEEDSTOCKS}

Primary biomass is produced directly by photosynthesis and includes all terrestrial plants now used for food, feed, fiber and fuelwood. All plants in natural and conservation areas (as well as algae and other aquatic plants growing in ponds, lakes, oceans, or artificial ponds and bioreactors) are also considered primary biomass. However, only a small portion of the primary biomass produced will ever be harvested as feedstock material for the production of bioenergy and bioproducts.

Primary biomass feedstocks are thus primary biomass that is harvested or collected from the field or forest where it is grown. Examples of primary biomass feedstocks currently being used for bioenergy include grains and oilseed crops used for transportation fuel production, plus some crop residues (such as orchard trimmings and nut hulls) and some residues from logging and forest operations that are currently used for heat and power production. In the future it is anticipated that a larger proportion of the residues inherently generated from food crop harvesting, as well as a larger proportion of the residues generated from ongoing logging and forest operations, will be used for bioenergy. Additionally, as the bioenergy industry develops, both woody and herbaceous perennial crops will be planted and harvested specifically for bioenergy and bioproducts end-uses.

Because this version of the Data Book is focusing primarily on the bioenergy industry as it exists today, including the biomass feedstocks actually used, only information on the grain and oilseeds crops are included. It would be desirable to include information on the amount and types of crop residues and forest logging, or pulp fiber residues currently being used for energy on a state by state basis, but that information is not readily available. Clearly there is also no nationwide source of information on woody or herbaceous crops being used for energy since this is occurring only on a very small scale in a few isolated experimental situations.

This Data Book covers only current usage of biomass and does not attempt to address the potential for biomass feedstock. Nonetheless, other sources of information do exist concerning the future potential of biomass. Tables, maps and explanations for assumptions behind the potential biomass resource calculations that have been performed by Oak Ridge National Laboratory biomass economists can be found on the Bioenergy Feedstock Information Network (BFIN) Web site at www.bioenergy.ornl.gov.

\section{Source:}

Lynn Wright, Oak Ridge, TN. 
Table 5.1

Barley: Area, Yield, Production, and Value, 1996-2007

\begin{tabular}{|c|c|c|c|c|c|c|}
\hline \multirow[b]{2}{*}{ Year } & \multicolumn{2}{|c|}{ Area } & \multirow[b]{2}{*}{$\begin{array}{c}\text { Yield per } \\
\text { harvested } \\
\text { acre }\end{array}$} & \multirow[b]{2}{*}{ Production } & \multirow[b]{2}{*}{$\begin{array}{c}\text { Marketing year } \\
\text { average price per } \\
\text { bushel received by } \\
\text { farmers }\end{array}$} & \multirow[b]{2}{*}{$\begin{array}{l}\text { Value of } \\
\text { production }\end{array}$} \\
\hline & Planted $^{\mathrm{a}}$ & Harvested & & & & \\
\hline & $\begin{array}{l}1,000 \\
\text { Acres }\end{array}$ & 1,000 Acres & Bushels & 1,000 Bushels & Dollars & 1,000 Dollars \\
\hline 1996 & $\overline{7,094}$ & 6,707 & 58.5 & 392,433 & 2.74 & $1,080,940$ \\
\hline 1997 & 6,706 & 6,198 & 58.1 & 359,878 & 2.38 & 861,620 \\
\hline 1998 & 6,325 & 5,854 & 60.1 & 351,569 & 1.98 & 685,734 \\
\hline 1999 & 4,983 & 4,573 & 59.5 & 271,996 & 2.13 & 578,425 \\
\hline 2000 & 5,801 & 5,200 & 61.1 & 317,804 & 2.11 & 647,966 \\
\hline 2001 & 4,951 & 4,273 & 58.1 & 248,329 & 2.22 & 535,110 \\
\hline 2002 & 5,008 & 4,123 & 55 & 226,906 & 2.72 & 605,635 \\
\hline 2003 & 5,348 & 4,727 & 58.9 & 278,283 & 2.83 & 755,140 \\
\hline 2004 & 4,527 & 4,021 & 69.6 & 279,743 & 2.48 & 698,184 \\
\hline 2005 & 3,875 & 3,269 & 64.8 & 211,896 & 2.53 & 527,633 \\
\hline 2006 & 3,452 & 2,951 & 61.1 & 180,165 & 2.85 & 498,691 \\
\hline 2007 & 4,020 & 3,508 & 60.4 & 211,825 & 4.10 & 851,682 \\
\hline
\end{tabular}

Source:

U.S. Department of Agriculture, 2008 Agricultural Statistics, Table 1-53 and annual, http://www.nass.usda.gov/Publications/Ag Statistics/index.asp

${ }^{a}$ Barley sown for all purposes, including barley sown in the preceding fall.

${ }^{b}$ Preliminary. 
Table 5.2

Barley: Area, Yield, and Production, by State, 2005-2007

\begin{tabular}{|c|c|c|c|c|c|c|c|c|c|c|c|c|}
\hline & \multicolumn{3}{|c|}{ Area planted $^{\mathrm{a}}$} & \multicolumn{3}{|c|}{ Area harvested } & \multicolumn{3}{|c|}{ Yield per harvested acre } & \multicolumn{3}{|c|}{ Production } \\
\hline & 2005 & 2006 & 2007 & 2005 & 2006 & 2007 & 2005 & 2006 & 2007 & 2005 & 2006 & 2007 \\
\hline & 1,000 & 1,000 & 1,000 & 1,000 & 1,000 & 1,000 & & & & 1,000 & 1,000 & 1,000 \\
\hline & Acres & Acres & Acres & Acres & Acres & Acres & Bushels & Bushels & Bushels & Bushels & Bushels & Bushels \\
\hline Arizona & 34 & 25 & 35 & 30 & 22 & 33 & 100 & 115 & 115 & 3,000 & 2,530 & 3,795 \\
\hline California & 100 & 90 & 85 & 60 & 65 & 40 & 63 & 55 & 60 & 3,780 & 3,575 & 2,400 \\
\hline Colorado & 60 & 47 & 60 & 59 & 42 & 58 & 130 & 115 & 125 & 7,670 & 4,830 & 7,250 \\
\hline Delaware & 29 & 27 & 21 & 27 & 24 & 19 & 81 & 80 & 78 & 2,187 & 1,920 & 1,482 \\
\hline Idaho & 630 & 530 & 570 & 600 & 510 & 550 & 87 & 84 & 80 & 52,200 & 42,840 & 44,000 \\
\hline Kansas & 19 & 24 & 20 & 14 & 18 & 13 & 42 & 27 & 48 & 588 & 486 & 624 \\
\hline Kentucky & 10 & 15 & 10 & 9 & 14 & 3 & 83 & 88 & 35 & 747 & 1,232 & 105 \\
\hline Maine & 23 & 18 & 18 & 22 & 17 & 17 & 60 & 50 & 70 & 1320 & 850 & 1190 \\
\hline Maryland & 46 & 50 & 45 & 41 & 32 & 34 & 86 & 87 & 84 & 3,526 & 2,784 & 2,856 \\
\hline Michigan & 15 & 15 & 14 & 11 & 14 & 13 & 47 & 49 & 56 & 517 & 686 & 728 \\
\hline Minnesota & 125 & 105 & 130 & 90 & 90 & 110 & 43 & 60 & 56 & 3,870 & 5,400 & 6,160 \\
\hline Montana & 900 & 770 & 900 & 700 & 620 & 720 & 56 & 50 & 44 & 39,200 & 31,000 & 31,680 \\
\hline Nevada & 4 & 4 & 3 & 2 & 2 & 1 & 85 & 100 & 90 & 170 & 200 & 90 \\
\hline New Jersey & 3 & 3 & 3 & 2 & 2 & 2 & 71 & 57 & 68 & 142 & 114 & 136 \\
\hline New York & 17 & 17 & 13 & 15 & 12 & 11 & 49 & 55 & 46 & 735 & 660 & 506 \\
\hline North Carolina & 24 & 24 & 22 & 19 & 17 & 14 & 78 & 80 & 53 & 1,482 & 1,360 & 742 \\
\hline North Dakota & 1,200 & 1,100 & 1,470 & 1,060 & 995 & 1,390 & 54 & 49 & 56 & 57,240 & 48,755 & 77,840 \\
\hline Ohio & 6 & 5 & 4 & 5 & 4 & 3 & 60 & 68 & 50 & 300 & 272 & 150 \\
\hline Oregon & 65 & 55 & 63 & 45 & 42 & 53 & 45 & 58 & 47 & 2,025 & 2,436 & 2,491 \\
\hline Pennsylvania & 55 & 55 & 55 & 47 & 46 & 42 & 72 & 81 & 73 & 3,384 & 3,726 & 3,066 \\
\hline South Dakota & 65 & 55 & 56 & 47 & 14 & 29 & 49 & 40 & 40 & 2,303 & 560 & 1,160 \\
\hline Utah & 40 & 40 & 38 & 24 & 30 & 22 & 80 & 76 & 78 & 1,920 & 2,280 & 1,716 \\
\hline Virginia & 60 & 58 & 48 & 45 & 42 & 30 & 87 & 77 & 71 & 3,915 & 3,234 & 2,130 \\
\hline Washington & 215 & 200 & 235 & 205 & 190 & 225 & 61 & 63 & 60 & 12,505 & 11,970 & 13,500 \\
\hline Wisconsin & 55 & 50 & 40 & 30 & 30 & 23 & 53 & 54 & 57 & 1,590 & 1,620 & 1,311 \\
\hline Wyoming & 75 & 70 & 62 & 60 & 57 & 53 & 93 & 85 & 89 & 5,580 & 4,845 & 4,717 \\
\hline US & 3,875 & 3,452 & 4,020 & 3,269 & 2,951 & 3,508 & 64.8 & 61.1 & 60.4 & 211,896 & 180,165 & 211,825 \\
\hline
\end{tabular}

Source:

U.S. Department of Agriculture, 2008 Agricultural Statistics, Table 1-56, http://www.nass.usda.gov/Publications/Ag Statistics/index.asp

${ }^{a}$ Includes area planted in the preceding fall. 
Table 5.3

Barley Production Costs and Returns per Planted Acre by Region, Excluding Government Payments, 2006-2007 ${ }^{\mathrm{a}}$ (Dollars per planted acre)

\begin{tabular}{|c|c|c|c|c|c|c|c|c|c|c|c|c|}
\hline \multirow[b]{2}{*}{ Item } & \multicolumn{2}{|c|}{ United States } & \multicolumn{2}{|c|}{ Northern Great Plains } & \multicolumn{2}{|c|}{ Basin and Range } & \multicolumn{2}{|c|}{ Fruitful Rim } & \multicolumn{2}{|c|}{ Northern Crescent } & \multicolumn{2}{|c|}{ Heartland } \\
\hline & 2006 & 2007 & 2006 & 2007 & 2006 & 2007 & 2006 & 2007 & 2006 & 2007 & 2006 & 2007 \\
\hline \multicolumn{13}{|l|}{ Gross value of production } \\
\hline Primary product: Barley grain & 134.64 & 178.19 & 101.864 & 162.624 & 124.576 & 148.512 & 215.784 & 246.33 & 133.874 & 161.76 & 95.55 & 133.62 \\
\hline Secondary product: Barley silage, straw, grazir & 9.27 & 10.53 & 4.79 & 5.44 & 9.92 & 11.26 & 14.17 & 16.10 & 64.83 & 73.64 & 15.92 & 18.09 \\
\hline Total, gross value of production & 143.91 & 188.72 & 106.65 & 168.06 & 134.50 & 159.77 & 229.95 & 262.43 & 198.70 & 235.40 & 111.47 & 151.71 \\
\hline \multicolumn{13}{|l|}{ Operating costs: } \\
\hline Seed & 9.20 & 10.04 & 7.83 & 8.54 & 10.31 & 11.25 & 12.37 & 13.50 & 12.43 & 13.56 & 10.30 & 11.24 \\
\hline Fertilizer $^{b}$ & 28.10 & 35.16 & 23.19 & 29.02 & 34.86 & 43.62 & 38.67 & 48.39 & 31.18 & 39.01 & 27.89 & 34.90 \\
\hline Chemicals & 13.14 & 13.34 & 12.86 & 13.06 & 12.93 & 13.13 & 16.48 & 16.74 & 3.04 & 3.08 & 5.31 & 5.39 \\
\hline Custom operations ${ }^{\mathrm{C}}$ & 7.58 & 7.70 & 6.03 & 6.13 & 7.06 & 7.17 & 11.70 & 11.89 & 15.69 & 15.95 & 12.84 & 13.05 \\
\hline Fuel, lube, and electricity & 19.39 & 21.42 & 13.25 & 14.63 & 19.70 & 21.76 & 41.09 & 45.39 & 17.45 & 19.27 & 13.11 & 14.48 \\
\hline Repairs & 16.58 & 17.13 & 15.60 & 16.12 & 16.94 & 17.51 & 21.01 & 21.72 & 10.66 & 11.02 & 10.56 & 10.92 \\
\hline Purchased irrigation water & 2.38 & 2.48 & 0.78 & 0.81 & 4.00 & 4.17 & 6.60 & 6.89 & 2.34 & 2.44 & 0.64 & 0.67 \\
\hline Interest on operating inputs & 2.32 & 2.58 & 1.91 & 2.12 & 2.54 & 2.85 & 3.56 & 3.96 & 2.23 & 2.51 & 1.94 & 2.18 \\
\hline Total, operating costs & 98.69 & 109.85 & 81.45 & 90.43 & 108.34 & 121.46 & 151.48 & 168.48 & 95.02 & 106.84 & 82.59 & 92.83 \\
\hline \multicolumn{13}{|l|}{ Allocated overhead: } \\
\hline Hired labor & 3.46 & 3.59 & 2.15 & 2.22 & 3.03 & 3.13 & 8.67 & 8.97 & 2.36 & 2.45 & 2.35 & 2.44 \\
\hline Opportunity cost of unpaid labor & 23.38 & 24.21 & 19.41 & 20.09 & 30.33 & 31.40 & 29.37 & 30.41 & 32.64 & 33.79 & 24.34 & 25.20 \\
\hline Capital recovery of machinery and equipment & 78.43 & 82.31 & 76.61 & 80.40 & 78.69 & 82.59 & 90.66 & 95.15 & 51.62 & 54.18 & 50.96 & 53.48 \\
\hline Opportunity cost of land (rental rate) & 46.32 & 57.91 & 31.75 & 39.69 & 62.22 & 77.78 & 82.63 & 103.29 & 47.17 & 58.96 & 51.48 & 64.35 \\
\hline Taxes and insurance & 8.29 & 9.62 & 8.50 & 9.87 & 8.20 & 9.52 & 8.43 & 9.78 & 4.70 & 5.45 & 5.45 & 6.32 \\
\hline General farm overhead & 9.58 & 9.91 & 9.03 & 9.35 & 9.55 & 9.88 & 11.69 & 12.09 & 8.99 & 9.30 & 8.16 & 8.45 \\
\hline Total, allocated overhead & 169.46 & 187.55 & 147.45 & 161.62 & 192.02 & 214.30 & 231.45 & 259.69 & 147.48 & 164.13 & 142.74 & 160.24 \\
\hline Total, costs listed & 268.15 & 297.40 & 228.90 & 252.05 & 300.36 & 335.76 & 382.93 & 428.17 & 242.50 & 270.97 & 225.33 & 253.07 \\
\hline Value of production less total costs listed & -124.24 & $\mid-108.68$ & -122.25 & -83.99 & -165.86 & -175.99 & -152.98 & -165.74 & -43.80 & -35.57 & -113.86 & -101.36 \\
\hline Value of production less operating costs & 45.22 & 78.87 & 25.20 & 77.63 & 26.16 & 38.31 & 78.47 & 93.95 & 103.68 & 128.56 & 28.88 & 58.88 \\
\hline \multicolumn{13}{|l|}{ Supporting information: } \\
\hline Yield (bushels per planted acre) & 51 & 51.5 & 43 & 48 & 46 & 41 & 73 & 69 & 54 & 48 & 39 & 39 \\
\hline Price (dollars per bushel at harvest) & 2.64 & 3.46 & 2.38 & 3.36 & 2.72 & 3.64 & 2.96 & 3.57 & 2.47 & 3.37 & 2.45 & 3.40 \\
\hline Enterprise size (planted acres) ${ }^{a}$ & 219 & 219 & 342 & 342 & 194 & 194 & 266 & 266 & 33 & 33 & 87 & 87 \\
\hline \multicolumn{13}{|l|}{ Production practices: ${ }^{\mathrm{a}}$} \\
\hline Feed barley (percent of acres) & 23 & 23 & 8 & 8 & 49 & 49 & 41 & 41 & 96 & 96 & 34 & 34 \\
\hline Malt barley (percent of acres) & 77 & 77 & 92 & 92 & 51 & 51 & 59 & 59 & c & c & 66 & 66 \\
\hline Spring barley (percent of acres) & 97 & 97 & 100 & 100 & 99 & 99 & 91 & 91 & 52 & 52 & 100 & 100 \\
\hline Winter barley (percent of acres) & c & c & 0 & 0 & c & ${ }^{\mathrm{c}}$ & 9 & 9 & 47 & 47 & 0 & 0 \\
\hline Dryland (percent of acres) & 80 & 80 & 94 & 94 & 70 & 70 & 38 & 38 & 98 & 98 & 100 & 100 \\
\hline Irrigated (percent of acres) & 20 & 20 & 6 & 6 & 30 & 30 & 62 & 62 & 2 & 2 & 0 & 0 \\
\hline Straw harvested (percent of acres) & 23 & 23 & 12 & 12 & 29 & 29 & 45 & 45 & 87 & 87 & 28 & 28 \\
\hline
\end{tabular}

Source:

Economic Research Service, US Department of Agriculture, http://www.ers.usda.gov/data/costsandreturns/testpick.htm

a Developed from survey base year, 2003.

${ }^{\mathrm{b}}$ Cost of commercial fertilizers, soil conditioners, and manure.

${ }^{c} 0.1$ to less than 5 percent. 
USDA's corn baseline projections show a continuing rise in bushels of corn allocated to fuel alcohol use, a continuing increase in corn yields, a slight increase in corn acreage, and an increase in net returns (over variable costs). This analysis is updated annually.

Table 5.4

Corn Baseline Projections, 2006 - 2018

\begin{tabular}{|c|c|c|c|c|c|c|c|c|c|c|c|c|}
\hline Item & $2006 / 07$ & $2007 / 08$ & $2008 / 09$ & $2009 / 10$ & $2010 / 11$ & $2011 / 12$ & $2012 / 13$ & $2013 / 14$ & $2014 / 15$ & $2015 / 16$ & $2016 / 17$ & $2017 / 18$ \\
\hline \multicolumn{13}{|l|}{$\overline{\text { Area (million acres): }}$} \\
\hline Planted acres & 78.3 & 93.6 & 88.0 & 91.0 & 93.0 & 92.0 & 91.0 & 91.0 & 91.5 & 91.5 & 91.5 & 92.0 \\
\hline Harvested acres & 70.6 & 86.1 & 80.6 & 83.6 & 85.6 & 84.6 & 83.6 & 83.6 & 84.1 & 84.1 & 84.1 & 84.6 \\
\hline \multicolumn{13}{|l|}{ Yields (bushels per acre): } \\
\hline Yield/harvested acre & 149.1 & 153.0 & 155.3 & 157.3 & 159.3 & 161.3 & 163.3 & 165.3 & 167.3 & 169.3 & 171.3 & 173.3 \\
\hline \multicolumn{13}{|c|}{ Supply and use (million bushels): } \\
\hline Beginning stocks & 1,967 & 1,304 & 1,897 & 1,327 & 1,202 & 1,402 & 1,502 & 1,447 & 1,377 & 1,372 & 1,327 & 1,262 \\
\hline Production & 10,535 & 13,168 & 12,515 & 13,150 & 13,635 & 13,645 & 13,650 & 13,820 & 14,070 & 14,240 & 14,405 & 14,660 \\
\hline Imports & 12 & 15 & 15 & 15 & 15 & 15 & 15 & 15 & 15 & 15 & 15 & 15 \\
\hline Supply & 12,514 & 14,487 & 14,427 & 14,492 & 14,852 & 15,062 & 15,167 & 15,282 & 15,462 & 15,627 & 15,747 & 15,937 \\
\hline Feed \& residual & 5,598 & 5,650 & 5,450 & 5,425 & 5,525 & 5,550 & 5,600 & 5,650 & 5,700 & 5,750 & 5,775 & 5,825 \\
\hline Food, seed, \& industrial & 3,488 & 4,590 & 5,500 & 5,715 & 5,800 & 5,885 & 5,970 & 6,055 & 6,140 & 6,225 & 6,310 & 6,400 \\
\hline Fuel alcohol use ${ }^{a}$ & 2,117 & 3,200 & 4,100 & 4,300 & 4,375 & 4,450 & 4,525 & 4,600 & 4,675 & 4,750 & 4,825 & 4,900 \\
\hline Domestic & 9,086 & 10,240 & 10,950 & 11,140 & 11,325 & 11,435 & 11,570 & 11,705 & 11,840 & 11,975 & 12,085 & 12,225 \\
\hline Exports & 2,125 & 2,350 & 2,150 & 2,150 & 2,125 & 2,125 & 2,150 & 2,200 & 2,250 & 2,325 & 2,400 & 2,475 \\
\hline Total use & 11,210 & 12,590 & 13,100 & 13,290 & 13,450 & 13,560 & 13,720 & 13,905 & 14,090 & 14,300 & 14,485 & 14,700 \\
\hline Ending stocks & 1,304 & 1,897 & 1,327 & 1,202 & 1,402 & 1,502 & 1,447 & 1,377 & 1,372 & 1,327 & 1,262 & 1,237 \\
\hline Stocks/use ratio, percent & 11.6 & 15.1 & 10.1 & 9.0 & 10.4 & 11.1 & 10.5 & 9.9 & 9.7 & 9.3 & 8.7 & 8.4 \\
\hline \multicolumn{13}{|l|}{ Prices (dollars per bushel): } \\
\hline Farm price & 3.04 & 3.50 & 3.75 & 3.80 & 3.60 & 3.50 & 3.50 & 3.55 & 3.55 & 3.55 & 3.60 & 3.60 \\
\hline Loan rate & 1.95 & 1.95 & 1.95 & 1.95 & 1.95 & 1.95 & 1.95 & 1.95 & 1.95 & 1.95 & 1.95 & 1.95 \\
\hline \multicolumn{13}{|c|}{ Variable costs of production (dollars): } \\
\hline Per acre & 203.41 & 226.68 & 237.48 & 244.16 & 247.88 & 251.42 & 254.57 & 257.32 & 260.84 & 264.45 & 268.06 & 271.43 \\
\hline Per bushel & 1.36 & 1.48 & 1.53 & 1.55 & 1.56 & 1.56 & 1.56 & 1.56 & 1.56 & 1.56 & 1.56 & 1.57 \\
\hline \multicolumn{13}{|c|}{ Returns over variable costs (dollars per acre): } \\
\hline Net returns ${ }^{a}$ & 249.85 & 308.82 & 344.90 & 353.58 & 325.60 & 313.13 & 316.98 & 329.49 & 333.08 & 336.56 & 348.62 & 352.45 \\
\hline
\end{tabular}

Source:

USDA Long-Term Agricultural, Projection Tables to 2018, February 2008, Table 8 - U.S. Corn Projections, http://usda.mannlib.cornell.edu/MannUsda/viewDocumentInfo.do?documentID=1192

Note: Marketing year beginning September 1 for corn.

${ }^{a}$ Corn used in ethanol production is accounted for in fuel alcohol use. Distiller's grains, a coproduct of ethanol production, is not accounted for in the balance sheet for corn. 
The figure below shows that corn use for ethanol production more than quadrupled from 2001 to 2007.

Figure 5.1

Corn Used for Ethanol Production, 1985-2007

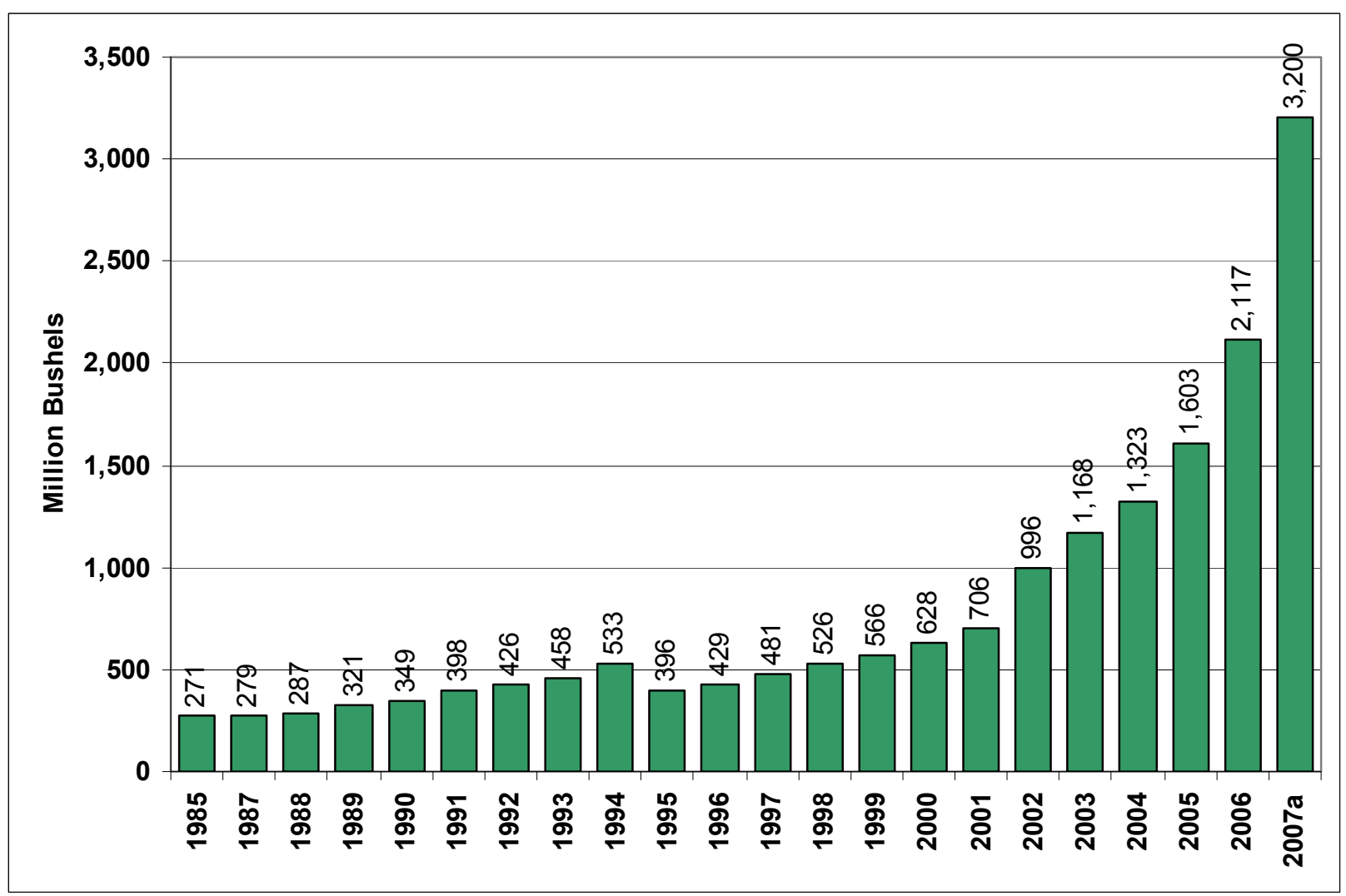

Source:

National Corn Growers Association, The World of Corn, 2004-2008, http://www.ncga.com

Note: Marketing year ending August 31, 2008 
In 2007, ethanol production accounted for about 25 percent of the overall corn consumption and just slightly less than the amount used for export.

Figure 5.2

Corn Usage by Segment, 2007

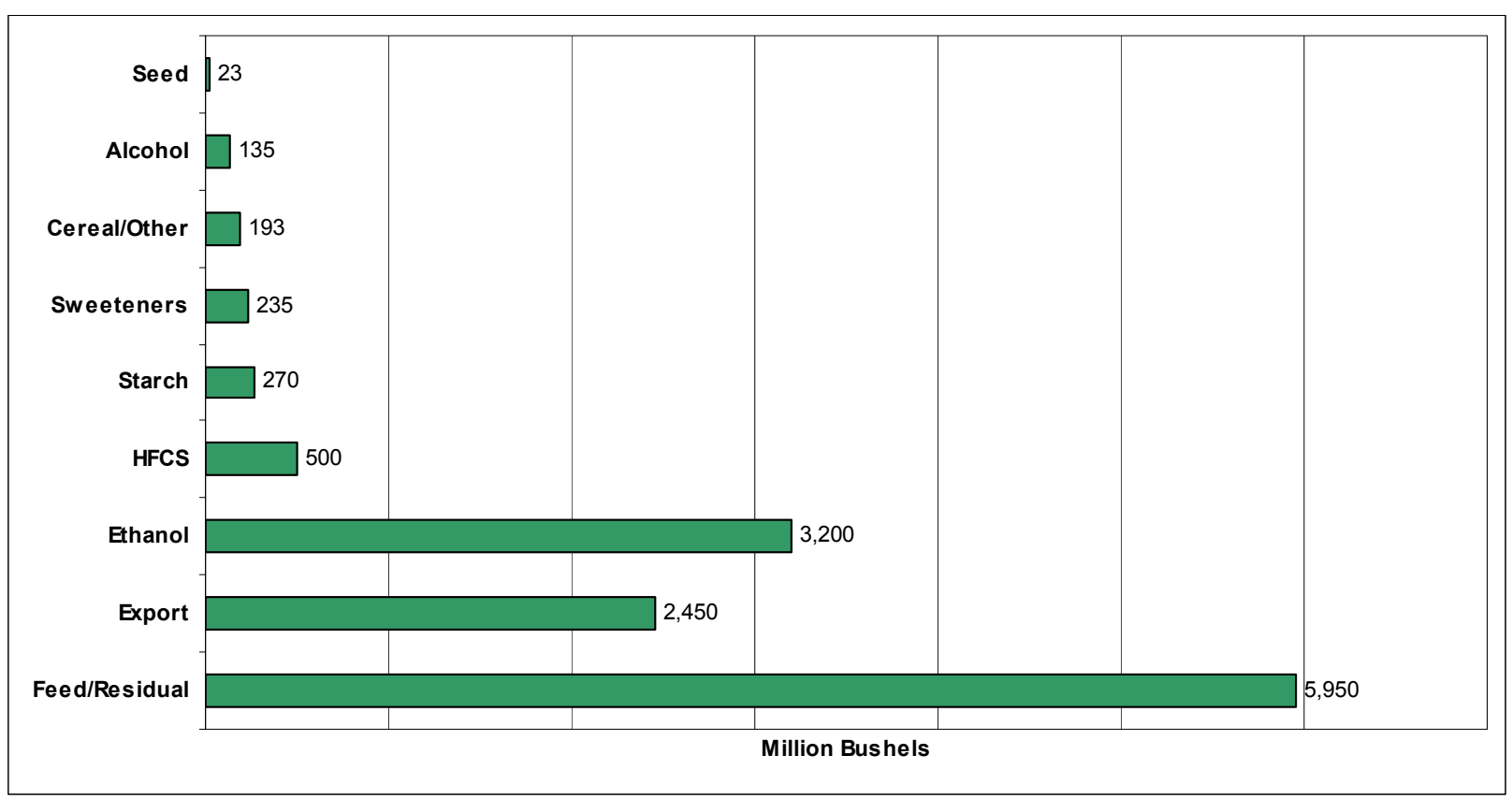

Source:

National Corn Growers Association, The World of Corn, 2008, http://www.ncga.com/WorldOfCorn/main/consumption1.asp

Note: Marketing year ending August 31, 2008. 
Overall, the price for corn has been declining due to improvements in farming techniques. Though there has always been variation in corn price from year to year due to factors such as weather, affecting yield, much of the increase beginning in 2005 is likely attributable to increased demand for corn by ethanol producers.

Figure 5.3

Corn: Price per Bushel, 1975-2007

(Constant 2007 dollars)

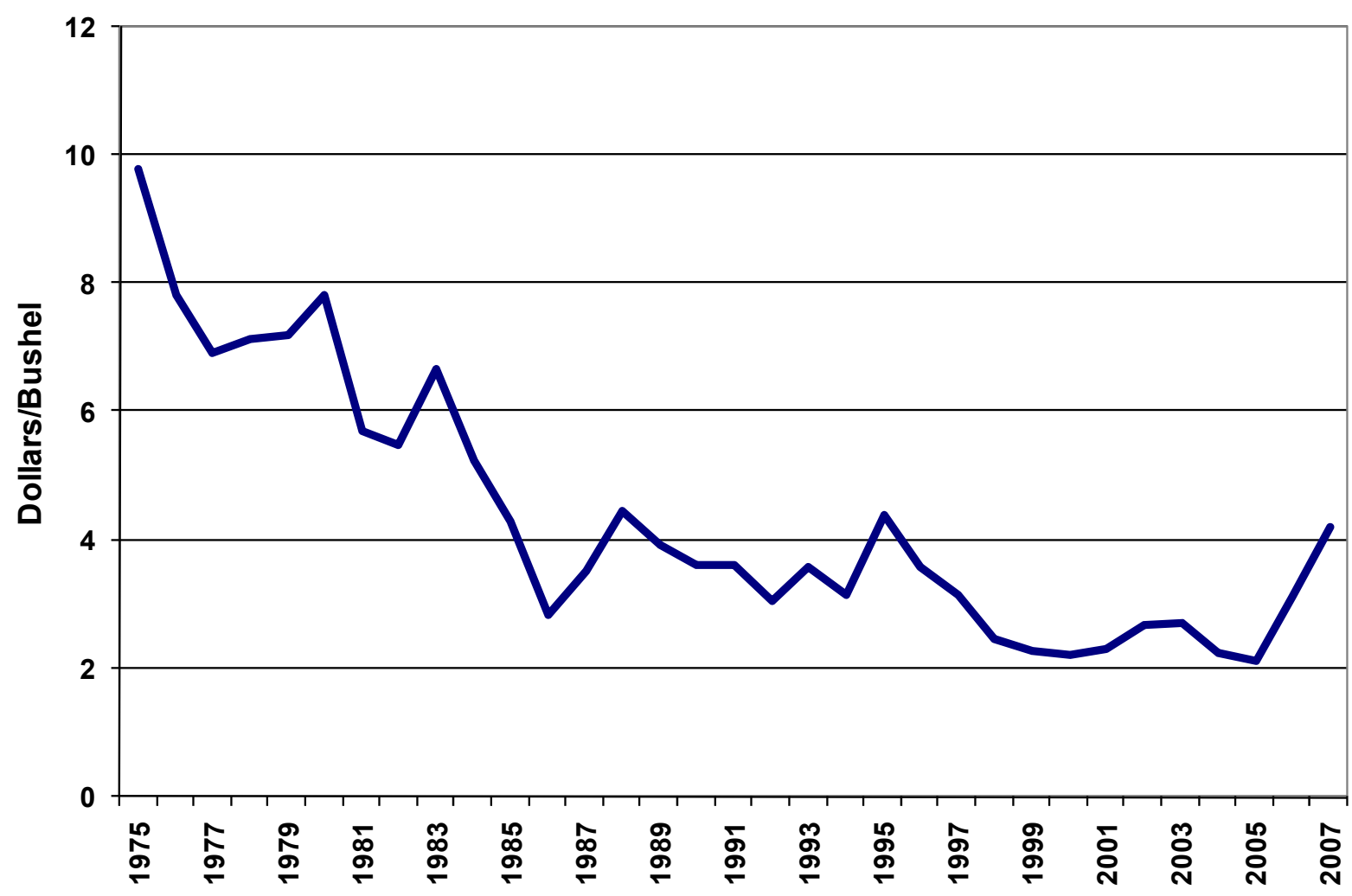

Source:

U.S. Department of Agriculture, National Agricultural Statistics Service, http://www.nass.usda.gov/ 
In the baseline year of 2001, $7.5 \%$ of all corn grain produced was used for ethanol production. Over the past 10 years the corn acres planted have varied between about 71 and 81 million acres; acreage variation is related to feed and export demands, crop subsidy programs, previous year grain prices and animal demand for silage. Yield variation relates to climate variation and improved varieties. The year 2004 provided an unusually favorable climate for high corn yields over much of the corn belt.

Table 5.5

Corn: Area, Yield, Production, and Value, 1996-2007

\begin{tabular}{|c|c|c|c|c|c|c|c|c|c|}
\hline \multirow[b]{2}{*}{ Year } & \multirow[b]{2}{*}{$\begin{array}{c}\text { Area } \\
\text { Planted } \\
\text { for all } \\
\text { purposes }\end{array}$} & \multicolumn{5}{|c|}{ Corn for grain } & \multicolumn{3}{|c|}{ Corn for silage } \\
\hline & & $\begin{array}{c}\text { Area } \\
\text { harvested }\end{array}$ & $\begin{array}{c}\text { Yield per } \\
\text { harvested } \\
\text { acre }\end{array}$ & Production & $\begin{array}{l}\text { Marketing } \\
\text { year } \\
\text { average } \\
\text { price per } \\
\text { bushel }\end{array}$ & $\begin{array}{c}\text { Value of } \\
\text { production }\end{array}$ & $\begin{array}{c}\text { Area } \\
\text { Harvested }\end{array}$ & $\begin{array}{c}\text { Yield per } \\
\text { harvested } \\
\text { acre }\end{array}$ & Production \\
\hline & $\begin{array}{l}1,000 \\
\text { Acres }\end{array}$ & 1,000 Acres & Bushels & 1,000 Bushels & Dollars & 1,000 Dollars & $\begin{array}{l}1,000 \\
\text { Acres }\end{array}$ & Tons & 1,000 Tons \\
\hline 1996 & 79,229 & 72,644 & 127.1 & $9,232,557$ & 2.71 & $25,149,013$ & 5,607 & 15.4 & 86,581 \\
\hline 1997 & 79,537 & 72,671 & 126.7 & $9,206,832$ & 2.43 & $22,351,507$ & 6,054 & 16.1 & 97,192 \\
\hline 1998 & 80,165 & 72,589 & 134.4 & $9,758,685$ & 1.94 & 18,92 & 5,913 & 16.1 & 95,479 \\
\hline 1999 & 77,386 & 70,487 & 133.8 & $9,430,612$ & 1.82 & 17, & 6,037 & 15.8 & 95,633 \\
\hline 2000 &, 551 & 40 & 13 & $9,915,051$ & 1.85 & 02 & 6,082 & 16.8 & 102,156 \\
\hline 2001 & 75,702 & 68,768 & 138.2 & $9,502,580$ & 1.97 & 18,8 & 6,142 & 16.6 & 101,992 \\
\hline 2002 & 78,894 & 69,330 & 129.3 & $8,966,787$ & 2.32 & $20,882,448$ & 7,122 & 14.4 & 102,293 \\
\hline 2003 & 78,603 & 70,944 & 142.2 & $10,089,222$ & 2.42 & $24,476,803$ & 6,583 & 16.3 & 107,378 \\
\hline 2004 & 80,929 & 73,631 & 160.4 & $11,807,086$ & 2.06 & 24,3 & 6,101 & 17.6 & 107,293 \\
\hline 2005 & 81,779 & 75,117 & 148 & $11,114,082$ & 2.00 & 22,1 & 5,930 & 18 & 106,486 \\
\hline 2006 & 78,327 & 70,648 & 149.1 & $10,534,868$ & 3.04 & $32,094,586$ & 6,477 & 16.2 & 105,129 \\
\hline 2007 & 93,600 & 86,542 & 151.1 & $13,073,893$ & 4.20 & $52,090,108$ & 6,071 & 17.5 & 106,328 \\
\hline
\end{tabular}

\section{Source:}

U.S. Department of Agriculture, 2008 Agricultural Statistics, Table 1-35 and annual. http://www.nass.usda.gov/Publications/Ag Statistics/index.asp 
Production of sufficient quantities of corn to support ethanol production facilities occurs primarily in the mid-western states. Yields vary considerably across the states. High yields in the western states occur under irrigation.

Table 5.6

Corn: Area, Yield, and Production, by State, 2005-2007

\begin{tabular}{|c|c|c|c|c|c|c|c|c|c|c|c|c|}
\hline \multirow{3}{*}{ State } & \multicolumn{3}{|c|}{ Area planted for all purposes } & \multicolumn{9}{|c|}{ Corn for grain } \\
\hline & \multirow[b]{2}{*}{2005} & \multirow[b]{2}{*}{2006} & \multirow[b]{2}{*}{$2007^{a}$} & \multicolumn{3}{|c|}{ Area harvested } & \multicolumn{3}{|c|}{ Yield per harvested acre } & \multicolumn{3}{|c|}{ Production } \\
\hline & & & & 2005 & 2006 & $2007^{a}$ & 2005 & 2006 & $2007^{\mathrm{a}}$ & 2005 & 2006 & $2007^{a}$ \\
\hline & 1,000 & 1,000 & 1,000 & 1,000 & 1,000 & 1,000 & & & & 1,000 & 1,000 & 1,000 \\
\hline & Acres & Acres & Acres & Acres & Acres & Acres & Bushels & Bushels & Bushels & Bushels & Bushels & Bushels \\
\hline Alabama & 220 & 200 & 340 & 200 & 165 & 280 & 119 & 72 & 79 & 23,800 & 11,880 & 22,120 \\
\hline Arizona & 50 & 50 & 55 & 22 & 18 & 23 & 195 & 170 & 185 & 4,290 & 3,060 & 4,255 \\
\hline Arkansas & 240 & 190 & 610 & 230 & 180 & 590 & 131 & 146 & 168 & 30,130 & 26,280 & 99,120 \\
\hline California & 560 & 520 & 650 & 130 & 110 & 200 & 172 & 165 & 180 & 22,360 & 18,150 & 36,000 \\
\hline Colorado & 1,100 & 1,000 & 1,200 & 950 & 860 & 1060 & 148 & 156 & 142 & 140,600 & 134,160 & 150,520 \\
\hline Connecticut & 28 & 27 & 26 & b & b & $\mathrm{b}$ & $\mathrm{b}$ & b & $\mathrm{b}$ & b & b & $\mathrm{b}$ \\
\hline Delaware & 160 & 170 & 195 & 154 & 161 & 185 & 143 & 145 & 97 & 22,022 & 23,345 & 17,945 \\
\hline Florida & 65 & 60 & 75 & 28 & 30 & 35 & 94 & 82 & 95 & 2,632 & 2,460 & 3,325 \\
\hline Georgia & 270 & 280 & 510 & 230 & 225 & 450 & 129 & 112 & 130 & 29,670 & 25,200 & 58,500 \\
\hline Idaho & 235 & 270 & 310 & 60 & 65 & 105 & 170 & 170 & 165 & 10,200 & 11,050 & 17,325 \\
\hline Illinois & 12,100 & 11,300 & 13,200 & 11,950 & 11,150 & 13,050 & 143 & 163 & 175 & $1,708,850$ & $1,817,450$ & $2,283,750$ \\
\hline Indiana & 5,900 & 5,500 & 6,500 & 5,770 & 5,380 & 6,370 & 154 & 157 & 155 & 888,580 & 844,660 & 987,350 \\
\hline lowa & 12,800 & 12,600 & 14,200 & 12,500 & 12,350 & 13,850 & 173 & 166 & 171 & $2,162,500$ & $2,050,100$ & $2,368,350$ \\
\hline Kansas & 3,650 & 3,350 & 3,900 & 3,450 & 3,000 & 3,700 & 135 & 115 & 140 & 465,750 & 345,000 & 518,000 \\
\hline Kentucky & 1,250 & 1,120 & 1,450 & 1,180 & 1,040 & 1,360 & 132 & 146 & 129 & 155,760 & 151,840 & 175,440 \\
\hline Louisiana & 340 & 300 & 740 & 330 & 290 & 730 & 136 & 140 & 165 & 44,880 & 40,600 & 120,450 \\
\hline Maine & 26 & 26 & 28 & b & b & b & b & $b$ & b & b & b & b \\
\hline Maryland & 470 & 490 & 540 & 400 & 425 & 455 & 135 & 142 & 103 & 54,000 & 60,350 & 46,865 \\
\hline Massachusetts & 20 & 18 & 18 & b & b & b & b & b & b & b & b & b \\
\hline Michigan & 2,250 & 2,200 & 2,650 & 2,010 & 1,960 & 2,350 & 143 & 147 & 124 & 287,430 & 288,120 & 291,400 \\
\hline Minnesota & 7,300 & 7,300 & 8,400 & 6,850 & 6,850 & 7,800 & 174 & 161 & 146 & $1,191,900$ & $1,102,850$ & $1,138,800$ \\
\hline Mississippi & 380 & 340 & 960 & 365 & 325 & 940 & 129 & 110 & 150 & 47,085 & 35,750 & 141,000 \\
\hline Missouri & 3,100 & 2,700 & 3,450 & 2,970 & 2,630 & 3,250 & 111 & 138 & 142 & 329,670 & 362,940 & 461,500 \\
\hline Montana & 65 & 65 & 84 & 17 & 18 & 38 & 148 & 146 & 145 & 2,516 & 2,628 & 5,510 \\
\hline Nebraska & 8,500 & 8,100 & 9,400 & 8,250 & 7,750 & 9,200 & 154 & 152 & 160 & $1,270,500$ & $1,178,000$ & $1,472,000$ \\
\hline Nevada & 5 & 4 & 5 & $b$ & $b$ & $b$ & $\mathrm{~b}$ & $b$ & $b$ & b & $b$ & $\mathrm{~b}$ \\
\hline New Hampshire & 15 & 14 & 14 & $\mathrm{~b}$ & b & $\mathrm{b}$ & b & b & $\mathrm{b}$ & b & b & b \\
\hline New Jersey & 80 & 80 & 95 & 62 & 64 & 82 & 122 & 129 & 125 & 7,564 & 8,256 & 10,250 \\
\hline New Mexico & 140 & 130 & 135 & 55 & 45 & 55 & 175 & 185 & 175 & 9,625 & 8,325 & 9,625 \\
\hline New York & 990 & 950 & 1050 & 460 & 480 & 550 & 124 & 129 & 127 & 57,040 & 61,920 & 69,850 \\
\hline North Carolina & 750 & 790 & 1100 & 700 & 740 & 1020 & 120 & 132 & 100 & 84,000 & 97,680 & 102,000 \\
\hline North Dakota & 1,410 & 1,690 & 2,550 & 1,200 & 1,400 & 2,350 & 129 & 111 & 116 & 154,800 & 155,400 & 272,600 \\
\hline Ohio & 3,450 & 3,150 & 3,850 & 3,250 & 2,960 & 3,610 & 143 & 159 & 150 & 464,750 & 470,640 & 541,500 \\
\hline Oklahoma & 290 & 270 & 320 & 250 & 220 & 270 & 115 & 105 & 145 & 28,750 & 23,100 & 39,150 \\
\hline Oregon & 53 & 51 & 60 & 25 & 29 & 35 & 160 & 180 & 195 & 4,000 & 5,220 & 6,825 \\
\hline Pennsylvania & 1,350 & 1,350 & 1,410 & 960 & 960 & 980 & 122 & 122 & 128 & 117,120 & 117,120 & 125,440 \\
\hline Rhode Island & 2 & 2 & 2 & b & b & b & b & b & b & b & $b$ & b \\
\hline South Carolina & 300 & 310 & 400 & 285 & 290 & 370 & 116 & 110 & 100 & 33,060 & 31,900 & 37,000 \\
\hline South Dakota & 4,450 & 4,500 & 5,000 & 3,950 & 3,220 & 4,500 & 119 & 97 & 121 & 470,050 & 312,340 & 544,500 \\
\hline Tennessee & 650 & 550 & 870 & 595 & 500 & 785 & 130 & 125 & 106 & 77,350 & 62,500 & 83,210 \\
\hline Texas & 2,050 & 1,760 & 2,150 & 1,850 & 1,450 & 2,000 & 114 & 121 & 148 & 210,900 & 175,450 & 296,000 \\
\hline Utah & 55 & 65 & 70 & 12 & 17 & 22 & 163 & 157 & 148 & 1,956 & 2,669 & 3,256 \\
\hline Vermont & 95 & 85 & 92 & $b$ & $b$ & $b$ & $b$ & $b$ & $b$ & $b$ & $b$ & $\mathrm{~b}$ \\
\hline Virginia & 490 & 480 & 550 & 360 & 345 & 405 & 118 & 120 & 85 & 42,480 & 41,400 & 34,425 \\
\hline Washington & 150 & 140 & 195 & 80 & 75 & 120 & 205 & 210 & 210 & 16,400 & 15,750 & 25,200 \\
\hline West Virginia & 45 & 45 & 46 & 28 & 26 & 27 & 109 & 120 & 111 & 3,052 & 3,120 & 2,997 \\
\hline Wisconsin & 3,800 & 3,650 & 4,050 & 2,900 & 2,800 & 3,280 & 148 & 143 & 135 & 429,200 & 400,400 & 442,800 \\
\hline Wyoming & 80 & 85 & 95 & 49 & 45 & 60 & 140 & 129 & 129 & 6,860 & 5,805 & 7,740 \\
\hline US & 81,779 & 78,327 & 93,600 & 75,117 & 70,648 & 86,542 & 148 & 149.1 & 151.1 & $11,114,082$ & $10,534,868$ & $13,073,893$ \\
\hline
\end{tabular}

Source:

U.S. Department of Agriculture, 2008 Agricultural Statistics, Table 1-37, http://www.nass.usda.gov/Publications/Ag Statistics/index.asp

${ }^{\text {a }}$ Preliminary.

${ }^{\mathrm{b}}$ Not estimated. 
The large majority of U.S. corn grain is produced in just a few mid-western states. The highest concentration of corn production is found in central Illinois, northern lowa/southern Minnesota, and eastern Nebraska.

Figure 5.4

Corn for Grain, Harvested Acres, 2002

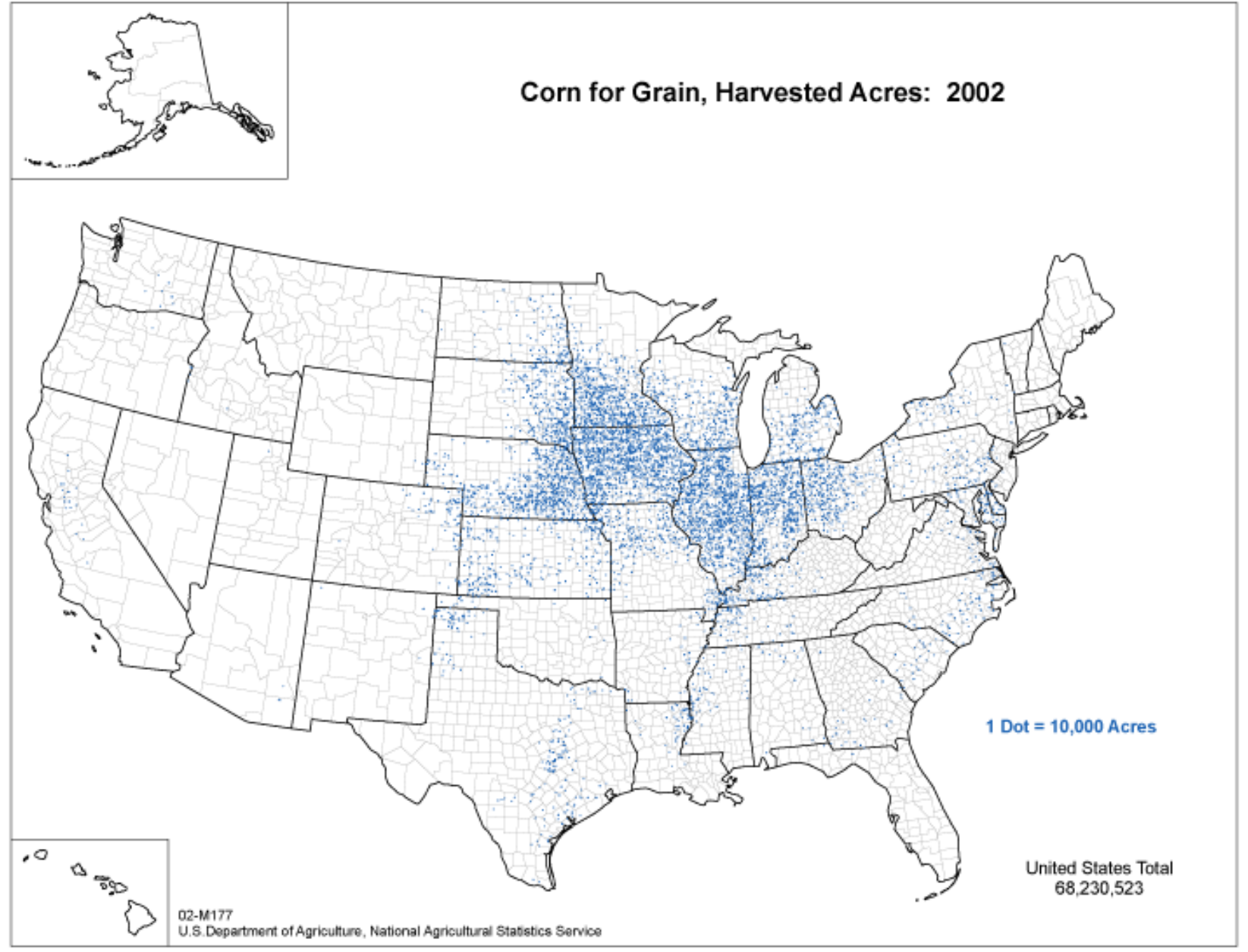

\section{Source:}

U.S. Department of Agriculture, National Agricultural Statistics Service, www.nass.usda.gov/research/atlas02/atlas-crops.html 
Due largely to increased ethanol demand, there was a remarkable increase in the number of corn acres planted in 2007. Acres harvested for grain are always less than planted acres due to silage and crop failure.

Figure 5.5

Corn Acres Planted and Harvested, 1975-2007

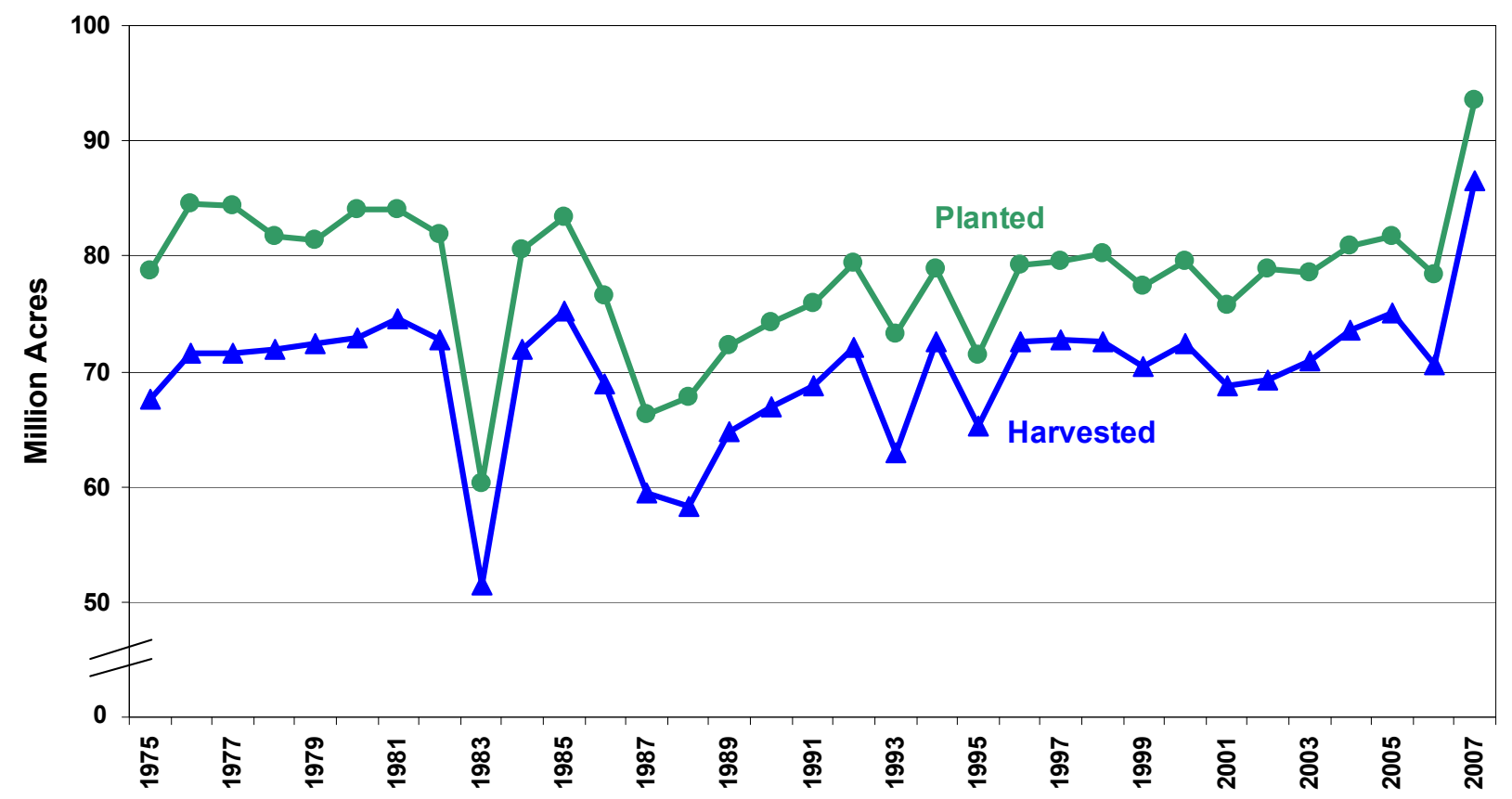

Source:

U.S. Department of Agriculture, National Agricultural Statistics Service, http://www.nass.usda.gov/ 
Doberman et. al., noted in 2002 that average corn yields have increased linearly at a rate of 1.7 bushels per acre (bu/ac) per year. At present that translates to a rate of 1.1\% per year, but if the same average linear rate continues, the percentage rate will decline. Corn yields must continue to increase at a rate of at least $1 \%$ per year to meet the demands created by expected population growth.

In 2002 average corn yields approached 140 bu/ac with progressive farmers routinely harvesting 160 to 220 bu/ac. Yields rose in the 60's and 70's largely due to increasing application of fertilizer to responsive corn hybrids; however, after 1980 yield increases were maintained without continued fertilizer increases due to significant increases in nutrient use efficiency. In the past 15 years, yields have continued to increase due to improved hybrids with greater stress resistance together with improved crop management techniques such as conservation tillage, higher plant densities and improved seed qualities.

Yields at a given site fluctuate as much as $10-15 \%$ from year to year due to normal variations in solar radiation and temperature regimes assuming suitable moisture levels. Lack of sufficient moisture is the most important factor reducing yields in most of the U.S. corn belt where most corn is not irrigated. The yield potential of corn continues to be much greater than the average yields currently being obtained in most locations in the U.S.

Genetic improvements (particularly in drought resistance) are expected to continue to contribute to yield increases, but continued improvements in crop management will be ever more important. Key references on yield potential follow.

Figure 5.6

Corn Yield, 1975-2007

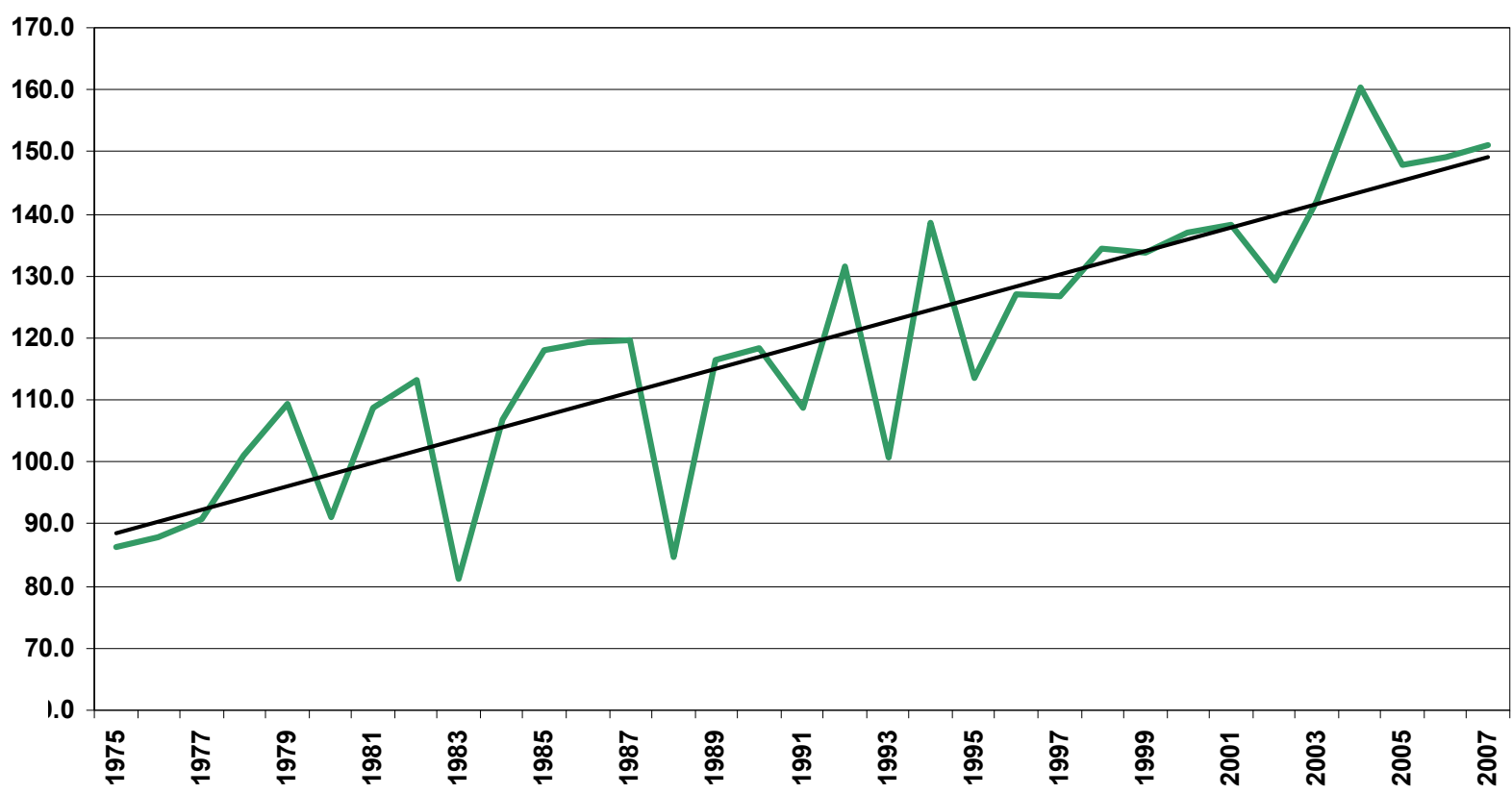

Source:

U.S. Department of Agriculture, National Agricultural Statistics Service, http://www.nass.usda.gov/

\section{Additional References:}

Dobermann, A., T. Arkebauer, K. Cassman, J. Lindquist, J. Specht, D. Walters, and H. Yang. 2002, Understanding and Managing Corn Yield Potential. Proceedings of the Fertilizer Industry Round Table, Charleston, South Carolina. The Fertilizer Industry Round Table, Forest Hill, Maryland, October. Retrieved 5 January 2005 from: 


\section{Figure 5.6 (Continued) \\ Corn Yield, 1975-2007}

Dobermann, A., T. Arkebauer, K.G. Cassman, R.A. Drijber, J.L. Lindquist, J.E. Specht, D.T. Walters, H. Yang, D. Miller, D.L. Binder, G. Teichmeier, R.B. Ferguson, and C.S. Wortmann. 2003. Understanding Corn Yield Potential in Different Environments. p. 67-82. In L.S. Murphy (ed.) Fluid focus: the third decade. Proceedings of the 2003 Fluid Forum, Vol. 20. Fluid Fertilizer Foundation, Manhattan, KS.

Both Doberman, et al. references can be obtained at the following url:

http://soilfertility.unl.edu/Materials\%20to\%20include/Research\%20Pubs/Ecological\%20Intensificatio n.htm

Tollenaar, M. and E. A. Lee. Yield Potential, Yield Stability, and Stress Tolerance in Maize. Field Crops Research 75 (2002):161-169.

Duvick, D.N. and K.G. Cassman. 1999. "Post-green Revolution Trends in Yield Potential of Temperature Maize in the North-Central United States," Crop Sci. 39:1622-1630. 
Production of food for domestic livestock is the largest single use of corn grain, accounting for nearly half of all corn grain produced. Ethanol production is included in the food, seed and industrial category.

Table 5.7

Corn: Supply and Disappearance, 1996-2007 (Million bushels)

\begin{tabular}{|c|c|c|c|c|c|c|c|c|c|c|c|c|}
\hline \multirow[b]{3}{*}{$\begin{array}{c}\text { Year } \\
\text { (beginning } \\
\text { September 1) }\end{array}$} & \multicolumn{4}{|c|}{ Supply } & \multicolumn{5}{|c|}{ Disappearance } & \multicolumn{3}{|c|}{ Ending stocks August 31} \\
\hline & \multirow[b]{2}{*}{$\begin{array}{c}\text { Beginning } \\
\text { stocks }\end{array}$} & \multirow[b]{2}{*}{ Production } & \multirow[b]{2}{*}{ Imports } & \multirow[b]{2}{*}{ Total } & \multicolumn{3}{|c|}{ Domestic use } & \multirow{2}{*}{\multicolumn{2}{|c|}{\begin{tabular}{|cc} 
& $\begin{array}{c}\text { Total } \\
\text { disappear- } \\
\text { Exports }\end{array}$ \\
ance
\end{tabular}}} & \multirow[b]{2}{*}{$\begin{array}{c}\text { Privately } \\
\text { held }^{\mathrm{a}}\end{array}$} & \multirow[b]{2}{*}{$\begin{array}{c}\text { Govern - } \\
\text { ment }\end{array}$} & \multirow[b]{2}{*}{ Total } \\
\hline & & & & & $\begin{array}{c}\text { Feed and } \\
\text { residual }\end{array}$ & $\begin{array}{l}\text { Food, } \\
\text { seed, and } \\
\text { industrial }\end{array}$ & Total & & & & & \\
\hline 1996 & 426 & 9,233 & 13 & 9,672 & 5,277 & 1,714 & 6,991 & 1,797 & 8,789 & 881 & 2 & 883 \\
\hline 1997 & 883 & 9,207 & 9 & 10,099 & 5,482 & 1,805 & 7,287 & 1,504 & 8,791 & 1,304 & 4 & 1,308 \\
\hline 1998 & 1,308 & 9,759 & 19 & 11,085 & 5,471 & 1,846 & 7,318 & 1,984 & 9,298 & 1,775 & 12 & 1,787 \\
\hline 1999 & 1,787 & 9,431 & 15 & 11,232 & 5,664 & 1,913 & 7,578 & 1,937 & 9,515 & 1,704 & 14 & 1,718 \\
\hline 2000 & 1,718 & 9,915 & 7 & 11,639 & 5,842 & 1,957 & 7,799 & 1,941 & 9,740 & 1,891 & 8 & 1,899 \\
\hline 2001 & 1,899 & 9,503 & 10 & 11,412 & 5,864 & 2,046 & 7,911 & 1,905 & 9,815 & 1,590 & 6 & 1,596 \\
\hline 2002 & 1,596 & 8,967 & 14 & 10,578 & 5,563 & 2,340 & 7,903 & 1,588 & 9,491 & 1,083 & 4 & 1,087 \\
\hline 2003 & 1,087 & 10,089 & 14 & 11,190 & 5,795 & 2,537 & 8,332 & 1,900 & 10,232 & 958 & 0 & 958 \\
\hline 2004 & 958 & 11,807 & 11 & 12,776 & 6,157 & 2,687 & 8,844 & 1,818 & 10,662 & 2,113 & 1 & 2,114 \\
\hline 2005 & 2,114 & 11,114 & 9 & 13,237 & 6,155 & 2,981 & 9,136 & 2,134 & 11,270 & 1,967 & 0 & 1,967 \\
\hline $2006^{b}$ & 1,967 & 10,535 & 12 & 12,514 & 5,598 & 3,488 & 9,086 & 2,125 & 11,210 & 1,304 & 0 & 1,304 \\
\hline $2007^{c}$ & 1,304 & 13,168 & 15 & 14,487 & 5,650 & 4,590 & 10,240 & 2,350 & 12,590 & 1,897 & 0 & 1,897 \\
\hline
\end{tabular}

Source:

U.S. Department of Agriculture, 2006 Agricultural Statistics, Table 1-37, http://www.nass.usda.gov/Publications/Ag Statistics/index.asp

a Includes quantity under loan and farmer-owned reserve.

${ }^{\mathrm{b}}$ Preliminary.

${ }^{c}$ Projected as of January 11, 2008, World Agricultural Supply and Demand Estimates. Totals may not add due to rounding. 
Prices of corn used for ethanol production may vary for each mill depending on whether the mills are owned by farmers' cooperatives or whether the corn is purchased on the open market. Prices vary across states considerably.

Table 5.8

Corn for Grain: Marketing Year Average Price and Value, by State, Crop of 2005, 2006, and 2007

\begin{tabular}{|c|c|c|c|c|c|c|}
\hline \multirow[b]{2}{*}{ State $^{a}$} & \multicolumn{3}{|c|}{ Marketing year average price per bushel } & \multicolumn{3}{|c|}{ Value of production } \\
\hline & 2005 & 2006 & 2007 & 2005 & 2006 & 2007 \\
\hline & Dollars & Dollars & Dollars & 1,000 Dollars & 1,000 Dollars & 1,000 Dollars \\
\hline Alabama & 2.50 & 2.91 & 3.90 & 59,500 & 34,571 & 86,268 \\
\hline Arizona & 3.18 & 4.37 & 4.75 & 13,642 & 13,372 & 20,211 \\
\hline Arkansas & 2.15 & 2.73 & 3.75 & 64,780 & 71,744 & 371,700 \\
\hline California & 2.70 & 3.35 & 4.40 & 60,372 & 60,803 & 158,400 \\
\hline Colorado & 2.23 & 3.02 & 4.00 & 313,538 & 405,163 & 602,080 \\
\hline Delaware & 2.25 & 3.61 & 4.45 & 49,550 & 84,275 & 79,855 \\
\hline Florida & 2.00 & 2.80 & 3.80 & 5,264 & 6,888 & 12,635 \\
\hline Georgia & 2.20 & 3.00 & 3.85 & 65,274 & 75,600 & 225,225 \\
\hline Idaho & 2.68 & 3.89 & 4.75 & 27,336 & 42,985 & 82,294 \\
\hline Illinois & 2.08 & 3.07 & 4.05 & $3,554,408$ & $5,579,572$ & $9,249,188$ \\
\hline Indiana & 2.00 & 3.17 & 4.05 & $1,777,160$ & $2,677,572$ & $3,998,768$ \\
\hline lowa & 1.94 & 3.03 & 4.00 & $4,195,250$ & $6,211,803$ & $9,473,400$ \\
\hline Kansas & 2.07 & 3.08 & 4.00 & 964,103 & $1,062,600$ & $2,072,000$ \\
\hline Kentucky & 2.21 & 3.18 & 4.10 & 344,230 & 482,851 & 719,304 \\
\hline Louisiana & 2.25 & 2.80 & 3.80 & 100,980 & 113,680 & 457,710 \\
\hline Maryland & 2.19 & 3.41 & 4.35 & 118,260 & 205,794 & 203,863 \\
\hline Michigan & 1.88 & 3.10 & 3.95 & 540,368 & 893,172 & $1,151,030$ \\
\hline Minnesota & 1.86 & 2.89 & 3.85 & $2,216,934$ & $3,187,237$ & $4,384,380$ \\
\hline Mississippi & 2.22 & 2.84 & 3.70 & 104,529 & 101,530 & 521,700 \\
\hline Missouri & 2.03 & 3.06 & 3.95 & 669,230 & $1,110,596$ & $1,822,925$ \\
\hline Montana & 2.54 & 3.93 & 4.75 & 6,391 & 10,328 & 26,173 \\
\hline Nebraska & 1.92 & 3.00 & 4.00 & $2,439,360$ & $3,534,000$ & $5,888,000$ \\
\hline New Jersey & 2.12 & 3.37 & 4.25 & 16,036 & 27,823 & 43,563 \\
\hline New Mexico & 2.60 & 3.70 & 4.45 & 25,025 & 30,803 & 42,831 \\
\hline New York & 2.29 & 3.42 & 4.30 & 130,622 & 211,766 & 300,355 \\
\hline North Carolina & 2.33 & 3.03 & 3.85 & 195,720 & 295,970 & 392,700 \\
\hline North Dakota & 1.80 & 2.77 & 3.75 & 278,640 & 430,458 & $1,022,250$ \\
\hline Ohio & 1.98 & 3.08 & 3.95 & 920,205 & $1,449,571$ & $2,138,925$ \\
\hline Oklahoma & 2.39 & 3.17 & 4.05 & 68,713 & 73,227 & 158,558 \\
\hline Oregon & 2.59 & 3.24 & 4.45 & 10,360 & 16,913 & 30,371 \\
\hline Pennsylvania & 2.30 & 3.54 & 4.35 & 269,376 & 414,605 & 545,664 \\
\hline South Carolina & 2.19 & 2.98 & 3.75 & 72,401 & 95,062 & 138,750 \\
\hline South Dakota & 1.79 & 2.88 & 3.85 & 841,390 & 899,539 & $2,096,325$ \\
\hline Tennessee & 2.07 & 2.93 & 3.70 & 160,115 & 183,125 & 307,877 \\
\hline Texas & 2.47 & 3.20 & 4.15 & 520,923 & 561,440 & $1,228,400$ \\
\hline Utah & 2.77 & 3.29 & 4.60 & 5,418 & 8,781 & 14,978 \\
\hline Virginia & 2.14 & 3.07 & 4.05 & 90,907 & 127,098 & 139,421 \\
\hline Washington & 2.81 & 3.72 & 4.55 & 46,084 & 58,590 & 114,660 \\
\hline West Virginia & 2.17 & 3.57 & 4.20 & 6,623 & 11,138 & 12,587 \\
\hline Wisconsin & 1.94 & 3.04 & 3.90 & 832,648 & $1,217,216$ & $1,726,920$ \\
\hline Wyoming & 2.45 & 2.64 & 3.60 & 16,807 & 15,325 & 27,864 \\
\hline US & 2.00 & 3.04 & 4.20 & $22,198,472$ & $32,094,586$ & $52,090,108$ \\
\hline
\end{tabular}

Source:

U.S. Department of Agriculture, 2008 Agricultural Statistics, Table 1-40, http://www.nass.usda.gov/Publications/Ag Statistics/index.asp

a States with no data are not listed. 
These data show that government subsidies are vital to ensuring a profit to farmers, when land and labor opportunity costs are considered. However, many farmers only factor operating costs into the calculation, making corn the most profitable commodity crop in most regions of the country. If the residue from corn production also had a market as a bioenergy feedstock, then farmers in areas of high corn yield may come closer to making a profit without subsidies.

Table 5.9

Corn Production Costs and Returns per Planted Acre by Region, Excluding Government Payments, 2006-2007 ${ }^{\mathrm{a}}$

(Dollars per planted acre)

\begin{tabular}{|c|c|c|c|c|c|c|c|c|c|c|c|c|c|c|}
\hline \multirow[b]{2}{*}{ Item } & \multicolumn{2}{|c|}{ United States } & \multicolumn{2}{|c|}{ Heartland } & \multicolumn{2}{|c|}{ Northern Crescent } & \multicolumn{2}{|c|}{ Northern Great Planes } & \multicolumn{2}{|c|}{ Prairie Gateway } & \multicolumn{2}{|c|}{ Eastern Uplands } & \multicolumn{2}{|c|}{ Southern Seaboard } \\
\hline & 2006 & 2007 & 2006 & 2007 & 2006 & 2007 & 2006 & 2007 & 2006 & 2007 & 2006 & 2007 & 2006 & 2007 \\
\hline \multicolumn{15}{|l|}{ Gross value of production } \\
\hline Primary product: Corn grain & 350.52 & 467.61 & 377.5 & 500.65 & 265 & 348.84 & 302.56 & 401.32 & 324.87 & 474.6 & 357.68 & 406.56 & 319.7 & 358 \\
\hline Secondary product: Corn silage & 1.35 & 1.33 & 0.67 & 0.62 & 3.23 & 3.06 & 2.34 & 3.67 & 3.10 & 3.27 & 6.68 & 4.27 & 0.00 & 0.00 \\
\hline Total, gross value of production & 351.87 & 468.94 & 378.17 & 501.27 & 268.23 & 351.90 & 304.90 & 404.99 & 327.97 & 477.87 & 364.36 & 410.83 & 319.70 & 358.00 \\
\hline \multicolumn{15}{|l|}{ Operating costs: } \\
\hline Seed & 43.55 & 49.04 & 43.83 & 49.40 & 43.83 & 49.40 & 41.82 & 47.14 & 43.54 & 49.07 & 39.98 & 45.06 & 38.84 & 43.78 \\
\hline Fertilizer & 80.17 & 93.13 & 82.79 & 96.13 & 89.27 & 103.65 & 52.69 & 61.18 & 63.36 & 73.57 & 100.21 & 116.35 & 83.79 & 97.29 \\
\hline Chemicals & 23.62 & 24.38 & 25.73 & 26.55 & 20.77 & 21.43 & 16.47 & 16.99 & 20.02 & 20.66 & 23.18 & 23.92 & 22.37 & 23.08 \\
\hline Custom operations $^{\mathrm{c}}$ & 10.58 & 10.93 & 9.40 & 9.80 & 13.03 & 13.59 & 9.58 & 9.99 & 14.74 & 15.37 & 9.27 & 9.67 & 6.76 & 7.05 \\
\hline Fuel, lube, and electricity & 28.73 & 31.58 & 22.48 & $\begin{array}{r}25.00 \\
25.00\end{array}$ & 27.98 & 31.05 & 28.60 & 31.92 & 66.16 & 76.30 & $\begin{array}{r}19.27 \\
19.76\end{array}$ & 21.23 & 25.10 & 26.82 \\
\hline Repairs & 14.45 & 14.86 & 12.67 & 13.11 & 14.60 & 15.10 & 15.79 & 16.33 & 22.83 & 23.62 & 12.28 & 12.70 & 20.99 & 21.71 \\
\hline Purchased irrigation water & 0.12 & 0.13 & 0.00 & 0.00 & 0.02 & 0.02 & 1.57 & 1.64 & 0.19 & 0.20 & 0.00 & 0.00 & 0.00 & 0.00 \\
\hline Interest on operating capital & 4.76 & 4.94 & 4.66 & 4.85 & 4.95 & 5.16 & 3.94 & 4.08 & 5.46 & 5.71 & 4.84 & 5.05 & 4.68 & 4.85 \\
\hline Total, operating costs & 205.98 & 228.99 & 201.56 & 224.84 & 214.45 & 239.40 & 170.46 & 189.27 & 236.30 & 264.50 & 209.52 & 233.98 & 202.53 & 224.58 \\
\hline \multicolumn{15}{|l|}{ Allocated overhead: } \\
\hline Hired labor & 2.19 & 2.26 & 1.46 & 1.51 & 3.14 & 3.25 & 3.42 & 3.54 & 3.79 & 3.92 & 1.21 & 1.25 & 6.33 & 6.55 \\
\hline Opportunity cost of unpaid la & 23.56 & 24.34 & 20.52 & 21.24 & 32.94 & 34.10 & 22.06 & 22.83 & 25.12 & 26.00 & 39.12 & 40.49 & 25.59 & 26.49 \\
\hline Capital recovery of machiner & 66.71 & 69.77 & 63.59 & 66.73 & 63.68 & 66.83 & 72.66 & 76.25 & 86.23 & 90.49 & 59.77 & 62.73 & 66.93 & 70.24 \\
\hline Opportunity cost of land (rental rate) & 90.84 & 97.21 & 103.16 & 110.48 & 75.90 & 81.28 & 58.82 & 62.99 & 69.67 & 74.61 & 61.75 & 66.13 & 53.80 & 57.62 \\
\hline Taxes and insurance & 7.01 & 7.52 & 6.37 & 6.88 & 9.47 & 10.23 & 4.27 & 4.61 & 8.42 & 9.10 & 5.40 & 5.83 & 8.28 & 8.95 \\
\hline General farm overhead & 13.45 & 13.88 & 12.57 & 13.00 & 18.30 & 18.93 & 9.53 & 9.86 & 13.09 & 13.54 & 10.92 & 11.30 & 17.45 & 18.05 \\
\hline Total, allocated overhead & 203.76 & 214.98 & 207.67 & 219.84 & 203.43 & 214.62 & 170.76 & 180.08 & 206.32 & 217.66 & 178.17 & 187.73 & 178.38 & 187.90 \\
\hline Total, costs listed & 409.74 & 443.97 & 409.23 & 444.68 & 417.88 & 454.02 & 341.22 & 369.35 & 442.62 & 482.16 & 387.69 & 421.71 & 380.91 & 412.48 \\
\hline Value of produc & -57.87 & 24.97 & -31.06 & 56.59 & -149.65 & $\frac{-102.12}{-102.12}$ & $\frac{-1.124}{-36.32}$ & 35.64 & -114.65 & -4.29 & -23.33 & $\frac{-12.11}{-10.88}$ & $\frac{3001}{-61.21}$ & -54.48 \\
\hline Value of production less operating costs & 145.89 & 239.95 & 176.61 & 276.43 & 53.78 & 112.50 & 134.44 & 215.72 & 91.67 & 213.37 & 154.84 & $\begin{array}{r}-176.85 \\
\end{array}$ & 117.17 & 133.42 \\
\hline \multicolumn{15}{|l|}{ Supporting information: } \\
\hline Yield (bushels per plante & 138 & 143 & 151 & 155 & 106 & 108 & 122 & 127 & 119 & 140 & 136 & 121 & 115 & 100 \\
\hline Price (dollars per bushel at harvest) & 2.54 & 3.27 & 2.50 & 3.23 & 2.50 & 3.23 & 2.48 & 3.16 & 2.73 & 3.39 & 2.63 & 3.36 & 2.78 & 3.58 \\
\hline Enterprise size (planted acres) a & 250 & 250 & 281 & 281 & 128 & 128 & 341 & 341 & 322 & 322 & 77 & 77 & 146 & 146 \\
\hline \multicolumn{15}{|l|}{ Production practices: ${ }^{a}$} \\
\hline Irrigated (percent) & 12 & 12 & 5 & 5 & 5 & 5 & 21 & 21 & 48 & 48 & 2 & 2 & 13 & 13 \\
\hline Dryland (percent) & 88 & 88 & 95 & 95 & 95 & 95 & 79 & 79 & 52 & 52 & 98 & 98 & 87 & 87 \\
\hline
\end{tabular}

Source:

Economic Research Service, U.S. Department of Agriculture, http://www.ers.usda.gov/data/costsandreturns/testpick.htm

${ }^{a}$ Developed from survey base year, 2005.

${ }^{\mathrm{b}}$ Cost of commercial fertilizers, soil conditioners, and manure.

${ }^{\mathrm{c}}$ Cost of custom operations, technical services, and commercial drying. 
Table 5.10

Oats: Area, Yield, Production, and Value, 1996-2007

\begin{tabular}{|c|c|c|c|c|c|c|}
\hline \multirow[b]{2}{*}{ Year } & \multicolumn{2}{|c|}{ Area } & \multirow[b]{2}{*}{$\begin{array}{l}\text { Yield per } \\
\text { harvested } \\
\text { acre }\end{array}$} & \multirow[b]{2}{*}{ Production } & \multirow[b]{2}{*}{$\begin{array}{c}\text { Marketing year } \\
\text { average price per } \\
\text { bushel received by } \\
\text { farmers }\end{array}$} & \multirow[b]{2}{*}{$\begin{array}{l}\text { Value of } \\
\text { production }\end{array}$} \\
\hline & Planted $^{\mathrm{a}}$ & Harvested & & & & \\
\hline & $\begin{array}{l}1,000 \\
\text { Acres }\end{array}$ & 1,000 Acres & Bushels & 1,000 Bushels & Dollars & 1,000 Dollars \\
\hline 1996 & 4,638 & 2,655 & 57.7 & 153,245 & 1.96 & 313,910 \\
\hline 1997 & 5,068 & 2,813 & 59.5 & 167,246 & 1.60 & 273,284 \\
\hline 1998 & 4,891 & 2,752 & 60.2 & 165,768 & 1.10 & 199,475 \\
\hline 1999 & 4,668 & 2,445 & 59.6 & 145,628 & 1.12 & 174,307 \\
\hline 2000 & 4,473 & 2,325 & 64.2 & 149,165 & 1.10 & 175,432 \\
\hline 2001 & 4,401 & 1,911 & 61.5 & 117,602 & 1.59 & 197,181 \\
\hline 2002 & 4,995 & 2,058 & 56.4 & 116,002 & 1.81 & 212,078 \\
\hline 2003 & 4,597 & 2,220 & 65 & 144,383 & 1.48 & 224,910 \\
\hline 2004 & 4,085 & 1,787 & 64.7 & 115,695 & 1.48 & 178,327 \\
\hline 2005 & 4,246 & 1,823 & 63 & 114,878 & 1.63 & 195,150 \\
\hline 2006 & 4,168 & 1,566 & 59.8 & 93,638 & 1.87 & 181,005 \\
\hline $2007^{b}$ & 3,760 & 1,505 & 60.9 & 91,599 & 2.50 & 228,613 \\
\hline
\end{tabular}

Source:

U.S. Department of Agriculture, 2008 Agricultural Statistics, Table 1-45 and annual, http://www.nass.usda.gov/Publications/Ag Statistics/index.asp

${ }^{a}$ Oats sown for all purposes, including oats sown in the preceding fall.

${ }^{\mathrm{b}}$ Preliminary. 
Table 5.11

Oats: Area, Yield, and Production, by State, 2005-2007

\begin{tabular}{|c|c|c|c|c|c|c|c|c|c|c|c|c|}
\hline & \multicolumn{3}{|c|}{ Area planted $^{\mathrm{a}}$} & \multicolumn{3}{|c|}{ Area harvested } & \multicolumn{3}{|c|}{ Yield per harvested acre } & \multicolumn{3}{|c|}{ Production } \\
\hline & 2005 & 2006 & 2007 & 2005 & 2006 & 2007 & 2005 & 2006 & 2007 & 2005 & 2006 & 2007 \\
\hline & $\begin{array}{l}1,000 \\
\text { Acres }\end{array}$ & $\begin{array}{l}1,000 \\
\text { Acres }\end{array}$ & $\begin{array}{l}1,000 \\
\text { Acres }\end{array}$ & $\begin{array}{l}1,000 \\
\text { Acres }\end{array}$ & $\begin{array}{l}1,000 \\
\text { Acres }\end{array}$ & $\begin{array}{l}1,000 \\
\text { Acres }\end{array}$ & Bushels & Bushels & Bushels & $\begin{array}{c}1,000 \\
\text { Bushels }\end{array}$ & $\begin{array}{c}1,000 \\
\text { Bushels }\end{array}$ & $\begin{array}{c}1,000 \\
\text { Bushels }\end{array}$ \\
\hline Arizona & 50 & 50 & 45 & 20 & 10 & 16 & 55 & 40 & 58 & 1,100 & 400 & $\overline{928}$ \\
\hline California & 270 & 270 & 210 & 20 & 20 & 20 & 75 & 86 & 93 & 1,500 & 1,720 & 1,860 \\
\hline Colorado & 75 & 85 & 75 & 15 & 10 & 10 & 75 & 70 & 80 & 1,125 & 700 & 800 \\
\hline Georgia & 75 & 70 & 70 & 20 & 30 & 30 & 60 & 53 & 56 & 1,200 & 1,590 & 1,680 \\
\hline Idaho & 90 & 90 & 70 & 20 & 20 & 20 & 64 & 72 & 61 & 1,280 & 1,440 & 1,220 \\
\hline Illinois & 60 & 60 & 35 & 40 & 40 & 24 & 79 & 77 & 68 & 3,160 & 3,080 & 1,632 \\
\hline Indiana & 20 & 25 & 25 & 9 & 14 & 8 & 69 & 80 & 55 & 621 & 1,120 & 440 \\
\hline lowa & 210 & 210 & 145 & 125 & 110 & 67 & 79 & 76 & 71 & 9,875 & 8,360 & 4,757 \\
\hline Kansas & 100 & 100 & 90 & 40 & 40 & 35 & 59 & 45 & 38 & 2,360 & 1,800 & 1,330 \\
\hline Maine & 32 & 31 & 31 & 28 & 30 & 30 & 70 & 55 & 70 & 1960 & 1650 & 2100 \\
\hline Michigan & 90 & 80 & 70 & 75 & 65 & 55 & 61 & 62 & 58 & 4,575 & 4,030 & 3,190 \\
\hline Minnesota & 310 & 290 & 270 & 205 & 200 & 180 & 62 & 56 & 60 & 12,710 & 11,200 & 10,800 \\
\hline Missouri & 35 & 40 & 25 & 20 & 28 & 8 & 65 & 65 & 50 & 1,300 & 1,820 & 400 \\
\hline Montana & 90 & 70 & 75 & 35 & 24 & 35 & 53 & 46 & 52 & 1,855 & 1,104 & 1,820 \\
\hline Nebraska & 150 & 160 & 120 & 60 & 45 & 35 & 73 & 45 & 68 & 4380 & 2025 & 2380 \\
\hline New York & 95 & 85 & 100 & 75 & 67 & 60 & 54 & 74 & 57 & 4,050 & 4,958 & 3,420 \\
\hline North Carolina & 50 & 60 & 50 & 23 & 26 & 15 & 73 & 65 & 51 & 1,679 & 1,690 & 765 \\
\hline North Dakota & 490 & 420 & 460 & 240 & 120 & 260 & 59 & 41 & 59 & 14,160 & 4,920 & 15,340 \\
\hline Ohio & 80 & 70 & 75 & 60 & 55 & 55 & 60 & 75 & 62 & 3,600 & 4,125 & 3,410 \\
\hline Oklahoma & 45 & 35 & 80 & 10 & 8 & 15 & 41 & 30 & 31 & 410 & 240 & 465 \\
\hline Oregon & 40 & 50 & 60 & 18 & 20 & 22 & 78 & 95 & 93 & 1,404 & 1,900 & 2,046 \\
\hline Pennsylvania & 140 & 135 & 115 & 110 & 110 & 80 & 55 & 64 & 56 & 6,050 & 7,040 & 4,480 \\
\hline South Carolina & 35 & 33 & 33 & 20 & 18 & 13 & 59 & 55 & 52 & 1,180 & 990 & 676 \\
\hline South Dakota & 380 & 380 & 330 & 180 & 95 & 125 & 72 & 57 & 74 & 12,960 & 5,415 & 9,250 \\
\hline Texas & 690 & 760 & 710 & 110 & 100 & 100 & 43 & 37 & 40 & 4,730 & 3,700 & 4,000 \\
\hline Utah & 50 & 45 & 35 & 7 & 7 & 5 & 73 & 77 & 85 & 511 & 539 & 425 \\
\hline Virginia & 14 & 16 & 16 & 3 & 4 & 5 & 61 & 55 & 68 & 183 & 220 & 340 \\
\hline Washington & 25 & 30 & 30 & 8 & 8 & 9 & 75 & 86 & 61 & 600 & 688 & 549 \\
\hline Wisconsin & 400 & 370 & 270 & 215 & 230 & 160 & 64 & 63 & 67 & 13,760 & 14,490 & 10,720 \\
\hline Wyoming & 55 & 48 & 40 & 12 & 12 & 8 & 50 & 57 & 47 & 600 & 684 & 376 \\
\hline US & 4,246 & 4,168 & 3,760 & 1,823 & 1,566 & 1,505 & 63 & 59.8 & 60.9 & 114,878 & 93,638 & 91,599 \\
\hline
\end{tabular}

\section{Source:}

U.S. Department of Agriculture, 2008 Agricultural Statistics, Table 1-49, http://www.nass.usda.gov/Publications/Ag Statistics/index.asp

${ }^{a}$ Relates to the total area of oats sown for all purposes, including oats sown in the preceding fall. 
Table 5.12

Oats Production Costs and Returns per Planted Acre by Region, Excluding Government Payments, 2006-2007 ${ }^{\mathrm{a}}$ (Dollars per planted acre)

\begin{tabular}{|c|c|c|c|c|c|c|c|c|c|c|}
\hline \multirow[b]{2}{*}{ Item } & \multicolumn{2}{|c|}{ United States } & \multicolumn{2}{|c|}{ Northern Great Plains } & \multicolumn{2}{|c|}{ Prarie Gateway } & \multicolumn{2}{|c|}{ Northern Crescent } & \multicolumn{2}{|c|}{ Heartland } \\
\hline & 2006 & 2007 & 2006 & 2007 & 2006 & 2007 & 2006 & 2007 & 2006 & 2007 \\
\hline \multicolumn{11}{|l|}{ Gross value of production } \\
\hline Primary product: Oats & 106.1052 & 144.286 & 61.6003 & 136.6604458 & 47.32 & 68.221 & 122.18 & 130.46806 & 83.094914 & 133.632 \\
\hline Secondary product: Straw & 51.22 & 36.38 & 12.75 & 19.96 & 3.85 & 3.87 & 75.19 & 52.26 & 51.16 & 52.94 \\
\hline Secondary product: Hay, silage, grazing & 10.96 & 16.87 & 11.28 & 15.95 & 31.09 & 44.02 & 7.47 & 11.47 & 7.96 & 12.30 \\
\hline Total, gross value of production & 168.29 & 197.54 & 85.63 & 172.57 & 82.26 & 116.11 & 204.84 & 194.20 & 142.21 & 198.87 \\
\hline \multicolumn{11}{|l|}{ Operating costs: } \\
\hline Seed & 9.31 & 9.99 & 6.48 & 7.57 & 7.23 & 8.44 & 10.26 & 11.99 & 9.76 & 11.40 \\
\hline Fertilizer $^{b}$ & 26.85 & 29.29 & 12.07 & 15.10 & 36.47 & 45.64 & 32.88 & 41.14 & 20.91 & 26.17 \\
\hline Chemicals & 1.93 & 2.26 & 3.23 & 3.28 & 0.83 & 0.85 & 2.10 & 2.13 & 1.72 & 1.74 \\
\hline Custom operations & 8.85 & 7.40 & 2.45 & 2.55 & 2.67 & 2.78 & 10.49 & 10.93 & 11.00 & 11.46 \\
\hline Fuel, lube, and electricity & 16.74 & 17.25 & 12.78 & 14.12 & 11.31 & 12.49 & 19.84 & 21.91 & 16.19 & 17.88 \\
\hline Repairs & 11.70 & 12.41 & 13.10 & 13.55 & 9.64 & 9.98 & 12.31 & 12.74 & 11.27 & 11.66 \\
\hline Purchased irrigation water & 2.92 & 2.40 & 0.78 & 0.80 & 0.25 & 0.26 & 1.85 & 1.92 & 5.73 & 5.93 \\
\hline Interest on operating inputs & 1.88 & 1.81 & 1.22 & 1.28 & 1.64 & 1.80 & 2.15 & 2.30 & 1.84 & 1.93 \\
\hline Total, operating costs & 80.18 & 82.82 & 52.11 & 58.25 & 70.04 & 82.24 & 91.88 & 105.06 & 78.42 & 88.17 \\
\hline \multicolumn{11}{|l|}{ Allocated overhead: } \\
\hline Hired labor & 0.77 & 0.67 & 0.34 & 0.35 & 0.36 & 0.38 & 1.49 & 1.54 & 0.20 & 0.20 \\
\hline Opportunity cost of unpaid labor & 33.97 & 31.64 & 21.09 & 21.83 & 26.28 & 27.20 & 41.78 & 43.24 & 31.38 & 32.48 \\
\hline Capital recovery of machinery and equipment & 54.49 & 58.73 & 61.51 & 64.55 & 43.66 & 45.82 & 54.33 & 57.01 & 56.33 & 59.11 \\
\hline Opportunity cost of land (rental rate) & 63.83 & 67.09 & 44.22 & 50.93 & 35.04 & 40.36 & 59.92 & 69.02 & 84.19 & 96.97 \\
\hline Taxes and insurance & 4.60 & 5.04 & 3.57 & 4.14 & 4.90 & 5.69 & 4.62 & 5.36 & 4.77 & 5.53 \\
\hline General farm overhead & 8.37 & 8.26 & 7.15 & 7.39 & 5.24 & 5.42 & 8.92 & 9.23 & 9.18 & 9.49 \\
\hline Total, allocated overhead & 166.03 & 171.44 & 137.88 & 149.19 & 115.48 & 124.87 & 171.06 & 185.40 & 186.05 & 203.78 \\
\hline Total, costs listed & 246.20 & 254.25 & 189.99 & 207.44 & 185.52 & 207.11 & 262.94 & 290.46 & 264.47 & 291.95 \\
\hline Value of production less total costs listed & -77.92 & -56.72 & -104.36 & -34.87 & -103.26 & -91.00 & -58.10 & -96.26 & -122.25 & -93.08 \\
\hline Value of production less operating costs & 88.11 & 114.72 & 33.52 & 114.32 & 12.22 & 33.87 & 112.96 & 89.14 & 63.80 & 110.70 \\
\hline \multicolumn{11}{|l|}{ Supporting information: } \\
\hline Yield (bushels per planted acre) & 56.41499 & 58.86958 & 37 & 58 & 26 & 26 & 82 & 57 & 48 & 50 \\
\hline Price (dollars per bushel at harvest) & 1.880797 & 2.450943 & 1.68 & 2.38 & 1.82 & 2.58 & 1.49 & 2.29 & 1.74 & 2.69 \\
\hline Enterprise size (planted acres) $^{a}$ & 27 & 27 & 66 & 66 & 47 & 47 & 25 & 25 & 23 & 23 \\
\hline \multicolumn{11}{|l|}{ Production practices: ${ }^{a}$} \\
\hline Irrigated (percent of acres) & 1 & 1 & 1.88 & 1.88 & 5 & 5 & 0 & 0 & 0 & 0 \\
\hline Dryland (percent of acres) & 99 & 99 & 98 & 98 & 95 & 95 & 100 & 100 & 100 & 100 \\
\hline Straw (percent of acres) & 71 & 71 & 47 & 47 & 18.24 & 18.24 & 79 & 79 & 82 & 82 \\
\hline
\end{tabular}

Source:

Economic Research Service, US Department of Agriculture, http://www.ers.usda.gov/data/costsandreturns/testpick.htm

${ }^{\mathrm{a}}$ Developed from survey base year, 2005.

${ }^{\mathrm{b}}$ Cost of commercial fertilizers, soil conditioners, and manure. 
Table 5.13

Rice $^{\mathrm{a}}$ : Area, Yield, Production, and Value, 1996-2007

\begin{tabular}{|c|c|c|c|c|c|c|}
\hline \multirow[b]{2}{*}{ Year } & \multicolumn{2}{|c|}{ Area } & \multirow[b]{2}{*}{$\begin{array}{l}\text { Yield per } \\
\text { harvested } \\
\text { acre }\end{array}$} & \multirow[b]{2}{*}{ Production } & \multirow[b]{2}{*}{$\begin{array}{l}\text { Marketing year } \\
\text { average price per } \\
\text { cwt. received by } \\
\text { farmers }\end{array}$} & \multirow[b]{2}{*}{$\begin{array}{c}\text { Value of } \\
\text { production }\end{array}$} \\
\hline & Planted & Harvested & & & & \\
\hline & 1,000 Acres & 1,000 Acres & Pounds & 1,000 cwt. & Dollars & 1,000 Dollars \\
\hline 1996 & 2,824 & 2,804 & 6,120 & 171,599 & 9.96 & $1,690,270$ \\
\hline 1997 & 3,125 & 3,103 & 5,897 & 182,992 & 9.70 & $1,756,136$ \\
\hline 1998 & 3,285 & 3,257 & 5,663 & 184,443 & 8.89 & $1,654,157$ \\
\hline 1999 & 3,531 & 3,512 & 5,866 & 206,027 & 5.93 & $1,231,207$ \\
\hline 2000 & 3,060 & 3,039 & 6,281 & 190,872 & 5.61 & $1,049,961$ \\
\hline 2001 & 3,334 & 3,314 & 6,496 & 215,270 & 4.25 & 925,055 \\
\hline 2002 & 3,240 & 3,207 & 6,578 & 210,960 & 4.49 & 979,628 \\
\hline $2003^{b}$ & 3,022 & 2,997 & 6,670 & 199,897 & 8.08 & $1,628,948$ \\
\hline 2004 & 3,347 & 3,325 & 6,988 & 232,362 & 7.33 & $1,701,822$ \\
\hline 2005 & 3,384 & 3,364 & 6,636 & 223,235 & 7.65 & $1,741,721$ \\
\hline 2006 & 2,838 & 2,821 & 6,868 & 193,736 & 9.96 & $1,982,696$ \\
\hline 2007 & 2,761 & 2,748 & 7,185 & 197,456 & 11.50 & $2,273,955$ \\
\hline
\end{tabular}

Source:

U.S. Department of Agriculture, 2008 Agricultural Statistics, Table 1-21 and annual, http://www.nass.usda.gov/Publications/Ag Statistics/index.asp

\footnotetext{
${ }^{a}$ Rough.
}

${ }^{\mathrm{b}}$ Sweet rice yield and production included in 2003 as short grain but not in previous years. 
Table 5.14

Rice: Area, Yield, and Production by State, 2005-2007

\begin{tabular}{|c|c|c|c|c|c|c|c|c|c|c|c|c|}
\hline \multirow[b]{2}{*}{ State $^{a}$} & \multicolumn{3}{|c|}{ Area Planted } & \multicolumn{3}{|c|}{ Area harvested } & \multicolumn{3}{|c|}{ Yield per harvested acre } & \multicolumn{3}{|c|}{ Production } \\
\hline & 2005 & 2006 & $2007^{b}$ & 2005 & 2006 & $2007^{b}$ & 2005 & 2006 & $2007^{b}$ & 2005 & 2006 & $2007^{b}$ \\
\hline & 1,000 & 1,000 & & 1,000 & 1,000 & 1,000 & & & & & & \\
\hline & Acres & Acres & 1,000 Acres & Acres & Acres & Acres & Pounds & Pounds & Pounds & $1,000 \mathrm{cwt}$. & $1,000 \mathrm{cwt}$. & $1,000 \mathrm{cwt}$ \\
\hline Arkansas & $1,643.0$ & $1,406.0$ & $1,331.0$ & $1,635.0$ & $1,400.0$ & $1,325.0$ & 6,650 & 6,850 & 7,130 & 108,792 & 95,917 & 94,487 \\
\hline California & 528.0 & 526.0 & 534.0 & 526.0 & 523.0 & 533.0 & 7,380 & 7,660 & 8,220 & 38,836 & 40,040 & 43,822 \\
\hline Louisiana & 530.0 & 350.0 & 380.0 & 525.0 & 345.0 & 378.0 & 5,900 & 5,820 & 6,140 & 30,983 & 20,093 & 23,222 \\
\hline Mississippi & 265.0 & 190.0 & 190.0 & 263.0 & 189.0 & 189.0 & 6,400 & 7,000 & 7,450 & 16,832 & 13,230 & 14,081 \\
\hline Missouri & 216.0 & 216.0 & 180.0 & 214.0 & 214.0 & 178.0 & 6,600 & 6,400 & 6,900 & 14,124 & 13,696 & 12,279 \\
\hline Texas & 202.0 & 150.0 & 146.0 & 201.0 & 150.0 & 145.0 & 6,800 & 7,170 & 6,600 & 13,668 & 10,760 & 9,565 \\
\hline US & $3,384.0$ & $2,838.0$ & $2,761.0$ & $3,364.0$ & $2,821.0$ & $2,748.0$ & 6,636 & 6,868 & 7,185 & 223,235 & 193,736 & 197,456 \\
\hline
\end{tabular}

Source:

U.S. Department of Agriculture, 2008 Agricultural Statistics, Table 1-27, http://www.nass.usda.gov/Publications/Ag Statistics/index.asp

${ }^{\text {a }}$ States with no data are not listed.

${ }^{\mathrm{b}}$ Preliminary. 
Table 5.15

Rice Production Costs and Returns per Planted Acre by Region, Excluding Government Payments, 2006-2007

(Dollars per planted acre)

\begin{tabular}{|c|c|c|c|c|c|c|c|c|c|c|}
\hline \multirow[b]{2}{*}{ Item } & \multicolumn{2}{|c|}{ United States } & \multicolumn{2}{|c|}{ Ark Non-Delta } & \multicolumn{2}{|c|}{ California } & \multicolumn{2}{|c|}{ Mississippi River Deltt } & \multicolumn{2}{|c|}{ Gulf Coast } \\
\hline & 2006 & 2007 & 2006 & 2007 & 2006 & 2007 & 2006 & 2007 & 2006 & 2007 \\
\hline \multicolumn{11}{|l|}{ Gross value of production } \\
\hline Primary product: Rice & 623.14 & 776.99 & 596.18 & 734.06 & 715.63 & 951.56 & 628.92 & 761.67 & 587.88 & 564.68 \\
\hline Total, gross value of production & 623.14 & 776.99 & 596.18 & 734.06 & 715.63 & 951.56 & 628.92 & 761.67 & 587.88 & 564.68 \\
\hline \multicolumn{11}{|l|}{ Operating costs: } \\
\hline Seed & 36.75 & 40.75 & 34.38 & 38.03 & 41.41 & 45.81 & 39.35 & 43.53 & 35.08 & 38.81 \\
\hline Fertilizer $^{b}$ & 60.49 & 75.89 & 51.99 & 64.69 & 69.58 & 86.58 & 59.34 & 73.84 & 75.15 & 93.51 \\
\hline Chemicals & 65.96 & 66.15 & 56.75 & 57.64 & 90.88 & 92.30 & 56.10 & 56.98 & 67.38 & 68.43 \\
\hline Custom operations $^{c}$ & 41.90 & 45.18 & 27.93 & 29.13 & 82.00 & 85.51 & 34.05 & 35.51 & 48.73 & 50.82 \\
\hline Fuel, lube, and electricity & 95.90 & 105.60 & 102.66 & 113.40 & 63.72 & 70.39 & 97.23 & 107.40 & 111.17 & 122.80 \\
\hline Repairs & 26.40 & 27.25 & 27.66 & 28.61 & 25.45 & 26.33 & 24.94 & 25.80 & 25.66 & 26.54 \\
\hline Purchased irrigation water & 10.36 & 11.75 & 0.18 & 0.19 & 43.00 & 44.84 & 0.00 & 0.00 & 15.98 & 16.66 \\
\hline Commercial drying & 20.61 & 21.99 & 12.90 & 14.92 & 32.49 & 38.69 & 10.47 & 12.13 & 35.41 & 31.70 \\
\hline Interest on operating inputs & 8.11 & 8.35 & 7.24 & 7.43 & 9.98 & 10.12 & 7.46 & 7.68 & 9.10 & 9.35 \\
\hline Total, operating costs & 366.48 & 402.91 & 321.69 & 354.04 & 458.51 & 500.57 & 328.94 & 362.87 & 423.66 & 458.62 \\
\hline \multicolumn{11}{|l|}{ Allocated overhead: } \\
\hline Hired labor & 18.42 & 19.21 & 19.61 & 20.30 & 23.72 & 24.55 & 19.77 & 20.46 & 9.18 & 9.50 \\
\hline Opportunity cost of unpaid labor & 41.23 & 43.34 & 35.32 & 36.56 & 65.18 & 67.47 & 28.94 & 29.96 & 46.55 & 48.18 \\
\hline Capital recovery of machinery and equipment & 96.80 & 101.52 & 98.55 & 103.42 & 101.22 & 106.23 & 89.75 & 94.19 & 95.13 & 99.83 \\
\hline Opportunity cost of land (rental rate) & 118.31 & 128.70 & 89.46 & 95.80 & 234.25 & 250.86 & 84.48 & 90.47 & 109.98 & 117.78 \\
\hline Taxes and insurance & 15.49 & 17.08 & 16.28 & 17.59 & 13.67 & 14.77 & 19.77 & 21.36 & 12.70 & 13.72 \\
\hline General farm overhead & 24.24 & 24.84 & 19.13 & 19.79 & 34.46 & 35.65 & 26.89 & 27.82 & 21.38 & 22.12 \\
\hline Total, allocated overhead & 314.49 & 334.70 & 278.35 & 293.46 & 472.50 & 499.53 & 269.60 & 284.26 & 294.92 & 311.13 \\
\hline Total, costs listed & 680.97 & 737.61 & 600.04 & 647.50 & 931.01 & $1,000.10$ & 598.54 & 647.13 & 718.58 & 769.75 \\
\hline Value of production less total costs listed & -57.83 & 39.38 & -3.86 & 86.56 & -215.38 & -48.54 & 30.38 & 114.54 & -130.70 & -205.07 \\
\hline Value of production less operating costs & 256.66 & 374.07 & 274.49 & 380.02 & 257.12 & 450.99 & 299.98 & 398.80 & 164.22 & 106.06 \\
\hline \multicolumn{11}{|l|}{ Supporting information: } \\
\hline Price (dollars per cwt at harvest) & 8.62 & 10.26 & 8 & 10 & 9 & 12 & 8 & 10 & 9 & 10 \\
\hline Yield (cwt per planted acre) & 72.29 & 75.73 & 70.89 & 74.21 & 76.62 & 82.60 & 74.34 & 77.96 & 69.00 & 55.93 \\
\hline Enterprise size (planted acres) $^{a}$ & 511 & 511 & 521 & 521 & 431 & 431 & 634 & 634 & 469 & 469 \\
\hline
\end{tabular}

Source:

Economic Research Service, US Department of Agriculture, http://www.ers.usda.gov/data/costsandreturns/testpick.htm

${ }^{a}$ Developed from survey base year, 2006.

${ }^{\mathrm{b}}$ Cost of commercial fertilizers, soil conditioners, and manure. 
Sorghum is currently a small contributor to ethanol production, but because it is largely grown in an area of the country that does not significantly overlap with corn production, it could become important in expanding the range of locations of ethanol production facilities.

Figure 5.7

Sorghum for Grain, Harvested Acres, 2002

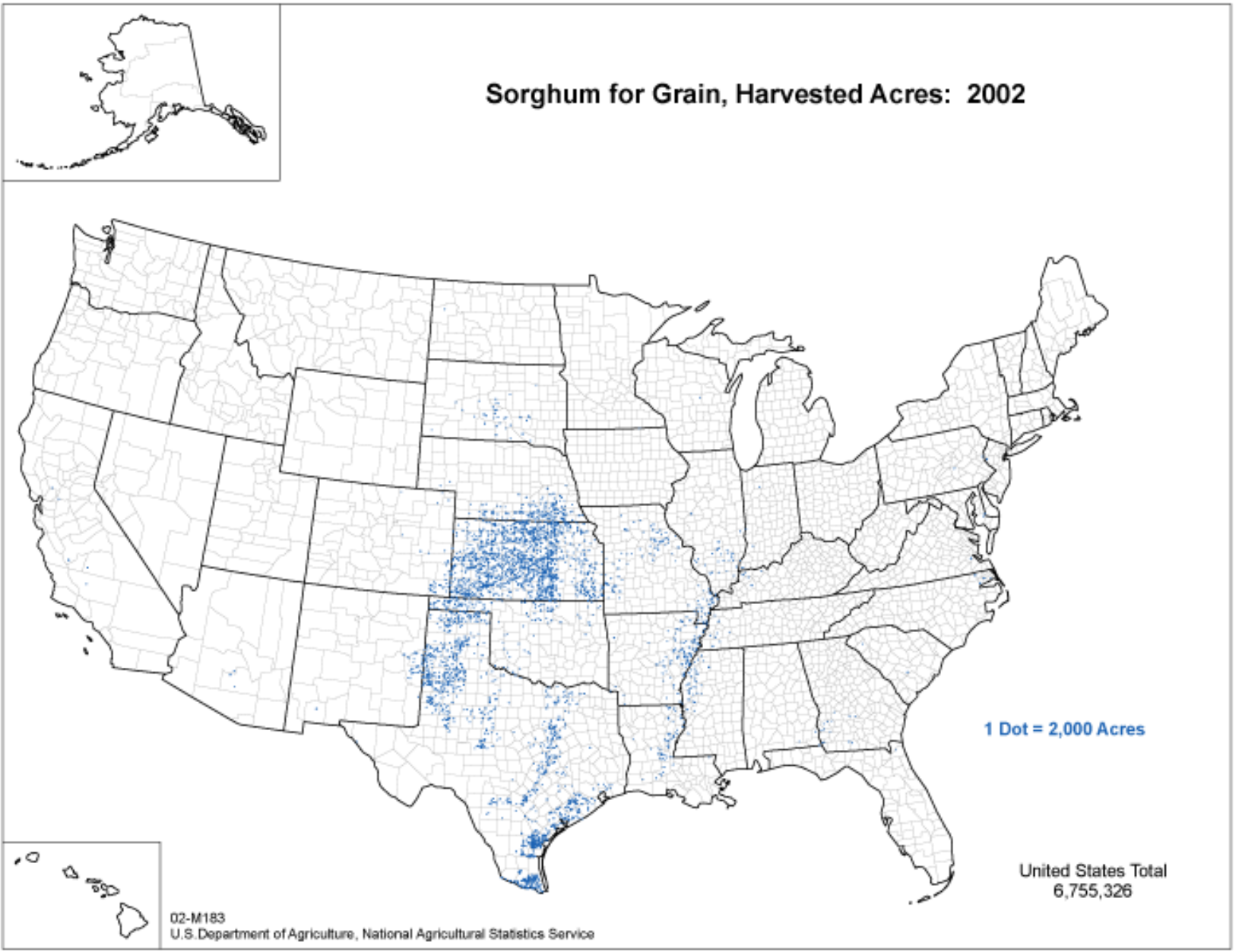

\section{Source:}

U.S. Department of Agriculture, National Agricultural Statistics Service, www.nass.usda.gov/research/atlas02/atlas-crops.html 
The price for sorghum declined from 1975 to 1999 but has stabilized and even shown some increase in recent years. Sorghum has a different geographic distribution than corn but has similar properties, making it a viable crop for the production of ethanol. The price fluctuation for sorghum is also very similar to that of corn.

Figure 5.8

Sorghum: Price per Bushel, 1975-2007

(Constant 2007 dollars)

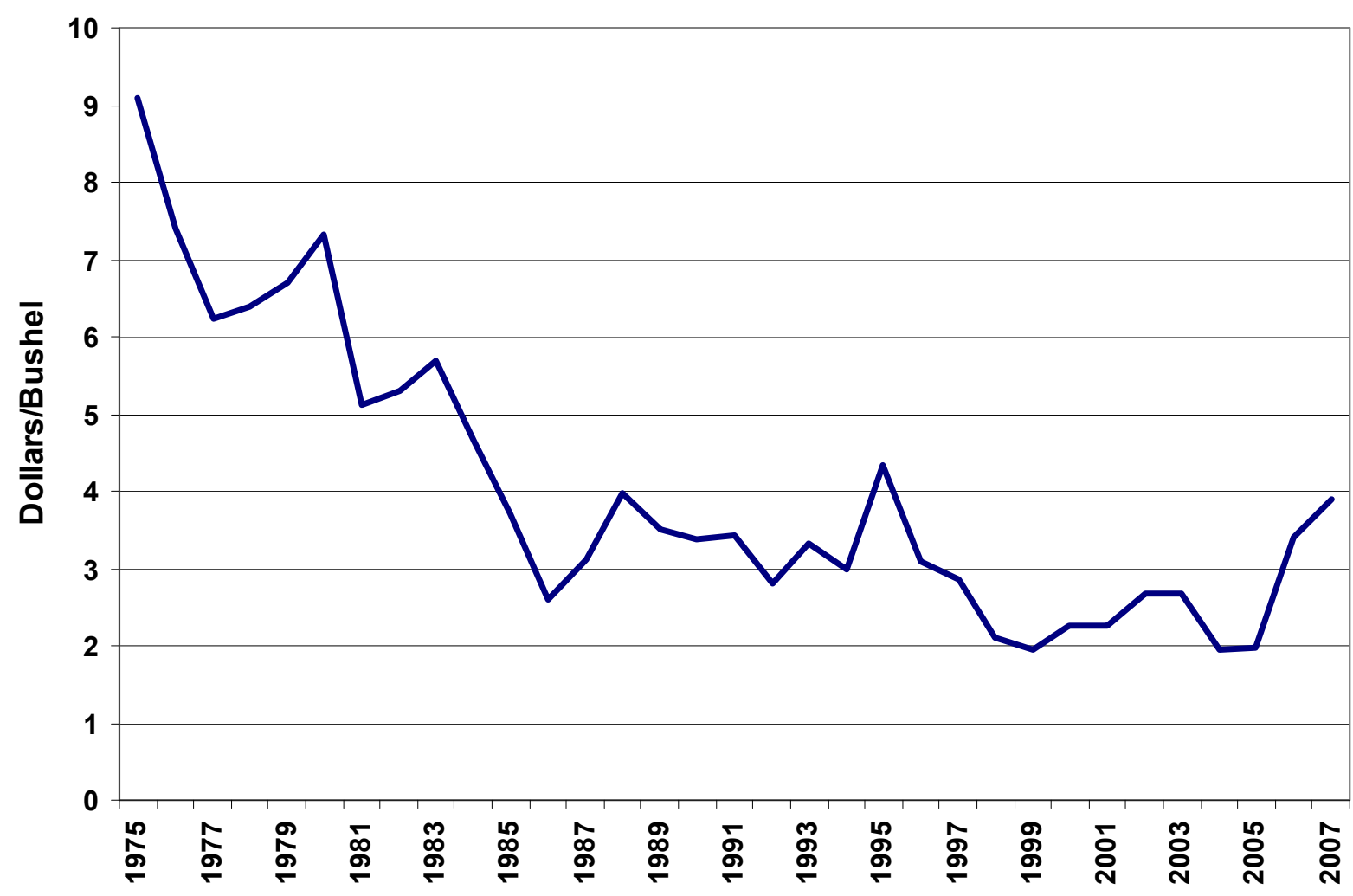

Source:

U.S. Department of Agriculture, National Agricultural Statistics Service, http://www.nass.usda.gov/ 
Sorghum is grown in areas that are generally too dry for unirrigated corn, thus potential resource areas for starch based ethanol can be expanded through use of sorghum. Grain weight per bushel is $56 \mathrm{lbs}$. at assumed harvest moisture content of $14 \%$.

Table 5.16

Sorghum: Area, Yield, Production, and Value, 1996-2007

\begin{tabular}{|c|c|c|c|c|c|c|c|c|c|}
\hline \multirow[b]{2}{*}{ Year } & \multirow[b]{2}{*}{$\begin{array}{c}\text { Area } \\
\text { Planted } \\
\text { for all } \\
\text { purposes }^{a}\end{array}$} & \multicolumn{5}{|c|}{ Sorghum for grain ${ }^{D}$} & \multicolumn{3}{|c|}{ Sorghum for silage } \\
\hline & & $\begin{array}{c}\text { Area } \\
\text { harvested }\end{array}$ & $\begin{array}{l}\text { Yield per } \\
\text { harvested } \\
\text { acre }\end{array}$ & Production & $\begin{array}{l}\text { Marketing year } \\
\text { average price per } \\
\text { cwt }^{\text {cd }}\end{array}$ & $\begin{array}{c}\text { Value of } \\
\text { production }^{\text {cd }}\end{array}$ & $\begin{array}{c}\text { Area } \\
\text { Harvested }\end{array}$ & $\begin{array}{c}\text { Yield per } \\
\text { harvested } \\
\text { acre }\end{array}$ & Production \\
\hline & 1,000 & & & 1,000 & & & 1,000 & & \\
\hline & Acres & 1,000 Acres & Bushels & Bushels & Dollars & 1,000 Dollars & Acres & Tons & 1,000 Tons \\
\hline 1996 & 13,097 & 11,811 & 67.3 & 795,274 & 4.17 & $1,986,316$ & 423 & 11.8 & 4,976 \\
\hline 1997 & 10,052 & 9,158 & 69.2 & 633,545 & 3.95 & $1,408,534$ & 412 & 13.1 & 5,385 \\
\hline 1998 & 9,626 & 7,723 & 67.3 & 519,933 & 2.97 & 904,123 & 308 & 11.4 & 3,526 \\
\hline 1999 & 9,288 & 8,544 & 69.7 & 595,166 & 2.80 & 937,081 & 320 & 11.6 & 3,716 \\
\hline 2000 & 9,195 & 7,726 & 60.9 & 470,526 & 3.37 & 845,755 & 278 & 10.5 & 2,932 \\
\hline 2001 & 10,248 & 8,579 & 59.9 & 514,040 & 3.46 & 978,783 & 352 & 11.0 & 3,860 \\
\hline 2002 & 9,589 & 7,125 & 50.6 & 360,713 & 4.14 & 855,140 & 408 & 9.6 & 3,913 \\
\hline 2003 & 9,420 & 7,798 & 52.7 & 411,237 & 4.26 & 964,978 & 343 & 10.4 & 3,552 \\
\hline 2004 & 7,486 & 6,517 & 69.6 & 453,654 & 3.19 & 843,464 & 352 & 13.6 & 4,776 \\
\hline 2005 & 6,454 & 5,736 & 68.5 & 392,933 & 3.33 & 737,038 & 311 & 13.6 & 4,218 \\
\hline 2006 & 6,522 & 4,937 & 56.2 & 277,538 & 5.88 & 885,394 & 347 & 13.4 & 4,642 \\
\hline $2007^{d}$ & 7,718 & 6,805 & 74.2 & 504,993 & 6.95 & $1,950,936$ & 399 & 15.6 & 6,206 \\
\hline
\end{tabular}

\section{Source:}

USDA, 2008 Agricultural Statistics, Table 1-62,

http://www.nass.usda.gov/Publications/Ag Statistics/index.asp

${ }^{\text {a }}$ Grain and sweet sorghum for all uses, including syrup.

${ }^{\mathrm{b}}$ Includes both grain sorghum for grain, and sweet sorghum for grain or seed.

${ }^{c}$ Based on the reported price of grain sorghum; cwt $=100$ pounds.

${ }^{\mathrm{d}}$ Preliminary. 
Sorghum is used for ethanol production only in the two states that planted over 2 million acres, Kansas and Texas.

Table 5.17

Sorghum: Area, Yield, and Production, by State, 2005-2007

\begin{tabular}{|c|c|c|c|c|c|c|c|c|c|c|c|c|}
\hline \multirow{3}{*}{ State } & \multicolumn{3}{|c|}{ Area planted for all purposes } & \multicolumn{9}{|c|}{ Sorghum for grain } \\
\hline & \multirow[b]{2}{*}{2005} & \multirow[b]{2}{*}{2006} & \multirow[b]{2}{*}{$2007^{a}$} & \multicolumn{3}{|c|}{ Area harvested } & \multicolumn{3}{|c|}{ Yield per harvested acre } & \multicolumn{3}{|c|}{ Production } \\
\hline & & & & 2005 & 2006 & $2007^{a}$ & 2005 & 2006 & $2007^{a}$ & 2005 & 2006 & $2007^{\mathrm{a}}$ \\
\hline & 1,000 & 1,000 & 1,000 & 1,000 & 1,000 & 1,000 & & & & 1,000 & 1,000 & 1,000 \\
\hline & Acres & Acres & Acres & Acres & Acres & Acres & Bushels & Bushels & Bushels & Bushels & Bushels & Bushels \\
\hline Alabama & 10 & 10 & 12 & 6 & 5 & 6 & 53 & 43 & 45 & 318 & 215 & 270 \\
\hline Arizona & 23 & 24 & 45 & 7 & 7 & 21 & 95 & 95 & 95 & 665 & 665 & 1995 \\
\hline Arkansas & 66 & 63 & 225 & 62 & 60 & 215 & 80 & 85 & 94 & 4,960 & 5,100 & 20,210 \\
\hline California & 26 & 32 & 34 & 10 & 10 & 11 & 90 & 105 & 90 & 900 & 1,050 & 990 \\
\hline Colorado & 160 & 280 & 220 & 110 & 130 & 150 & 31 & 26 & 37 & 3,410 & 3,380 & 5,550 \\
\hline Georgia & 40 & 40 & 65 & 27 & 26 & 45 & 50 & 45 & 46 & 1,350 & 1,170 & 2,070 \\
\hline Illinois & 85 & 75 & 80 & 83 & 72 & 77 & 92 & 89 & 81 & 7,636 & 6,408 & 6,237 \\
\hline Kansas & 2,750 & 2,750 & 2,800 & 2,600 & 2,500 & 2,650 & 75 & 58 & 80 & 195,000 & 145,000 & 212,000 \\
\hline Kentucky & 25 & 18 & 15 & 24 & 16 & 12 & 90 & 85 & 90 & 2,160 & 1,360 & 1,080 \\
\hline Louisiana & 90 & 90 & 250 & 88 & 87 & 245 & 99 & 96 & 97 & 8,712 & 8,352 & 23,765 \\
\hline Mississippi & 25 & 15 & 145 & 23 & 13 & 115 & 80 & 80 & 82 & 1,840 & 1,040 & 9,430 \\
\hline Missouri & 135 & 100 & 110 & 130 & 95 & 105 & 76 & 85 & 96 & 9,880 & 8,075 & 10,080 \\
\hline Nebraska & 340 & 370 & 350 & 250 & 240 & 240 & 87 & 80 & 98 & 21,750 & 19,200 & 23,520 \\
\hline New Mexico & 120 & 110 & 105 & 97 & 60 & 75 & 45 & 35 & 40 & 4,365 & 2,100 & 3,000 \\
\hline North Carolina & 16 & 17 & 15 & 13 & 13 & 9 & 50 & 47 & 60 & 650 & 611 & 540 \\
\hline Oklahoma & 270 & 270 & 240 & 240 & 200 & 220 & 48 & 34 & 58 & 11,520 & 6,800 & 12,760 \\
\hline Pennsylvania & 11 & 13 & 15 & 4 & 5 & 3 & 50 & 66 & 56 & 200 & 330 & 168 \\
\hline South Carolina & 10 & 11 & 10 & 7 & 7 & 7 & 51 & 51 & 34 & 357 & 357 & 238 \\
\hline South Dakota & 180 & 220 & 210 & 85 & 80 & 130 & 52 & 36 & 62 & 4,420 & 2,880 & 8,060 \\
\hline Tennessee & 22 & 14 & 22 & 20 & 11 & 19 & 92 & 95 & 70 & 1,840 & 1,045 & 1,330 \\
\hline Texas & 2,050 & 2,000 & 2,750 & 1,850 & 1,300 & 2,450 & 60 & 48 & 66 & 111,000 & 62,400 & 161,700 \\
\hline US & 6,454 & 6,522 & 7,718 & 5,736 & 4,937 & 6,805 & 68.5 & 56.2 & 74.2 & 392,933 & 277,538 & 504,993 \\
\hline
\end{tabular}

\section{Source:}

USDA, 2006 Agricultural Statistics, Table 1-62, http://www.nass.usda.gov/Publications/Ag Statistics/index.asp

${ }^{a}$ Preliminary. 
The lower yields of sorghum grain results in lower profit in sorghum production compared to corn. Sorghum biomass production can be quite high, making it a potential source of crop residue in some areas of the country.

Table 5.18

Sorghum Production Costs and Returns per Planted Acre by Region, Excluding Government Payments, 2006-2007 (Dollars per planted acre)

\begin{tabular}{|c|c|c|c|c|c|c|c|c|c|c|}
\hline \multirow[b]{2}{*}{ Item } & \multicolumn{2}{|c|}{ United States } & \multicolumn{2}{|c|}{ Heartland } & \multicolumn{2}{|c|}{ Prairie Gateway } & \multicolumn{2}{|c|}{ Fruitful Rim } & \multicolumn{2}{|c|}{ Northern Great Plains } \\
\hline & 2006 & 2007 & 2006 & 2007 & 2006 & 2007 & 2006 & 2007 & 2006 & 2007 \\
\hline \multicolumn{11}{|l|}{ Gross value of production: } \\
\hline Primary product: Sorghum & 126.85 & 235.28 & 215.66 & 303.62 & 135 & 240.1 & 90.42 & 222.65 & 93.31 & 179.82 \\
\hline Secondary product: Sorgum silage & 6.23 & 10.81 & 0 & 0 & 7.92 & 14.35 & 0 & 0 & 3.31 & 6.72 \\
\hline Total, gross value of production & 133.08 & 246.09 & 215.66 & 303.62 & 142.92 & 254.45 & 90.42 & 222.65 & 96.62 & 186.54 \\
\hline \multicolumn{11}{|l|}{ Operating costs: } \\
\hline Seed & 5.38 & 5.62 & 8.87 & 9.18 & 4.96 & 5.13 & 6.46 & 6.68 & 6.93 & 7.17 \\
\hline Fertilizer $^{b}$ & 25.8 & 30.11 & 50.9 & 59.1 & 25.14 & 29.19 & 27.49 & 31.92 & 21.92 & 25.45 \\
\hline Chemicals & 18.07 & 18.15 & 20.28 & 20.92 & 20.56 & 21.21 & 7.5 & 7.74 & 14.46 & 14.92 \\
\hline Custom operations & 9.91 & 10.4 & 5.93 & 6.18 & 9.95 & 10.38 & 10.79 & 11.25 & 7.78 & 8.11 \\
\hline Fuel, lube, and electricity & 34.46 & 43.15 & 15.94 & 18.25 & 39.56 & 49.77 & 21.84 & 29.24 & 6.44 & 8.43 \\
\hline Repairs & 17.76 & 18.35 & 15.96 & 16.51 & 18.84 & 19.49 & 15.98 & 16.53 & 8.37 & 8.66 \\
\hline Purchased irrigation water & 0.11 & 0.14 & 0 & 0 & 0 & 0 & 0.6 & 0.63 & 0.16 & 0.17 \\
\hline Interest on operating inputs & 2.63 & 2.78 & 2.79 & 2.87 & 2.81 & 2.98 & 2.14 & 2.29 & 1.56 & 1.61 \\
\hline Total, operating costs & 114.12 & 128.7 & 120.67 & 133.01 & 121.82 & 138.15 & 92.8 & 106.28 & 67.62 & 74.52 \\
\hline \multicolumn{11}{|l|}{ Allocated overhead: } \\
\hline Hired labor & 5.04 & 5.69 & 2.39 & 2.47 & 3.48 & 3.6 & 13.95 & 14.44 & 0.6 & 0.62 \\
\hline Opportunity cost of unpaid labor & 27.35 & 28.21 & 25.64 & 26.54 & 28.98 & 30 & 23.63 & 24.46 & 15.95 & 16.51 \\
\hline Capital recovery of machinery and equipment & 64.34 & 67.48 & 56.87 & 59.68 & 66.91 & 70.22 & 60.06 & 63.03 & 43.03 & 45.16 \\
\hline Opportunity cost of land & 34.4 & 36.92 & 66.08 & 70.77 & 33.4 & 35.77 & 35.05 & 37.54 & 36.62 & 39.22 \\
\hline Taxes and insurance & 4.28 & 4.55 & 21.86 & 23.62 & 4.1 & 4.43 & 2.83 & 3.06 & 5.74 & 6.2 \\
\hline General farm overhead & 8 & 8.4 & 27.03 & 27.96 & 6.82 & 7.06 & 10.46 & 10.82 & 11.19 & 11.58 \\
\hline Total, allocated overhead & 143.41 & 151.25 & 199.87 & 211.04 & 143.69 & 151.08 & 145.98 & 153.35 & 113.13 & 119.29 \\
\hline Total costs listed & 257.53 & 279.95 & 320.54 & 344.05 & 265.51 & 289.23 & 238.78 & 259.63 & 180.75 & 193.81 \\
\hline Value of production less total costs listed & -124.45 & -33.86 & -104.88 & -40.43 & -122.59 & -34.78 & -148.36 & -36.98 & -84.13 & -7.27 \\
\hline Value of production less operating costs & 18.96 & 117.39 & 94.99 & 170.61 & 21.1 & 116.3 & -2.38 & 116.37 & 29 & 112.02 \\
\hline \multicolumn{11}{|l|}{ Supporting information: } \\
\hline Sorghum Yield: bushels per planted acre & 43 & 68 & 82 & 94 & 45 & 70 & 33 & 61 & 31 & 54 \\
\hline Price: dollars per bushel & 2.95 & 3.46 & 2.63 & 3.23 & 3 & 3.43 & 2.74 & 3.65 & 3.01 & 3.33 \\
\hline Enterprise size (planted acres) ${ }^{a}$ & 297 & 297 & 125 & 125 & 68 & 269 & 785 & 785 & 272 & 272 \\
\hline \multicolumn{11}{|l|}{ Production practices: ${ }^{a}$} \\
\hline Irrigated (percent) & 11 & 11 & 6 & 6 & 13 & 13 & 13 & 13 & 13 & 13 \\
\hline Dryland (percent) & 89 & 89 & 94 & 94 & 87 & 87 & 87 & 87 & 87 & 87 \\
\hline
\end{tabular}

Source:

Economic Research Service, U.S. Department of Agriculture, http://www.ers.usda.gov/data/costsandreturns/testpick.htm

a Developed from survey base year, 2003.

${ }^{\mathrm{b}}$ Commercial fertilizer and soil conditioners. 
USDA's wheat baseline projections show a continuing rise in yield per harvested acre, but a leveling off of planted acres and net returns (over variable costs). This analysis is updated annually.

Table 5.19

Wheat Baseline Projections, 2006 - 2018

\begin{tabular}{|c|c|c|c|c|c|c|c|c|c|c|c|c|}
\hline Item & $2006 / 07$ & $2007 / 08$ & $2008 / 09$ & $2009 / 10$ & $2010 / 11$ & $2011 / 12$ & $2012 / 13$ & $2013 / 14$ & $2014 / 15$ & $2015 / 16$ & $2016 / 17$ & $2017 / 18$ \\
\hline \multicolumn{13}{|l|}{ Area (million acres): } \\
\hline Planted acres & 57.3 & 60.4 & 65.0 & 60.0 & 58.5 & 57.5 & 56.5 & 56.5 & 56.0 & 56.0 & 55.5 & 55.5 \\
\hline Harvested acres & 46.8 & 51.0 & 55.3 & 51.0 & 49.7 & 48.9 & 48.0 & 48.0 & 47.6 & 47.6 & 47.2 & 47.2 \\
\hline \multicolumn{13}{|l|}{ Yields (bushels per acre): } \\
\hline Yield/harvested acre & 38.7 & 40.5 & 42.5 & 42.8 & 43.1 & 43.4 & 43.7 & 44.0 & 44.3 & 44.6 & 44.9 & 45.2 \\
\hline \multicolumn{13}{|c|}{ Supply and use (million bushels): } \\
\hline Beginning stocks & 571 & 456 & 312 & 606 & 703 & 742 & 749 & 732 & 716 & 696 & 683 & 661 \\
\hline Production & 1,812 & 2,067 & 2,350 & 2,185 & 2,140 & 2,120 & 2,100 & 2,110 & 2,110 & 2,125 & 2,120 & 2,135 \\
\hline Imports & 122 & 90 & 100 & 100 & 105 & 105 & 110 & 110 & 115 & 115 & 120 & 120 \\
\hline Supply & 2,505 & 2,613 & 2,762 & 2,891 & 2,948 & 2,967 & 2,959 & 2,952 & 2,941 & 2,936 & 2,923 & 2,916 \\
\hline Feed $\&$ residual & 934 & 940 & 950 & 959 & 968 & 977 & 986 & 995 & 1,004 & 1,013 & 1,022 & 1,031 \\
\hline Food, seed, \& industrial & 81 & 86 & 81 & 79 & 78 & 76 & 76 & 76 & 76 & 75 & 75 & 75 \\
\hline Fuel alcohol use $^{a}$ & 125 & 125 & 175 & 200 & 210 & 215 & 215 & 215 & 215 & 215 & 215 & 215 \\
\hline Domestic & 1,140 & 1,151 & 1,206 & 1,238 & 1,256 & 1,268 & 1,277 & 1,286 & 1,295 & 1,303 & 1,312 & 1,321 \\
\hline Exports & 909 & 1,150 & 950 & 950 & 950 & 950 & 950 & 950 & 950 & 950 & 950 & 950 \\
\hline Total use & 2,049 & 2,301 & 2,156 & 2,188 & 2,206 & 2,218 & 2,227 & 2,236 & 2,245 & 2,253 & 2,262 & 2,271 \\
\hline Ending stocks & 456 & 312 & 606 & 703 & 742 & 749 & 732 & 716 & 696 & 683 & 661 & 645 \\
\hline Stocks/use ratio, percent & 22.3 & 13.6 & 28.1 & 32.1 & 33.6 & 33.8 & 32.9 & 32.0 & 31.0 & 30.3 & 29.2 & 28.4 \\
\hline \multicolumn{13}{|l|}{ Prices (dollars per bushel): } \\
\hline Farm price & 4.26 & 6.10 & 5.50 & 5.00 & 4.65 & 4.50 & 4.50 & 4.50 & 4.55 & 4.55 & 4.60 & 4.65 \\
\hline Loan rate & 2.75 & 2.75 & 2.75 & 2.75 & 2.75 & 2.75 & 2.75 & 2.75 & 2.75 & 2.75 & 2.75 & 2.75 \\
\hline \multicolumn{13}{|c|}{ Variable costs of production (dollars): } \\
\hline Per acre & 85.50 & 93.84 & 98.38 & 101.32 & 103.01 & 104.63 & 106.10 & 107.43 & 109.10 & 110.79 & 112.49 & 114.10 \\
\hline Per bushel & 2.21 & 2.32 & 2.31 & 2.37 & 2.39 & 2.41 & 2.43 & 2.44 & 2.46 & 2.48 & 2.51 & 2.52 \\
\hline \multicolumn{13}{|c|}{ Returns over variable costs (dollars per acre): } \\
\hline Net returns ${ }^{a}$ & 79.36 & 153.21 & 135.37 & 112.68 & 97.41 & 90.67 & 90.55 & 90.57 & 92.47 & 92.14 & 94.05 & 96.08 \\
\hline
\end{tabular}

Source:

USDA Long-Term Agricultural, Projection Tables to 2018, February 2008, Table 12 - U.S. wheat longterm projections,

http://usda.mannlib.cornell.edu/MannUsda/viewDocumentInfo.do?documentID=1192

Note: Marketing year beginning June 1 for corn. 
Overall, the price for corn has been declining due to improvements in farming techniques.

Figure 5.9

Wheat: Price per Bushel, 1975-2007

(Constant 2007 dollars)

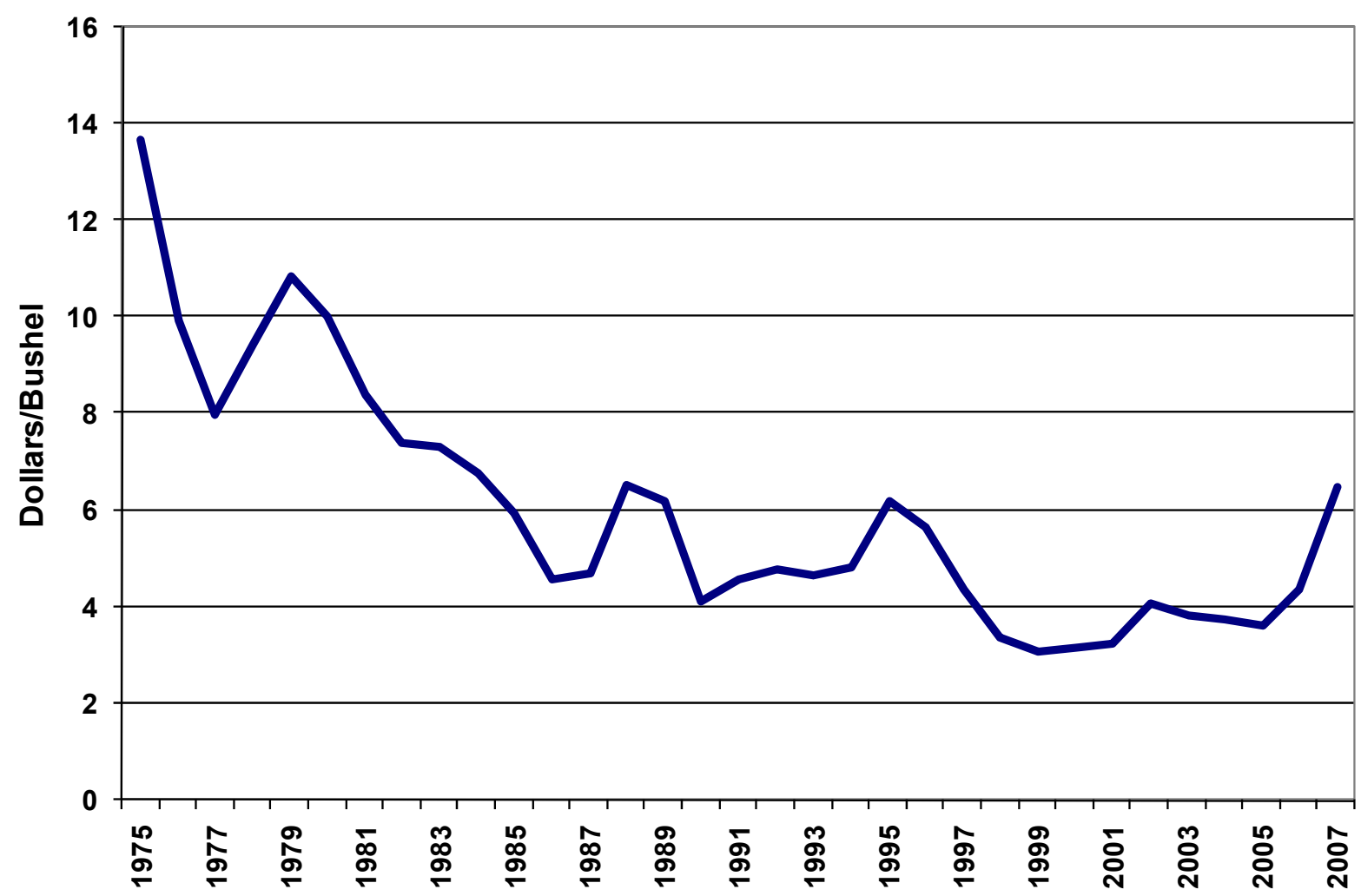

Source:

U.S. Department of Agriculture, National Agricultural Statistics Service, http://www.nass.usda.gov/ 
Table 5.20

Wheat: Area, Yield, Production, and Value, 1996-2007

\begin{tabular}{|c|c|c|c|c|c|c|}
\hline \multirow[b]{2}{*}{ Year } & \multicolumn{2}{|c|}{ Area } & \multirow{2}{*}{$\begin{array}{c}\text { Yield per } \\
\text { harvested acre }\end{array}$} & \multirow[b]{2}{*}{ Production } & \multirow{2}{*}{$\begin{array}{c}\text { Marketing year average } \\
\text { price per bushel received } \\
\text { by farmers }\end{array}$} & \multirow{2}{*}{$\begin{array}{c}\text { Value of } \\
\text { production }^{\text {b }}\end{array}$} \\
\hline & Planted $^{\mathrm{a}}$ & harvested & & & & \\
\hline & 1,000 Acres & 1,000 Acres & Bushels & 1,000 Bushels & Dollars & 1,000 Dollars \\
\hline 1996 & 75,105 & 62,819 & 36.3 & $2,277,388$ & 4.30 & $9,782,238$ \\
\hline 1997 & 70,412 & 62,840 & 39.5 & $2,481,466$ & 3.38 & $8,286,741$ \\
\hline 1998 & 65,821 & 59,002 & 43.2 & $2,547,321$ & 2.65 & $6,780,623$ \\
\hline 1999 & 62,664 & 53,773 & 42.7 & $2,295,560$ & 2.48 & $5,586,675$ \\
\hline 2000 & 62,549 & 53,063 & 42.0 & $2,228,160$ & 2.62 & $5,771,786$ \\
\hline 2001 & 59,432 & 48,473 & 40.2 & $1,947,453$ & 2.78 & $5,412,834$ \\
\hline 2002 & 60,318 & 45,824 & 35.0 & $1,605,878$ & 3.56 & $5,637,416$ \\
\hline 2003 & 62,141 & 53,063 & 44.2 & $2,344,760$ & 3.40 & $7,929,039$ \\
\hline 2004 & 59,674 & 49,999 & 43.2 & $2,158,245$ & 3.40 & $7,283,324$ \\
\hline 2005 & 57,229 & 50,119 & 42.0 & $2,104,690$ & 3.42 & $7,171,441$ \\
\hline 2006 & 57,344 & 46,810 & 38.7 & $1,812,036$ & 4.26 & $7,710,014$ \\
\hline 2007 & 60,433 & 51,011 & 40.5 & $2,066,722$ & 6.65 & $13,669,482$ \\
\hline
\end{tabular}

Source:

U.S. Department of Agriculture, 2008 Agricultural Statistics, Table 1-2 and annual, http://www.nass.usda.gov/Publications/Ag Statistics/index.asp

${ }^{a}$ Includes area seeded in preceding fall for winter wheat.

b Includes allowance for loans outstanding and purchases by the Government valued at the average loan and purchase rate, by States, where applicable. 
Table 5.21

Wheat: Area, Yield, and Production, by State, 2005-2007

\begin{tabular}{|c|c|c|c|c|c|c|c|c|c|c|c|c|}
\hline \multirow{2}{*}{ State } & \multicolumn{3}{|c|}{ Area planted $^{\mathrm{a}}$} & \multicolumn{3}{|c|}{ Area harvested } & \multicolumn{3}{|c|}{ Yield per harvested acre } & \multicolumn{3}{|c|}{ Production } \\
\hline & 2005 & 2006 & 2007 & 2005 & 2006 & 2007 & 2005 & 2006 & 2007 & 2005 & 2006 & 2007 \\
\hline & 1,000 & 1,000 & 1,000 & 1,000 & 1,000 & 1,000 & & & & 1,000 & 1,000 & 1,000 \\
\hline & Acres & Acres & Acres & Acres & Acres & Acres & Bushels & Bushels & Bushels & Bushels & Bushels & Bushels \\
\hline Alabama & 100 & 100 & 120 & 45 & 45 & 80 & 50.0 & 58.0 & 43.0 & 2,250 & 2,610 & 3,440 \\
\hline Arizona & 85 & 79 & 86 & 81 & 76 & 83 & 99.5 & 99.7 & 99.5 & 8,060 & 7,580 & 8,260 \\
\hline Arkansas & 220 & 365 & 820 & 160 & 305 & 700 & 52.0 & 61.0 & 41.0 & 8,320 & 18,605 & 28,700 \\
\hline California & 570 & 520 & 585 & 369 & 315 & 315 & 76.3 & 66.5 & 83.6 & 28,155 & 20,935 & 26,325 \\
\hline Colorado & 2,570 & 2,170 & 2,520 & 2219 & 1,919 & 2369 & 24.4 & 21.6 & 40.3 & 54,035 & 41,515 & 95,520 \\
\hline Delaware & 52 & 48 & 57 & 51 & 45 & 55 & 70.0 & 67.0 & 68.0 & 3,570 & 3,015 & 3,740 \\
\hline Florida & 18 & 8 & 13 & 8 & 5 & 9 & 45.0 & 42.0 & 57.0 & 360 & 210 & 513 \\
\hline Georgia & 280 & 230 & 360 & 140 & 120 & 230 & 52.0 & 49.0 & 40.0 & 7,280 & 5,880 & 9,200 \\
\hline Idaho & 1,260 & 1,255 & 1,235 & 1,200 & 1,195 & 1,175 & 83.8 & 75.6 & 71.2 & 100,590 & 90,315 & 83,675 \\
\hline Illinois & 630 & 930 & 1,000 & 600 & 910 & 890 & 61.0 & 67.0 & 57.0 & 36,600 & 60,970 & 50,730 \\
\hline Indiana & 360 & 470 & 420 & 340 & 460 & 370 & 72.0 & 69.0 & 57.0 & 24,480 & 31,740 & 21,090 \\
\hline lowa & 20 & 25 & 35 & 15 & 18 & 28 & 50.0 & 66.0 & 50.0 & 750 & 1,188 & 1,400 \\
\hline Kansas & 10,000 & 9,800 & 10,400 & 9,500 & 9,100 & 8,600 & 40.0 & 32.0 & 33.0 & 380,000 & 291,200 & 283,800 \\
\hline Kentucky & 390 & 430 & 440 & 300 & 320 & 250 & 68.0 & 71.0 & 49.0 & 20,400 & 22,720 & 12,250 \\
\hline Louisiana & 110 & 115 & 235 & 100 & 105 & 220 & 48.0 & 53.0 & 54.0 & 4,800 & 5,565 & 11,880 \\
\hline Maryland & 155 & 210 & 220 & 140 & 125 & 170 & 66.0 & 68.0 & 68.0 & 9,240 & 8,500 & 11,560 \\
\hline Michigan & 600 & 660 & 560 & 590 & 650 & 540 & 66.0 & 73.0 & 65.0 & 38,940 & 47,450 & 35,100 \\
\hline Minnesota & 1,820 & 1,750 & 1,765 & 1,745 & 1,695 & 1,710 & 41.0 & 47.4 & 47.0 & 71,470 & 80,340 & 80,430 \\
\hline Mississippi & 70 & 85 & 370 & 65 & 73 & 330 & 50.0 & 59.0 & 56.0 & 3,250 & 4,307 & 18,480 \\
\hline Missouri & 590 & 1,000 & 1,050 & 540 & 910 & 880 & 54.0 & 54.0 & 43.0 & 29,160 & 49,140 & 37,840 \\
\hline Montana & 5,340 & 5,300 & 5,170 & 5,235 & 5,215 & 5,065 & 36.8 & 29.4 & 29.6 & 192,480 & 153,075 & 149,820 \\
\hline Nebraska & 1,850 & 1,800 & 2,050 & 1,760 & 1,700 & 1,960 & 39.0 & 36.0 & 43.0 & 68,640 & 61,200 & 84,280 \\
\hline Nevada & 14 & 23 & 23 & 8 & 10 & 13 & 100.6 & 105.6 & 100.0 & 805 & 1,056 & 1,300 \\
\hline New Jersey & 28 & 25 & 31 & 23 & 22 & 28 & 53.0 & 60.0 & 51.0 & 1,219 & 1,320 & 1,428 \\
\hline New Mexico & 450 & 440 & 490 & 270 & 120 & 300 & 36.0 & 32.0 & 26.0 & 9,720 & 3,840 & 7,800 \\
\hline New York & 100 & 105 & 100 & 95 & 95 & 85 & 54.0 & 61.0 & 52.0 & 5,130 & 5,795 & 4,420 \\
\hline North Carolina & 560 & 560 & 630 & 435 & 420 & 500 & 57.0 & 59.0 & 40.0 & 24,795 & 24,780 & 20,000 \\
\hline North Dakota & 9,090 & 8,800 & 8,595 & 8,835 & 8,290 & 8,405 & 34.4 & 30.4 & 35.7 & 303,765 & 251,770 & 300,050 \\
\hline Ohio & 860 & 990 & 820 & 830 & 960 & 730 & 71.0 & 68.0 & 63.0 & 58,930 & 65,280 & 45,990 \\
\hline Oklahoma & 5,700 & 5,700 & 5,900 & 4,000 & 3,400 & 3,500 & 32.0 & 24.0 & 28.0 & 128,000 & 81,600 & 98,000 \\
\hline Oregon & 955 & 880 & 875 & 895 & 845 & 855 & 59.8 & 52.6 & 54.7 & 53,560 & 44,440 & 46,785 \\
\hline Pennsylvania & 150 & 160 & 170 & 145 & 150 & 155 & 54.0 & 59.0 & 58.0 & 7,830 & 8,850 & 8,990 \\
\hline South Carolina & 170 & 130 & 160 & 165 & 123 & 135 & 52.0 & 50.0 & 31.0 & 8,580 & 6,150 & 4,185 \\
\hline South Dakota & 3,315 & 3,310 & 3,509 & 3,193 & 2,576 & 3,328 & 41.8 & 32.6 & 44.3 & 133,420 & 84,090 & 147,516 \\
\hline Tennessee & 240 & 280 & 420 & 150 & 190 & 260 & 56.0 & 64.0 & 41.0 & 8,400 & 12,160 & 10,660 \\
\hline Texas & 5,500 & 5,550 & 6,200 & 3,000 & 1,400 & 3,800 & 32.0 & 24.0 & 37.0 & 96,000 & 33,600 & 140,600 \\
\hline Utah & 163 & 144 & 146 & 148 & 136 & 132 & 48.0 & 45.0 & 48.6 & 7,099 & 6,120 & 6,420 \\
\hline Virginia & 180 & 190 & 230 & 160 & 155 & 205 & 63.0 & 68.0 & 64.0 & 10,080 & 10,540 & 13,120 \\
\hline Washington & 2,280 & 2,280 & 2,170 & 2,225 & 2,225 & 2,137 & 62.6 & 62.9 & 60.2 & 139,300 & 140,050 & 128,722 \\
\hline West Virginia & 7 & 8 & 8 & 5 & 6 & 6 & 60.0 & 61.0 & 58.0 & 300 & 366 & 348 \\
\hline Wisconsin & 208 & 261 & 299 & 182 & 240 & 278 & 56.4 & 76.2 & 68.0 & 10,262 & 18,290 & 18,910 \\
\hline Wyoming & 169 & 158 & 146 & 152 & 141 & 130 & 30.7 & 27.5 & 26.5 & 4,665 & 3,879 & 3,445 \\
\hline US & 57,229 & 57,344 & 60,433 & 50,119 & 46,810 & \begin{tabular}{|l|}
51,011 \\
\end{tabular} & 42.0 & 38.7 & 40.5 & $2,104,690$ & $1,812,036$ & $2,066,722$ \\
\hline
\end{tabular}

Source:

U.S. Department of Agriculture, 2008 Agricultural Statistics, Table 1-6, http://www.nass.usda.gov/Publications/Ag Statistics/index.asp

${ }^{a}$ Includes area planted preceding fall. 
Table 5.22

Wheat: Supply and Disappearance, 1996-2007 (Million bushels)

\begin{tabular}{|c|c|c|c|c|c|c|c|c|c|c|c|}
\hline \multirow{3}{*}{$\begin{array}{c}\text { Year } \\
\text { (beginning } \\
\text { September 1) }\end{array}$} & \multicolumn{4}{|c|}{ Supply } & \multicolumn{6}{|c|}{ Disappearance } & \multirow{3}{*}{$\begin{array}{l}\text { Ending } \\
\text { stocks } \\
\text { May } 31\end{array}$} \\
\hline & \multirow[b]{2}{*}{$\begin{array}{c}\text { Beginning } \\
\text { stocks }\end{array}$} & \multirow[b]{2}{*}{ Production } & \multirow[b]{2}{*}{ Imports } & \multirow[b]{2}{*}{ Total } & \multicolumn{4}{|c|}{ Domestic use } & \multirow[b]{2}{*}{ Exports } & \multirow{2}{*}{$\begin{array}{c}\text { Total } \\
\text { disappea } \\
\text { rance }\end{array}$} & \\
\hline & & & & & Food & Seed & Feed & Total & & & \\
\hline 1996 & 376 & 2,277 & 92 & 2,746 & 891 & 102 & 308 & 1,301 & 1,002 & 2302 & 444 \\
\hline 1997 & 444 & 2,481 & 95 & 3,020 & 914 & 92 & 251 & 1,257 & 1,040 & 2,298 & 722 \\
\hline 1998 & 722 & 2,547 & 103 & 3,373 & 909 & 81 & 391 & 1,381 & 1,046 & 2,427 & 946 \\
\hline 1999 & 946 & 2,296 & 95 & 3,336 & 929 & 92 & 279 & 1,300 & 1,086 & 2,386 & 950 \\
\hline 2000 & 950 & 2,228 & 90 & 3,268 & 950 & 79 & 300 & 1,330 & 1,062 & 2,392 & 876 \\
\hline 2001 & 876 & 1,947 & 108 & 2,931 & 926 & 83 & 182 & 1,192 & 962 & 2,154 & 777 \\
\hline 2002 & 777 & 1,606 & 77 & 2,460 & 919 & 84 & 116 & 1,119 & 850 & 1,969 & 491 \\
\hline 2003 & 491 & 2,345 & 63 & 2,899 & 912 & 80 & 203 & 1,194 & 1,158 & 2353 & 546 \\
\hline 2004 & 546 & 2,158 & 71 & 2,775 & 907 & 78 & 182 & 1,169 & 1,066 & 2,235 & 540 \\
\hline 2005 & 540 & 2,105 & 81 & 2,726 & 915 & 78 & 160 & 1,152 & 1,003 & 2,155 & 571 \\
\hline 2006 & 571 & 1,812 & 122 & 2,505 & 934 & 81 & 125 & 1,140 & 909 & 2,049 & 456 \\
\hline $2007^{c}$ & 456 & 2,067 & 90 & 2,613 & 940 & 86 & 125 & 1,151 & 1,150 & 2,301 & 312 \\
\hline
\end{tabular}

Source:

U.S. Department of Agriculture, 2008 Agricultural Statistics, Table 1-7, and annual, http://www.nass.usda.gov/Publications/Ag Statistics/index.asp

${ }^{a}$ Imports and exports include flour and other products expressed in wheat equivalent.

${ }^{\mathrm{b}}$ Approximates feed and residual use and includes negligible quantities used for distilled spirits.

${ }^{c}$ Preliminary. Totals may not add due to independent rounding. 
Like corn and soybeans, the price per bushel of wheat rose considerably between 2006 and 2007.

Table 5.23

Wheat: Marketing Year Average Price and Value, by State, Crop of 2005, 2006, and 2007

\begin{tabular}{|c|c|c|c|c|c|c|}
\hline \multirow[b]{2}{*}{ State $^{a}$} & \multicolumn{3}{|c|}{ Marketing year average price per bushel } & \multicolumn{3}{|c|}{ Value of production } \\
\hline & 2005 & 2006 & $2007^{b}$ & 2005 & 2006 & $2007^{b}$ \\
\hline & Dollars & Dollars & Dollars & 1,000 Dollars & 1,000 Dollars & 1,000 Dollars \\
\hline Alabama & 3.10 & 3.95 & 5.15 & 6,975 & 10,310 & 17,716 \\
\hline Arizona & 4.19 & 4.85 & 6.95 & 33,756 & 36,774 & 57,370 \\
\hline Arkansas & 3.32 & 3.52 & 4.95 & 27,622 & 65,490 & 142,065 \\
\hline California & 3.74 & 4.14 & 5.90 & 104,458 & 86,686 & 156,139 \\
\hline Colorado & 3.43 & 4.54 & 6.35 & 185,921 & 189,027 & 607,844 \\
\hline Delaware & 3.01 & 3.27 & 5.90 & 10,746 & 9,859 & 22,066 \\
\hline Florida & 3.10 & 3.15 & 4.30 & 1,116 & 662 & 2,206 \\
\hline Georgia & 3.05 & 3.70 & 5.70 & 22,204 & 21,756 & 52,440 \\
\hline Idaho & 3.31 & 4.16 & 6.95 & 330,372 & 375,608 & 582,478 \\
\hline Illinois & 3.24 & 3.40 & 5.45 & 118,584 & 207,298 & 276,479 \\
\hline Indiana & 3.15 & 3.41 & 5.45 & 77,112 & 108,233 & 114,941 \\
\hline lowa & 3.10 & 3.35 & 5.25 & 2,325 & 3,980 & 7,350 \\
\hline Kansas & 3.31 & 4.56 & 6.20 & $1,257,800$ & $1,327,872$ & $1,759,560$ \\
\hline Kentucky & 3.31 & 3.45 & 5.75 & 67,524 & 78,384 & 70,438 \\
\hline Louisiana & 3.20 & 3.60 & 5.20 & 15,360 & 20,034 & 61,776 \\
\hline Maryland & 3.12 & 3.43 & 5.95 & 28,829 & 29,155 & 68,782 \\
\hline Michigan & 3.13 & 3.41 & 5.35 & 121,882 & 161,805 & 187,785 \\
\hline Minnesota & 3.66 & 4.55 & 7.35 & 261,440 & 364,404 & 589,145 \\
\hline Mississippi & 3.30 & 3.52 & 4.30 & 10,725 & 15,161 & 79,464 \\
\hline Missouri & 3.35 & 3.52 & 5.35 & 97,686 & 172,973 & 202,444 \\
\hline Montana & 3.63 & 4.54 & 7.60 & 698,286 & 693,854 & $1,138,176$ \\
\hline Nebraska & 3.36 & 4.57 & 6.20 & 230,630 & 279,684 & 522,536 \\
\hline Nevada & 3.28 & 4.15 & 6.50 & 2,638 & 4,356 & 8,425 \\
\hline New Jersey & 3.25 & 3.80 & 5.25 & 3,962 & 5,016 & 7,497 \\
\hline New Mexico & 3.25 & 4.55 & 5.50 & 31,590 & 17,472 & 42,900 \\
\hline New York & 3.34 & 4.03 & 6.75 & 17,134 & 23,354 & 29,835 \\
\hline North Carolina & 3.07 & 3.26 & 4.90 & 76,121 & 80,783 & 98,000 \\
\hline North Dakota & 3.55 & 4.50 & 7.70 & $1,077,147$ & $1,130,352$ & $2,332,400$ \\
\hline Ohio & 3.16 & 3.35 & 5.50 & 186,219 & 218,688 & 252,945 \\
\hline Oklahoma & 3.39 & 4.70 & 6.30 & 433,920 & 383,520 & 617,400 \\
\hline Oregon & 3.35 & 4.48 & 7.70 & 177,361 & 198,411 & 360,245 \\
\hline Pennsylvania & 3.50 & 3.52 & 6.60 & 27,405 & 31,152 & 59,334 \\
\hline South Carolina & 2.80 & 3.05 & 4.55 & 24,024 & 18,758 & 19,042 \\
\hline South Dakota & 3.65 & 4.44 & 6.55 & 484,694 & 374,316 & 960,515 \\
\hline Tennessee & 3.34 & 3.53 & 4.90 & 28,056 & 42,925 & 52,234 \\
\hline Texas & 3.44 & 4.47 & 6.30 & 330,240 & 150,192 & 885,780 \\
\hline Utah & 3.80 & 4.85 & 7.80 & 27,002 & 29,385 & 50,124 \\
\hline Virginia & 2.91 & 3.24 & 5.45 & 29,333 & 34,150 & 71,504 \\
\hline Washington & 3.32 & 4.49 & 7.60 & 456,316 & 625,821 & 978,287 \\
\hline West Virginia & 3.07 & 3.50 & 5.70 & 921 & 1,281 & 1,984 \\
\hline Wisconsin & 2.90 & 3.47 & 5.30 & 29,775 & 63,490 & 100,433 \\
\hline Wyoming & 3.48 & 4.53 & 6.40 & 16,230 & 17,583 & 21,398 \\
\hline US & 3.42 & 4.26 & 6.65 & $7,171,441$ & $7,710,014$ & $13,669,482$ \\
\hline
\end{tabular}

Source:

U.S. Department of Agriculture, 2008 Agricultural Statistics, Table 1-10, http://www.nass.usda.gov/Publications/Ag Statistics/index.asp

${ }^{\text {a }}$ States with no data are not listed.

${ }^{\mathrm{b}}$ Preliminary. 
Table 5.24

Wheat Production Costs and Returns per Planted Acre by Region, Excluding Government Payments, 2006-2007a (Dollars per planted acre)

\begin{tabular}{|c|c|c|c|c|c|c|c|c|c|c|c|c|c|c|}
\hline \multirow[b]{2}{*}{ Item } & \multicolumn{2}{|c|}{ United States } & \multicolumn{2}{|c|}{ Northern Great Plains } & \multicolumn{2}{|c|}{$\begin{array}{l}\text { Prarie Gateway } \\
\end{array}$} & \multicolumn{2}{|c|}{ Basin and Range } & \multicolumn{2}{|c|}{ Fruitful Rim } & \multicolumn{2}{|c|}{ Northern Crescent } & \multicolumn{2}{|c|}{ Heartland } \\
\hline & 2006 & 2007 & 2006 & 2007 & 2006 & 2007 & 2006 & 2007 & 2006 & 2007 & 2006 & 2007 & 2006 & 2007 \\
\hline \multicolumn{15}{|l|}{ Gross value of production } \\
\hline Primary product: Wheat grain & 136.784 & 196.35 & 138.61 & 221.408 & 95.89 & 142.13 & 198.258 & 294.58 & 219.584 & 323.19 & 221.776 & 343.116 & 217.848 & 279.306 \\
\hline Secondary product: Silage, straw, grazing & 7.23 & 7.76 & 3.03 & 3.25 & 8.56 & 9.19 & 3.30 & 3.54 & 10.12 & 10.87 & 24.39 & 26.18 & 14.62 & 15.70 \\
\hline Total, gross value of production & 144.01 & 204.11 & 141.64 & 224.66 & 104.45 & 151.32 & 201.56 & 298.12 & 229.70 & 334.06 & 246.17 & 369.30 & 232.47 & 295.01 \\
\hline \multicolumn{15}{|l|}{ Operating costs: } \\
\hline Seed & 8.46 & 9.77 & 8.71 & 10.22 & 5.86 & 6.87 & 11.70 & 13.72 & 9.99 & 11.71 & 21.71 & 25.46 & 17.22 & 20.19 \\
\hline Fertilizer & 28.44 & 35.33 & 24.26 & 30.36 & 24.80 & 31.04 & 39.18 & 49.02 & 32.01 & 40.06 & 58.60 & 73.33 & 56.35 & 70.52 \\
\hline Chemicals & 8.84 & 8.82 & 15.08 & 15.32 & 3.97 & 4.03 & 14.78 & 15.01 & 9.30 & 9.44 & 5.69 & 5.78 & 5.09 & 5.17 \\
\hline Custom operations $^{\mathrm{c}}$ & 6.71 & 6.79 & 6.97 & 7.08 & 6.40 & 6.50 & 6.42 & 6.52 & 6.98 & 7.09 & 10.95 & 11.13 & 6.03 & 6.13 \\
\hline Fuel, lube, and electricity & 17.81 & 19.77 & 9.10 & 10.05 & 22.10 & 24.41 & 13.59 & 15.01 & 55.45 & 61.25 & 10.94 & 12.08 & 8.68 & 9.59 \\
\hline Repairs & 12.42 & 12.86 & 10.53 & 10.88 & 13.48 & 13.94 & 13.38 & 13.83 & 19.17 & 19.81 & 11.35 & 11.73 & 9.46 & 9.78 \\
\hline Purchased irrigation water & 0.33 & 0.33 & 0.11 & 0.11 & 0.08 & 0.08 & 0.81 & 0.85 & 2.93 & 3.06 & 0.81 & 0.85 & 0.56 & 0.59 \\
\hline Interest on operating inputs & 2.00 & 2.10 & 1.80 & 1.88 & 1.84 & 1.95 & 2.40 & 2.55 & 3.27 & 3.41 & 2.89 & 3.14 & 2.49 & 2.73 \\
\hline Total, operating costs & 85.01 & 95.77 & 76.56 & 85.90 & 78.53 & 88.82 & 102.26 & 116.51 & 139.10 & 155.83 & 122.94 & 143.50 & 105.88 & 124.70 \\
\hline \multicolumn{15}{|l|}{ Allocated overhead: } \\
\hline Hired labor & 2.49 & 2.57 & 1.92 & 1.99 & 2.43 & 2.51 & 4.21 & 4.36 & 7.53 & 7.80 & 1.24 & 1.28 & 1.09 & 1.13 \\
\hline Opportunity cost of unpaid labor & 21.69 & 22.52 & 14.90 & 15.42 & 25.22 & 26.11 & 28.27 & 29.26 & 35.18 & 36.42 & 26.01 & 26.93 & 17.51 & 18.12 \\
\hline Capital recovery of machinery and equipment & 51.33 & 53.71 & 47.69 & 50.05 & 49.38 & 51.82 & 62.10 & 65.18 & 81.64 & 85.68 & 57.09 & 59.92 & 49.98 & 52.45 \\
\hline Opportunity cost of land (rental rate) & 40.86 & 43.54 & 38.73 & 41.76 & 30.60 & 33.00 & 52.19 & 56.28 & 78.09 & 84.21 & 67.48 & 72.78 & 74.67 & 80.53 \\
\hline Taxes and insurance & 6.86 & 7.88 & 8.71 & 10.11 & 4.94 & 5.73 & 8.73 & 10.13 & 8.71 & 10.11 & 9.85 & 11.43 & 6.32 & 7.33 \\
\hline General farm overhead & 8.54 & 8.74 & 9.74 & 10.07 & 6.72 & 6.95 & 9.10 & 9.41 & 12.09 & 12.50 & 15.24 & 15.76 & 8.96 & 9.27 \\
\hline Total, allocated overhead & 131.77 & 138.96 & 121.69 & 129.40 & 119.29 & 126.12 & 164.60 & 174.62 & 223.24 & 236.72 & 176.91 & 188.10 & 158.53 & 168.83 \\
\hline Total, costs listed & 216.78 & 234.73 & 198.25 & 215.30 & 197.82 & 214.94 & 266.86 & 291.13 & 362.34 & 392.55 & 299.85 & 331.60 & 264.41 & 293.53 \\
\hline Value of production less total costs listed & -72.77 & -30.62 & -56.61 & 9.36 & -93.37 & -63.62 & -65.30 & 6.99 & -132.64 & -58.49 & -53.68 & 37.70 & -31.94 & 1.48 \\
\hline Value of production less operating costs & 59.00 & 108.34 & 65.08 & 138.76 & 25.92 & 62.50 & 99.30 & 181.61 & 90.60 & 178.23 & 123.23 & 225.80 & 126.59 & 170.31 \\
\hline \multicolumn{15}{|l|}{ Supporting information: } \\
\hline Yield (bushels per planted acre) & 33.2 & 37.4 & 33 & 41 & 22 & 28 & 52 & 52 & 58 & 57 & 66 & 71 & 63 & 53 \\
\hline Price (dollars per bushel at harvest) & 4.12 & 5.25 & 4.15 & 5.44 & 4.30 & 5.04 & 3.82 & 5.72 & 3.76 & 5.70 & 3.34 & 4.86 & 3.48 & 5.26 \\
\hline Enterprise size (planted acres) ${ }^{a}$ & 412 & 412 & 618 & 618 & 443 & 443 & 858 & 858 & 584 & 584 & 87 & 87 & 104 & 104 \\
\hline \multicolumn{15}{|l|}{ Production practices: ${ }^{a}$} \\
\hline Winter wheat (percent of acres) & 67 & 67 & 27 & 27 & 100 & 100 & 75 & 75 & 72 & 72 & 93 & 93 & 83 & 83 \\
\hline Spring wheat (percent of acres) & 28 & 28 & 61 & 61 & 0 & 0 & 25 & 25 & 27 & 27 & 7 & 7 & 17 & 17 \\
\hline Durum wheat (percent of acres) & c & c & 12 & 12 & 0 & 0 & 0 & 0 & c & c & 0 & 0 & 0 & 0 \\
\hline Irrigated (percent of acres) & 5 & 5 & c & c & 7 & 7 & 8 & 8 & 23 & 23 & 0 & 0 & 0 & 0 \\
\hline Dryland (percent of acres) & 95 & 95 & 99 & 99 & 93 & 93 & 92 & 92 & 67 & 67 & 100 & 100 & 100 & 100 \\
\hline Straw (percent of acres) & 7 & 7 & 5 & 5 & c & ${ }^{\circ}$ & 6 & 6 & 13 & 13 & 42 & 42 & 23 & 23 \\
\hline
\end{tabular}

Source:

Economic Research Service, US Department of Agriculture, http://www.ers.usda.gov/data/costsandreturns/testpick.htm

a Developed from survey base year, 2004.

${ }^{\mathrm{b}}$ Cost of commercial fertilizers, soil conditioners, and manure.

${ }^{c} 0.1$ to less than 5 percent. 
Table 5.25

Oil per Acre Production for Various Crops

\begin{tabular}{llc|llc}
\hline \multicolumn{1}{c}{ Plant } & \multicolumn{1}{c|}{ Latin Name } & $\begin{array}{c}\text { Oil/Acre } \\
\text { (gallons) }\end{array}$ & \multicolumn{1}{c|}{ Plant } & \multicolumn{1}{c}{ Latin Name } & $\begin{array}{c}\text { OII/Acre } \\
\text { (gallons) }\end{array}$ \\
\hline Oil Palm & Elaeis guineensis & 610 & Rice & Oriza sativa L. & 85 \\
Macauba Palm & Acrocomia aculeata & 461 & Buffalo Gourd & Cucurbita foetidissima & 81 \\
Pequi & Caryocar brasiliense & 383 & Safflower & Carthamus tinctorius & 80 \\
Buriti Palm & Mauritia flexuosa & 335 & Crambe & Crambe abyssinica & 72 \\
Oiticia & Licania rigida & 307 & Sesame & Sesamum indicum & 71 \\
Coconut & Cocos nucifera & 276 & Camelina & Camelina sativa & 60 \\
Avocado & Persea americana & 270 & Mustard & Brassica alba & 59 \\
Brazil Nut & Bertholletia excelsa & 245 & Coriander & Coriandrum sativum & 55 \\
Macadamia Nut & Macadamia terniflora & 230 & Pumpkin Seed Cucurbita pepo & 55 \\
Jatropa & Jatropha curcas & 194 & Euphorbia & Euphorbia lagascae & 54 \\
Babassu Palm & Orbignya martiana & 188 & Hazelnut & Corylus avellana & 49 \\
Jojoba & Simmondsia chinensis & 186 & Linseed & Linum usitatissimum & 49 \\
Pecan & Carya illinoensis & 183 & Coffee & Coffea arabica & 47 \\
Bacuri & Platonia insignis & 146 & Soybean & Glycine max & 46 \\
Castor Bean & Ricinus communis & 145 & Hemp & Cannabis sativa & 37 \\
Gopher Plant & Euphorbia lathyris & 137 & Cotton & Gossypium hirsutum & 33 \\
Piassava & Attalea funifera & 136 & Calendula & Calendula officinalis & 31 \\
Olive Tree & Olea europaea & 124 & Kenaf & Hibiscus cannabinus L. & 28 \\
Rapeseed & Brassica napus & 122 & Rubber Seed & Hevea brasiliensis & 26 \\
Opium Poppy & Papaver somniferum & 119 & Lupine & Lupinus albus & 24 \\
Peanut & Ariachis hypogaea & 109 & Palm & Erythea salvadorensis & 23 \\
Cocoa & Theobroma cacao & 105 & Oat & Avena sativa & 22 \\
Sunflower & Helianthus annuus & 98 & Cashew Nut & Anacardium occidentale & 18 \\
Tung Oil Tree & Aleurites fordii & 96 & Corn & Zea mays & 18 \\
\hline
\end{tabular}

Source:

Amanda Hill, Al Kurki, and Mike Morris. 2006. Biodiesel: The Sustainability Dimensions, ATTRA Publication, Butte, MT: National Center for Appropriate Technology, Pages 4-5. 
Table 5.26

Cotton: Area, Yield, Production, and Value, 1996-2007

\begin{tabular}{|c|c|c|c|c|c|c|}
\hline \multirow[b]{2}{*}{ Year } & \multicolumn{2}{|c|}{ Area } & \multirow[b]{2}{*}{$\begin{array}{l}\text { Yield per } \\
\text { harvested } \\
\text { acre }\end{array}$} & \multirow[b]{2}{*}{ Production } & \multirow[b]{2}{*}{$\begin{array}{l}\text { Marketing year } \\
\text { average price per } \\
\text { pound received by } \\
\text { farmers }\end{array}$} & \multirow[b]{2}{*}{$\begin{array}{l}\text { Value of } \\
\text { production }\end{array}$} \\
\hline & Planted & Harvested & & & & \\
\hline & $\begin{array}{l}1,000 \\
\text { Acres }\end{array}$ & 1,000 Acres & Pounds & 1,000 bales $^{a}$. & Cents & 1,000 Dollars \\
\hline 1996 & 14,653 & 12,888 & 705 & 18,942 & 70.50 & $6,408,144$ \\
\hline 1997 & 13,898 & 13,406 & 673 & 18,793 & 66.20 & $5,975,585$ \\
\hline 1998 & 13,393 & 10,684 & 625 & 13,918 & 61.70 & $4,119,911$ \\
\hline 1999 & 14,874 & 13,425 & 607 & 16,968 & 46.80 & $3,809,560$ \\
\hline 2000 & 15,517 & 13,053 & 632 & 17,188 & 51.60 & $4,260,417$ \\
\hline 2001 & 15,769 & 13,828 & 705 & 20,303 & 32.00 & $3,121,848$ \\
\hline 2002 & 13,958 & 12,417 & 665 & 17,209 & 45.70 & $3,777,132$ \\
\hline 2003 & 13,480 & 12,003 & 730 & 18,255 & 63.00 & $5,516,761$ \\
\hline 2004 & 13,659 & 13,057 & 855 & 23,251 & 44.70 & $4,993,565$ \\
\hline 2005 & 14,245 & 13,803 & 831 & 23,890 & 49.70 & $5,695,217$ \\
\hline 2006 & 15,274 & 12,732 & 814 & 21,588 & 48.40 & $5,013,238$ \\
\hline $2007^{\mathrm{D}}$ & 10,830 & 10,492 & 871 & 19,033 & 56.90 & $5,196,688$ \\
\hline
\end{tabular}

\section{Source:}

U.S. Department of Agriculture, 2008 Agricultural Statistics, Table 2-1 and annual, http://www.nass.usda.gov/Publications/Ag Statistics/index.asp

\footnotetext{
${ }^{\text {a }} 480$ pound net weight bales.

${ }^{\mathrm{b}}$ Preliminary.
} 
Table 5.27

Cotton: Area, Yield, and Production by State, 2005-2007

\begin{tabular}{|c|c|c|c|c|c|c|c|c|c|c|c|c|}
\hline \multirow{2}{*}{$\begin{array}{c}\text { State }^{\mathrm{a}} \text { and } \\
\text { cotton } \\
\text { classification }\end{array}$} & \multicolumn{3}{|c|}{ Area Planted } & \multicolumn{3}{|c|}{ Area Harvested } & \multicolumn{3}{|c|}{ Yield per Harvested Acre } & \multicolumn{3}{|c|}{ Production $^{a}$} \\
\hline & 2005 & 2006 & $2007^{b}$ & 2005 & 2006 & $2007^{b}$ & 2005 & 2006 & $2007^{b}$ & 2005 & 2006 & $2007^{b}$ \\
\hline & 1,000 & & 1,000 & & 1,000 & & & & & 1,000 & 1,000 & 1,000 \\
\hline Upland: & Acres & 1,000 Acres & Acres & 1,000 Acres & Acres & 1,000 Acres & Pounds & Pounds & Pounds & bales $^{\mathrm{C}}$ & bales $^{\mathrm{C}}$ & bales $^{\mathrm{c}}$ \\
\hline Alabama & 550 & 575 & 400 & 545 & 560 & 385 & 747 & 579 & 499 & 848 & 675 & 400 \\
\hline Arizona & 230 & 190 & 170 & 229 & 188 & 168 & 1,289 & 1,420 & 1,429 & 615 & 556 & 500 \\
\hline Arkansas & 1,050 & 1,170 & 860 & 1,040 & 1,160 & 850 & 1,016 & 1,045 & 1,062 & 2,202 & 2,525 & 1,880 \\
\hline California & 430 & 285 & 195 & 428 & 283 & 194 & 1,194 & 1,321 & 1,559 & 1,065 & 779 & 630 \\
\hline Florida & 86 & 103 & 85 & 85 & 101 & 81 & 762 & 789 & 652 & 135 & 166 & 110 \\
\hline Georgia & 1,220 & 1,400 & 1,030 & 1,210 & 1,370 & 995 & 849 & 818 & 796 & 2,140 & 2,334 & 1,650 \\
\hline Kansas & 74 & 115 & 47 & 66 & 110 & 43 & 638 & 511 & 558 & 88 & 117 & 50 \\
\hline Louisiana & 610 & 635 & 335 & 600 & 630 & 330 & 878 & 946 & 1,004 & 1,098 & 1,241 & 690 \\
\hline Mississippi & 1,210 & 1,230 & 660 & 1,200 & 1,220 & 655 & 859 & 829 & 975 & 2,147 & 2,107 & 1,330 \\
\hline Missouri & 440 & 500 & 380 & 438 & 496 & 379 & 947 & 953 & 975 & 864 & 985 & 770 \\
\hline New Mexico & 56 & 50 & 46 & 51 & 48 & 42 & 1,016 & 930 & 1,234 & 108 & 93 & 108 \\
\hline North Carolina & 815 & 870 & 500 & 810 & 865 & 490 & 852 & 713 & 769 & 1,437 & 1,285 & 785 \\
\hline Oklahoma & 255 & 320 & 175 & 240 & 180 & 165 & 716 & 541 & 945 & 358 & 203 & 325 \\
\hline South Carolina & 266 & 300 & 180 & 265 & 298 & 158 & 743 & 697 & 486 & 410 & 433 & 160 \\
\hline Tennessee & 640 & 700 & 515 & 635 & 695 & 510 & 848 & 945 & 579 & 1,122 & 1,368 & 615 \\
\hline Texas & 5,950 & 6,400 & 4,900 & 5,600 & 4,100 & 4,700 & 723 & 679 & 827 & 8,440 & 5,800 & 8,100 \\
\hline Virginia & 93 & 105 & 60 & 92 & 104 & 59 & 955 & 717 & 854 & 183 & 155 & 105 \\
\hline Total & 13,975 & 14,948 & $0,538.0$ & 13,534 & 12,408 & 10,204 & 825 & 806 & 857 & 23,260 & 20,822 & 18,208 \\
\hline \multicolumn{13}{|l|}{ American-Pima: } \\
\hline Arizona & 4 & 7 & 3 & 4 & 7 & 3 & 820 & 919 & 960 & 7 & 13 & 5 \\
\hline California & 230 & 275 & 260 & 229 & 274 & 257 & 1,170 & 1,204 & 1,419 & 558 & 687 & 760 \\
\hline New Mexico & 12 & 13 & 5 & 12 & 13 & 5 & 918 & 768 & 1,123 & 22 & 20 & 11 \\
\hline Texas & 25 & 31 & 25 & 24 & 30 & 24 & 870 & 720 & 980 & 44 & 45 & 49 \\
\hline Total & 270 & 326 & 292 & 269 & 324 & 288 & 1,127 & 1,136 & 1,374 & 631 & 765 & 825 \\
\hline U.S. Total & 14,245 & 15,274 & 10,830 & 13,803 & 12,732 & 10,492 & 831 & 814 & 871 & 23,890 & 21,588 & 19,033 \\
\hline
\end{tabular}

\section{Source:}

U.S. Department of Agriculture, 2008 Agricultural Statistics, Table 2-2, http://www.nass.usda.gov/Publications/Ag Statistics/index.asp

\footnotetext{
a Production ginned and to be ginned.

${ }^{\mathrm{b}}$ Preliminary.

${ }^{c} 480$-pound net weight bale.
} 
Table 5.28

\section{Cotton Production Costs and Returns per Planted Acre by Region, Excluding Government Payments, 2006-2007a (Dollars per planted acre)}

\begin{tabular}{|c|c|c|c|c|c|c|c|c|c|c|c|c|c|c|}
\hline \multirow[b]{2}{*}{ Item } & \multicolumn{2}{|c|}{ United States } & \multicolumn{2}{|c|}{ Heartland } & \multicolumn{2}{|c|}{ Prarie Gateway } & \multicolumn{2}{|c|}{$\begin{array}{l}\text { Southern } \\
\text { Seaboard }\end{array}$} & \multicolumn{2}{|c|}{ Fruitful Rim } & \multicolumn{2}{|c|}{$\begin{array}{l}\text { Mississippi } \\
\text { Portal }\end{array}$} & \multicolumn{2}{|c|}{ Eastern Uplands } \\
\hline & 2006 & 2007 & 2006 & 2007 & 2006 & 2007 & 2006 & 2007 & 2006 & 2007 & 2006 & 2007 & 2006 & 2007 \\
\hline \multicolumn{15}{|l|}{ Gross value of production } \\
\hline $\begin{array}{l}\text { Primary product: Cotton } \\
\text { Secondary product: Cottonseed }\end{array}$ & 254.84 & 357.99 & 276.50 & 394.06 & 252.08 & 332.66 & 180.20 & 299.42 & 227.22 & 348.93 & 208.80 & 477.29 & 194.48 & 243.85 \\
\hline Total, gross value of production & 254.84 & 357.99 & 276.50 & 394.06 & 252.08 & 332.66 & 180.20 & 299.42 & 227.22 & 348.93 & 208.80 & 477.29 & 194.48 & 243.85 \\
\hline \multicolumn{15}{|l|}{ Operating costs: } \\
\hline Seed & 32.30 & 38.92 & 32.01 & 38.54 & 34.67 & 41.75 & 34.36 & 41.37 & 30.69 & 36.96 & 31.44 & 37.86 & 30.23 & 36.40 \\
\hline Fertilizer $^{\mathrm{b}}$ & 13.05 & 16.06 & 12.73 & 15.84 & 19.62 & 24.41 & 6.15 & 7.65 & 7.63 & 9.49 & 21.11 & 26.27 & 34.76 & 43.25 \\
\hline Chemicals & 14.46 & 14.56 & 14.38 & 14.60 & 13.92 & 14.14 & 12.47 & 12.66 & 12.94 & 13.14 & 11.49 & 11.67 & 15.75 & 16.00 \\
\hline Custom operations & 6.01 & 6.38 & 5.27 & 5.58 & 8.17 & 8.64 & 5.05 & 5.34 & 7.69 & 8.14 & 7.24 & 7.66 & 5.34 & 5.65 \\
\hline Fuel, lube, and electricity & 13.51 & 14.76 & 10.99 & 12.14 & 12.45 & 13.75 & 10.12 & 11.18 & 26.34 & 29.10 & 11.66 & 12.88 & 9.98 & 11.02 \\
\hline Repairs & 11.80 & 12.13 & 10.59 & 10.96 & 10.53 & 10.89 & 12.27 & 12.69 & 16.85 & 17.43 & 10.50 & 10.86 & 9.62 & 9.95 \\
\hline Purchased irrigation water & 0.11 & 0.11 & 0.00 & 0.00 & 0.00 & 0.00 & 0.00 & 0.00 & 1.54 & 1.63 & 0.00 & 0.00 & 0.00 & 0.00 \\
\hline Interest on operating capital & 2.17 & 2.31 & 2.04 & 2.19 & 2.36 & 2.54 & 1.91 & 2.04 & 2.46 & 2.60 & 2.22 & 2.40 & 2.51 & 2.74 \\
\hline Total, operating costs & 93.41 & 105.23 & 88.01 & 99.85 & 101.72 & 116.12 & 82.33 & 92.93 & 106.14 & 118.49 & 95.66 & 109.60 & 108.19 & 125.01 \\
\hline \multicolumn{15}{|l|}{ Allocated overhead: } \\
\hline Hired labor & 1.78 & 1.80 & 1.15 & 1.19 & 1.17 & 1.21 & 1.50 & 1.55 & 1.90 & 1.97 & 2.70 & 2.79 & 2.65 & 2.74 \\
\hline Opportunity cost of unpaid labor & 15.20 & 15.70 & 14.33 & 14.83 & 16.71 & 17.30 & 13.21 & 13.67 & 19.03 & 19.70 & 16.63 & 17.21 & 17.43 & 18.04 \\
\hline Capital recovery of machinery and equipment & 60.38 & 63.22 & 58.48 & 61.37 & 52.98 & 55.60 & 65.82 & 69.07 & 72.62 & 76.21 & 54.77 & 57.48 & 51.25 & 53.78 \\
\hline Opportunity cost of land (rental rate) & 86.17 & 92.92 & 101.33 & 108.52 & 70.99 & 76.02 & 46.65 & 49.96 & 60.64 & 64.94 & 56.61 & 60.62 & 39.18 & 41.96 \\
\hline Taxes and insurance & 7.93 & 8.55 & 7.94 & 8.58 & 9.99 & 10.79 & 6.89 & 7.44 & 8.01 & 8.65 & 6.16 & 6.66 & 6.83 & 7.38 \\
\hline General farm overhead & 13.22 & 13.79 & 13.50 & 13.97 & 17.36 & 17.96 & 10.75 & 11.12 & 14.72 & 15.23 & 13.14 & 13.59 & 10.04 & 10.39 \\
\hline Total, allocated overhead & 184.68 & 195.98 & 196.73 & 208.46 & 169.20 & 178.88 & 144.82 & 152.81 & 176.92 & 186.70 & 150.01 & 158.35 & 127.38 & 134.29 \\
\hline Total costs listed & 278.09 & 301.21 & 284.74 & 308.31 & 270.92 & 295.00 & 227.15 & 245.74 & 283.06 & 305.19 & 245.67 & 267.95 & 235.57 & 259.30 \\
\hline Value of production less total costs listed & -23.25 & 56.78 & -8.24 & 85.76 & -18.84 & 37.65 & -46.95 & 53.68 & -55.84 & 43.75 & -36.87 & 209.34 & -41.09 & -15.45 \\
\hline Value of production less operating costs & 161.43 & 252.76 & 188.49 & 294.22 & 150.36 & 216.53 & \begin{tabular}{|l|l}
97.87 \\
\end{tabular} & 206.49 & 121.08 & 230.45 & 113.14 & 367.69 & 86.29 & 118.84 \\
\hline \multicolumn{15}{|l|}{ Supporting information: } \\
\hline Cotton Yield (pounds per plantec & 686 & 855 & 946 & 965 & 436 & 809 & 737 & 704 & 1291 & 1501 & 931 & 914 & 563 & 480 \\
\hline Price (dollars per pound) & 0.47 & 0.55 & 0.49 & 0.54 & 0.46 & 0.55 & 0.48 & 0.55 & 0.46 & 0.55 & 0.49 & 0.55 & 0.44 & 0.53 \\
\hline Cottonseed Yield (pounds per planted acre) & 1,113 & 1,407 & 1,530 & 1,561 & 706 & 1,308 & $3 \quad 1,193$ & 1,140 & 2,088 & 2,428 & 1,505 & 1,479 & 912 & 777 \\
\hline Price (dollars per pound) & 0.06 & 0.07657 & 0.0505 & 0.0813 & 0.06 & 0.08 & 0.0458 & 0.074 & 0.0892 & 0.08 & 0.05 & 0.08 & 0.04 & 0.07 \\
\hline Enterprise size (planted acres) ${ }^{a}$ & 740 & 740 & 893 & 893 & 764 & 764 & 535 & 535 & 614 & 614 & 1016 & 1016 & 807 & 807 \\
\hline \multicolumn{15}{|l|}{ Production practices: ${ }^{a}$} \\
\hline Irrigated (percent) & 31 & 31 & 51 & 51 & 31 & 31 & 16 & 16 & 45 & 45 & 33 & 33 & 4 & 4 \\
\hline Dryland (percent) & 69 & 69 & 49 & 49 & 69 & 69 & 84 & 84 & 55 & 55 & 67 & 67 & 96 & 96 \\
\hline
\end{tabular}

\section{Source:}

Economic Research Service, U.S. Department of Agriculture, http://www.ers.usda.gov/data/costsandreturns/testpick.htm

${ }^{a}$ Developed from survey base year, 2006.

${ }^{\mathrm{b}}$ Commercial fertilizer, soil conditioners, and manure. 
USDA's 2008 soybean baseline projections do not specifically show oil produced for use as a biofuel and do not reflect in the projections the probable increase in demand for soybean oil as a biofuel which is anticipated due to the Energy Policy Act of 2005. It is likely that future USDA soybean baseline projections will reflect the market changes.

Table 5.29

Soybeans and Products Baseline Projections, 2006-2018

\begin{tabular}{|c|c|c|c|c|c|c|c|c|c|c|c|c|}
\hline Item & $2006 / 07$ & $2007 / 08$ & $2008 / 09$ & $2009 / 10$ & $2010 / 11$ & $2011 / 12$ & $2012 / 13$ & $2013 / 14$ & $2014 / 15$ & $2015 / 16$ & $2016 / 17$ & $2017 / 18$ \\
\hline \multicolumn{13}{|l|}{ Area (million acres): } \\
\hline Planted & 75.5 & 63.7 & 71.0 & 69.5 & 69.0 & 68.5 & 68.5 & 68.5 & 68.0 & 68.0 & 68.0 & 68.0 \\
\hline Harvested & 74.6 & 62.8 & 70.1 & 68.6 & 68.1 & 67.6 & 67.6 & 67.6 & 67.1 & 67.1 & 67.1 & 67.1 \\
\hline Yield/harvested acre (bushels) & 42.7 & 41.3 & 42.1 & 42.6 & 43.0 & 43.5 & 43.9 & 44.4 & 44.8 & 45.3 & 45.7 & 46.2 \\
\hline \multicolumn{13}{|l|}{ Supply (million bushels) } \\
\hline Beginning stocks, Sept 1 & 449 & 573 & 210 & 219 & 210 & 202 & 193 & 199 & 204 & 204 & 203 & 201 \\
\hline Production & 3,188 & 2,594 & 2,950 & 2,920 & 2,930 & 2,935 & 2,970 & 3,000 & 3,005 & 3,035 & 3,065 & 3,095 \\
\hline Imports & 9 & 6 & 6 & 4 & 4 & 4 & 4 & 4 & 4 & 4 & 4 & 4 \\
\hline Total supply & 3,647 & 3,173 & 3,166 & 3,143 & 3,144 & 3,141 & 3,167 & 3,203 & 3,213 & 3,243 & 3,272 & 3,300 \\
\hline \multicolumn{13}{|l|}{ Disposition (million bushels) } \\
\hline Crush & 1,806 & 1,825 & 1,865 & 1,895 & 1,920 & 1,950 & 1,975 & 2,000 & 2,020 & 2,045 & 2,070 & 2,095 \\
\hline Seed and residual & 149 & 163 & 177 & 173 & 172 & 173 & 174 & 174 & 174 & 175 & 176 & 177 \\
\hline Exports & 1,118 & 975 & 905 & 865 & 850 & 825 & 820 & 825 & 815 & 820 & 825 & 825 \\
\hline Total disposition & 3,074 & 2,963 & 2,947 & 2,933 & 2,942 & 2,948 & 2,969 & 2,999 & 3,009 & 3,040 & 3,071 & 3,097 \\
\hline \multicolumn{13}{|l|}{ Carryover stocks, August 31} \\
\hline Total ending stocks & 573 & 210 & 219 & 210 & 202 & 193 & 199 & 204 & 204 & 203 & 201 & 204 \\
\hline Stocks/use ratio, percent & 18.6 & 7.1 & 7.4 & 7.2 & 6.9 & 6.5 & 6.7 & 6.8 & 6.8 & 6.7 & 6.5 & 6.6 \\
\hline \multicolumn{13}{|l|}{ Prices (dollars per bushel) } \\
\hline Loan rate & 5.00 & 5.00 & 5.00 & 5.00 & 5.00 & 5.00 & 5.00 & 5.00 & 5.00 & 5.00 & 5.00 & 5.00 \\
\hline Soybean price, farm & 6.43 & 9.00 & 8.85 & 8.90 & 8.75 & 8.80 & 8.80 & 8.80 & 8.85 & 8.90 & 8.95 & 9.00 \\
\hline \multicolumn{13}{|c|}{ Variable costs of production (dollars): } \\
\hline Per acre & 96.75 & 105.46 & 109.45 & 112.63 & 113.94 & 115.19 & 116.39 & 117.50 & 118.84 & 120.20 & 121.58 & 122.90 \\
\hline Per bushel & 2.27 & 2.55 & 2.60 & 2.64 & 2.65 & 2.65 & 2.65 & 2.65 & 2.65 & 2.65 & 2.66 & 2.66 \\
\hline \multicolumn{13}{|c|}{ Returns over variable costs (dollars per acre): } \\
\hline Net returns & 178 & 266 & 263 & 267 & 262 & 268 & 270 & 273 & 278 & 283 & 287 & 293 \\
\hline \multicolumn{13}{|l|}{ Soybean oil (million pounds) } \\
\hline Beginning stocks, Oct. 1 & 3,010 & 2,912 & 2,017 & 1,882 & 1,967 & 1,967 & 1,987 & 1,947 & 1,872 & 1,782 & 1,757 & 1,772 \\
\hline Production & 20,484 & 20,715 & 21,215 & 21,575 & 21,880 & 22,240 & 22,545 & 22,850 & 23,100 & 23,405 & 23,710 & 24,020 \\
\hline Imports & 40 & 40 & 50 & 60 & 70 & 80 & 90 & 100 & 110 & 120 & 130 & 140 \\
\hline Total supply & 23,533 & 23,667 & 23,282 & 23,517 & 23,917 & 24,287 & 24,622 & 24,897 & 25,082 & 25,307 & 25,597 & 25,932 \\
\hline Domestic disappearance & 18,721 & 20,100 & 20,150 & 20,300 & 20,550 & 20,775 & 21,100 & 21,400 & 21,650 & 21,900 & 22,150 & 22,400 \\
\hline For methyl ester ${ }^{a}$ & 2,794 & 4,200 & 4,200 & 4,200 & 4,250 & 4,250 & 4,350 & 4,400 & 4,400 & 4,400 & 4,400 & 4,400 \\
\hline Exports & 1,900 & 1,550 & 1,250 & 1,250 & 1,400 & 1,525 & 1,575 & 1,625 & 1,650 & 1,650 & 1,675 & 1,700 \\
\hline Total demand & 20,621 & 21,650 & 21,400 & 21,550 & 21,950 & 22,300 & 22,675 & 23,025 & 23,300 & 23,550 & 23,825 & 24,100 \\
\hline Ending stocks, Sept. 30 & 2,912 & 2,017 & 1,882 & 1,967 & 1,967 & 1,987 & 1,947 & 1,872 & 1,782 & 1,757 & 1,772 & 1,832 \\
\hline Soybean oil price $(\$ / \mathrm{lb})$ & 0.3102 & 0.3950 & 0.3850 & 0.3850 & 0.3825 & 0.3825 & 0.3825 & 0.3825 & 0.3850 & 0.3850 & 0.3850 & 0.3850 \\
\hline Soybean meal (thousand short & 314 & 351 & 300 & 300 & 300 & 300 & 300 & 300 & 300 & 300 & 300 & 300 \\
\hline Beginning stocks, Oct. 1 & 43,021 & 43,384 & 44,385 & 45,085 & 45,735 & 46,385 & 46,985 & 47,560 & 48,135 & 48,710 & 49,310 & 49,910 \\
\hline Production & 155 & 165 & 165 & 165 & 165 & 165 & 165 & 165 & 165 & 165 & 165 & 165 \\
\hline Imports & 43,489 & 43,900 & 44,850 & 45,550 & 46,200 & 46,850 & 47,450 & 48,025 & 48,600 & 49,175 & 49,775 & 50,375 \\
\hline Total supply & 34,288 & 35,300 & 35,850 & 36,400 & 36,950 & 37,500 & 38,050 & 38,625 & 39,200 & 39,775 & 40,375 & 40,975 \\
\hline Domestic disappearance & 8,850 & 8,300 & 8,700 & 8,850 & 8,950 & 9,050 & 9,100 & 9,100 & 9,100 & 9,100 & 9,100 & 9,100 \\
\hline Exports & 43,138 & 43,600 & 44,550 & 45,250 & 45,900 & 46,550 & 47,150 & 47,725 & 48,300 & 48,875 & 49,475 & 50,075 \\
\hline Total demand & 351 & 300 & 300 & 300 & 300 & 300 & 300 & 300 & 300 & 300 & 300 & 300 \\
\hline Ending stocks, Sept. 30 & 205 & 250 & 240 & 243 & 237 & 238 & 238 & 239 & 239 & 240 & 242 & 243 \\
\hline Soybean meal price (\$/ton) & 174.17 & 177.50 & 200.00 & 205.00 & 205.00 & 195.00 & 192.50 & 190.00 & 188.50 & 186.50 & 185.00 & 185.00 \\
\hline \multicolumn{13}{|c|}{ Crushing yields (pounds per bushel) } \\
\hline Soybean oil & 11.34 & 11.35 & 11.38 & 11.39 & 11.40 & 11.41 & 11.42 & 11.43 & 11.44 & 11.45 & 11.46 & 11.47 \\
\hline Soybean meal & 47.64 & 47.54 & 47.60 & 47.60 & 47.60 & 47.60 & 47.60 & 47.60 & 47.60 & 47.60 & 47.60 & 47.60 \\
\hline Crush margin ( $\$$ per bushel) & 1.98 & 1.43 & 1.24 & 1.25 & 1.25 & 1.23 & 1.23 & 1.25 & 1.23 & 1.22 & 1.21 & 1.20 \\
\hline
\end{tabular}

Source:

U.S.Department of Agriculture, Agricultural Baseline Projections to 2014, February 2008, Table 13 - U.S. soybean and products, http://usda.mannlib.cornell.edu/MannUsda/viewDocumentInfo.do?documentID=1192

${ }^{a}$ Soybean oil used for methyl ester for production of biodiesel, history from the U.S. Department of Commerce. 
The price for soybeans has declined since the mid 70s but has shown a modest increase since reaching a low of about five dollars a bushel in 2001.

Figure 5.10

Soybeans: Price per Bushel, 1975-2007

(Constant 2007 dollars)

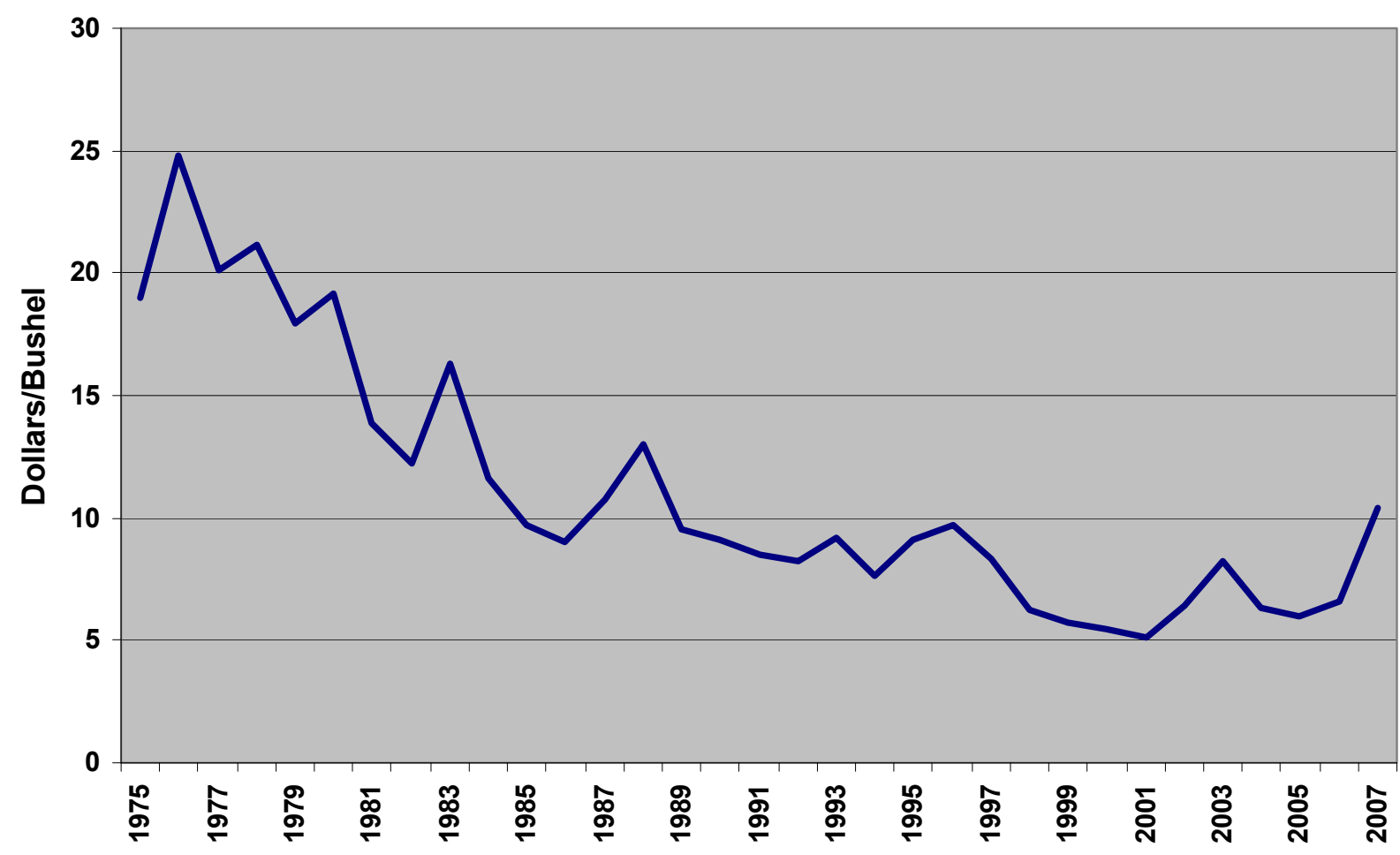

Source:

U.S. Department of Agriculture, National Agricultural Statistics Service, http://www.nass.usda.gov/ 
In 2001, only 5 million gallons of biodiesel fuel was produced requiring a very small amount of all soybeans harvested. By 2007, about 450 million gallons of biodiesel fuel was produced with about $90 \%$ being derived from soybeans. At a conversion rate of 1.5 gallons of biodiesel per bushel of soybeans ${ }^{a}$, the total bushels of soybeans used in biodiesel production was approximately 675 million bushels.

Table 5.30

Soybeans: Area, Yield, Production, and Value, 1996-2007

\begin{tabular}{|c|c|c|c|c|c|c|}
\hline \multirow[b]{2}{*}{ Year } & \multirow[b]{2}{*}{ Area Planted } & \multicolumn{5}{|c|}{ Soybeans for beans } \\
\hline & & $\begin{array}{c}\text { Area } \\
\text { harvested }\end{array}$ & $\begin{array}{c}\text { Yield per } \\
\text { acre }\end{array}$ & Production & $\begin{array}{l}\text { Marketing year } \\
\text { average price per } \\
\text { bushel raised by } \\
\text { farmers }\end{array}$ & $\begin{array}{l}\text { Value of } \\
\text { production }\end{array}$ \\
\hline & 1,000 Acres & 1,000 Acres & Bushels & 1,000 Bushels & Dollars & 1,000 Dollars \\
\hline 1996 & 64,195 & 63,349 & 37.6 & $2,380,274$ & 7.35 & $17,439,971$ \\
\hline 1997 & 70,005 & 69,110 & 38.9 & $2,688,750$ & 6.47 & $17,372,628$ \\
\hline 1998 & 72,025 & 70,441 & 38.9 & $2,741,014$ & 4.93 & $13,493,891$ \\
\hline 1999 & 73,730 & 72,446 & 36.6 & $2,653,758$ & 4.63 & $12,205,352$ \\
\hline 2000 & 74,266 & 72,408 & 38.1 & $2,757,810$ & 4.54 & $12,466,572$ \\
\hline 2001 & 74,075 & 72,975 & 39.6 & $2,890,682$ & 4.38 & $12,605,717$ \\
\hline 2002 & 73,963 & 72,497 & 38.0 & $2,756,147$ & 5.53 & $15,252,691$ \\
\hline 2003 & 73,404 & 72,476 & 33.9 & $2,453,665$ & 7.34 & $18,013,753$ \\
\hline 2004 & 75,208 & 73,958 & 42.2 & $3,123,686$ & 5.74 & $17,894,948$ \\
\hline 2005 & 72,032 & 71,251 & 43.0 & $3,063,237$ & 5.66 & $17,269,138$ \\
\hline 2006 & 75,522 & 74,602 & 42.7 & $3,188,247$ & 6.43 & $20,415,948$ \\
\hline 2007 & 63,631 & 62,820 & 41.2 & $2,585,207$ & 10.40 & $26,752,197$ \\
\hline
\end{tabular}

Source:

U.S. Department of Agriculture, 2008 Agricultural Statistics, Table 3-32, http://www.nass.usda.gov/Publications/Ag Statistics/index.asp

${ }^{a}$ National Biodiesel Board. 
Soybean production is highly variable by state, with the Mid-west producing the largest amount. States with the highest production levels are Illinois and lowa.

Table 5.31

Soybeans: Area, Yield, and Production, by State, 2005-2007

\begin{tabular}{|c|c|c|c|c|c|c|c|c|c|c|c|c|}
\hline \multirow{3}{*}{ State } & \multicolumn{3}{|c|}{ Area planted } & \multicolumn{9}{|c|}{ Soybeans for beans } \\
\hline & \multirow[b]{2}{*}{2005} & \multirow[b]{2}{*}{2006} & \multirow[b]{2}{*}{2007} & \multicolumn{3}{|c|}{ Area harvested } & \multicolumn{3}{|c|}{ Yield per harvested acre } & \multicolumn{3}{|c|}{ Production } \\
\hline & & & & 2005 & 2006 & 2007 & 2005 & 2006 & 2007 & 2005 & 2006 & 2007 \\
\hline & 1,000 & 1,000 & 1,000 & 1,000 & 1,000 & 1,000 & & & & 1,000 & 1,000 & 1,000 \\
\hline & Acres & Acres & Acres & Acres & Acres & Acres & Bushels & Bushels & Bushels & Bushels & Bushels & Bushels \\
\hline Alabama & 150 & 160 & 190 & 145 & 150 & 180 & 33.0 & 20.0 & 21.0 & 4,785 & 3,000 & 3,780 \\
\hline Arizona & 3,030 & 3,110 & 2,830 & 3,000 & 3,070 & 2,790 & 34.0 & 35.0 & 36.0 & 102,000 & 107,450 & 100,440 \\
\hline Delaware & 185 & 180 & 150 & 182 & 177 & 145 & 26.0 & 31.0 & 24.0 & 4,732 & 5,487 & 3,480 \\
\hline Florida & 9 & 7 & 14 & 8 & 5 & 12 & 32.0 & 27.0 & 24.0 & 256 & 135 & 288 \\
\hline Georgia & 180 & 155 & 285 & 175 & 140 & 275 & 26.0 & 25.0 & 30.0 & 4,550 & 3,500 & 8,250 \\
\hline Illinois & 9,500 & 10,100 & 8,200 & 9,450 & 10,050 & 8,150 & 46.5 & 48.0 & 43.0 & 439,425 & 482,400 & 350,450 \\
\hline Indiana & 5,400 & 5,700 & 4,700 & 5,380 & 5,680 & 4,680 & 49.0 & 50.0 & 45.0 & 263,620 & 284,000 & 210,600 \\
\hline lowa & 10,050 & 10,150 & 8,550 & 10,000 & 10,100 & 8,520 & 52.5 & 50.5 & 51.5 & 525,000 & 510,050 & 438,780 \\
\hline Kansas & 2,900 & 3,150 & 2,600 & 2,850 & 3,080 & 2,550 & 37.0 & 32.0 & 33.0 & 105,450 & 98,560 & 84,150 \\
\hline Kentucky & 1,250 & 1,380 & 1,100 & 1,240 & 1,370 & 1,080 & 43.0 & 44.0 & 26.0 & 53,320 & 60,280 & 28,080 \\
\hline Louisiana & 880 & 870 & 605 & 850 & 840 & 590 & 34.0 & 35.0 & 42.0 & 28,900 & 29,400 & 24,780 \\
\hline Maryland & 480 & 470 & 400 & 470 & 465 & 380 & 34.0 & 34.0 & 27.0 & 15,980 & 15,810 & 10,260 \\
\hline Michigan & 2,000 & 2,000 & 1,750 & 1,990 & 1,990 & 1,740 & 38.5 & 45.0 & 39.0 & 76,615 & 89,550 & 67,860 \\
\hline Minnesota & 6,900 & 7,350 & 6,250 & 6,800 & 7,250 & 6,150 & 45.0 & 44.0 & 41.0 & 306,000 & 319,000 & 252,150 \\
\hline Mississippi & 1,610 & 1,670 & 1,450 & 1,590 & 1,650 & 1,420 & 36.5 & 26.0 & 40.0 & 58,035 & 42,900 & 56,800 \\
\hline Missouri & 4,950 & 5,150 & 4,600 & 4,910 & 5,110 & 4,550 & 37.0 & 38.0 & 37.0 & 181,670 & 194,180 & 168,350 \\
\hline Nebraska & 4,700 & 5,050 & 3,800 & 4,660 & 5,010 & 3,770 & 50.5 & 50.0 & 50.5 & 235,330 & 250,500 & 190,385 \\
\hline New Jersey & 95 & 88 & 81 & 91 & 86 & 79 & 28.0 & 35.0 & 31.0 & 2,548 & 3,010 & 2,449 \\
\hline New York & 190 & 200 & 205 & 188 & 198 & 203 & 42.0 & 46.0 & 38.0 & 7,896 & 9,108 & 7,714 \\
\hline North Carolina & 1,490 & 1,370 & 1,420 & 1,460 & 1,360 & 1,360 & 27.0 & 32.0 & 21.0 & 39,420 & 43,520 & 28,560 \\
\hline North Dakota & 2,950 & 3,900 & 3,050 & 2,900 & 3,870 & 2,990 & 36.0 & 31.0 & 35.0 & 104,400 & 119,970 & 104,650 \\
\hline Ohio & 4,500 & 4,650 & 4,150 & 4,480 & 4,620 & 4,130 & 45.0 & 47.0 & 47.0 & 201,600 & 217,140 & 194,110 \\
\hline Oklahoma & 325 & 310 & 185 & 305 & 215 & 175 & 26.0 & 17.0 & 24.0 & 7,930 & 3,655 & 4,200 \\
\hline Pennsylvania & 430 & 430 & 425 & 420 & 425 & 420 & 41.0 & 40.0 & 41.0 & 17,220 & 17,000 & 17,220 \\
\hline South Carolina & 430 & 400 & 450 & 420 & 390 & 425 & 20.5 & 29.0 & 19.0 & 8,610 & 11,310 & 8,075 \\
\hline South Dakota & 3,900 & 3,950 & 3,200 & 3,850 & 3,850 & 3,180 & 35.0 & 34.0 & 42.0 & 134,750 & 130,900 & 133,560 \\
\hline Tennessee & 1,130 & 1,160 & 1,040 & 1,100 & 1,130 & 970 & 38.0 & 39.0 & 18.0 & 41,800 & 44,070 & 17,460 \\
\hline Texas & 260 & 225 & 86 & 230 & 155 & 82 & 26.0 & 24.0 & 37.0 & 5,980 & 3,720 & 3,034 \\
\hline Virginia & 530 & 520 & 500 & 510 & 510 & 480 & 30.0 & 31.0 & 27.0 & 15,300 & 15,810 & 12,960 \\
\hline West Virginia & 18 & 17 & 15 & 17 & 16 & 14 & 35.0 & 42.0 & 33.0 & 595 & 672 & 462 \\
\hline Wisconsin & 1,610 & 1,650 & 1,350 & 1,580 & 1,640 & 1,330 & 44.0 & 44.0 & 39.0 & 69,520 & 72,160 & 51,870 \\
\hline US & 72,032 & 75,522 & 63,631 & 71,251 & 74,602 & 62,820 & 43.0 & 42.7 & 41.2 & $3,063,237$ & $3,188,247$ & $2,585,207$ \\
\hline
\end{tabular}

\section{Source:}

U.S. Department of Agriculture, 2008 Agricultural Statistics, Table 3-37, and annual, http://www.nass.usda.gov/Publications/Ag Statistics/index.asp 
In 2006, soybean stocks and production reached its greatest level during the period 1995-2006.

Table 5.32

Soybeans: Supply and Disappearance, 1995-2006

(Thousand bushels)

\begin{tabular}{|c|c|c|c|c|c|}
\hline \multirow{3}{*}{$\begin{array}{c} \\
\text { Year } \\
\text { beginning } \\
\text { September }\end{array}$} & \multicolumn{5}{|c|}{ Supply } \\
\hline & \multicolumn{3}{|c|}{ Stocks by Position } & \multirow[b]{2}{*}{ Production } & \multirow[b]{2}{*}{ Total $^{a}$} \\
\hline & Farm & $\begin{array}{l}\text { Terminal market, } \\
\text { interior mill, } \\
\text { elevator, and } \\
\text { warehouse }\end{array}$ & Total & & \\
\hline 1995 & $\overline{105,130}$ & 229,684 & 334,814 & $2,174,254$ & $2,513,524$ \\
\hline 1996 & 59,523 & 123,935 & 183,458 & $2,380,274$ & $2,572,636$ \\
\hline 1997 & 43,600 & 88,233 & 131,833 & $2,688,750$ & $2,825,589$ \\
\hline 1998 & 84,300 & 115,499 & 199,799 & $2,741,014$ & $2,944,334$ \\
\hline 1999 & 145,000 & 203,482 & 348,482 & $2,653,758$ & $3,006,411$ \\
\hline 2000 & 112,500 & 177,662 & 290,162 & $2,757,810$ & $3,051,540$ \\
\hline 2001 & 83,500 & 164,247 & 247,747 & $2,890,682$ & $3,140,749$ \\
\hline 2002 & 62,700 & 145,361 & 208,061 & $2,756,147$ & $2,968,869$ \\
\hline 2003 & 58,000 & 120,329 & 178,329 & $2,453,665$ & $2,637,556$ \\
\hline 2004 & 29,400 & 83,014 & 112,414 & $3,123,686$ & $3,241,678$ \\
\hline 2005 & 99,700 & 156,038 & 255,738 & $3,063,237$ & $3,322,347$ \\
\hline $2006^{b}$ & 176,300 & 273,026 & 449,326 & $3,188,247$ & $3,646,607$ \\
\hline \multicolumn{2}{|c|}{ Table continued } & \multicolumn{4}{|c|}{ Disappearance } \\
\hline \multicolumn{2}{|c|}{$\begin{array}{c}\text { Year beginning } \\
\text { September }\end{array}$} & Crushed $^{\mathrm{c}}$ & $\begin{array}{l}\text { Seed, feed } \\
\text { and residual }\end{array}$ & Exports & Total \\
\hline \multicolumn{2}{|c|}{1995} & $1,369,541$ & 111,441 & 849,084 & $2,330,066$ \\
\hline \multicolumn{2}{|c|}{1996} & $1,436,961$ & 118,954 & 885,888 & $2,440,803$ \\
\hline \multicolumn{2}{|c|}{1997} & $1,596,980$ & 154,476 & 874,334 & $2,625,790$ \\
\hline \multicolumn{2}{|c|}{1998} & $1,589,787$ & 201,414 & 804,651 & $2,595,852$ \\
\hline \multicolumn{2}{|c|}{1999} & $1,577,650$ & 165,194 & 973,405 & $2,716,249$ \\
\hline \multicolumn{2}{|c|}{2000} & $1,639,670$ & 168,252 & 995,871 & $2,803,793$ \\
\hline \multicolumn{2}{|c|}{2001} & $1,699,741$ & 169,296 & $1,063,651$ & $2,932,688$ \\
\hline \multicolumn{2}{|c|}{2002} & $1,614,787$ & 131,380 & $1,044,372$ & $2,790,540$ \\
\hline \multicolumn{2}{|c|}{2003} & $1,529,699$ & 108,892 & 886,551 & $2,525,142$ \\
\hline \multicolumn{2}{|c|}{2004} & $1,696,081$ & 192,702 & $1,097,156$ & $2,985,940$ \\
\hline \multicolumn{2}{|c|}{2005} & $1,738,852$ & 194,291 & 939,879 & $2,873,021$ \\
\hline \multicolumn{2}{|c|}{$2006^{\mathrm{D}}$} & $1,806,204$ & 149,604 & $1,118,021$ & $3,073,829$ \\
\hline
\end{tabular}

Source:

U.S. Department of Agriculture, 2008 Agricultural Statistics, Table 3-35, and annual. http://www.nass.usda.gov/Publications/Ag Statistics/index.asp

${ }^{a}$ Includes imports, beginning with 1988.

${ }^{\mathrm{b}}$ Preliminary.

${ }^{\mathrm{c}}$ Reported by the U.S. Department of Commerce.

Biomass Energy Data Book: Edition 2 -- DRAFT 
Prices for soybeans used for biodiesel production may vary for each mill depending on whether the mills are owned by farmer's cooperatives or whether the soybeans are purchased on the open market. The average price per bushel rose by about 77 cents from 2005 to 2006 and then rose sharply by nearly 4 dollars between 2006 and 2007.

Table 5.33

Soybeans for Beans: Marketing Year Average Price and Value, by State, Crop of 2005, 2006, and 2007

\begin{tabular}{|c|c|c|c|c|c|c|}
\hline \multirow[b]{2}{*}{ State $^{a}$} & \multicolumn{3}{|c|}{ Marketing year average price per bushel } & \multicolumn{3}{|c|}{ Value of production } \\
\hline & 2005 & 2006 & $2007^{b}$ & 2005 & 2006 & $2007^{b}$ \\
\hline & Dollars & Dollars & Dollars & 1,000 Dollars & 1,000 Dollars & 1,000 Dollars \\
\hline Alabama & 5.95 & 6.85 & 10.50 & 28,471 & 20,550 & 39,690 \\
\hline Arkansas & 5.92 & 6.41 & 9.80 & 603,840 & 688,755 & 984,312 \\
\hline Delaware & 5.65 & 6.60 & 10.60 & 26,736 & 36,214 & 36,888 \\
\hline Florida & 5.40 & 6.25 & 8.90 & 1,382 & 844 & 2,563 \\
\hline Georgia & 5.50 & 6.85 & 9.75 & 25,025 & 23,975 & 80,438 \\
\hline Illinois & 5.76 & 6.68 & 11.00 & $2,531,088$ & $3,222,432$ & $3,854,950$ \\
\hline Indiana & 5.78 & 6.53 & 10.50 & $1,523,724$ & $1,854,520$ & $2,211,300$ \\
\hline lowa & 5.54 & 6.58 & 10.90 & $2,908,500$ & $3,356,129$ & $4,782,702$ \\
\hline Kansas & 5.45 & 6.37 & 10.60 & 574,703 & 627,827 & 891,990 \\
\hline Kentucky & 5.86 & 6.68 & 10.70 & 312,455 & 402,670 & 300,456 \\
\hline Louisiana & 5.97 & 5.94 & 8.85 & 172,533 & 174,636 & 219,303 \\
\hline Maryland & 5.53 & 6.40 & 10.50 & 88,369 & 101,184 & 107,730 \\
\hline Michigan & 5.73 & 6.27 & 9.85 & 439,004 & 561,479 & 668,421 \\
\hline Minnesota & 5.53 & 6.26 & 10.10 & $1,692,180$ & $1,996,940$ & $2,546,715$ \\
\hline Mississippi & 5.92 & 6.23 & 9.25 & 343,567 & 267,267 & 525,400 \\
\hline Missouri & 5.67 & 6.47 & 10.50 & $1,030,069$ & $1,256,345$ & $1,767,675$ \\
\hline Nebraska & 5.55 & 6.05 & 9.95 & $1,306,082$ & $1,515,525$ & $1,894,331$ \\
\hline New Jersey & 5.65 & 6.25 & 9.75 & 14,396 & 18,813 & 23,878 \\
\hline New York & 5.20 & 6.19 & 9.75 & 41,059 & 56,379 & 75,212 \\
\hline North Carolina & 5.64 & 6.35 & 10.50 & 222,329 & 276,352 & 299,880 \\
\hline North Dakota & 5.37 & 5.98 & 9.80 & 560,628 & 717,421 & $1,025,570$ \\
\hline Ohio & 5.74 & 6.46 & 10.10 & $1,157,184$ & $1,402,724$ & $1,960,511$ \\
\hline Oklahoma & 5.45 & 6.35 & 9.60 & 43,219 & 23,209 & 40,320 \\
\hline Pennsylvania & 5.60 & 6.25 & 9.75 & 96,432 & 106,250 & 167,895 \\
\hline South Carolina & 5.55 & 6.80 & 10.00 & 47,786 & 76,908 & 80,750 \\
\hline South Dakota & 5.39 & 6.03 & 9.80 & 726,303 & 789,327 & $1,308,888$ \\
\hline Tennessee & 5.73 & 6.30 & 10.50 & 239,514 & 277,641 & 183,330 \\
\hline Texas & 5.45 & 5.40 & 9.00 & 32,591 & 20,088 & 27,306 \\
\hline Virginia & 5.53 & 6.54 & 10.50 & 84,609 & 103,397 & 136,080 \\
\hline West Virginia & 5.49 & 6.40 & 9.90 & 3,267 & 4,301 & 4,574 \\
\hline Wisconsin & 5.64 & 6.04 & 9.70 & 392,093 & 435,846 & 503,139 \\
\hline US & 5.66 & 6.43 & 10.40 & $17,269,138$ & $20,415,948$ & $26,752,197$ \\
\hline
\end{tabular}

Source:

U.S. Department of Agriculture, 2008 Agricultural Statistics, Table 3-39, http://www.nass.usda.gov/Publications/Ag Statistics/index.asp

\footnotetext{
${ }^{a}$ States with no data are not listed.

${ }^{\mathrm{b}}$ Preliminary.
} 
Soybean production area is similar to corn production area, with the addition of more area in North and South Dakota and along the Mississippi Delta.

Figure 5.11

Soybeans for Beans, Harvested Acres in the United States, 2002

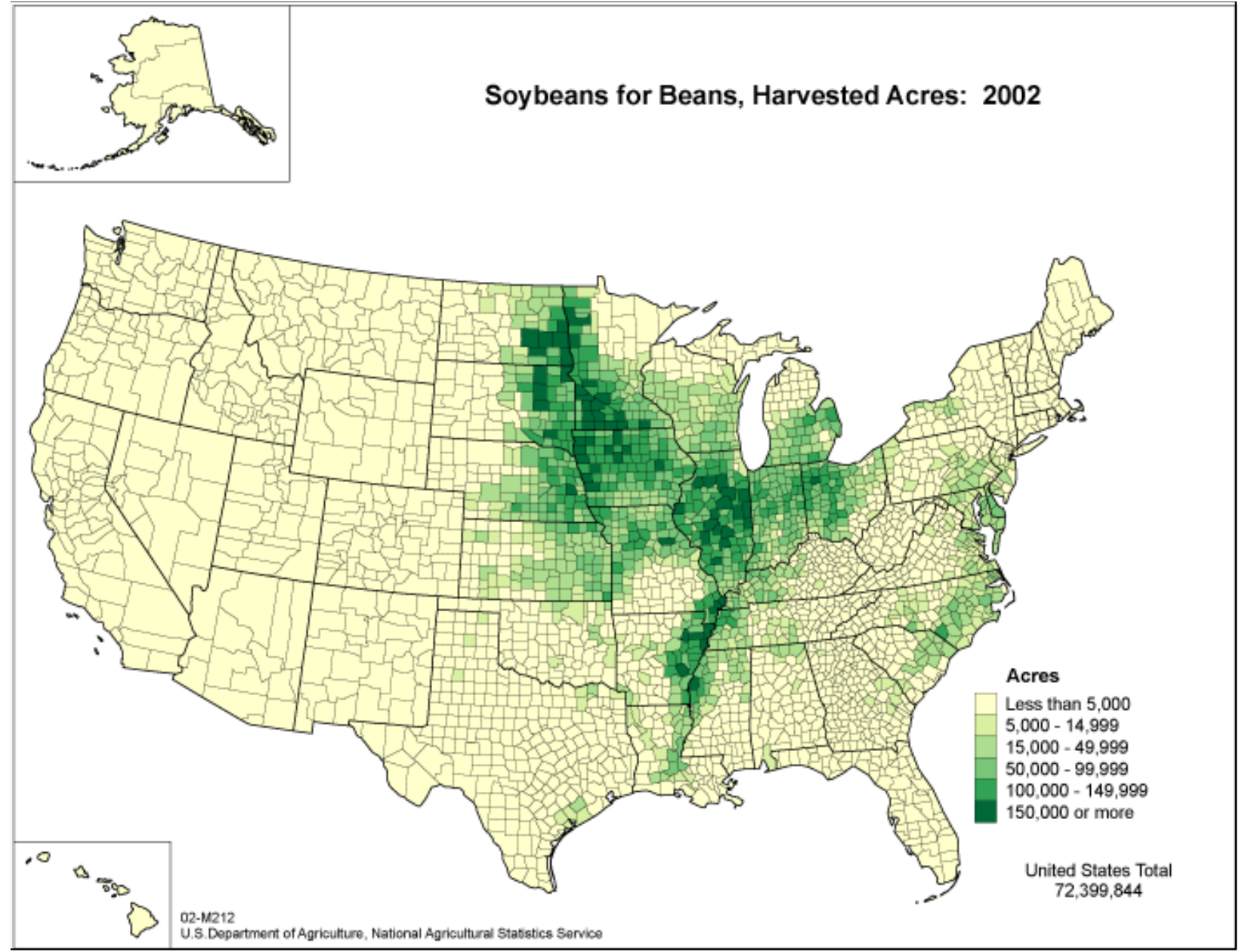

\section{Source:}

U.S. Department of Agriculture, National Agricultural Statistics Service, http://www.nass.usda.gov/research/atlas02/atlas-crops.html 
As with all agricultural crops, soybean costs and returns per acre vary by region. In general, soybean returns are a little less than returns for corn when only operating costs are considered.

Table 5.34

Soybean Production Costs and Returns per Planted Acre by Region, Excluding Government Payments, 2006-2007 (Dollars per planted acre)

\begin{tabular}{|c|c|c|c|c|c|c|c|c|c|c|c|c|c|c|c|c|}
\hline \multirow[b]{2}{*}{ Item } & \multicolumn{2}{|c|}{ United States } & \multicolumn{2}{|c|}{ Heartland } & \multicolumn{2}{|c|}{$\begin{array}{l}\begin{array}{l}\text { Northern } \\
\text { Crescent }\end{array} \\
\end{array}$} & \multicolumn{2}{|c|}{\begin{tabular}{|c|}
$\begin{array}{c}\text { Northern Great } \\
\text { Plains }\end{array}$ \\
\end{tabular}} & \multicolumn{2}{|c|}{ Prarie Gateway } & \multicolumn{2}{|c|}{$\begin{array}{l}\text { Eastern } \\
\text { Uplands }\end{array}$} & \multicolumn{2}{|c|}{$\begin{array}{l}\text { Southern } \\
\text { Seaboard }\end{array}$} & \multicolumn{2}{|c|}{$\begin{array}{l}\text { Mississippi } \\
\text { Portal }\end{array}$} \\
\hline & 2006 & 2007 & 2006 & 2007 & 2006 & 2007 & 2006 & 2007 & 2006 & 2007 & 2006 & 2007 & 2006 & 2007 & 2006 & 2007 \\
\hline \multicolumn{17}{|l|}{ Gross value of production } \\
\hline Primary product: Soybeans & 254.84 & 357.99 & 276.50 & 394.06 & 252.08 & 332.66 & 180.20 & 299.42 & 227.22 & 348.93 & 208.80 & 477.29 & 194.48 & 243.85 & 213.84 & 293.65 \\
\hline Total, gross value of produ & 54.84 & 357.99 & 276.50 & 394.06 & 252.08 & 332.66 & 180.20 & 299.42 & 227.22 & 348.93 & 208.80 & 477.29 & 194.48 & 243.85 & 213.84 & 293.65 \\
\hline \multicolumn{17}{|l|}{ Operating costs: } \\
\hline Seed & 32.30 & 38.92 & 32.01 & 38.54 & 34.67 & 41.75 & 34.36 & 41.37 & 30.69 & 36.96 & 31.44 & 37.86 & 30.23 & 36.40 & 32.59 & 39.24 \\
\hline Fertilizer $^{b}$ & 13.05 & 16.06 & 12.73 & 15.84 & 19.62 & 24.41 & 6.15 & 7.65 & 7.63 & 9.49 & 21.11 & 26.27 & 34.76 & 43.25 & 13.00 & 16.18 \\
\hline Chemicals & 14.46 & 14.56 & 14.38 & 14.60 & 13.92 & 14.14 & 12.47 & 12.66 & 12.94 & 13.14 & 11.49 & 11.67 & 15.75 & 16.00 & 18.57 & 18.86 \\
\hline Custom operations & 6.01 & 6.38 & 5.27 & 5.58 & 8.17 & 8.64 & 5.05 & 5.34 & 7.69 & 8.14 & 7.24 & 7.66 & 5.34 & 5.65 & 9.15 & 9.68 \\
\hline Fuel, lube, and electricity & 13.51 & 14.76 & 10.99 & 12.14 & 12.45 & 13.75 & 10.12 & 11.18 & 26.34 & 29.10 & 11.66 & 12.88 & 9.98 & 11.02 & 26.66 & 29.45 \\
\hline Repairs & 11.80 & 12.13 & 10.59 & 10.96 & 10.53 & 10.89 & 12.27 & 12.69 & 16.85 & 17.43 & 10.50 & 10.86 & 9.62 & 9.95 & 17.89 & 18.51 \\
\hline Purchased irrigat & 0.11 & 0.11 & 0.00 & 0.00 & 0.00 & 0.00 & 0.00 & 0.00 & 1.54 & 1.63 & 0.00 & 0.00 & 0.00 & 0.00 & 0.00 & 0.00 \\
\hline Interest on operating capita & 2.17 & 2.31 & 2.04 & 2.19 & 2.36 & 2.54 & 1.91 & 2.04 & 2.46 & 2.60 & 2.22 & 2.40 & 2.51 & 2.74 & 2.80 & 2.96 \\
\hline Total, operating costs & 93.41 & 105.23 & 88.01 & 99.85 & 101.72 & 116.12 & 82.33 & 92.93 & 106.14 & 118.49 & 95.66 & 109.60 & 108.19 & 125.01 & 120.66 & 134.88 \\
\hline \multicolumn{17}{|l|}{ Allocated overhead: } \\
\hline Hired labor & 1.78 & 1.80 & 1.15 & 1.19 & 1.17 & 1.21 & 1.50 & 1.55 & 1.90 & 1.97 & 2.70 & 2.79 & 2.65 & 2.74 & 6.68 & 6.91 \\
\hline Opportunity cost of unpaic & 15.20 & 15.70 & 14.33 & 14.83 & 16.71 & 17.30 & 13.21 & 13.67 & 19.03 & 19.70 & 16.63 & 17.21 & 17.43 & 18.04 & 18.13 & 18.77 \\
\hline Capital recovery & 60.38 & 63.22 & 58.48 & 61.37 & 52.98 & 55.60 & 65.82 & 69.07 & 72.62 & 76.21 & 54.77 & 57.48 & 51.25 & 53.78 & 68.95 & 72.36 \\
\hline Opportunity cost of land (rental rat & 86.17 & 92.92 & 101.33 & 108.52 & 70.99 & 76.02 & 46.65 & 49.96 & 60.64 & 64.94 & 56.61 & 60.62 & 39.18 & 41.96 & 64.34 & 68.90 \\
\hline Taxes and insurance & 7.93 & 8.55 & 7.94 & 8.58 & 9.99 & 10.79 & 6.89 & 7.44 & 8.01 & 8.65 & 6.16 & 6.66 & 6.83 & 7.38 & 7.50 & 8.10 \\
\hline General farm overhead & 13.22 & 13.79 & 13.50 & 13.97 & 17.36 & 17.96 & 10.75 & 11.12 & 14.72 & 15.23 & 13.14 & 13.59 & 10.04 & 10.39 & 9.71 & 10.04 \\
\hline Total, allocated overhead & 184.68 & 195.98 & 196.73 & 208.46 & 169.20 & 178.88 & 144.82 & 152.81 & 176.92 & 186.70 & 150.01 & 158.35 & 127.38 & 134.29 & 175.31 & 185.08 \\
\hline Total costs listed & 278.09 & 301.21 & 284.74 & 308.31 & 270.92 & 295.00 & 227.15 & 245.74 & 283.06 & 305.19 & 245.67 & 267.95 & 235.57 & 259.30 & 295.97 & 319.96 \\
\hline Value of produc & -23.25 & 56.78 & -8.24 & 85.76 & -18.84 & 37.65 & -46.95 & 53.68 & -55.84 & 43.75 & -36.87 & 209.34 & -41.09 & -15.45 & -82.13 & -26.30 \\
\hline Value of production less of & 161.43 & 252.76 & 188.49 & 294.22 & 150.36 & 216.53 & 97.87 & 206.49 & 121.08 & 230.45 & 113.14 & 367.69 & 86.29 & 118.84 & 93.18 & 158.78 \\
\hline \multicolumn{17}{|l|}{ Supporting information: } \\
\hline Yield (bushels per plantec & 46 & 45 & 50 & 48 & 46 & 41 & 34 & 38 & 42 & 42 & 36 & 57 & 34 & 30 & 36 & 37 \\
\hline Price (dollars per bushel at $h$ & 5.54 & 7.95529 & 5.53 & 8.2173 & 5.48 & 8.02 & 5.3 & 7.7989 & 5.41 & 8.21 & 5.8 & 8.3226 & 5.72 & 8.21 & 5.94 & 7.87 \\
\hline Enterprise size (planted acres) $)^{a}$ & 303 & 303 & 299 & 299 & 164 & 164 & 164 & 164 & 254 & 254 & 321 & 321 & 240 & 240 & 676 & 676 \\
\hline \multicolumn{17}{|l|}{ Production practices: ${ }^{a}$} \\
\hline Irrigated (percent) & 9 & 9 & 4 & 4 & 2 & 2 & 2 & 2 & 32 & 32 & 6 & 6 & 0 & 0 & 38 & 38 \\
\hline Dryland (percent) & 91 & 91 & 96 & 96 & 98 & 98 & 98 & 98 & 68 & 68 & 94 & 94 & 100 & 100 & 62 & 62 \\
\hline
\end{tabular}

Source:

Economic Research Service, U.S. Department of Agriculture, http://www.ers.usda.gov/data/costsandreturns/testpick.htm

a Developed from survey base year, 2006.

${ }^{\mathrm{b}}$ Commercial fertilizer, soil conditioners, and manure. 
Figure 5.12

Projected Total Switchgrass, 2017

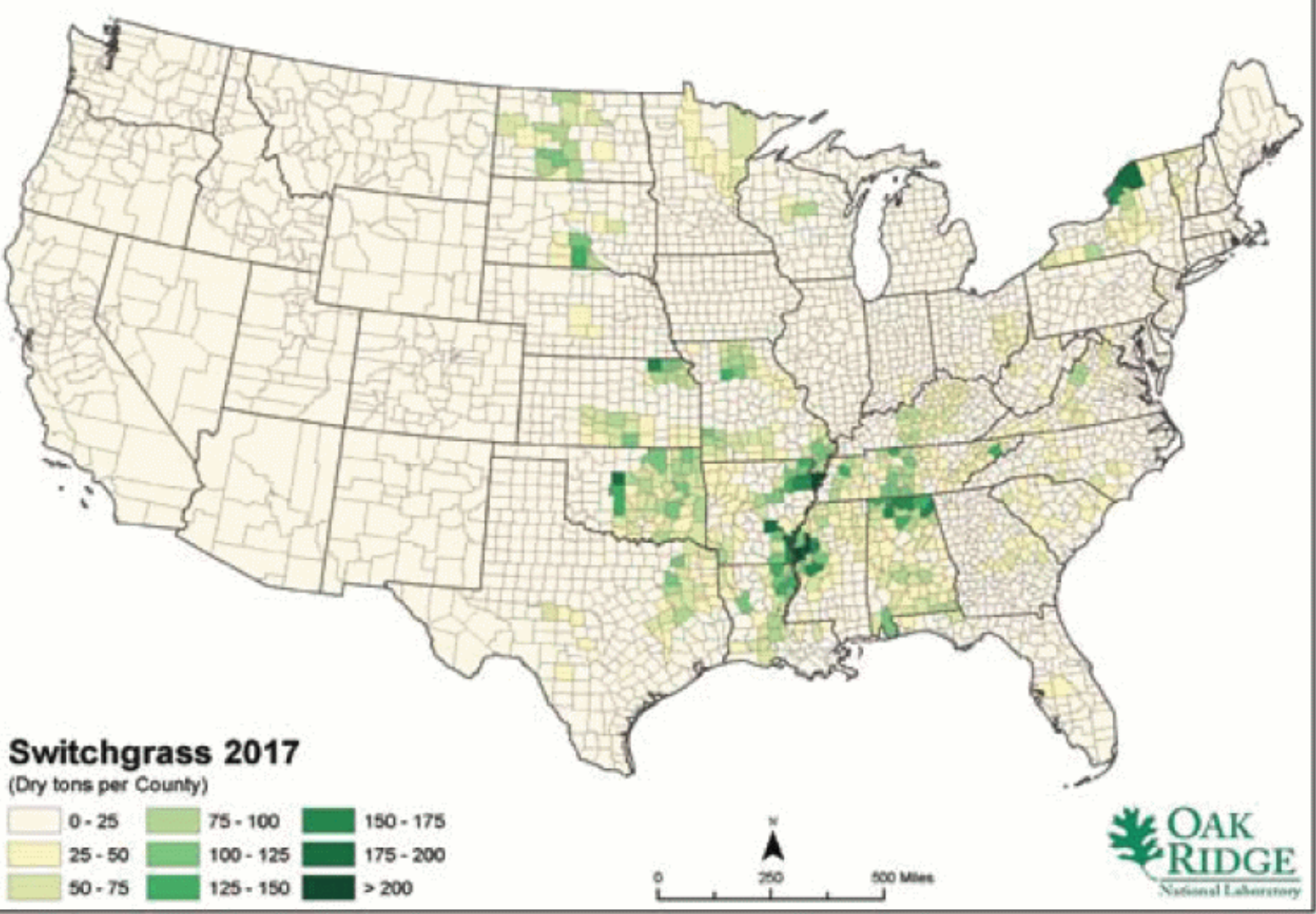

\section{Source:}

Biomass Research and Development Technical Advisory Committee, Biomass Research and Development Initiative, Roadmap for Bioenergy and Biobased Products in the United States, October 2007. 
Discussion of the potential of herbaceous grasses such as switchgrass.

Figure 5.13

Location of Areas Where Switchgrass is Likely to be Grown on Cropland

Map to be added

\section{Source:}

Bioenergy Resource and Engineering Systems Program, Oak Ridge National Laboratory. 
Discussion of the potential of woody crops, such as poplar and willow.

Figure 5.14

Location of Areas Where Woody Crops are Likely to be Grown on Cropland

Map to be added

\section{Source:}

Bioenergy Resource and Engineering Systems Program, Oak Ridge National Laboratory. 
Logging residues are the unused portions of growing-stock and non-growing-stock trees cut or killed by logging and left in the woods.

Figure 5.15

Total Availability of Logging Residue from Timberlands, 2007

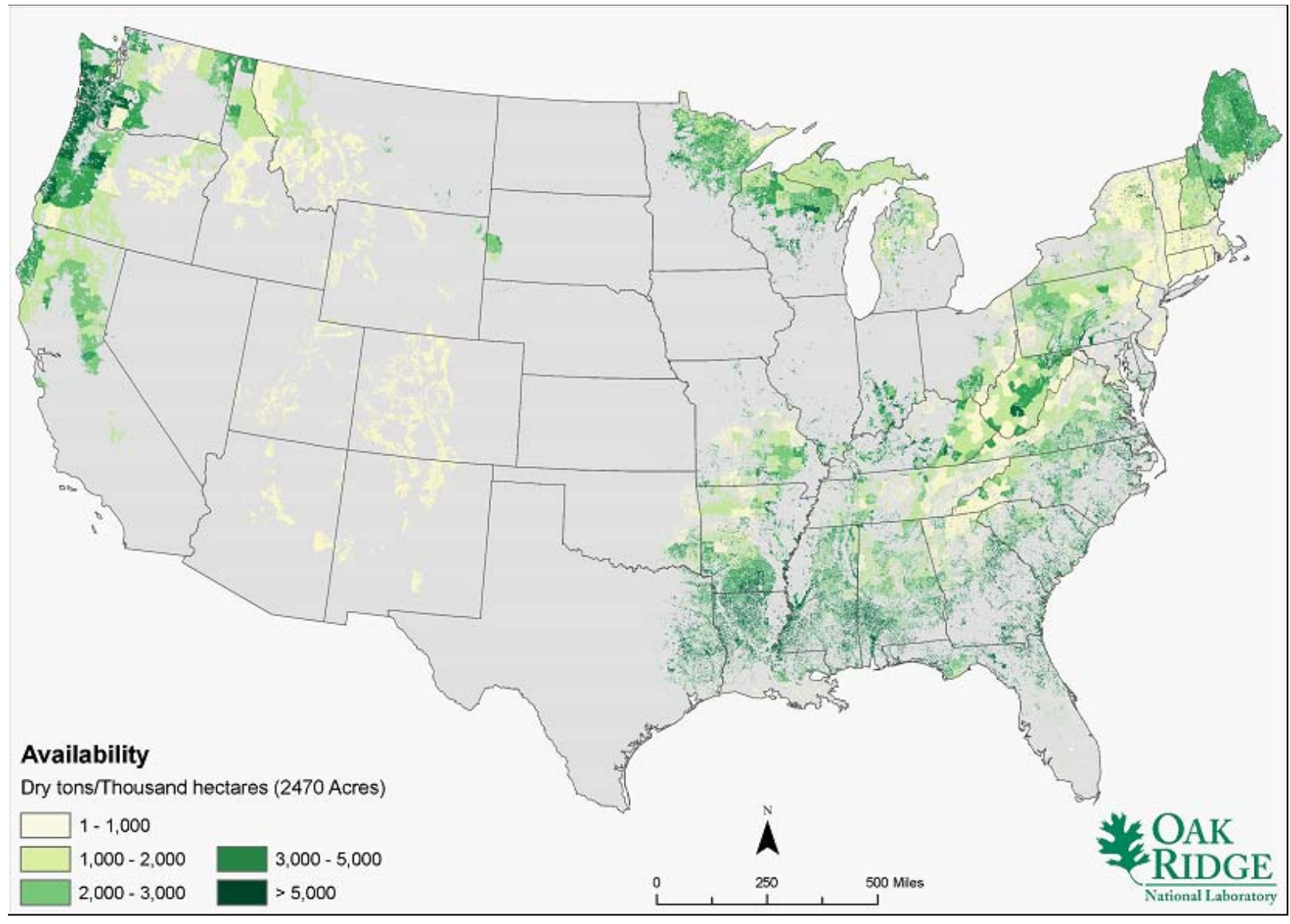

Source:

Bioenergy Resource and Engineering Systems Program, Oak Ridge National Laboratory. 
Fuel treatment thinnings are the material generated from fuel treatment operations and thinnings designed to reduce the risk of loss to wildfire on timberlands. Timberland is forestland that is capable of producing in excess of 20 cubic feet per acre per year of industrial products in natural stands and is not withdrawn from timber utilization by statute or administrative regulation. These lands are distributed throughout the United States. As with logging residues, economics, site-specific characteristics and costs affect the recoverability of this material.

Figure 5.16

Total Availability of Fuel Treatment Thinnings from Timberlands, 2007

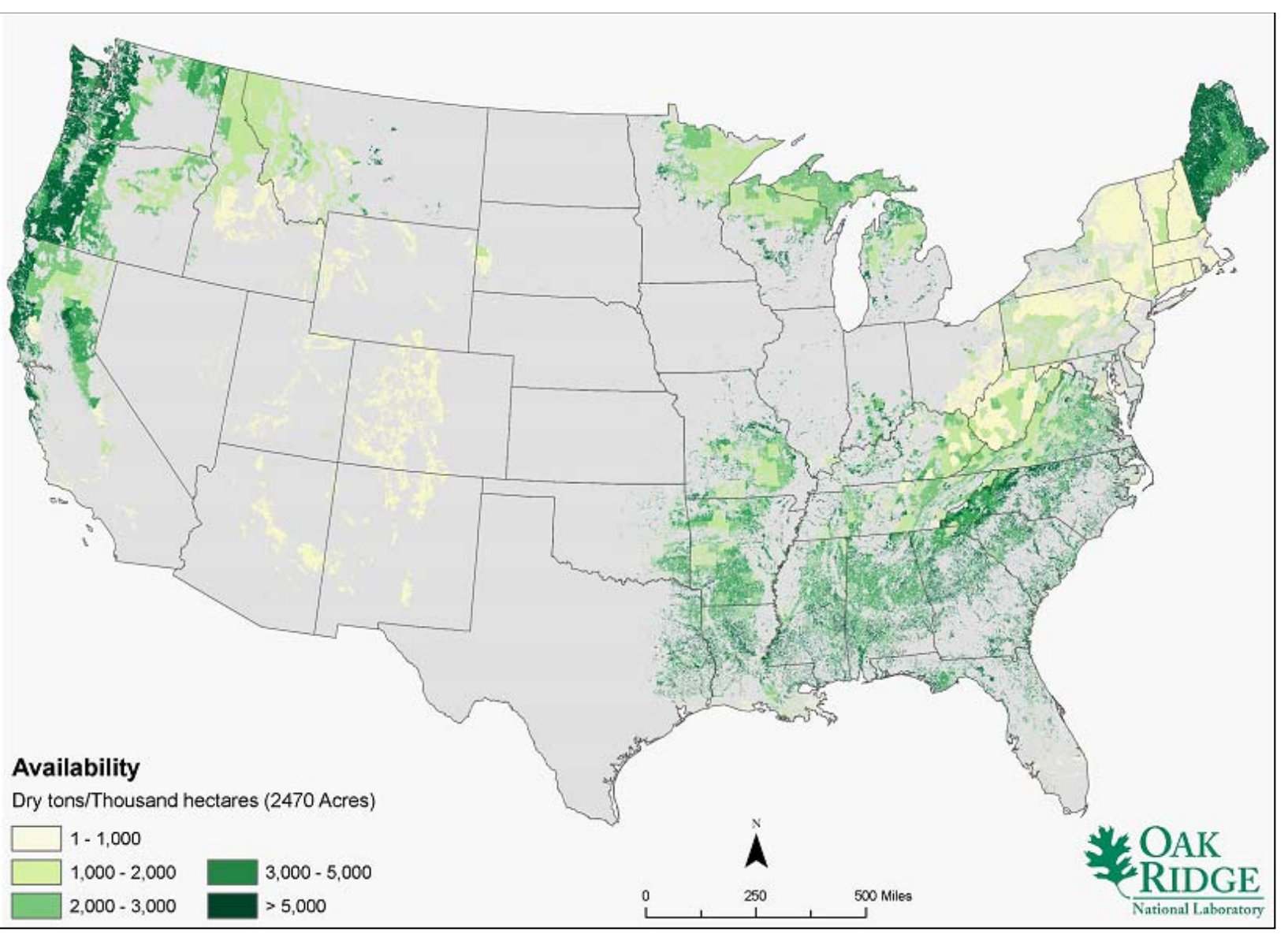

Source:

Bioenergy Resource and Engineering Systems Program, Oak Ridge National Laboratory. 
Other removal residues are the unutilized wood volume from cut or otherwise killed growing stock, from cultural operations such as pre-commercial thinnings, or from timberland clearing. Does not include volume removed from inventory through reclassification of timberland to productive reserved forest land.

Figure 5.17

Total Availability of Other Removal Residue from Timberlands, 2007

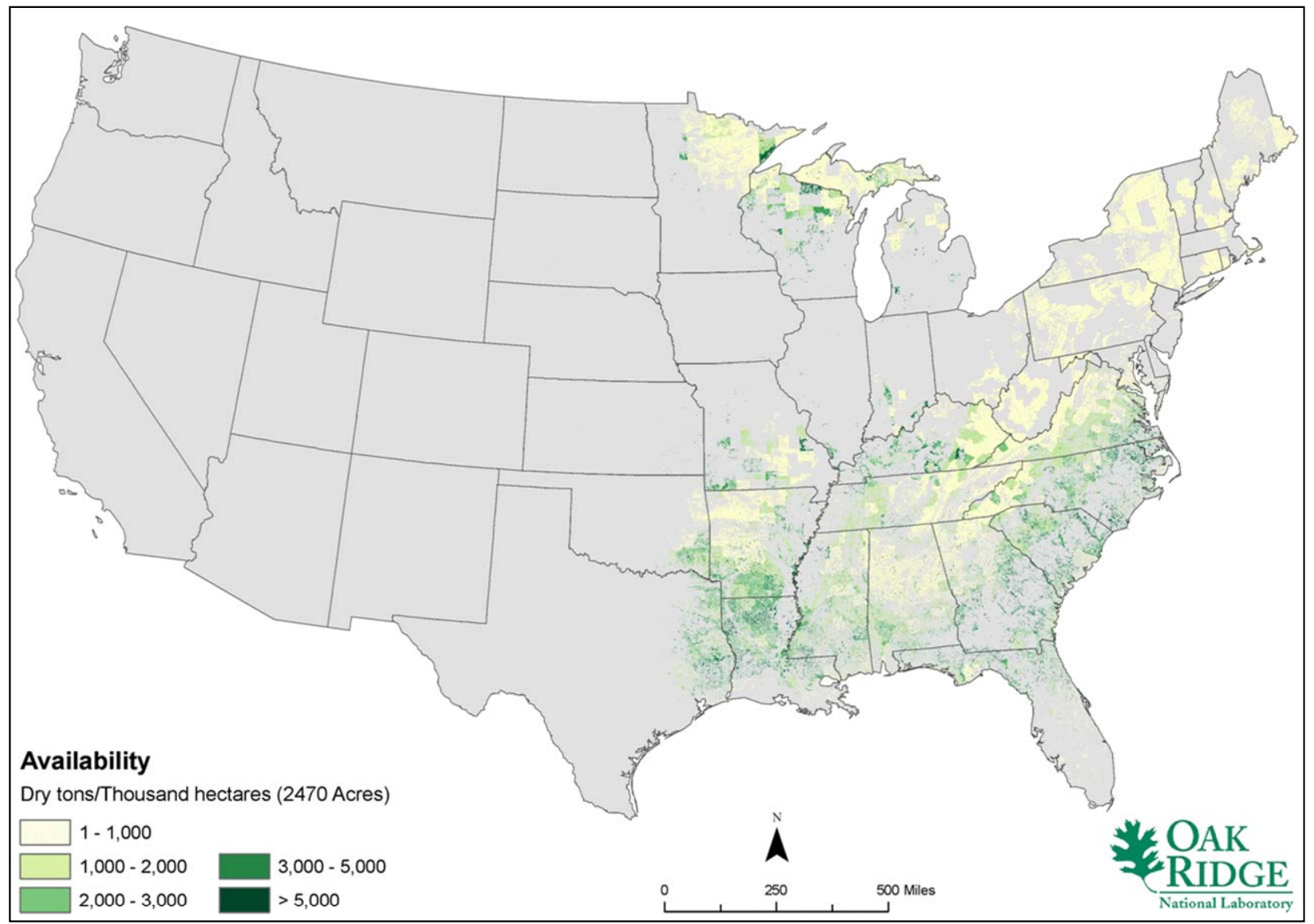

\section{Source:}

Bioenergy Resource and Engineering Systems Program, Oak Ridge National Laboratory. 
Table 5.35

Estimated Availability of Primary Forest Residues, 2007

\begin{tabular}{|c|c|c|c|}
\hline State & Logging residue & Other removal residue & Fuel treatment thinnings on timberlands \\
\hline Alabama & $2,442,510$ & 539,120 & $2,051,240$ \\
\hline Arizona & 36,140 & 0 & 91,580 \\
\hline Arkansas & $1,800,920$ & 820,010 & $1,645,880$ \\
\hline California & $1,402,420$ & 0 & $3,070,540$ \\
\hline Colorado & 35,330 & 0 & 53,490 \\
\hline Connecticut & 8,920 & 260 & 20,930 \\
\hline Delaware & 37,270 & 20 & 13,400 \\
\hline Florida & $1,158,230$ & 548,450 & $1,171,120$ \\
\hline Georgia & $3,208,320$ & $1,020,440$ & $2,737,170$ \\
\hline Idaho & 579,970 & 0 & 789,420 \\
\hline Illinois & 322,020 & 233,840 & 225,840 \\
\hline Indiana & 577,580 & 93,980 & 444,510 \\
\hline lowa & 112,100 & 61,480 & 96,210 \\
\hline Kansas & 14,660 & 69,980 & 19,390 \\
\hline Kentucky & $1,046,690$ & 658,610 & 896,770 \\
\hline Louisiana & $2,691,930$ & 909,770 & $1,305,630$ \\
\hline Maine & $2,586,300$ & 690 & $3,756,240$ \\
\hline Maryland & 203,810 & 1,380 & 81,990 \\
\hline Massachusetts & 82,400 & 170 & 27,630 \\
\hline Michigan & 983,310 & 293,110 & $2,076,960$ \\
\hline Minnesota & $1,414,330$ & 654,600 & $1,200,580$ \\
\hline Mississippi & $3,186,170$ & 768,020 & $1,659,490$ \\
\hline Missouri & 867,670 & 531,940 & $1,270,710$ \\
\hline Montana & 559,420 & 0 & $1,049,880$ \\
\hline Nebraska & 21,850 & 18,870 & 23,350 \\
\hline Nevada & 3,130 & 0 & 4,570 \\
\hline New Hampshire & 346,750 & 540 & 104,800 \\
\hline New Jersey & 9,540 & 80 & 4,870 \\
\hline New Mexico & 39,300 & 0 & 63,970 \\
\hline New York & 845,940 & 74,260 & 383,060 \\
\hline North Carolina & $2,062,740$ & $1,300,680$ & $2,692,440$ \\
\hline North Dakota & 3,070 & 15,160 & 7,680 \\
\hline Ohio & 429,060 & 5,100 & 177,020 \\
\hline Oklahoma & 351,590 & 210,670 & 426,440 \\
\hline Oregon & $2,941,430$ & 0 & $4,168,920$ \\
\hline Pennsylvania & $1,293,930$ & 1,450 & 635,950 \\
\hline Rhode Island & 1,910 & 40 & 5,600 \\
\hline South Carolina & $1,475,930$ & 746,650 & $1,345,850$ \\
\hline South Dakota & 86,240 & 13,980 & 56,320 \\
\hline Tennessee & 660,280 & 458,170 & 983,140 \\
\hline Texas & $1,256,110$ & 485,780 & 922,740 \\
\hline Utah & 14,810 & 0 & 30,250 \\
\hline Vermont & 223,960 & 110 & 158,950 \\
\hline Virginia & $1,511,680$ & 851,870 & $1,440,000$ \\
\hline Washington & $2,546,800$ & 0 & $3,663,550$ \\
\hline West Virginia & 981,640 & 1,020 & 568,400 \\
\hline Wisconsin & $1,519,710$ & $1,047,060$ & $1,613,390$ \\
\hline Wyoming & 49,030 & 0 & 54,620 \\
\hline Total & $44,034,850$ & $12,437,360$ & $45,292,480$ \\
\hline
\end{tabular}

Source:

Bioenergy Resource and Engineering Systems Program, Oak Ridge National Laboratory. 
Figure 5.18

Total Availability of Corn Stover Residue, 2007 (Preliminary)

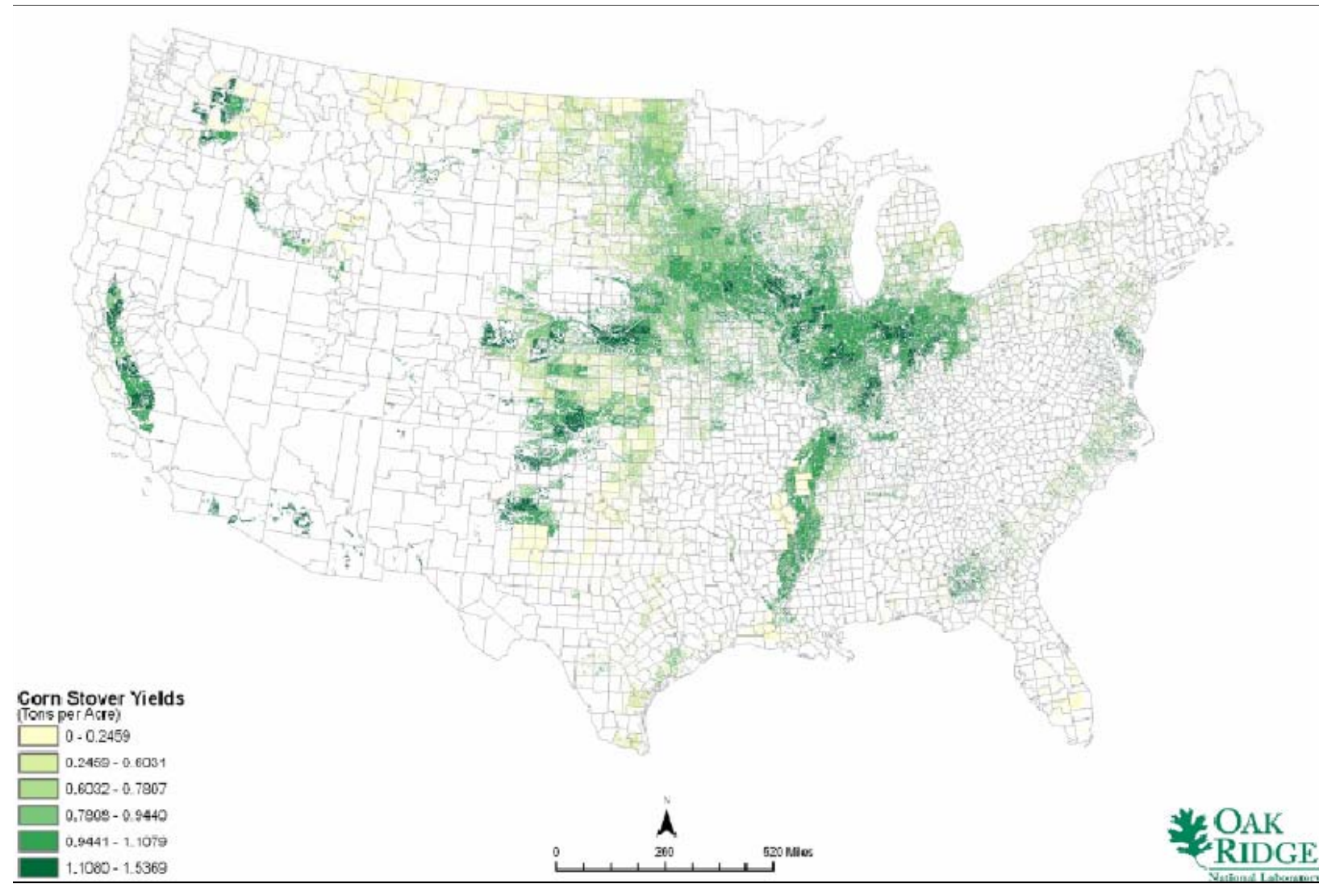

Source:

Bioenergy Resource and Engineering Systems Program, Oak Ridge National Laboratory. 
Figure 5.19

Total Availability of Wheat Straw Residue, 2007

Note: The map below will be replaced with the correct wheat map for the final version.

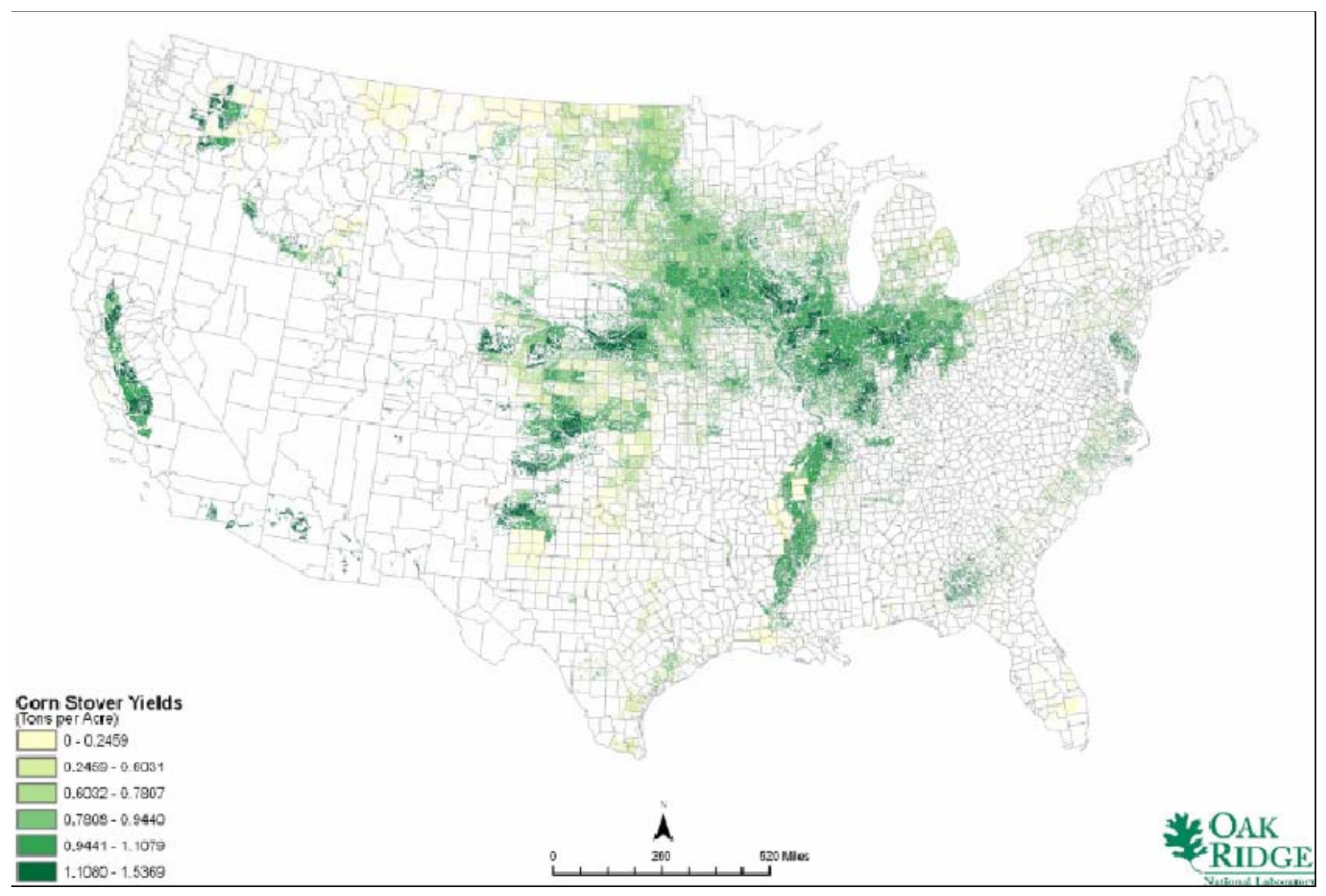

Source:

Bioenergy Resource and Engineering Systems Program, Oak Ridge National Laboratory. 
Table 5.36

Estimated Availability of Corn Stover, Wheat Straw, and Other Crop Residues, 2007

\begin{tabular}{|c|c|c|c|c|}
\hline State & Corn stover Wheat straw & $\begin{array}{c}\text { Other crop } \\
\text { residues }\end{array}$ & $\begin{array}{l}\text { Other crop } \\
\text { residues }\end{array}$ & $\begin{array}{l}\text { Other crop } \\
\text { residues }\end{array}$ \\
\hline \multicolumn{5}{|l|}{$\overline{\text { Alabama }}$} \\
\hline \multicolumn{5}{|l|}{ Arizona } \\
\hline \multicolumn{5}{|l|}{ Arkansas } \\
\hline \multicolumn{5}{|l|}{ California } \\
\hline \multicolumn{5}{|l|}{ Colorado } \\
\hline \multicolumn{5}{|l|}{ Connecticut } \\
\hline \multicolumn{5}{|l|}{ Delaware } \\
\hline \multicolumn{5}{|l|}{ Florida } \\
\hline \multicolumn{5}{|l|}{ Georgia } \\
\hline \multicolumn{5}{|l|}{ Idaho } \\
\hline \multicolumn{5}{|l|}{ Illinois } \\
\hline \multicolumn{5}{|l|}{ Indiana } \\
\hline \multicolumn{5}{|l|}{ lowa } \\
\hline \multicolumn{5}{|l|}{ Kansas } \\
\hline \multicolumn{5}{|l|}{ Kentucky } \\
\hline Louisiana & & To be Completed & & \\
\hline \multicolumn{5}{|l|}{ Maine } \\
\hline \multicolumn{5}{|l|}{ Maryland } \\
\hline \multicolumn{5}{|l|}{ Massachusetts } \\
\hline \multicolumn{5}{|l|}{ Michigan } \\
\hline \multicolumn{5}{|l|}{ Minnesota } \\
\hline \multicolumn{5}{|l|}{ Mississippi } \\
\hline \multicolumn{5}{|l|}{ Missouri } \\
\hline Montana & & & & \\
\hline Nebraska & & & & \\
\hline Nevada & & & & \\
\hline New Hampshire & & & & \\
\hline New Jersey & & & & \\
\hline New Mexico & & & & \\
\hline New York & & & & \\
\hline North Carolina & & & & \\
\hline North Dakota & & & & \\
\hline Ohio & & & & \\
\hline Oklahoma & & & & \\
\hline Oregon & & & & \\
\hline Pennsylvania & & & & \\
\hline Rhode Island & & & & \\
\hline South Carolina & & & & \\
\hline South Dakota & & & & \\
\hline Tennessee & & & & \\
\hline Texas & & & & \\
\hline Utah & & & & \\
\hline Vermont & & & & \\
\hline Virginia & & & & \\
\hline Washington & & & & \\
\hline West Virginia & & & & \\
\hline Wisconsin & & & & \\
\hline Wyoming & & & & \\
\hline Total & & & & \\
\hline
\end{tabular}




\section{SECONDARY BIOMASS FEEDSTOCKS}

Residues and byproduct streams from food, feed, fiber, wood, and materials processing plants are the main source of secondary biomass. Secondary biomass feedstocks differ from primary biomass feedstocks in that the secondary feedstocks are a by-product of processing of the primary feedstocks. By "processing" it is meant that there is substantial physical or chemical breakdown of the primary biomass and production of by-products. "Processors" may be factories or animals. Field processes such as harvesting, bundling, chipping or pressing do not cause a biomass resource that was produced by photosynthesis (e.g., tree tops and limbs) to be classified as secondary biomass.

Specific examples of secondary biomass includes sawdust from sawmills, black liquor (which is a byproduct of paper making), and cheese whey (which is a by-product of cheese making processes). Manures from concentrated animal feeding operations are collectable secondary biomass resources. Vegetable oils used for biodiesel that are derived directly from the processing of oilseeds for various uses are also a secondary biomass resource.

It is difficult to find good direct sources of information on secondary biomass resources. In most cases, one has to estimate availability based on information and assumptions about the industries or companies generating the biomass. These estimates can be inaccurate because the amount of material that is a byproduct to a given process can change over time as processes become more efficient or new uses are found for some by-product components.

The estimates provided in this Data Book were generated either by industries using secondary biomass to make a marketable fuel (e.g., the pellet fuel industry), or were generated by Forest Service staff using the Timber Product Output database http://www.fia.fs.fed.us/tools-data/tools/. This database is based on wood harvest and use inventories conducted every 5 years; the 2002 inventory is the latest source of information. The wood already used for energy provides insight on current bioenergy produced and the "unused" biomass represents wood that is already collected and potentially very easy to make available for additional energy production. Though a relatively small amount, it would likely be some of the first wood used if bioenergy use is accelerated in the U.S.

Information on black liquor production and use for energy is kept and tracked by the forest products industry but is proprietary. An estimate of black liquor production could be made based on publicly available information on pulp mills. However, any current listing of pulp mills in operation will be out-ofdate within a month or two of publication because of the frequent closing of mills that is occurring. Thus, though a very important resource for bioenergy production today, no attempt is made to include a state level estimate of black liquor production in this book.

\section{Source:}

Lynn Wright, Oak Ridge, TN. 
The Forest Service's State and Private Forestry, Technology Marketing Unit, at the agency has awarded grants to stimulate utilization of woody biomass, especially of wood from areas needing hazardous fuels reduction. The projects are small and often support the purchase of equipment by small companies. The primary objective of the Forest Service is to increase the removal and use of small diameter wood from forests. Only 2007 and 2008 projects are shown in this summary. A report is available on the status of projects funded in 2005 and 2006. We have categorized the projects by whether the activity concerns feedstock supply, or production of bioenergy or bioproducts.

Table 5.37

U.S. Forest Service - Woody Biomass Utilization Grantees 2007 \& 2008

\begin{tabular}{|c|c|c|c|}
\hline Company Name & Location & Award \$\$ & Project Name (shortened)/descriptions \\
\hline \multicolumn{4}{|c|}{2008 Grant Summary } \\
\hline \multicolumn{4}{|l|}{ Feedstock Supply } \\
\hline Nevada Div. of Forestry & Carson City, NV & 250,000 & Western Nevada Biomass Transportation Project \\
\hline Northridge Forest Products & Mora, NM & 250,000 & Woody Biomass Utilization (thinning and harvesting) \\
\hline $\begin{array}{l}\text { Watershed Research and Training } \\
\text { Center }\end{array}$ & Hayfork, CA & 245,000 & $\begin{array}{l}\text { Establishing Mechanical Harvesting Capacity for } \\
\text { Restoration of Forest }\end{array}$ \\
\hline Coquille Tribe & North Bend, OR & 250,000 & $\begin{array}{l}\text { Use of Roll On/Off Container System to Capture Biomass } \\
\text { and Reduce Fuel Treatment Costs }\end{array}$ \\
\hline Osler Logging, Inc. & Bozeman, MT & 250,000 & Haul Truck Acquisition for Woody Biomass Production \\
\hline Perkins Timber Harvesting & Williams, AZ & 250,000 & $\begin{array}{l}\text { Increasing Capacity to Harvest Woody Biomass } \\
\text { (purchase of a harvester/forwarder) }\end{array}$ \\
\hline Kootenai Business Park Ind. Dist & Libby, MT & 250,000 & $\begin{array}{l}\text { Biomass Production/Purchase of truck scales, grinder } \\
\text { and chip bin }\end{array}$ \\
\hline Quicksilver Contracting & Bend, OR & 250,000 & $\begin{array}{l}\text { Portable Chip Trailer Chipper to Facilite Interstate } \\
\text { Transportation of Woody Biomass }\end{array}$ \\
\hline \multicolumn{4}{|l|}{ Bioenergy } \\
\hline Bear Mountain Forest Products & Portland, OR & 250,000 & $\begin{array}{l}\text { New Market for Low-Value Biomass Through Wood } \\
\text { Briquette Production }\end{array}$ \\
\hline \multicolumn{4}{|l|}{ Bioproducts } \\
\hline Winner's Circle Soil Products & Taylor, AZ & 250,000 & Wood Shavings Packing Project \\
\hline K\&B Timberworks, Inc & Reserve, NM & 250,000 & $\begin{array}{l}\text { Woody Biomass Equipment Improvement/ Purchase of a } \\
\text { Helle Scragg Mill }\end{array}$ \\
\hline Big Sky Shavings & Hall, MT & 250,000 & $\begin{array}{l}\text { Additional Capacity for Biomass Utilization (expanding a } \\
\text { wood shavings mill) }\end{array}$ \\
\hline Marks Ranch and Lumber & Clancy, MT & 211,000 & $\begin{array}{l}\text { Improve Recovery and Utilization of Sawlogs (purchase a } \\
\text { thin-kerf bandsaw) }\end{array}$ \\
\hline Sandford Logging, Inc & Spearfish, SD & 250,000 & Post and Pole Manuracturing Plant \\
\hline UpStream 21 Corp & Portland, OR & 250,000 & Log Merchandizing Facility \\
\hline Renewable Fiber, Inc & Ft. Lupton, CO & 250,000 & Wood Shaving Plant Upgrade \\
\hline Diamond Ridge Lumber & Caldwell, ID & 168,200 & $\begin{array}{l}\text { Forest Restoration Activities/ Purchase of security } \\
\text { equipment for animal shaving and sawmill }\end{array}$ \\
\hline
\end{tabular}

Table Continued on Next Page 
Table 5.37 (Continued)

U.S. Forest Service - Woody Biomass Utilization Grantees 2007 \& 2008

\begin{tabular}{|c|c|c|c|}
\hline Company Name & Location & Award \$\$ & Project Name (shortened)/descriptions \\
\hline \multicolumn{4}{|c|}{2007 Grant Summary } \\
\hline \multicolumn{4}{|l|}{ Feedstock Supply } \\
\hline Intrinergy, LLC & Ashland, VA & 250,000 & $\begin{array}{l}\text { Establish a supply of woody biomass feedstock from } \\
\text { Desoto National Forest }\end{array}$ \\
\hline Olguin's Sawmill, Inc & El Prado, NM & 250,000 & $\begin{array}{l}\text { Forest Restoration Activity/ purchase of a feller buncher } \\
\text { and planer }\end{array}$ \\
\hline Mt. Taylor Millwork, Inc & Milan, NM & 250,000 & $\begin{array}{l}\text { Woody Biomass Utilization, Forest Restoration, and } \\
\text { Tamarisk Eradication Project/buy chipper }\end{array}$ \\
\hline Barala Timber & Las Vegas, NM & 250,000 & $\begin{array}{l}\text { Diversified Woody Biomass Utilization/purchase of } \\
\text { excavator mounted feller-buncher and horizontal grinder }\end{array}$ \\
\hline Dept. Forestry, NCSU & Raleigh, NC & 247,802 & $\begin{array}{l}\text { Machine System Development for Harvesting Woody } \\
\text { Biomass and Reducing Hazardous Fuels }\end{array}$ \\
\hline Baker Timber Products & Rapid City, SD & 250,000 & Forest Biomass to Ethanol/funds for purchase of wood \\
\hline John Jump Trucking & Kalispell, MT & 250,000 & Transfer Truck Acquisition/buy trucks \\
\hline \multicolumn{4}{|l|}{ Bioenergy } \\
\hline Kane Area School District & Kane, PA & 250,000 & School District Woody Biomass Utilization Project \\
\hline St Maries Joint School District & St. Maries, ID & 250,000 & School District Heating Project \\
\hline Elk Regional Health System & St. Mary, PA & 250,000 & $\begin{array}{l}\text { Elk Regional Health System Alternative Fuels Project } \\
\text { (heating and cooling system ) }\end{array}$ \\
\hline Mountain Parks, Electric, Inc & Granby, CO & 243,500 & $\begin{array}{l}\text { Development of a 3-4 MW Woody Biomass CHP facility/ } \\
\text { supporting design, verification and specifications }\end{array}$ \\
\hline Mescalero Forest Products & Mescalero, NM & 250,000 & $\begin{array}{l}\text { Forest Products Pellet Mill/purchase of a pellet plant and } \\
\text { marketing of pellets for energy }\end{array}$ \\
\hline \multicolumn{4}{|l|}{ Bioproducts } \\
\hline Malheur Lumber Company & John Day, OR & 250,000 & Small Log Value Added Shaving Facility \\
\hline JTS Animal Bedding & Redmond, OR & 250,000 & Animal Bedding Small Pine Utilization Project \\
\hline High County Green Waste, LLC & Lakeside, AZ & 249,400 & $\begin{array}{l}\text { Serving Biomass Markets from Fire Hazard Mitigation } \\
\text { Activities/equipment purchases for using biomass }\end{array}$ \\
\hline Parma Post \& Pole, Inc & Parma, ID & 245,180 & $\begin{array}{l}\text { Small Diameter Doweling Expansion } \\
\text { Operation/equipment purchase for biomass use }\end{array}$ \\
\hline $\begin{array}{l}\text { Woodland Restoration, Inc/North } \\
\text { Slop Sustainable Wood LLC }\end{array}$ & Missoula, MT & 248,950 & $\begin{array}{l}\text { Developing National Market for Larch and Fir Flooring } \\
\text { from Small Diameter Trees }\end{array}$ \\
\hline Bearlodge Forest Products, Inc & Hulett, WY & 250,000 & $\begin{array}{l}\text { Manufacturing Pallet Parts from Hazardous Fuel } \\
\text { Reductions/pallet making equipment purchase }\end{array}$ \\
\hline Southwest Forest Products & Phoenix, AZ & 250,000 & $\begin{array}{l}\text { Increased Utilization and Market Development/purchase } \\
\text { and installation of a debarking system }\end{array}$ \\
\hline Forest Fuels Solutions & Salmon, ID & 250,000 & Post and Pole Manufacturing/equipment purchases \\
\hline $\begin{array}{l}\text { Healty Forests, Healty Community } \\
\text { (HFHC) Utilization Program }\end{array}$ & Portland, OR & 250,000 & $\begin{array}{l}\text { HFHC will provide strategic financial and technical } \\
\text { assistance to } 4 \text { local projects treating at risk forests and } \\
\text { processing the small diameter wood. }\end{array}$ \\
\hline Mountain Valley Lumber & Saguache, $\mathrm{CO}$ & 179,260 & $\begin{array}{l}\text { Woody Biomass Equipment Acquisition and } \\
\text { Installation/purchase of a dowel mill }\end{array}$ \\
\hline Piute County Dept. of Econ. Dev & Junction, UT & 249,800 & $\begin{array}{l}\text { Woody Biomass Utilization/ financing to develop a } \\
\text { process and manufacturing incubator park }\end{array}$ \\
\hline Kuykendall and Sons & Tres Piedras, NM & 250,000 & $\begin{array}{l}\text { Equipment Expansion for Woody Biomass Utilization/mill } \\
\text { upgrade equipment }\end{array}$ \\
\hline Ranch Creek Limited & Granby, CO & 144,000 & $\begin{array}{l}\text { Low-value Timer Utilization/purchase of a log lathe for } \\
\text { producing house logs }\end{array}$ \\
\hline
\end{tabular}

\section{Source:}

U.S. Forest Service State \& Private Forestry Technology Marketing Unit Web site, http://www.fpl.fs.fed.us/tmu/index.html 
The map below showing feedlot capacity and distribution throughout the United States is important as an indication of manure availability.

Figure 5.20

Feedlot Capacity and Distribution, 2004

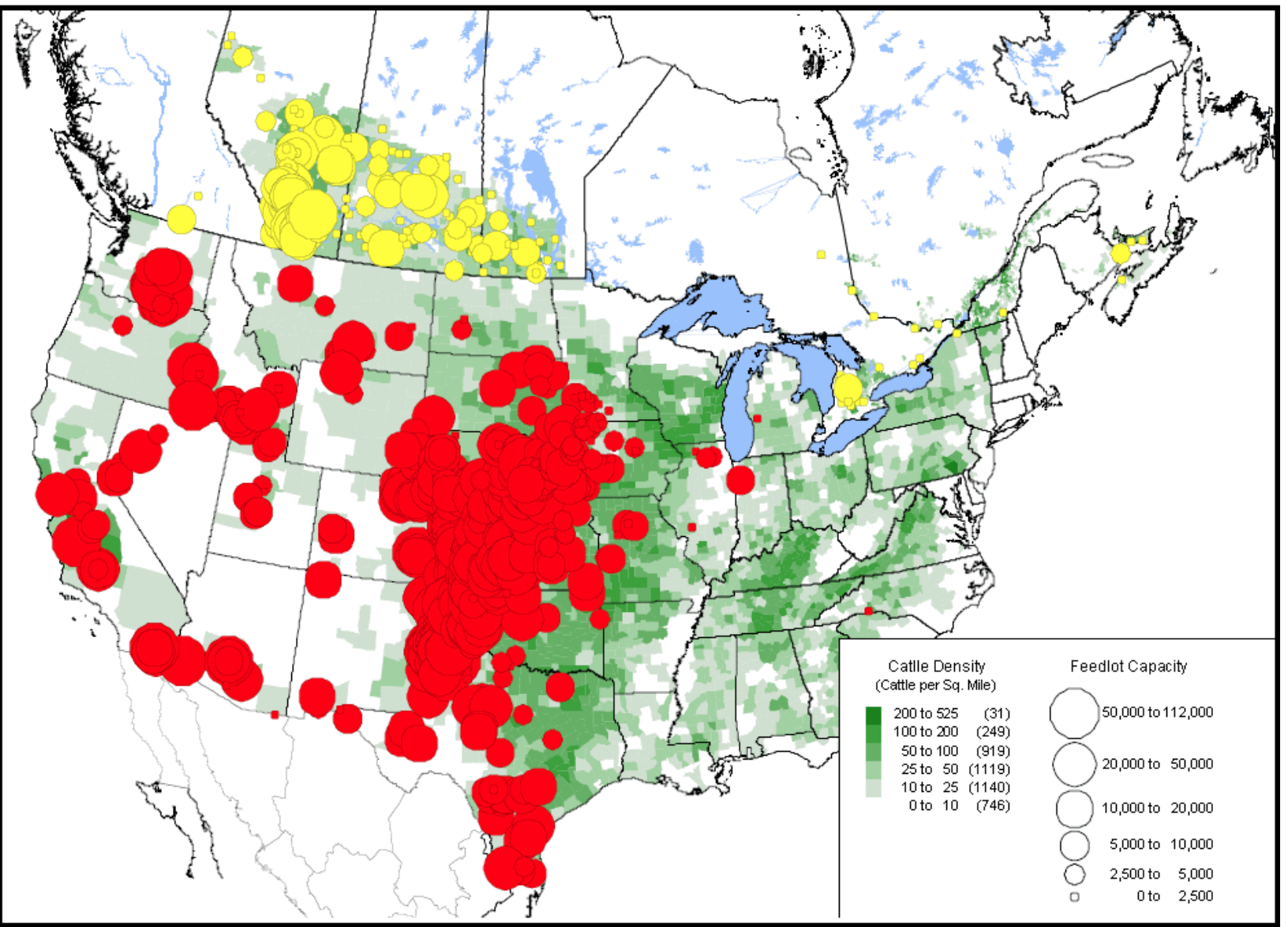

\section{Source:}

United States Department of Agriculture, U.S. Biobased Products Market Potential and Projections through 2025, Page 224, OCE-2008-1, February 2008. 
The Forest Service classifies primary mill residues into three categories: bark, coarse residues (chunks and slabs) and fine residues (shavings and sawdust). These mill residues are excellent sources of biomass for cellulosic ethanol because they tend to be clean, uniform, concentrated, have low moisture content, and are already located at a processing facility. These traits make mill residues excellent feedstocks for energy and biomass needs as well.

Table 5.38

Primary Mill Residue Production and Use by State, 2007 (Dry tons)

\begin{tabular}{|c|c|c|c|c|c|}
\hline State & $\begin{array}{l}\text { Total residue } \\
\text { produced }\end{array}$ & Fiber byproducts & Fuel byproducts & $\begin{array}{l}\text { Miscellaneous } \\
\text { byproducts }\end{array}$ & Unused mill residues \\
\hline Alabama & $6,770,270$ & $2,319,180$ & $3,990,970$ & 453,010 & 7,120 \\
\hline Arizona & 97,190 & 31,920 & 520 & 63,400 & 1,350 \\
\hline Arkansas & $5,372,030$ & $2,456,840$ & $2,710,020$ & 192,280 & 12,890 \\
\hline California & $3,629,030$ & $1,476,540$ & $1,665,350$ & 422,040 & 65,090 \\
\hline Colorado & 113,930 & 31,680 & 21,990 & 57,960 & 2,300 \\
\hline Connecticut & 45,860 & 3,440 & 5,080 & 33,390 & 3,950 \\
\hline Delaware & 21,500 & 0 & 2,560 & 18,940 & 0 \\
\hline Florida & $2,513,390$ & 847,310 & $1,171,030$ & 492,860 & 2,200 \\
\hline Georgia & $6,994,830$ & $2,972,760$ & $2,889,040$ & $1,087,890$ & 45,140 \\
\hline Idaho & $2,219,550$ & $1,265,060$ & 825,880 & 122,610 & 6,010 \\
\hline Illinois & 282,420 & 61,060 & 97,910 & 104,920 & 18,520 \\
\hline Indiana & 766,650 & 243,420 & 150,360 & 362,240 & 10,630 \\
\hline lowa & 181,810 & 3,280 & 28,460 & 149,910 & 160 \\
\hline Kansas & 27,500 & 5,530 & 3,000 & 10,250 & 8,720 \\
\hline Kentucky & $1,550,470$ & 432,260 & 463,290 & 599,730 & 55,200 \\
\hline Louisiana & $4,611,930$ & $1,756,760$ & $2,677,480$ & 147,610 & 30,080 \\
\hline Maine & 506,010 & 190,440 & 166,820 & 106,270 & 42,480 \\
\hline Maryland & 222,510 & 40,070 & 12,330 & 153,030 & 17,070 \\
\hline Massachusetts & 126,770 & 23,340 & 41,200 & 62,230 & 0 \\
\hline Michigan & $1,850,630$ & 517,590 & 946,470 & 372,800 & 13,760 \\
\hline Minnesota & $1,232,550$ & 133,450 & 996,530 & 75,700 & 26,880 \\
\hline Mississippi & $6,542,100$ & $2,423,340$ & $3,284,510$ & 739,120 & 95,140 \\
\hline Missouri & $1,146,430$ & 206,690 & 148,650 & 711,310 & 79,790 \\
\hline Montana & $1,510,080$ & $1,075,350$ & 286,000 & 139,600 & 9,140 \\
\hline Nebraska & 46,710 & 0 & 7,800 & 33,930 & 4,970 \\
\hline Nevada & 0 & 0 & 0 & 0 & 0 \\
\hline New Hampshire & 335,450 & 82,920 & 125,670 & 119,850 & 7,020 \\
\hline New Jersey & 8,720 & 0 & 1,340 & 5,950 & 1,440 \\
\hline New Mexico & 114,000 & 58,000 & 8,710 & 42,390 & 4,900 \\
\hline New York & $1,236,310$ & 210,720 & 453,000 & 545,200 & 27,390 \\
\hline North Carolina & $5,249,660$ & $2,229,160$ & $1,772,510$ & $1,235,180$ & 12,810 \\
\hline North Dakota & 430 & 0 & 80 & 90 & 260 \\
\hline Ohio & 352,880 & 40,670 & 140,010 & 149,600 & 22,600 \\
\hline Oklahoma & 826,190 & 282,710 & 466,650 & 76,340 & 500 \\
\hline Oregon & $7,577,270$ & $5,439,820$ & $1,559,250$ & 561,870 & 16,320 \\
\hline Pennsylvania & $1,628,140$ & 351,080 & 419,530 & 686,560 & 170,970 \\
\hline Rhode Island & 15,310 & 0 & 290 & 14,640 & 390 \\
\hline South Carolina & $2,808,670$ & $1,140,530$ & $1,454,330$ & 212,760 & 1,050 \\
\hline South Dakota & 230,500 & 148,030 & 31,730 & 48,440 & 2,290 \\
\hline Tennessee & $2,009,600$ & 622,210 & 844,040 & 355,770 & 187,580 \\
\hline Texas & $4,843,870$ & $1,686,570$ & $2,728,800$ & 425,480 & 3,020 \\
\hline Utah & 41,110 & 360 & 5,240 & 31,070 & 4,440 \\
\hline Vermont & 104,440 & 59,940 & 44,500 & 0 & 0 \\
\hline Virginia & $2,897,960$ & $1,130,530$ & $1,211,790$ & 516,280 & 39,370 \\
\hline Washington & $5,278,350$ & $2,682,220$ & $1,593,360$ & 981,320 & 21,450 \\
\hline West Virginia & 843,300 & 272,170 & 281,230 & 171,120 & 118,780 \\
\hline Wisconsin & $1,708,220$ & 357,640 & 947,400 & 342,770 & 60,410 \\
\hline Wyoming & 219,840 & 96,940 & 44,910 & 43,980 & 34,010 \\
\hline Total & $86,712,401$ & $35,409,538$ & $36,727,621$ & $13,279,682$ & $1,295,560$ \\
\hline
\end{tabular}

Source:

Bioenergy Resource and Engineering Systems Program, Oak Ridge National Laboratory. 
Although the mill residues shown in the map below are currently unused, they represent a source of biomass that could be utilized fairly easily compared with other sources of biomass.

Figure 5.21

Unused Mill Residues in the U.S. by County

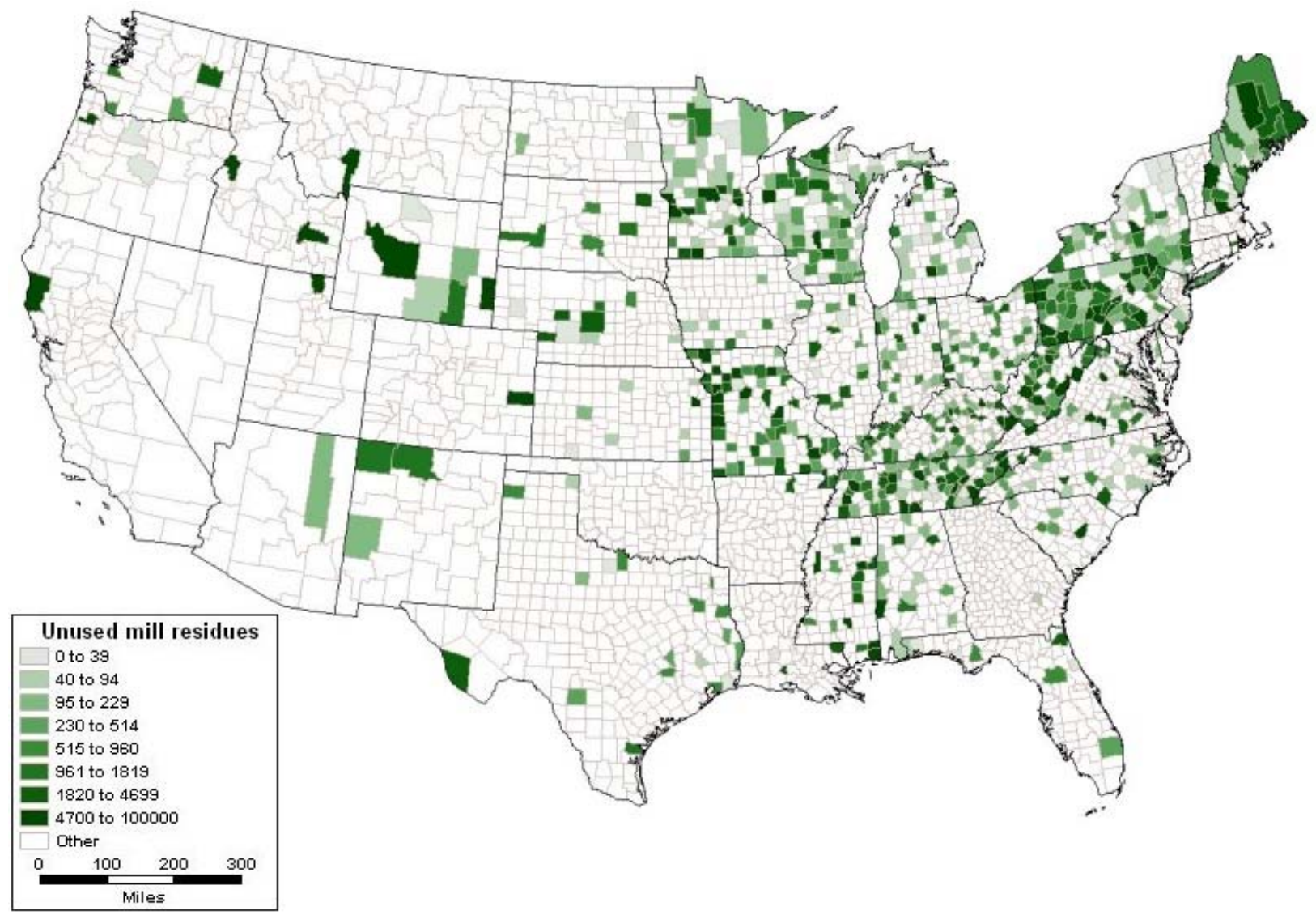

\section{Source:}

Bioenergy Resource and Engineering Systems Program, Oak Ridge National Laboratory.

Note: For information on estimation methods used, see: Appendix C - Estimation Methods for Logging Residues, Fuel Treatment Thinnings and Primary Forest Product Mill Residues. 
Table 5.39

Pellet Fuel Shipments from Pellet Fuel Manufacturers (Tons)

\begin{tabular}{|c|c|c|c|c|c|c|c|c|c|c|c|}
\hline Region & 1994-1995 & $1995-1996$ & $1996-1997$ & $1997-1998$ & 1998-1999 & $1999-2000$ & $2000-2001$ & $2001-2002$ & $2002-2003^{a}$ & $2003-2004^{a}$ & $2004-2005^{a}$ \\
\hline$\overline{\text { Pacific }}$ & 293,000 & 262,000 & 228,000 & 236,000 & 231,000 & 235,500 & 204,000 & 229,000 & 269,000 & 241,000 & 183,323 \\
\hline Mountain & 120,000 & 123,000 & 108,000 & 108,000 & 120,000 & 89,000 & 121,000 & 130,000 & 105,000 & 131,000 & 101,509 \\
\hline Central & 15,000 & 19,000 & 36,000 & 49,000 & 31,000 & 17,500 & 43,000 & 39,000 & 49,000 & 76,000 & 49,176 \\
\hline Great Lakes & 24,000 & 36,000 & 45,000 & 22,000 & 27,000 & 19,100 & 26,000 & 44,000 & 41,000 & 53,000 & 56,656 \\
\hline Northeast & 84,000 & 107,000 & 143,000 & 154,000 & 135,000 & 147,000 & 197,000 & 226,000 & 254,000 & 272,000 & 241,344 \\
\hline Southeast & 34,000 & 39,000 & 49,000 & 49,000 & 58,000 & 62,000 & 63,000 & 59,000 & 43,000 & 43,000 & 35,772 \\
\hline Total & 570,000 & 586,000 & 609,000 & 618,000 & 602,000 & 570,100 & 654,000 & 727,000 & 761,000 & 816,000 & 667,780 \\
\hline
\end{tabular}

Source:

http://www.pelletheat.org/3/industry/marketResearch.html\#

a Represents heating season, not annual season. 1st Quarter April-June; 2nd Quarter JulySeptember; 3rd Quarter October-December; 4th Quarter January-March. 
Shipments of pellet appliances nearly quadrupled between 1998 and 2006 while cordwood appliance shipments have remained relatively level although, by volume, cordwood appliances are by far the largest share of wood burning appliances.

Table 5.40

Pellet and Cordwood Appliance Shipments from Manufacturers, 1998-2007

\begin{tabular}{rrrrr}
\hline & Pellet Appliances & \% Change & Cordwood Appliances & \% Change \\
\hline $\mathbf{1 9 9 8}$ & 34,000 & a & 652,500 & a \\
$\mathbf{1 9 9 9}$ & 18,360 & $-46 \%$ & 795,767 & $22 \%$ \\
$\mathbf{2 0 0 0}$ & 30,970 & $69 \%$ & 609,332 & $-23 \%$ \\
$\mathbf{2 0 0 1}$ & 53,473 & $73 \%$ & 637,856 & $5 \%$ \\
$\mathbf{2 0 0 2}$ & 33,978 & $-36 \%$ & 534,406 & $-16 \%$ \\
$\mathbf{2 0 0 3}$ & 48,669 & $43 \%$ & 503,699 & $-6 \%$ \\
$\mathbf{2 0 0 4}$ & 67,467 & $39 \%$ & 498,630 & $-1 \%$ \\
$\mathbf{2 0 0 5}$ & 118,746 & $76 \%$ & 561,696 & $13 \%$ \\
$\mathbf{2 0 0 6}$ & 133,105 & $12 \%$ & 525,097 & $-7 \%$ \\
$\mathbf{2 0 0 7}$ & 54,032 & $-59 \%$ & 361,492 & $-30 \%$ \\
\hline
\end{tabular}

Source:

Hearth, Patio \& Barbecue Association, http://www.hpba.org/index.php?id=238

${ }^{\mathrm{a}}$ Data not available. 


\section{TERTIARY BIOMASS FEEDSTOCKS}

Tertiary biomass includes post consumer residues and wastes, such as fats, greases, oils, construction and demolition wood debris, other waste wood from the urban environments, as well as packaging wastes, municipal solid wastes, and landfill gases.

The category "other wood waste from the urban environment" could include trimmings from urban trees, which technically fits the definition of primary biomass. However, because this material is normally handled as a waste stream along with other post-consumer wastes from urban environments (and included in those statistics), it makes the most sense to consider it to be part of the tertiary biomass stream.

The proper categorization of fats and greases may be debatable since those are byproducts of the reduction of animal biomass into component parts. However, since we are considering animals to be a type of biomass processing factory, and since most fats and greases, and some oils, are not available for bioenergy use until after they become a post-consumer waste stream, it seems appropriate for them to be included in the tertiary biomass category. Vegetable oils derived from processing of plant components and used directly for bioenergy (e.g. soybean oil used in biodiesel) would be a secondary biomass resource, though amounts being used for bioenergy are most likely to be tracked together with fats, greases and waste oils.

\section{Source:}

Lynn Wright, Oak Ridge, TN. 
Construction and demolition produce a sizeable amount of biomass material, though; recovery and use of those materials pose economic challenges.

Figure 5.22

Total Construction and Demolition Debris Wood Residues, 2007

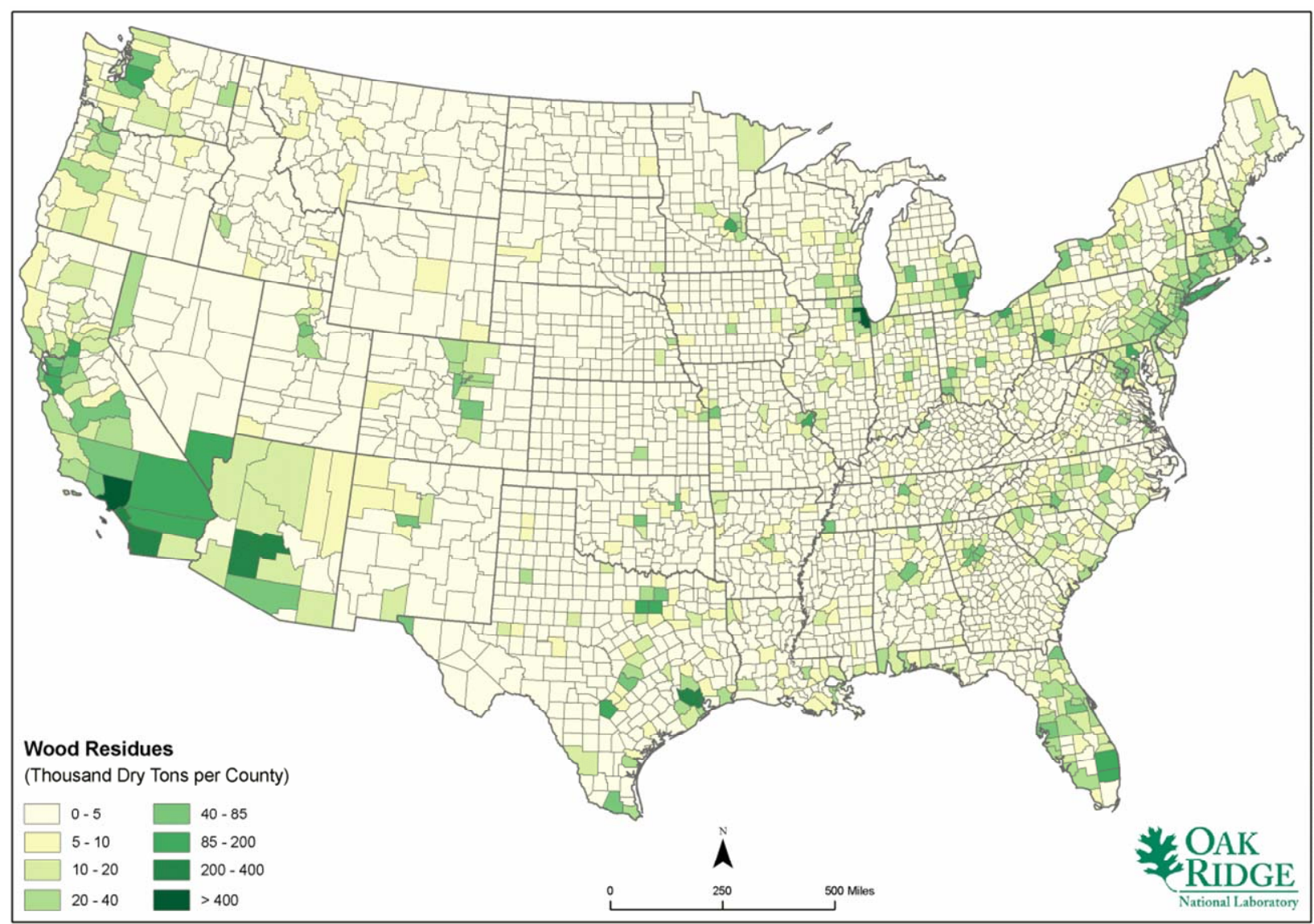

\section{Source:}

Bioenergy Resource and Engineering Systems Program, Oak Ridge National Laboratory.

Note: For information on estimation methods used, see: Appendix C - Estimation Methods for Urban Wood Residues. 
Table 5.41

Construction and Demolition Wood Debris by State, 2007 (Dry tons)

\begin{tabular}{|c|c|c|c|c|}
\hline State & Demolition waste wood & $\begin{array}{c}\text { Construction waste } \\
\text { wood }\end{array}$ & $\begin{array}{c}\text { Remodeling waste } \\
\text { wood }\end{array}$ & Total \\
\hline Alabama & 189,280 & 59,600 & 85,380 & 334,260 \\
\hline Arizona & 277,220 & 83,650 & 119,850 & 480,720 \\
\hline Arkansas & 116,990 & 36,630 & 52,470 & 206,090 \\
\hline California & $1,538,050$ & 478,550 & 685,650 & $2,702,250$ \\
\hline Colorado & 209,590 & 63,800 & 91,390 & 364,780 \\
\hline Connecticut & 140,370 & 44,780 & 64,170 & 249,320 \\
\hline Delaware & 35,160 & 11,070 & 15,860 & 62,090 \\
\hline Florida & 22,640 & 7,310 & 10,480 & 40,430 \\
\hline District of Columbia & 795,630 & 242,590 & 347,610 & $1,385,830$ \\
\hline Georgia & 406,970 & 124,710 & 178,730 & 710,410 \\
\hline Idaho & 63,220 & 19,420 & 27,860 & 110,500 \\
\hline Illinois & 518,330 & 164,660 & 235,980 & 918,970 \\
\hline Indiana & 257,530 & 81,410 & 116,690 & 455,630 \\
\hline lowa & 120,520 & 38,250 & 54,840 & 213,610 \\
\hline Kansas & 113,650 & 35,820 & 51,350 & 200,820 \\
\hline Kentucky & 172,980 & 54,480 & 78,100 & 305,560 \\
\hline Louisiana & 177,460 & 55,740 & 79,830 & 313,030 \\
\hline Maine & 54,330 & 17,120 & 24,530 & 95,980 \\
\hline Maryland & 235,040 & 73,410 & 105,170 & 413,620 \\
\hline Massachusetts & 259,600 & 82,550 & 118,270 & 460,420 \\
\hline Michigan & 411,190 & 130,130 & 186,430 & 727,750 \\
\hline Minnesota & 217,030 & 67,640 & 96,960 & 381,630 \\
\hline Mississippi & 119,680 & 37,650 & 54,000 & 211,330 \\
\hline Missouri & 241,980 & 75,940 & 108,870 & 426,790 \\
\hline Montana & 39,520 & 12,340 & 17,660 & 69,520 \\
\hline Nebraska & 72,220 & 22,890 & 32,700 & 127,810 \\
\hline Nevada & 114,910 & 33,910 & 48,570 & 197,390 \\
\hline New Hampshire & 55,480 & 17,290 & 24,750 & 97,520 \\
\hline New Jersey & 351,720 & 111,840 & 160,310 & 623,870 \\
\hline New Mexico & 83,790 & 25,870 & 37,090 & 146,750 \\
\hline New York & 766,470 & 245,570 & 351,840 & $1,363,880$ \\
\hline North Carolina & 370,920 & 115,810 & 165,910 & 652,640 \\
\hline North Dakota & 26,110 & 8,240 & 11,780 & 46,130 \\
\hline Ohio & 462,560 & 147,140 & 210,760 & 820,460 \\
\hline Oklahoma & 147,470 & 46,380 & 66,470 & 260,320 \\
\hline Oregon & 156,830 & 48,690 & 69,800 & 275,320 \\
\hline Pennsylvania & 498,170 & 158,960 & 227,710 & 884,840 \\
\hline Rhode Island & 43,020 & 13,690 & 19,610 & 76,320 \\
\hline South Carolina & 180,250 & 56,380 & 80,830 & 317,460 \\
\hline South Dakota & 32,370 & 10,180 & 14,560 & 57,110 \\
\hline Tennessee & 252,390 & 78,900 & 112,960 & 444,250 \\
\hline Texas & $1,013,750$ & 312,100 & 447,100 & $1,772,950$ \\
\hline Utah & 112,120 & 34,190 & 48,990 & 195,300 \\
\hline Vermont & 25,970 & 8,120 & 11,660 & 45,750 \\
\hline Virginia & 323,640 & 100,480 & 143,970 & 568,090 \\
\hline Washington & 272,320 & 84,360 & 120,880 & 477,560 \\
\hline West Virginia & 73,080 & 23,280 & 33,350 & 129,710 \\
\hline Wisconsin & 229,200 & 72,110 & 103,260 & 404,570 \\
\hline Wyoming & 21,730 & 6,770 & 9,680 & 38,180 \\
\hline Total & $12,420,450$ & $3,882,400$ & $5,562,670$ & $21,865,520$ \\
\hline
\end{tabular}

\section{Source:}

Bioenergy Resource and Engineering Systems Program, Oak Ridge National Laboratory.

Note: For information on estimation methods used, see: Appendix C - Estimation Methods for Urban Wood Residues. 
Urban wood wastes include wood (discarded furniture, pallets, containers, packaging materials and lumber scraps), yard and tree trimmings, and construction and demolition wood. This can be a significant

Figure 5.23

Total Municipal Solid Waste Wood Residues, 2007

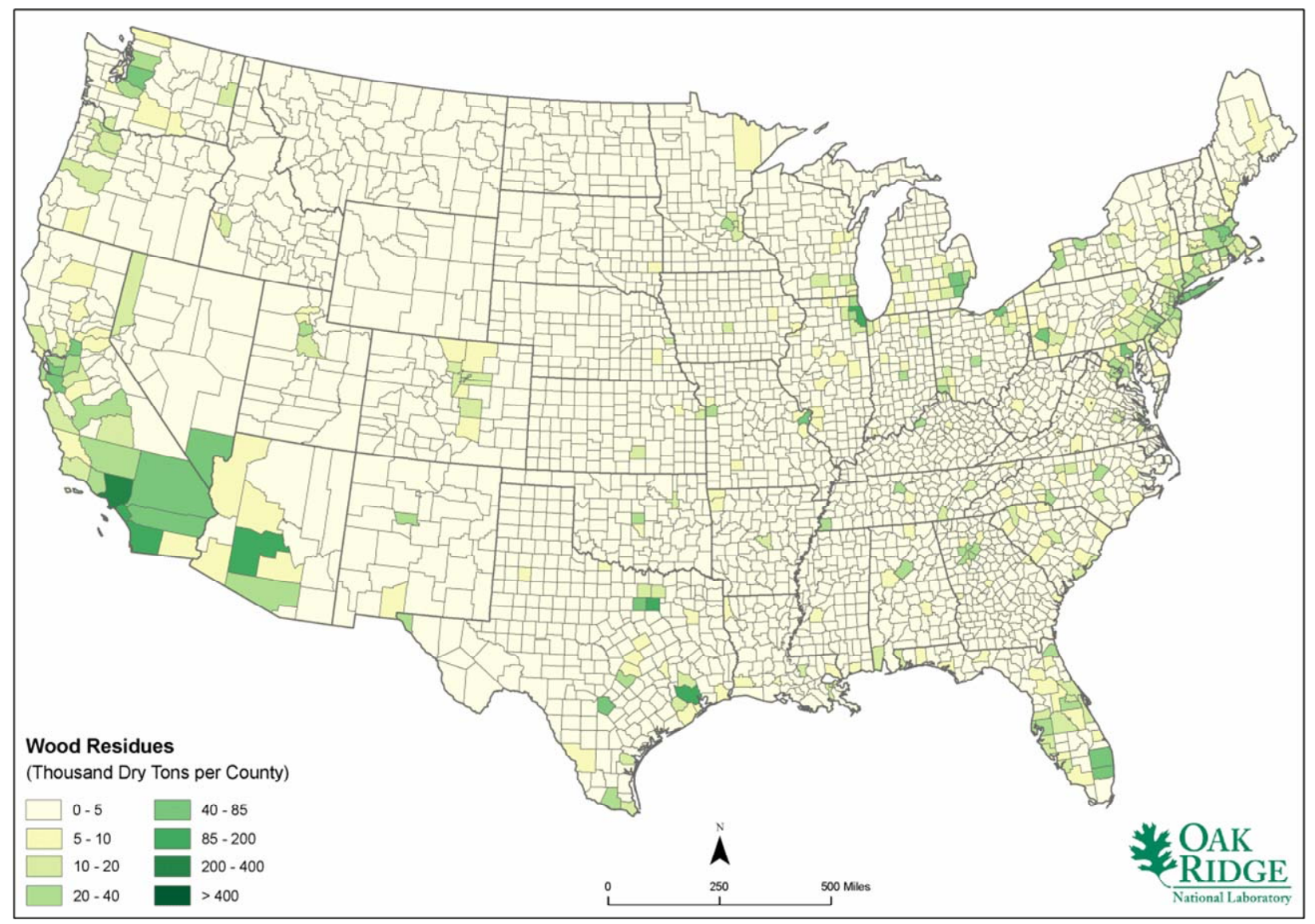

\section{Source:}

Bioenergy Resource and Engineering Systems Program, Oak Ridge National Laboratory.

Note: For information on estimation methods used, see: Appendix C - Estimation Methods for Urban Wood Residues. 
Table 5.42

Residues from Municipal Solid Waste Landfills by State, 2007 (Dry tons)

\begin{tabular}{|c|c|c|c|}
\hline State & MSW waste wood & MSW yard trimmings & Total \\
\hline Alabama & 87,880 & 65,600 & 153,480 \\
\hline Arizona & 123,360 & 92,100 & 215,460 \\
\hline Arkansas & 54,090 & 40,360 & 94,450 \\
\hline California & 705,800 & 526,880 & $1,232,680$ \\
\hline Colorado & 94,190 & 70,250 & 164,440 \\
\hline Connecticut & 66,060 & 49,300 & 115,360 \\
\hline Delaware & 16,330 & 12,190 & 28,520 \\
\hline Florida & 10,790 & 8,050 & 18,840 \\
\hline District of Columbia & 357,830 & 267,070 & 624,900 \\
\hline Georgia & 184,100 & 137,310 & 321,410 \\
\hline Idaho & 28,690 & 21,400 & 50,090 \\
\hline Illinois & 242,880 & 181,310 & 424,190 \\
\hline Indiana & 120,160 & 89,650 & 209,810 \\
\hline lowa & 56,450 & 42,140 & 98,590 \\
\hline Kansas & 52,800 & 39,380 & 92,180 \\
\hline Kentucky & 80,390 & 60,030 & 140,420 \\
\hline Louisiana & 82,180 & 61,330 & 143,510 \\
\hline Maine & 25,260 & 18,850 & 44,110 \\
\hline Maryland & 108,260 & 80,810 & 189,070 \\
\hline Massachusetts & 121,750 & 90,880 & 212,630 \\
\hline Michigan & 191,930 & 143,250 & 335,180 \\
\hline Minnesota & 99,860 & 74,510 & 174,370 \\
\hline Mississippi & 55,550 & 41,470 & 97,020 \\
\hline Missouri & 112,020 & 83,600 & 195,620 \\
\hline Montana & 18,190 & 13,600 & 31,790 \\
\hline Nebraska & 33,710 & 25,130 & 58,840 \\
\hline Nevada & 50,010 & 37,330 & 87,340 \\
\hline New Hampshire & 25,480 & 19,010 & 44,490 \\
\hline New Jersey & 164,980 & 123,160 & 288,140 \\
\hline New Mexico & 38,170 & 28,480 & 66,650 \\
\hline New York & 362,190 & 270,310 & 632,500 \\
\hline North Carolina & 170,850 & 127,520 & 298,370 \\
\hline North Dakota & 12,140 & 9,080 & 21,220 \\
\hline Ohio & 216,990 & 162,010 & 379,000 \\
\hline Oklahoma & 68,410 & 51,060 & 119,470 \\
\hline Oregon & 71,800 & 53,590 & 125,390 \\
\hline Pennsylvania & 234,400 & 174,940 & 409,340 \\
\hline Rhode Island & 20,180 & 15,070 & 35,250 \\
\hline South Carolina & 83,140 & 62,040 & 145,180 \\
\hline South Dakota & 15,020 & 11,170 & 26,190 \\
\hline Tennessee & 116,320 & 86,840 & 203,160 \\
\hline Texas & 460,270 & 343,520 & 803,790 \\
\hline Utah & 50,450 & 37,640 & 88,090 \\
\hline Vermont & 11,990 & 8,940 & 20,930 \\
\hline Virginia & 148,200 & 110,630 & 258,830 \\
\hline Washington & 124,450 & 92,860 & 217,310 \\
\hline West Virginia & 34,320 & 25,660 & 59,980 \\
\hline Wisconsin & 106,320 & 79,400 & 185,720 \\
\hline Wyoming & 9,960 & 7,450 & 17,410 \\
\hline Total & $5,726,550$ & $4,274,160$ & $10,000,710$ \\
\hline
\end{tabular}

Source:

Bioenergy Resource and Engineering Systems Program, Oak Ridge National Laboratory.

Note: For information on estimation methods used, see: Appendix C - Estimation Methods for Urban Wood Residues. 
Landfill gas is becoming a more prominent source of energy; all but nine states are using landfill gas to some extent. There are a number of states that are utilizing the majority of landfill sites available to them.

Table 5.43

Landfill Gas Projects and Candidate Landfills by State, July 2008

\begin{tabular}{|c|c|c|}
\hline State & Operational Projects & Candidate Landfills \\
\hline Alabama & 3 & 20 \\
\hline Alaska & 0 & 1 \\
\hline Arizona & 3 & 13 \\
\hline Arkansas & 3 & 4 \\
\hline California & 73 & 36 \\
\hline Colorado & 0 & 9 \\
\hline Connecticut & 2 & 5 \\
\hline Delaware & 3 & a \\
\hline Florida & 11 & 22 \\
\hline Georgia & 9 & 22 \\
\hline Hawaii & 0 & 8 \\
\hline Idaho & 2 & 2 \\
\hline Illinois & 35 & 23 \\
\hline Indiana & 19 & 15 \\
\hline lowa & 4 & 11 \\
\hline Kansas & 5 & 6 \\
\hline Kentucky & 6 & 18 \\
\hline Louisiana & 4 & 8 \\
\hline Maine & 1 & 2 \\
\hline Maryland & 5 & 10 \\
\hline Massachusetts & 20 & 3 \\
\hline Michigan & 28 & 9 \\
\hline Minnesota & 6 & 7 \\
\hline Mississippi & 1 & 12 \\
\hline Missouri & 8 & 16 \\
\hline Montana & 1 & 4 \\
\hline Nebraska & 2 & 4 \\
\hline Nevada & 0 & 5 \\
\hline New Hampshire & 5 & 3 \\
\hline New Jersey & 17 & 2 \\
\hline New Mexico & 2 & 1 \\
\hline New York & 19 & 13 \\
\hline North Carolina & 14 & 34 \\
\hline North Dakota & 1 & 1 \\
\hline Ohio & 17 & 18 \\
\hline Oklahoma & 4 & 11 \\
\hline Oregon & 6 & 4 \\
\hline Pennsylvania & 27 & 15 \\
\hline Rhode Island & 2 & a \\
\hline South Carolina & 7 & 15 \\
\hline South Dakota & 0 & 2 \\
\hline Tennessee & 6 & 11 \\
\hline Texas & 22 & 55 \\
\hline Utah & 3 & 5 \\
\hline Vermont & 3 & a \\
\hline Virginia & 18 & 12 \\
\hline Washington & 6 & 8 \\
\hline West Virginia & 0 & 9 \\
\hline Wisconsin & 23 & 10 \\
\hline Wyoming & 0 & 1 \\
\hline U.S. Total & 456 & 525 \\
\hline
\end{tabular}

Source:

Bioenergy Resource and Engineering Systems Program, Oak Ridge National Laboratory.

Note: For information on estimation methods used, see: Appendix C - Estimation Methods for Urban Wood Residues. 
Biomass Energy Data Book: Edition 2 -- DRAFT 


\section{APPENDIX A CONVERSIONS}


Biomass Energy Data Book: Edition 2 -- DRAFT 
Table A.1

Lower and Higher Heating Values of Gas, Liquid and Solid Fuels

\begin{tabular}{|c|c|c|c|c|c|c|c|}
\hline Fuels & \multicolumn{3}{|c|}{ Lower Heating Value (LHV) [1] } & \multicolumn{3}{|c|}{ Higher Heating Value (HHV) [1] } & \multirow{2}{*}{$\begin{array}{c}\text { Density } \\
\text { grams/ft3 }\end{array}$} \\
\hline Gaseous Fuels @ 32 F and 1 atm & Btu/ft3 [2] & Btu/lb [3] & $\mathrm{MJ} / \mathrm{kg}[4]$ & Btu/ft3 [2] & Btu/lb [3] & MJ/kg [4] & \\
\hline Natural gas & 983 & 20,267 & 47.141 & 1089 & 22,453 & 52.225 & 22.0 \\
\hline Hydrogen & 290 & 51,682 & 120.21 & 343 & 61,127 & 142.18 & 2.55 \\
\hline Still gas (in refineries) & 1458 & 20,163 & 46.898 & 1,584 & 21,905 & 50.951 & 32.8 \\
\hline Liquid Fuels & Btu/gal [2] & Btu/lb [3] & MJ/kg [4] & Btu/gal [2] & Btu/lb [3] & MJ/kg [4] & grams/gal \\
\hline Crude oil & 129,670 & 18,352 & 42.686 & 138,350 & 19,580 & 45.543 & 3,205 \\
\hline Conventional gasoline & 116,090 & 18,679 & 43.448 & 124,340 & 20,007 & 46.536 & 2,819 \\
\hline Reformulated or low-sulfur gasoline & 113,602 & 18,211 & 42.358 & 121,848 & 19,533 & 45.433 & 2,830 \\
\hline CA reformulated gasoline & 113,927 & 18,272 & 42.500 & 122,174 & 19,595 & 45.577 & 2,828 \\
\hline U.S. conventional diesel & 128,450 & 18,397 & 42.791 & 137,380 & 19,676 & 45.766 & 3,167 \\
\hline Low-sulfur diesel & 129,488 & 18,320 & 42.612 & 138,490 & 19,594 & 45.575 & 3,206 \\
\hline Petroleum naphtha & 116,920 & 19,320 & 44.938 & 125,080 & 20,669 & 48.075 & 2,745 \\
\hline NG-based FT naphtha & 111,520 & 19,081 & 44.383 & 119,740 & 20,488 & 47.654 & 2,651 \\
\hline Residual oil & 140,353 & 16,968 & 39.466 & 150,110 & 18,147 & 42.210 & 3,752 \\
\hline Methanol & 57,250 & 8,639 & 20.094 & 65,200 & 9,838 & 22.884 & 3,006 \\
\hline Ethanol & 76,330 & 11,587 & 26.952 & 84,530 & 12,832 & 29.847 & 2,988 \\
\hline Butanol & 99,837 & 14,775 & 34.366 & 108,458 & 16,051 & 37.334 & 3,065 \\
\hline Acetone & 83,127 & 12,721 & 29.589 & 89,511 & 13,698 & 31.862 & 2,964 \\
\hline E-Diesel Additives & 116,090 & 18,679 & 43.448 & 124,340 & 20,007 & 46.536 & 2,819 \\
\hline Liquefied petroleum gas (LPG) & 84,950 & 20,038 & 46.607 & 91,410 & 21,561 & 50.152 & 1,923 \\
\hline Liquefied natural gas (LNG) & 74,720 & 20,908 & 48.632 & 84,820 & 23,734 & 55.206 & 1,621 \\
\hline Dimethyl ether (DME) & 68,930 & 12,417 & 28.882 & 75,610 & 13,620 & 31.681 & 2,518 \\
\hline Dimethoxy methane (DMM) & 72,200 & 10,061 & 23.402 & 79,197 & 11,036 & 25.670 & 3,255 \\
\hline Methyl ester (biodiesel, BD) & 119,550 & 16,134 & 37.528 & 127,960 & 17,269 & 40.168 & 3,361 \\
\hline Fischer-Tropsch diesel (FTD) & 123,670 & 18,593 & 43.247 & 130,030 & 19,549 & 45.471 & 3,017 \\
\hline Renewable Diesel I (SuperCetane) & 117,059 & 18,729 & 43.563 & 125,294 & 20,047 & 46.628 & 2,835 \\
\hline Renewable Diesel II (UOP-HDO) & 122,887 & 18,908 & 43.979 & 130,817 & 20,128 & 46.817 & 2,948 \\
\hline Renewable Gasoline & 115,983 & 18,590 & 43.239 & 124,230 & 19,911 & 46.314 & 2,830 \\
\hline Liquid Hydrogen & 30,500 & 51,621 & 120.07 & 36,020 & 60,964 & 141.80 & 268 \\
\hline Methyl tertiary butyl ether (MTBE) & 93,540 & 15,094 & 35.108 & 101,130 & 16,319 & 37.957 & 2,811 \\
\hline Ethyl tertiary butyl ether (ETBE) & 96,720 & 15,613 & 36.315 & 104,530 & 16,873 & 39.247 & 2,810 \\
\hline Tertiary amyl methyl ether (TAME) & 100,480 & 15,646 & 36.392 & 108,570 & 16,906 & 39.322 & 2,913 \\
\hline Butane & 94,970 & 19,466 & 45.277 & 103,220 & 21,157 & 49.210 & 2,213 \\
\hline Isobutane & 90,060 & 19,287 & 44.862 & 98,560 & 21,108 & 49.096 & 2,118 \\
\hline Isobutylene & 95,720 & 19,271 & 44.824 & 103,010 & 20,739 & 48.238 & 2,253 \\
\hline Propane & 84,250 & 19,904 & 46.296 & 91,420 & 21,597 & 50.235 & 1,920 \\
\hline Solid Fuels & Btu/ton [2] & Btu/lb [5] & MJ/kg [4] & Btu/ton [2] & Btu/lb [5] & MJ/kg [4] & \\
\hline Coal (wet basis) [6] & $19,546,300$ & 9,773 & 22.732 & $20,608,570$ & 10,304 & 23.968 & \\
\hline Bituminous coal (wet basis) [7] & $22,460,600$ & 11,230 & 26.122 & $23,445,900$ & 11,723 & 27.267 & \\
\hline Coking coal (wet basis) & $24,600,497$ & 12,300 & 28.610 & $25,679,670$ & 12,840 & 29.865 & \\
\hline Farmed trees (dry basis) & $16,811,000$ & 8,406 & 19.551 & $17,703,170$ & 8,852 & 20.589 & \\
\hline Herbaceous biomass (dry basis) & $14,797,555$ & 7,399 & 17.209 & $15,582,870$ & 7,791 & 18.123 & \\
\hline Corn stover (dry basis) & $14,075,990$ & 7,038 & 16.370 & $14,974,460$ & 7,487 & 17.415 & \\
\hline Forest residue (dry basis) & $13,243,490$ & 6,622 & 15.402 & $14,164,160$ & 7,082 & 16.473 & \\
\hline Sugar cane bagasse & $12,947,318$ & 6,474 & 15.058 & $14,062,678$ & 7,031 & 16.355 & \\
\hline Petroleum coke & $25,370,000$ & 12,685 & 29.505 & $26,920,000$ & 13,460 & 31.308 & \\
\hline
\end{tabular}

Source:

GREET Transportation Fuel Cycle Analysis Model, GREET 1.8b, developed by Argonne National Laboratory, Argonne, IL, released May 8, 2008.

http://www.transportation.anl.gov/software/GREET/index.html

Notes:

[1] The lower heating value (also known as net calorific value) of a fuel is defined as the amount of heat released by combusting a specified quantity (initially at $25^{\circ} \mathrm{C}$ ) and returning the temperature of the combustion products to $150^{\circ} \mathrm{C}$, which assumes the latent heat of vaporization of water in the reaction products is not recovered. The LHV are the useful calorific values in boiler combustion plants and are frequently used in Europe.

[2] Btu = British thermal unit.

[3] The heating values for gaseous fuels in units of Btu/lb are calculated based on the heating values in units of Btu/ft3 and the corresponding fuel density values. The heating values for liquid fuels in units of Btu/lb are calculated based on heating values in units of Btu/gal and the corresponding fuel density values.

[4] The heating values in units of $\mathrm{MJ} / \mathrm{kg}$, are converted from the heating values in units of Btu/lb. 


\section{Table A.1 (Continued)}

\section{Lower and Higher Heating Values of Gas, Liquid and Solid Fuels}

[5] For solid fuels, the heating values in units of Btu/lb are converted from the heating values in units of Btu/ton.

[6] Coal characteristics assumed by GREET for electric power production.

[7] Coal characteristics assumed by GREET for hydrogen and Fischer-Tropsch diesel production. 
Table A.2

Heat Content Ranges for Various Biomass Fuels (dry weight basis ${ }^{a}$ ) with English and Metric Units

\begin{tabular}{|c|c|c|c|c|c|c|c|}
\hline \multirow[t]{3}{*}{ Fuel type \& source } & \multicolumn{3}{|c|}{ English } & \multicolumn{4}{|c|}{ Metric $^{b}$} \\
\hline & \multicolumn{3}{|c|}{ Higher Heating Value } & \multicolumn{2}{|c|}{ Higher Heating Value } & \multicolumn{2}{|c|}{ Lower Heating Value } \\
\hline & Btu/lbc & Btu/lb & MBtu/ton & $\mathbf{k j} / \mathbf{k g}$ & $\mathrm{MJ} / \mathbf{k g}$ & kj/kg & $\mathrm{MJ} / \mathbf{k g}$ \\
\hline \multicolumn{8}{|l|}{ Agricultural Residues } \\
\hline Corn stalks/stover $(1,2,6)$ & 7,487 & $7,587-7,967$ & $15.2-15.9$ & $17,636-18,519$ & $17.6-18.5$ & $16,849-17,690$ & $16.8-18.1$ \\
\hline Sugarcane bagasse $(1,2,6)$ & 7,031 & $7,450-8,349$ & $14.9-16.7$ & $17,317-19,407$ & $17.3-19.4$ & $17,713-17,860$ & $17.7-17.9$ \\
\hline Wheat straw $(1,2,6)$ & & $6,964-8,148$ & $13.9-16.3$ & $16,188-18,940$ & $16.1-18.9$ & $15,082-17,659$ & $15.1-17.7$ \\
\hline hulls, shells, prunings $(2,3)$ & & $6,811-8,838$ & $13.6-17.7$ & $15,831-20,543$ & $15.8-20.5$ & & \\
\hline fruit pits (2-3) & & $8,950-10,000$ & $17.9-20.0$ & & & & \\
\hline Herbaceous Crops & 7,791 & & & & & & \\
\hline Miscanthus (6) & & & & $18,100-19,580$ & $18.1-19.6$ & $17,818-18,097$ & $17.8-18.1$ \\
\hline switchgrass $(1,3,6)$ & & $7,754-8,233$ & $15.5-16.5$ & $18,024-19,137$ & $18.0-19.1$ & $16,767-17,294$ & $16.8-18.6$ \\
\hline Other grasses (6) & & & & $18,185-18,570$ & $18.2-18.6$ & $16,909-17,348$ & $16.9-17.3$ \\
\hline Bamboo (6) & & & & $19,000-19,750$ & $19.0-19.8$ & & \\
\hline Woody Crops & 8,852 & & & & & & \\
\hline Black locust $(1,6)$ & & $8,409-8,582$ & $16.8-17.2$ & $19,546-19,948$ & $19.5-19.9$ & 18,464 & 18.5 \\
\hline eucalyptus $(1,2,6)$ & & $8,174-8,432$ & $16.3-16.9$ & $19,000-19,599$ & $19.0-19.6$ & 17,963 & 18.0 \\
\hline hybrid poplar $(1,3,6)$ & & $8,183-8,491$ & $16.4-17.0$ & $19,022-19,737$ & $19.0-19.7$ & 17,700 & 17.7 \\
\hline willow $(2,3,6)$ & & $7,983-8,497$ & $16.0-17.0$ & $18,556-19,750$ & $18.6-19.7$ & $16,734-18,419$ & $16.7-18.4$ \\
\hline Forest Residues & 7,082 & & & & & & \\
\hline Hardwood wood $(2,6)$ & & $8,017-8,920$ & $16.0-17.5$ & $18,635-20,734$ & $18.6-20.7$ & & \\
\hline Softwood wood $(1,2,3,4,5,6)$ & & $8,000-9,120$ & $16.0-18.24$ & $18,595-21,119$ & $18.6-21.1$ & $17,514-20,768$ & $17.5-20.8$ \\
\hline \multicolumn{8}{|l|}{ Urban Residues } \\
\hline MSW $(2,6)$ & & $5,644-8,542$ & $11.2-17.0$ & $13,119-19,855$ & $13.1-19.9$ & $11,990-18,561$ & $12.0-18.6$ \\
\hline $\operatorname{RDF}(2,6)$ & & $6,683-8,563$ & $13.4-17.1$ & $15,535-19,904$ & $15.5-19.9$ & $14,274-18,609$ & $14.3-18.6$ \\
\hline newspaper $(2,6)$ & & $8,477-9,550$ & $17-19.1$ & $19,704-22,199$ & $19.7-22.2$ & $18,389-20,702$ & $18.4-20.7$ \\
\hline corrugated paper $(2,6)$ & & $7,428-7,939$ & $14.9-15.9$ & $17,265-18,453$ & $17.3-18.5$ & 17,012 & \\
\hline waxed cartons (2) & & $11,727-11,736$ & $23.5-23.5$ & $27,258-27,280$ & 27.3 & 25,261 & \\
\hline
\end{tabular}

\section{Sources:}

[1] http://www1.eere.energy.gov/biomass/feedstock databases.html

[2] Jenkins, B., Properties of Biomass, Appendix to Biomass Energy Fundamentals, EPRI Report TR102107, January, 1993.

[3] Jenkins, B., Baxter, L., Miles, T. Jr., and Miles, T., Combustion Properties of Biomass, Fuel Processing Technology 54, pg. 17-46, 1998.

[4] Tillman, David, Wood as an Energy Resource, Academic Press, New York, 1978

[5] Bushnell, D., Biomass Fuel Characterization: Testing and Evaluating the Combustion Characteristics of Selected Biomass Fuels, BPA report, 1989

[6] http://www.ecn.nl/phyllis

${ }^{a}$ This table attempts to capture the variation in reported heat content values (on a dry weight basis) in the United States and European literature based on values in the Phyllis database, the U.S. DOE/EERE feedstock database, and selected literature sources. Table A.3 of this document provides information on heat contents of materials "as received" with varying moisture contents.

${ }^{b}$ Metric values include both HHV and LHV since Europeans normally report the LHV (or net calorific values) of biomass fuels.

${ }^{c}$ HHV assumed by GREET model given in Table A. 1 of this document 
The heating value of any fuel is the heat release per unit mass when the fuel initially at $25^{\circ} \mathrm{C}(770 \mathrm{~F})$ reacts completely with oxygen, and the products are returned to $25^{\circ} \mathrm{C}(770 \mathrm{~F})$. The heating value is reported as the higher heating value (HHV) when the water is condensed or as the lower heating value ( $L H V$ ) when the water is not condensed. The LHV is obtained from the HHV by subtracting the heat of vaporization of water in the products. Thus: $L H V=H H V-((\mathrm{mH} 20 / \mathrm{mfuel}) * h f g) \quad$ where $m=$ mass and $\mathrm{hfg}$ is the latent heat of vaporization of water at $25^{\circ} \mathrm{C}(770 \mathrm{~F})$ which equals $2,440 \mathrm{~kJ} / \mathrm{kg}$ water $(1,050$ $B t u / l \mathrm{lbm})$. The water includes moisture in the fuel as well as water formed from hydrogen in the fuel.

The HHV and LHV provided in Tables 1 and 2 of the Biomass Energy Data Book, Appendix A assume that the fuels contain $0 \%$ water. Since recently harvested wood fuels usually contain 30 to $55 \%$ water it is useful to understand the effect of moisture content on the heating value of wood fuels. The table below shows the effect of percent moisture content $(M C)$ on the higher heating value as-fired (HHV-AF) of a wood sample starting at 8,500 Btu/lb (oven-dry).

Table A.3

The Effect of Fuel Moisture on Wood Heat Content ${ }^{a}$

\begin{tabular}{|c|c|c|c|c|c|c|c|c|c|c|c|}
\hline $\begin{array}{l}\text { Moisture Content (MC) wet } \\
\text { basis (\%) }\end{array}$ & 0 & 15 & 20 & 25 & 30 & 35 & 40 & 45 & 50 & 55 & 60 \\
\hline $\begin{array}{l}\text { Higher Heating Value as fired } \\
\text { (HHV-AF) Btus/lb }\end{array}$ & 8,500 & 7,275 & 6,800 & 6,375 & 5,950 & 5,525 & 5,100 & 4,575 & 4,250 & 3,825 & 3,400 \\
\hline
\end{tabular}

\section{Sources:}

[1] Borman, G.L. and K.W. Ragland. Combustion Engineering. McGraw-Hill. 1998. 613 pp.

[2] Maker, T.M. Wood-Chip Heating Systems: A Guide for Institutional and Commercial Biomass Installations. 1994 (revised 2004 by Biomass Energy Resource Center).

[3] American Pulpwood Association, Southern Division Office. The Forester's Wood Energy Handbook. 1980.

Notes: Moisture contents (MC) wet and dry weight basis are calculated as follows:

$M C$ (dry basis) $=100$ (wet weight-dry weight)/dry weight;

MC (wet basis) $=100$ (wet weight - dry weight)/wet weight;

To convert MC wet basis to MC dry basis: $M C($ dry) $=100 \times M C$ (wet) $/ 100-M C$ (wet);

To convert MC dry basis to MC wet basis: $M C($ wet $)=100 \times M C($ dry $) / 100+M C($ dry $)$.

Some sources report heat contents of fuels "as-delivered" rather than at $0 \%$ moisture for practical reasons. Because most wood fuels have bone dry (oven-dry) heat contents in the range of 7,600 to 9,600 Btu/lb $(15,200,000$ to $19,200,000$ Btu/ton or 18 to $22 \mathrm{GJ} / \mathrm{Mg})$, lower values will always mean that some moisture is included in the delivered fuel. Grass fuels are usually delivered at $<20 \%$ MC.

${ }^{a}$ If the oven-dry HHV (Btu /lb )is known (e.g. 8,500) then the HHV-AF can be calculated as follows: oven-dry HHV x (1-MC wet basis/100). 
Table A.4

Forestry Volume Unit to Biomass Weight Considerations

There are several reasons why biomass weights are derived from forestry units. Methods differ for each type of estimation and the same standing volume of wood could result in three very different biomass estimates depending on the purpose of the calculation and the methods used. The diagrams below further illuminate the problem.

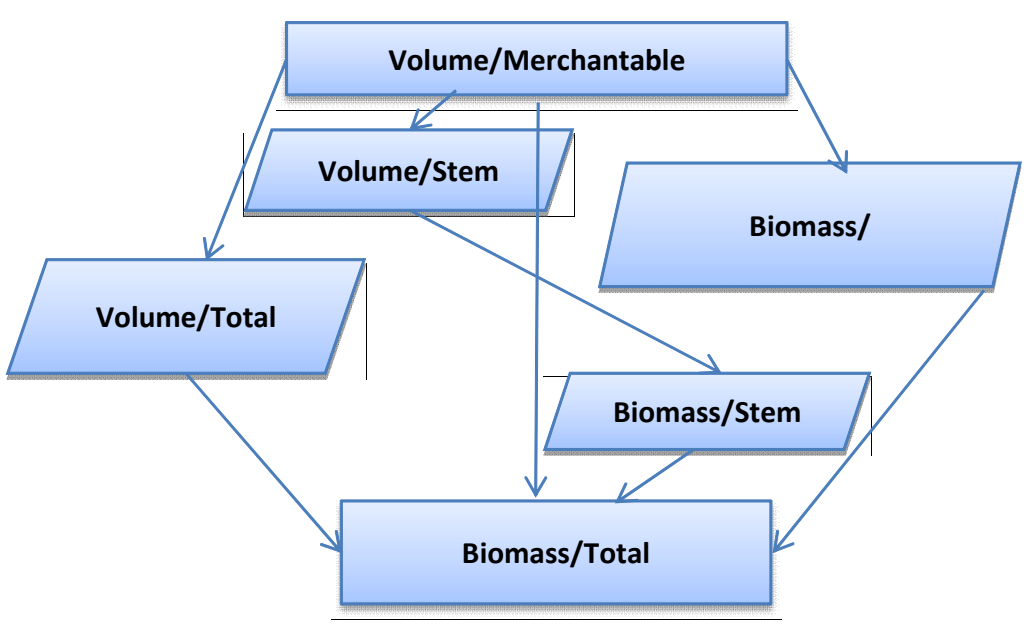

The diagram shows that biomass estimates from volume may be calculated based on either a merchantable volume, a stem volume, or a total volume (including top, branches and sometimes even roots).

Sometimes the only available number is merchantable volume from forest inventories. Biomass energy estimates need stem or total above ground volume values.

Diagram Source: Somogyi Z. et al. Indirect Methods of Large-scale Biomass Estimation. Eur J Forest Res (2006) DOE 10.1007/s10342-006-0125-7

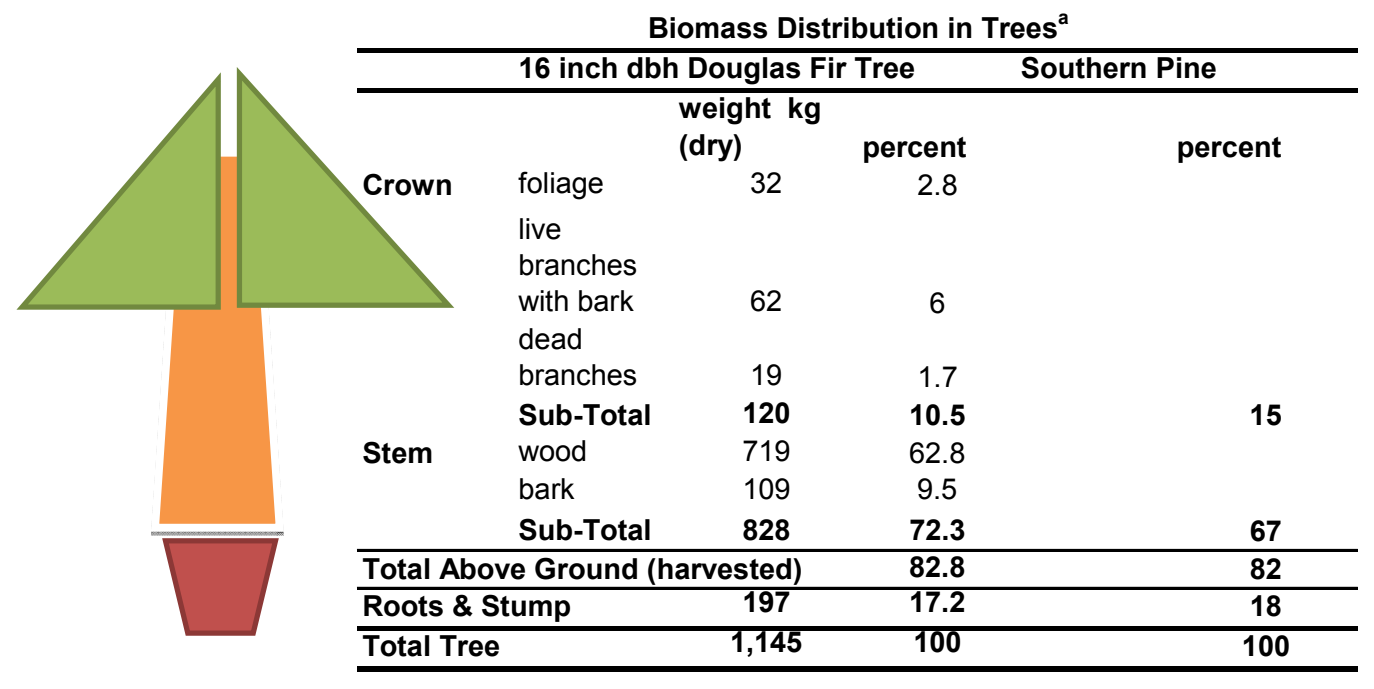

\section{Sources:}

Douglas Fir Tree - Briggs, D. Forest Products Measurements and Conversion Factors. College of Forest Resources, University of Washington.1994. Available at www.ruraltech.org/projects/conversions/briggs conversions/briggs book.asp

Southern Pine - The Forester's Wood Energy Handbook. American Pulpwood Association. Southern Division Office, April 1980. (Not found online)

${ }^{a}$ Hardwoods may have 30 to $40 \%$ of tree biomass in tops and branches. 
Table A.5

Forestry Volume Unit to Biomass Weight Equations

Estimation of biomass energy resources from forest inventory volume data can be quite complicated because definitions of the units are often not given, and in many cases definitions used by biomass researchers and the foresters developing the volume data are inconsistent (1). As shown in Table 4 (Appendix A) the first issue is whether volume values include total tree volumes including roots, total aboveground only, stem only, or stem merchantable portion only. Volume numbers expressed as cords or thousand board feet are describing stacked roundwood or lumber and conversion to weight is suitable for purposes of sales or transportation but not necessarily biomass resource estimates. The preferred volume data for biomass resource estimation is either total above ground volume (including tops and branches) if whole tree removal is assumed, or stem volume only if one assume tops and branches will not be removed from the forest. Assuming that one has the desired volume data, the basic equation for calculating weight of wood is as follows:

weight $=($ volume $)$ * (specific gravity $)$ * (density of $\mathrm{H} 2 \mathrm{O}) *(1+\mathrm{MCod} / 100)$ where volume is expressed in cubic feet or cubic meters, and the density of water is $62.4 \mathrm{lb} / \mathrm{ft} 3$ or $1,000 \mathrm{~kg} / \mathrm{m} 3$. MCod equals oven dry moisture content. If the only volume information available is merchantable volume, it is possible to obtain or develop "volume expansion factors" to arrive at the desired type of weight estimates (2).

Specific gravity (SG) is another critical element of the volume to biomass estimation equation. The SG content should correspond to the moisture content of the volume involved. SG varies considerably from species to species, differs for wood and bark, and is closely related to the moisture content. Examples of SG of wood and bark are given for selected species in Table 6 of Appendix A. Reference (3) below gives wood and bark SG numbers for 38 individual species.

\section{Sources:}

[1] Briggs D. Forest Products Measurements and Conversion Factors. College of Forest Resources Imoversotu pf Washington. Available as of 9/29/2008 at http://www.ruraltech.org/projects/conversions/briggs conversions/briggs book.asp

[2] Somogyi Z, Cienciala E, Makipaa ., Muukkonen P, Lehtonen A., Weiss P. Indirect Methods of Largescale Forest Biomass Estimation. Eur. J. Forest Res (2006) DOI 10.1007/s10342-006-0125-7

[3] Smith B. Factors and Equations to Estimate Forest Biomass in the North Central Region. USDA Forest Service, North Central Forest Experiment Station. Research Paper NC-268. 
Biomass researchers are always looking for that single number that will allow them to quickly estimate biomass tonnage available from a given location or part of the country based on forest inventory data. However many "rule of thumb" guides available in forestry literature and on the web can lead to very misleading estimates because insufficient information is often given to interpret the information (see note below). Additional discussions on considerations and issues associated with estimating biomass from forestry volume are found in tables A.4 and A.5 of this appendix. Selected information shown in the table below is derived from an excellent paper on estimating biomass species in the North Central Region.

Table A.6

Forestry Volume Unit to Biomass Weight Examples (Selected Examples from the North Central Region)

\begin{tabular}{|c|c|c|c|c|c|c|c|c|}
\hline Species Group & $\begin{array}{l}\text { Specific } \\
\text { Gravity } \\
\text { wood, bark }^{\mathrm{a}}\end{array}$ & $\begin{array}{l}\text { Green } \\
\text { MC } \\
\text { wood \& } \\
\text { bark (\%) }\end{array}$ & $\begin{array}{l}\text { Green } \\
\text { Weight } \\
\text { wood \& } \\
\text { bark lb/ft }\end{array}$ & $\begin{array}{l}\text { Dry } \\
\text { Weight } \\
\text { wood \& } \\
\text { bark } \\
\text { lb/ft }^{3}\end{array}$ & $\begin{array}{l}\text { Solid Green } \\
\text { Weight of } \\
\text { Standard } \\
\text { Cord (Ibs) }\end{array}$ & $\begin{array}{l}\text { Green } \\
\text { Tons per } \\
\text { standard } \\
\text { cord }^{b}\end{array}$ & $\begin{array}{l}\text { Air-Dry } \\
\text { Tons per } \\
\text { cord }(79 \\
\left.\mathrm{ft}^{3}\right) 15 \% \\
\mathrm{MC}^{\mathrm{b}}\end{array}$ & $\begin{array}{l}\text { Oven-dry Tons } \\
\text { per cord }\left(79 \mathrm{ft}^{3}\right) \\
0 \% \mathrm{MC}^{\mathrm{b}}\end{array}$ \\
\hline \multicolumn{9}{|l|}{ Softwood } \\
\hline Southern Pine & $0.47,0.32$ & 50 & 64 & 32 & 5,056 & 2.5 & 1.5 & 1.3 \\
\hline Jack Pine & $0.40,0.34$ & 47 & 54 & 29 & 4,266 & 2.1 & 1.3 & 1.1 \\
\hline Red Pine & $0.41,0.24$ & 47 & 54 & 29 & 4,266 & 2.1 & 1.3 & 1.1 \\
\hline White Pine & $0.37,0.49$ & 47 & 53 & 28 & 4,187 & 2.1 & 1.3 & 1.1 \\
\hline \multicolumn{9}{|l|}{ Hardwood } \\
\hline Red Oak & $0.56,0.65$ & 44 & 73 & 41 & 5,767 & 2.9 & 1.9 & 1.6 \\
\hline Beech & $0.56,0,56$ & 41 & 64 & 38 & 5,056 & 2.5 & 1.7 & 1.5 \\
\hline Sycamore & $0.46,0.45$ & 55 & 62 & 28 & 4,898 & 2.4 & 1.3 & 1.1 \\
\hline Cottonwood & $0.37,0.43$ & 55 & 59 & 27 & 4,661 & 2.3 & 1.2 & 1.0 \\
\hline Willow & $0.34,0.43$ & 55 & 56 & 25 & 4,424 & 2.2 & 1.1 & 1.0 \\
\hline
\end{tabular}

\section{Source:}

Smith, B. Factors and Equations to Estimate Forest Biomass in the North Central Region. USDA Forest Service, North Central Experimental Station. Research Paper NC-268 (This paper quotes many original literature sources for the equations and estimates.)

Note: In extensive online research for reference sources that could provide guidance on estimating biomass for energy, several sources of conversion factors and "rules of thumb" were found that provided insufficient information to discern whether they were applicable to estimation of biomass tonnages. One example is the Southern Wood Conversion Factors and Rules of Thumb at: http://members.aol.com/Jostnix/convert.htm. If used for the purposes intended, such as the estimation of green tons of pine and hardwood pulpwood, the guide is a useful "rule of thumb," but it could be easily misinterpreted by someone not understanding the guide's intent since the tonnage value given does not specify moisture content.

a The SG numbers are based on weight oven-dry and volume when green (Smith, 1985;table 1) of wood and bark respectively. Wood and bark are combined for other columns (Smith, 19085, table 2).

$\mathrm{b}$ These columns contain numbers calculated by Lynn Wright based on reported numbers of standard cords per ton, moisture contents, and green weights ft3 provided in the Smith (1985) paper. 
Table A.7

Stand Level Biomass Estimation

Biomass estimation at the individual field or stand level is relatively straight forward, especially if being done for plantation grown trees that are relatively uniform in size and other characteristics. The procedure involves first developing a biomass equation that predicts individual tree biomass as a function of diameter at breast height $(D B H)$, or of dbh plus height. Secondly, the equation parameters (dbh and height) need to be measured on a sufficiently large sample size to minimize variation around the mean values, and thirdly, the mean individual tree weight results are scaled to the area of interest based on percent survival or density information (trees per acre or hectare). Regression estimates are developed by directly sampling and weighing enough trees to cover the range of sizes being included in the estimation. They often take the form of:

In $Y$ (weight in $\mathrm{kg})=$-factor $1+$ factor $2 x \ln X$ (where $X$ is $d b h$ or $d b h 2$ theight/100) Regression equations can be found for many species in a wide range of literature. Examples for trees common to the Pacific Northwest are provided in reference 1 below. The equations will differ depending on whether foliage or live branches are included, so care must be taken in interpreting the biomass data. For plantation trees grown on cropland or marginal cropland it is usually assumed that tops and branches are included in the equations but that foliage is not. For trees harvested from forests on lower quality land, it is usually recommended that tops and branches should not be removed (see reference 2 below) in order to maintain nutrient status and reduce erosion potential, thus biomass equations should assume regressions based on the stem weight only.

\section{Sources:}

[1] Briggs, D. Forest Products Measurements and Conversion Factors. College of Forest Resources University of Washington. Available as of 9/29/2008 at http://www.ruraltech.org/projects/conversions/briggs conversions/briggs book.asp

[2] Pennsylvania Department of Conservation and Natural Resources. Guidance on Harvesting Woody Biomass for Energy in Pennsylvania. September, 2007. Available as of 9-29-08 at: http://www.denr.state.pa.us/PA Biomass guidance final.pdf 
Table A.8

Number of Trees per Acre and per Hectare by Various Tree Spacing Combinations

\begin{tabular}{|c|c|c|c|c|c|c|c|}
\hline $\begin{array}{c}\text { Spacing } \\
\text { (feet) }=\end{array}$ & $\begin{array}{c}\text { Trees } \\
\text { per Acre } \\
=\end{array}$ & $\begin{array}{c}\text { Spacing } \\
\text { (meters) }=\end{array}$ & $\begin{array}{l}\text { Trees per } \\
\text { Hectare }^{\mathrm{a}}\end{array}$ & $\begin{array}{c}\text { Spacing } \\
\text { (meters) }=\end{array}$ & $\begin{array}{l}\text { Trees per } \\
\text { Hectare }\end{array}$ & $\begin{array}{l}\text { Spacing (ft } \\
\text { and in) }=\end{array}$ & $\begin{array}{c}\text { Trees per } \\
\text { Acre }^{\text {b }}\end{array}$ \\
\hline$\overline{1 \times 1}$ & 43,560 & $0.3 \times 0.3$ & 107,637 & $0.1 \times 0.1$ & $1,000,000$ & $4 " \times 4 "$ & 405,000 \\
\hline $2 \times 2$ & 10,890 & $0.6 \times 0.6$ & 26,909 & $0.23 \times 0.23$ & 189,035 & $9 " \times 9 "$ & 76,559 \\
\hline $2 \times 4$ & 5,445 & $0.6 \times 1.2$ & 13,455 & $0.3 \times 0.3$ & 107,593 & $1^{\prime} \times 1^{\prime}$ & 43,575 \\
\hline $3 \times 3$ & 4,840 & $0.9 \times 0.9$ & 11,960 & $0.5 \times 0.5$ & 40,000 & 1'8" x 1'8" & 16,200 \\
\hline $4 \times 4$ & 2,722 & $1.2 \times 1.2$ & 6,726 & $0.5 \times 1.0$ & 20,000 & 1'8" x 3'3" & 8,100 \\
\hline $4 \times 5$ & 2,178 & $1.2 \times 1.5$ & 5,382 & $0.5 \times 2.0$ & 10,000 & 1'8" x 6'7" & 4,050 \\
\hline $4 \times 6$ & 1,815 & $1.2 \times 1.8$ & 4,485 & $0.75 \times 0.75$ & 17,778 & $2^{\prime} 6^{\prime \prime}$ x 2'6" & 7,200 \\
\hline $4 \times 7$ & 1,556 & $1.2 \times 2.1$ & 3,845 & $0.75 \times 1.0$ & 13,333 & 2'6" x 3'3" & 5,400 \\
\hline $4 \times 8$ & 1,361 & $1.2 \times 2.4$ & 3,363 & $0.75 \times 1.5$ & 8,889 & 2'5" x 4'11" & 3,600 \\
\hline $4 \times 9$ & 1,210 & $1.2 \times 2.7$ & 2,990 & $1.0 \times 1.0$ & 10,000 & 3'3" x 3'3" & 4,050 \\
\hline $4 \times 10$ & 1,089 & $1.2 \times 3.0$ & 2,691 & $1.0 \times 1.5$ & 6,667 & 3'3" x 4'11" & 2,700 \\
\hline $5 \times 5$ & 1,742 & $1.5 \times 1.5$ & 4,304 & $1.0 \times 2.0$ & 5,000 & 3'3" x 6'6" & 2,025 \\
\hline $5 \times 6$ & 1,452 & $1.5 \times 1.8$ & 3,588 & $1.0 \times 3.0$ & 3,333 & 3'3" x 9'10" & 1,350 \\
\hline $5 \times 7$ & 1,245 & $1.5 \times 2.1$ & 3,076 & $1.5 \times 1.5$ & 4,444 & 4'11"x4'11" & 1,800 \\
\hline $5 \times 8$ & 1,089 & $1.5 \times 2.4$ & 2,691 & $1.5 \times 2.0$ & 3,333 & 4'11"x 6'6" & 1,350 \\
\hline $5 \times 9$ & 968 & $1.5 \times 2.7$ & 2,392 & $1.5 \times 3.0$ & 2,222 & 4'11"x9'10" & 900 \\
\hline $5 \times 10$ & 871 & $1.5 \times 3.0$ & 2,152 & $2.0 \times 2.0$ & 2,500 & 3'3" x 3'3" & 1,013 \\
\hline $6 \times 6$ & 1,210 & $1.8 \times 1.8$ & 2,990 & $2.0 \times 2.5$ & 2,000 & $3^{\prime} 3^{\prime \prime}$ x 8'2" & 810 \\
\hline $6 \times 7$ & 1,037 & $1.8 \times 2.1$ & 2,562 & $2.0 \times 3.0$ & 1,667 & 3'3" x 9'10" & 675 \\
\hline $6 \times 8$ & 908 & $1.8 \times 2.4$ & 2,244 & $2.0 \times 4.0$ & 1,250 & 3'3" x 13'1" & 506 \\
\hline $6 \times 9$ & 807 & $1.8 \times 2.7$ & 1,994 & $2.5 \times 2.5$ & 1,600 & 8'2" x 8'2" & 648 \\
\hline $6 \times 10$ & 726 & $1.8 \times 3.0$ & 1,794 & $2.5 \times 3.0$ & 1,333 & 8'2" x 9'10" & 540 \\
\hline $6 \times 12$ & 605 & $1.8 \times 3.7$ & 1,495 & $3.0 \times 3.0$ & 1,111 & 9'10"x9'10" & 450 \\
\hline $7 \times 7$ & 889 & $2.1 \times 2.1$ & 2,197 & $3.0 \times 4.0$ & 833 & 9'10"x13'1" & 337 \\
\hline $7 \times 8$ & 778 & $2.1 \times 2.4$ & 1,922 & $3.0 \times 5.0$ & 666 & 9'10"x13'1" & 270 \\
\hline $7 \times 9$ & 691 & $2.1 \times 2.7$ & 1,707 & $4.0 \times 4.0$ & 625 & $13^{\prime} 1 " \mathrm{x}$ x 13'1" & 253 \\
\hline $7 \times 10$ & 622 & $2.1 \times 3.0$ & 1,537 & $5.0 \times 5.0$ & 400 & $16^{\prime} 5 "$ x 16'5" & 162 \\
\hline $7 \times 12$ & 519 & $3.1 \times 3.7$ & 1,282 & & & & \\
\hline $8 \times 8$ & 681 & $2.4 \times 2.4$ & 1,683 & & & & \\
\hline $8 \times 9$ & 605 & $2.4 \times 2.7$ & 1,495 & & & & \\
\hline $8 \times 10$ & 544 & $2.4 \times 3.0$ & 1,344 & & & & \\
\hline $8 \times 12$ & 454 & $2.4 \times 3.7$ & 1,122 & & & & \\
\hline $9 \times 9$ & 538 & $2.7 \times 2.7$ & 1,329 & & & & \\
\hline $9 \times 10$ & 484 & $2.7 \times 3.0$ & 1,196 & & & & \\
\hline $9 \times 12$ & 403 & $2.7 \times 3.7$ & 996 & & & & \\
\hline $10 \times 10$ & 436 & $3.0 \times 3.0$ & 1,077 & & & & \\
\hline $10 \times 12$ & 363 & $3.0 \times 3.7$ & 897 & & & & \\
\hline $10 \times 15$ & 290 & $3.0 \times 4.5$ & 717 & & & & \\
\hline $12 \times 12$ & 302 & $3.7 \times 3.7$ & 746 & & & & \\
\hline $12 \times 15$ & 242 & $3.7 \times 4.6$ & 598 & & & & \\
\hline
\end{tabular}
2.471

${ }^{a}$ The spacing is approximated to nearest centimeter but trees per hectare $=$ trees per acre $\mathrm{x}$

${ }^{\mathrm{b}}$ The spacing is approximated to nearest inch but trees per acre $=$ trees per hectare $\times 0.405$ 
Table A.9

Wood and Log Volume Conversion Factors

\begin{tabular}{lccccccc}
\hline & \multicolumn{6}{c}{ Average conversions across all wood types } \\
\cline { 2 - 8 } & $\begin{array}{c}\text { Standard } \\
\text { cord }\end{array}$ & $\begin{array}{c}\text { Solid } \\
\text { cord }\end{array}$ & Cunit & $\begin{array}{c}\text { Board } \\
\text { foot }\end{array}$ & $\begin{array}{c}\mathbf{1 , 0 0 0} \\
\text { Board } \\
\text { feet }\end{array}$ & $\begin{array}{c}\text { Cubic foot } \\
\text { lumber } \\
\text { average }\end{array}$ & $\begin{array}{c}\text { Cubic meters } \\
\text { lumber } \\
\text { average }\end{array}$ \\
\hline standard cord & 1 & 1.6 & 1.28 & 1,536 & 1.536 & 128 & 3.6246 \\
solid cord & 0.625 & 1 & 0.8 & 960 & 0.96 & $80^{\mathrm{a}}$ & 2.2653 \\
cunit & 0.7813 & 1.25 & 1 & 1,200 & 1.2 & 100 & 2.832 \\
$\begin{array}{l}\text { lumber } \\
\mathbf{1 , 0 0 0} \text { board feet }\end{array}$ & 0.00065 & 0.00104 & 0.00083 & 1 & 0.001 & $0.0833^{\mathrm{b}}$ & 0.0024 \\
(MBF) lumber & 0.651 & 1.0416 & 0.8333 & 1,000 & 1 & $83.33^{\mathrm{b}}$ & 2.3598 \\
$\begin{array}{l}\text { cubic foot lumber } \\
\text { cubic meters }\end{array}$ & 0.0078 & 0.0125 & 0.01 & 12 & 0.012 & 1 & 0.0283 \\
lumber & 0.2759 & 0.4414 & 0.3531 & 423.77 & 0.4238 & 35.3146 & 1 \\
\hline
\end{tabular}

Source:

www.unitconversion.org, verified with several other sources.

Brief Definitions of the Forestry Measures:

A standard cord is $4 \mathrm{ft} \times 4 \mathrm{ft} \times 8 \mathrm{ft}$ stack of roundwood including bark and air A solid cord is the net volume of roundwood in a standard cord stack

A cunit is 00 cubic feet of solid wood

1 board foot (bf) is a plank of lumbar measuring 1 inch $x 1$ foot $x 1$ foot $(1 / 12 \mathrm{ft} 3)$

1000 board feet (MBF) is a standard measure used to buy and sell lumber

1 cubic foot of lumber is a $1 \mathrm{ft} \times 1 \mathrm{ft} \times 1 \mathrm{ft}$ cube

1 cubic meter of lumber is a $1 \mathrm{~m} \times 1 \mathrm{~m} \times 1 \mathrm{~m}$ cube

Notes: The conversions in this table are only suitable for converting units of harvested roundwood or processed sawtimber to approximate alternative units.

${ }^{a}$ The estimate of 80 cubic feet (or 2.26 cubic meters) in a solid cord is an average value for stacked lumber and also for hardwood roundwood with bark. Values for all roundwood wood types with and without bark can range from 60 to 95 cubic feet or (1.69 to 2.69 cubic meters) .depending on wood species, moisture content and other factors.

${ }^{b}$ The relationship of 83.3 cubic feet per 1000 board $\mathrm{ft}$ is correct if one is converting the stacked board feet to a cubic volume, however some forestry "rules of thumb" stated that 1000 board feet is equal to 183 cubic feet with a range of 160 to 220 . The explanation for the difference is unclear. 
To use these conversion factors, first decide the mill type, which is based on equipment; then determine the average scaling diameter of the logs. If the equipment indicates a mill type $B$ and the average scaling diameter is 13 inches, then look in section $B$, line 2. This line shows that for every thousand board feet of softwood lumber sawed, 0.42 ton of bark, 1.18 tons of chippable material, and 0.92 ton of fines are produced, green weight. Equivalent hard hardwood and soft hardwood data are also given. Converting factors for shavings are omitted as they are zero for sawmills.

Table A.10

Estimating Tons of Wood Residue per Thousand Board Feet of Lumber Produced by Sawmills, by Species and Type of Residue

\begin{tabular}{|c|c|c|c|c|c|c|c|c|c|c|c|c|c|c|c|c|c|c|c|}
\hline \multirow[b]{3}{*}{ Mill Type $^{a}$} & \multirow{3}{*}{$\begin{array}{l}\text { Small end } \\
\text { diameter }^{\mathrm{b}}\end{array}$} & \multicolumn{6}{|c|}{ Softwood $^{\mathrm{C}}$} & \multicolumn{6}{|c|}{ Hard hardwood $^{\mathrm{C}}$} & \multicolumn{6}{|c|}{ Soft hardwood $^{\mathrm{C}}$} \\
\hline & & \multicolumn{2}{|c|}{ Bark } & \multicolumn{2}{|c|}{ Chippable } & \multicolumn{2}{|c|}{ Fine $^{f}$} & \multicolumn{2}{|c|}{ Bark } & \multicolumn{2}{|c|}{ Chipable } & \multicolumn{2}{|c|}{ Fine } & \multicolumn{2}{|c|}{ Bark } & \multicolumn{2}{|c|}{ Chipable } & \multicolumn{2}{|c|}{ Fine } \\
\hline & & $\mathrm{G}^{\mathrm{d}}$ & $\mathrm{OD}^{\mathrm{e}}$ & G & OD & G & OD & G & OD & G & OD & G & OD & G & OD & G & OD & G & OD \\
\hline \multirow{4}{*}{$\begin{array}{c}\mathrm{A}, \mathrm{B}, \mathrm{C}, \mathrm{H}, \\
\text { and I }\end{array}$} & 1 & 0.46 & 0.31 & 1.57 & 0.78 & 0.98 & 0.48 & 0.84 & 0.59 & 1.84 & 1.04 & 1.26 & 0.71 & 0.58 & 0.41 & 1.27 & 0.72 & 0.86 & 0.49 \\
\hline & 2 & 0.42 & 0.29 & 1.18 & 0.58 & 0.92 & 0.45 & 0.72 & 0.51 & 1.53 & 0.87 & 1.34 & 0.76 & 0.50 & 0.35 & 1.06 & 0.60 & 0.91 & 0.52 \\
\hline & 3 & 0.41 & 0.28 & 1.07 & 0.53 & 1.00 & 0.49 & 0.56 & 0.39 & 1.17 & 0.66 & 1.08 & 0.61 & 0.39 & 0.27 & 0.81 & 0.46 & 0.74 & 0.42 \\
\hline & 4 & 0.31 & 0.21 & 0.88 & 0.43 & 0.91 & 0.45 & 0.49 & 0.35 & 1.03 & 0.58 & 1.05 & 0.60 & 0.34 & 0.24 & 0.72 & 0.41 & 0.72 & 0.41 \\
\hline \multirow{4}{*}{$D$ and $E$} & 1 & 0.29 & 0.20 & 1.57 & 0.78 & 0.90 & 0.45 & 0.84 & 0.59 & 1.84 & 1.04 & 0.92 & 0.52 & 0.58 & 0.41 & 1.27 & 0.72 & 0.63 & 0.36 \\
\hline & 2 & 0.29 & 0.20 & 1.18 & 0.58 & 0.76 & 0.38 & 0.72 & 0.51 & 1.53 & 0.87 & 0.84 & 0.48 & 0.50 & 0.35 & 1.06 & 0.60 & 0.58 & 0.33 \\
\hline & 3 & 0.29 & 0.20 & 1.07 & 0.53 & 0.71 & 0.35 & 0.56 & 0.39 & 1.17 & 0.66 & 0.84 & 0.48 & 0.39 & 0.27 & 0.81 & 0.46 & 0.58 & 0.33 \\
\hline & 4 & 0.29 & 0.20 & 0.88 & 0.43 & 0.64 & 0.32 & 0.49 & 0.35 & 1.03 & 0.58 & 0.80 & 0.45 & 0.34 & 0.24 & 0.72 & 0.41 & 0.55 & 0.31 \\
\hline & 1 & 0.29 & 0.20 & 1.57 & 0.78 & 0.98 & 0.48 & 0.84 & 0.59 & 1.84 & 1.04 & 1.26 & 0.71 & 0.58 & 0.41 & 1.27 & 0.72 & 0.86 & 0.49 \\
\hline & 2 & 0.29 & 0.20 & 1.18 & 0.58 & 0.92 & 0.45 & 0.72 & 0.51 & 1.53 & 0.87 & 1.34 & 0.76 & 0.50 & 0.35 & 1.06 & 0.60 & 0.91 & 0.52 \\
\hline & 3 & 0.29 & 0.20 & 1.07 & 0.53 & 1.00 & 0.49 & 0.56 & 0.39 & 1.17 & 0.66 & 1.08 & 0.61 & 0.39 & 0.27 & 0.81 & 0.46 & 0.74 & 0.42 \\
\hline $\mathrm{F}$ & 4 & 0.29 & 0.20 & 0.88 & 0.43 & 0.91 & 0.45 & 0.49 & 0.35 & 1.03 & 0.58 & 1.05 & 0.60 & 0.34 & 0.24 & 0.72 & 0.41 & 0.72 & 0.41 \\
\hline \multirow{4}{*}{ G } & 1 & 0.29 & 0.20 & 1.90 & 0.94 & 0.57 & 0.28 & 0.84 & 0.59 & 2.23 & 1.28 & 0.53 & 0.28 & 0.58 & 0.41 & 1.54 & 0.88 & 0.36 & 0.20 \\
\hline & 2 & 0.29 & 0.20 & 1.34 & 0.66 & 0.60 & 0.30 & 0.72 & 0.51 & 1.72 & 0.98 & 0.65 & 0.37 & 0.50 & 0.35 & 1.19 & 0.68 & 0.45 & 0.25 \\
\hline & 3 & 0.29 & 0.20 & 1.17 & 0.58 & 0.61 & 0.30 & 0.56 & 0.39 & 1.29 & 0.73 & 0.72 & 0.41 & 0.39 & 0.27 & 0.89 & 0.51 & 0.50 & 0.28 \\
\hline & 4 & 0.29 & 0.20 & 0.98 & 0.48 & 0.54 & 0.28 & 0.49 & 0.35 & 1.15 & 0.65 & 0.68 & 0.38 & 0.34 & 0.24 & 0.80 & 0.46 & 0.47 & 0.26 \\
\hline
\end{tabular}

Source:

Bridgette K. Ellis and Janice A. Brown, Tennessee Valley Authority, Production and Use of Industrial Wood and Bark Residues in the Tennessee Valley Region, August 1984.

a Mill Type: A. Circular headsaw with or without trim saw; B. Circular headsaw with edger and trim saw; C. Circular headsaw with vertical band resaw, edger, trim saw; D. Band headsaw with edger, trim saw; E. Band headsaw with horizontal band resaw, edger, trim saw; F. Band headsaw with cant gangsaw, edger, trim saw; G. Chipping head rig; H. Round log mill; I. Scragg mill.

${ }^{b}$ Average small-end log (scaling) diameter classes: 1. 5-10 inches; 2. 11-13 inches; 3. 14-16 inches; 4.17 inches and over.

' See Appendix A for species classification, i.e., softwood, hard hardwood, and soft hardwood.

${ }^{\mathrm{d}} \mathrm{G}=$ green weight, or initial condition, with the moisture content of the wood as processed

e $\mathrm{OD}=$ Oven Dry. It is the weight at zero percent moisture.

${ }^{f}$ Fine is sawdust and other similar size material. 
Table A.11

Estimating Tons of Wood Residue per Thousand Board Feet of Wood Used for Selected Products

\begin{tabular}{|c|c|c|c|c|c|c|c|c|}
\hline \multirow[b]{2}{*}{ Type of Plant } & \multicolumn{8}{|c|}{ Softwood ${ }^{\mathrm{a}}$} \\
\hline & Bark & $\% \mathrm{MC}$ & Chipable $^{\mathrm{D}}$ & $\% \mathrm{MC}$ & Shavings & $\% \mathrm{MC}$ & Fine $^{c}$ & $\% \mathrm{MC}$ \\
\hline Planing mill & - & - & 0.05 & 19 & 0.42 & 19 & - & - \\
\hline Wood chip mill $^{\mathrm{d}}$ & 0.60 & 50 & - & - & - & - & - & - \\
\hline Wooden furniture frames & - & - & 0.22 & 12 & 0.25 & 12 & 0.05 & 12 \\
\hline Shingles \& cooperage stock & 0.42 & 50 & 1.29 & 100 & - & - & 1.01 & 100 \\
\hline Plywood & - & - & 0.13 & 9 & - & - & 0.21 & 9 \\
\hline Veneer & 0.42 & 50 & 1.77 & 100 & - & - & - & - \\
\hline Pallets and skids & - & - & 0.42 & 60 & 0.21 & 60 & 0.07 & 60 \\
\hline Log homes & - & - & 0.17 & 80 & - & - & 0.05 & 80 \\
\hline Untreated posts, poles, and & & & & & & & & \\
\hline pilings & 0.46 & 50 & 0.40 & 100 & - & - & 0.05 & 100 \\
\hline Particleboard & 0.60 & 60 & - & - & - & - & 0.21 & 6 \\
\hline \multirow[t]{3}{*}{ Pulp, paper, and paperboard } & 0.60 & 70 & - & - & - & - & - & - \\
\hline & \multicolumn{8}{|c|}{ Hard hardwood ${ }^{\mathrm{a}}$} \\
\hline & Bark & $\% \mathrm{MC}$ & Chipable $^{\mathrm{b}}$ & $\% \mathrm{MC}$ & Shavings & $\% \mathrm{MC}$ & Fine $^{c}$ & $\% \mathrm{MC}$ \\
\hline Planing mill & 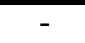 & - & 0.06 & 19 & 0.54 & 19 & - & - \\
\hline Wood chip mill & 0.90 & 60 & - & - & - & - & - & - \\
\hline Hardwood flooring & - & - & 0.12 & 6 & 0.57 & 6 & - & - \\
\hline Wooden furniture frames & - & - & 0.31 & 9 & 0.36 & 9 & 0.07 & 9 \\
\hline Shingles \& cooperage stock & 0.56 & 60 & 1.66 & 70 & - & - & 1.47 & 70 \\
\hline Plywood & - & - & 0.16 & 9 & - & - & 0.26 & 9 \\
\hline Veneer & 0.72 & 60 & 2.70 & 70 & - & - & - & - \\
\hline Pallets and skids & - & - & 0.50 & 60 & 0.25 & 60 & 0.08 & 60 \\
\hline \multirow[t]{3}{*}{ Pulp, paper, and paperboard } & 0.90 & 60 & - & - & - & - & - & - \\
\hline & \multicolumn{8}{|c|}{ Soft hardwood ${ }^{a}$} \\
\hline & Bark & $\% \mathrm{MC}$ & Chipable $^{\mathrm{D}}$ & $\% \mathrm{MC}$ & Shavings & $\% \mathrm{MC}$ & Fine $^{c}$ & $\% \mathrm{MC}$ \\
\hline Planing mill & - & - & 0.04 & 19 & 0.40 & 19 & - & - \\
\hline Wood chip mill & 0.62 & 88 & - & - & - & - & - & - \\
\hline Wooden furniture frames & - & - & 0.22 & 9 & 0.26 & 9 & 0.05 & 9 \\
\hline Plywood & - & - & 0.13 & 9 & - & - & 0.21 & 9 \\
\hline Veneer & 0.50 & 88 & 2.13 & 95 & - & - & - & - \\
\hline Pallets and skids & - & - & 0.34 & 60 & 0.17 & 60 & 0.06 & 60 \\
\hline Particleboard & 0.60 & 60 & - & - & - & - & 0.21 & 6 \\
\hline Pulp, paper, and paperboard & 0.62 & 88 & - & - & - & - & - & - \\
\hline
\end{tabular}

Source:

Bridgette K. Ellis and Janice A. Brown, Tennessee Valley Authority, Production and Use of Industrial Wood and Bark Residues in the Tennessee Valley Region" August 1984.

Notes: For shingles and cooperage stock the table indicates that for every thousand board feet of softwood logs used, 1.29 tons of chippable material could be expected, with an average moisture content (MC) of $100 \%$, based on ovendry weight. If the Average MC of the wood used is greater or less than $100 \%$, proportionally greater or lesser weight of material could be expected.

${ }^{a}$ For definitions of species, see next page

${ }^{\mathrm{b}}$ Chippable is material large enough to warrant size reduction before being used by the paper, particleboard, or metallurgical industries.

${ }^{c}$ Fines are considered to be sawdust or sanderdust.

${ }^{d}$ For chipping mills with debarkers only 
Table A.12

Area and Length Conversions

\begin{tabular}{|c|c|c|}
\hline \multicolumn{3}{|c|}{ Area } \\
\hline Multiply & by & To Obtain \\
\hline$\overline{\text { acres }(\mathrm{ac})^{\mathrm{a}}}$ & 0.4047 & hectares \\
\hline hectares (ha) & 2.4710 & acres \\
\hline hectares (ha) & 0.0039 & square miles \\
\hline hectares (ha) & 10000 & square meters \\
\hline square kilometer $\left(\mathrm{km}^{2}\right)$ & 247.10 & acres \\
\hline square kilometer $\left(\mathrm{km}^{2}\right)$ & 0.3861 & square miles \\
\hline square kilometer $\left(\mathrm{km}^{2}\right)$ & 100 & hectares \\
\hline square mile $\left(\mathrm{mi}^{2}\right)$ & 258.9990 & hectares. \\
\hline square mile $\left(\mathrm{mi}^{2}\right)$ & 2.5900 & square kilometers \\
\hline square mile $\left(\mathrm{mi}^{2}\right)$ & 640 & acres \\
\hline square yards $\left(\mathrm{yd}^{2}\right)$ & 0.8361 & square meters \\
\hline square meters $\left(\mathrm{m}^{2}\right)$ & 1.1960 & square yards \\
\hline square foot $\left(\mathrm{ft}^{2}\right)$ & 0.0929 & square meters \\
\hline square meters $\left(\mathrm{m}^{2}\right)$ & 10.7639 & square feet \\
\hline square inchs $\left(\mathrm{in}^{2}\right)$ & 6.4516 & square centimeters (exactly). \\
\hline square decimeter $\left(\mathrm{dm}^{2}\right)$ & 15.5000 & square inches \\
\hline square centimeters $\left(\mathrm{cm}^{2}\right)$ & 0.1550 & square inches \\
\hline square millimeter $\left(\mathrm{mm}^{2}\right)$ & 0.0020 & square inches \\
\hline square feet $\left(\mathrm{ft}^{2}\right)$ & 929.03 & square centimeters \\
\hline square rods $\left(\mathrm{rd}^{2}\right)$, sq pole, or sq perch & 25.2930 & square meters \\
\hline \multicolumn{3}{|l|}{ Length } \\
\hline Multiply & by & To Obtain \\
\hline miles (mi) & 1.6093 & kilometers \\
\hline miles (mi) & $1,609.34$ & meters \\
\hline miles (mi) & $1,760.00$ & yards \\
\hline miles (mi) & $5,280.00$ & feet \\
\hline kilometers $(\mathrm{km})$ & 0.6214 & miles \\
\hline kilometers $(\mathrm{km})$ & $1,000.00$ & meters \\
\hline kilometers $(\mathrm{km})$ & $1,093.60$ & yards \\
\hline kilometers $(\mathrm{km})$ & $3,281.00$ & feet \\
\hline feet $(\mathrm{ft})$ & 0.3048 & meters \\
\hline meters $(\mathrm{m})$ & 3.2808 & feet \\
\hline yard (yd) & 0.9144 & meters \\
\hline meters $(\mathrm{m})$ & 1.0936 & yards \\
\hline inches (in) & 2.54 & centimeters \\
\hline centimeters $(\mathrm{cm})$ & 0.3937 & inches \\
\hline
\end{tabular}

\section{Source:}

National Institute of Standards and Technology, General Tables of Units and Measurements, http://ts.nist.gov/WeightsAndMeasures/Publications/upload/h4402 appenc.pdf

${ }^{a}$ An acre is a unit of area containing 43,560 square feet. It is not necessarily square, or even rectangular. But, if it is square, then the length of a side is equal to the square root of 43,560 or about 208.71 feet. 
Table A.13

Mass Units and Mass per Unit Area Conversions

Mass

\begin{tabular}{lcl}
\hline \multicolumn{1}{c}{ Multiply } & by & To Obtain \\
\hline ounces $(\mathrm{oz})$ & 28.3495 & grams \\
grams $(\mathrm{gm})$ & 0.0353 & ounces \\
pounds (lbs) & 0.4536 & kilograms \\
pounds (lbs) & 436.6 & grams \\
kilograms $(\mathrm{kg})$ & 2.2046 & pounds \\
kilograms $(\mathrm{kg})$ & 0.0011 & U.S. or short tons, \\
metric tons or tonne $(\mathrm{t})$ & 1 & a \\
metric tons or tonne $(\mathrm{t})$ & 2205 & pounds \\
metric tons or tonne $(\mathrm{t})$ & 1000 & kilograms \\
metric tons or tonne $(\mathrm{t})$ & 1.102 & short tons \\
metric tons or tonne $(\mathrm{t})$ & 0.9842 & long tons \\
U.S. or short tons, $(\mathrm{ts})$ & 2000 & pounds \\
U.S. or short tons, $(\mathrm{ts})$ & 907.2 & kilograms \\
U.S. or short tons, $(\mathrm{ts})$ & 0.9072 & Megagrams \\
U.S. or short tons, $(\mathrm{ts})$ & 0.8929 & Imperial or long tons \\
Imperial or long tons $(\mathrm{tl})$ & 2240 & pounds \\
Imperial or long tons $(\mathrm{tl})$ & 1.12 & short tons \\
Imperial or long tons $(\mathrm{tl})$ & 1016 & kilograms \\
Imperial or long tons $(\mathrm{tl})$ & 1.016 & Megagrams \\
\hline
\end{tabular}

Mass per Unit Area

\begin{tabular}{lcl}
\hline \multicolumn{1}{c}{ Multiply } & by & To Obtain \\
\hline Megagram per hectare $\left(\mathrm{Mg} \mathrm{ha}^{-1}\right)$ & 0.4461 & short tons per acre \\
kilograms per square meter $\left(\mathrm{kg} \mathrm{m}^{-1}\right)$ & 4.461 & short tons per acre \\
tons (short US) per acre $\left(\mathrm{t} \mathrm{ac}^{-1}\right)$ & 2.2417 & Megagram per hectare \\
tons (short US) per acre $\left(\mathrm{t} \mathrm{ac}^{-1}\right)$ & 0.2241 & kilograms per square meter \\
kilograms per square meter $\left(\mathrm{kg} \mathrm{m}^{2}-1\right)$ & 0.2048 & pounds per square foot \\
pounds per square foot $\left(\mathrm{lb} \mathrm{ft}^{2}\right)$ & 4.8824 & kilogram per square meter \\
kilograms per square meter $(\mathrm{kg} \mathrm{m}-1)$ & 21.78 & short tons per acre \\
kilogram per hectare $\left(\mathrm{kg} \mathrm{ha}^{-1}\right)$ & 0.892 & pounds per acre \\
pounds per acre $\left(\mathrm{lb} \mathrm{ac}^{-1}\right)$ & 1.12 & kilogram per hectare \\
\hline
\end{tabular}

\section{Source:}

Web sites www.gordonengland.co.uk/conversion and www.convert-me.com/en/convert and the Family Farm Series Publication, Vegetable Crop Production at Web site www.sfc.ucdavis.edu/pubs/Family Farm Series/Veg/Fertilizing/appendix.htm/\#tables

${ }^{a}$ The proper SI unit for a metric ton or tonne is megagram (MG) however "t" is commonly used in practice as in dt ha-1 for dry ton per hectare. Writers in the United States also normally use "t" for short ton as in dt ac-1 for dry ton per acre, so noting the context in the interpretation of "t" is important. 
Table A.14

Distance and Velocity Conversions

\begin{tabular}{rlrl}
\hline 1 inch (in) & $=0.0833 \mathrm{ft}$ & 1 centimeter $(\mathrm{cm})$ & $=0.3937 \mathrm{in}$ \\
& $=0.0278 \mathrm{yd}$ & & $0.0328 \mathrm{ft}$ \\
& $=0.0109 \mathrm{yd}$ \\
& $=2.54 \mathrm{~cm}$ & & \\
& $=0.0254 \mathrm{~m}$ & & \\
& & & \\
$1 \mathrm{foot}(\mathrm{ft})$ & $=12.0 \mathrm{in}$. & 1 meter $(\mathrm{m})$ & \\
& $=0.3333 \mathrm{yd}$ & & $=3.3700 \mathrm{in}$ \\
& $=30.48 \mathrm{~cm}$ & & $=1.0936 \mathrm{yd}$ \\
& $=0.3048 \mathrm{~m}$ & & \\
& & & \\
1 mile $(\mathrm{mi})$ & $=63360 \mathrm{in}$. & 1 kilometer $(\mathrm{km})$ & $=39370 \mathrm{in}$. \\
& $=5280 \mathrm{ft}$ & & $=3281 \mathrm{ft}$ \\
& $=1760 \mathrm{yd}$ & & $=1093.6 \mathrm{yd}$ \\
& $=1609 \mathrm{~m}$ & & $=0.6214 \mathrm{mile}$ \\
& $=1.609 \mathrm{~km}$ & & $=1000 \mathrm{~m}$ \\
\hline
\end{tabular}

$1 \mathrm{in} / \mathrm{hr}=2.54 \mathrm{~cm} / \mathrm{hr}$
$1 \mathrm{~cm} / \mathrm{hr}=0.3937 \mathrm{in} / \mathrm{hr}$
$1 \mathrm{ft} / \mathrm{sec}=0.3048 \mathrm{~m} / \mathrm{s}=0.6818 \mathrm{mph}=1.0972 \mathrm{~km} / \mathrm{h}$
$1 \mathrm{~m} / \mathrm{sec}=3.281 \mathrm{ft} / \mathrm{s}=2.237 \mathrm{mph}=3.600 \mathrm{~km} / \mathrm{h}$
$1 \mathrm{~km} / \mathrm{h}=0.9114 \mathrm{ft} / \mathrm{s}=0.2778 \mathrm{~m} / \mathrm{s}=0.6214 \mathrm{mph}$
$1 \mathrm{mph}=1.467 \mathrm{ft} / \mathrm{s}=0.4469 \mathrm{~m} / \mathrm{s}=1.609 \mathrm{~km} / \mathrm{h}$

Source:

Davis, S.C., et al., Transportation Energy Data Book: Edition 27, ORNL-6981, Oak Ridge National Laboratory, Oak Ridge, TN, 2008. 
Table A.15

Capacity, Volume and Specific Volume Conversions ${ }^{a}$

Capacity and Volume

\begin{tabular}{|c|c|c|c|c|c|c|}
\hline 1 U.S. gallon (gal) & $\begin{array}{cc}= & 3.785 \\
= & 4 \\
= & 0.8327 \\
= & 0.0238 \\
= & 0.0039 \\
= & 0.1337 \\
= & 231\end{array}$ & $\begin{array}{l}\text { liters }(\mathrm{L}) \\
\text { US quarts }(\mathrm{qt}) \\
\text { UK gallon }(\mathrm{gal}) \\
\text { barrels oil }(\mathrm{bbl}) \\
\text { cubic meters }\left(\mathrm{m}^{3}\right) \\
\text { cubic feet }\left(\mathrm{ft}^{3}\right) \\
\text { cubic inches }\left(\mathrm{in}^{3}\right)\end{array}$ & 1 liter $(\mathrm{L})$ & $\begin{array}{l}= \\
= \\
= \\
= \\
= \\
= \\
=\end{array}$ & $\begin{array}{c}0.2642 \\
0.22 \\
1.056 \\
0.00629 \\
61.02 \\
0.03531 \\
0.001\end{array}$ & $\begin{array}{l}\text { US gal } \\
\text { UK gal } \\
\text { US qt } \\
\text { bbl (oil) } \\
\text { in }^{3} \\
\mathrm{ft}^{3} \\
\mathrm{~m}^{3}\end{array}$ \\
\hline 1 imperial (UK) gallon (gal) & $\begin{array}{ll}= & 4.546 \\
= & 4.803 \\
= & 1.201 \\
= & 0.0286 \\
= & 0.0045 \\
= & 0.1605 \\
= & 277.4\end{array}$ & $\begin{array}{l}\text { liters } \\
\text { US qt } \\
\text { US gal } \\
\text { bbl (oil) } \\
\mathrm{m}^{3} \\
\mathrm{ft}^{3} \\
\text { in. }^{3}\end{array}$ & 1 barrel (bbl) oil & $\begin{array}{l}= \\
= \\
= \\
= \\
= \\
=\end{array}$ & $\begin{array}{c}158.97 \\
168 \\
42 \\
34.97 \\
0.15897 \\
5.615 \\
9702\end{array}$ & $\begin{array}{l}\mathrm{L} \\
\text { US gt } \\
\text { US gal } \\
\text { UK gal } \\
\mathrm{m}^{3} \\
\mathrm{ft}^{3} \\
\text { in. }^{3}\end{array}$ \\
\hline 1 cubic meter (m3) & $\begin{array}{lc}= & 264.172 \\
= & 1000 \\
= & 1056 \\
= & 6.2898 \\
= & 35.3145 \\
& 1.3079\end{array}$ & $\begin{array}{l}\text { US gal } \\
L \\
\text { US qt } \\
\text { bbl (oil) } \\
\mathrm{ft}^{3} \\
\mathrm{yd}^{3}\end{array}$ & 1 cubic foot (ft3) & $=$ & $\begin{array}{c}7.4805 \\
28.3168 \\
29.9221 \\
0.1781 \\
0.0283 \\
0.037\end{array}$ & $\begin{array}{l}\text { US gal } \\
L \\
\text { US qt } \\
\text { bbl (oil) } \\
\mathrm{m}^{3} \\
\mathrm{yd}^{3}\end{array}$ \\
\hline 1 cubic centimeter $\left(\mathrm{cm}^{3}\right)$ & 0.061 & $\mathrm{in}^{3}$ & 1 cubic inches $\left(i^{3}\right)$ & $=$ & 16.3872 & $\mathrm{~cm}^{3}$ \\
\hline 1 Liter (L) dry volume & $\begin{array}{ll}= & 1.8161 \\
= & 0.908 \\
= & 0.1135 \\
= & 0.1099 \\
= & 0.0284 \\
= & 0.0275 \\
= & 0.0086\end{array}$ & $\begin{array}{l}\text { US pint (pt) } \\
\text { US qt } \\
\text { US peck (pk) } \\
\text { UK pk } \\
\text { US bushel (bu) } \\
\text { UK bu } \\
\text { US bbl dry }\end{array}$ & 1 US bushel & $\begin{array}{l}= \\
= \\
= \\
= \\
= \\
= \\
=\end{array}$ & $\begin{array}{c}64 \\
32 \\
35.239 \\
4 \\
3.8757 \\
0.9700 \\
0.3947\end{array}$ & $\begin{array}{l}\text { US pt } \\
\text { US qt } \\
\text { L } \\
\text { US pk } \\
\text { UK pk } \\
\text { UK bu } \\
\text { US bbl dry }\end{array}$ \\
\hline 1 barrell (dry) & $\begin{array}{l}=13.1248 \\
=3.2812\end{array}$ & $\begin{array}{l}\text { US pk } \\
\text { US bu }\end{array}$ & 1 barrell (dry) & $\begin{array}{l}= \\
=\end{array}$ & $\begin{array}{c}12.7172 \\
3.1793 \\
\end{array}$ & $\begin{array}{l}\text { UK pk } \\
\text { UK bu }\end{array}$ \\
\hline \multicolumn{7}{|l|}{ Specific Volume } \\
\hline $\begin{array}{l}1 \text { US gallon per pound } \\
\text { (gal//b) }\end{array}$ & $\begin{array}{lr}= & 0.832 \\
= & 0.1337 \\
= & 8.3454 \\
= & 0.0083 \\
= & 0.0083 \\
= & 8.3451\end{array}$ & $\begin{array}{l}\text { UK gal/lb } \\
\mathrm{ft}^{3} / \mathrm{lb} \\
\mathrm{L} / \mathrm{kg} \\
\mathrm{L} / \mathrm{g} \\
\mathrm{m}^{3} / \mathrm{kg} \\
\mathrm{cm}^{3} / \mathrm{g}\end{array}$ & $\begin{array}{l}1 \text { liter per kilogram } \\
(\mathrm{L} / \mathrm{kg})\end{array}$ & $\begin{array}{l}= \\
= \\
= \\
= \\
= \\
=\end{array}$ & $\begin{array}{c}0.0997 \\
0.1118 \\
0.016 \\
0.0353 \\
1 \\
1000\end{array}$ & $\begin{array}{l}\text { UK gal } / \mathrm{lb} \\
\text { US gal//b } \\
\mathrm{ft}^{3} / \mathrm{lb} \\
\mathrm{ft}^{3} / \mathrm{kg} \\
\mathrm{m}^{3} / \mathrm{kg} \\
\mathrm{cm}^{3} / \mathrm{g}\end{array}$ \\
\hline
\end{tabular}

Source:

Web sites www.gordonengland.co.uk/conversion/power.html and www.unitconversion.org were used to make or check conversions.

${ }^{a}$ Forestry unit relationships are provided in Table A.9 
Table A.16

Power Unit Conversions

Per second basis

\section{TO}

\begin{tabular}{|c|c|c|c|c|c|c|c|}
\hline \multirow{2}{*}{ FROM } & \\
\hline & hp & hp-metric & $\mathrm{kW}$ & $\mathrm{Btu}_{\mathrm{TT}} \mathrm{s}^{-1}$ & $\mathrm{ft}-\mathrm{lbf} \mathrm{s}^{-1}$ & kgf m s-1 & $\mathrm{kcal} \mathrm{s}^{-1}$ \\
\hline Horsepower & 1 & 1.014 & 0.7457 & 0.7068 & 550 & 76.04 & 0.1781 \\
\hline $\begin{array}{l}\text { Metric } \\
\text { horsepower }\end{array}$ & 0.9863 & 1 & 0.7355 & 0.6971 & 542.5 & 75 & 0.1757 \\
\hline Kilowatt & 1.341 & 1.360 & 1 & 0.9478 & 737.6 & 101.97 & 0.239 \\
\hline $\mathrm{Btu}_{\mathrm{IT}}$ per sec & 1.415 & 1.434 & 1.055 & 1 & 778.2 & 107.59 & 0.2520 \\
\hline $\begin{array}{l}\text { Foot pound- } \\
\text { force per sec }\end{array}$ & $1.36 \times 10^{-3}$ & $1.84 \times 10^{-3}$ & $1.356 \times 10^{-3}$ & $1.285 \times 10^{-3}$ & 1 & 0.1383 & $0.3238 \times 10^{-3}$ \\
\hline $\begin{array}{l}\text { Kilogram-force } \\
\text { meter per sec }\end{array}$ & $13.15 \times 10^{-3}$ & $9.81 \times 10^{-3}$ & $13.33 \times 10^{-3}$ & $9.81 \times 10^{-3}$ & 7.233 & 1 & $9.29 \times 10^{-3}$ \\
\hline $\begin{array}{l}\text { Kilocalories } \\
\text { per sec }\end{array}$ & 5.615 & 5.692 & 4.184 & 3.968 & 3088 & 426.93 & 1 \\
\hline \multicolumn{8}{|c|}{ Per hour basis } \\
\hline & \multicolumn{7}{|c|}{ TO } \\
\hline FROM & $\mathrm{hp}$ & hp- metric & $\mathrm{kW}$ & $\mathrm{Btu}_{\mathrm{IT}} \mathrm{hr}^{-1}$ & $\mathrm{ft}-\mathrm{lbf} \mathrm{hr}^{-1}$ & $\mathrm{~J} \mathrm{hr}-1$ & kcal hr ${ }^{-1}$ \\
\hline Horsepower & 1 & 1.014 & 0.7457 & 2544 & $198.0 \times 10^{4}$ & $268.5 \times 10^{4}$ & 641.63 \\
\hline $\begin{array}{l}\text { Metric } \\
\text { horsepower }\end{array}$ & 0.9863 & 1 & 0.7355 & 2510 & $195.3 \times 10^{4}$ & $265.8 \times 10^{4}$ & 632.85 \\
\hline Kilowatt & 1.341 & 1.360 & 1 & 3412 & $265.5 \times 10^{4}$ & $360 \times 10^{4}$ & 860.44 \\
\hline $\mathrm{Btu}_{\mathrm{IT}}$ per hr & $3.93 \times 10^{-4}$ & $3.98 \times 10^{-4}$ & $2.93 \times 10^{-4}$ & 1 & 778.16 & 1055 & 0.2520 \\
\hline $\begin{array}{l}\text { Foot pound- } \\
\text { force per } \mathrm{hr}\end{array}$ & $5.05 \times 10^{-7}$ & $5.12 \times 10^{-7}$ & $3.766 \times 10^{-7}$ & $1.285 \times 10^{-3}$ & 1 & 1.356 & $0.3240 \times 10^{-3}$ \\
\hline Joule per hr & $3.73 \times 10^{-7}$ & $3.78 \times 10^{-7}$ & $2.78 \times 10^{-7}$ & $9.48 \times 10^{-4}$ & 0.7376 & 1 & $2.39 \times 10^{-4}$ \\
\hline $\begin{array}{l}\text { Kilocalories } \\
\text { per hr }\end{array}$ & $1.55 \times 10^{-3}$ & $1.58 \times 10^{-3}$ & $1.162 \times 10^{-3}$ & 3.966 & 3086 & 426.64 & 1 \\
\hline
\end{tabular}

Sources:

www.gordonengland.co.uk/conversion/power.html and www.convert-me.com/en/convert/power were used to make conversions 
Table A.17

Small Energy Units and Energy per Unit Weight Conversions

\begin{tabular}{|c|c|c|c|c|}
\hline \multicolumn{5}{|c|}{ Energy Units } \\
\hline \multirow[b]{2}{*}{ FROM } & \multicolumn{4}{|c|}{ TO } \\
\hline & J & $\mathrm{kWh}$ & $\mathrm{Btu}_{\mathrm{th}}$ & $\mathrm{cal}_{\text {th }}$ \\
\hline joule $(\mathrm{J})^{\mathrm{a}}$ & 1 & $.278 \times 10^{-6}$ & $0.948 \times 10^{-3}$ & 0.239 \\
\hline $\begin{array}{l}\text { Kilowatt } \\
\text { hours (k W h) }\end{array}$ & $3.6 \times 10^{6}$ & 1 & 3414.42 & $8.6042 \times 10^{5}$ \\
\hline $\mathrm{Btu}_{\mathrm{th}}$ & 1054.349 & $2.928 \times 10^{-4}$ & 1 & 251.996 \\
\hline calorie $_{\text {th }}\left(\mathrm{Cal}_{\mathrm{th}}\right)^{\mathrm{D}}$ & 4.184 & $1.162 \times 10^{-0}$ & $3.9683 \times 10^{-}$ & 1 \\
\hline
\end{tabular}

\section{Energy per Unit Weight}

\begin{tabular}{|c|c|c|c|c|c|}
\hline \multirow[b]{2}{*}{ FROM } & \multicolumn{5}{|c|}{ TO } \\
\hline & $\mathrm{jg}^{-1}$ & $\mathrm{j} \mathrm{kg}^{-1}$ & $\mathrm{kj} \mathrm{kg-1}$ & $\mathrm{cal}_{\mathrm{th}} \mathrm{g}^{-1}$ & $\mathrm{Btu}_{\text {th }} \mathrm{Ib}^{-1}$ \\
\hline $\begin{array}{l}\text { joule per } \\
\text { gram }\left(\mathrm{j} \mathrm{g}^{-1}\right)\end{array}$ & 1 & 0.001 & 1 & 0.239 & 0.4302 \\
\hline $\begin{array}{l}\text { joule per } \\
\text { kilogram }\left(\mathrm{j} \mathrm{kg}^{-1}\right)\end{array}$ & 0.001 & 1 & 0.001 & $2.39 \times 10^{-4}$ & $4.302 \times 10^{-4}$ \\
\hline $\begin{array}{l}\text { kilojoules per } \\
\text { kilogram }\left(\mathrm{kj} \mathrm{kg}^{-1}\right)\end{array}$ & 1 & 1000 & 1 & 0.239 & 0.4302 \\
\hline 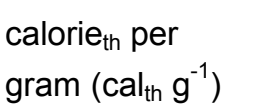 & 4.184 & 4184 & 4.184 & 1 & 1.8 \\
\hline $\begin{array}{l}\mathrm{Btu}_{\mathrm{IT}} \text { per } \\
\text { pound }\left(\mathrm{Btu}_{\mathrm{th}} \mid \mathrm{lb}^{-1}\right)\end{array}$ & 2.324 & 2324.4 & 2.324 & 0.5555 & 1 \\
\hline
\end{tabular}

Commonly used related energy unit conversions:

1 Quadrillion Btu's (Quad) $=1 \times 1015$ Btu $=1.055$ Exajoules $(E J)=1.055 \times 1018 \mathrm{~J}$

1 Million Btu's $(\mathrm{Mbtu})=1 \times 106 \mathrm{Btu}=1.055$ Gigajoules $(\mathrm{GJ})=1.055 \times 109 \mathrm{~J}$

$1000 \mathrm{Btu}$ per pound $=2 \mathrm{Mbtu}$ per ton $=2.326 \mathrm{Gj}$ per $\mathrm{Mg}$

e.g. 8500 Btu per pound (average HHV of wood) $=17$ Mbtu per ton = 19.8 GJ per Mg

\section{Sources:}

www.gordonengland.co.uk/conversion/power.html and www.convert-me.com/en/convert/power and

www.unitconversion.org/unit converter/fuel-efficiency-mass were used to make or check conversions second

${ }^{a}$ One joule is the exact equivalent of one Newton meter $(\mathrm{N} \mathrm{m})$ and one Watt

${ }^{b}$ calorie $_{\text {th }}$ where "th" stands for "thermal"

Biomass Energy Data Book: Edition 2 -- DRAFT 
Table A.18

Large Energy Unit Conversions

\begin{tabular}{rccccc}
\hline To: & Terajoules & $\begin{array}{c}\text { Giga- } \\
\text { calories }\end{array}$ & $\begin{array}{c}\text { Million tonnes of } \\
\text { oil equivalent }\end{array}$ & $\begin{array}{c}\text { Million } \\
\text { Btu }\end{array}$ & $\begin{array}{c}\text { Gigawatt- } \\
\text { hours }\end{array}$ \\
\hline From: & multiply by: & & & & \\
Terajoules & 1 & 238.8 & $2.388 \times 10^{-5}$ & 947.8 & 0.2778 \\
Gigacalories & $4.1868 \times 10^{-3}$ & 1 & $10^{-7}$ & 3.968 & $1.163 \times 10^{-3}$ \\
$\begin{array}{r}\text { Million tonnes } \\
\text { of oil equivalent }\end{array}$ & $4.1868 \times 10^{4}$ & 107 & 1 & $3.968 \times 10^{7}$ & 11,630 \\
Million Btu & $1.0551 \times 10^{-3}$ & 0.252 & $2.52 \times 10^{-8}$ & 1 & $2.931 \times 10^{-4}$ \\
Gigawatthours & 3.6 & 860 & $8.6 \times 10^{-5}$ & 3412 & 1 \\
\hline
\end{tabular}

Source:

Davis, S.C., et al., Transportation Energy Data Book: Edition 27, Appendix B.7. ORNL-6981, Oak Ridge National Laboratory, Oak Ridge, TN. 2008

Table A.19

Alternative Measures of Greenhouse Gases

\begin{tabular}{lll}
\hline $\begin{array}{l}1 \text { pound methane, measured in carbon } \\
\text { units }\left(\mathrm{CH}_{4}\right)\end{array}$ & $\begin{array}{l}1.333 \text { pounds methane, measured at } \\
\text { full molecular weight }\left(\mathrm{CH}_{4}\right)\end{array}$ \\
$\begin{array}{l}1 \text { pound carbon dioxide, measured in } \\
\text { carbon units }\left(\mathrm{CO}_{2}-\mathrm{C}\right)\end{array}$ & $=\begin{array}{l}3.6667 \text { pounds carbon dioxide, measured at } \\
\text { full molecular weight }\left(\mathrm{CO}_{2}\right)\end{array}$ \\
$\begin{array}{l}1 \text { pound carbon monoxide, measured in } \\
\text { carbon units }(\mathrm{CO}-\mathrm{C})\end{array}$ & $=\begin{array}{l}2.333 \text { pounds carbon monoxide, measured at } \\
\text { full molecular weight }(\mathrm{CO})\end{array}$ \\
$\begin{array}{l}1 \text { pound nitrous oxide, measured in } \\
\text { nitrogen units }\left(\mathrm{N}_{2} \mathrm{O}-\mathrm{N}\right)\end{array}$ & $=\begin{array}{l}1.571 \text { pounds nitrous oxide, measured at } \\
\text { full molecular weight }\left(\mathrm{N}_{2} \mathrm{O}\right)\end{array}$ \\
\hline
\end{tabular}

Source:

Davis, S.C., et al., Transportation Energy Data Book: Edition 27, Appendix B.9, ORNL-6981, Oak Ridge National Laboratory, Oak Ridge, TN. 2008. 
Table A.20

Fuel Efficiency Conversions

\begin{tabular}{cccc}
\hline MPG & Miles/liter & Kilometers/L & L/100 kilometers \\
\hline 10 & 2.64 & 4.25 & 23.52 \\
15 & 3.96 & 6.38 & 15.68 \\
20 & 5.28 & 8.50 & 11.76 \\
25 & 6.60 & 10.63 & 9.41 \\
30 & 7.92 & 12.75 & 7.84 \\
35 & 9.25 & 14.88 & 6.72 \\
40 & 10.57 & 17.00 & 5.88 \\
45 & 11.89 & 19.13 & 5.23 \\
50 & 13.21 & 21.25 & 4.70 \\
55 & 14.53 & 23.38 & 4.28 \\
60 & 15.85 & 25.51 & 3.92 \\
65 & 17.17 & 27.63 & 3.62 \\
70 & 18.49 & 29.76 & 3.36 \\
75 & 19.81 & 31.88 & 3.14 \\
80 & 21.13 & 34.01 & 2.94 \\
85 & 22.45 & 36.13 & 2.77 \\
90 & 23.77 & 38.26 & 2.61 \\
95 & 25.09 & 40.38 & 2.48 \\
100 & 26.42 & 42.51 & 2.35 \\
105 & 27.74 & 44.64 & 2.24 \\
110 & 29.06 & 46.76 & 2.14 \\
115 & 30.38 & 48.89 & 2.05 \\
120 & 31.70 & 51.01 & 1.96 \\
125 & 33.02 & 53.14 & 1.88 \\
130 & 34.34 & 55.26 & 1.81 \\
135 & 35.66 & 57.39 & 1.74 \\
140 & 36.98 & 59.51 & 1.68 \\
145 & 38.30 & 61.64 & 1.62 \\
150 & 39.62 & 63.76 & 1.57 \\
\hline Formula & MPG/3.785 & MPG/[3.785/1.609] & $235.24 / \mathrm{MPG}$ \\
\hline & & &
\end{tabular}

Source:

Davis, S.C., et al., Transportation Energy Data Book: Edition 27, Appendix B.13, ORNL-6981, Oak Ridge National Laboratory, Oak Ridge, TN. 2008. 
Table A.21

SI Prefixes and Their Values

\begin{tabular}{|c|c|c|c|}
\hline & Value & Prefix & Symbol \\
\hline One million million millionth & $10^{-18}$ & atto & $\bar{a}$ \\
\hline One thousand million millionth & $10^{-15}$ & femto & $\mathrm{f}$ \\
\hline One million millionth & $10^{-12}$ & pico & $p$ \\
\hline One thousand millionth & $10^{-9}$ & nano & $\mathrm{n}$ \\
\hline One millionth & $10^{-6}$ & micro & $\mu$ \\
\hline One thousandth & $10^{-3}$ & milli & $\mathrm{m}$ \\
\hline One hundredth & $10^{-2}$ & centi & c \\
\hline One tenth & $10^{-1}$ & deci & $d$ \\
\hline One & $10^{0}$ & & \\
\hline Ten & $10^{1}$ & deca & da \\
\hline One hundred & $10^{2}$ & hecto & $\mathrm{h}$ \\
\hline One thousand & $10^{3}$ & kilo & $\mathrm{k}$ \\
\hline One million & $10^{6}$ & mega & M \\
\hline One billion $^{a}$ & $10^{9}$ & giga & G \\
\hline One trillion ${ }^{a}$ & $10^{12}$ & tera & $\mathrm{T}$ \\
\hline One quadrillion $^{a}$ & $10^{15}$ & peta & $\mathrm{P}$ \\
\hline One quintillion $^{\mathrm{a}}$ & $10^{18}$ & exa & $E$ \\
\hline
\end{tabular}

\section{Source:}

Davis, S.C., et al., Transportation Energy Data Book: Edition 27, Appendix B.14, ORNL-6981, Oak Ridge National Laboratory, Oak Ridge, TN. 2008.

${ }^{a}$ Care should be exercised in the use of this nomenclature, especially in foreign correspondence, as it is either unknown or carries a different value in other countries. A "billion," for example, signifies a value of 1012 in most other countries. 
Table A.22

Metric Units and Abbreviations

\begin{tabular}{lll}
\hline \multicolumn{1}{c}{ Quantity } & \multicolumn{1}{c}{ Unit name } & \multicolumn{1}{c}{ Symbol } \\
\hline Energy & joule & $\mathrm{J}$ \\
Specific energy & joule/kilogram & $\mathrm{J} / \mathrm{kg}$ \\
Specific energy consumption & joule/kilogram•kilometer & $\mathrm{J} /(\mathrm{kg} \cdot \mathrm{km})$ \\
Energy consumption & joule/kilometer & $\mathrm{J} / \mathrm{km}$ \\
Energy economy & kilometer/kilojoule & $\mathrm{km} / \mathrm{kJ}$ \\
Power & kilowatt & $\mathrm{Kw}$ \\
Specific power & watt/kilogram & $\mathrm{W} / \mathrm{kg}$ \\
Power density & watt/meter ${ }^{3}$ & $\mathrm{~W} / \mathrm{m}^{3}$ \\
Speed & kilometer/hour & $\mathrm{km} / \mathrm{h}$ \\
Acceleration & meter/second & $\mathrm{m} / \mathrm{s}^{2}$ \\
Range (distance) & kilometer & $\mathrm{km}$ \\
Weight & kilogram & $\mathrm{kg}$ \\
Torque & newton•meter & $\mathrm{N} \cdot \mathrm{m}$ \\
Volume & meter & $\mathrm{m}$ \\
Mass; payload & kilogram & $\mathrm{kg}$ \\
Length; width & meter & $\mathrm{m}$ \\
Brake specific fuel consumption & kilogram/joule & $\mathrm{kg} / \mathrm{J}$ \\
Fuel economy (heat engine) & liters $/ 100 \mathrm{~km}$ & $\mathrm{~L} / 100 \mathrm{~km}$ \\
\hline
\end{tabular}

Source:

Davis, S.C., et al., Transportation Energy Data Book: Edition 27, Appendix B.15, ORNL-6981, Oak Ridge National Laboratory, Oak Ridge, TN. 2008.

Table A.23

Cost per Unit Conversions

\begin{tabular}{ccc}
\hline Multiply & by & To Obtain \\
\hline \$/ton & 1.1023 & $\$ / \mathrm{Mg}$ \\
$\$ / \mathrm{Mg}$ & 0.9072 & $\$ /$ ton \\
\$/Mbtu & 0.9407 & $\$ / \mathrm{GJ}$ \\
\$/GJ & 1.0559 & $\$ / \mathrm{Mbtu}$ \\
\hline
\end{tabular}




\section{APPENDIX B}

\section{BIOMASS CHARACTERISTICS}


Biomass Energy Data Book: Edition 2 -- DRAFT 


\section{APPENDIX B: BIOMASS CHARACTERISTICS}

Biomass feedstocks and fuels exhibit a wide range of physical, chemical, and agricultural process engineering properties. Despite their wide range of possible sources, biomass feedstocks are remarkably uniform in many of their fuel properties, compared with competing feedstocks such as coal or petroleum. For example, there are many kinds of coals whose gross heating value ranges from 20 to $30 \mathrm{GJ} /$ tonne (gigajoules per metric tonne; 8600-12900 Btu/lb). However, nearly all kinds of biomass feedstocks destined for combustion fall in the range 15-19 GJ/tonne (6450-8200 Btu/lb). For most agricultural residues, the heating values are even more uniform - about 15-17 GJ/tonne (6450-7300 Btu/lb); the values for most woody materials are 18-19 GJ/tonne (7750-8200 Btu/lb). Moisture content is probably the most important determinant of heating value. Air-dried biomass typically has about $15-20 \%$ moisture, whereas the moisture content for oven-dried biomass is around $0 \%$. Moisture content is also an important characteristic of coals, varying in the range $2-30 \%$. However, the bulk density (and hence energy density) of most biomass feedstocks is generally low, even after densification - between about 10 and $40 \%$ of the bulk density of most fossil fuels - although liquid biofuels have comparable bulk densities.

Most biomass materials are easier to gasify than coal, because they are more reactive, with higher ignition stability. This characteristic also makes them easier to process thermochemically into highervalue fuels such as methanol or hydrogen. Ash content is typically lower than for most coals, and sulphur content is much lower than for many fossil fuels. Unlike coal ash, which may contain toxic metals and other trace contaminants, biomass ash may be used as a soil amendment to help replenish nutrients removed by harvest. A few biomass feedstocks stand out for their peculiar properties, such as high silicon or alkali metal contents - these may require special precautions for harvesting, processing and combustion equipment. Note also that mineral content can vary as a function of soil type and the timing of feedstock harvest. In contrast to their fairly uniform physical properties, biomass fuels are rather heterogeneous with respect to their chemical elemental composition.

Among the liquid biomass fuels, biodiesel (vegetable oil ester) is noteworthy for its similarity to petroleumderived diesel fuel, apart from its negligible sulfur and ash content. Bioethanol has only about $70 \%$ the heating value of petroleum distillates such as gasoline, but its sulfur and ash contents are also very low. Both of these liquid fuels have lower vapor pressure and flammability than their petroleum-based competitors - an advantage in some cases (e.g. use in confined spaces such as mines) but a disadvantage in others (e.g. engine starting at cold temperatures).

\section{Sources for further information:}

US DOE Biomass Feedstock Composition and Property Database.

PHYLLIS - database on composition of biomass and waste.

Nordin, A. (1994) Chemical elemental characteristics of biomass fuels. Biomass and Bioenergy 6, 339347.

\section{Source:}

All information in Appendix B was taken from a fact sheet by Jonathan Scurlock, Oak Ridge National Laboratory, Bioenergy Feedstock Development Programs. P.O. Box 2008, Oak Ridge, TN 378316407 
Table B.1

Characteristics of Selected Feedstocks and Fuels

\begin{tabular}{|c|c|c|c|c|c|}
\hline & & $\begin{array}{l}\text { Cellulose } \\
\text { (Percent) }\end{array}$ & $\begin{array}{l}\text { Hemi-cellulose } \\
\text { (Percent) }\end{array}$ & $\begin{array}{l}\text { Lignin } \\
\text { (Percent) }\end{array}$ & $\begin{array}{c}\text { Extractives } \\
\text { (Percent) }\end{array}$ \\
\hline Bioenergy & Corn stover $^{a}$ & $30-38$ & $19-25$ & $17-21$ & $3.3-11.9$ \\
\hline \multirow[t]{10}{*}{ Feedstocks } & Sweet sorghum & 27 & 25 & 11 & \\
\hline & Sugarcane bagasse ${ }^{a}$ & $32-43$ & $19-25$ & $23-28$ & $1.5-5.5$ \\
\hline & Sugarcane leaves & $b$ & $b$ & $b$ & \\
\hline & Hardwood & 45 & 30 & 20 & \\
\hline & Softwood & 42 & 21 & 26 & \\
\hline & Hybrid poplar $^{a}$ & $39-46$ & $17-23$ & $21-8$ & $1.6-6.9$ \\
\hline & Bamboo & $41-49$ & $24-28$ & $24-26$ & \\
\hline & Switchgrass $^{a}$ & $31-34$ & $24-29$ & $17-22$ & $4.9-24.0$ \\
\hline & Miscanthus & 44 & 24 & 17 & \\
\hline & Giant Reed & 31 & 30 & 21 & \\
\hline \multirow[t]{2}{*}{ Liquid Biofuels } & Bioethanol & $\bar{N} / \mathrm{A}$ & $\bar{N} / \mathrm{A}$ & $\overline{\mathrm{N} / \mathrm{A}}$ & $\bar{N} / \mathrm{A}$ \\
\hline & Biodiesel & $\mathrm{N} / \mathrm{A}$ & $\mathrm{N} / \mathrm{A}$ & $\mathrm{N} / \mathrm{A}$ & N/A \\
\hline \multirow[t]{3}{*}{ Fossil Fuels } & $\begin{array}{l}\text { Coal (low rank; } \\
\text { lignite/sub-bituminous) } \\
\text { Coal (high rank }\end{array}$ & $\mathrm{N} / \mathrm{A}$ & N/A & $\mathrm{N} / \mathrm{A}$ & $\mathrm{N} / \mathrm{A}$ \\
\hline & bituminous/anthracite) & $\mathrm{N} / \mathrm{A}$ & $\mathrm{N} / \mathrm{A}$ & $\mathrm{N} / \mathrm{A}$ & $\mathrm{N} / \mathrm{A}$ \\
\hline & Oil (typical distillate) & N/A & N/A & $\mathrm{N} / \mathrm{A}$ & N/A \\
\hline
\end{tabular}

\section{Source:}

Oak Ridge National Laboratory, Bioenergy Feedstock Development Program. P.O. Box 2008, Oak Ridge, TN 37831-6407 (compiled by Jonathon Scurlock in 2002, updated by Lynn Wright in 2008).

Notes: N/A = Not Applicable.

\footnotetext{
a Updated using http://www1.eere.energy.gov/biomass/feedstock databases.html

${ }^{\mathrm{b}}$ Data not available.
} 
Table B.1 (Continued)

Characteristics of Selected Feedstocks and Fuels

\begin{tabular}{|c|c|c|c|c|c|}
\hline & & Ash \% & $\begin{array}{l}\text { Sulfur } \\
\text { (Percent) }\end{array}$ & $\begin{array}{l}\text { Potassium } \\
\text { (Percent) }\end{array}$ & $\begin{array}{l}\text { Ash melting } \\
\text { temperature } \\
\text { [some ash } \\
\text { sintering } \\
\text { observed] (C) }\end{array}$ \\
\hline \multirow[t]{9}{*}{ Bioenergy Feedstocks } & $\begin{array}{l}\text { Corn stover }{ }^{\mathrm{a}} \\
\text { Sweet sorghum }\end{array}$ & $\begin{array}{c}9.8-135 \\
5.5\end{array}$ & $\begin{array}{c}.06-.1 \\
b\end{array}$ & $\begin{array}{l}\mathrm{b} \\
\mathrm{b}\end{array}$ & $\begin{array}{l}\mathrm{b} \\
\mathrm{b}\end{array}$ \\
\hline & Sugarcane bagasse $\mathrm{a}^{\mathrm{a}}$ & $2.8-9.4$ & $.02-.03$ & $0.73-0.97$ & $\mathrm{~b}$ \\
\hline & Sugarcane leaves & 7.7 & b & b & b \\
\hline & Hardwood & 0.45 & 0.009 & 0.04 & [900] \\
\hline & Softwood & 0.3 & 0.01 & b & b \\
\hline & $\begin{array}{l}\text { Hybrid poplar }{ }^{a} \\
\text { Bamboo }\end{array}$ & $\begin{array}{c}0.4-2.4 \\
0.8-2.5\end{array}$ & $\begin{array}{l}.02-.03 \\
0.03-0.05\end{array}$ & $\begin{array}{c}0.3 \\
0.15-0.50\end{array}$ & $\begin{array}{c}1,350 \\
b\end{array}$ \\
\hline & Switchgrass $^{a}$ & $2.8-7.5$ & $.07-.11$ & $\mathrm{~b}$ & 1,016 \\
\hline & Miscanthus & $1.5-4.5$ & 0.1 & $0.37-1.12$ & $1,090[600]$ \\
\hline & Giant reed & $5-6$ & 0.07 & b & b \\
\hline \multirow[t]{2}{*}{ Liquid Biofuels } & Bioethanol & $\mathrm{b}$ & $<0.01$ & $\mathrm{~b}$ & N/A \\
\hline & Biodiesel & $<0.02$ & $<0.05$ & $<0.0001$ & $\mathrm{~N} / \mathrm{A}$ \\
\hline \multirow[t]{2}{*}{ Fossil Fuels } & $\begin{array}{l}\text { Coal (low rank; } \\
\text { lignite/sub-bituminous) }\end{array}$ & $5-20$ & $1.0-3.0$ & $0.02-0.3$ & $\sim 1,300$ \\
\hline & $\begin{array}{l}\text { Coal (high rank } \\
\text { bituminous/anthracite) } \\
\text { Oil (typical distillate) }\end{array}$ & $\begin{array}{c}1-10 \\
0.5-1.5\end{array}$ & $\begin{array}{l}0.5-1.5 \\
0.2-1.2\end{array}$ & $\begin{array}{c}0.06-0.15 \\
b\end{array}$ & $\begin{array}{c}\sim 1,300 \\
\text { N/A }\end{array}$ \\
\hline
\end{tabular}

Source:

Oak Ridge National Laboratory, Bioenergy Feedstock Development Program. P.O. Box 2008, Oak Ridge, TN 37831-6407 (compiled by Jonathon Scurlock in 2002, updated by Lynn Wright in 2008).

Notes: N/A $=$ Not Applicable

\footnotetext{
a Updated using http://www1.eere.energy.gov/biomass/feedstock databases.html

${ }^{\mathrm{b}}$ Data not available.
} 
Table B.1 (Continued)

Characteristics of Selected Feedstocks and Fuels

\begin{tabular}{|c|c|c|c|c|}
\hline & & $\begin{array}{l}\text { Cellulose fiber } \\
\text { length (mm) }\end{array}$ & $\begin{array}{l}\text { Chopped density } \\
\text { at harvest } \\
(\mathrm{kg} / \mathrm{m} 3)\end{array}$ & $\begin{array}{c}\text { Baled density } \\
\text { [compacted bales] } \\
(\mathrm{kg} / \mathrm{m} 3)\end{array}$ \\
\hline Bioenergy & Corn stover $^{a}$ & 1.5 & $\mathrm{~b}$ & $\bar{b}$ \\
\hline \multirow[t]{10}{*}{ Feedstocks } & Sweet sorghum & $b$ & $b$ & $b$ \\
\hline & Sugarcane bagasse ${ }^{a}$ & 1.7 & $50-75$ & $b$ \\
\hline & Sugarcane leaves & b & $25-40$ & b \\
\hline & Hardwood & 1.2 & b & $b$ \\
\hline & Softwood & $b$ & $b$ & $b$ \\
\hline & Hybrid poplar ${ }^{a}$ & $1-1.4$ & 150 (chips) & $b$ \\
\hline & Bamboo & $1.5-3.2$ & b & $b$ \\
\hline & Switchgrass $^{a}$ & $\mathrm{~b}$ & 108 & $105-133$ \\
\hline & Miscanthus & $\mathrm{b}$ & $70-100$ & $130-150[300]$ \\
\hline & Giant reed & 1.2 & $b$ & $b$ \\
\hline Liquid Biofue & & & & $\begin{array}{l}\text { (typical bulk densities } \\
\text { or range given below) }\end{array}$ \\
\hline & Bioethanol & $\mathrm{N} / \mathrm{A}$ & $\mathrm{N} / \mathrm{A}$ & 790 \\
\hline & Biodiesel & $\mathrm{N} / \mathrm{A}$ & $\mathrm{N} / \mathrm{A}$ & 875 \\
\hline \multirow[t]{3}{*}{ Fossil Fuels } & $\begin{array}{l}\text { Coal (low rank; lignite/sub- } \\
\text { bituminous) } \\
\text { Coal (high rank }\end{array}$ & $\mathrm{N} / \mathrm{A}$ & $\mathrm{N} / \mathrm{A}$ & 700 \\
\hline & bituminous/anthracite) & $\mathrm{N} / \mathrm{A}$ & $\mathrm{N} / \mathrm{A}$ & 850 \\
\hline & Oil (typical distillate) & N/A & N/A & $700-900$ \\
\hline
\end{tabular}

Source:

Oak Ridge National Laboratory, Bioenergy Feedstock Development Program. P.O. Box 2008, Oak Ridge, TN 37831-6407 (compiled by Jonathon Scurlock in 2002, updated by Lynn Wright in 2008).

Notes: N/A $=$ Not Applicable.

\footnotetext{
a Updated using http://www1.eere.energy.gov/biomass/feedstock databases.html

${ }^{\mathrm{b}}$ Data not available.
} 


\section{APPENDIX C \\ (To Be Updated) \\ ASSUMPTIONS}


Biomass Energy Data Book: Edition 2 -- DRAFT 


\section{APPENDIX C: ASSUMPTIONS}

\section{ESTIMATION METHODS FOR PRIMARY MILL RESIDUES}

The forestry residue data included in this book are the same as that used in the DOE/USDA publication entitled "Biomass as Feedstock for a Bioenergy and Bioproducts Industry: The Technical Feasibility of a Billion Ton Annual Supply. The resource estimates contained in the following tables have been disaggregated to states.

\section{Primary Mill Residues}

Primary mill residues include bark, coarse residues (chunks and slabs), and fine residues (shavings and sawdust) generated at sawmills that process harvested wood. The mill residue data were downloaded by state and county from the U.S. Forest Service's Timber Product Output database (http://www.fia.fs.fed.us/tools-data/tools/). Because primary mill residues tend to be clean, uniform, concentrated, and of low moisture content, most of these materials are already used for products or boiler fuel at the mills. The U.S Forest Service estimates current usage by type as follows:

- Bark $-80 \%$ used as fuel and $13 \%$ used in products

- Coarse residues $-85 \%$ used in products and $13 \%$ used as fuel

- Fine residues $-55 \%$ used as fuel and $42 \%$ used in products

This leaves a very small amount $(\sim 2 \%)$ of unused primary mill material available for energy. Residues are also generated at secondary processing mills (e.g., millwork, furniture, flooring, containers, etc.). Secondary mill residue data are not collected by the U.S. Forest Service.

\section{ESTIMATION METHODS FOR URBAN WOOD RESIDUES}

The state-level estimates provided for urban wood residues are consistent with the estimates found in the DOE/USDA publication entitled "Biomass as Feedstock for a Bioenergy and Bioproducts Industry: The Technical Feasibility of a Billion Ton Annual Supply."

\section{Residues for MSW Landfills}

MSW consists of a variety of items ranging from organic food scraps to discarded furniture and appliances. Wood and yard and tree trimmings are the two sources within this residue stream that are potentially recoverable for energy use. The wood component includes discarded furniture, pallets, containers, packaging materials, lumber scraps (other than new construction and demolition), and wood residuals from manufacturing. McKeever (2004) estimates the total wood component of the MSW stream at slightly more than 13 million dry tons. About $55 \%$ of this material is either recycled as compost, burned for power production, or unavailable for recovery because of excessive contamination. In total about 6 million dry tons of MSW wood is potentially available for energy. The other component of the MSW stream - yard and tree trimmings - is estimated at 9.8 million dry tons. However, only 1.5 million dry tons is considered potentially available for recovery after accounting for what is currently used and what is unusable.

\section{Residues from Construction and Demolition Debris Landfills}

The amount of available construction and demolition residue is correlated with economic activity (e.g., housing starts), population, demolition activity, and the extent of recycling and reuse programs. McKeever (2004) estimates annual generation of construction and demolition debris at 11.6 and 27.7 million dry tons, respectively. About 8.6 million dry tons of construction debris and 11.7 million dry tons of demolition debris are considered potentially available for energy. Unlike construction residue, which tends to be 
relatively clean and can be more easily source-separated, demolition debris is often contaminated, making recovery much more difficult and expensive.

Reference:

McKeever, D. 2004. "Inventories of Woody Residues and Solid Wood Waste in the United States, 2002," Ninth International Conference, Inorganic-Bonded Composite Materials, Vancouver, British Columbia. October 10-13. 


\section{APPENDIX D}

\section{SUSTAINABILITY}

Biomass Energy Data Book: Edition 2 -- DRAFT 
Biomass Energy Data Book: Edition 2 -- DRAFT 


\section{APPENDIX D: SUSTAINABILITY}

\section{SUSTAINABLE BIOMASS CROP PRODUCTION RESEARCH}

Biomass, especially wood, has been used by mankind for thousands of years to provide heat and cooking fuel (bioenergy) with the resource being derived primarily from forested areas. Throughout the history of mankind, excessive removals of wood for lumber, fiber, energy, or other needs have led to severe environmental degradation in many parts of the world. Thus in the late 1970's when the U.S. Government oil supply disruptions caused the U.S. government to begin to support research on biomass feedstocks for fuels and chemicals, the renewability of the bioenergy resources was an important criteria. All of the projects initiated as a result of the U.S. Department of Energy's (DOE's) first biomass research solicitation in 1977 were directed toward evaluating the potential for wood production and harvest scenarios that would supply renewable and sustainable bioenergy resources.

However renewability and sustainability are not entirely synonymous terms and the meaning of sustainability was just beginning to be debated. Environmental scientists of Oak Ridge National Laboratory, which managed the biomass feedstock research for DOE, published one of the first analyses addressing environmental implications of biomass energy systems (Braunstein et al., 1981). While there was, and continues to be, debate about what truly signifies a sustainable system, it was with a high level of environmental sensitivity in the 1980's, that DOE's biomass feedstock research efforts focused on screening for high-yield woody crops that could be produced on cropland or cropland pasture and result in environmental benefits. By the mid 1980's the DOE research program began screening > 30 herbaceous biomass crop species including high-yield annuals as well as many different types of perennial grasses primarily on marginal cropland. Erosion reduction potential, soil carbon increase potential, and other environmental factors were considered in the process of selecting crops for further development.

The research program resulted in the selection of crop production systems that minimized land area requirements, minimized chemical inputs, and increased soil carbon storage relative to most food crop production techniques in the mid to late 1990's. A special issue of the journal Biomass and Bioenergy (Vol. 14, No. 4, 1998) contained several papers by energy crop researchers summarizing what was known and what information was needed to ensure the development and implementation of environmentally beneficial biomass production systems.

The Department of Energy's Biomass Program continues, in 2008, to be committed to developing the technologies, processes and systems needed to sustainably convert a broad range of cellulosic feedstocks into clean, abundant biofuels. Program literature states that it aims to develop processes and products that reduce carbon emissions, protects human health and the environment, and add value to the biofuel life cycle. As a consequence current feedstock research has the following objectives.

1. Explore a range of non-food feedstocks.

2. Improve understanding of regional factors tied to feedstock production (e.g., soil types, fertilizer requirements, climatic conditions, land use, and water issues).

3. Develop technology to harvest biomass components efficiently while maintaining soil health.

4. Foster forestry practices that enhance long-term forest vitality.

5. Evaluate the economic, social and environmental aspects of emerging technologies and infrastructure for the large-scale production and use of biofuels.

Most agriculture, forestry and plants sciences researchers working on developing bioenergy feedstock supply systems conclude that some substantial amount of biomass feedstocks can be produced and supplied in a way that meets sustainability criteria. Differences of opinion exist on how much can be sustainably produced, details of production techniques for specific areas, and worldwide impacts resulting from competition for land. These questions are stimulating additional research and analysis. Documents 
referred to above, as well as several recent documents addressing topics related to the sustainability of biomass production systems, are listed below.

Braunsetin HM, Kanciruk P, Roop RD, Sharples FE, Tatum JS, Oakes KM. Biomass Energy Systems and the Environment. Pergamon Press. 1981.

Tolbert, V. Guest Editorial. Biomass and Bioenergy 1998;14(4). (Several papers of interest can be found in this issue).

Selected Reports of Committees or Working Groups on Biomass Sustainability:

The Royal Society. Sustainable Biofuels: Prospects and Challenges. ISBN 978085403662 2. 2008. available online at:

National Research Council. Water Implications of Biofuels Production in the United States. ISBN: 978-0309-11361-8. 2008. 86 pages. Free executive summary available online.

Selected Publications of Interest Relevant to Energy Crop Sustainability:

Heller MC, Keoleian GA, Volk TA. Life cycle assessment of a willow bioenergy cropping system. Biomass and Bioenergy 2003;25:147-165.

Johnson JMF, Reicosky DC, Allmaras RR, Archer D, and Wilhelm WW. A Matter of Balance: Conservation and Renewable Energy. J Soil and Water Conservation 2006;63(4): 125A-129A,.

Johnson JMF, Coleman MD, Gesch R, Jaradat A, Mitchell R, Reicosky D, Wilhelm WW. BiomassBioenergy Crops in the United States: A Changing Paradigm. The Americas Journal of Plant Science and Biotechnology 2007;1(1): 1-28,.

Mann L, and Tolbert V. Soil Sustainability in Renewable Biomass Plantings. Ambio 2000;29(8): 492-498.

Robertson P, Dale VH, Doering OC, Hamburg SP, Melillo JM, Wander MM, Parton WJ, Pouyat R, Adler PR, Barney J, Cruse RM, Duke CS, Fearnside PM, Follett RF, Gibbs HK, Goldemberg J, Mladenoff D, Ojima D, Palmer MW, Sharpley A, Wallace L, Weathers KC, Wiens JA, Wilhelm WW. Sustainable biofuels redux. Science 2008; (3 October).

Searchinger T, Heimlich R, Haughton RA., Dong F, Elobeid A, Fabiosa J, Tokgoz,S, Hayes D, Yu,TunHsiang. Use of U.S. Croplands for Biofuels Increases Greenhouse Gases through Emissions from Land Use Change. ScienceExpress online publication 7 February 2008;10.1126/Science.1151861. available at: www.sciencemag.org

Tilman D, Hill J, Lehman C. Carbon-Negative Biofuels from Low-Input High-Diversity Grassland Biomass. Science 2006;314: 1598-1600. 


\section{GLOSSARY}

Biomass Energy Data Book: Edition 2 -- DRAFT 
Biomass Energy Data Book: Edition 2 -- DRAFT 
Agricultural Residue - Agricultural crop residues are the plant parts, primarily stalks and leaves, not removed from the fields with the primary food or fiber product. Examples include corn stover (stalks, leaves, husks, and cobs); wheat straw; and rice straw. With approximately 80 million acres of corn planted annually, corn stover is expected to become a major biomass resource for bioenergy applications.

Air dry - The state of dryness at equilibrium with the water content in the surrounding atmosphere. The actual water content will depend upon the relative humidity and temperature of the surrounding atmosphere.

Alcohol - The family name of a group of organic chemical compounds composed of carbon, hydrogen, and oxygen. The molecules in the series vary in chain length and are composed of a hydrocarbon plus a hydroxyl group. Alcohol includes methanol and ethanol.

Alkaline metals - Potassium and sodium oxides $(\mathrm{K} 2 \mathrm{O}+\mathrm{Na} 2 \mathrm{O})$ that are the main chemicals in biomass solid fuels that cause slagging and fouling in combustion chambers and boilers.

Anaerobic digestion - Decomposition of biological wastes by micro-organisms, usually under wet conditions, in the absence of air (oxygen), to produce a gas comprising mostly methane and carbon dioxide.

Annual removals - The net volume of growing stock trees removed from the inventory during a specified year by harvesting, cultural operations such as timber stand improvement, or land clearing.

ASABE Standard X593 - The American Society of Agricultural and Biological Engineers (ASABE) in 2005 produced a new standard (Standard X593) entitled "Terminology and Definitions for Biomass Production, Harvesting and Collection, Storage, Processing, Conversion and Utilization." The purpose of the standard is to provide uniform terminology and definitions in the general area of biomass production and utilization. This standard includes many terminologies that are used in biomass feedstock production, harvesting, collecting, handling, storage, pre-processing and conversion, bioenergy, biopower and bioproducts. The terminologies were reviewed by many experts from all of the different fields of biomass and bioenergy before being accepted as part of the standard. The full-text is included on the online Technical Library of ASABE (http://asae.frymulti.com); members and institutions holding a site license can access the online version. Print copies may be ordered for a fee by calling 269-429-0300, e-mailing martin@asabe.org, or by mail at: ASABE, 2950 Niles Rd., St. Joseph, MI 49085.

Asexual reproduction - The naturally occurring ability of some plant species to reproduce asexually through seeds, meaning the embryos develop without a male gamete. This ensures the seeds will produce plants identical to the mother plant.

Avoided costs - An investment guideline describing the value of a conservation or generation resource investment by the cost of more expensive resources that a utility would otherwise have to acquire.

Baghouse - A chamber containing fabric filter bags that remove particles from furnace stack exhaust gases. Used to eliminate particles greater than 20 microns in diameter.

Barrel of oil equivalent - (BOE) The amount of energy contained in a barrel of crude oil, i.e. approximately $6.1 \mathrm{GJ}(5.8$ million Btu), equivalent to $1,700 \mathrm{kWh}$. A "petroleum barrel" is a liquid measure equal to 42 U.S. gallons (35 Imperial gallons or 159 liters); about 7.2 barrels are equivalent to one tonne of oil (metric).

Biobased product - The term 'biobased product,' as defined by Farm Security and Rural Investment Act (FSRIA), means a product determined by the U.S. Secretary of Agriculture to be a commercial or 
industrial product (other than food or feed) that is composed, in whole or in significant part, of biological products or renewable domestic agricultural materials (including plant, animal, and marine materials) or forestry materials.

Biochemical conversion - The use of fermentation or anaerobic digestion to produce fuels and chemicals from organic sources.

Biological oxygen demand (BOD) - An indirect measure of the concentration of biologically degradable material present in organic wastes. It usually reflects the amount of oxygen consumed in five days by biological processes breaking down organic waste.

Biodiesel - Fuel derived from vegetable oils or animal fats. It is produced when a vegetable oil or animal fat is chemically reacted with an alcohol.

Bioenergy - Useful, renewable energy produced from organic matter - the conversion of the complex carbohydrates in organic matter to energy. Organic matter may either be used directly as a fuel, processed into liquids and gasses, or be a residual of processing and conversion.

Bioethanol - Ethanol produced from biomass feedstocks. This includes ethanol produced from the fermentation of crops, such as corn, as well as cellulosic ethanol produced from woody plants or grasses.

Biorefinery - A facility that processes and converts biomass into value-added products. These products can range from biomaterials to fuels such as ethanol or important feedstocks for the production of chemicals and other materials. Biorefineries can be based on a number of processing platforms using mechanical, thermal, chemical, and biochemical processes.

Biofuels - Fuels made from biomass resources, or their processing and conversion derivatives. Biofuels include ethanol, biodiesel, and methanol.

Biogas - A combustible gas derived from decomposing biological waste under anaerobic conditions. Biogas normally consists of 50 to 60 percent methane. See also landfill gas.

Biogasification or biomethanization - The process of decomposing biomass with anaerobic bacteria to produce biogas.

Biomass - Any organic matter that is available on a renewable or recurring basis, including agricultural crops and trees, wood and wood residues, plants (including aquatic plants), grasses, animal manure, municipal residues, and other residue materials. Biomass is generally produced in a sustainable manner from water and carbon dioxide by photosynthesis. There are three main categories of biomass - primary, secondary, and tertiary.

Biomass energy - See Bioenergy.

Biomass processing residues - Byproducts from processing all forms of biomass that have significant energy potential. For example, making solid wood products and pulp from logs produces bark, shavings and sawdust, and spent pulping liquors. Because these residues are already collected at the point of processing, they can be convenient and relatively inexpensive sources of biomass for energy.

Biopower - The use of biomass feedstock to produce electric power or heat through direct combustion of the feedstock, through gasification and then combustion of the resultant gas, or through other thermal conversion processes. Power is generated with engines, turbines, fuel cells, or other equipment. 
Biorefinery - A facility that processes and converts biomass into value-added products. These products can range from biomaterials to fuels such as ethanol or important feedstocks for the production of chemicals and other materials. Biorefineries can be based on a number of processing platforms using mechanical, thermal, chemical, and biochemical processes.

Bone dry - Having zero percent moisture content. Wood heated in an oven at a constant temperature of $100^{\circ} \mathrm{C}\left(212^{\circ} \mathrm{F}\right)$ or above until its weight stabilizes is considered bone dry or oven dry.

Bottoming cycle - A cogeneration system in which steam is used first for process heat and then for electric power production.

Bound nitrogen - Some fuels contain about $0.1-5 \%$ of organic bound nitrogen which typically is in forms of aromatic rings like pyridine or pyrrole.

Black liquor - Solution of lignin-residue and the pulping chemicals used to extract lignin during the manufacture of paper.

British thermal unit - (Btu) A non-metric unit of heat, still widely used by engineers. One Btu is the heat energy needed to raise the temperature of one pound of water from $60^{\circ} \mathrm{F}$ to $61^{\circ} \mathrm{F}$ at one atmosphere pressure. $1 \mathrm{Btu}=1055$ joules $(1.055 \mathrm{~kJ})$.

BTL - Biomass-to-Liquids.

Bulk density - Weight per unit of volume, usually specified in pounds per cubic foot.

Bunker - A storage tank.

Buyback Rate - The price a utility pays to purchase electricity from an independent generator.

By-product - Material, other than the principal product, generated as a consequence of an industrial process or as a breakdown product in a living system.

Capacity factor - The amount of energy that a power plant actually generates compared to its maximum rated output, expressed as a percentage.

Carbonization - The conversion of organic material into carbon or a carbon-containing residue through pyrolysis.

Carbon Cycle - The carbon cycle includes the uptake of carbon dioxide by plants through photosynthesis, its ingestion by animals and its release to the atmosphere through respiration and decay of organic materials. Human activities like the burning of fossil fuels contribute to the release of carbon dioxide in the atmosphere.

Carbon dioxide (CO2) - A colorless, odorless, non-poisonous gas that is a normal part of the ambient air. Carbon dioxide is a product of fossil fuel combustion.

Catalyst - A substance that increases the rate of a chemical reaction, without being consumed or produced by the reaction. Enzymes are catalysts for many biochemical reactions.

Cellulose - The main carbohydrate in living plants. Cellulose forms the skeletal structure of the plant cell wall. 
Chemical oxygen demand (COD) - The amount of dissolved oxygen required to combine with chemicals in wastewater. A measure of the oxygen equivalent of that portion of organic matter that is susceptible to oxidation by a strong chemical oxidizing agent.

Closed-loop biomass - Crops grown, in a sustainable manner, for the purpose of optimizing their value for bioenergy and bioproduct uses. This includes annual crops such as maize and wheat, and perennial crops such as trees, shrubs, and grasses such as switchgrass.

Cloud point - The temperature at which a fuel, when cooled, begins to congeal and take on a cloudy appearance due to bonding of paraffins.

Coarse materials - Wood residues suitable for chipping, such as slabs, edgings, and trimmings.

Combustion turbine - A type of generating unit normally fired by oil or natural gas. The combustion of the fuel produces expanding gases, which are forced through a turbine, which produces electricity by spinning a generator.

Commercial species - Tree species suitable for industrial wood products.

Condensing turbine - A turbine used for electrical power generation from a minimum amount of steam. To increase plant efficiency, these units can have multiple uncontrolled extraction openings for feed-water heating.

Conservation reserve program - CRP provides farm owners or operators with an annual per-acre rental payment and half the cost of establishing a permanent land cover in exchange for retiring environmentally sensitive cropland from production for 10 to 15 years. In 1996, Congress reauthorized CRP for an additional round of contracts, limiting enrollment to 36.4 million acres at any time. The 2002 Farm Act increased the enrollment limit to 39 million acres. Producers can offer land for competitive bidding based on an Environmental Benefits Index (EBI) during periodic signups, or can automatically enroll more limited acreages in practices such as riparian buffers, field windbreaks, and grass strips on a continuous basis. CRP is funded through the Commodity Credit Corporation (CCC).

Construction and Demolition (C\&D) Debris - Building materials and solid waste from construction, deconstruction, remodeling, repair, cleanup or demolition operations.

Coppicing - A traditional method of woodland management, by which young tree stems are cut down to a low level, or sometimes right down to the ground. In subsequent growth years, many new shoots will grow up, and after a number of years the cycle begins again and the coppiced tree or stool is ready to be harvested again. Typically a coppice woodland is harvested in sections, on a rotation. In this way each year a crop is available.

Cord - A stack of wood comprising 128 cubic feet $\left(3.62 \mathrm{~m}^{\wedge} 3\right)$; standard dimensions are $4 \times 4 \times 8$ feet, including air space and bark. One cord contains approx. 1.2 U.S. tons (oven-dry) $=2400$ pounds $=$ $1089 \mathrm{~kg}$.

Corn Distillers Dried Grains (DDG) - is obtained after the removal of ethanol by distillation from the yeast fermentation of a grain or a grain mixture by separating the resultant coarse grain fraction of the whole stillage and drying it by methods employed in the grain distilling industry.

Cropland - Total cropland includes five components: cropland harvested, crop failure, cultivated summer fallow, cropland used only for pasture, and idle cropland.

Cropland used for crops - Cropland used for crops includes cropland harvested, crop failure, and cultivated summer fallow. Cropland harvested includes row crops and closely sown crops; hay 
and silage crops; tree fruits, small fruits, berries, and tree nuts; vegetables and melons; and miscellaneous other minor crops. In recent years, farmers have double-cropped about 4 percent of this acreage. Crop failure consists mainly of the acreage on which crops failed because of weather, insects, and diseases, but includes some land not harvested due to lack of labor, low market prices, or other factors. The acreage planted to cover and soil improvement crops not intended for harvest is excluded from crop failure and is considered idle. Cultivated summer fallow refers to cropland in sub-humid regions of the West cultivated for one or more seasons to control weeds and accumulate moisture before small grains are planted. This practice is optional in some areas, but it is a requirement for crop production in the drier cropland areas of the West. Other types of fallow, such as cropland planted with soil improvement crops but not harvested and cropland left idle all year, are not included in cultivated summer fallow but are included as idle cropland.

Cropland pasture - Land used for long-term crop rotation. However, some cropland pasture is marginal for crop uses and may remain in pasture indefinitely. This category also includes land that was used for pasture before crops reached maturity and some land used for pasture that could have been cropped without additional improvement.

Cull tree - A live tree, 5.0 inches in diameter at breast height (d.b.h.) or larger that is non-merchantable for saw logs now or prospectively because of rot, roughness, or species. (See definitions for rotten and rough trees.)

d.b.h. - The diameter measured at approximately breast high from the ground.

Deck - (also known as "landing", "ramp", "set-out") An area designated on a logging job for the temporary storage, collection, handling, sorting and/or loading of trees or logs.

Denatured - In the context of alcohol, it refers to making alcohol unfit for drinking without impairing its usefulness for other purposes.

Deoxygenation - A chemical reaction involving the removal of molecular oxygen (O2) from a reaction mixture or solvent.

Digester - An airtight vessel or enclosure in which bacteria decomposes biomass in water to produce biogas.

Dimethyl ether - Also known as methoxymethane, methyl ether, wood ether, and DME, is a colorless, gaseous ether with with an ethereal smell. Dimethyl ether gas is water soluble and has the formula $\mathrm{CH} 3 \mathrm{OCH} 3$. Dimethyl ether is used as an aerosol spray propellant. Dimethyl ether is also a cleanburning alternative to liquified petroleum gas, liquified natural gas, diesel and gasoline. It can be made from natural gas, coal, or biomass.

Discount rate - A rate used to convert future costs or benefits to their present value.

Distillers Dried Grains (DDG) - The dried grain byproduct of the grain fermentation process, which may be used as a high-protein animal feed.

Distillers Wet Grains (DWG) - is the product obtained after the removal of ethyl alcohol by distillation from the yeast fermentation of corn.

Distributed generation - The Generation of electricity from many small on-site energy sources. It has also been called also called dispersed generation, embedded generation or decentralized generation. 
Downdraft gasifier - A gasifier in which the product gases pass through a combustion zone at the bottom of the gasifier.

Dutch oven furnace - One of the earliest types of furnaces, having a large, rectangular box lined with firebrick (refractory) on the sides and top. Commonly used for burning wood. Heat is stored in the refractory and radiated to a conical fuel pile in the center of the furnace.

Effluent - The liquid or gas discharged from a process or chemical reactor, usually containing residues from that process.

Emissions - Waste substances released into the air or water. See also Effluent.

Energy crops - Crops grown specifically for their fuel value. These include food crops such as corn and sugarcane, and nonfood crops such as poplar trees and switchgrass. Currently, two energy crops are under development; short-rotation woody crops, which are fast-growing hardwood trees harvested in 5 to 8 years, and herbaceous energy crops, such as perennial grasses, which are harvested annually after taking 2 to 3 years to reach full productivity.

Enzyme - A protein or protein-based molecule that speeds up chemical reactions occurring in living things. Enzymes act as catalysts for a single reaction, converting a specific set of reactants into specific products.

Ethanol - Otherwise known as ethyl alcohol, alcohol, or grain-spirit. A clear, colorless, flammable oxygenated hydrocarbon with a boiling point of 78.5 degrees Celsius in the anhydrous state. In transportation, ethanol is used as a vehicle fuel by itself ( $E 100-100 \%$ ethanol by volume), blended with gasoline (E85 - 85\% ethanol by volume), or as a gasoline octane enhancer and oxygenate ( $10 \%$ by volume).

Exotic species - Introduced species not native or endemic to the area in question.

Externality - A cost or benefit not accounted for in the price of goods or services. Often "externality" refers to the cost of pollution and other environmental impacts.

Fast pyrolysis - Thermal conversion of biomass by rapid heating to between 450 and 600 degrees Celsius in the absence of oxygen.

Fatty acids - A group of chemical compounds characterized by a chain made up of carbon and hydrogen atoms and having a carboxylic acid $(\mathrm{COOH})$ group on one end of the molecule. They differ from each other in the number of carbon atoms and the number and location of double bonds in the chain. When they exist unattached to the other compounds, they are called free fatty acids.

Feedstock - A product used as the basis for manufacture of another product.

Feller-buncher - A self-propelled machine that cuts trees with giant shears near ground level and then stacks the trees into piles to wait skidding.

Fermentation - Conversion of carbon-containing compounds by micro-organisms for production of fuels and chemicals such as alcohols, acids or energy-rich gases.

Fiber products - Products derived from fibers of herbaceous and woody plant materials. Examples include pulp, composition board products, and wood chips for export.

Fischer-Tropsch Fuels - Liquid hydrocarbon fuels produced by a process that combines carbon monoxide and hydrogen. The process is used to convert coal, natural gas and low-value refinery products into a high-value diesel substitute fuel. 
Fine materials - Wood residues not suitable for chipping, such as planer shavings and sawdust.

Firm power - (firm energy) Power which is guaranteed by the supplier to be available at all times during a period covered by a commitment. That portion of a customer's energy load for which service is assured by the utility provider.

Flash pyrolysis - See fast pyrolysis.

Flash vacuum pyrolysis (FVP) - Thermal reaction of a molecule by exposing it to a short thermal shock at high temperature, usually in the gas phase.

Flow control - A legal or economic means by which waste is directed to particular destinations. For example, an ordinance requiring that certain waste be sent to a landfill is waste flow control.

Flow rate - The amount of fluid that moves through an area (usually pipe) in a given period of time.

Fluidized-bed boiler - A large, refractory-lined vessel with an air distribution member or plate in the bottom, a hot gas outlet in or near the top, and some provisions for introducing fuel. The fluidized bed is formed by blowing air up through a layer of inert particles (such as sand or limestone) at a rate that causes the particles to go into suspension and continuous motion. The super-hot bed material increased combustion efficiency by its direct contact with the fuel.

Fly ash - Small ash particles carried in suspension in combustion products.

Forest land - Land at least 10 percent stocked by forest trees of any size, including land that formerly had such tree cover and that will be naturally or artificially regenerated. Forest land includes transition zones, such as areas between heavily forested and nonforested lands that are at least 10 percent stocked with forest trees and forest areas adjacent to urban and built-up lands. Also included are pinyon-juniper and chaparral areas in the West and afforested areas. The minimum area for classification of forest land is 1 acre. Roadside, streamside, and shelterbelt strips of trees must have a crown width of at least 120 feet to qualify as forest land. Unimproved roads and trails, streams, and clearings in forest areas are classified as forest if less than 120 feet wide.

Forestry residues - Includes tops, limbs, and other woody material not removed in forest harvesting operations in commercial hardwood and softwood stands, as well as woody material resulting from forest management operations such as precommercial thinnings and removal of dead and dying trees.

Forest health - A condition of ecosystem sustainability and attainment of management objectives for a given forest area. Usually considered to include green trees, snags, resilient stands growing at a moderate rate, and endemic levels of insects and disease. Natural processes still function or are duplicated through management intervention.

Forwarder - A self-propelled vehicle to transport harvested material from the stump area to the landing. Trees, logs, or bolts are carried off the ground on a stake-bunk, or are held by hydraulic jaws of a clam-bunk. Chips are hauled in a dumpable or open-top bin or chip-box.

Fossil fuel - Solid, liquid, or gaseous fuels formed in the ground after millions of years by chemical and physical changes in plant and animal residues under high temperature and pressure. Oil, natural gas, and coal are fossil fuels.

Fouling - The coating of heat transfer surfaces in heat exchangers such as boiler tubes caused by deposition of ash particles.

Fuel cell - A device that converts the energy of a fuel directly to electricity and heat, without combustion. 
Fuel cycle - The series of steps required to produce electricity. The fuel cycle includes mining or otherwise acquiring the raw fuel source, processing and cleaning the fuel, transport, electricity generation, waste management and plant decommissioning.

Fuel Treatment Evaluator (FTE) - A strategic assessment tool capable of aiding the identification, evaluation, and prioritization of fuel treatment opportunities.

Fuelwood - Wood used for conversion to some form of energy, primarily for residential use.

Furnace - An enclosed chamber or container used to burn biomass in a controlled manner to produce heat for space or process heating.

Gasohol - A mixture of $10 \%$ anhydrous ethanol and $90 \%$ gasoline by volume; $7.5 \%$ anhydrous ethanol and $92.5 \%$ gasoline by volume; or $5.5 \%$ anhydrous ethanol and $94.5 \%$ gasoline by volume. There are other fuels that contain methanol and gasoline, but these fuels are not referred to as gasohol.

Gas turbine - (combustion turbine) A turbine that converts the energy of hot compressed gases (produced by burning fuel in compressed air) into mechanical power. Often fired by natural gas or fuel oil.

Gasification - A chemical or heat process to convert a solid fuel to a gaseous form.

Gasifier - A device for converting solid fuel into gaseous fuel. In biomass systems, the process is referred to as pyrolitic distillation. See Pyrolysis.

Genetic selection - Application of science to systematic improvement of a population, e.g. through selective breeding.

Gigawatt (GW) - A measure of electrical power equal to one billion watts $(1,000,000 \mathrm{~kW})$. A large coal or nuclear power station typically has a capacity of about $1 \mathrm{GW}$.

Global Climate Change - Global climate change could result in sea level rises, changes to patterns of precipitation, increased variability in the weather, and a variety of other consequences. These changes threaten our health, agriculture, water resources, forests, wildlife, and coastal areas.

Global warming - A term used to describe the increase in average global temperatures due to the greenhouse effect.

Grassland pasture and range - All open land used primarily for pasture and grazing, including shrub and brush land types of pasture; grazing land with sagebrush and scattered mesquite; and all tame and native grasses, legumes, and other forage used for pasture or grazing. Because of the diversity in vegetative composition, grassland pasture and range are not always clearly distinguishable from other types of pasture and range. At one extreme, permanent grassland may merge with cropland pasture, or grassland may often be found in transitional areas with forested grazing land.

Greenhouse effect - The effect of certain gases in the Earth's atmosphere in trapping heat from the sun.

Greenhouse gases - Gases that trap the heat of the sun in the Earth's atmosphere, producing the greenhouse effect. The two major greenhouse gases are water vapor and carbon dioxide. Other greenhouse gases include methane, ozone, chlorofluorocarbons, and nitrous oxide.

Green Power - Electricity that is generated from renewable energy sources is often referred to as "green power." Green power products can include electricity generated exclusively from renewable resources or, more frequently, electricity produced from a combination of fossil and renewable resources. Also known as "blended" products, these products typically have lower prices than 100 
percent renewable products. Customers who take advantage of these options usually pay a premium for having some or all of their electricity produced from renewable resources.

Green Power Purchasing/Aggregation Policies - Municipalities, state governments, businesses, and other non-residential customers can play a critical role in supporting renewable energy technologies by buying electricity from renewable resources. At the local level, green power purchasing can mean buying green power for municipal facilities, streetlights, water pumping stations and other public infrastructure. Several states require that a certain percentage of electricity purchased for state government buildings come from renewable resources. A few states allow local governments to aggregate the electricity loads of the entire community to purchase green power and even to join with other communities to form an even larger green power purchasing block. This is often referred to as "Community Choice". Green power purchasing can be achieved via utility green pricing programs, green power marketers (in states with retail competition), special contracts, or community aggregation.

Grid - An electric utility company's system for distributing power.

Growing stock - A classification of timber inventory that includes live trees of commercial species meeting specified standards of quality or vigor. Cull trees are excluded. When associated with volume, includes only trees 5.0 inches in d.b.h. and larger.

Habitat - The area where a plant or animal lives and grows under natural conditions. Habitat includes living and non-living attributes and provides all requirements for food and shelter.

Hammermill - A device consisting of a rotating head with free-swinging hammers which reduce chips or wood fuel to a predetermined particle size through a perforated screen.

Hardwoods - Usually broad-leaved and deciduous trees.

Heat rate - The amount of fuel energy required by a power plant to produce one kilowatt-hour of electrical output. A measure of generating station thermal efficiency, generally expressed in Btu per net kWh. It is computed by dividing the total Btu content of fuel burned for electric generation by the resulting net kWh generation.

Heat transfer efficiency - useful heat output released / actual heat produced in the firebox.

Heating value - The maximum amount of energy that is available from burning a substance.

Hectare - Common metric unit of area, equal to 2.47 acres. 100 hectares $=1$ square kilometer.

Hemicellulose - Hemicellulose consists of short, highly branched chains of sugars. In contrast to cellulose, which is a polymer of only glucose, a hemicellulose is a polymer of five different sugars. It contains five-carbon sugars (usually $\mathrm{D}$-xylose and L-arabinose) and six-carbon sugars (Dgalactose, D-glucose, and D-mannose) and uronic acid. The sugars are highly substituted with acetic acid. The branched nature of hemicellulose renders it amorphous and relatively easy to hydrolyze to its constituent sugars compared to cellulose. When hydrolyzed, the hemicellulose from hardwoods releases products high in xylose (a five-carbon sugar). The hemicellulose contained in softwoods, by contrast, yields more six-carbon sugars.

Herbaceous - Non-woody type of vegetation, usually lacking permanent strong stems, such as grasses, cereals and canola (rape).

HFCS - High fructose corn syrup. 
Higher heating value - (HHV) The maximum potential energy in dry fuel. For wood, the range is from 7,600 to $9,600 \mathrm{Btu} / \mathrm{lb}(17.7$ to $22.3 \mathrm{GJ} / \mathrm{t})$.

Hog - A chipper or mill which grinds wood into an acceptable form to be used for boiler fuel.

Horsepower - (electrical horsepower; hp) A unit for measuring the rate of mechanical energy output, usually used to describe the maximum output of engines or electric motors. $1 \mathrm{hp}=550$ foot-pounds per second $=2,545$ Btu per hour $=745.7$ watts $=0.746 \mathrm{~kW}$

Hydrocarbon - A compound containing only hydrogen and carbon. The simplest and lightest forms of hydrocarbon are gaseous. With greater molecular weights they are liquid, while the heaviest are solids.

Hydrolysis - A process of breaking chemical bonds of a compound by adding water to the bonds.

Idle cropland - Land in cover and soil improvement crops, and cropland on which no crops were planted. Some cropland is idle each year for various physical and economic reasons. Acreage diverted from crops to soil-conserving uses (if not eligible for and used as cropland pasture) under federal farm programs is included in this component. Cropland enrolled in the Federal Conservation Reserve Program (CRP) is included in idle cropland.

Incinerator - Any device used to burn solid or liquid residues or wastes as a method of disposal. In some incinerators, provisions are made for recovering the heat produced.

Inclined grate- A type of furnace in which fuel enters at the top part of a grate in a continuous ribbon, passes over the upper drying section where moisture is removed, and descends into the lower burning section. Ash is removed at the lower part of the grate.

Incremental energy costs - The cost of producing and transporting the next available unit of electrical energy. Short run incremental costs (SRIC) include only incremental operating costs. Long run incremental costs (LRIC) include the capital cost of new resources or capital equipment.

Independent power producer - A power production facility that is not part of a regulated utility.

Indirect liquefaction - Conversion of biomass to a liquid fuel through a synthesis gas intermediate step.

Industrial wood - All commercial roundwood products except fuelwood.

Invasive species - A species that has moved into an area and reproduced so aggressively that it threatens or has replaced some of the original species.

lodine number - A measure of the ability of activated carbon to adsorb substances with low molecular weights. It is the milligrams of iodine that can be adsorbed on one gram of activated carbon.

Joule - Metric unit of energy, equivalent to the work done by a force of one Newton applied over a distance of one meter $(=1 \mathrm{~kg} \mathrm{~m} 2 / \mathrm{s} 2)$. One joule $(\mathrm{J})=0.239$ calories $(1$ calorie $=4.187 \mathrm{~J})$.

Kilowatt - $(\mathrm{kW})$ A measure of electrical power equal to 1,000 watts. $1 \mathrm{~kW}=3412 \mathrm{Btu} / \mathrm{hr}=1.341$ horsepower. See also watt.

Kilowatt hour - $(\mathrm{kWh}) \mathrm{A}$ measure of energy equivalent to the expenditure of one kilowatt for one hour. For example, $1 \mathrm{kWh}$ will light a 100 -watt light bulb for 10 hours. $1 \mathrm{kWh}=3412 \mathrm{Btu}$. 
Landfill gas - A type of biogas that is generated by decomposition of organic material at landfill disposal sites. Landfill gas is approximately 50 percent methane. See also biogas.

Landing - A cleared working area on or near a timber harvest site at which processing steps are carried out.

Legume - Any plant belonging to the leguminous family. Characterized by pods as fruits and root nodules enabling the storage of nitrogen.

Levelized life-cycle cost - The present value of the cost of a resource, including capital, financing and operating costs, expressed as a stream of equal annual payments. This stream of payments can be converted to a unit cost of energy by dividing the annual payment amount by the annual kilowatthours produced or saved. By levelizing costs, resources with different lifetimes and generating capabilities can be compared.

Lignin - Structural constituent of wood and (to a lesser extent) other plant tissues, which encrusts the cell walls and cements the cells together.

Live cull - A classification that includes live cull trees. When associated with volume, it is the net volume in live cull trees that are 5.0 inches in d.b.h. and larger.

Logging residues - The unused portions of growing-stock and non-growing-stock trees cut or killed by logging and left in the woods.

Lower heating value (LHV) - The potential energy in a fuel if the water vapor from combustion of hydrogen is not condensed.

Megawatt - (MW) A measure of electrical power equal to one million watts (1,000 kW). See also watt.

Merchantable - Logs from which at least some of the volume can be converted into sound grades of lumber ("standard and better" framing lumber).

Methanol - A Methyl alcohol having the chemical formula $\mathrm{CH} 30 \mathrm{H}$. Also known as wood alcohol, methanol is usually produced by chemical conversion at high temperatures and pressures. Although usually produced from natural gas, methanol can be produced from gasified biomass (syngas).

Mill/kWh - A common method of pricing electricity in the U.S. Tenths of a U.S. cent per kilowatt hour.

Mill residue - Wood and bark residues produced in processing logs into lumber, plywood, and paper.

MMBtu - One million British thermal units.

Moisture content - (MC) The weight of the water contained in wood, usually expressed as a percentage of weight, either oven-dry or as received.

Moisture content, dry basis - Moisture content expressed as a percentage of the weight of oven-dry wood, i.e.: [(weight of wet sample - weight of dry sample) / weight of dry sample] $\times 100$

Moisture content, wet basis - Moisture content expressed as a percentage of the weight of wood asreceived, i.e.: [(weight of wet sample - weight of dry sample) / weight of wet sample] x 100

Monoculture - The cultivation of a single species crop. 
Municipal solid waste (MSW) - Garbage. Refuse offering the potential for energy recovery; includes residential, commercial, and institutional wastes.

National Environmental Policy Act (NEPA) - A federal law enacted in 1969 that requires all federal agencies to consider and analyze the environmental impacts of any proposed action. NEPA requires an environmental impact statement for major federal actions significantly affecting the quality of the environment. NEPA requires federal agencies to inform and involve the public in the agency's decision making process and to consider the environmental impacts of the agency's decision.

Net Metering - For those consumers who have their own electricity generating units, net metering allows for the flow of electricity both to and from the customer through a single, bi-directional meter. With net metering, during times when the customer's generation exceeds his or her use, electricity from the customer to the utility offsets electricity consumed at another time. In effect, the customer is using the excess generation to offset electricity that would have been purchased at the retail rate. Under most state rules, residential, commercial, and industrial customers are eligible for net metering, but some states restrict eligibility to particular customer classes.

Net present value - The sum of the costs and benefits of a project or activity. Future benefits and costs are discounted to account for interest costs.

Nitrogen fixation - The transformation of atmospheric nitrogen into nitrogen compounds that can be used by growing plants.

Nitrogen oxides (NOx) - Gases consisting of one molecule of nitrogen and varying numbers of oxygen molecules. Nitrogen oxides are produced from the burning of fossil fuels. In the atmosphere, nitrogen oxides can contribute to the formation of photochemical ozone (smog), can impair visibility, and have health consequences; they are thus considered pollutants.

Noncondensing, controlled extraction turbine - A turbine that bleeds part of the main steam flow at one (single extraction) or two (double extraction) points.

Nonforest land - Land that has never supported forests and lands formerly forested where use of timber management is precluded by development for other uses. (Note: Includes area used for crops, improved pasture, residential areas, city parks, improved roads of any width and adjoining clearings, powerline clearings of any width, and 1- to 4.5-acre areas of water classified by the Bureau of the Census as land. If intermingled in forest areas, unimproved roads and nonforest strips must be more than 120 feet wide, and clearings, etc., must be more than 1 acre in area to qualify as nonforest land.)

Nonattainment area - Any area that does not meet the national primary or secondary ambient air quality standard established by the Environmental Protection Agency for designated pollutants, such as carbon monoxide and ozone.

Nonindustrial private - An ownership class of private lands where the owner does not operate woodusing processing plants.

Oilseed crops - Primarily soybeans, sunflower seed, canola, rapeseed, safflower, flaxseed, mustard seed, peanuts and cottonseed, used for the production of cooking oils, protein meals for livestock, and industrial uses. These specific oilseeds are eligible for Other oilseed crops include castor beans and sesame.

Old growth - Timber stands with the following characteristics; large mature and over-mature trees in the overstory, snags, dead and decaying logs on the ground, and a multi-layered canopy with trees of several age classes. 
Open-loop biomass - Biomass that can be used to produce energy and bioproducts even though it was not grown specifically for this purpose. Examples of open-loop biomass include agricultural livestock waste and residues from forest harvesting operations and crop harvesting.

Organic compounds - Chemical compounds based on carbon chains or rings and also containing hydrogen, with or without oxygen, nitrogen, and other elements.

Other forest land - Forest land other than timberland and reserved forest land. It includes available forest land, which is incapable of annually producing 20 cubic feet per acre of industrial wood under natural conditions because of adverse site conditions such as sterile soils, dry climate, poor drainage, high elevation, steepness, or rockiness.

Other removals - Unutilized wood volume from cut or otherwise killed growing stock, from cultural operations such as precommercial thinnings, or from timberland clearing. Does not include volume removed from inventory through reclassification of timberland to productive reserved forest land.

Other sources - Sources of roundwood products that are not growing stock. These include salvable dead, rough and rotten trees, trees of noncommercial species, trees less than 5.0 inches d.b.h., tops, and roundwood harvested from non-forest land (for example, fence rows).

Oxygenate - A substance which, when added to gasoline, increases the amount of oxygen in that gasoline blend. Includes fuel ethanol, methanol, and methyl tertiary butyl ether (MTBE).

Particulate - A small, discrete mass of solid or liquid matter that remains individually dispersed in gas or liquid emissions. Particulates take the form of aerosol, dust, fume, mist, smoke, or spray. Each of these forms has different properties.

Photosynthesis - Process by which chlorophyll-containing cells in green plants concert incident light to chemical energy, capturing carbon dioxide in the form of carbohydrates.

Pilot scale - The size of a system between the small laboratory model size (bench scale) and a full-size system.

Poletimber trees - Live trees at least 5.0 inches in d.b.h. but smaller than sawtimber trees.

Pour point - The minimum temperature at which a liquid, particularly a lubricant, will flow.

Prescribed fire - Any fire ignited by management actions to meet specific objectives. Prior to ignition, a written, approved prescribed fire plan must exist, and National Environmental Protection Act requirements must be met.

Present value - The worth of future receipts or costs expressed in current value. To obtain present value, an interest rate is used to discount future receipts or costs.

Primary wood-using mill - A mill that converts roundwood products into other wood products. Common examples are sawmills that convert saw logs into lumber and pulp mills that convert pulpwood roundwood into wood pulp.

Process heat - Heat used in an industrial process rather than for space heating or other housekeeping purposes.

Producer gas - Fuel gas high in carbon monoxide $(\mathrm{CO})$ and hydrogen $(\mathrm{H} 2)$, produced by burning a solid fuel with insufficient air or by passing a mixture of air and steam through a burning bed of solid fuel. 
Proximate analysis - An analysis which reports volatile matter, fixed carbon, moisture content, and ash present in a fuel as a percentage of dry fuel weight.

Public power - The term used for not-for-profit utilities that are owned and operated by a municipality, state or the federal government.

Public utility commissions - State agencies that regulate investor-owned utilities operating in the state.

Public utility regulatory policies act - (PURPA) A federal law requiring a utility to buy the power produced by a qualifying facility at a price equal to that which the utility would otherwise pay if it were to build its own power plant or buy power from another source.

Pulpwood - Roundwood, whole-tree chips, or wood residues that are used for the production of wood pulp.

Pulp chips - Timber or residues processed into small pieces of wood of more or less uniform dimensions with minimal amounts of bark.

Pyrolysis - The thermal decomposition of biomass at high temperatures (greater than $400^{\circ} \mathrm{F}$, or $200^{\circ} \mathrm{C}$ ) in the absence of air. The end product of pyrolysis is a mixture of solids (char), liquids (oxygenated oils), and gases (methane, carbon monoxide, and carbon dioxide) with proportions determined by operating temperature, pressure, oxygen content, and other conditions.

Quad: One quadrillion Btu $\left(10^{\wedge} 15 \mathrm{Btu}\right)=1.055$ exajoules $(\mathrm{EJ})$, or approximately 172 million barrels of oil equivalent.

Reburning - Reburning entails the injection of natural gas, biomass fuels, or other fuels into a coal-fired boiler above the primary combustion zone-representing 15 to 20 percent of the total fuel mix-can produce NOx reductions in the 50 to 70 percent range and SO2 reductions in the 20 to 25 percent range. Reburning is an effective and economic means of reducing NOx emissions from all types of industrial and electric utility boilers. Reburning may be used in coal or oil boilers, and it is even effective in cyclone and wet-bottom boilers, for which other forms of NOx control are either not available or very expensive.

Recovery boiler - A pulp mill boiler in which lignin and spent cooking liquor (black liquor) is burned to generate steam.

Refractory lining - A lining, usually of ceramic, capable of resisting and maintaining high temperatures.

Refuse-derived fuel - (RDF) Fuel prepared from municipal solid waste. Noncombustible materials such as rocks, glass, and metals are removed, and the remaining combustible portion of the solid waste is chopped or shredded. RDF facilities process typically between 100 and 3,000 tons of MSW per day.

Renewable diesel - Defined in the Internal Revenue Code (IRC) as fuel produced from biological material using a process called "thermal depolymerization" that meets the fuel specification requirements of ASTM D975 (petroleum diesel fuel) or ASTM D396 (home heating oil). Produced in free-standing facilities.

Renewable Fuel Standards - Under the Energy Policy Act of 2005, EPA is responsible for promulgating regulations to ensure that gasoline sold in the United States contains a minimum volume of renewable fuel. A national Renewable Fuel Program (also known as the Renewable Fuel Standard Program, or RFS Program) will increase the volume of renewable fuel required to be blended into gasoline, starting with 4.0 billion gallons in calendar year 2006 and nearly doubling to 7.5 billion 
gallons by 2012. The RFS program was developed in collaboration with refiners, renewable fuel producers, and many other stakeholders.

Renewables Portfolio Standards/Set Asides - Renewables Portfolio Standards (RPS) require that a certain percentage of a utility's overall or new generating capacity or energy sales must be derived from renewable resources, i.e., $1 \%$ of electric sales must be from renewable energy in the year 200x. Portfolio Standards most commonly refer to electric sales measured in megawatt-hours (MWh), as opposed to electric capacity measured in megawatts(MW). The term "set asides" is frequently used to refer to programs where a utility is required to include a certain amount of renewables capacity in new installations.

Reserve margin - The amount by which the utility's total electric power capacity exceeds maximum electric demand.

Residues - Bark and woody materials that are generated in primary wood-using mills when roundwood products are converted to other products. Examples are slabs, edgings, trimmings, sawdust, shavings, veneer cores and clippings, and pulp screenings. Includes bark residues and wood residues (both coarse and fine materials) but excludes logging residues.

Return on investment- (ROI) The interest rate at which the net present value of a project is zero. Multiple values are possible.

Rotation - Period of years between establishment of a stand of timber and the time when it is considered ready for final harvest and regeneration.

Rotten tree - A live tree of commercial species that does not contain a saw log now or prospectively primarily because of rot (that is, when rot accounts for more than 50 percent of the total cull volume).

Rough tree - (a) A live tree of commercial species that does not contain a saw log now or prospectively primarily because of roughness (that is, when sound cull, due to such factors as poor form, splits, or cracks, accounts for more than 50 percent of the total cull volume) or (b) a live tree of noncommercial species.

Roundwood products - Logs and other round timber generated from harvesting trees for industrial or consumer use.

Saccharification - The process of breaking down a complex carbohydrate, such as starch or cellulose, into its monosaccharide components.

Salvable dead tree - A downed or standing dead tree that is considered currently or potentially merchantable by regional standards.

Saplings - Live trees 1.0 inch through 4.9 inches in d.b.h.

Saturated steam- Steam at boiling temperature for a given pressure.

Secondary wood processing mills - A mill that uses primary wood products in the manufacture of finished wood products, such as cabinets, moldings, and furniture.

Shaft horsepower - A measure of the actual mechanical energy per unit time delivered to a turning shaft. See also horsepower.

Silviculture - Theory and practice of controlling the establishment, composition, structure and growth of forests and woodlands.

Biomass Energy Data Book: Edition 2 -- DRAFT 
Slagging - The coating of internal surfaces of fireboxes and in boilers from deposition of ash particles.

Softwood - Generally, one of the botanical groups of trees that in most cases have needle-like or scalelike leaves; the conifers; also the wood produced by such trees. The term has no reference to the actual hardness of the wood. The botanical name for softwoods is gymnosperms.

Sound dead - The net volume in salvable dead trees.

Species - A group of organisms that differ from all other groups of organisms and that are capable of breeding and producing fertile offspring. This is the smallest unit of classification for plants and animals.

spp. - This notation means that many species within a genus are included but not all.

SRIC - Short rotation intensive culture - the growing of tree crops for bioenergy or fiber, characterized by detailed site preparation, usually less than 10 years between harvests, usually fast-growing hybrid trees and intensive management (some fertilization, weed and pest control, and possibly irrigation).

Stand - (of trees) A tree community that possesses sufficient uniformity in composition, constitution, age, spatial arrangement, or condition to be distinguishable from adjacent communities.

Stand density - The number or mass of trees occupying a site. It is usually measured in terms of stand density index or basal area per acre.

Starch - A naturally abundant nutrient carbohydrate, found chiefly in the seeds, fruits, tubers, roots, and stem pith of plants, notably in corn, potatoes, wheat, and rice, and varying widely in appearance according to source but commonly prepared as a white amorphous tasteless powder.

Steam turbine- A device for converting energy of high-pressure steam (produced in a boiler) into mechanical power which can then be used to generate electricity.

Stover - The dried stalks and leaves of a crop remaining after the grain has been harvested.

Sulfur Dioxide (SO2) - Formed by combustion of fuels containing sulfur, primarily coal and oil. Major health effects associated with SO2 include asthma, respiratory illness, and aggravation of existing cardiovascular disease. SO2 combines with water and oxygen in the atmosphere to form acid rain, which raises the acid levels of lakes and streams, affecting the ability of fish and some amphibians to survive. It also damages sensitive forests and ecosystems, particularly in the eastern part of the United States. It also accelerates the decay of buildings. Making electricity is responsible for twothirds of all Sulfur Dioxide.

Superheated steam - Steam which is hotter than boiling temperature for a given pressure.

Surplus electricity- Electricity produced by cogeneration equipment in excess of the needs of an associated factory or business.

Sustainable- An ecosystem condition in which biodiversity, renewability, and resource productivity are maintained over time.

Synthetic ethanol - Ethanol produced from ethylene, a petroleum by-product.

Systems benefit charge - A small surcharge collected through consumer electric bills that are designated to fund certain "public benefits" that are placed at risk in a more competitive industry. Systems benefit charges typically help to fund renewable energy, research and development, and energy efficiency. 
Therm - A unit of energy equal to 100,000 Btus (= 105.5 MJ); used primarily for natural gas.

Thermal NOx - Nitrous Oxide (NOx) emissions formed at high temperature by the reaction of nitrogen present in combustion air. cf. fuel NOx.

Thermochemical conversion - Use of heat to chemically change substances from one state to another, e.g. to make useful energy products.

Timberland - Forest land that is producing or is capable of producing crops of industrial wood, and that is not withdrawn from timber utilization by statute or administrative regulation. Areas qualifying as timberland are capable of producing more than 20 cubic feet per acre per year of industrial wood in natural stands. Currently inaccessible and inoperable areas are included.

Timber Product Output Database Retrieval System (TPO) - Developed in support of the 1997 Resources Planning Act (RPA) Assessment, this system acts as an interface to a standard set of consistently coded TPO data for each state and county in the country. This set of national TPO data consists of 11 data variables that describe for each county the roundwood products harvested, the logging residues left behind, the timber otherwise removed, and the wood and bark residues generated by its primary wood-using mills.

Tipping fee - A fee for disposal of waste.

Ton, Tonne - One U.S. ton (short ton) $=2,000$ pounds. One Imperial ton (long ton or shipping ton) $=$ 2,240 pounds. One metric tonne(tonne) $=1,000$ kilograms $(2,205$ pounds). One oven-dry ton or tonne (ODT, sometimes termed bone-dry ton/tonne) is the amount of wood that weighs one ton/tonne at $0 \%$ moisture content. One green ton/tonne refers to the weight of undried (fresh) biomass material - moisture content must be specified if green weight is used as a fuel measure.

Topping cycle - A cogeneration system in which electric power is produced first. The reject heat from power production is then used to produce useful process heat.

Topping and back pressure turbines - Turbines which operate at exhaust pressure considerably higher than atmospheric (noncondensing turbines). These turbines are often multistage types with relatively high efficiency.

Total Solids - The amount of solids remaining after all volatile matter has been removed from a biomass sample by heating at $105^{\circ} \mathrm{C}$ to constant weight.

Transmission- The process of lo

Transesterification - A chemical process which reacts an alcohol with the triglycerides contained in vegetable oils and animal fats to produce biodiesel and glycerin.

Traveling grate- A type of furnace in which assembled links of grates are joined together in a perpetual belt arrangement. Fuel is fed in at one end and ash is discharged at the other.

Trommel screen - A revolving cylindrical sieve used for screening or sizing compost, mulch, and solid biomass fuels such as wood chips.

Tub grinder - A shredder used primarily for woody, vegetative debris. A tub grinder consists of a hammermill, the top half of which extends up through the stationary floor of a tub. As the hammers encounter material, they rip and tear large pieces into smaller pieces, pulling the material down below the tub floor and ultimately forcing it through openings in a set of grates below the mill. Various sized openings in the removable grates are used to determine the size of the end product. 
Turbine - A machine for converting the heat energy in steam or high temperature gas into mechanical energy. In a turbine, a high velocity flow of steam or gas passes through successive rows of radial blades fastened to a central shaft.

Turn down ratio- The lowest load at which a boiler will operate efficiently as compared to the boiler's maximum design load.

Ultimate analysis - A description of a fuel's elemental composition as a percentage of the dry fuel weight.

Unmerchantable wood - Material which is unsuitable for conversion to wood products due to poor size, form, or quality.

Urban wood waste - Woody biomass generated from tree and yard trimmings, the commercial tree care industry, utility line thinning to reduce wildfire risk or to improve forest health, and greenspace maintenance.

Volatile matter - Those products, exclusive of moisture, given off by a material as a gas or vapor, determined by definite prescribed methods that may vary according to the nature of the material. One definition of volatile matter is part of the proximate analysis group usually determined as described in ASTM D 3175.

Volatile organic compounds (VOC) - Non-methane hydrocarbon gases, released during combustion or evaporation of fuel.

Waste streams - Unused solid or liquid by-products of a process.

Water-cooled vibrating grate - A boiler grate made up of a tuyere grate surface mounted on a grid of water tubes interconnected with the boiler circulation system for positive cooling. The structure is supported by flexing plates allowing the grid and grate to move in a vibrating action. Ashes are automatically discharged.

Watershed - The drainage basin contributing water, organic matter, dissolved nutrients, and sediments to a stream or lake.

Watt - The common base unit of power in the metric system. One watt equals one joule per second, or the power developed in a circuit by a current of one ampere flowing through a potential difference of one volt. One Watt $=3.412 \mathrm{Btu} / \mathrm{hr}$. See also kilowatt.

Wheeling - The process of transferring electrical energy between buyer and seller by way of an intermediate utility or utilities.

Whole-tree chips - Wood chips produced by chipping whole trees, usually in the forest. Thus the chips contain both bark and wood. They are frequently produced from the low-quality trees or from tops, limbs, and other logging residues.

Whole-tree harvesting - A harvesting method in which the whole tree (above the stump) is removed.

Yarding - The initial movement of logs from the point of felling to a central loading area or landing. 